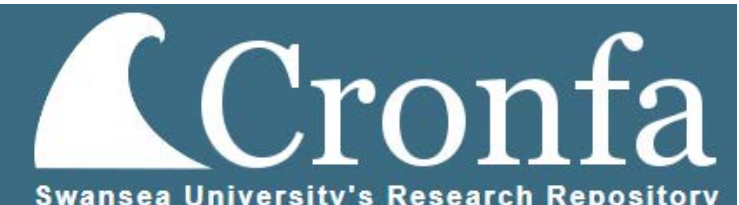

\title{
Russia on a Throne of Bayonets: Militarisation without the Military in Yeltsin's Russia, 1990-2000
}

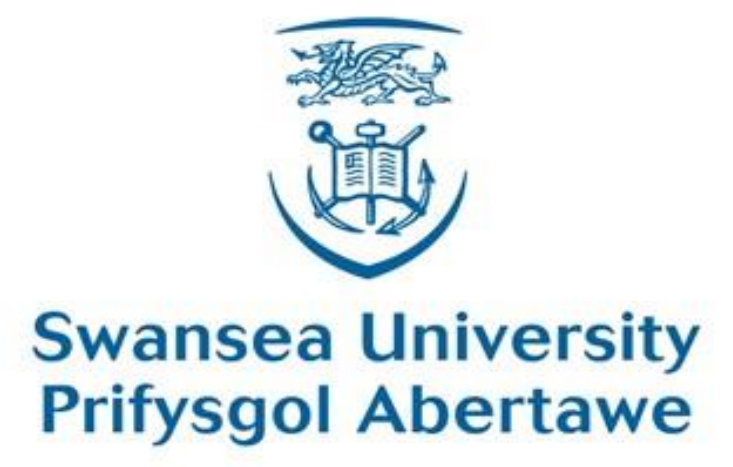

Allyson Sinead Edwards

Submitted to Swansea University in fulfillment of the requirements for the Degree of Doctor of Philosophy

Swansea University

2021

Copyright: The author, Allyson S. Edwards, 2021. 


\begin{abstract}
Scholars of Boris Yeltsin's Russia argue that it was a period of demilitarisation. Research largely focuses on militarisation in terms of its physical dimensions and by investigating subjects, individuals and institutions with a direct link to the military. These scholars instead attribute the success of Russian militarism in the post-Soviet period to Vladimir Putin. However, this is not entirely the case. This thesis challenges the assumption that the collapse of the Soviet Union constituted a break in the militarisation of society, arguing that the focus of current literature is too narrow to provide a comprehensive understanding of Russian militarism at this time. Instead, the research investigates Russian militarisation during the 1990s through a cultural lens by examining the prominent discourses across four societal domains: media, education; social welfare; and commemoration. Two discourses of a militaristic nature prevailed, including the moral obligation and civic duty of Russian people to protect the fatherland, and Russia as a besieged fortress. These narratives underpin Russian identity and have contributed towards the survival of Russian militarism beyond regime change. The thesis examines political documents, including laws, notes and letters, from the State Archive of the Russian Federation and the Yeltsin Centre, Russian newspapers and Russian school historical textbooks from the Russian State Library to answer the following questions: what top-down mechanisms militarise society? What discourses are prominent in the four societal domains and in what way do they contribute towards the militarisation of society? How do the discourses within the different societal domains fit into (and add to) current literature on the state of militarism and militarisation in Post-Soviet Russia? The thesis found that the rituals of the Putin era were rooted in Yeltsin's Russia, and that through a cultural lens, societal militarisation can be seen to persist without a strong military apparatus.
\end{abstract}




\title{
DECLARATIONS AND STATEMENTS
}

\author{
DECLARATION
}

This work has not previously been accepted in substance for any degree and is not being concurrently submitted in candidature for any degree.

Signed: (Candidate)

Date: 10.04 .2021

\section{STATEMENT 1}

This thesis is the result of my own investigations, except where otherwise stated. Other sources are acknowledged by footnotes giving explicit references. A bibliography is appended.

Signed: (Candidate)

\section{STATEMENT 2}

I hereby give consent for my thesis, if accepted, to be available for photocopying and for inter-library loans after expiry of a bar on access approved by Swansea University

Signed: (Candidate)

Date: 10.04.2021. 


\section{ACKNOWLEDGEMENTS}

This thesis examined prominent narratives in the discourses of four dominant societal domains of 1990s Russia. One of the main narratives that underpinned Russian identity was of ancestral sacrifice and dedication. Though not in terms of war, this thesis was the result of the many sacrifices of my family and friends who read endless drafts and listened to me talk endlessly about militarism and Yeltsin. This thesis would be nothing without your sacrifice and support - thank you.

First, I would like to thank my supervisors, Dr Eugene Miakinkov, Professor Michael Sheehan and Professor Alan Collins. I am so grateful for the impromptu meetings and for constantly challenging me. You all made me a better academic, guided me to the right path and motivated me on this journey. As Eugene would tell me, 'it's a marathon, not a sprint.' You were not wrong! To my informal mentor, Professor Bettina Renz, thank you for your constant support and encouragement. I would also like to thank the Economic and Social Research Council (Wales) for financially supporting me in the pursuit of this thesis.

My experience at Swansea University was made even more special by the support and friendship of my colleagues within the Department of Political and Cultural Studies. Bettina Petersohn and Katya Kolpinskaya, I am forever grateful to you for the writing retreats and your readiness to give advice and to listen. Dion Curry, Luca Trenta, Cahir O'Doherty and Matt Wall, you've sent me 'May be of interest' links on twitter, invited me to the pub and reached out to check on me. You really have made me feel like an equal member of the team. I would also like to thank our HOD, Professor Gerard Clarke, for providing me with opportunities to grow and develop. I am grateful to you all.

I would not have been able to complete the thesis without the help and support of my wonderful friends. To my (former) desk buddy Gemma, who kept me motivated and Jay, Rachel, Jack, Hillary and Brandi - you brought a lot of laughter to my $\mathrm{PhD}$ experience. To Doc Martin, my 'brawd,' thank you for reading many of my abstracts, job applications and for joining me for vegan burger Wednesdays!

To my family - Mam and Paul, Dad and Jayne, I will never be able to thank you for the support you have given me, not just now but throughout my life. Love and thanks to my grandparents - Grampa Edwards, you instilled me with a love of History and Grampa Tudor, you sparked my interest in Russia and the Russian language - I will be forever 
grateful to you both. To my wonderful sister Hayley, you've been riding shotgun since day one, always supporting me and acting interested in whatever I'm doing - I am so grateful to you for it.

And finally, to Graham. I would not have been able to get through this experience without your love and support. You dealt with long research trips, a long-distance relationship, endless evenings alone while I worked but you remained supportive, encouraging. Thank you. 


\section{CONTENTS}

LIST OF FIGURES

LIST OF DEFINITIONS AND ABBREVIATIONS $\quad \mathbf{9 - 1 0}$

$\begin{array}{lr}\text { INTRODUCTION } & \mathbf{1 1 - 2 9}\end{array}$

CHAPTER 1: A (DE)Militarised RusSia $\quad 30-80$

CHAPTER 2: "RUSSIA IN A RING OF ENEMIES": MILITARISATION THROUGH THE MEDIA

CHAPTER 3: GEROI, VRAGI \& KONFLIKTY: THE MILITARISATION OF RUSSIA'S HISTORICAL EDUCATION

CHAPTER 4: “CARING FOR PARTICIPANTS OF WAR IS A HISTORICAL DUTY OF THE STATE": VETERAN WELFARE POLICY AS A MECHANISM OF MILITARISATION

191-230

CHAPTER 5: PAYING THE DEBT: A CASE STUDY OF THE 1995 VICTORY

DAY PARADES AND ASSOCIATING CELEBRATIONS 


\section{LIST OF FIGURES}

\section{CHAPTER FOUR}

FIGURE 1. Diagram of sponsorship process.

$<$ Amended version of one created in Tony Meenaghan, "Understanding

Sponsorship Effects," Psychology and Marketing, (2001), 105-106>

\section{CHAPTER FIVE}

FIGURE 1. Image of soldiers marching in St. Petersburg, $9^{\text {th }}$ May 1995.

$<$ Screenshot APArchive>

FIGURE 2. Image of formations marching up Kutuzov Avenue, $9^{\text {th }}$ May 1995.

<Screenshot Youtube>

FIGURE 3. Image of unveiling of Marshall Zhukov on Manezhe Square, $8^{\text {th }}$ May 1995. <Screenshot APArchive>

FIGURE 4. Image of soldiers marching before Marshall Zhukov's monument, $8^{\text {th }}$ May 1995. < Screenshot APArchives

FIGURE 5. Image of Obelisk at Moscow's Victory Park.

$<$ Authors copy>

FIGURE 6. Image of the base of the Obelisk at Moscow's Victory Park.

<Authors copy>

FIGURE 7. Image of unveiling of Obelisk at Moscow's Victory Park, $9^{\text {th }}$ May 1995. <Screenshot APArchive>

FIGURE 8. Image of crowds gathered for the opening of the Victory Park, $9^{\text {th }}$ May 1995. <Screenshot APArchive>

FIGURE 9. Image of monument in Hall of Remembrance and Sorrow, in

Great Patriotic War Museum. <Authors copy>

FIGURE 10. Image of "Soldier of Victory" monument in Hall of Glory, in Great Patriotic War Museum. <Copyright Pinterest>

FIGURE 11. Image of Soviet-themed emblem displayed on ceiling of Hall of Glory, in Great Patriotic War Museum. <Authors copy>

FIGURE 12. Image of "Soldier of Victory" monument in Hall of Glory, in Great Patriotic War Museum. <Authors Copy>

FIGURE 13. “50 ann WW2 obverse," Wikimedia, last modified 14 October 2020, https://bit.ly/3ruzC22. <Copyright Wikicommons> 
FIGURE 14. “Stamp Russia 1995 Konclager,” Wikimedia, last modified 18 November 2020, https://bit.ly/3w8eYbq. <Copyright Wikicommons>

FIGURE 15. Image of Commemoration stamp released for $50^{\text {th }}$

anniversary of the Great Patriotic War, with the inscription "Eternal memory of the Fallen in the Great Patriotic War." <Copyright Wikicommons>

FIGURE 16. Image of Commemoration stamp released for $50^{\text {th }}$ anniversary

of the Great Patriotic War, with the inscription "Victory Parade."

$<$ Copyright Wikicommons>

FIGURE 17. Image of Three commemorative coins release for $50^{\text {th }}$

anniversary of the Great Patriotic War, with the inscription " $50^{\text {th }}$ anniversary of the Great Victory." <Copyright Wikicommons>

FIGURE 18. Image of Three commemorative coins release for $50^{\text {th }}$ anniversary of the Great Patriotic War, with the inscription "The Liberation of Europe from Fascism." <Copyright Wikicommons> 


\section{LIST OF DEFINITIONS AND ABBREVIATIONS}

$\underline{\text { DEFINITIONS }}$

DEDOVSHCHINA: Hazing; the process in which a senior military officialbullies a younger recruit

GLASNOST: The policy initiated by leader Mikhail Gorbachev, pushing for more transparency between the government and society

PERESTROIKA: Policy initiated by leader Mikhail Gorbachev, reforming the economic and political system of the Soviet Union

SAMOBYTNOST': The term is central to Russian debates about national identity. Used to describe the individuality and independence of Russia; to describe Russia's unique destiny; a specific Russian way of living; and the messianic role of the Russian people.

SILOVIKI: A political figure with a military or security background

SUBBOTNIK: Subbotnik and Voskresnik are days of unpaid work on weekends, most commonly associated with the Soviet period. The origin of the word comes from the Russian word Subbota (Saturday) and Voskresenia (Sunday).

\section{$\underline{\text { ABBREVIATIONS }}$}

CIS: Commonwealth of Independent States

CPSU: Communist Party of the Soviet Union

CSM: Committee of Soldiers' Mothers

DOSAAF: Rus: Dobrovolnoe Obshchestvo Sodeistviia Armii, Aviatsii I Flotu Eng:

Volunteer Society for Cooperation with the Army, Aviation and Navy

FSB: Rus: Federal'naia sluzhba bezopasnosti Rossiiskoi Federatsii Eng: Federal

Security Service

FSU: Former Soviet Union

GARF Rus: Gosudarstvennoi Arkhiv Rossiiskoi Federastii Eng: State Archive of the Russian Federation

GDP: Gross Domestic Product

GMI: Global Militarisation Index 
KGB: Rus: Comitet Gosudarstvennoy Bezopasnosti Eng: Committee for State Security MERF: Ministry of Education of the Russian Federation NATO: North Atlantic Treaty Organisation

RSL: Rus: Biblioteka imena Lenina Eng: Lenin's Library/ Russian State Library USA/US: United States of America

USSR: Union of Soviet Socialist Republics 


\section{INTRODUCTION}

On the $24^{\text {th }}$ June 2020 , Russia celebrated the $75^{\text {th }}$ anniversary of the Great Patriotic War. ${ }^{1}$ While parades usually take place on the $9^{\text {th }}$ May, quarantine measures imposed by COVID-19 forced the Russian government to postpone the Victory Day. Instead, they celebrated the $75^{\text {th }}$ anniversary of the first Victory Day parade, which took place on June $24^{\text {th }}, 1945$. The parade emphasised the historical, with 14,000 soldiers taking to Red Square in Soviet uniform alongside military hardware from the Great Patriotic War and the current military inventory. Russia Today (RT) used headlines such as "Victorious then, as now: WW2 and Latest Tech alongside each other" to highlight a connection between the past and present, with the notion of victory bridging the eras. In his speech President Vladimir Putin emphasised the temporal dimensions between past and present, stating his fear of where the world would be today "had it not been for the Red Army." His speech focused on three elements: the Soviet Union's role in the Great Patriotic War; Russia's obligation to perpetuate the memory of those who forged the victory over Nazism; and Russia's desire to collaborate with countries on existing and emerging threats. ${ }^{2}$ Two main discourses underpin Russian identity today: 1) the moral obligation and civic duty of Russian people to sacrifice themselves to protect the fatherland; and 2) Russia as a besieged fortress.

These discourses form the foundations of Russian militarism and their current success is often attributed to Putin's leadership, with the preceding Yeltsin era being characterised as one of demilitarisation. Yet, this is not entirely the case. Rather, these discourses were revived in the Yeltsin era and enabled the militarisation of society when the physical dimensions of the military were in decay. To this end, this thesis disputes the general assumption that the collapse of the Soviet Union constituted a break in the militarisation of society. ${ }^{3}$ It argues that militarism persisted in the newly formed Russian

\footnotetext{
${ }^{1}$ The Great Patriotic War (1941-1944) refers specifically to the Soviet Union's conflict with Nazi Germany during the Second World War.

2 "Putin's Victory Day Parade Speech."

${ }^{3}$ For scholarship on Russian demilitarisation in the 1990s, please see: Leon Aron, "Russia's New Foreign Policy," American Enterprise Institute, (1998), accessed 14 December 2019, https://www.aei.org/research-products/report/russias-new-foreign-
} 
Federation despite mass cuts to military budgets and efforts to reduce the size of, and funding for, the Armed Forces. The argument is foregrounded on the basis that militarised narratives remained salient in the discourse among four important societal domains and spheres of cultural activity: in the media; in Russia's historical education; in the realm of social welfare; and the country's commemorative practices. The prominence sustained cultural militarisation without the presence of a strong military.

\section{AIMS OF THE THESIS}

The thesis aims to locate which mechanisms drove processes of latent militarisation in 1990s Russia. To further current understanding of militarisation under Yeltsin, the thesis answers three overarching questions, including: 1) what top-down mechanisms militarise society?; 2) What discourses and narratives are prominent across the four societal domains, and in what way do they contribute towards the militarisation of society?; 3) How do these discourses fit into (and add to) current literature on the state of militarism and militarisation in Post-Soviet Russia? In the process, the thesis also identifies militarised foundations, which Vladimir Putin has been able to build his own militarisation project.

Through the examination of the sources, and by answering these questions, the thesis argues that there were militarised continuities between Imperial Russia, the Soviet regime, and the formative years of the Russian Federation. The resilience of military tradition from Peter I through to the Yeltsin period was a product of two discourses that have gained relevance under each of the regimes since 1682, specifically Russia as a besieged fortress and of the honour and heroism attached to sacrifice at war. The thesis

policy/; Dmitri Trenin, "The Revival of the Russian Military," Foreign Affairs 95, No. 3 (2016) http://foreignaffairs.com/articles/russia-fsu/2016-04-18/revival-russian-military; Dale Herspring, "Dedovshchina in the Russian Army: The Problem that won't go away," The Journal of Slavic Military Studies 18, No. 4 (2005): 609-610; Dale Herspring, "Undermining Combat Readiness in the Russian Military, 1992-2005," Armed Forces \& Society 32, No. 4 (2006): 515-516; Dale Herspring, "Vladimir Putin and Military Reform in Russia," European Security 14, No. 1 (2005): 140; Catherine J. Danks, Russian Politics and Society: An Introduction (Essex: Pearson Education, 2001), 174-176; Rodric Braithwaite, "Dedovshchina: Bullying in the Russian Army," Open Democracy, (2010), accessed 14 November 2017, https://www.opendemocracy.net/en/odr/dedovshchinabullying-in-russian-army/; Maya Eichler, Militarising Men: Gender, Conscription and War in Post-Soviet Russia (California: Stanford University Press, 2012), 63. 
does not outwardly dispute current literature arguing that a process of physical demilitarisation took place during the 1990s. However, it does contest the viewpoint that the Yeltsin period was one of demilitarisation as a whole, as in many ways, seen through the prism of culture, it was also a period of maintained militarisation. This cultural dimension (beyond the barracks) is vastly overlooked in contemporary literature on this topic and is the primary focus of this thesis. Therefore, the thesis argues that a process of militarisation continued to exist in Russia, despite cuts to the military budget and Russia's military failure in the Chechen region, due to the prominence of militarised narratives and rituals that continued and were revived under the leadership of Boris Yeltsin.

This thesis conceptualises the process of militarisation through a cultural lens, and builds on the work of Joanna Waley-Cohen, who examines cultural militarisation as the "pervasive injection of military themes and references into the cultural arena." ${ }^{4}$ During the 1980s and 1990s, economic constraints meant that Russia needed to rein in the physical dimensions of its military due to financial cutbacks. Scholars of the Yeltsin period have linked the physical decay of the military to the demilitarisation of Russian society. A closer look at Yeltin's tenure reveals that the 1990s was more militarised that originally accepted.

\section{YELTSIN ON A TANK}

Boris Yeltsin was Russia's President from June $12^{\text {th }} 1991$ until $31^{\text {st }}$ December 1999. His premiership began on top of a tank, as he spoke against the August Putschists in 1991. It was at this defining moment that Yeltsin's popularity dramatically rose and when he became seriously considered as an appropriate leader that would guide Russia on its path towards democracy. This democracy resulted in the physical demilitarisation of society. Yeltsin, like Gorbachev, was a civilian leader. Like Gorbachev, Russia's demilitarisation was attributed to Yeltsin's lack of experience in the military. It was Yeltsin's worldviews and his democratic principles that were deemed as the roots of the

${ }^{4}$ Joanna Waley-Cohen, "Militarisation of culture in eighteenth-century China," in Military Culture in Imperial China, ed. by Robin D. S. Yates and Ralph D. Sawyer (Cambridge: Massachusetts: Harvard University Press, 2009), 279. 
failure of Russia's Armed Forces in the 1990s. Yet, even without a military background, Yeltsin's time in office was characterised by war.

His autobiographical account Midnight Diaries showcased his tenure as one characterised by conflicts. From 1990 to 1996 for example, he was convinced that the danger of a "civil war hung over Russia." As an example to explain a potential military threat to Russian domestic politics, Yeltsin used the growth of the general-politician caste, with actors such as Alexander Lebed becoming increasingly prominent in bureaucracy. ${ }^{6}$ The 1997 Svyazinvest auction was also characterised within a militarised frame. Yeltsin considered the "bank wars" a "harsh warfare without rules inside the business elite [that] not only threatened to topple the whole economy but took hold of politics and undermined the stability of the entire political system." ${ }^{7}$ Vladimir Potonin won the "bank wars" of 1997. ${ }^{8}$ Potonin's opponent, Pavel Gusinsky started a campaign within the media, accusing the state of taking bribes from Potonin. ${ }^{9}$ The miners' strikes of 1998 were also defined through a military lens. The 1998 financial crisis led to miners' strikes, in which the "coal workers' union staged a rail war."10 The "famous rail wars" of 1998 began after miners of the Kuzbass region had not received pay for a number of months. In retaliation the miners obstructed railroad lines, which acted as an internal blockade as many of Russia's regions were dependent on railroad links. ${ }^{11}$

While the focus remains on conflict within an economic setting, Jack Hirshleifer acknowledges that warfare serves as an appropriate metaphor for nonmilitary topics that include issues of 'strife and contention." 12 It was contentious issues, such as the miners' strike and the Svyazinvest auction that deserved the name "Rail wars" and "Bank Wars,"

\footnotetext{
${ }^{5}$ Boris Yeltsin, Midnight Diaries (Great Britain: Weidenfeld \& Nicolson, 2000), 53.

${ }^{6}$ Alexander Lebed (1950-2002) was a Soviet and Russian military officer turned politician who competed for the Russian Presidency in 1996. He served as Secretary of the Security Council under Boris Yeltsin in 1996 and was Governor of Krasnoyarsk Krai region between 1998 and 2002.

${ }^{7}$ Yeltsin, Midnight Diaries, 95.

Svyazinvest is a Russian telecommunications holding company.

${ }^{8} \mathrm{Ibid}, 193$. Background information of the 'Bank wars' noted in footnote 13 alongside information on the Svyazinvest auction.

${ }^{9}$ Ibid, 95.

${ }^{10}$ Ibid, 169.

${ }^{11}$ Ibid, 169-171.
}

I. S. Solovenko, “'Rel'sovye Voiny' v Rossii v 1998 g.: k Postanovke Problemy," Istoriia 3, No. 11 (2010): 206.

12 Jack Hirshleifer, The Dark Side of the Force: Economic Foundations of Conflict Theory (Cambridge: Cambridge University Press, 2001), 1-2. 
which were commonly used by the media. ${ }^{13}$ Izvestiia, for example, reported, "Miners start 'rail war'" [Rel'sovoi voiny] with 1,500 miners blocking the Moscow-Vorkuta line. ${ }^{14}$ Nezavisimaia Gazeta and Krasnaia Zvezda are other media outlets that commented on the impact of the "Rail wars" on Russian life. ${ }^{15}$ Alongside domestic "wars," Yeltsin was also dealing with wars in the near abroad and in Chechnya. He wrote extensively about the First Chechen War (1994-1996) in his autobiography, justifying Russian intervention on the basis that, "Dudaev threatened Russia, blackmailing it with terrorist acts and explosions at military bases and nuclear plants. On principle, a person who proclaims such things should not and cannot be negotiated with." ${ }^{16}$ Russia's second invasion of Chechnya in 1999 was underpinned by the notion of the Chechen terrorist. The apartment block bombings of 1999, in which three buildings in the suburbs of Moscow were blown up, led to Russia's second invasion of the region. As Yeltsin wrote, "The terrorists' calculation was exact. They had already used this tactic once before in 1995 in Budyonnovsk. But now their intent was even more diabolical. They didn't just want to take a district hospital hostage, as they had in Budyonnovsk. They wanted to take the whole country hostage." ${ }^{17}$ Russia was involved in a war with Chechnya from 1994 to

\footnotetext{
13 The Russian Government established the Svyazinvest telecommunications holding company in 1994 and remained a state-owned company until the late 1990s. In 1997, 25\% of shares plus one was placed on sale by the government. The phrase 'bank wars' originated from the battle that ensued between banks including, the Cypriot Consortium Mustcom Ltd and Dutch company Telefam BV. The Mustcom Ltd group included Vladimir Potanin's ONESKSIMbank, while the Telefam BV group included Vladimir Gusinsky, Alfa-Bank and Boris Berezovsky. The Mustcom Ltd group presented the highest bid, winning the auction. Competitors of Vladimir Potanin threatened an 'information war,' with Gusinsky and Berezovsky utilising their media outlets to state their position. A history of the auction can be found here: "Bor'ba oligarkhov za 'Sviaz'invest.' Spravka," RIA Novosti, published 25 July 2011, https://ria.ru/20110725/406846261.html.

Vladimir Potanin (1961- present) is a Russian billionaire, former First Deputy Prime Minister of the Russian Federation (August 1996- March 1997) and part owner of the company 'Norilsk Nickel.' Vladimir Gusinsky (1952- present) is founder of the MediaMost Company that includes news channel 'NTV,' newspaper 'Sevodnya,' and radio station 'Echo of Moscow.' Boris Berezovsky (1946-2013) was a Russian oligarch with ties to the government. He was owner of 'Channel One,' and served as Deputy Secretary of Russia's Security Council (October 1996 - November 1997)

14 “Shakhtry Nachali 'Rel'sovoi voiny,"” Izvestiia, 16 May 1998.

15 "Rel'sovaia Voina,” Nezavisimaia Gazeta, 27 May 1998.

Valerii Gromok, “Zalukhniki Rel’sovoi voiny,” Krasnaia Zvezda, 10 February 1998.

${ }^{16}$ Yeltsin, Midnight Diaries, 55.

${ }^{17}$ Ibid, 337.
} 
1996 and then again in 1999, but it is clear that the Chechen problem did not remain within the tight confines of the dates above and oscillated between periods of resolution and aggravation.

For a country undergoing a physical demilitarisation, Russia was overwhelmed by conflict on many fronts. The sheer militarisation of society is showcased by the media's militarisation of non-military issues through language use. It was the media that characterised the Svyazinvest auction and miners' strikes of 1998 as war and used statements of hostage taking and Russia's battle against issues of corruption, for example, as an appropriate metaphor to describe the events. Yeltsin referred to these events as wars, showcasing the success of the media in cultivating and promoting discourses through repetition and reproduction. This dominance was furthered by the fact that the Yeltsin era was one of attempted coups (1991 and 1993), military conflicts in its near abroad, and domestic crises that were framed militaristically. These are elements that must be taken into consideration when assessing Russian militarism in the 1990s.

In addition, we could consider Yeltsin as a mechanism of militarisation on the basis that he re-established and founded a set of rituals or trends, which Putin adopted and used as foundations for his own militarisation project. First, Yeltsin placed a number of ex-military personnel in elite political positions. Literature suggests that leaders with a background in the military or security sector shape their foreign and domestic policies around militarised worldviews. While not a member of the Soviet or Russian military, Yeltsin was socialised in a militarised society - the Soviet Union - and made a number of moves in support of the military institution. He differed from a leader with a military background in the sense that he was critical of the military's ineffectiveness and prioritised social institutions in terms of the state budget, for example. However, he did (initially) appreciate Alexander Lebed's role in the administration. He found Lebed to be a "very strong fellow," and started to consider a career general as the best future leader for Russia. He had a particular type of general in mind. Yeltsin claimed:

"At some point in 1993, I first thought to myself that something was wrong with some of our generals. They were missing something important, perhaps a certain nobility, sophistication, or some sort of inner resolve...I was waiting for a new general to appear, unlike any other. Or rather, a general who was like the generals I read about in books when I was young. I was waiting... Time passed, and such a general appeared. And soon after his arrival, it became obvious to our whole 
society how really courageous and highly professional our military people were. The 'general' was named Colonel Vladimir Putin."'18

A number of former military personnel tried to gain the presidency in 1996 with the view of influencing the Duma towards pro-military policies, including Alexander Lebed. ${ }^{19}$ Yeltsin passed the baton to Putin, essentially inserting an ex-security elite into a prime political position. Second, he reproduced the symbolisms and rituals of the Soviet Victory Day parades, copying the choreography, order, design and music of previous parades. He added to the Soviet ritual by establishing new traditions, for example, the use of military hardware and establishing the parade and Victory Day celebrations as annual events. Putin too, adopted this basic structure and order of the parades, but also added new elements from the beginning of his premiership. As indicated in chapter three, the de-ideologicisation of the history textbooks was actually about de-communisation. Therefore the communist ideology was replaced with patriotic militarism, symbolised in the way Yeltsin changed Post Number One from Lenin's mausoleum to the Tomb of the Unknown Soldier. ${ }^{20}$ Yeltsin wrote, "Now the guards march here, at the symbolic grave of all our soldiers who have died for the motherland."21 On December $8^{\text {th }} 1997$ Yeltsin signed a Presidential Decree, which assigned a permanent Guard of Honor post at the Tomb. ${ }^{22}$ The tradition established during the Yeltsin period still exists today.

Through a closer examination of Yeltsin and his presidency, it is clear that there was an underlying process of militarisation of everyday life. It was subtle but visible. Yet current literature argues that the Yeltsin era was one of demilitarisation. Scholarship on 1990s Russia focuses largely on the physical aspects of militarisation, including military funding and conscription problems. Those that do consider the cultural aspects of the military, do so within the confines of the Armed Forces. ${ }^{23}$ The Militarisation school, in

\footnotetext{
${ }^{18}$ Yeltsin, Midnight Diaries, 69-70.

${ }^{19}$ Robert V. Barylski, The Soldier in Russian Politics, 1988-1996: Duty, Dictatorship and Democracy under Gorbachev and Yeltsin (New Brunswick: Transaction Publishers, 1998), 335.

${ }^{20}$ The postal code for Moscow starts with number one. Therefore Post Number One is the first postal code of the Russian state. Placing the Tomb of the Unknown Soldier under Post Number One signified its prominent position of importance to the government.

${ }^{21}$ Yeltsin, Midnight Diaries, 73.

${ }^{22}$ Yeltsin Centre, f. 8, op. 1, d. 7, 1. 33-35, [Undated].

23 For example, please see: Julian Cooper, "Demilitarising the Russian Defence Economy: A Commentary," Security Dialogue 26, No. 1 (1995): 38; Herspring, "Dedovshchina in the Russian Army," 609-610; Herspring, "Undermining Combat
} 
contrast, argues that Russia has been and is currently highly militarised. However, the Yeltsin period is largely overlooked, with a jump from the Gorbachev era to militarisation under Vladimir Putin. ${ }^{24}$

\section{METHODOLOGY}

\section{Conducting Archival Research}

The research required three trips to Moscow, and more specifically to the Russian State Library (RSL) and the State Archives of the Russian Federation (GARF). In preparation for the first three-month field trip, months were spent collating a list of potential sources for examination - the online catalogues of the State Archive and Library allowed online viewing only for a small portion of their documents. The Yeltsin Centre, situated in Yekaterinburg, holds a larger selection of available online primary sources.

Source acquisition at the State Archive was difficult at times, especially on the availability of archival materials on contentious topics - for example, the Chechen War. In addition, much of the archival materials on topics needed for the thesis were within the 30-year declassification boundary. Therefore, many of the documents on the Chechen War were, for the most part, closed. While the relationship between Russia and Chechnya is currently somewhat stable, it remains problematic. Under the supervision of archivists on the sixth floor of building five at GARF, I was able to access open documents of the same files that included closed documents.

To overcome such limitations, the project largely focuses on discourses accessible to the public in educational textbooks, laws, speeches, and the media. In addition, topics of contention, such as the Chechen War, were found through channels not directly linked to the military or government - for example, the reports in the media. The thesis would benefit from those materials that remain tightly sealed in the brown envelopes of the Russian archives to understand the state's handling of the conflict. However, the media

Readiness," 515-516; Trenin, "The Revival of the Russian Military," 23-24; Aron, "Russia's New Foreign Policy."

${ }^{24}$ For example, please see: Michael C. Paul, "The Military Revolution in Russia, 15501682," The Journal of Military History 68, No. 1 (2004): 10; David R. Stone, A Military History of Russia: From Ivan the Terrible to the war in Chechnya (Westport, Conneticut: Praeger Security International, 2006), 44; Richard Pipes, "Militarism and the Soviet State," Daedalus 109, No. 4 (1980): 3; Dmitri K. Simes, "The Military and Militarism," International Security 6, No. 3 (Winter 1981-1982): 126. 
was able to show the discussions available for public view, and in some cases, society's response to the crisis.

The thesis examined eight different Russian newspapers and magazines between the years 1991 and 1999: Pravda; Izvestiia, Argumenty i Fakty; Krasnaia Zvezda; Ogoniok; Sovetskaia Rossiia; Kommersant; and Novaia Gazeta. The newspapers and magazines are of different nature. Newspapers were located in the Russian State Library (RSL) and articles were searched by year to identify dominant discourses. Once prominent stories were identified, like Chechnya, NATO and Russia's peacekeeping missions, the later searches became more specific. Since these sources were identified via a database at RSL, there was no ability to focus specifically on letters to the editor, editorials or front-page news, with little indication of page numbers. Comparing the news outlets against one another in depth was not possible, as I was unable cross-reference how often these particular stories made front-page news across the different news outlets, for example. Despite this limitation, I was instead able to focus on what the discourses were and identify how they differed across the various newspapers.

Pravda (created in 1912) was originally a workers' daily and eventually became the main voice of the Bolshevik movement, emerging as the official party paper under each Soviet government. In 1992, the paper was sold to a Greek investor, who transformed Pravda into a paper that became the voice of the conservative-nationalist opposition. Later in 1997, it became the chief paper of the Communist Party of the Russian Federation. This was the only print-edition of pravda, but other versions of Pravda (for example, the website pravda.ru) appeared and offered a Russian nationalist perspective, which was not controlled by the Communist party. Traditionally, the newspaper was not the same as traditional printing press outlets - it did not sensationalise news or promote scandal - rather, it was used to promote unity within the Soviet Union. 100,000 copies were in circulation by $1994 .^{25}$

Izvestiia (founded in 1917) is characterised as a "newspaper of record," which is undefined by a set structure. Its initial purpose was to popularise the views of the Menshevik and Social-Revolutionary Parties. Similar to Pravda, it became the official mouthpiece of the Soviet government, and changed following the collapse of the Soviet Union. It is now described as a national newspaper of the Russian Federation. Researchers

${ }^{25}$ Andrei G. Richter, "The Russian Press after Perestroika," Canadian Journal of Communication 20, No. 1 (1995): 4. 
like Katrin Voltmer and Svetlana Juskevits found by conducting a comparative study on front-page news of Izvestiia between 1988 and 1996 that there was a 'coexistence of old and new journalistic norms when news became more factual, more timely and broader in the selection of topics and the same time there are traces of a high degreee of journalistic subjective evaluations." 26 800,000 copies of Izvestiia were in circulation by $1994 .{ }^{27}$

Established in 1978, Argumenty i Fakty is a weekly newspaper based in Moscow. Founded by an All-Union organisation "Knowledge" [Znaniye], a propagandist organisation, it served as a mouthpiece of the Soviet government and was one of the leading publications during Glasnost. At the start of the 1990s, 33.2 million copies of Argumenty i Fakty were in circulation; by 1994 the newspaper was printing 3.5 million copies a week. ${ }^{28}$ In 1995 it was awarded "The best newspaper of the Year" at the International Press Festival, and in 1996 it was awarded "Best editor and newspaper of the year" by the Russian Journalists' Union." ${ }^{29}$ According to Argumenty $i$ Fakty, the newspaper was run with little control of the state. Argumenty i Fakty's website notes, "From this position it was able to put forward the views of the general population and was a key mechanism for collecting and dissemintating unbiased news and opinion." 30

Krasnaia Zvezda is the newspaper of the Ministry of Defence. ${ }^{31}$ First published in 1924, the newspaper was particularly popular during the Great Patriotic War and was awarded numerous awards, such as the Orders of Lenin and the October Revolution. In 1992, the newspaper became the central mouthpiece of the Ministry of Defence of the Russian Federation. As of 1998, Nikolai Nikolayevich Efimov has edited it. ${ }^{32}$ While established under Soviet leadership, the newspaper's loyalty has remained with the

\footnotetext{
${ }^{26}$ Katrin Voltmer, "Constructing the Political Reality in Russia. Izvestiya - Between Old and New Journalistic Practices," European Journal of Communication 15, No. 4 (2000): 469-500; Svetlana Juskevits, "Professional Roles of Russian Journalists at the end of the 1990s: A Case Study of St. Petersburg Media," Licentiates diss., (University of Tampere, 2002), 31.

${ }^{27}$ Richter, "The Russian Press after Perestroika," 4.

${ }^{28}$ Ibid.

29 “About "Argumenty i Fakty"” <corp.aif.ru/page/89> [Accessed 20 November 2020]. ${ }^{30}$ Ibid.

${ }^{31}$ Ali Askerov, "The Chechen Wars, media and democracy in Russia," Innovative issues and approaches in Social Sciences 8, No. 2 (2015): 17.

32 "About the Newspaper," Zvezda.ru, accessed 23 November 2020, http://redstar.ru/ogazete/?attempt=1.
} 
Armed forces. Despite the collapse of communism, journalists promoted Russia's military cause and defended the image of the Russian soldier. ${ }^{33}$

Ogoniok is the oldest weekly magazine printed in Russia. First published in 1899, it has undergone many changes to suit the needs of the different regimes that have collapsed and grown since its creation. The magazine was particularly popular during the Perestroika years, selling 4.6 million copies in 1990. In the 1990s, Ogoniok magazine was owned by Boris Berezovsky and seen as a mouthpiece of the Russian government, considering Berezovsky's close relationship with Yeltsin. ${ }^{34}$ The magazine became less popular under his ownership. A member of Ogoniok's editorial office confirmed that the magazine printed 300,000 copies in 1993. However, she remarked, "one should bear in mind the studies that show that one copy of the magazine is read by an average of 2 to 7 people." The economic hardships stopped state funding of many media outlets, which led to the decline in readership figures, as people could not afford subscription costs. This should be taken into consideration for every print-media during this time. ${ }^{35}$

The newspaper Sovetskaia Rossiia (first published in 1956) is characterised as political in nature. During the Perestroika years, the newspaper tried to "warn" its readership of the dangers of Gorbachev and his policies. ${ }^{36}$ The newspaper is passionately defined on its website as loyal to the regime it was established under. Following the collapse of the Soviet Union, the newspaper kept its name. While it has redefined itself as an independent leftist paper, it has close ties to the Communist Party. ${ }^{37}$

Kommersant is a predominantly business-political newspaper. In 1992, it moved from publishing weekly to daily, serving the liberal-business community. ${ }^{38}$ Vladimir Egorovich Yakovlev founded the newspaper in 1989 and was recognised for his role in

${ }^{33}$ Askerov, "The Chechen Wars, media and democracy in Russia," 17-22.

34 Gregory J. Simons, "The Impact of Political and Business Interests of the Contemporary Russian Media," Masters diss., (University of Canterbury, 2001), 21.

${ }^{35}$ Natalia Rybkina (Editorial Staff at Ogoniok), email to Allyson Edwards, 4 October 2017.

Laura Belin, "The Russian Media in the 1990s," The Journal of Communist Studies and Transition Politics 18, No. 1 (2002): 140.

36 "About the Newspaper," Sovross.ru, accessed 23 November 2020, sovross.ru/newspaper.

${ }^{37}$ Ibid.

${ }^{38}$ Katya Koikkalainen, "The Local and the International in Russian Business Journalism: Structures and Practices," in Globalisation, Freedom and the Media after Communism: The Past as Future, ed. by Birgit Beumers, Stephen Hutchings and Natalia Rulyova (Oxon: Routledge, 2009), 75. 
the organisation of the election of the President of the Russian Federation by Boris Yeltsin in 1996. Its name derives from the newspaper 'Kommersant' that existed in Russia from 1909 and before the Russian Revolution of 1917. Katya Koikkalainen notes that while print-press in the 1990s lost much of its audience to television, "the demand for special area information such as business information has grown with the rise of the economy in Russia." 39 According to Andrei G. Richter, Kommersant was one of the few publications to reject state help in the post-Soviet period, to remain free. ${ }^{40}$

Novaia Gazeta is known for its critical and investigative journalism. Formed in 1993 by a group of Komsomolskaya Pravda journalists, the newspaper is the only one in this thesis to be established after the collapse of the Soviet Union. Mikhail Gorbachev helped found the newspaper by using funds from his 1990s Nobel Peace Prize. ${ }^{41}$ While circulation figures are not available for the 1990s, Laura Belin notes Novaya Gazeta had a small circulation and was mostly available in Moscow. ${ }^{42}$ The newspaper has gained popularity since the 1990s for its critical stance of the government. It has been the topic of international news outlets numerous times, as a result of the assassination of a number of its journalists, especially in the early 2000s. The media outlets discuss a number of topics from various viewpoints and together represent a diverse set of opinions, although it is interesting to see which discourses garner agreement among the different outlets.

The thesis also examined a mixture of political documents from within the State Duma. The State Duma makes up the lower chamber of the Federal Assembly of the Russian Federation, with the Federation Council being the upper house. These documents include laws, draft of laws, recommendations, open letters, decrees and memorandums. President Boris Yeltsin, Prime Minister Viktor Chernomyrdin and State Duma chairman Ivan Rubkin are key figures within the documents shared. Communist Party leader Gennady Zyuganov and separate Committees like the Committee on Disability, Veterans of War and Labour, Social Protection of Military Personnel and Members of their families and Committee of Public Unions and Religious Organisations and organisations such as the Veteran Organisation of Novosibirsk also played a significant role in producing some of the documentation examined in the thesis. The documents examined at GARF do not explicitly concern contentious issues such as the

\footnotetext{
${ }^{39}$ Ibid, 72.

${ }^{40}$ Richter, "The Russian Press after Perestroika," 8.

${ }^{41}$ Ibid.

${ }^{42}$ Belin, "The Russian Media in the 1990s," 157.
} 
War in Chechnya. These documents are still unavailable for public view. Searching the catalogue in GARF by date, I found folders with a significant amount of documentation on the topic of the $50^{\text {th }}$ anniversary parade and on the welfare rights of Russia's veteran and military community. These are topics that remain understudied and deserve attention. The laws and decrees demonstrated government action on a chosen subject and were signed off, usually with immediate effect, by Boris Yeltsin. Whereas draft of laws, memorandums, letters, explanatory notes and appeals documented the discussions and plans that underpinned some of the laws adopted and published in the 1990s. Some of the documents in GARF did not include the authorship or date, which posed some difficulty with interpretation. Efforts were made to group documents under topics or themes, which helped when understanding the background and context that these documents were created.

In addition, the thesis consulted 25 Russian historical school textbooks published during the 1990s, located at the Russian State Library. Textbook context is addressed directly in chapter 3 This section takes a closer look at the main publishers of the 1990s. Similar to the media sector, the collapse of the Soviet Union alongside economic and educative decentralisation led to the emergence of new publishers that catered to the educational sector. Defined as a period of "policy of no policy," there was little reform in the area of educational studies. Schools were forced to create their own educational policy and strategy. ${ }^{43}$ Schools had greater autonomy over the choice of textbooks with a larger collection to choose from. This section will provide an overview of the different publishers, creating the textbooks used in this thesis, including DROFA, Vlados and Terra.

DROFA (established in 1991) is a publishing house that specialises in educational literature. Characterised as "one of the largest [publishers] in Russia," in 1994 the publishing house signed an agreement with the Ministry of General and Professional Education of Russia for resources used in the 1995/1996 academic year. ${ }^{44}$ While schools were able to choose textbooks, between 1991 and 1994 the federal government introduced

\footnotetext{
${ }^{43}$ Isak Froumin and Igor Remorenko, "From the 'Best-in-the World' Soviet school to a Modern Globally Competitive School System," in Audacious Education Purposes: How Governments Transform the Goals of Education Systems, ed. by Fernando M. Reimers (Switzerland: Springer Open, 2020), 234.

44 "The Deputy Director of the DROFA publishing house was killed," Kommersant, 16 November 1996, No. 196, accessed 11 December 2020, https://www.kommersant.ru/doc/243221.
} 
a Training and Methodology Complex [UMK] for "History of Russia" which aimed to create a "historical and cultural standard." 45 The UMK provided a set of documentation, teaching and control tools, including guides for structuring work for all disciplines and also offers guides for other areas of the former Soviet Union. ${ }^{46}$ The introduction of the UMK system demonstrates increased governmental control over compulsory education.

Vlados was also founded in 1991. As noted on its website "Most of the books have passed the state examination and are recommended by the Ministry of Education and Science of the Russian Federation, Educational-methodical associations and Scientific-methodological councils as textbooks and teaching aids." ${ }^{47}$ Characterised as a "Leading publishing house," Vlados also specialises in educational textbooks and reference materials for teachers and students. Having also adhered to the UMK, as noted in the quote above, the publishing house adopted similar controls to DROFA.

Izdatel 'stvo Terra was established in 1989 and is situated in Moscow. It was partly funded by German Publishing firm Bertelsmann, helping overcome some of the economic issues facing other publishing firms. Publishing around 600 books a year by 1997 with a 10,000 print-run roughly per book, Terra is characterised as a smaller publishing firm but of great popularity. ${ }^{48}$ Infra- $M$ (founded in 1992) is a Moscow-based publishing company uniting "eight Russian publishing houses; specialising in the publication of scientific and educational literature." ${ }^{49}$ Nestor publishing house was established in 1997 and is situated in Moscow. It specialises in educational and foreign literature. "Mo "Most" authors of books published by Nestor have degrees and work in universities. ${ }^{51}$ Bratiia Gruniny is a publisher based in Volgograd. One of the few publishers outside of the Moscow region,

45 "History," Rossiiskii Uchebnik, accessed 11 December 2020, https://rosuchebnik.ru/about/.

46 "Obshie Trebovaniia K Tekstovym dokumentam: Edinaia sistema konstruktorskoi dokumentatsii," Mezhgosudarstvennyi Standart, 8 August 1995, accessed 20 November 2020, http://docs.cntd.ru/document/1200001260.

47 "Ob izdatel'stve," Izdatel'stvo Vlados, accessed 11 December 2020, http://vlados.ru/ob-izdatelstve/.

48 “Izdel'stvy 'Terra' knizhnaia iarmarka vruchila priz: Knigu utrom, knigu vecherom," Kommersant, 5 September 1997, accessed 17 December 2020, https://www.kommersant.ru/doc/183569.

49 "O Kompanii," INFRA-M Gruppa Kompanii, accessed 17 December 2020, https://infra-m.ru/about/o_kompanii/.

50 "O Izdatel'stvo," Izdatel'stvo Nestor Akademik, accessed 17 December 2020, http://www.nestor.su/about.html.

${ }^{51}$ Ibid. 
textbooks published by this publisher and used in this thesis reach a smaller audience. The publisher is still active today. In 1994, Ves Mir publishing company was established. As noted on its website, "Although university textbooks are not our priority, some of the IVM books have become one of the most widely read among students...Every year, IVM publishes about 50 titles of books with a total circulation of over 100,000 copies."52

The textbooks used for this project span various grades and levels and cover different periods of Russian history. Search criteria used to locate these resources at the Russian State Library included the dates between 1991 and 1999 and the search terms "Istoriia Rossii" and "Istoriia Rossiisskaia." The decision to focus on historical textbooks specifically on Russian history was purposeful. Russia regularly draws upon its history to inform current and future state goals - as demonstrated at the start and throughout this thesis. The project therefore examines how the prominent themes in Russia's historical textbooks provided an understanding of the goals and aims of the state, since education provides a basis for identity formation. Many of the textbooks used in the thesis were under the recommendation of the Ministry of Education, therefore highlighting governmental interference in the education of society and showcasing again a state-led effort to reproduce and build on pre-existing militarised discourses that spoke of Russian youth's civic duty and Russia's historical vulnerability against hostile neighbours.

The thesis fills a large gap. First, it draws upon a multitude of Russian sources not currently available in the UK. Second, it aims to create a more holistic understanding of the state of militarisation in Yeltsin's Russia, focusing on militarisation from a cultural perspective. Scholars of the Tsarist, Soviet and Putin era have examined militarisation through a cultural lens, yet this same level of examination has not been afforded to the Yeltsin era. Finally, the thesis highlights the different discourses that the public were confronted with at various stages of their lives. The thesis creates a foundation upon which further study should be pursued. The next section introduces the structure of the thesis, outlining the scope of the thesis and the ways that each chapter interlink.

\section{Critical Discourse Analysis}

The thesis adopts the process of Critical Discourse Analysis (CDA). Scholars of CDA are interested in texts and discursive interactions and how they link to social life,

52 “O Izdatel'stve," Ves' Mir Izdatel'stvo, accessed 17 December 2020, https://www.vesmirbooks.ru/about/. 
especially in terms of power relations. ${ }^{53}$ This thesis is focusing on prominent militarised discourses across four societal domains as representative of the state and its associating institutions to militarise society. In doing so, the thesis engages with the context that such discourses arise and how the discourse fits into the wider scope and aims of the Yeltsin administration.

CDA is an especially useful tool of analysis because the main discourses identified in this thesis are an outcome of statements, narratives, images, symbols and signs that are connected under a shared premise and collectively contribute towards a larger discourse. ${ }^{54}$ For example, the notion that defence of the fatherland is an integral part of civic duty is embedded in the statements of the political elite, in the topics of the educational textbooks, and in the symbolisms of historical monuments and commemorative collectables. This thesis utilises the collection of different sub-narratives from various discursive spaces and examines their contribution towards a greater discourse. Since the creation of a discourse implies a process of power relations, where one discourse will prevail over another, the thesis seeks to understand how the greater discourses facilitate and promote militarisation. ${ }^{55}$

Critical Discourse Analysis (CDA) is the most appropriate form of analysis over alternatives such as content analysis (CA), narrative analysis (NA), and discourse analysis (DA). Although CA provides a means of coding verbal text to generalise trends and patterns - and is readily replicable - it nevertheless processes text prima facie and lacks the capacity to capture nuance. ${ }^{56} \mathrm{By}$ contrast, CDA offers improved prospects for comprehending context, including how text is constructed more broadly. NA has good suitability for processing verbal or textual data such as interview transcripts because its primary focus is on texts taken in isolated or specific instances, for example semi-

${ }^{53}$ Norman Fairclough, "Critical Discourse Analysis," 27-28.

${ }^{54}$ For example, please see: Marike Finley - de Monchy, Powermatics: A Discursive Critique of New Communications Technology (Abingdon: Routledge, 2015), Introduction; Ruth Wodak, "The Discourse-Historical Approach," in Methods of Critical Discourse Analysis, ed. by Ruth Wodak and Michael Meyer (London: SAGE, 2001), 66; Norman Fairclough, Analysing Discourse: Textual Analysing for Social Research (London: Routledge, 2003), 123-124; Moira P. F. Chimombo and Robert L. Roseberry, The Power of Discourse: An Introduction of Discourse Analysis (New Jersey: Lawrence Erlbaum Associates, Inc. Publishers, 1998), 3.

${ }^{55}$ Ruth Wodak, "Critical Discourse Analysis at the End of the $20^{\text {th }}$ Century," Research on Language and Social Interaction 32, No. 1-2 (1999): 186-187.

${ }^{56}$ Steve Stemler, "An Overview of Content Analysis," Practical Assessment, Research and Evaluation 7, No. 17 (2000): 1; Margrit Schreier, "Qualitative Content Analysis," in The Sage Handbook of Qualitative Data Analysis, ed. by Uwe Flick (London: SAGE publications, 2013), 2-6. 
structured interviews. ${ }^{57} \mathrm{CDA}$ offers improved utility over narrative analysis because it permits the collation and processing of a broader range of constitutive elements of the broader discourse, including statements, narratives, signs, symbols, and events. Where NA's singular focus limits its capacity to process these dissimilar sources, CDA offers a means to analyse them as part of the broader panoply. Finally, discourse analysis (DA) - by its nature - is concerned with a shallower comprehension of discourse without context. Focusing on what is being communicated, discourse analysis has limited utility for comprehending why discourse exists. By contrast, CDA permits analysis of discursive outputs in the context of state, institutional, and political ideology. Compared with DA, a critical approach facilitates placing discourse within wider considerations of militarised values through the (re)production of narratives and statements in a political or ideological context.

Having considered the alternatives above, critical discourse analysis offers the most appropriate methodology for tracking the existence of cultural militarisation throughout this thesis. Moreover, it enables the systematic analysis of the process of militarisation by examining the wider discourse across four distinct but related societal domains. As areas of pedagogy, the authors and creators of discourses within these domains are characterised as dominant voices - those who have the ability to popularise certain topics and raise awareness through production, reproduction and repetition of discourses because as communicators to the masses, they have a sense of power. The discourses of these domains propagate particular values and belief systems to the public. In the case of this thesis, two primary discourses exist: 1) That a vulnerable Russia is living in a hostile world; and 2) ancestral sacrifice in war deserves respect and remembrance. The prominent use and reproduction of such discourses, altered to suit the needs of the issue under debate, demonstrate the adaptability and importance of such discourses to fostering militaristic sentiments and demonstrates a clear state and institutional led effort to project certain militarised belief systems onto society.

57 Jane Elliott, Using Narrative in Social Research: Qualitative and Quantitative Approaches (London: SAGE Publications, 2005), 2; 5-6.

Charlotte Burck, "Comparing qualitative research methodologies for systemic research: the use of grounded theory, discourse analysis and narrative analysis," Journal of Family Therapy 27, No. 3 (2005): 251-252.

Nollaig Frost, "Qualitative Research in Psychology," in Qualitative Research Methods in Psychology: Combining Core Approaches, ed. by Nollaig Frost (New York: Open University Press, 2011), 4.

Cigdem Esin, "Narrative Analysis Approaches," in Qualitative Research Methods in Psychology: Combining Core Approaches, ed. by Nollaig Frost (New York: Open University Press, 2011), 92. 


\section{STRUCTURE}

Chapter one of this thesis provides an overview of the current and existing historiographical debates on the conceptual differences between the terms militarisation and militarism. It then outlines and analyses literature on Russian militarism from two respective viewpoints - the militarisation school and demilitarisation school. Structured chronologically, scholars of the militarisation school show that militarism is historically embedded in Russian society through emphasis on external threats and ancestral sacrifice. The demilitarisation school, which emerged during the years of Perestroika and Glasnost, outlines the general decay of Russia's military power and suggests that Russia was not as deeply militarised as previously thought. However, its scholarship shows that the physical demise of the Russian Armed Forces only showcased Russia's reliance on its military institution and motivated a deeper mission and effort for restoration of the military's prestige. The chapter argues that discourses of external threat and ancestral sacrifice underpinned the identity of Russia's many regimes and provided militarism with the resilience it needed to survive regime change.

Chapter two examines prominent discourses in the media. Investigating the main discourses of eight newspapers and magazines published in the 1990s, the chapter shows that journalists used militarisation tactics to mobilise society. The topics of Chechnya and NATO, especially, emphasised rising threat to Russia's territorial integrity. NATO was presented in the media as the returning threat of a former adversary, playing an integral role in the establishment and formation of a siege mentality. This concern in the media of emerging threats affected members of society, who boycotted American goods and sent letters to the editor which noted the Russian State's naive response to NATO expansionism.

Chapter three focuses on the militarisation of Russia's education in the 1990s. It adopts the structure of Robert Sutherland's "Hidden Persuaders: Political Ideologies in Literature for Children." The chapter examines the main discourses of 25 historical textbooks on the history of Russia. The chapter argues that authors of these textbooks created pro-patriotic discourses by adopting militarising tactics that glorified the actions of Russian heroes against evil enemies. The textbooks also underscored Russia's extensive love affair with conflict, underlining Russia's need to continuously defend itself. 
Chapter four surveys changes made to veteran and military social welfare policies during the 1990s. The chapter argues that militarisation in this sense can be captured through the concept of sponsorship, with the act of providing exclusive pensions and benefits being a form of sponsorship that elevated the position of the veteran and military in society. The concept of sponsorship in the case of veteran and military social welfare acknowledged the government's desire to push certain militarised values and worldviews onto society.

The penultimate chapter of this thesis engages with the Victory Day of 1995 and the preparations for the event by examining political discussions within the State Duma in the lead up to the celebratory day. The chapter also studies the symbolisms and discourses associated within the celebration by analysing the parades, the Great Patriotic War Museum (opened on the anniversary date), monuments and commemorative timepieces created for the celebration. It argues that Yeltsin established a debt ideology, whereby emphasis on the sacrificial deeds of the current generations' ancestors meant they were obligated to show gratitude for such sacrifice. They were to do this through their participation in commemorative events and own loyalty to the state. The different sources showcase a state-led effort to mythologise the event and thus militarise society. The conclusion forms the final chapter of the thesis, establishing scope for further research. 


\section{CHAPTER 1}

\section{A (DE)MILITARISED RUSSIA}

As one Russian textbook author put it, "The following geopolitical conditions usually affect the specifics of Russian history: a vast, sparsely populated territory, a border unprotected by natural barriers, isolation from almost the whole of history from the seas and sea trade, a river network conducive to the territorial unity of Russia, an immediate position between Europe and Asia." 1 This 1990s educational textbook highlighted Russia's vulnerability to outside invasion. The "border unprotected by natural barriers" (especially on the western borders of Russia) easily explains why so many Western countries have tried to conquer the vast space. The geography also accounts for the failure of invasions, as the inability to sustain supply lines, and the weather, forced many invaders to retreat. ${ }^{2}$ On the Eastern front the geography hinders conquest, with hostile weather and change in terrain acting as a natural barrier. This, however, does not stop Russia from worrying about external enemies and potential invasion - in fact, Russian history is presented in such a way to legitimate it. ${ }^{3}$ Since 862 , external danger plagued Russia, threatening its territorial integrity for at least the last 500 years, where Russia has hosted frequent warfare. The besieged fortress mentality found its roots in these invasions - with court poet Vasili Petrov detailing the alliance of European countries conspiring against Russia. ${ }^{4}$ His ode on the declaration of war, went as follows:

From the South, West and East

From the gates of Mecca and Cairo

Where the name of the false prophet is praised,

Where the Nile splashes, and the Tigris and Euphrates,

The enemies of Russia,

Are already gathering towards Byzantium,

The Troops in from crowd above the Danube,

But their rear edge,

\footnotetext{
${ }^{1}$ L. I. Tugan-Baranovskaia, Istorii Rossii dlia Uchashchikhsia 8-go Klassa; Otvety na Ekzamenatsionnye bilety (Volgograd: Bratiia Grininy, 1996), 4.

2 Tim Marshall, Prisoners of Geography: Ten maps that explain everything about the world (London: Elliott and Thompson, 2016), 13.

${ }^{3}$ Ibid.

${ }^{4}$ Luba Golburt, "Vasili Petrov and the Poetics of Patronage," E-Journal of EighteenthCentury Russian Studies 3, (2015): 56.
} 


\section{Still moves in Istanbul. ${ }^{5}$}

He used the growing power of European countries and their global aspirations as evidence of Russia's increasing vulnerability to external hostility. This approach was similar to that of Russian 1990s history textbooks, which referred to the growing power and colonial ambitions of Japan, the US and Germany at the start of the twentieth century as a reason for Russia's war with Japan between 1904 and 1905 and Russia's involvement in the First World War. ${ }^{6}$ These discourses find roots and usability in other historical events and begin to display a trend within Russian politics, reflecting a hostile, imperialistic and militaristic world.

This worldview found its place in each of the regimes that have existed since its first mention in the $18^{\text {th }}$ century and has permeated state and societal discourses - from the speeches of state officials, the media, to the educational textbooks read by Russia's future generation. It is a process that, to date, continued to circulate and underpin Russia's identity and is one aspect that has sewn the different regimes together. A notable solution for such threats has been the military. A series of Russian defeats at the end of the $17^{\text {th }}$ century drove Peter I to introduce comprehensive military reforms. Similarly, Soviet military leader M. V. Frunze saw the military success of the Soviet Union as rooted in the total mobilisation of society. ${ }^{7}$ Even scholars of post-Soviet Russia, like Dmitri Trenin, considered military reform and military-technological development as a prerequisite for rebuilding Russia's great power status. Contemporary use of the besieged fortress mentality has been largely attributed to Putin. Yet this is not entirely accurate. Its use in the post-Soviet period originated in the subtle state and societal discourses of the Yeltsin era. Rooted in Russia's historical past, it maintained the cultural militarisation of society, as physical military power continued to decay.

Scholars of the post-Soviet period, for example, Dale Herspring and Leon Aron, largely argue that 1990s Russia was demilitarised. They claim that the deterioration in

\footnotetext{
${ }^{5}$ Andrei Zorin, By Fables Alone: Literature and State ideology in late eighteenth - earlynineteenth- century Russia (United States: Academic Studies Press, 2019), Chapter 1, Section 3.

${ }^{6}$ G. A. Ammona, Istoriia Rossii, IX-XX vv. Uchebnoe pospobie $v$ dvukh tamakh (Moscow: Infra-M, 1998), 440-441.

${ }^{7}$ E. V. Anisimov and A. B. Kamenskiy, Istoriia Rossii, 1682-1861 (Moscow: Terra, 1996), 20-21.

William Odom, "The Militarization of Soviet Society," Problems of Communism 25, No. 5 (1976): 34-35.
} 
military power constituted a break in the militarisation of society. ${ }^{8}$ However, historiography and the research of the thesis shows that militarism was so deeply entrenched in Russian society, politics and culture that the physical dimensions of demilitarisation during the tumultuous post-Soviet era did very little to challenge the cultural militarisations that persisted during this period. In fact, the image of a depleted military served the 'siege mentality' discourse that was cultivated across numerous societal domains of the former communist state. This is because it highlighted weaknesses within Russia when external countries were growing in power. First, this chapter will define militarisation, and then explore the different scholarly perspectives of the opposing militarisation and demilitarisation schools in the context of Russian history.

\section{MILITARISM AND MILITARISATION}

Linda Åhäll notes that the terms militarisation and militarism are different. ${ }^{9}$ For one, militarisation is generally used as a verb, whereas militarism is classed as a noun. ${ }^{10}$ The distinction was first made during the $19^{\text {th }}$ century, during France's Second Empire (1852-1870), then in Britain after 1864 and in Germany from 1870. ${ }^{11}$ Alfred Vagts and John R. Gillis defined militarism as the "domination of the military man over the civilian, an undue preponderance of military demands, and emphasis on military considerations, spirit, ideals, and scales of value, in the life of states." ${ }^{12}$ In comparison, they conceptualised militarisation as a process that does not indicate the dominance of the military or power of one particular ideology. ${ }^{13}$ Scholars accept that there are ideological or value-driven aspects to both, with militarism leading to an acceptance or unprotested

\footnotetext{
${ }^{8}$ For example, please see: Julian Cooper, "Demilitarising the Russian Defence Economy: A Commentary," Security Dialogue 26, No. 1 (1995): 38; Herspring, "Dedovshchina in the Russian Army," 609-610; Herspring, "Undermining Combat Readiness," 515-516; Trenin, "The Revival of the Russian Military," 23-24; Aron, "Russia's New Foreign Policy."

${ }^{9}$ Linda Åhäll, "The Dance of Militarisation: A Feminist Security Studies Take on 'the political,", Critical Studies on Security 4, No. 2 (2016): 8-9.

10 Åhäll, "The Dance of Militarisation," 8.

${ }^{11}$ Alfred Vagts, The History of Militarism: Civilian and Military (New York: The Free Press, 1959), 14.

${ }^{12}$ Vagts, The History of Militarism, 14.

John R. Gillis, The Militarization of the Western World (London: Rutgers University Press, 1989), 1.

${ }^{13}$ Ibid, 1.
} 
use of the military to solve non-military problems, in the same way that to militarise something is not only a physical process, but one which can lead to the acquisition of a military character. Some scholars use the terms interchangeably. J. A. Mangan, for example, uses militarism and militarisation in an equivalent manner, claiming that militarism, just like militarisation "embraces attitudes as well as systems." 14 In addition to Mangan, Stephen Webber extends the boundaries of militarism including the ideological scope and its impact on beliefs and worldviews. ${ }^{15}$ A majority of scholars accept that militarisation is not a straightforward process, but one that fluctuates depending on political, economic and social conditions. ${ }^{16}$ Linda Åhäll best conceptualises militarism and militarisation. She sees both militarism and militarisation as processes which prepare society for war, but argues that militarism is more overt, visible "and a conscious display of, and belief in, militaristic ideology," whereas she understands militarisation as a much more understated and pervasive process, normalising the military character of society. ${ }^{17}$ The following section works to understand the terms of militarism and militarisation.

\section{$\underline{\text { Understanding Militarism }}$}

Militarism is most commonly defined as the belief or desire of the government or its people that a state should maintain a strong military capability and to use it aggressively to expand national interests or values. ${ }^{18}$ Other scholars like Vagts, Cynthia Enloe and Michael Mann define militarism as the state where the demands of the military supersede the needs of society, the dominance of former military personnel in bureaucracy or governmental roles, where the military is both physically and emotionally present in society and is used and called upon as a solution to non-military problems. ${ }^{19} \mathrm{~A}$

14 J. A. Mangan, "Prologue: Combative Sports and Combative Societies," in Militarism, Sport, Europe: War without Weapons, ed. by J. A. Mangan (London: Routledge, 2004), 2-3.

${ }^{15}$ Stephen L. Webber, "Introduction: The Society-Military Interface in Russia," in Military and Society in post-Soviet Russia, ed. by Stephen L. Webber and Jennifer G. Mathers (Manchester and New York: Manchester University Press, 2006), 10-11.

${ }^{16}$ Ibid.

17 Åhäll, "The Dance of Militarisation," 12-13.

18 Lexico.com, S.v. "Militarism," accessed 12 June 2020, https://www.lexico.com/en/definition/militarism.

${ }^{19}$ For definitions of Militarism; please see Vagts, A History of militarism, 13; Anna Stavrianakis and Jan Selby, "Militarism and international relations in the twenty-first century," in Militarism and International Relations: Political Economy, Security and 
feminist perspective argues that studies on militarism should focus on the people, since the process is also within social practices and not just the values driven by prominent societal figures that prepare people for war. ${ }^{20}$ Scholars like Enloe, John Keep, Richelle Bernazzoli and Colin Flint offer the conceptual characteristics of militarism as a set of functions in a checklist. ${ }^{21}$ These checklists have been placed in a table below.

Checklists for identifying militarism

\begin{tabular}{|c|c|c|}
\hline Cynthia Enloe 22 & John Keep ${ }^{23}$ & $\begin{array}{l}\text { Richelle Bernazzoli and } \\
\qquad \text { Colin Flint }{ }^{24}\end{array}$ \\
\hline $\begin{array}{llr}\text { Armed } & \text { Force is the } \\
\text { ultimate } & \text { resolver of } \\
\text { tensions. } & & \end{array}$ & $\begin{array}{l}\text { An Excessive emphasis of } \\
\text { the military ceremonial. }\end{array}$ & $\begin{array}{l}\text { Soldiers possess certain } \\
\text { values and qualities that } \\
\text { are desirable in civil } \\
\text { society. }\end{array}$ \\
\hline $\begin{array}{l}\text { Human nature is prone to } \\
\text { conflict. }\end{array}$ & $\begin{array}{l}\text { An ideology supportive of } \\
\text { military ideals. }\end{array}$ & $\begin{array}{l}\text { Military superiority is a } \\
\text { source of national pride. }\end{array}$ \\
\hline $\begin{array}{l}\text { Having enemies is a } \\
\text { natural condition. }\end{array}$ & $\begin{array}{l}\text { Regular inculcation of such } \\
\text { ideals through the } \\
\text { educational system. }\end{array}$ & $\begin{array}{l}\text { Those who do not support } \\
\text { military actions are } \\
\text { unpatriotic. }\end{array}$ \\
\hline
\end{tabular}

Theory, ed. by Anna Stavrianakis and Jan Selby (New York: Routledge, 2002), 3-18, Cynthia Enloe, Globalisation and Militarism: Feminists made the link (Maryland: Rowman and Littlefield, 2016), 11; Robert Kohl as quoted in Roberto J. Gonzales, Hugh Gusterson and Gustaaf Houfman, Militarisation: A Reader (Durham and London: Duke University Press, 2019), Kindle Edition, 389; Michael Mann, "The Roots and Contradictions of Modern Militarism," New Left Review 1, No. 162 (1987): 35-50.

20 Åhäll, "The Dance of Militarisation," 10.

${ }^{21}$ It should be noted that John Keep adopted a checklist created in the 1950s, whereas Enloe's checklist was created in 2004. Bernazzoli and Flint created their list in 2009, but still have reservations about using the term 'militarism,' arguing that militarism could easily be changed to security. Some aspects of Keep's ideas remain prominent in studies on militarisation, however, what Enloe, Bernazzoli and Flint introduce is the more invisible aspects of militarism - the effect of militarisation on values, attitudes, behaviours and mindsets.

${ }^{22}$ Cynthia Enloe, The Curious Feminist: Searching for Women in a new age of Empire (Berkley: University of California Press, 2004), 219.

${ }^{23}$ John Keep, "The Origins of Russian Militarism," Cahiers du Monde russe et sovietique 26, No. 1 (1985): 7.

24 Richelle Bernazzoli and Colin Flint. "Power, Place and Militarism: Toward a Comparative Geographic Analysis of Militarisation," Geography Compass 3, No. 1 (2009): 401. 


\begin{tabular}{|c|c|c|}
\hline $\begin{array}{l}\text { Hierarchical relations } \\
\text { produce effective action. }\end{array}$ & $\begin{array}{l}\text { Disproportionately heavy } \\
\text { state expenditure on } \\
\text { military ends. }\end{array}$ & $\begin{array}{l}\text { Those who do not support } \\
\text { military actions are anti- } \\
\text { soldier. }\end{array}$ \\
\hline $\begin{array}{l}\text { That a state without a } \\
\text { military is naïve, scarcely } \\
\text { modern, and barely } \\
\text { legitimate. }\end{array}$ & $\begin{array}{l}\text { Willingness to bear } \\
\text { inordinately high casualties } \\
\text { in warfare (or war-induced } \\
\text { social catastrophes). }\end{array}$ & \multirow[t]{4}{*}{$\begin{array}{l}\text { For the state to engage in } \\
\text { armed conflict is to serve } \\
\text { the will of God. }\end{array}$} \\
\hline $\begin{array}{l}\text { In times of crisis those who } \\
\text { are feminine needed armed } \\
\text { protection }\end{array}$ & $\begin{array}{l}\text { Readiness to commit the } \\
\text { armed forces in foreign and } \\
\text { domestic conflicts. }\end{array}$ & \\
\hline \multirow[t]{2}{*}{$\begin{array}{l}\text { In times of crisis any man } \\
\text { who refuses to engage in } \\
\text { armed violent action is } \\
\text { jeopardizing his own status } \\
\text { as a manly man. }\end{array}$} & $\begin{array}{l}\text { Covert or overt } \\
\text { intervention by the military } \\
\text { in political decision- } \\
\text { making. }\end{array}$ & \\
\hline & $\begin{array}{l}\text { Extensive controls over the } \\
\text { life of society for military } \\
\text { purposes. }\end{array}$ & \\
\hline
\end{tabular}

While the functions included in these checklists are present in militarised societies, the checklist itself simplifies a vastly complex process. The most important consideration that must be addressed here is the fact that not all functions need to be 'ticked off' in order to show that a country is militarised. This is because the process of militarisation happens differently in each country based on that country's historical, geographic, political and even economic background. Rather, it is more helpful to examine militarism in categories with an acceptance that while a country's military may not possess a large and superior physical military presence, militarism can manifest in other ways. Researchers use four categories to define and understand militarism. These are ideological, physical, institutional and societal.

Scholars like Vagts and Enloe define militarism along the lines of its ideological boundaries. They largely consider militarism as a vehicle for the expansion of militarised values into society. As a consequence, militarism normalises the military's prominent position in society and allows civilians to rank the needs of the military above their own. ${ }^{25}$

${ }^{25}$ Stavrianakis and Selby, "Militarism and International Relations," 12-13.

Victoria M. Basham discusses the need for 'emotional energy in polity' as a way of motivating civilians to volunteer to defend its country when under threat. Basham's 
Understanding militarism as an ideology shifts the focus towards the glorification of war and military institutions in society, shaping citizens' views of the military. The ideological understanding of militarism emerged in Germany during World War Two, when it was considered a "basic cultural value." ${ }^{26}$ In agreement with Vagts and Enloe, Mangan notes that society is instilled with values of sacrifice, heroism and military glory through cultural avenues, for example, the use of military history or the 'memory of war' in museums, war memorials and educational textbooks. ${ }^{27}$ Scholars of this approach view militarism as a process that underscores preparations for military activities. ${ }^{28}$

Militarism is also conceptualised by the amount of material and manpower allocated for military purposes. This definition differs from Vagts and Enloe, instead focusing on the extent that the military physically dominated society. These definitions measure militarism by evaluating the size of the forces, and level of arms procurement and defence budget. ${ }^{29}$ Scholars using this definition usually emphasise the extensive costs of war, stressing the negative impact it had on the rest of society. John Keep, for example, highlighted the impact of militarism on Russian society in the $17^{\text {th }}$ century, claiming the volume of resources allocated to the army burdened the agrarian population who were obligated to donate resources for the war effort. ${ }^{30}$ Similarly, Clifford G. Gaddy's study, The Price of the Past, uses the economic burden of the Soviet Union's militaristic ventures and its impact on Yeltsin's Russia to communicate the wider persistence of militarisation during this period. ${ }^{31}$ Many of the scholars within this school measure militarism through a number of quantitative indicators. The "Global Militarisation Index" measures militarism by determining military spending of a country in comparison to its

perception works well with the scholarship of Bernazzoli and Flint. Bernazzoli and Flint classify militarism as present when those who do not support military action are deemed unpatriotic and anti-soldier. For more, please see: Victoria M. Basham, "Gender, Race, Militarism and Remembrance: The Everyday Geopolitics of the Poppy," Gender, Place and Culture: A Journal of Feminist Geography 23, No. 6 (2016): 884; Bernazzoli and Flint, "Power, Place and Militarism," 401.

${ }^{26}$ Ibid.

${ }^{27}$ Mangan, "Prologue: Combative Sports and Combative Societies," 1.

${ }^{28}$ Annica Kronsell and Erika Svedberg, "Introduction: Making Gender, Making War," in Making Gender, Making War: Violence, Military and Peacekeeping Practices, ed. by Annica Kronsell and Erika Svedberg (New York: Routledge, 2011), 5.

${ }^{29}$ Ibid.

${ }^{30}$ Keep, "The Origins of Russian Militarism," 6.

${ }^{31}$ Clifford G. Gaddy, The Price of the Past: Russia's Struggle with the Legacy of a Militarised Economy (Washington DC: Brookings Institution Press, 1997), 1-6. 
Gross Domestic Product, and assessing it against the amount dedicated by the country to its health spending. ${ }^{32}$

Institutional definitions of militarism emerged in response to the ideological and physical definitions, with an emphasis on the relationship between civil society and military power. This school argues that militarism exists when the military institution is ranked above those of the civilians. Scholars of civil-military relations refer to dominance of ex-military personnel in high-ranking civilian roles and examine military coups. Militocracy is a key term used to describe the dominance of former soldiers in political roles. ${ }^{33}$ Scholars of Russian militarism, such as Olga Kryshtanovskaya and Stephen White, claim that a third of all deputy ministers appointed by Vladimir Putin between 2000 and 2003 had a military or security background, with the view that their militarised backgrounds would inform (and thus militarise) political policies. ${ }^{34}$ In a different manner but still within the Russian context, scholar Brian D. Taylor uses military coups to understand civil military relations in Russian society between 1689 and 2000. He claims a lack of military intervention suggests a lack of militarism, linking little to no military coups as a sign of military subversion to civilian authorities. ${ }^{35}$ His book highlights a different perspective from those before him. However, he fails to recognise that military intervention in politics is not an integral aspect of militarism. Andrew Bacevich notes that America, for example, has not experienced military interventions, even during periods where the corporate interests of Officer Corps were compromised, but is still highly militarised. ${ }^{36}$

Finally, militarism is interpreted as a condition whereby the military is called upon to solve non-military issues. ${ }^{37}$ This interpretation sits within the school of Civil-Military relations and has synergies with the ideological school as it references the role of ideology (especially in terms of security) in a society's desire to use the military to ensure

\footnotetext{
32 Åhäll, "The Dance of Militarisation," 9.

${ }^{33}$ Webber, "Introduction," 9.

${ }^{34}$ Olga Kryshtanovskaya and Stephen White, "Putin's Militocracy," Post-Soviet Affairs 19, No. 4 (2003): 296.

${ }^{35}$ Brian D. Taylor, Politics and the Russian Army: Civil Military Relations 1689-2000 (Cambridge: Cambridge University Press, 2003), 1, 154-164, 312.

${ }^{36}$ Andrew Bacevich, The New American Militarism: How Americans are seduced by War (New York: Oxford University Press, 2013), 55.

37 Martin Shaw, "Twenty-First Century Militarism: A historical-sociological framework", in Anna Stavrianakis and Jan Selby, Militarism and International Relations: Political Economy, Security and Theory (New York: Routledge, 2002), 19.
} 
international and domestic security. ${ }^{38}$ This was the case with America. It used American exceptionalism to justify foreign intervention. "It remained, according to [George W.] Bush, America's 'responsibility to lead in this great mission," "wrote Andrew Bacevich. ${ }^{39}$ The military has been used in a domestic policing role in numerous regions such as Latin America to bring order and stability to the different states and was even called upon by the Russian elite during the 1991 failed Soviet coup and 1993 Presidential crisis. ${ }^{40}$ In recent years, the military has been used in West Africa to hinder the proliferation of the Ebola virus, and is regularly called upon to assist clean up missions and to help aid convoys following national disasters. ${ }^{41}$ These last examples highlight militarism from a physical aspect also because they suggest that the military is utilised to handle these issues because they have the assets available to address the problems, whereas civil state apparatus does not. Scholars of the behavioural approach also show how militarism affected people's behaviour. Cynthia Enloe, for example, examined how the militarisation of discursive spaces and its power altered the behaviours of society. For example, Enloe first demonstrates that militarism changes the behaviours of marketing and soup corporations of the 1980s, who marketed a 'Star Wars' tomato noodle soup in the view of increasing sales. Then, Enloe showed how the mother was 'maneuvered' by military power in her desire to provide her child with a healthy meal - seeing the space weapon shaped noodles as an appealing element that would convince the child to eat the soup. ${ }^{42}$ In Enloe's conception, the mother has continued the process of militarisation, not only demonstrating a clear triumph of marketing by the soup corporations, but in bringing

${ }^{38}$ In this sense, we can consider security as an umbrella term not only for securing American's borders from external threats, but for offering stability in other regions under the term 'peacekeeping' - this was an especially salient justification used by Russia to legitimise its military role in the near abroad, following the collapse of the Soviet Union. ${ }^{39}$ Bacevich, The New American Militarism, 13.

${ }^{40}$ Dirk Kruijt and Kees Koonings, "From Political Armies to the 'war against crime:' The Transformation of Militarism in Latin America," in Militarism and International Relations: Political economy, security and theory, ed. by Anna Stavrianakis and Jan Selby (New York: Routledge, 2002), 91-103.

${ }^{41}$ James Gallagher, "Ebola: British Military sent to tackle West Africa," BBC News, 8 September 2014, accessed 28 February 2017, https://www.bbc.co.uk/news/health29113530 .

"Japan Tsunami: Military begins search for bodies," 1 April 2011, BBC News, accessed 28 February 2017, http://www.bbc.co.uk/news/world-asia-pacific-12931418.

${ }^{42}$ Cynthia Enloe, Maneuvers: The International Politics of Militarizing Women's Lives (California: University of California Press, 2000), 1-2. 
the militarised soup can into the home. ${ }^{43}$ Her account highlights the impact that militarism has on the behaviours of people, companies and industries.

Vagts and Nancy Rosenblum document the growing relationship between militarism and notions of morality and justice. Vagts associates mass militarism with the romantic age, arguing that previous definitions of the soldier as the "drilled murderer" were replaced with "emotionalism" during the period of romanticism. ${ }^{44}$ According to Vagts, statesman Klemens Von Metternich argued that the military was ranked second only to the church, claiming, "labours through the word from the pulpit for the moral truth, and other on the battlefield by their deeds for right and justice. Church and army are serving order through the power of discipline and through hierarchical arrangement." 45 Expanding on the work of Vagts, Nancy Rosenblum claims that literature now focused on the war as a process of enacting justice, and righting the wrongs of the world. ${ }^{46}$ This is very similar to Bacevich' interpretation of American militarism, which sees America's role in the world, and through its military, as a value of instilling good. ${ }^{47}$ It also aligns with the work of Bernazzoli and Flint. They claim that militarism should be studied through a patriotic, nationalistic and religious lens, in order to understand how the notion of moral obligation becomes an unprotested and natural justification in the process of war making. They add, "for a state to engage in armed conflicts is to serve the will of God" to their checklist of militarism. ${ }^{48}$ It is through the emotional and ideological dimensions of militarism that society accepts and normalises the use of the military.

The four approaches listed above denote wider synergies between the different understandings of militarism and have a pressing influence on the strengths of each type of militarism. While there may be four approaches to understanding militarism, they cannot work in isolation - the physical will impact the behavioural, just as the ideological will affect the institutional. As there are sub-militarisms, there are also submilitarisations, and the subgroups are the reasons that no one accepted understanding of the concepts exists. The next section will aim to understand the different and competing conceptualisations of militarisation.

\footnotetext{
43 Åhäll, "The Dance of Militarisation,"15.

${ }^{44}$ Vagts, The History of Militarism, 17.

${ }^{45}$ Ibid, 18.

${ }^{46}$ Nancy Rosenblum, "Romantic Militarism," Journal of the History of Ideas 43, No. 2 (1982): 249.

${ }^{47}$ Bacevich, The New American Militarism, 13.

${ }^{48}$ Benazzoli and Flint, "Power, Place and Militarism," 401.
} 


\section{$\underline{\text { Understanding militarisation }}$}

To militarise is to: 1) Equip or supply (a place or organisation) with soldiers and other military resources; and 2) Give (something) a military character. ${ }^{49}$ Reflecting back on the above definitions of militarism, militarism is the finished product of militarisation. ${ }^{50}$ For example, to measure whether militarism exists within a country through the counting of a military budget, weapon procurement and standing army, is to consider to what extent something has been militarised through the process of militarisation. Without some form of militarisation i.e. the physical equipping or supply of the military, there would be no resources to count. To understand whether militarism exists in a country based on its values is to examine what efforts are in place to militarise public consciousness. ${ }^{51}$ It seems, that in an effort to distinguish militarism from militarisation, militarism has found domination in new scholarship and now the quest for an up-to-date conceptualisation of militarisation remains understudied.

Those studies that exist on militarisation will rarely discuss the term in the same detail as militarism, or will use both terms interchangeably without a discussion. Only few scholars have made this distinction. For example, Åhäll attempts to re-establish our connection with militarisation, providing a clear distinction of militarism as an overt and open process, meanwhile militarisation is considered a more subtle process, which prepares society for the idea of war. ${ }^{52}$ She agrees that both militarism and militarisation

49 Lexico.com, s.v. "Militarise," accessed 14 June 2020, https://www.lexico.com/en/definition/militarise.

${ }^{50}$ Although this does not suggest that militarism is the goal of a state undergoing the process of militarisation. Cynthia Enloe subscribes to this viewpoint, claiming militarisation is a 'step-by-step process (social, political and psychological) by which any person, any group, or any society absorbs ideas and resultant practices of militarism." For example, please see: Enloe, Globalisation and Militarism, 11.

${ }^{51}$ Andrew L. Ross quotes the World Council of Churches' understanding of militarisation based on their 1977 report, in which they consider militarisation as the process in which 'military values, ideology and patterns of behaviour achieve a dominating influence on the political, social, economic and external affairs of the state" to which the state can then be considered as militarised. For more, please see: Andrew L. Ross, "The Dimensions of Militarisation in the Third World," Armed Forces and Society 13, No. 4 (1987): 567.

52 Åhäll's views are in contrast with Michael Mann. Mann conceptualisation modern militarism [of 1987] as 'not upfront, subtle and diverse.' His work, however was published in 1987. Åhäll's piece builds upon a new understanding of militarism as overt and open, in contrast to militarisation (which she claims is the new subtle process) in which she conceptualises as a dance, which delicately influences different sections of 
are ideological and that both prepare society for war in one form or another. ${ }^{53}$ In both aspects it is also agreed that militarisation and militarism do not just impact on one social group or aspect of society, but make its values a central part of everyday life. ${ }^{54}$ Catherine Lutz is another scholar who aims to make a distinction. She attributes militarism to the martial values of war-making, where militarisation is considered a discursive process that works to shift societal belief and value systems to legitimise use of force, and the need for strong armies. Again, these functions overlap. Lutz does, however, make a very interesting statement, claiming that military institutional development and the glorification of militarised worldviews should not be considered to work in tandem. She claims that while the US military spending remained relatively low in the $19^{\text {th }}$ and early $20^{\text {th }}$ centuries, "political culture glorified the war and the martial spirit," therefore highlighting that the physical and cultural aspects of militarisation and not mutually exclusive. ${ }^{55}$

Andrew Ross talks of specific militarisation, and the 'second form of militarisation' in understanding third-world militarisation, which relies on the physical aspects of militarisation and can be measured by arms imports, production and size of armed forces. ${ }^{56}$ The first form of militarisation, according to Ross is both behavioural (i.e. excess use of violence) and 'militarism of the mind' (i.e. militaristic values, ideologies and worldviews). ${ }^{57}$ In line with Åäll and Lutz, this thesis considers militarisation as a subtle discursive process, whereby the domination of militarised discourses does not necessarily imply a sudden increase in army recruits, but a wider shift in societal belief that accepts (or at least allows a consideration of acceptance) the role of the military as a guarantor of security in Post-Soviet Russia.

The definition of militarisation is a 'moving target' for many authors. For example, Ross claims the nature of militarisation in the third world is largely physical i.e. military build-up. In liberal democracies, militarism and the process of militarisation is

society. For more, please see: Mann, "The Roots and Contradictions of Modern Militarism," 35-50.

53 Åhäll, "The Dance of Militarisation," 12-13.

${ }^{54}$ Henry A. Giroux, "War on Terror: The Militarising of Public Space and Culture in the United States," Third Text 18, No. 4 (2004): 211.

${ }^{55}$ Catherine Lutz, "Making war at home in the United States: Militarisation and the current crisis," American Anthropologist 104, No. 3 (2002): 723-725.

${ }^{56}$ Ross, "The Dimensions of Militarisation in the Third World," 568-570.

${ }^{57}$ Ibid. 
shaped toward preparing society to support the waging of war - which has been conceptualised under the umbrella of culture, as a process which militarises ideologies, and values of the state. ${ }^{58}$ Militarisation in Russia has reflected both aspects, the physical and cultural. In Imperial Russia and the Soviet Union, emphasis was placed on both the physical perimeters of militarisation and the cultural - with the ideological premises of "Russia as a besieged fortress" for example, playing a legitimising role for the increased physical militarisation of society.

Under Tsarist rule, more emphasis was placed on the ideological - with physical war being considered the spoils of an army. ${ }^{59}$ Lack of military reform led to many losses under this regime, but Russia was still considered militarised because of the strength of cultural militarisation - a process that continued the military ceremonial and furthered the discourse of Russia surrounded by hostile neighbours. The discourse of a weak and vulnerable Russia, encircled by enemies, continued into the post-Soviet period as new security concerns engulfed the newly formed Russian Federation. While the physical dimensions of militarisation were in decay, the cultural dimensions of militarisation were sustained in the history textbooks of school children, the media and within political discourses. Commemorative practices told society of its moral obligation to celebrate and continue the victories of its ancestors, while education discourses told students to show their patriotism by protecting it from inevitable external enemies. The cultural aspect of militarisation receives vast attention from scholars researching Imperial, Soviet and Putin's Russia. Yet the same attention has not been given to Russia under Yeltsin's leadership. Building on the work of scholars like Catherine Lutz and Henry Giroux, this thesis hopes to pay larger attention to the nodes of cultural militarisation that simmered in the background during this transformative and chaotic period.

This study focuses on the cultural militarisation of Russian society from a topdown perspective. To this end, the thesis remains in dialogue with the conceptualisations of cultural militarisation by Henry Giroux, who examines militarisation through a cultural lens and considers it as a function of "public pedagogy," enforcing pro-militaristic values and worldviews through the discourse of four societal domains: educational; media; social welfare; and commemorative practices (in Giroux's account, these domains are

\footnotetext{
${ }^{58}$ Basham, "Gender, Race, Militarism and Remembrance," 883.

${ }^{59}$ Vagts, A History of Militarism, 15.
} 
considered pedagogical sites and cultural venues). ${ }^{60}$ The process is subtle (with exception of the case study chapter, which examines militarisation through the commemorative activities of 1995). ${ }^{61}$ This is why the thesis also remains in dialogue with Joanna WaleyCohen's understanding of the process of militarisation, as the "pervasive injection of military themes and references into the cultural arena." ${ }^{2}$ The discourses under review are those established by authority figures: political elites; journalists; educational authors under the 'rekomendatsi' of the Ministry of Education, with the different societal domains acting as discursive, pedagogical spaces where state-led processes of militarisation can take place. ${ }^{63}$ The understanding of militarisation in this sense will highlight that a society can still be militarised (and pinpoint where) without the physical presence of a strong military apparatus.

In the subsequent sections of this chapter, the thesis explores two opposed historiographical schools, including the Militarisation School and Demilitarisation School. The focus of the Militarisation school remains on Imperial Russia, Soviet Russia and Putin's Russia, with very little discussion of the Yeltsin period. In contrast, scholars of the demilitarisation school explore the Yeltsin period in depth and this is where this current work hopes to make a contribution. The next part of this chapter will examine the scholarship of the Militarisation School. It charts the historical roots of Russian militarism from Peter I through the Soviet period and its manifestations under Putin.

${ }^{60}$ Giroux, "War on Terror," 215-216.

61 Åhäll, "The Dance of Militarisation," 12-13.

${ }^{62}$ Waley-Cohen, "Militarisation of Culture in Eighteenth-Century China," 279.

${ }^{63}$ Eric Meyer, "Memory and Politics," in A Companion to Cultural Memory Studies: An International and Interdisciplinary Handbook, ed. by Astrid Erll, Ansgar Nünning, and Sara Young (Germany: Walter De Gruyter, 2008), 176.

In 1988, the Soviet Ministry of Education, State Committee for Vocational and Technical Education and Ministry of Higher and Specialised Secondary Education was replaced with the State Committee of Public Education. This committee did not receive ministry status until 1993. The Ministry of Education in the 1990s was a reformulated version of the one that existed in the Soviet Union - the renaming was approved and enforced by law on 16 May 1992. In 1996 the Ministry of Education joined the State Committee of the Russian Federation for Higher Education and became known as the Ministry of General and Professional Education of the Russian Federation. Eduard Dneprov was Education Minister from 1990-1992 and was replaced by Evgeny Tkachenko from 1992 until 1996. For more, please see: Anthony Jones, "The educational legacy of the Soviet period," in Education and Society in the New Russia, ed. by Anthony Jones (New York: M. E. Sharpe, 1994), 5. 


\section{MILITARISED RUSSIA}

Russian militarism emerged as a topic of scholarly interest in the 1970s. This literature, which argues that Russia was historically, and is presently militarised, finds its origins in the military reforms of Peter I. While aspects of Russian militarism existed during the fifteenth century, argue some historians, like Keep and Michael C. Paul, fullscale militarism emerged in Russia during the reign of Peter I in the $18^{\text {th }}$ century. It was motivated by the European military revolution of the late $17^{\text {th }}$ and early $18^{\text {th }}$ centuries and continuous warfare. ${ }^{64}$ In agreement, David Stone notes, “There is little in Peter's eventful reign that can be meaningfully separated from war and the military." The challenges from Sweden, Poland and Turkey led Peter towards a series of military reforms. ${ }^{65}$

Richard Pipes and Dmitri K Simes claim that militarism under Peter I influenced society on a different and more intense level than under Muscovite rule, propelling Russia to a Great Power status. ${ }^{66}$ To Keep and Pipes, the allocation of resources to the military and the cultivation of human power from agriculture and towards the purposes of war, decreased the quality of civilian life. The checklist adopted by Keep included "disproportionately heavy state expenditure on military ends" and "extensive controls over the life of society for military purposes." ${ }^{\circ 7}$ This chapter unpacks the different schools of thought, debating the existence (or lack of) and nature of Russian militarism. The first section examines the different aspects of Russian militarism which sit within the Militarisation School. It focuses on four key elements - physical, institutional/administrative, educational and cultural. It is structured chronologically, to demonstrate the continuities and resilience of militarism and the process of militarisation beyond the breaks of different regimes.

\section{Military-Industrial Complex}

${ }^{64}$ Keep, "The Origins of Russian Militarism," 5; Michael C. Paul, "The Military Revolution in Russia, 1550-1682," The Journal of Military History 68, No. 1 (2004): 10. ${ }^{65}$ Stone, A Military History of Russia, 44; Denis Shaw, "'A strong and prosperous condition': The Geography of state building and social reform in Peter the Great's Russia," Political Geography 18, No. 8 (1999): 1000.

${ }^{66}$ Pipes, "Militarism and the Soviet State," 3; Simes, "The Military and Militarism," 126. ${ }^{67}$ L. I. Radway, "Militarism," in Encyclopedia of the Social Sciences, ed. by D. L. Sills (New York: MacMillan Co and Free Press, 1968), 300-305. 
Scholars examining Russian militarism from a 'military build-up' perspective measure use of manpower, weapon procurement and military budgets. In their understanding of militarism, the military needs excessive access to manpower for military purposes. In Russia, this was driven by consistent warfare, war fatality and the geography of Russia. Scholars like Oliver Allen Ray and Ellen Jones focus on military service. They argue that Russia and subsequently the Soviet Union, introduced military service as a means to deal with conflict and societal issues (infrastructure building, for example). Under Muscovite leaders, military service began at the age of 15 and lasted for life, with the perimeters of conscription being reduced by Empress Ann from life to 25 years. ${ }^{68}$ Jerome Blum claims that the implementation of an obligatory military service strengthened conscription significantly, with conscripts being picked based on their social standing. ${ }^{69}$ The introduction of a levy system also contributed towards increasing levels of manpower within the military. In 1705, Peter divided the country into blocks of twenty households, stating that one twenty-year-old was required from each block, per year. William C. Fuller notes that if a recruit died, fled or became ill, another eligible person from the block immediately replaced him. ${ }^{70}$ In this way, Peter I began to bureaucratise the process of conscription making it a duty of the twenty year old to perform military service. In addition, it highlighted that life was expendable, with the quick replacement of the injured or killed soldier highlighting a prioritisation of the Russian elite to preserve a well-manned Russian military over the lives of young men. Blum and Fuller's claims sit in line with those made by Ray and Jones, which showed that Russian militarism prioritised the military apparatus over the needs of the civilian population.

In 1707 , serf owners unable to serve in the military were asked to provide one in five of their household serfs. If this demand was not satisfied, the owner had to pay fifteen roubles. This price was increased in 1711 to 30 roubles per man. ${ }^{71}$ These initial efforts did not provide Peter with the sufficient amount of manpower, leading to additional levies

\footnotetext{
${ }^{68}$ Oliver Allen Ray, “The Imperial Russian Army Officers," Political Science Quarterly 76, No. 4 (1961): 577-578.

69 Jerome Blum, Lord and Peasant in Russia: From the Ninth to the Nineteenth Century (Princeton: Princeton University Press, 1971), 465-466; Ellen Jones, "Manning the Soviet Military," International Security 7, No. 1 (1982): 105-106.

${ }^{70}$ William C. Fuller, Strategy and Power in Russia, 1600-1914 (New York: The Free Press, 1998), Chapter Three.

${ }^{71}$ Lindsey Hughes, Russia in the Age of Peter the Great (New Haven and London: Yale University Press, 2004), 68-69.
} 
that not only targeted individuals but social groups. Fuller claims that in 1721, levies for clerical estate including the drafting of priests and deacons, "depleted the Russian clergy by almost two-thirds of its numbers," again highlighting the burden that the prioritisation of the military placed on other aspects of society. ${ }^{72}$ By 1700 , Russia required 40,000 additional soldiers, and by 1725 , this number rose to $90,000{ }^{73}$ During the course of his reign, Peter initiated 59 recruitment calls to make up for disease, combat fatalities and desertion. ${ }^{74}$ Keep and Richard Pipes note that as a result of Peter's reforms, the "military participation ratio" was at $4.4 \%$, a number "high by international standards" with this percentage being "three times higher" than its Western counterparts. ${ }^{75}$ The scholars focusing on conscription policy highlight a greater level of manpower in the Russian Armed Forces than other countries during this time, noting the unique nature of Russian militarism. It shows a clear prioritisation of the military over the needs of Russian civilians, who were burdened by these policies. Some of these reforms were developed under subsequent leaders.

Under the reign of Anna Ioannova (1730-1740), for example, the starting age for military service was moved from the age of fifteen to twenty. ${ }^{76}$ She created the Minnikh commission that limited the regular field army to 90,000, distributed across three guards infantry regiments, 36 regular infantry regiments, one Guards cuirassier regiment, 25 regular dragoon and cuirassier regiments. A mixture of garrison regiments, militia and Cossacks regulars alongside 33,500 troops assigned to the 'lower corps,' raised the wartime ground force to around 230,000 men. ${ }^{77}$ Bruce Menning documents an increase under Peter II's reign (1727-1730). He shows that between 1726 and 1759, annual military recruitment calls led to the recruitment of over 700,000 men from the peasant population. ${ }^{78}$ The military's acceptance of peasant recruits, and not just nobility,

\footnotetext{
${ }^{72}$ Fuller, Strategy and Power in Russia, Chapter Three.

${ }^{73}$ Ibid.

${ }^{74}$ Paul Bushkovitch, "The Romanov Transformation 1613-1725," in The Military History of Tsarist Russia, ed. by Fredrick W. Kagan and Robin Higham (New York: Palgrave, 2002), 41.

${ }^{75}$ Keep, "The Origins of Russian Militarism," 9; Pipes, "Militarism and the Soviet State," 3.

${ }^{76}$ Ray, "The Imperial Russian Army Officers," 577-578.

${ }^{77}$ Bruce W. Menning, “The Imperial Russian Army, 1725-1796," in The Military History of Tsarist Russia, ed. by Fredrick W. Kagan and Robin Higham (New York: Palgrave, 2002), 48-49.

${ }^{78}$ Menning, "The Imperial Russian Army," 55.
} 
showcased the all-encompassing role of the military in Russian society during this period, highlighting the state's desire for quantity in lieu of quality (in hereditary terms). Mass mobilisation continued beyond the reign of Peter II. On the eve of Catherine II's first Turkish War (1768-1774), the number of infantry alone had reached 135,404, with an increase to 279,575 within a thirty-year period.

Although the age and period of service had decreased since the reign of Peter I, soldiers were required to remain in service if there was a war. Elise Kimerling Wirtschafter shows that from 1796 to 1815 Russia was involved in continuous warfare. ${ }^{79}$ In this case, the Russian elite continued to recruit for war. Menning notes that by 1805 , the size of the regular army had grown to 400,000 men. ${ }^{80}$ The Russian Army during the reign of Alexander I (1801-1825) defeated Napoleon as a result of its excessive manpower. ${ }^{81}$ In contrast to Alexander, Napoleon did not have the ability to replenish his army, whereas Russian conscripts were dispatched to Kutuzov continuously. Furthermore, Fuller claims that three levies in 1812 alone produced 400,000 soldiers for service in the Russian Army. ${ }^{82}$ The number of Russia's population included in the army rose from 292,000 in 1762 , to 446,000 in 1797 , to $1,118,000$ in $1850 .{ }^{83}$

These numbers highlight the excessive cultivation of manpower to serve purposes of war. Each Imperial leader played a role in ensuring a large standing army. From Peter's reign until the $1860 \mathrm{~s}$, an estimated six million men were recruited into the army at different times. ${ }^{84}$ As noted by Wirtschafter, between 1796 and 1855, Russia amassed one of the largest Armies in Europe. ${ }^{85}$ Universal conscription was introduced in 1874, and while efforts have been made to professionalise the Russian army, economic constraints mean that compulsory military service still exists in Russia today. ${ }^{86}$

${ }^{79}$ Elise Kimerling Wirtschafter, From Serf to Russian Soldier (Princeton: Princeton University Press, 1990), 3.

${ }^{80}$ Menning, The Imperial Russian Army," 64.

${ }^{81}$ Fuller, Strategy and Power in Russia, Chapter 3.

${ }^{82}$ Ibid.

${ }^{83}$ Walker M. Pinter, “The Burden of Defense in Imperial Russia, 1725-1914” The Russian Review 43, No. 3 (1984): 246-247.

${ }^{84}$ Keep, "The Origins of Russian Militarism," 10.

${ }^{85}$ Wirtschafter, "From Serf to Russian Soldiers," 3.

86 Jones, "Manning the Soviet Military," 105-106; Ulrich Albrecht, "Red Militarism," Journal of Peace Research 17, No. 2 (1980): 137; Taylor, Politics and the Russian Army, 105-106. 
Jones and Ulrich Albrecht show that the tradition of conscription remained an important part of Soviet society. During the formative years of the Soviet Union, new leaders experimented with a voluntary system, but abandoned it almost immediately in favour of a system that enforced military service, under the conditions of the civil war. ${ }^{87}$ The Bolsheviks enforced conscription in May 1918 and their methods extensively increased the amount of manpower within the military establishment. ${ }^{88}$ In agreement, Jacob W. Kipp shows that by 1921, Lenin rounded up an army of 5.5 million men in the Red Army's battle against the White Army. ${ }^{89}$ Even during peacetime, in 1924, an army of 562,000 was maintained. ${ }^{90}$ These policies are particularly interesting, since the principles of Marxism-Leninism are anti-war and consider war an outcome of the imperialistic goals of capitalist nations. It shows that Russian militarism formed an important foundation of Russian society since the communist Soviet Union did not remain true to such principles, with the maintenance and prioritisation of a large standing army. By measuring the force ratio of 32 countries, James L. Payne found that established Marxist countries displayed a higher force ratio than countries that were new to Marxism or partly Marxist. ${ }^{91}$ Payne attributes the higher force ratio to ideology, with the capitalist classes consistently threatening socialism, and to dictatorship. The dictatorship hypothesis surrounds the notion that bureaucracies want to expand, like military organisations and that they adopt similar strategies for increasing in size and have an ability to suppress dissent. In Payne's understanding of this hypothesis, class warfare and Marxist bureaucracy go hand in hand with militarism..$^{92}$ In addition, leaders of the Soviet Union, like Joseph Stalin, were increasingly paranoid about external threats to the communist state and used the maintenance of a strong military apparatus to curb outside threats to the USSR's sovereignty. Jeremy Isaacs and Taylor Downing, for example, note that towards the end of World War Two, Russia committed six million men from the Red Army to defend the border from Leningrad to the Ukraine. ${ }^{93}$ During periods in which the

\footnotetext{
${ }^{87}$ Ibid, 138.

${ }^{88}$ Ibid, 106.

${ }^{89}$ Jacob W. Kipp, "Lenin and Clausewitz, The Militarisation and Marxism, 1914-1921," Military Affairs 49, No. 4 (1985): 75.

${ }^{90}$ David R. Stone, Hammer and Rifle: The Militarisation of the Soviet Union, 1926-1933 (Lawrence, Kansas: University Press of Kanvas, 2000), 20.

${ }^{91}$ James L. Payne, "Marxism and Militarism," Polity 19, No. 2 (1986): 275-276.

92 Ibid, 286-288.

93 Jeremy Isaacs and Taylor Downing, Cold War: For forty-five years the World held its breath (London: Abacus, 2008), 15.
} 
number of those reaching the draft age was disproportionately larger than the required number, the extras were drafted and trained as reservists. ${ }^{94}$ Army conscription was not limited to the barracks; at one point an extra 600,000 men were recruited to complete both military and infrastructural building projects. ${ }^{95}$

A large standing army was necessary for Russia, not only to globally demonstrate its military might, but to accommodate the excessive casualties experienced during wars from the time of Peter I to date. From 1789 to 1814, battle and disease accounted for 600,000 fatalities. This number approximates to nearly half of the army's maximum force within that timeframe. ${ }^{96}$ Calculations based on World War One estimated Russia's total fatality figure for the military as 1,660,000. This number includes those killed by disease, in captivity or those who were missing. This estimate brings the number of casualties in war from 7.2 million to 8.5 million. However, Abbott Gleason suggests these estimations are problematic with recent calculations increasing the fatality count from 1.7 million to over 3.37 million. ${ }^{97}$ Ellen Jones asserts that the Soviet Union lost twenty million people during World War Two, with fourteen percent of its total population perishing during the war years. ${ }^{98}$ A lack of certainty over the number of fatalities within the military is problematic, however the existing data support the notion that a large number of fatalities occurred as a result of war.

Conscription during the Tsarist era has been characterised as burdensome, not only for households who faced potential loss of a breadwinner, but for the country. As noted by M. M. Speransky, conscription threatened the division of families, a life in poverty and harmed the other industrial prospects of society. ${ }^{99}$ The demands of military service highlight the lack of consideration of Imperial leaders towards civilian society, in their quests to meet their militaristic desires. To this end, through conscription we can identify a prioritisation of the military over society, which was often attributed to Russia's low living standards and acts as a defining divide between militarism in Russia and

\footnotetext{
${ }^{94}$ Jones, "Manning the Soviet Military," 109.

${ }^{95}$ Ibid, 106.

${ }^{96}$ Keep, "The Origins of Militarism," 11.

${ }^{97}$ Melissa Stockdale, "The Russian Experience of the First World War," in A Companion of Russian History, ed. by Abbott Gleason (UK: Wiley-Blackwell, 2009), 326.

98 Jones, "Manning the Soviet Military," 106-107.

Doris Weatherford, American Women During World War II: An Encyclopaedia (New York: Routledge, 2010), 401.

${ }^{99}$ Wirtschafter, "From Serf to Russian Soldiers," 4.
} 
militarism in other countries. Keep, Jones and Gleason highlighted the necessity of conscription for Russia as a way to cope with the extreme and devastating fatalities that Russia experienced from the late $18^{\text {th }}$ and $19^{\text {th }}$ centuries (without accounting for casualties in the surrounding period). The Soviet Union adopted conscription, with little room for changes to be made before a war broke out. In the Post-Soviet period, efforts were made to professionalise the Armed Forces, but the economic situation in Russia forced it to rely on a two-year conscription. In addition to manpower, and adding to the burdens of society, the Russian/ Soviet Armed Forces devoured a significant amount of state resources.

The prioritisation of the state budget for military needs is another example of militarism in Russian history. Keep, William Pinter and Gaddy argue that Imperial and Soviet Russia committed a vast amount of monetary resources to the military institution and to factories producing equipment for war. From 1701 to 1708 , the military consumed circa $80 \%$ of the annual state budget. ${ }^{100}$ In 1705 , the Navy alone cost 179,469 roubles, while education took just 3,786 roubles of the state fund. The navy received a remarkable percentage of the state budget; however what they received was nothing in comparison to the army. The high level of funding dedicated to the different branches of the Armed Forces demonstrated a clear prioritisation of the military over other aspects of society, and in this case, the education sector. This highlighted a clear state commitment to the fostering and development of the Armed Forces, while other sectors of society were left to struggle with minimal resources. In 1705, 264,274 roubles were dedicated towards artillery costs. In 1724, army regiments and Don Cossacks claimed 1,237,240 roubles from the state funds, with an extra 137,187 roubles of the budget cultivated for artillery costs. These figures declined, and from 1725 to 1914, the total percentage distribution of state budget on the army and navy dropped from $64.5 \%$ in 1725 to $25.2 \%$ between 1910 and 1914. This is surprising, since the Russian military was still recruiting excessive manpower, and participating in wars. Pinter links the decline from 1910 to 1914 to economic, population and industrial growth within the 1890s and from 1907 to $1914 .{ }^{101}$ Furthermore, he claims that the government turned to new important functions, such as funding the railway. From 1885, the ministry of transport absorbed $2.5 \%$ of the total

${ }^{100}$ Keep, "The Origins of Russian Militarism," 9.

${ }^{101}$ Pinter, "The Burden of Defence in Imperial Russia," 248. 
budget. By 1908, it reached 20\%. ${ }^{102}$ It must also be noted that war expenses for the periods between 1800 and 1884 and from 1900 to 1909 are excluded.

According to Max Raeff, the military establishment burdened the lives of others in Russian society because it consumed a large per cent of the state budget. The middle classes of society were obligated to support the military through taxation, while the rural population was bound to give food resources to the military institution. Raeff claims, "The urban population were bound to tax duties." 103 This system was already evident under Muscovite rule. The obligations of the people within Russia were towards the state; therefore the military endeavours and funding of them, which were not new, were adopted by Peter's predecessors.

The military continued to enjoy a substantial percentage of the annual state funds into the Soviet period. During the civil war, the Soviet Union imposed War Communism - which centralised and nationalised all means of production for the purposes of war. ${ }^{104}$ David Stone notes that following the end of the Civil War, Lenin abandoned the economic structure and introduced the New Economic Policy (NEP). The NEP introduced the Soviet Union to a mixed economy and allowed the existence of small entrepreneurs. ${ }^{105} \mathrm{P}$. P. Karatugin suggested the Soviet Union should introduce the process of "military assimilation," which would bring the civilian and military industries together. He claimed that industry should have the elements and core functions available to produce munitions, even during peacetime. ${ }^{106}$ The maintenance of a militarised economy and industry during peacetime demonstrated the all-encompassing nature of Russian militarism beyond war. It also highlighted underlying anxieties of the Soviet state with external threat underpinning its desire to maintain a level of mobilisation. Altering civilian industry to support the production of military equipment denotes the wider pervasion of the military into all aspects of Soviet life. Stone shows that from 1923 to 1926, the money spent on defence ranged from 330 million roubles to 600 million roubles per year. Even during periods of economic crisis, the Soviet defence sector received 410 million roubles of the state fund. ${ }^{107}$ This again, outlines the prioritisation of the military sector, and the

\footnotetext{
102 Ibid, 249-250.

${ }^{103}$ Marc Raeff, Peter the Great: Reformer or Revolutionary? (Lexington, Massachusetts: D.C. Heath \& Company, 1966), 5.

${ }^{104}$ Kipp, Lenin and Clausewitz, 75.

105 Stone, Hammer and Rifle, 13.

106 Ibid, 17.

${ }^{107}$ Ibid, 19.
} 
commitment of the state in the development of military technology and defence even when other elements of Soviet society were in decline and to the detriment of its people. In the early years of his leadership, Stalin embarked on a comprehensive military buildup. ${ }^{108}$ Stalin's five-year plans aimed to accelerate Soviet rearmament. The rapid period of industrialisation flourished under Stalin's desire to build a strong military. Stone claims that the Stalin era was 'undeniably military,' with prominent narratives of fronts, attacks and shock brigades. ${ }^{109}$ During this period, the Soviet Union reverted back to life under a war economy. The leadership even reintroduced rationing. ${ }^{110}$

Isaacs and Downing note that Stalin launched a new five-year plan in the 1940s, concentrating on the atomic bomb's production. Following the detonation of the bomb by America, Stalin trebled the science budget for the fiscal year of 1946 . He also increased the salaries of those working on the bomb project. ${ }^{111}$ The provision of enhanced salaries emphasised the importance of those working on the bomb project, making the statement that their service to the state (in a military-scientific capacity) was one worthy of a higher salary than those in a civilian role. In the 1980s, the dominant role that defence played in society was exposed to Soviet civilians. Julian Cooper notes that in 1989, Mikhail Gorbachev claimed he was making a $14 \%$ cut to the defence budget, which at that point stood at 77.3 billion roubles. ${ }^{112}$ John P. Moran emphasised the shock felt among Soviet citizens and Western onlookers who learnt of the expensive price tag of the military, especially since the general state of the Soviet economy was in decline. ${ }^{113}$ This burden was confirmed by a number of scholars such as Keep, Pipes and Gaddy. Gorbachev asked, how could a country accomplish military superiority and the creation of nuclear weapons but deliver subpar and low quality civilian appliances? ${ }^{114}$

\footnotetext{
108 Vojtech Mastny, The Cold War and Soviet Insecurity: The Stalin Years (New York and Oxford: Oxford University Press, 1998), 13.

${ }^{109}$ Stone, Hammer and Rifle, 110.

${ }^{110}$ Peter Kenez, A History of the Soviet Union from the beginning to the end (Cambridge: Cambridge University Press, 1999), 90.

${ }^{111}$ Isaacs and Downing, Cold War, 163.

112 Julian Cooper, "Social-Military Relations in Russia: The Economic Dimension," in Military and Society in Post-Soviet Russia, ed. by Stephen Webber and Jennifer G. Mathers (Manchester and New York: Manchester University Press, 2005), 136.

${ }^{113}$ John P. Moran, From Garrison State to Nation State: Political Power and the Russian Military under Gorbachev and Yeltsin (Westport: Praeger, 2002), 113-114.

${ }^{114}$ Gaddy, The Price of the Past, 49.
} 
Russia's defence industry enjoyed extensive funding from the different regimes of the Russian/ Soviet sphere. The volume of state funds allocated for purposes of the military, especially in comparison to the civilian sectors, highlights the great extent to which the various administrations prioritised the military institution over other societal factions. This prioritisation stemmed from Russia's insecurity due to the many external threats that plagued the country. As Keep notes, Russian militarism formed in the $18^{\text {th }}$ century, alongside the militarisation efforts of Prussia, Austria and Sweden who "developed similar responses to the challenge that a hostile and competitive international environment posed to their survival." 115 During the Cold War, the Soviet Union maintained a strong military capability through the excessive funding of the defence sector to maintain a conventional and nuclear parity with America. It was therefore, through procuring Mutually Assured Destruction that the Soviet Union was able to confirm its security against the threats of the Cold War. As noted by Jones, "The Soviets are careful not to say that they will start a war; but they insist they are prepared to emerge victorious in the event war does occur."116

Gaddy claims that during the demise of the Soviet Union, it was clear to Gorbachev that the defence industry would not be able to continue to make such a high demand on the state budget. ${ }^{117}$ However, in his assessment, Gorbachev aimed to convert the defence industry so that it was creating tools for civilian use. Gaddy made the interesting point that through such a conversion, the defence industry would gain even more importance. ${ }^{118}$ Richard Sakwa asserts that even after budget cuts, as of 1996, the Russian Federation still had one of the most militarised economies in the world. ${ }^{119}$ The military character of the economy seeped into other aspects of society, militarising the administrative structures of Russian/ Soviet society.

The majority of scholarship about Russian militarism focused on or attempted to explain militarism in Russia by focusing on manpower, money and resources as a measure of militarism. The explanations presented in this section focused on the vast amount of manpower dedicated to war by Tsarist and Soviet leaders through the policy of

\footnotetext{
${ }^{115}$ Keep, "The Origins of Russian Militarism," 6.

${ }^{116}$ Jones, "Manning the Soviet Military," 106.

${ }^{117}$ Gaddy, The Price of the Past, 47.

${ }^{118}$ Ibid, 48.

${ }^{119}$ Richard Sakwa, Russian Politics and Society, 2nd edition (New York and London: Routledge, 1996), 304.
} 
conscription. Some scholars, like Gaddy, noted the prioritisation of the state budget for the needs of the military, and the demand of industry to create products needed for war (including armaments). Both approaches noticed that these prioritisations became an issue for subsequent regimes. In the instance of military conscription, the Soviet regime found that it was unable to cope with the demands of the civil war without readopting military service. Scholars of the post-soviet era established that the tradition of military service and the economic demands of the country had an impact on the country's ability to professionalise its Armed Forces. Therefore, military service remains an important part of Russian citizenship today. Gaddy found that the burden of the military-industrial complex established in the Soviet period contributed towards the high percentage of state funds that the military continued to receive in the wake of the Union's collapse. Even in the Gorbachev era, the MIC sought to receive even greater amounts of money in exchange that they create common household goods. The military still dominates a large proportion of the state budget.

\section{Military bureaucracy}

According to scholars of the militarisation school, Russia's military institution has remained closely entwined with the administrative structures of society. This involves the use of the Armed Forces to carry out infrastructure work, and for more senior members of the military to play governing roles in regional and federal governments. Scholars like James Hassell, Stephen White and Olga Kryshtanovskaya and John Keep claim that the extended role militarisation of administration has wider implications for the militarisation of society, through the transfer of values and worldviews closely associated with the structure being implemented or the person implementing them.

In the $16^{\text {th }}$ century, a military administration of some sort existed, known as the 'Razriad,' a system whereby a hierarchy based on authority and a system of role assignment was established, it served as a 'pace-maker' for Russia bureaucracy. Keep notes that while the Razriad system brought about a semblance of order, it was woefully inefficient. ${ }^{120}$ In 1722, Peter I established the 'Table of Ranks.' The table created a system of promotion, whereby commoners could achieve nobility status through services they had performed for the state. ${ }^{121}$ The nobles listed under the Table of Ranks lived like

${ }^{120}$ Keep, "The Origins of Russian Militarism," 8.

${ }^{121}$ Raeff, Peter the Great, 93. 
ordinary soldiers and at times, a commoner who had progressed through the system might instruct a noble. ${ }^{122}$ The Tables of Ranks was a really important factor in the militarisation of society as it placed those who performed military acts at the top of a hierarchical system. James Hassell supports this observation claiming that the word 'rank' stipulated a man's status. ${ }^{123}$ Those working within a civilian role would not experience the same promotion possibilities. Furthermore, legislation was adjusted to impede the possibility of civilian progression in the rank more rapidly than its military counterpart. ${ }^{124}$ The Table of ranks created a hierarchy whereby those performing a role of a militaristic nature trumped those within the civilian sector; it also underscored a new understanding of worthiness, with the quicker promotion of the military counterpart being based on their service to the state. It glorified the military career, placing civilian roles at the bottom of societal order. In addition, under Peter I, a shortage of civilian personnel meant that soldiers were called upon to carry out administrative duties. This was abandoned after his death; however a different and more established type of militarised bureaucracy emerged. ${ }^{125}$

It was during Paul I's reign that Russia first experienced the excesses of bureaucratic rule that was to become a trait of the age of Nicholas I. ${ }^{126}$ Keep claims that Paul I established a militarised bureaucracy in three ways; by allocating the military definitive roles in civil administration; removing power from the aristocratic elites and assigning it to professional administrators; and by altering the character of public service by militarising it. ${ }^{127}$ Voennye Gubernatory (military governors), Komendanty (commanders) and Plats-Maiory (town majors) were established in major cities. The military governors militarised the main centres, creating barracks and leading infrastructure-building projects. ${ }^{128}$ The militaristic character of the administrative system was not only cultivated through the increased visibility of the military man in prominent bureaucratic roles, but also in the leadership of major cities. This was particularly salient

\footnotetext{
122 Ibid.

123 James Hassell, "Implementation of the Russian Table of Ranks during the Eighteenth Century," Slavic Review 29, No. 2 (1970): 283.

${ }^{124}$ Ibid, 285.

${ }^{125}$ Keep "The Origins of Russian Miltiarism," 9.

${ }^{126}$ John Keep, "Paul I and the Militarisation of Government," Canadian-American Slavic Studies 7, No. 1 (1973): 2-3.

${ }^{127}$ Ibid.

${ }^{128}$ Ibid, 6.
} 
in the Soviet period, whereby military personnel were given the authority to impose martial law and even sentence people to death. ${ }^{129}$

In 1940, the role of the commissar changed substantially and those who recently held that role were now replaced with deputy commanders for political work. ${ }^{130}$ Dmitri Simes states that within the Soviet Armed Forces there were no roles for civilians. "There are no civilian filters between the military and political leadership that could completely challenge the professional judgements of the top command," he wrote. ${ }^{131}$ In agreement, Alexander Golts and Tanya Putnam claim that the Soviet military held an excessive amount of administrative and operational independence that subsequently hindered military reform in the Post-Soviet period. Supporting the views of Simes and Pipes, who claimed that the military was involved in low-level bureaus of the CPSU (Communist Party of the Soviet Union) and that they maintained a strong relationship with top state authorities, Putnam and Golts acknowledge that this relationship began to erode in the 1980s, when the military failed to accept responsibility for attempting to suppress nationalist movements. However, there remained a strong emphasis on the influence of the military on administrational structures of the CPSU. ${ }^{132}$

From Peter I to the present date, the Russian and Soviet leaders played a significant role within the military. Paul I, Alexander II and Nicholas II had militaristic upbringings. Nicholas II, for example, served in the military from 1887 and regularly participated in military-led summer camps. Vladimir N. Dezhnev, for example, notes that Nicholas II's participation within the military structures formed his great understanding of the system before gaining power. ${ }^{133}$ The militaristic upbringing of the Romanov rulers has been the topic of many studies, by John Keep for example, who claimed their childhood had an effect on the relationship they maintained with the military when in power, and their foreign and domestic policies. Thus, it was the worldviews that were cultivated in their early childhood that influenced their prioritisation of the military economically and administratively.

\footnotetext{
${ }^{129}$ Pipes, "Militarism and the Soviet State," 3-4.

${ }^{130}$ Simes, "The Military and Militarism," 131.

${ }^{131}$ Ibid, 132.

${ }^{132}$ Alexander M. Golts and Tonya L. Putnam, "State Militarism and Its Legacies: Why Military Reform Has Failed in Russia," International Security 29, No. 2 (2004): 130.

${ }^{133}$ Vladimir N. Dezhnev and G. Shadrinsk, "Nikolai II i Rossiikaia Imperatorskaia Armiia," Vestnik Shadrinkskogo Gosudarstvennogo Pedagogicheskogo Universiteta (2016), 147.
} 
During the Soviet era, a number of top Soviet officials had a career within the national security or military sector. Joseph Stalin, Nikita Khrushchev, Leonid Brezhnev and Konstantin Chernenko enjoyed military careers, while Yuri Andropov had a career within the KGB. The physical demilitarisation of the Gorbachev years has been attributed to his civilian background, with the manifestations of military power under Stalin and the cult of the Great Patriotic War under Brezhnev characterised as an outcome of their militarised worldviews. Scholars largely agree that leaders with a background in the military are more likely to lead a government with a militaristic character. Yet, when reexamining Yeltsin (with a civilian background) and his leadership, there is clear evidence his presidency was more militarised than previously thought. His period of leadership was characterised by warfare (internationally and domestically), he led the Russian army into a number of neighbouring conflicts under the guise of "peacekeeping" and ordered troops into Chechnya. He issued a military response to domestic issues and appreciated the general-political figure for their pragmatic and commanding nature.

Extensive literature has emerged within recent years focusing on the number of ex-military personnel in high-ranking political positions of the Putin regime. Pioneers Olga Kryshtanovskaya and Stephen White published a highly innovative study outlining the emergence of a Siloviki within the top positions of the Russian government under Putin. They claim that at least one out of four of the elite within the political hierarchy have a military background. ${ }^{134}$ David and Sharon Rivera, however, argue that there is an issue with data and that the definition of elite by White and Kryshtanovskaya is problematic. They state that data on the emergence of the Siloviki is actually much less than previously calculated and that the conceptual and empirical evidence presented by White and Kryshtanovskaya does not match. Rivera claim that a definitive answer about Russia as a militocracy is not possible and calls for further research that establishes a more accurate pool of data. ${ }^{135}$ Bettina Renz synthesises both accounts, arguing while the role of the Siloviki is more modest than explained by Kryshtanovskaya and White, its existence in Russian politics is problematic. She claims that the appointment of military and ex-military personnel within the political hierarchy was not purposeful, and based on institutional channels of elite recruitment established by previous leaders. Most

${ }^{134}$ White and Kryshtanovskaya, "Putin's Militocracy," 289.

135 David W. Rivera and Sharon Werning Rivera, "Is Russia a militocracy? Conceptual Issues and extant findings regarding elite militarisation," Post-Soviet Affairs 30, No. 1 (2014): 31-33. 
importantly, she pinpoints, and rightly so, that those recruited from military backgrounds had different "military mind-sets" and so placing these political and military figures under one label is a problem in itself. She states, "The individuals concerned are too different to be treated as one analytical unit."136

Scholars claiming that Russia was militarised through its bureaucracy focus on the militaristic nature of Imperial Russian, Soviet and Post-Soviet leaders. Many of these studies focus on the worldviews of the leaders as key to the militarisation of the administration, its domestic and foreign policies and its desire to pursue goals of a militaristic nature. This is certainly not unfounded, although Renz would argue that not all ex-servicemen would share the same experiences of war, and that the assumption that their worldviews would therefore be the same is an oversimplification. This topic is still under debate. On the other hand, and as noted in the literature, the militarisation of civilian sectors of society highlights clear prominence of militarisation in Russian society. Under Peter I, and built upon by Paul I, there was the creation of a hierarchical societal system which the military dominated. The Table of Ranks implemented a system whereby someone of a military rank was promoted at a much faster rate than their civilian counterpart, on the merit of their role in militaristic endeavours. The militarisation of the administrative landscape was achieved through the creation of military mayors, which also increased the image of military figures in high-ranking civilian roles. Both examples highlight an effort of the state to create a hierarchical system and to promote a career in the military over careers in the civilian sector. While the aims of the military were for security purposes, the above examples highlight the autonomous role of the military in administrative and organisational duties.

\section{Military culture}

Golts and Putnam convincingly argue that military reform failed in Post-Soviet Russia because of the accumulation of political and cultural attitudes that created a "defence-mindedness," which they claim was created from the military's influence on the discourse of social institutions. ${ }^{137}$ The creation of a militarised mentality is not something that happens overnight. Similar to siege mentality, a military mentality is built upon a

\footnotetext{
${ }^{136}$ Bettina Renz, "Putin's Militocracy? An Alternative Interpretation of the Siloviki in Contemporary Russian Politics,” Europe-Asia Studies 58, No. 6 (2006): 922.

${ }^{137}$ Golts, and Putnam, "State Militarism and Its Legacies," 124.
} 
historical tradition of persecution in the case of Israel, and years of military invasions in the case of Russia. Dima Adamsky defines siege mentality as a sense of societal insecurity. This phrase is usually associated with Israel and the years of persecution its Jewish population had suffered, with the creation of a mentality in belief that the State of Israel remains under threat. ${ }^{138}$ The phrase 'siege mentality' finds its relevance in Russia's feelings of insecurity, which generates the belief that the presence of a strong military would offer Russia the defence it needed. This not only translated into the creation of a mass army, but also the presence of the military in everyday society - taking us far beyond simple notions of Russia as a besieged fortress and seeing the military as a solution to a problem of paranoia. The prominent vision of military uniforms on the streets, the existence of a militarised media discourse, the creation of a military-educational complex and a concentration on the ceremonial aspects of the military all contributed to the creation of a strong and impenetrable military mentality.

Alongside the promotion of stories of domestic and international threats in the media, the construction of a military mentality also relied on these pervasive processes of militarisation. On a societal level, the military played a significant role in the unification and socialisation of the masses. Education and training was provided to the offspring of serving soldiers, establishing a cohort of future generations readily prepared for war. Taylor and John Bushnell claim that Peter I united nobility and peasants for service not only by bringing together different classes under the conditions of war but also ensuring their different backgrounds would hinder a union that could and would challenge the rule of state actors. ${ }^{139}$ The notion that these ceremonial aspects of militarism allowed the leaders to exercise unquestioned control over the military is not new. According to Keep, the Tsars felt insecure on their thrones and therefore needed the military to support their autocratic leadership styles. ${ }^{140}$ In agreement, Bushnell claims it was the disciplinary nature of the military that made it responsible for civilising peasants, with the military drills and schooling being an important method of discipline in the "pre-technological

\footnotetext{
${ }^{138}$ Dima Adamsky, The Culture of Military Innovation: The Impact of Cultural Factors on the Revolution in Military Affairs in Russia, the US and Israel (Stanford: Stanford University Press, 2010), Chapter 4, Section: Israeli Strategic culture, siege mentality and aversion to planning.

139 Taylor, Politics and the Russian Army, 40; John Bushnell, "Peasants in Uniform: The Tsarist Army as a Peasant Society," Journal of Social History 13, No. 4 (1980): 565.

140 John Keep, “Military Style of Romanov Rulers,” War and Society 1, No. 2 (1983): 63.
} 
age. ${ }^{141}$ Paul I commanded parades on a daily basis, which was considered beneficial to the soldiers who became familiar with the commands and could unite when necessary to perform them. Alexander I staged parades that would include 150,000 Russian troops. ${ }^{142}$ The emphasis on the ceremonial was one aspect that separated Russian militarism from the conditions of militarism in other European countries. Russian military drills were known to strike fear among other nations. Vagts notes that real war was considered the 'spoils of the army,' especially because loss in conflict would ruin the discipline and power cultivated in these ceremonial parades. These drills were an important aspect to Russian militarism under the Tsars as they created images of great military power that could not be achieved in any other form than outright war.

During the Soviet period, military parades took place on Red Square at a national level and locally within the different regions to commemorate the anniversary of the October Revolution and the victory of the Great Patriotic War. ${ }^{143}$ These parades included military drills, which demonstrated Russia's colossal military power in the form of military technology, organised along Moscow's Red Square. Webber asserts that the tanks and missile launchers "served to reinforce the perception of the threat that the Soviet Union posed, and in the USSR were presented as a symbol of the country's might and international standing." ${ }^{144}$ Similar to the Tsars, the military-ceremonial became an important aspect of Russian militarism under the Soviet regime. Studies by Bushnell and Vagts reinforce points from Keep's checklist, which noted an emphasis on the militaryceremonial as an integral part of Russian militarism.

\section{Military Education}

A militarised education is an important factor for scholars of the militarisation school, arguing that the success of creating a patriotic society is rooted in the current and future generations receiving a military-patriotic education. During the $18^{\text {th }}$ century, a military-educational system was established to prepare future generations for war. Considered a key form of socialisation, the pervasion of the educational sector with

\footnotetext{
${ }^{141}$ Bushnell, "Peasants in Uniform," 565; Keep, "The Military Style of the Romanov Rulers," 62.

Paradomania refers to the practice of perfecting marches and parade-ground drills

${ }^{142}$ Keep, "The Military Style of Romanov Rulers," 70-71, 80.

${ }^{143}$ Webber, Military and Society in Post-Soviet Russia, 1.

${ }^{144}$ Ibid.
} 
militaristic-patriotic messages targeted youth at key points in their development. It ensured their worldviews were shaped with patriotic-militaristic messages at a young age, and that they were readily prepared (and trained) for military service upon their graduation. This system continued to develop under the reign of Anna Ivanova, when the Noble Cadet Corps were established. Roughly 1,500 of the gentry youth graduated from the Corps and studied a number of subjects, including arithmetic, military drill and theology. According to Menning, students also participated in fortification, drafting and history classes. Two-thirds of those, who graduated from the Corps were promoted to officer ranks. ${ }^{145}$

The mixture of academic classes with physical training highlighted efforts of the state to ensure that students were not only mentally trained for war, but that they were knowlegable of the different defensive strategies of the state. Catherine II increased the Army Noble Cadet Corps in 1762. The curriculum was reorganised and broadened to include training for both military and civilian service. From 1762 to 1800, 2,000 cadets graduated from the corps, with 820 becoming officers. ${ }^{146}$ The Artillery and Engineer Noble Cadet Corps were established in 1762 and renamed in 1800 as the Second Noble Cadet Corps. The curriculum was based on mechanics, mathematics and engineering. From 1965 to 1800 , 1,500 graduates from the Second Noble Cadet Corps entered Russia's military service. ${ }^{147}$ Odom claims that by 1850,30 percent of elementary school children were enrolled in a military education, and the number of Cadet Corps grew to nineteen by the mid- $19^{\text {th }}$ century. ${ }^{148}$ In parallel with the growth in the number of cadet corps and military academies, the establishment of military schools in 1863 greatly increased the amount of military graduates, with access to military school depending on whether the pupil had successfully completed secondary education. ${ }^{149}$ Graduating from a prestigious military school with a high grade determined where the officer was assigned. As noted by Ray, graduates of the School of Pages were, for the most part, assigned to the Guards Regiments. ${ }^{150}$ Military service began as students graduated therefore the military-

\footnotetext{
${ }^{145}$ Menning, "The Imperial Russian Army," 54-55.

${ }^{146}$ Bruce W. Menning, "Paul I and Catherine II's Military Legacy, 1762-1801," The Military History of Tsarist Russia, ed. by Fredrick W. Kagan and Robin Higham (New York: Palgrave, 2002), 81.

${ }^{147}$ Ibid.

${ }^{148}$ Odom, "The 'Militarisation' of Soviet Society," 40.

${ }^{149}$ Ray, "The Imperial Russian Army Officer," 580-584.

${ }^{150}$ Ibid, 587.
} 
educational complex became a socialisation process that assisted the transition from boyhood to manhood. The Tsars used education as an avenue for militarisation, preparing society for the physical demands of the military while shaping their worldviews. Military educational systems increased in the Soviet period, not only building on the youth's physical training but also instilling the younger generations with patriotism and military values.

Odom claims that numerous specialists participating in the military during the demise of the Tsarist regime belonged to the Imperial Army. Despite wanting to create a new cohort of Red Army leaders, in the wake of the Civil War, the Bolsheviks relied on the Imperial officers to train future military specialists. ${ }^{151}$ Unsurprisingly, the methods and curriculum adopted by the Soviet Union were based on those from the Imperial General Staff Training System. This changed in the 1920s. Taylor notes that the Bolsheviks made a number of changes, which led to a decrease in the number of officer corps and ex-Tsarist officers in teaching positions. ${ }^{152}$ Despite the fact that the army offered training upon entering military service, real efforts were made to introduce a military education to lower levels of society. For conscription to work effectively, it became necessary that the process of militarisation started from a young age. As the Commissar for Naval affairs, Mikhail Vasilyevich Frunze stressed, military education was important at a primary level because it ensured the total preparation of society for war. ${ }^{153}$ This point is particularly important and underscores the existence of a siege mentality, whereby the Soviet Union felt its only opportunity to warn off external threat was through a readily mobilised military sector. In addition, Frunze's statement also stressed that Soviet military victory depended on the mobilisation of the entire society, and the engrained patriotic beliefs that Soviet citizens should protect the motherland from any danger. From 1939, the number of military-education institutions increased from 123 to 161 , though this figure is conservative since it does not include institutions that trained those for the KGB. ${ }^{154}$

In 1970, the Soviet Union introduced military departments in civilian 'higher' education institutions, making participation in military programmes an obligation. ${ }^{155}$

\footnotetext{
${ }^{151}$ Odom, "The 'Militarisation' of Soviet Society," 36.

152 Taylor, Politics and the Russian Army, 140-141.

${ }^{153}$ Odom, "The 'Militarisation' of Soviet Society," 34-35.

${ }^{154}$ Ibid, 37.

${ }^{155}$ Ibid, 40.
} 
There was no civilian equivalent in military educational institutions. The insertion of military departments into higher education institutions demonstrated the pervasive nature of militarism. For the Soviet youth, the decision to adopt a patriotic stance was less afforded by opportunity. Rather, they were force-fed pro militaristic-nationalistic narratives through compulsory education. Norman M. Naimark et al., for example, notes that the Soviet youth were instilled with notions that "their country is always right, that it is worth fighting and dying for, and that they must learn and sharpen the skills needed to fight well on behalf of the motherland." 156 This was completed by instruction and through textbooks and manuals, which taught students that they needed to know how to defend the motherland. ${ }^{157}$ Odom notes that DOSAAF (Dobrovol'noye Obshchestvo Sodeystviia Armii, Aviatsii i Floti), a voluntary organisation that provided training to complement the secondary and higher military programmes, was established in 1951. From 1967 to 1971, the DOSAAF recruited a further 9 million members and 20,000 new primary organisations. ${ }^{158}$ Simes argues that while the organisation was seen as 'voluntary,' the DOSAAF required dues to be paid by every Soviet student and employee. ${ }^{159}$

As will be highlighted in chapter three, education is a popular tool of indoctrination and socialisation, utilised by many regimes in order to promote a certain ideology. States who have harnessed the means of education as a form of communication include Nazi Germany and post-World War Two France. It is evident that leaders of Tsarist Russia and the Soviet Union wanted to use education to train and prepare its youth for military service. While on a physical level students were required to participate in drill performances and activities such as abseiling and parachuting, on a more ideological level the youth were also indoctrinated through the curriculum, which fed the students with historical myths of hostile neighbours. The militarisation of education was an important mechanism for ensuring the continued militarisation of society, especially since these students were the next generation of Russian/Soviet citizens. This literature documents a clear state-led initiative to create a military mentality among its youth, with the view they would continue the militaristic endeavours of the state.

\footnotetext{
${ }^{156}$ Norman M. Naimark, David E. Powell and Kurt M. Campbell, "Moscow's Cult of Militarism," The National Interest, No. 4 (1968): 54.

157 Ibid.

158 Odom, "The 'Militarisation' of Soviet Society," 44-45.

${ }^{159}$ Simes, "The Military and Militarism in Soviet Society," 140.
} 
According to scholars of the militarisation school, Russian society is built on militarism. Those with a physical conceptualisation of militarisation document the militarisation of Russia from its excessive use of state resources and funding. The high percentage of monetary and material help to the military significantly burdened other aspects of society. They outline a historical tradition of the former regimes in dedicating a vast amount of its budget capacity to the military, with the obvious burden on citizens serving as an indicator of the prioritisation of the military sector and showing evidence of state militarism. The burden of the defence sector is clearly documented by Clifford G. Gaddy, who claims that the historical dominance of the economy by the defence industry proved a problem to Post-Soviet Russia as it aimed to pare down its defence budget. Writing in 1996, he suggested that the burden would be a problem that Russia would need to bear with for a long time. ${ }^{160}$

The militarisation of bureaucracy from Peter I's Table of Ranks highlighted a state-led initiative to raise the profile of the military and create a hierarchical system in which the military stood at the apex. Civilians were disadvantaged in comparison to their military counterparts, who were promoted through the ranks based on their service to the state. The creation of this informal hierarchy was aimed to popularise the Armed Forces and place military personnel on a pedestal. It demonstrated to other members of society that they too, could gain similar promotions, should they serve the country in the same way as their military colleague. It demonstrated another situation where the military sector was prioritised by the state and therefore, the existence of militarism in Russia.

Scholars who focus on civil-military relations also examined the placement of exmilitary personnel into key areas of the political elite. Many of the Tsarist leaders, like Peter I, were obsessed with the military from a young age, which is used by scholars to underpin arguments that his childhood shaped his leadership style. Soviet leaders were also characterised in a similar way. Scholars such as Kryshtanovskaya and White claim that former soldiers in high ranking political positions would have an impact on the domestic and foreign policy goals of the state, as characterised through their worldviews. This claim is debatable, but sits within a wealth of scholarship with the dominant view that a militocracy is formed when an overwhelming amount of ex-military personnel take up key positions in the political administration. It must be noted, however, that countries such as America and some of the countries of Latin America have civilian leaders with

${ }^{160}$ Gaddy, The Price of the Past, 1-2. 
little to no experience in the military, and yet these countries are ranked high on the Global Militarisation Index.

The ideological dimension of militarisation is a popular example that accounts for Russia's historical relationship with militarism. Scholars focusing on the ideological dimension will examine the extent to which Russia's educational system was militarised. First, researchers tend to focus on the development of a military-educational complex by focusing on the rise of military training schools. These schools were created in order to prepare the students for military service. An important aspect of this was considered by the Soviet Union. The growth of military education is demonstrated by its increasing presence not only in military academies, but also its place in civilian colleges. In addition to formal military education, the Soviet Union introduced a number of youth organisations that were established to teach students skills. These organisations established military-patriotic narratives, reshaping civic duty as one that the youth would serve to protect their fatherland. This discourse was furthered in educational textbooks, as the curriculum promoted the image of glorified Russian heroes against an evil enemy. Students grew up with narratives of a hostile world, which not only cultivated the wellestablished Russian perception that Russia is within a vicious cycle of threat, but served as a form of legitimisation of a strong military and the need to prepare Russia's youth in case they are called upon to defend the nation. This is a discourse that remains a significant part of Russia's education in the Post-Soviet period. Golts and Putnam claim that the formation of social attitudes by the military institutions under the leadership of the Tsars and Soviets hindered significant military reforms (in particular, those reforms that would lead to the scaling back of Russia's military) in the Post-Soviet period because of an underlying "defence-mindedness," which facilitated the ongoing belief that Russia needed to maintain a strong military sector.

Together, scholars of the militarisation school convincingly argue that Russia has a historical relationship with the military. Underpinning the different aspects of Russian militarism is this constant threat under which Russia sees itself. The physical aspects of militarisation were legitimated by the ideological narratives, which viewed Russia's security as reliant on the military. Militarism found its foundations in Peter I's reign and continued as an underlying ideology of Russian regimes since. ${ }^{161}$ This research forms the basis for the work carried out in this dissertation. Studies within the militarisation school

${ }^{161}$ Paul, "The Military Revolution in Russia," 10. 
offer a thorough assessment of militarisation processes beyond its physical dimensions. The militarisation school also takes into account the cultural dimensions of militarisation with an assessment of the militarisation of societal domains like education and political structures.

\section{DEMILITARISED RUSSIA}

The 1980s brought about a period of significant change for the Soviet Union. In an effort to revitalise the waning Empire, Gorbachev introduced a number of reforms aimed at bringing communism and democracy together. ${ }^{162}$ The two main reforms of the Gorbachev era were Perestroika and Glasnost. Perestroika took aim at the economic and political system of the Soviet Union, while Glasnost, which translates as "openness," targeted the more ideological and societal beliefs of the Communist state as it began to unthread the tightly knitted narratives that underpinned Soviet life. The relaxation of censorship laws under Glasnost proved fatal to the Soviet system. The declassifying of previously classified documents revealed the extent of Stalinist oppression, war-related death and the amount of money being pumped into militaristic endeavours of the state, as the Soviet economy continued to deteriorate. Such revelations delegitimised the system and led to greater efforts, especially by Soviet satellite states, to gain independence from the Empire. The relaxation of censorship laws under the policy of Glasnost led to the rise of new scholarship that not only took aim at the system, but also institutions associated with it - for example, the Armed Forces. ${ }^{163}$ Scholars of the late 1980s and 1990s formed a large part of the demilitarisation school. Unlike scholars of the militarisation school, these researchers offered a revisionist account, questioning the power of the military in contemporary Russia and arguing in some cases that militarism was not as deeply embedded in Russian society as previously thought. Scholars of this school focus largely on the collapse of the Soviet Union, the relationship between democratisation and demilitarisation, on civil-military relations and military culture.

162 C. G. Jacobsen, "Russia's Revolutionary Arbiter?" Arms and Society, 1988-1994, Arms and Society 13, No. 1 (1995): 103; Sakwa, Russian Politics and Society, 3; Jennifer G. Mathers, "The Generals Manoeuvre of the Political Battlefield," World Today 51, No. 12 (1995): 231.

${ }^{163}$ Ibid. 
Scholars largely account for the demise of the Soviet/Russian Army at the hands of democratisation. Greater democratisation, which offered greater transparency between the political factions of society and the people, inevitably increased public discussion around controversial issues. Glasnost opened the government and associated institutions to criticism by attracting attention towards the more negative aspects of military service, including; corruption, dedovshchina and the high rates of suicides among conscripts. In addition, it raised concerns about the large amount of money being pumped into a waning institution when the Soviet economy was faltering. The collapse of the Soviet Union further exacerbated problems within the military. The collapse brought about a sense of unfamiliarity and lack of purpose. No longer were the Armed Forces fighting for the preservation of the Soviet Union or for the victory of Communism. Benjamin S. Lambeth notes that instead, and for some time, members of the new Russian Army needed to protect something that had not yet been fully defined. ${ }^{164}$ The financial issues of the Russian Federation meant soldiers regularly went without pay; loss of morale led to increasing use of drugs and alcohols, and the general loss of discipline led to increasing levels of corruption within the Armed Forces. ${ }^{165}$ The decaying prestige of the military has been accounted for as a result of the process of democratisation.

\section{Democratisation and Demilitarisation}

Scholars who focus most on the relationship between democratisation and demilitarisation within the context of Russia, include researchers such as David Holloway and Steven Fish. Unlike Harold D. Lasswell, who argued that a garrison state can exist alongside a democracy, Holloway argues that demilitarisation became a by-produce of democratisation efforts. ${ }^{166}$ The point of friction between the two scholars centres on the

164 Benjamin S. Lambeth, "Russia's Wounded Military," Foreign Affairs 74, No. 2 (1995): 88.

${ }^{165}$ A. James Melnick, "Beyond the Economy: Internal Factors Affecting the Future of the Russian Military," Naval War College Review 47, No. 3 (1994): 33-34.

William E. Odom, The Collapse of the Soviet Military (New Haven and London: Yale University Press, 2000), 289.

${ }^{166}$ Harold D. Lasswell, "The Garrison State," American Journal of Sociology 46, No. 4 (1941): 467-468. C. J. Jacobsen and Steven M. Fish suggest that demilitarisation occurred alongside the demise of the autocratic principles, which loosened state control over societal institutions. Please see: C.G. Jacobsen, The New World Order's defining Crises, the Clash of Promise and Essence (Dartmouth: Dartmouth Publishing Co. Ltd, 1996), 61; Steven M. Fish, "Reform and Demilitarization in Soviet Society from Brezhnev to Gorbachev," Peace and Change 15, No. 2 (1990): 168. 
issue of who controls the process of militarisation. According to Huntington, the maintenance of militarism in a democratic society is most successful when the views of the ruling elite are similar to those of the military. ${ }^{167}$ John P. Moran suggested, as of 2002, that the world was undergoing a shift in paradigm, where the "military mind accepts the radically different worldviews of military and democratic leaders." He suggested this was the case in Russia. ${ }^{168}$ On the other hand, Holloway makes ample reference to the change in priorities under civilian leadership as the apex of transformation to civil-military relations in the late 1980s.

This is an aspect argued above in the section on the Siloviki, as scholars such as White and Kryshtanovskaya claim that ex-military personnel in civilian roles equates to a more militarised society, since their worldviews will impact on their domestic and foreign policy goals. This claim, however, and the statements of Lasswell and Holloway were contradicted by Bettina Renz, who argued that former soldiers do not share the same experiences and that in some cases, their experiences in the military would not significantly shape their world views - suggesting that such a claim was too simplistic an explanation for the emergence of militarised domestic and foreign policies. ${ }^{169}$ To this end, we should pay more consideration to where else military power lies.

Jennifer G. Mathers, for example, argued that while Gorbachev threatened the material interests of the Armed Forces, the policy of Perestroika actually increased the opportunity for greater participation of the military in domestic politics by relinquishing the controls that previously existed between the Soviet Union's political and military leaders. ${ }^{170}$ As of 1995, a number of high-ranking military figures expressed interest in the Presidency. These figures included Alexander Lebed, Boris Gromov and Alexander Rutskoi. In addition, all of Russia's political parties sought support from the Armed Forces by recruiting prominent ex-military figures onto their electoral campaign. ${ }^{171}$ According to Renz, rising threat to the military's corporate interests, with Boris Yeltsin playing a considerable role in the criticism of the military's leadership, equated to greater

\footnotetext{
${ }^{167}$ Moran, From Garrison State to Nation State, 207.

168 Ibid

${ }^{169}$ Renz, "Putin's Militocracy?" 922.

${ }^{170}$ Mathers, "The Generals manoeuvre on the Political Battlefield," 231.

${ }^{171}$ Ibid, 232-233.
} 
visibility of prominent military figures on the political front. ${ }^{172}$ While civilian leadership and therefore, democracy, has been considered a mechanism of demilitarisation, it is also through the threat to the Armed Forces that former soldiers have used the aspects of Gorbachev's democratisation reforms to further the military cause into the political sphere.

\section{Civil-Military Relations}

Russia did not witness a military intervention in politics following the 1918 revolution. Scholars, most notably Brian D. Taylor, argue that infrequent military interventions demonstrate a weak military power. ${ }^{173}$ Moran maintains there was a lack of military intervention because the relationship with political leaders had already digressed from that of a garrison state to a nation state. ${ }^{174}$ Both investigate the impact of governmental decision-making on the military's corporate interests, including the reconstruction of the Imperial forces into the Red Army, the purges carried out by Stalin and the various reforms introduced under Gorbachev. The literature identifies these points as possible catalysts for military intervention. In 1990s Russia, although the military's corporate interests were under threat, the military remained subservient to the civilian leadership. Scholars argue that the absence of military action at these critical points poses the question as to whether Russia was actually militarised to begin with.

During the 1930s, the Soviet Union changed considerably. From 1937 to 1938, Joseph Stalin launched a number of repressive reforms, which targeted former kulaks and ethnic minorities. These occurred alongside the purging of the Red Army and contributed to the establishment of a period of Great Terror. ${ }^{175}$ Stalin and Red Army leadership called for an extensive purge of the military to root out any conspirators, and arrests quickly spread throughout the officer corps. ${ }^{176}$ The purge affected most of those in higher levels of the Red Army, including 76 of the 85 members of the Military Soviet. ${ }^{177}$ Peter Kenez

\footnotetext{
${ }^{172}$ Bettina Renz, "Media-military relations in Post-Soviet Russia: Who is the watchdog?" in Military and Society in Post-Soviet Russia, ed. by Jennifer G. Mathers and Stephen Webber (Manchester and New York: Manchester University Press, 2006), 69-71.

173 Taylor, Politics and the Russian army, 1-3.

${ }^{174}$ Moran, From Garrison State to Nation State, 18.

175 Peter Whitehood, "The Purge of the Red Army and the Soviet Mass Operations, 19371938," The Slavonic and East European Review 93, No. 2 (2015): 286.

176 Ibid.

177 Taylor, Politics and the Russian army, 154.
} 
refers to the "great purge trial," which saw the elimination of high commanders within the military, as "the most self-destructive event." ${ }^{\text {"178 }}$ During the purge, the military was criticized extensively. "Molotov criticized the army's political organs for their insufficient vigilance both in unmasking enemies in the armed forces and in the Political Administration itself." 179 Taylor emphasises the "extraordinary methods" that Soviet authorities and the secret police (NKVD) used to extract 'confessions.' 180 Those involved in the purge were accused of conspiring to overthrow the Soviet government. These concerns were declared publicly as part of Stalin's process to legitimise the purge. The purges not only threatened the military's image, but they also terrorised its members. Taylor argues that a military coup did not occur because the purges intimidated those within the military, leaving them too afraid to act against Soviet authority. ${ }^{181}$

The desire for the military to remain apolitical and concentrate on outside threats becomes another main point of discussion for Taylor. He claims that during the final years of Imperial Russia, the army's corporate interests were compromised significantly. "From the middle of the nineteenth century until the outbreak of World War I... [there was a] steady decline in military, particularly army, spending." Since the corporate interests of the Armed Forces were constantly under threat, it is surprising that a military coup did not occur until 1917. World War One, which began in 1914, distracted the military from inner state tensions and allowed them to prioritise the task of national defence. From 1945 to 1985, the military played a significant role in events, including Beria's arrest, the rise of the anti-party group, the Zhukov affair and the fall of Khrushchev. While the military resolved many of these events, they did not seek political leadership. In the August coup of 1991, Commander of the 106th airborne troops, Alexander Lebed disobeyed orders to send his troops to storm the White House. He asked General Grachev, “Are we soldiers? Are we executioners? Are we policemen? What are we?" ${ }^{182}$ His questions highlight his frustration with the Russia elite, who considered Russia's Army within a role beyond national security. Lebed's questions are parallel to Taylor's observation that the military did not seek involvement in political situations. The army's

\footnotetext{
${ }^{178}$ Kenez, A History of the Soviet Union from the Beginning to the End, 106.

179 Taylor, Politics and the Russian army, 158.

${ }^{180}$ Ibid, 156.

181 Ibid, 157.

${ }^{182}$ Alex Ivankine and Tom Perlmutter, "A Very Russian Coup (documentary)," Youtube video, 47:26, posted by docukino, 11 April 2014, accessed 18 February 2017, https://www.youtube.com/watch?v=KFkomwe7ZnM.
} 
'subservient' role to the political leaders supports the notion that Russia was not as militarised as previously suggested, as their role contradicts the argument from the Militarisation school that the military had great autonomy.

Reforms, like Glasnost and Perestroika, also compromised the military's corporate interest. "With all these attacks on the military's corporate interests by Russia's 'reformers,' it seemed natural that career military men would feel disenfranchised from the democratic power game and nostalgic for the days of socialism," wrote Moran. ${ }^{183}$ Yet, a military coup did not occur. The lack of support by the military paved the way for the failure of the coup in August 1991. The August Coup of 1991 was an intervention by communist hardliners, including Vladimir Kryuchkov and Dmitri Yazov, who wanted to resurrect Soviet structures. Again, it is surprising that the military failed to act on behalf of the communist hardliners who wanted to restore military prestige. However, C. J. Jacobsen notes that the military did not want to "prop up a now widely discredited ideology and largely delegitimized system." ${ }^{184}$ The public protested against the coup, forming a human shield around the White House. If the military had acted with these hardliners, the prestige of the military might have faltered even further. A documentary written by Alex Ivankine and Tom Perlmutter substantiates this notion that the military became less likely to act alongside the coup after witnessing the massive support for Gorbachev and the democratic reforms by the public. ${ }^{185}$ In addition, it was uncertain that the hardliners would be successful. Taylor supports this, arguing that the military did not intervene for three reasons; they were uncertain if the coup would be successful and did not want to be punished, second the military wanted to remain apolitical; and third, there was the belief that a coup would further divide the armed forces. ${ }^{186}$ While this contradicts the notion that Russia was militarised, because the military played a subservient role to the political leaders, Andrew Bacevich reminds us that the two are not mutually exclusive. A country can remain militarised in instances whereby the military was subservient to the civilian elite. ${ }^{187}$

\section{Starving the Military Industrial Complex}

\footnotetext{
${ }^{183}$ Moran, From Garrison State to Nation State, 2.

184 Jacobsen, "Russia's Revolutionary Arbiter," 112.

${ }^{185}$ Ivankine and Perlmutter, "A Very Russian Coup."

${ }^{186}$ Taylor, Politics and the Russian army, 246.

${ }^{187}$ Bacevich, The New American Militarism, 55.
} 
Glasnost, however, had a greater impact on the decay of the Soviet Russian military apparatus. Glasnost brought previously classified information into the public sphere. The defence budget went public for the first time in 1989. Julian Cooper, for example, wrote, "This was a breakthrough, but the new figure, 77.3 billion roubles, immediately provoked controversy, starting a public debate which contributed towards the fall of the USSR." ${ }^{188}$ Increased public participation, motivated by the realisation over the excessive scale at which the military consumed Soviet resources, contributed towards the process of demilitarisation. An influential group of Soviet civilian commentators openly re-examined national security measures and questioned the necessity of a large force, arguing that it should be reduced. ${ }^{189}$ Consequently, opening government documents to the public influenced the announcement by Gorbachev to cut back on manpower and defence spending within and on the military.

Gorbachev also grappled with the idea of using the defence sector for civilian needs, redefining the aim of the defence industry and implementing the policy of "conversion." 190 Conversion is defined as the "retooling of existing facilities and the retraining of employees for the purpose of producing alternative, civilian products." 191 Gorbachev wanted to divert the mission of the defence industry to serve the public, rather than the military. In 1986, Gorbachev changed the nature of the threat, claiming that the Soviet Union was not surrounded by "invincible armies, but superior economies." 192 Gaddy claims that Gorbachev's plans did not come into fruition until 1989, when he announced at the United Nations a reduction of Soviet Armed Forces by 500,000 and the withdrawal of some Soviet troops from Eastern Europe and Asia. ${ }^{193}$ While Gorbachev made promises to divert defence spending into other areas of Soviet society, by 1996, the Russian economy remained one of the most militarised in the world, with the scale of Russia's defence industry and the vast amount of money it garnered hindering attempts

\footnotetext{
${ }^{188}$ Cooper, "Social-Military Relations in Russia: The Economic Dimension," 136.

${ }^{189}$ William C. Frank and Phillip S. Gillette, Soviet Military Doctrine from Lenin to Gorbachev, 1915-1991 (Westport, Connecticut: Greenwood Publishing Group, 1992), 239.

${ }^{190}$ Gaddy, The Price of the Past, 47-48.

191 Julian Cooper, "Conversion is Dead, Long Live Conversion!" Journal of Peace Research 32, No. 2 (1995): 129.

${ }^{192}$ Gaddy, Price of the Past, 49.

${ }^{193}$ Ibid, 61.
} 
to slow down the military-industrial complex. ${ }^{194}$ To this end, it is not surprising that Yeltsin made similar commitments to Gorbachev.

In an aim to prioritise other aspects of the newly formed Russian State over the military, Yeltsin pledged extensive cuts to the military budgets and the manpower. Scholars of the demilitarisation school, like Herspring, Trenin and Aron, define these budget costs as the "starvation," "neglect," and the "rotting away" of the military. ${ }^{195}$ Aron shows this "starvation," claiming, Russia's military budget dropped dramatically in the formative years of the Russian Federation. Changes to Russia's economy saw an $80 \%$ cut in the budget for defence procurement, whereas the military's share of the Gross Domestic Product dropped from $20 \%$ to $5 \% .{ }^{196}$ There is, however, a lack of agreement over the total figure of reduction to military spending. Although efforts were made. Herspring argues that defence spending increased by five billion dollars in 1994 to 74 billion dollars, but dropped extensively between 1994 and 2000, with a defence budget of 30 billion in $2000 .{ }^{197}$ Similarly, Cooper states that military spending in 1998 was less than a third of that in $1991 .{ }^{198}$ As noted by Markus Heinrich, "most arms industries became antiquated," showing the true impact of budget cuts on the physical conditions of the military. 199

The cut to the defence budget had a severe impact on the physical militarisation of society, as it threatened efforts to modernise weapons. The cuts also left little money for adequate training and for the social welfare of the servicemen. This had a profound effect on the combat readiness of Russia's Army. ${ }^{200}$ These issues were exacerbated by localised conflicts in neighbouring and domestic regions of the Russian Federation. From 1992 to 2000, there was a lack of training. Herspring notes, even in 2003 pilots only

\footnotetext{
${ }^{194}$ Sakwa, Russia Politics and Society, 304.

${ }^{195}$ Herspring, "Dedovshchina in the Russian Army," 609-610; Herspring, "Undermining Combat Readiness in the Russian Army," 515-516; Dmitri Trenin, "The Revival of the Russian Military," Foreign Affairs, (2016): 23-24; Aron, Russia's New Foreign Policy. 196 Aron, "Russia's New Foreign Policy," 2.

${ }^{197}$ Herspring, "Dedovshchina in the Russian Army," 617.

${ }_{198}$ Cooper, "Society-Military relations in Russia: the economic dimension," 132.

${ }^{199}$ Markus Heinrich, "New Century, Old Rivalries: Russian Military Modernisation and NATO," E-International Relations, (2016), accessed 13 December 2019, https://www.eir.info/2016/06/25/new-century-old-rivalries-russian-military-modernisation-and-natoresponses/.

${ }^{200}$ Alexander Golts, Military Reform and Militarism in Russia (Washington D.C.: The Jamestown Foundation, 2018), 6.
} 
received 6-8 hours of training per year. ${ }^{201}$ Interestingly, Golts claims that such degradation of the Russian Military continued into the Putin era when the military budget was rising by $20 \%$ per year. He claimed, "Obviously, the problem was not only, and perhaps not at all, caused by a shortage of funds." 202

\section{Manning the Army}

Glasnost, as highlighted across a number of chapters in this thesis, also played a considerable role in the decaying prestige of the Soviet/Russian Armed Forces. Viktor Baranets, a prominent Russian military correspondent, stated that until 1991 the military was a "sacred cow" and that criticism of the military was not allowed unless given permission by the CPSU. ${ }^{203}$ Glasnost loosened censorship on the media and other discursive landscapes of the Soviet state, which led to an increasing amount of negative portrayals of the Soviet military in the political landscape. An excerpt in the army newspaper Krasnaia Zvezda stated, "Today for a lot of Russian "liberal" newspapers, any attack on the army is a god send." ${ }^{204}$ Furthermore Odom notes, the poor conditions for conscripts in the military were an open secret, but glasnost shed a light on the increasing hardships faced by new conscripts, especially the initiation ritual of Dedovshchina. ${ }^{205}$

Dedovshchina (also known as Grandfather-rule) is the process by which a young conscript is bullied/hazed by older ranks of the military. ${ }^{206}$ The duration of conscription was split into four six-month terms. A soldier in the first six months of his conscription period was known as "spirit" [dukh] or "young" [molodoi]. Anton Oleynik notes the use of spirit as purposeful in representing the rights of soldiers at the start of their military service - which were non-existent. An initiation allowed the soldier to move onto the next phase of his conscription journey, where he was referred to as a "pheasant" [Fazan].

\footnotetext{
${ }^{201}$ Herspring, "Vladimir Putin and Military Reform in Russia," 140.

${ }^{202}$ Golts, Military Reform and Militarism in Russia, 5.

${ }^{203}$ Renz, "Military-media relations in post-Soviet Russia," 63.

${ }^{204}$ Renz, "Military-media relations in post-Soviet Russia," 66.

Douglas J. Brown noted that Ogoniok, Moskovskii Komsolets and Komsomol'skaia Pravda were also criticised by conservative military publications, such as, Krasnaia Zvezda and Krasnyi Voin for making "dirty anti-army fabrications." Please see: Douglas J. Brown, "Dedovshchina: Caste Tyranny in the Soviet Armed Forces," The Journal of Soviet Military Studies 5, No. 1 (1992): 56.

205 Odom, The Collapse of the Soviet Military, 288; Brown, "Dedovshchina," 53; Herspring, "Dedovshchina in the Russian Army," 615.

206 The level of severity depended on the ded, carrying out the orders.
} 
During the third six-month term of the conscript's journey, they are referred to as a "salabon" or "scoop" [cherpak]. This was the first stage the conscript is able to instruct their younger colleagues. In the final six-month term, the conscript was given the status of "old" [starik] or "grandfather" [ded]. ${ }^{207}$ The molodoi was forced to do the ded's menial tasks, like laundry or cleaning his boots, and instructed to perform the more difficult tasks. ${ }^{208}$ In some cases, the younger soldiers were subject to sexual assault and beatings, which at times, left the conscript severely disabled and even dead. Suicide, as a result of this process, was common. ${ }^{209}$ Dedovshchina was one of the main issues that led to a decrease in the number of conscripts serving in the military. ${ }^{210}$ Maya Eichler confirms this, quoting Vadim, a Chechen conscript, who claimed:

I was afraid not just of the army, as much as of the fact that you have to suffer there. I was afraid of Dedovshchina [hazing] and hunger - there was no guarantee that I would return healthy and alive. ${ }^{211}$

The quote highlights problems within the Russian military that influenced increasing pushback against obligatory military service. The issue of conscription and draft evasion emerged as a topic of interest in Russia in recent years, blaming futile conflicts in Afghanistan, poor living conditions and Dedovshchina within the armed forces as contributing factors towards the decisions to evade the draft. ${ }^{212}$ Eichler, in Militarizing Men, interviewed draft-evaders and the organisations helping them do so. She examines the Committee of Soldiers' Mothers (CSM) organisation in Samara, citing

207 Anton Oleynik, "Dedovshchina as an Element of the "Small Society": Evidence from Russia and Other Countries," The Journal of Power Institutions in Post-Soviet Societies, No. 1 (2004), 22.

208 Brown, "Dedovshchina," 57.

${ }^{209}$ Odom, The Collapse of the Soviet Military, 287-288.

${ }^{210}$ In 2003 Theodore P. Gerber and Sarah E. Mendelson asked participants of nine focus groups conducted in three regions of Russia in the Summer of 2002 three questions in relation to draft dodging. They found that one reason that motivated widespread sympathy of young conscripts was based on Dedovshchina. $77 \%$ of participants answered 'definitely yes' to the question, "Should Officers who Tolerate Dedovshchina in their Ranks be Prosecuted?" For more, please see: Theodore P. Gerber and Sarah E. Mendelson, "Strong Public Support for Military Reform in Russia," PONARS Public Memo 288, (2003): 2-6; Herspring, "Undermining Combat Readiness in the Russian Army," 517; Herspring, Dedovshchina in the Russian Army, 619; Danks, Russian Politics and Society, 176; Golts, Military Reform and Militarism in Russia, 5-6.

${ }^{211}$ Eichler, Militarizing Men, 63.

${ }^{212}$ Markus Rachbauer, The Soldiers' Mothers of Russia, (Munich: GRIN Verlag, 2008), 4 
possible western influence over the organisations in St. Petersburg and Moscow. She claims that the organisation in Samara "shied away" from publicly opposing conflict but defended the rights of soldiers and draftees, whereas the organisations in Moscow and St. Petersburg publicly opposed war and lobbied "for the abolition of conscription."213 The organisation also worked to abolish Dedovshchina and lobbied for the right to undertake an alternative service, and for draft exemptions for students in higher education. ${ }^{214}$ Julie Fedor notes that the committee aimed to achieve its goals through exposing and drawing public attention to the uncomfortable issue of systemic violence within military culture. ${ }^{215}$ Valeria Zawilski agrees, claiming they would hold demonstrations and press conferences where the participation of mothers who lost sons during peacetime would play a significant role in highlighting a problem downplayed by the military. ${ }^{216}$ The documenting of these issues led to a string of protests, including the conscription revolts of 1989 and 1990 and the assignment of conscripts to suppress nationalist uprisings in the Soviet satellite states. ${ }^{217}$

The CSM movement picked up momentum during the First Chechen War, as mothers followed their sons to battle to beg for their release from the Russian military or to take them "from captivity." ${ }^{218}$ They also staged hunger strikes, worked with local authorities to organise prisoner of war swaps with the Chechen military authorities and

${ }^{213}$ Eichler, Militarizing Men, 13.

${ }^{214}$ Valeria Zawilski, 'Saving Russia's Sons: The Soldiers' Mothers and the RussianChechen Wars," in Military and Society in Post-Soviet Russia, ed. by Stephen Webber and Jennifer G. Mathers (Manchester and New York: Manchester University Press, 2005), 228; Brenda Vallance, "The Rule of Law and Russian Military Reform: The Role of Soldiers' Mothers in Russian Society," The Carl Beck Papers in Russian and East European Studies, No. 1407 (2000): 10.

215 Julie Fedor, "Dedovschina and the Committee of Soldiers' Mothers under Gorbachev," The Journal of Power Institutions in Post-Soviet Societies, No. 1 (2004): 25.

${ }^{216}$ Zawilski, "Saving Russia's Sons," 5-6; Lisa McIntosh Sunstrom, "Soldiers' Rights Groups in Russia: Civil Society Through Russia and Western Eyes," in Russian Civil Society: A Critical Assessment, ed. by Alfred B. Evans, Laura A. Henry, Lisa McIntosh Sunstrom (New York and London: M. E. Sharpe, 2006), 181.

${ }^{217}$ Andrew L. Spivak and William Alex Pridemore, "Conscription and Reform in the Russian Army," Problems of Post-Communism 51, No. 6 (2004): 16-17.

${ }^{218}$ Anna Colin Lebedev, 'From a mother's worry to Soldiers' Mothers' action: building collective action on personal concerns," in Understanding Russianness, ed. by Risto Alapuro, Arto Mustajoki and Pekka Pesonen (London: Routledge, 2011), 85; Amy Caiazza, Mothers and Soldiers: Gender, Conscription, and Civil Society in Contemporary Russia, (New York and London: Routledge, 2002), 140; Sundstrom, "Russian Civil Society," 181- 182. 
raised criminal cases against the army and officers who headed units where there were deaths of military personnel. ${ }^{219}$ Brenda Vallance claims that for their efforts, the CSM won the Sean MacBride Peace Prize in 1995 and was nominated for the 1996 Nobel Peace Prize. ${ }^{220}$ In Russian society, the CSM played a salient role in the changing perceptions of the military in society. First, it motivated public interest in the military, towards military reform and the war in Chechnya. Second, it made an important contribution toward the increasing number of draft evasions, by highlighting the poor and violent conditions of military culture. ${ }^{221}$

Glasnost played a particular role in the decay of Russia's military prestige, by publicising the issue of Dedovshchina within the military. Dedovshchina and poor living conditions had long plagued the military, from the Tsarist Army and throughout the Soviet period. ${ }^{222}$ Glasnost simply lifted the veil on these atrocities. The reality of Dedovshchina had an impact on the amount of conscripts evading the draft. This was to remain a feature of the Putin era, with conscripts either leaving home during the draft schedule (spring and fall), or by paying doctors to fake an illness. ${ }^{223}$ The CSM acted on the part of the soldiers, calling for better conditions within the military, for the end of obligatory military service, and for alternative service. The negative impact of Dedovshchina is best documented through figures in which $28 \%$ of officers committed suicide in 1996 alone, and 5,603 recruits evading the draft between 1998 and 1999.224 This issue highlighted a downfall of military prestige from as early as the mid-1980s, and remains a topic of concern under the leadership of Vladimir Putin.

To conclude, the above literature presented a revisionist viewpoint to that of the militarisation school. It acknowledges that the military had some control, especially under autocratic regimes. However, by emphasising the journey whereby Glasnost and Perestroika aided the process of democratization, which consequently revealed the poor living conditions and the existence of dedovshchina within the ranks, the scholars suggest that militarism in Russia was not as prevalent in daily life as suggested previously. The

\footnotetext{
${ }^{219}$ Vallance, "The Rule of Law and Russian Military Reform," 9.

${ }^{220}$ Ibid

${ }^{221}$ Caiazza, Mothers and Soldiers, 139-140.

${ }^{222}$ Rodric Braithwaite, "Dedovshchina: Bullying in the Russian Army."

${ }^{223}$ Jason P. Greash, "The Realities of Russian Military Conscription," Journal of Slavic Military Studies, 24:2 (2011): 197.

${ }^{224}$ Danks, Russian Politics and Society, 176.

Herspring, "Dedovshchina in the Russian Army," 619.
} 
lack of military interventions, highlighted by Taylor and Jacobsen, suggests the military's subservient position in society. However, acknowledging that the military made its own decision to remain apolitical during the August 1991 crisis contradicts claims made by Taylor. In choosing to remain apolitical, the military acted autonomously. Furthermore, Bacevich outlines many instances in America where the army felt distanced from society. However he maintains that America is militarised by highlighting the amount of funding and resources dedicated to the military establishment. ${ }^{225}$ Eichler, convincingly, emphasises the downfall of military prestige by highlighting the lack of desire family members had for their offspring or younger relatives to participate in the military sector. $^{226}$

The militarisation school demonstrates the longstanding development of militarism in Russia. Focusing on the physical, educational, administrative and societal dimensions of militarisation, the literature highlights a clear trajectory of militarisation. This aim is most noticeable in the Russian and Soviet leaders' dedication of excessive manpower, materials and funding for military purposes, at the cost of the civilian sector. Russian militarism is therefore most commonly characterised by the state's prioritisation of the military over other factions of society. Driven by over glorified, pro-militaristic narratives, unequal bureaucratic structures and a consistently high percentage of the federal budget, the military institution sat at the apex of an informal societal hierarchy. This prioritisation, as noted by scholars like Kryshtanovskaya and White, for example, is driven, in some cases, by the militarised upbringing of the country's rulers. In other cases, this commitment to the military institution was also motivated by the country's deeply rooted issues of insecurity and paranoia, fuelled by its extensive history of invasions.

The militarisation school shows that Russian militarism is incredibly resilient because it is grounded in myths and values that resonate within society. The maintenance of Russia's siege mentality, for example, has enabled the militarisation of the Russian state to persist beyond the breakdown of regimes because it has been able to re-emerge under different leaders. Yet despite the persistence of these discourses in 1990s Russia,

${ }^{225}$ Bacevich, The New American Militarism, 55.
${ }^{226}$ Eichler, Militarizing Men, 2. 
the Yeltsin period is largely absent from discussions in the militarisation school. Instead, the Yeltsin era features heavily in the literature of scholars of the demilitarisation school.

Scholars of the demilitarisation school typically argue that Russia demilitarised in the immediate Post-Soviet period. Topics of interest include the physical decay of Russia through manning and budget cuts, the neglect of the civilian leadership to bring about real military reform, the emergence of a corrupt military culture within the barracks and the relationship between democratisation and demilitarisation. Despite excessive budget cuts, the military still received a large percentage of the federal budget. In addition, while democratisation reforms like Glasnost lifted the veil of secrecy on issues such as military budget costs and Dedovschina, the reforms also removed barriers that hindered the military's role in politics. Increasing discontent of military figures caused by the downgrading and 'neglect' of Russia's military proved a motivating factor for their increased visibility in politics as a number of ex-and-current members of the military ended up campaigning in the 1996 Presidential election.

Scholars of the militarisation school essentially ignore the Yeltsin period, documenting militarisation in Russia from Peter I until the Gorbachev era and then remerging to discuss Putin's role in the militarisation of contemporary Russian society. While the Yeltsin era is more widely publicised under the demilitarisation school, it should be noted that a majority of these studies focus on subjects, institutions and events closely linked to the military, with an emphasis on the physical aspects of militarisation. This raises two interesting questions. First, can a country with a deep historical relationship with the military demilitarise in ten years? And second, could Putin remilitarise so quickly without solid foundations in place? The Yeltsin period, of course, while politically and economically chaotic, was also home to a number of small neighbouring conflicts and two conflicts with Chechnya and faced a perceived threat from NATO expansionism. In addition, and more interestingly, some of the 'demilitarising' methods proved to strengthen the cause of the military in society, with discontent in the decay of the state's handling of military affairs motivating the increasing role and visibility of the military in the political sphere. This thesis proposes a number of different mechanisms of militarisation that demonstrate the continued cultural militarisation of a society in lieu of its physical presence.

By examining prominent discourses across the media, in Russian historical school textbooks, in the political discourses of the state and in commemorative activities, it is 
clear that the militarisation of Russian society persisted culturally. This was achieved through the continued popularisation of two discourses that underpin Russian identity Russia as a besieged fortress and Russian citizens' moral obligation to sacrifice themselves to the state. These discourses had their roots in the $18^{\text {th }}$ century and are values that have made Russian militarism so resilient to regime change. To answer the first question, Russian militarism was so embedded in society, not only physically but ideologically, that while the physical aspects of the military were in decay, the militarisation of society continued culturally. In fact, some of the discourses and rituals established in the Yeltsin period formed the foundations of increased militarisation under Putin. Therefore, in answer to the second question, without the cultural militarisation of the Yeltsin period, Putin would not have been able to militarise contemporary Russian society so easily. Through the examination of militarised discourses in the societal domains of Russia, this thesis will argue that the collapse of the Soviet Union did not constitute a break in the militarisation of society. Rather, the militarisation of society continued culturally as values and discourses of Russia as a besieged fortress and notions of sacrifice and state loyalty persisted in everyday life. 


\section{CHAPTER 2}

\section{"RUSSIA IN A RING OF ENEMIES": MILITARISATION THROUGH THE}

\section{MEDIA}

During the 1980s and 1990s, Russia's media transformed. Glasnost, Gorbachev's democratisation reforms, changed the way the media operated. The press had more freedom in their reporting and state documents showcasing the true extent of Stalinist terror, war fatality numbers and the amount of the state budget dedicated for war purposes were declassified. Inevitably, criticism of the government and other state institutions grew. Yet, while rising negative press coverage suggests increasing demilitarisation, the persisting militarised discourses in the media meant the public remained exposed and open to what Cynthia Enloe calls the militarised worldview. ${ }^{1}$ In addition, those critical of the military and war did very little to challenge the status quo. In fact, they strengthened notions that Russia remained vulnerable to internal and external threats by keeping these issues in public view. ${ }^{2}$ To this end, the 1990s Russian media preserved the militarisation of society in two ways: first, through the prominence of militarised narratives; and second, by adopting key militaristic discourses.

This chapter analysed articles from eight newspapers located at the Russian State Library (RSL). It argues that the media sustained the militarisation of society in 1990s Russia. ${ }^{3}$ The research found that newspapers critical of the military did not deviate too

\footnotetext{
${ }^{1}$ Cynthia Enloe claims, "A less militarised military would be one less imbued with an institutional culture of masculinised violence. It would be a military less committed to a hierarchical, threat-filled worldview; having an enemy wouldn't be so central to the military's raison d'etre." Since the "threat-filled worldview" was salient in the media and more generally in Yeltsin's Russia, it supports the view that culturally, Russia was militarised. For more on this, please see: Enloe, Globalisation and Militarism, 79.

${ }^{2}$ As will be demonstrated more widely across this chapter, newspapers were not necessarily pro-war, but spoke about growing threats to Russia in terms of NATO's eastward expansion and threat of terrorist attack from Islamic regions of the Russian Federation.

${ }^{3}$ In depth details of the newspapers analysed in this chapter are included in the Introduction to the thesis. The articles for this chapter were chosen randomly, and were searched for by year. As the prominence of one event became noticeable, a narrower search was used to gather more information. As the catalogue at the RSL did not indicate
} 
far from dominant state discourses, and that even when critical these newspapers still adopted warmongering language. The prominence of the military in the media, despite positive or critical reception, was most important in developing the militarisation of society. Militarised discourses dominated the media landscape and offered the Russian readership little to no escape from the topic of war. To this end, Russia's media in the 1990s was a 'tool of warfare', bringing military action from far-flung regions to the forefront of public consciousness. ${ }^{4}$ A March 1999 article in Argumenty i Fakty, a general weekly newspaper, on the topic of the Yugoslav War (1991-2001) claimed, "Contrary to the impression of television reports, the capital of Yugoslavia lives a normal life." 5 The author noted, "The true horror of the bombing and missile strikes is known to the residents of Pristina and other settlements of Kosovo, where after NATO air raids, residential neighbourhoods blaze and people die. Ordinary citizens of Belgrade practically do not notice it. Well - so it was with us. The Chechen War claimed the lives of boy soldiers, but did it greatly affect the life of a calm and well-fed Moscow?" The reports showed that the media brought the war to the forefront of Yugoslav public consciousness, as was the case with the Chechen war. ${ }^{6}$

This chapter argues that democratisation actually furthered the militarisation of the media, with the economic fallout of the early post-Soviet period forcing the press to prioritise contentious topics and seek governmental financial support. In addition, increased criticism of the state pushed the government to regain control of narratives in the media. To this end, militarism became a side note of the media, as it struggled to deal with the freedoms and constraints of democratisation efforts.

\section{Critical Discourse Analysis and the Media}

whether an article was on the front page, an editorial or letter to the editor (apart from with Argumenty i Fakty), the articles used in this chapter are varied. To interpret them, I used the theories of Cynthia Enloe, which suggested that the militarisation lives outside the military. These newspapers were circulated outside the military. When examining these articles, I examined dominant discourses across the newspapers collected in a random sample. These samples were collected randomly by year.

${ }^{4}$ Andrew Hoskins and Ben O'Loughlin, War and Media; The Emergence of a Diffused War (Cambridge: Polity Press, 2010), 6-8.

${ }^{5}$ Boris Muradov and Igor Popov, "Yugoslavskie Strasti," Argumenty i Fakty, 30 March 1999, No. 13. At this time, the capital of Yugoslavia was Belgrade, but the NATO airstrikes were taking place in Pristina, the now capital of Kosovo.

${ }^{6}$ Ibid. 
The study of Critical Discourse Analysis (CDA) in relation to the mass media is vast. Defined as a 'multi-disiplinary approach,' CDA adds value to the analysis of this chapter in its ability not only to consider the text and discourse, but also to place it within wider social and cultural contexts. ${ }^{7}$ As agreed among scholars of CDA, this form of analysis links the use of text to the popularisation and domination of certain power structures within society, as a result of unique social, political, economic and historical contexts. ${ }^{8}$ The media, as noted by Aaminah Hassan, has a 'signifying power,' which allows the press to build media frames that manipulate the audience, legitimate dominant powers and promote the interests of a certain social group/class. ${ }^{9}$ In this case, stories in the media are representations of an interpretation of reality, rather than as windows to reality. ${ }^{10} \mathrm{CDA}$, as noted by Deti Anitasari, simply 'tries to illuminate ways in which dominant forces in society construct versions of reality that favour their interests. ${ }^{11}$ Referring to Van Dijk's ideological square, Ramanatham highlights the ability of CDA to account for the ideological nature of the media. ${ }^{12}$ This is a particular issue in this chapter, as tactics of othering played a salient role in how events of the 1990s Russia were discussed in the news.

'Othering' is a key militarising tactic, as it sets to unify one country/societal group against another. In this chapter, the newspapers report on an aggressive NATO, terrorist Chechens and the rise of Islamic fundamentalism to highlight internal and external threats to Russia and legitimise Russian military intervention in neighbouring regions. They add

\footnotetext{
${ }^{7}$ Renugah Ramanatham and Tan Bee Hoon, "Application of Critical Discourse Analysis in Media Discourse Studies," The Southeast Journal of English Language Studies 21, No. 2 (2015): 57-58.

8 Ramanatham and Hoon, "Application of Critical Discourse Analysis in Media Discourse Studies," 57-58; Pelegri Sancho Cremades, "An overview of Critical Discourse Analysis Approaches to Mass Communication," in Critical Discourse Analysis of Media Texts, ed. by Pelegri Sancho Cremades, Jose Maria Bernardo Paniagua, Guillermo Lopez Garcia and Enric Serra Alegre (Valencia: Los Autores, 2007), 17.

9 Aaminah Hassan, "Language, Media and Ideology: Critical Discourse Analysis of Pakistani News Bulletin Headlines and its impact on viewers," Humanities: SAGE Open 8, No. 3 (2018): 1-3.

${ }^{10}$ Cremades, "An overview of Critical Discourse Analysis Approaches to Mass Communication," in Critical Discourse in Media Texts, by Cremades et. al, 24.

${ }^{11}$ Deti Anitasari, "Critical Discourse Analysis: Mass Media," INA-Rxiv, 1-9 (January 2018) < doi: 10.31227/osf.io/a23y6> [Accessed 20 November 2020].

12 Ramanatham and Hoon, "Application of Critical Discourse Analysis in Media Discourse Studies," 59-60.
} 
to and reaffirm the larger societal discourse that Russia is a vulnerable country surrounded by hostile neighbours.

\section{DEMOCRACY, THE RUSSIAN MEDIA AND THE MILITARY}

In 1917, Vladimir Lenin claimed that, "Words are more dangerous than bombs and bullets," owing to the powerful role of the media in the dissemination of messages. ${ }^{13}$ He considered the press a vital "ideological weapon" available to the workers in their fight against Tsarism. ${ }^{14}$ As a result, the Communist Party adopted censorship. In 1985, Mikhail Gorbachev introduced the policy of Glasnost, which completely changed the role of the media. ${ }^{15}$ The media was to function as a fourth estate, facilitating a relationship between the state and society, to praise, criticise, and at times, educate. ${ }^{16}$ Whereas the purpose of the Soviet press was to educate the masses about the Soviet ideology, the new press of the post-Glasnost era was expected to raise issues of the state, advocate on behalf of the public and serve popular interests. ${ }^{17}$ As Gorbachev's democratisation reforms were introduced, the Soviet Union was still involved in the Soviet-Afghanistan War. Journalists reported on Soviet military incompetency, criticising the heavy use of state funds on the conflict when the domestic economic situation was dire. ${ }^{18}$ It was during this

\footnotetext{
${ }^{13}$ Brian McNair, "Reforming and Restructuring in the Soviet media: Before and after the August 1991 coup," in Getting the Message: News, Truth and Power, ed. by John Eldridge (Oxford: Taylor and Francis, 2003), 66.

${ }^{14}$ McNair, "Reforming and Restructuring in the Soviet Media," 55-66.

${ }^{15}$ Ivan Ivanovich Zassoursky, Media and Power in Post-Soviet Russia (Oxon: Routledge, 2016), 3-4; Camille Jackson, "Legislation as an indicator of Free Press in Russia; Patterns of Change from Yeltsin to Putin," Problems of Post-Communism, 63, No. 5-6 (2016): 12; Olessia Koltsova, News Media and Power in Russia (Oxon: Routledge, 2006), 29-30.

${ }^{16}$ Bettina Renz, "Media-military relations in Post-Soviet Russia," 64; Tina Burrett, "The end of independent television? Elite Conflict and the reconstruction of the Russian television landscape," in The Post-Soviet Russian Media: Conflicting Signals, ed. by Birgit Beumers, Stephen Hutching and Natalia Rulyova (Oxon: Routledge, 2009), 76; Jonathan Hassid, "Four Models of the Fourth Estate: A Typology of Contemporary Chinese Journalists," The China Quarterly 208, (2011): 820.

The term 'fourth estate' was created as a mediator of the other three branches of society, or as commonly known, the Estates of the realm (government, clergy and the people). For more, please see: Lucas A. Powe, The Fourth Estate and the Constitution: Freedom of the Press in America (Berkley: University of California Press, 1991), 260-261.

${ }^{17}$ Renz, "Media-military relations in Post-Soviet Russia," 64.

${ }^{18}$ Koltsova, News Media and Power in Russia, 29.
} 
time that the prestige of the military institution became under threat. The military's repressive role in the immediate Post-Soviet period did not help its cause.

During the Soviet collapse, the military worked in a policing capacity to suppress popular uprisings in the non-Russian Soviet republics. The press challenged the military's role. In February 1991 Georgii Rozhanov of Ogoniok, (a magazine owned by Boris Berezovsky, a close friend of Boris Yeltsin) asked why the military was suppressing disorder. He suggested that the military's role in Baku and Riga was ironic since it aimed to "establish public order and protect citizens through automatic bursts and sapper blades." ${ }^{\prime 19}$ He did, however, acknowledge the decision to apply a military solution as a call by the political elite and not the fault of the military itself. ${ }^{20}$

The declassification of state documents also ignited fierce debate within the media about the military and the USSR. Having discovered the extent of corruption and horror embedded within the Soviet system, the press began to revise Soviet history, for example, the Great Patriotic War. Veterans were targets of this criticism, marginalised for their supposed role in the empowerment of the oppressive system. ${ }^{21}$ These revisionist accounts affected the prestige of the Armed Forces in society. However, while media discourses largely criticised the media, increasing attention paid to the military kept the topic of the Armed Forces in public consciousness.

In response, the Ministry of Defence sought to curb criticism by integrating military journalists into the civilian press, hindering the media's role as a 'watch dog. ${ }^{22}$

\footnotetext{
${ }^{19}$ Georgii Rozhnov, "Voiska na Ulitsakh,” Ogoniok, February 1991, No. 7.

${ }^{20}$ Ibid.
}

${ }^{21}$ Anna Krylova, "Dancing on the Graves of the Dead: Building a World War Two Memorial in Post-Soviet Russia," in Memory and the impact of political transformations in public space, ed. by Daniel J. Walkowitz and Lisa Maya Knauer (North Carolina: Duke University Press, 2005), 87.

${ }^{22}$ Renz focuses on the discussion of dedovshchina in the media, and the reactions of such discussion by military and civilian leadership. She claims that media, which represented the official line of the government and military institutions (Krasnaia Zvezda and Rossiiskaia gazeta) did contain information about dedovshchina, including criticism of the mainstream media's discussion of the topic. They, alongside military commentators criticised the mainstream media's 'biased and destructive' approach to the issue, and for not offering solutions to the problem. Thus, military commentators undermined the efforts of the media to act out the role of a 'watch dog' by emphasising the bias and narrowness of the media's story. Efforts to undermine the media went beyond military commentary. As noted by Jackson, Yeltsin signed a Federal Law in 1995 On Rules for Coverage by State Mass Media of the activity of Bodies of State Power, which obliged the media to include interviews and speeches in their entirety, claiming that the use of snippets from previous meetings [in relation to the Chechen war], portrayed the Chechen 
The government was willing to sacrifice the media's freedom to ensure their policies were protected from public scrutiny. In this sense, Yeltsin's media policy was contradictory and inconsistent. ${ }^{23}$ Maria Lipman related this inconsistency to a tradition of Russian leaders undertaking westernising reforms, usually in the military and technological sphere, only to follow with an array of conservative, anti-western ones. ${ }^{24}$ Here Lipman links the changes in media policy to the 'confusion and turmoil within Russia' that were sparked by the reforms of the 1990s, with a number of economic issues threatening the liberty of the media. ${ }^{25}$

Within the first term of his Presidency, Yeltsin introduced a number of radical economic reforms. Although successful in other Post-Communist countries, the results were vastly different for Russia. These reforms ultimately led to the return of a cosy relationship between the state and media. On 2 January 1992, the state introduced 'price liberalisation,' privatisation and eliminated state subsidies. ${ }^{26}$ Many media outlets either collapsed or moved to weekly publications. In 1994 Yeltsin signed a presidential decree renewing financial benefits for state broadcasting but not for private broadcasters. ${ }^{27}$ The media brought issues of independence to meetings on state financial help. They

counterpart in a positive light, when the full meeting shows that the Russian government also made a positive contribution.

For more, please see: Renz, "Media-military relations in Post-Soviet Russia," 63-66; Jackson, "Legislation as an Indicator of Free Press in Russia," 5-6; Elisabeth SiecaKozlowski, "From Controlling Military Information to Controlling Society: Political Interests Involved in the Transformation of the Military Media Under Putin," Small Wars and Insurgencies 20, No. 2 (2009): 302.

${ }^{23}$ Ibid, 4.

${ }^{24}$ Maria Lipman, "Media Manipulation and Political Control in Russia: Russia and Eurasia Programme: REP PP 09/01," Chatham House, (2009), accessed 7 February 2020, https://www.chathamhouse.org/sites/default/files/public/Research/Russia\%20and\%20E urasia/300109lipman.pdf, 3-4.

${ }^{25}$ Lipman, "Media Manipulation and Political Control in Russia," 3-4.

Elena Vartanova explains that the media system of Russia was influenced largely by the transition of Soviet society into the Post-socialist era. The highs and lows of the transition ran alongside and were intertwined with the complicated introduction of democratisation and market reforms. For more, please see: Elena Vartanova, "The Russian Media Model in the Context of Post-Soviet Dynamics," in Comparing Media Systems Beyond the Western World, ed. by Daniel C. Hallin and Paolo Mancini (Cambridge: Cambridge University Press, 2011), https://doi.org/10.1017/CBO9781139005098, 122.

${ }^{26}$ Robert Service, The Penguin History of Modern Russia: From Tsarism to the TwentyFirst Century, 4th edition (London: Penguin, 2015), 511-512.

${ }^{27}$ Zassoursky, Media and Power in Post-Soviet Russia, 17-18.

Jackson, "Legislation as an Indicator of Free Press in Russia," 5. 
understood that they needed to give up their material independence but "[did] not want to lose their moral independence." 28 The government could not easily accept that they would be criticised by an outlet they were funding. Through financial help, Yeltsin began to retake control of the media. ${ }^{29}$ The economic crisis jeopardised the freedom of the press in other ways. First, it forced media outlets to find other sources of funding. As a result, several oligarchs took ownership of some of failing newspapers.

The economic crisis in Russia not only pushed the media to seek governmental financial support, but also to rely on topics they believed would interest readership. As noted by Paul McCann, journalist of The Independent, "War sells serious newspapers." 30 Josh Blackburn, when reporting on support from America's war in Iraq, states, "CNN online offers its hungry public an opportunity to fly their favourite missiles and aircrafts... You never knew that war could be this fun." 31 The media's ability to entertain was vital in shaping public opinion. As noted by Mehmet Evren Eken, the public should be "re-enchanted by war," with Archibald MacLeish arguing that the main battleground took place in the minds of people. Stahl similarly declared, once the media captured the people's minds and hearts that "souls would follow." 32 This re-enchantment would not only act as a tool of militarisation, but would draw in an audience, previously discouraged by expensive subscription costs. Blackburn ties together the sensationalist dimensions of war reporting and the economic aspect of the topic by arguing that it not only satisfied national strategy but also aided the economic growth of media outlets. ${ }^{33}$ In choosing to discuss, and sensationalise, war-related topics over other issues, the media purposely emphasised, erased and cherry-picked elements of different events and stories. ${ }^{34}$

${ }^{28}$ Zassoursky, Media and Power in Post-Soviet Russia, 17-18.

${ }^{29}$ Ibid.

${ }^{30}$ Paul McCann, "War Sells Serious Newspapers," The Independent, 20 April 1999, accessed 20 January 2017, https://www.independent.co.uk/arts-entertainment/war-sellsserious-newspapers-1088456.html.

${ }^{31}$ Joshua Blackburn, "War Sells,” Provokateur, March 2003, accessed 20 January 2017, www.provokateur.com/war-sells-1.

32 Roger Stahl, Militainment, Inc" War, Media and Popular Culture (New York: Routledge, 2010), 10; Mehmet Evren Eken, "The Unscene effects of on-demand access to war," in Understanding Popular Culture and world politics in the digital age, ed. by Laura J Shepherd and Caitlin Hamilton, (United States: Taylor and Francis, 2016), 140; Amil Kamar Singh, Military and Media (New Delhi, Lancer Publishers, 2006), 58.

${ }^{33}$ Ibid.

${ }^{34}$ In scholarship, this is referred to as framing theory. Derived from the work of Erving Goffman, who examines frameworks attached to interpretation of everyday events, framing theory relates to scholarship on media, which focuses on agenda setting and 
The government took control over the press to hinder its criticism of the government's military goals. This was clearly seen by the infiltration of the civilian press by military journalists. In another sense, the economic issues presented the government with an opportunity where they could take control over the media in a subtle way. In addition, journalists relied on the military to increase and attract readership, in an aim to overcome the financial issues of the post-Soviet period. They brought wars in far-flung areas to the forefront of society, when in fact these wars had very little impacton their lives, continued to show existing internal and external threats, which reaffirmed the discourse that Russia was a vulnerable country surrounded by hostile neighbours.

\section{Can we consider the Post-Soviet press as truly democratic?}

David Wedgwood Benn notes, "it may fairly be said that the Russian media in the 1990s have been more diverse, more outspoken and more influential than at any other previous time in the country's history." 35 Writing in 1996, Benn's article outlined the early threat 1990s new Russian media, concluding that its fight for freedom had not yet been won or lost. He considered the parlimentary crisis of 1993 a threat to journalistic freedom. ${ }^{36}$ Pravda and Sovetskaia Rossiia, for example, were banned for a period of time

frames chosen specifically by journalists in their analysis and interpretation of events. As noted by Goffman, when an event takes place, a number of frameworks appear that the individual can use in order to understand and intepret the event that has just taken place. He labels this transaction as a primary framework, where aspects of the original event are 'rendered meaningless' in the process of making the transaction meaningful. Similar to this individual's process of meaning making through the application of the primary framework, journalists choose to frame stories in certain ways based on their own world views, journalistic routines, political means and even editorial policy. Since interpretations of events are already biased in the sense that attached to the stories are their own worldviews, their reporting is not "just holding a mirror to events" but also an interpretation of how they see events. In turning the event into a story, the journalist provides their own interpretation of the event, selecting certain points of emphasis over others. In doing so, certain messages are being transported into the consciousness of the reader. Please see: Erving Goffman, Frame Analysis: An Essay on the Organisation of Experience (Boston: Northeastern University Press, 1996), 21-27; Dietram A. Scheufele, "Agenda-Setting, Priming, and Framing Revisited: Another Look at Cognitive Effects of Political Communication," Mass Communication and Society 3, No. 2-3 (2000): 307; Street, Mass Media, Politics and Democracy, 36.

${ }^{35}$ David Wedgewood Benn, "The Russian Media in Post-Soviet Conditions," EuropeAsia Studies 48, No. 3 (1996): 474.

${ }^{36}$ The Russian constitutional crisis (21 September 1993 - 4 October 1993) refers to the political deadlock between Boris Yeltsin and Russian parliament over the issue of dissolving the Congress of People's Deputies and the Supreme Soviet. Yeltsin held a 
in $1993 .{ }^{37}$ As mouthpieces of the former Soviet Union and the associating communist principles, their voices threatened Boris Yeltsin' aims. In this sense, banning the newspapers was in clear disregrard of the media laws established 3 years prior and an indication that the press did not have the same freedom as other democratic countries. Favouring pro-government media was something that continued even in the Glasnost years. The ascension of pro-democracy editors within the press, as a result of Gorbachev demonstrated an effort of the Soviet government to continue to politicise the press and steer the discourses within the media toward the aims and goals of the government. ${ }^{38}$

Another consideration is the role of Soviet journalists. With the advent of glasnost, Soviet journalists did not cease to exist - rather they adapted to the new conditions presented to them in the era of democratisation. These journalists suffered from years of censorship laws, training that was ideological and equal pay based on word count, rather than quality. At the Sixth Congress of the Union of Journalists in March 1987, chairman Viktor Afanasyev called for substantial changes to the Soviet mass media, in line with the issues presented above. ${ }^{39}$ Newspapers and magazines created prior and during the Soviet Union continued to exist also, for example, Ogoniok, Pravda and Izvestiia, while new newspapers emerged. Novaia Gazeta was a new newspaper entirely, whereas a team of journalists who formally worked for Komsomolskaia Pravda created Kommersant. The new media landscape of the 1990s consisted of Soviet journalists and Russian journalists. This is not to say that some of these publications and the journalists within were ideologically sworn to the socialist principles they previously upheld. Ogoniok for example, became a key publication in the Glasnost years. ${ }^{40}$

Despite these issues, Russia's media was the most free it had been in years. Benn, on the topic of media reporting during the First Chechen War, stated the "robust independence of Russian journalists greatly impressed the outside world."41 The freedom of the press is best shown in the diverging views of the different media outlets under

referendum in April 1993, which he used to make the changes. Military force was used by Yeltsin to storm the White house and the leaders of opposition were arrested.

${ }^{37}$ Benn, "The Russian Media in Post-Soviet Conditions," 472.

${ }^{38}$ Richter, "The Russian Press after Perestroika."

${ }^{39}$ Brian McNair, Glasnost, Perestroika and the Soviet Media (London: Routledge, 1991), 93; Viktor Afanasyev (1922-1994) was a Soviet politician and former-editor of newpaper Pravda.

${ }^{40}$ Richter, "The Russian press after Perestroika."

${ }^{41}$ Benn, "The Russian Media in Post-Soviet Conditions," 471 
review in this chapter. Krasnaia Zvezda journalists, for example, serving as a mouthpiece of the Russian Army, provided a more positive outlook on the position of the army in the 1990s. In contrast, Novaia Gazeta, Ogoniok and Izvestiia were more critical of the Russian Army's role in the Chechen region. At the same time, while Russia's role in the Chechen conflict was largely criticised, the media remained largely united on some of the threats that Russia faced in this period. For example, while against the prospect of war, Argumenty i Fakty and Sovetskaia Rossiia were largely anti-NATO and documented extensively on the threat of NATO expansionism. Since Putin's ascension to power, the role of the media in society has become more centralised.

Russia's media was not autocratic or democratic. Largely, it was anti-war, yet at times, especially regarding NATO, it understood Russia's role in the conflict. In addition, while wanting to avoid war, and at times, critical of the governmental stance, the media would agree that there were real threats to Russia's security in the post-Cold War world, in Chechnya, with NATO and in the former Soviet region. Generally, Russia's media was the most free it had been in years. However, the continued role of Soviet journalists alongside the economic crisis and governmental restraints meant the Russian media never fully achieved the freedoms of other democratic countries.

\section{MILITARISED DISCOURSES AND THE MEDIA}

The 1990s Russian media paid particular attention to two events; NATO expansion and the First Chechen War. Like those in Belgrade, Russian society was confronted with stories of an aggressive NATO and criminal Chechnya. The concentration on these topics within the media showcased the importance of these issues to Russian society, with the messages aimed at altering the perception of the reader towards NATO (and by extension America). The next section focuses on media narratives relating to Russia's security in the post Cold-War world. It argues that a primarily antiwar media played a particular role in the mobilisation of Russian society as it emphasised Russia's loss of regional power in the Former Soviet Union, the evolution of a 'peacekeeping' Russia in neighbouring conflicts and the threat of NATO in the region.

\section{Russia the peacekeeper}

Following the collapse of the Soviet Union, Russia's global influence plummeted. One key dimension of Russia's demise was its loss of territory after the dissolution of the 
USSR. This downfall began in 1989, when a wave of protests swept through regions of the Eastern bloc, initiated by independence movements. The Baltic States as well as Poland, Hungary, East Germany and Romania sought independence. The Warsaw pact ended while the Western-led North Atlantic Treaty Organisation (NATO) continued to flourish limiting the Soviet and Russian influence in the Eastern Bloc. In response to growing claims for independence, Gorbachev introduced the 'Union of Sovereign States' Treaty. This treaty aimed to devolve more powers to the regions seeking independence. In return these countries would remain part of the Union. Many of the regions rejected the treaty seeing their own journey for independence as their only option to gain sovereignty. ${ }^{42}$ Gorbachev's proposal led to an attempted coup d'etat by communist hardliners. The coup's failure led to the collapse of the Soviet Union. Because of the failed coup, the treaty was not ratified.

Instead the countries were granted independence, the Union disintegrated and Russia, Ukraine and Belarus formed the Commonwealth of Independent States (CIS) in December 1991. This new union included former Soviet states, excluding the three Baltic States and Georgia. The CIS aimed to unify former Soviet states on issues such as the economy and security. Members of the CIS signed agreements on economic prospects and collective security. However, Alexander V. Kozheniakin and Roger E. Kanet note that the CIS became a synonym for Russian control in the former communist region. ${ }^{43}$ For example, one agreement saw that nuclear weapons located across the former soviet space were returned to Russia, ensuring that Russia was the only country in the region with a nuclear capacity. In addition, Russia controlled the CIS with a high number of Russians in the commanding roles of the commonwealth's defence sector. In this sense, the Russian government relied on the military alliances formed under the CIS to help maintain its control over the former Soviet regions. Russia's desire to maintain control over the Eastern Bloc beyond the CIS was further demonstrated in Yeltsin's call to the United Nations to allow Russia to play a stabilising role in conflict-ridden regions like Yugoslavia. In July 1995 Krasnaia Zvezda reported on the peacekeeping efforts of the

${ }^{42}$ Galina Starovoitova, "Democratisation and Ethnic Conflict in Post-Soviet Society," in Ethnic Conflict in the Post-Soviet World: Case Studies and Analysis, ed. by Leokadia Drobizheva, Rose Gottemoeller, Catherine McArdle Kelleher and Lee Walker (New York: M. E. Sharpe, 1998), 151.

${ }^{43}$ Alexander V. Kozhemiakin and Roger E. Kanet, "Russia and its Western neighbours in the 'Near Abroad," in The Foreign Policy of the Russian Federation, ed. by Robert E. Kanet and Alexander V. Kozheimiakin (London: Palgrave, 1997), 29. 
CIS, quoted Andrey Kozurev in four speeches made during the week of the $8^{\text {th }}$ July 1995. ${ }^{44}$ Kozurev claimed, "Today, a more important task is strengthening the CIS... CIS countries will join the agreement on joint border protection." Stressing that the commonwealth "is gaining experience and potential of independent peacekeeping" he called on the Federation Council to "continue support for operations in Abkhazia, Tajikistan and other 'hot' spots. Here the minister found the support and understanding of regional leaders, who themselves were well aware of the consequences of instability in the post-Soviet space." ${ }^{45}$ Russia's new role within the CIS as a peacekeeper helped legitimise Russia's military policies. It showed that Russia relied on the military to stabilise and bring peace to neighbouring regions, which could threaten Russian stability. The media argued that independence brought a lot of instability to the region, which legitimised Russia/ CIS action. This instability was linked to rising ethnic tensions.

Russia adopted a hard-line approach to suppress dissent in countries seeking independence. Tanks rolled onto the streets of Lithuania, with the Russian military also suppressing dissent in Central Asia. ${ }^{46}$ Russia legitimised military action on the basis it ensured the protection of ethnic Russians choosing to remain in those countries. As noted in the business-political newspaper Kommersant in February 1993, "All questions related to the status of Russians and social guarantees for its officers and soldiers will be stipulated in special intergovernmental agreements, which are being worked on by experts of the two military departments." 47 This was an issue later used to justify Russian military intervention in the Chechen region, with stories of violence against ethnic Russians legitimising its military stance. Russian military action in other neighbouring regions was also defended on the basis that these tensions and instability could spill into Russia.

In February 1991 Ogoniok reporter, Vasily Selyunin acknowledged that new claims to sovereignty might affect the rights of ethnic minorities. However, he also argued that interethnic tensions already existed under the Soviet Union, yet the USSR did very little to protect ethnic minorities in the first place. He used the Nargorno-Karabakh conflict (1988-1994) as an example of this, claiming it would be hypocritical to link the

\footnotetext{
${ }^{44}$ In 1995, Andrey Kozurev was Russia's foreign minister at the time.

45 Alexander Golts, "Ukreplenie SNG - Vazneishaia Zadacha Nashei Diplomatii," Krasnaia Zvezda, 8 July 1995, No. 152-153.

${ }^{46}$ Starovoitova, "Democratisation and Ethnic Conflict in Post-Soviet Society," 151.

47 "Vizit Gracheva v Tadzhikistan," Kommersant, 6 February 1993, 21.
} 
rise of interethnic tensions to independence when these tensions already existed under previous leadership. ${ }^{48} \mathrm{He}$ argued that the use of Russia's military in the affairs of postsoviet countries also allowed Russia to build up a collection of allies that would eventually owe Russia. Russia's involvement in the Tajikistan War (1992-1997) and the Yugoslav war illustrates this point perfectly.

First, Russia supported both sitting governments in Tajikistan and Yugoslavia. This is an extremely important point to take into consideration, bearing in mind the internal threats facing Russia during this time. Yeltsin supported Rahmon Nabiyevich Nabiyev of Tajikistan and Slobodan Milosevic of Yugoslavia's government. This was not a coincidence. Yeltsin was also under threat from separatist movements within the Russian state. During this period, ethnic groups in Russia, including Tatars and Chechens, were seeking their own independence. While these movements did not peak until 1994, supporting separatist regimes would have endangered Russia's own claims to territorial integrity. In addition, providing military support to both Tajikistan and Yugoslavia created an informal alliance, where Russia expected similar support in return. These countries were expected to support Russia's territorial integrity and disapprove of Chechen separatism. The media acted as a vehicle of militarisation, showing that the government was willing to use its military to suppress separatist movements. It first showcased the separatist activity as a threat to Russian society, in terms of instability and presented military action as a necessary means of security.

Second, in relation to the Tajikistan War, Russia's involvement was motivated by border instability. Here, Russia's military role was justified on the basis that it aimed to stabilise the borders and secure Russia against similar issues. As noted in Kommersant (February 1993), during a visit to Tajikistan in 1993, Pavel Grachev agreed to restore a unified air defence system in the Central Asian Region, and to strengthen the protection of the southern borders of Tajikistan. He argued that strengthening the Tajik southern border was integral "to prevent the spread of 'aggressive' Islamic fundamentalism, which could lead to war, including on the territory of Russia." ${ }^{49}$ Grachev's statement surrounding securitisation was supported. The rise of Islamic fundamentalism, not only in Russia, but also in other post-soviet societies became a real concern for the region. As

\footnotetext{
${ }^{48}$ Vasily Selunin, "Chto u Nas Poluchitsia?” Ogoniok, February 1991, No. 6, 1. 49 "Vizit Gracheva v Tadzhikistan," 21.
}

Pavel Grachev (1948-2012) was a Russian Army General and served as the Defence Minister of the russian Federation (1992 -1996). 
conveyed in December 1992 in Kommersant, Uzbekistan feared that an Islamic republic would be established on its borders, and included information about an Uzbek train station and oil factory that were damaged by an Islamic attack. ${ }^{50}$ Since the situation in Tajikistan was following by that of the Iranian Islamic Revolution and the Gulf War, the narratives within Russia's newspapers matched those presented in the global media. Russia relied on military action in neighbouring countries to bring peace to the region and to tackle upcoming danger. The media's reporting of rising 'aggressive' Islamic fundamentalism showcased new and emerging threats to Russian security, reaffirming the military's role as a guarantor of peace.

However, at the same time, Russia's involvement in these 'peacekeeping' operations was considered a mechanism that helped further war. In April 1992, Ogoniok journalist Alexander Bolotin claimed that while Russia was not actively involved in combat, the provision of weapons to both Armenian and Azerbaijani militants "provided mechanisms of another war in the region." ${ }^{51}$ While Russia's involvement in neighbouring conflicts was criticised greatly, there were moments whereby the content of the media was questioned. News outlet Vesti, for example, was criticised for its reporting on Russia's role in the Tajikistan conflict. Kommersant insisted on sending in two of their own reporters to correct the "provocative disinformation" reported by Vesti. ${ }^{52}$ The article from December 1992 stated that information regarding reports suggesting an end to Russia's neutrality in the Tajikistan conflict was incorrect. "[Russia] thank god, had not yet reached the point of declaring, at their discretion, war on the territory of a sovereign state." This 'misinformation' subsequently led to a blackout in media communications with military personnel refusing to speak to journalists. ${ }^{53}$ As a result, the conflict in Tajikistan was counted as a "silent emergency," for the lack of military coverage, and Kommersant's report justified this through scrutinising the role of some press outlets, which they claimed reported incorrectly on unfolding events. ${ }^{54}$

\footnotetext{
50 "Situatsiia v Tadzhikistane," Kommersant, 15 December 1992, No. 61.

${ }^{51}$ Alexander Bolotin, "Eta Pulia Eshche ne tvoia," Ogoniok, April 1992, No. 14-15, 2-3.

${ }^{52}$ Vesti was a Russian broadcaster, now known as Russia-24. Under the control of stateowned broadcaster Vserossiiskaia gosudarstvennaia televizionnaia I radioveshchetel'naia kompaniia (VGTRK), it promotes the view of the state. VGTRK was founded in 1990 in Moscow.

53 "Situatsiia v Tadzhikistane."

${ }^{54}$ Peter Viggo Jakobsen, "Focus on the CNN Effect misses the point: The Real Media Impact on Conflict Management is Invisible and Direct," Journal of Peace Research 37, No. 2 (2000): 133.
} 
Discourse outlining neighbouring instability added to the notion that Russia was surrounded by adversity. The victory of separatist regimes in the former Soviet Union was a threat to Russia, since it had potential to influence separatist movements and strategies in Russia. The use of narratives discussing the threat these movements, and for example, Islamic fundamentalism had on Russia's security fed into the siege mentality, in which Russia remained paranoid to external and internal threat that could only be solved through the military.

Media reports on the CIS and Russia's 'peacekeeping' efforts in the FSU hinted at the larger aim of the Soviet Union to maintain power within Eurasia. First, Russia's 'responsibility' to monitor peace negotiations mirrored American exceptionalist claims that America's god given role in the world is to instil its values in other countries. This was used as a basis to legitimise intervention. ${ }^{55}$ Russia adopted a similar tactic. Russia's peacekeeping role suggested that it had the authority and the appropriate experience to meddle in peacekeeping efforts. Second, Russia's peacekeeping role was a guise for Russian power in the region. Having aided another country with the provision of resources to certain regimes, Russia expected loyalty in return. It is hardly coincidental that Russia supported a united Yugoslavia over the breakdown of the country, when Russia was threatened by Chechen separatism.

The media played a substantial role in the reporting of Russia's involvement in conflicts and uprisings that erupted in the former Communist space. While Russia was no longer in a Cold War with the West or seeking to balance NATO, the topic of confrontation dominated the media. Discourses on conflict in neighbouring regions, and Russia's peacekeeping role in the near abroad contributed towards the development of militarism during this period in a myriad of ways. First, Russian society remained exposed to stories of war. Second, Russia's role as a 'peacekeeper in the region' was similar to America's 'divine right' to pass its values onto another country. It emphasised the superiority of the Russian military, their strategy for implementing peace and in forming structures suitable for the maintenance of law and order. This was certainly the case during the demise of the Soviet Union. These media discourses militarised society by reaffirming the two notions that 1) Russia was surrounded by internal and external dangers and 2) the military provided necessary means of security.

${ }^{55}$ Bacevich, The New American Militarism, 11-13 


\section{NATO: Only a Matter of Time}

Following the end of the Cold War, the Warsaw Pact disintegrated. In contrast, the North Atlantic Treaty Organisation (NATO) continued to grow. ${ }^{56}$ In the absence of the Warsaw Pact, Yeltsin established the Commonwealth of Independent States. However, the CIS provided a platform through which Russia could maintain control in the former Communist region. ${ }^{57}$ This was most prominently showcased in Russia's role in the former Soviet space justified as 'peacekeeping. ${ }^{, 58}$ Russia's regional presence in the former communist sphere was seriously challenged by the expansion of NATO in the immediate Post-Cold War period.

While initially open to the possibility of NATO membership, criticism from Russia's parliament and military pushed Yeltsin to seek an equal partnership with America within the framework of NATO, and under the Partnership for Peace programme. He even prepared the foundations for an all-European organisation that would supersede NATO. NATO rejected this proposal. Discussions on the North Atlantic Treaty Organisation in the political arena spilled into public life. As a result, newspaper articles relating to NATO gained momentum from the mid 1990s. They debated the inclusion of Russia in NATO, criticised expansion of NATO eastwards and the role of NATO in the Yugoslav war (1991-2001). All issues were contentious. It not only led to the physical creation of a new alliance system (the CIS), but also resulted in the mobilisation of the media, which used militarisation methods to pit society against NATO. In the case of NATO, while not outwardly pro-war, the media fuelled anti-NATO sentiments further into society and mobilised society against potential threats to Russia's sovereignty. By using 'othering' techniques, the media was a mechanism of militarisation. It promoted the actions of Russia against an aggressive NATO,

\footnotetext{
${ }^{56}$ NATO enlargement was evident from as early as the 1990s. While the reunified Germany was included into NATO from 1990, Hungary, the Czech Republic and Poland were only invited to join in 1997. Discussions of their potential invitation began much earlier. According to Kimberly Marten, serious considerations to expand NATO were only taken by Bill Clinton in 1993 after attending the opening of the Holocaust museum in Washington, in which diplomats of Hungary, Czechslovakia and Poland campaigned about being included. For more, please see: Kimberly Marten, "Reconsidering NATO expansion: a counterfactual analysis of Russia and the West in the 1990s," European Journal of international Security 3, No. 2 (2018): 141-142,

${ }^{57}$ Kozhemiakin and Kanet, 'Russia and its Western Neighbours in the 'Near Abroad,' in the Foreign Policy of the Russian Federation, by Kozhemiakin and Kanet, 29.

58 Zbigniew K Brzezinski and Paige Sullivan, Russia and the Commonwealth of Independent States: Document, Data, and Analysis (New York: Routledge, 1997), 59.
} 
establishing anti-NATO rhetoric in the public sphere. It strengthened the discourse that Russia was vulnerable to external danger by outlining the reemerging threat of NATO, as it expanded eastwards. Together, the following discourses promoted anti-NATO sentiments, Russian nationalism and military preparedness.

As Soviet leaders mourned over the loss of the Warsaw Pact, NATO saw an opportunity to expand. As noted in February 1994 by Ilia Milshtein in Ogoniok, "Yesterday's friends rushed to flee the Warsaw pact. Yesterday's enemies rushed to help the weakened "Empire of Evil." ${ }^{59}$ Gorbachev allowed Post-Soviet states to choose security agreements that suited their individual needs, and signed away Soviet/ Russian power within the region. Initially, Yeltsin welcomed the idea of Russia's future inclusion in NATO ${ }^{60}$ On a visit to former communist countries, Poland and the Czech Republic, Yeltsin accepted NATO's first step towards expansion into central-eastern Europe. Discussions began regarding the accession of former Communist countries, like Poland, Czechslovakia and Hungary into NATO.

However, following immediate criticism within Russia, Yeltsin changed his stance. He insisted that his acceptance of NATO expansion was to be completed within the context of European integration. ${ }^{61}$ Izvestiia (defined as the national newspaper of the Russian Federation) reported in February 1995, Yeltsin claimed the collapse of the Warsaw Pact should have been succeeded by the dissolution of NATO and that "Any [new] defence body for security and cooperation in Europe should replace NATO." ${ }^{20}$ Still in 1999, expansion of NATO to possibly include Ukraine, attracted similar responses from Russia. As noted in Izvestiia:

The Russian leadership's attitude to the issue of NATO's eastward expansion remains the same. 'This movement is in the wrong direction,' said Russian

\footnotetext{
${ }^{59}$ Ilia Mishtein, "Nato ili ne nado?” Ogoniok, February 1994, No. 8, 3.

The phrase 'Empire of Evil' makes reference to former American President Ronald Regan's 1983 speech at the National Association of Evangelicals convention, where he called the Soviet Union an 'Empire of Evil.'

${ }^{60}$ Martin A. Smith, and Graham Timmins, "Russia, NATO and the EU in an Era of Enlargement: Vulnerability or Opportunity?" Geopolitics 6, No. 1 (2001): 73; Julianne Smith, The NATO-Russia Relationship: Defining Moment or Déjà vu? Europe, Russia and the United states: Finding a New Balance (Washington DC: Rowman and Littlefield Publishers/ Center for Strategic and International Studies, 2008), 2-3.

${ }^{61}$ Ibid.

${ }^{62}$ Vladimir Nadein, "Budushchee NATO reshaetsiia v Moskve" Izvestiia,14 February 1995, No. 28.
} 
Foreign Minister Igor Ivanov... European countries should strive to create a system of pan-European security that will serve the interests not of a group of separate states, but of the states of Europe as a whole. ${ }^{63}$

Initial opposition from Russia towards NATO expansion came primarily from Russian politicians and the military. They resented the loss of territory following the collapse of the Soviet Union, and the probable accession of former Soviet nations into an organisation that was once a former adversary. They also deemed NATO enlargement as a direct threat to Russia's security. ${ }^{64}$ Russia's military doctrine of 1993, published in the same year that NATO began to pursue new alliances, noted NATO expansion as a big threat facing Russia. ${ }^{65}$ This narrative persisted throughout the 1990s. As echoed in December 1997 in Argumenty $i$ Fakty, NATO expansion was placed within the top three threats facing Russian in $1997 .{ }^{66}$

Martin A. Smith and Graham Thomas focus on Russian anxiety towards NATO enlargement in the 1990s, and bring particular attention to the 'geopolitics of vulnerability.' This was a term coined to acknowledge vulnerability on a spatial and territorial level and "also [the] ingrained fear of territorial assault and invasion." 67 They refer to Sir Halford Mackinder and Nicholas Spykman's 1919 study, which claimed that the Heartland [Russia] was a pivotal state. Russia's position has a profound impact on global security. Implicit in Mackinder and Spykman's views, was the notion that Russia was a vulnerable state, with the view that whoever commanded Russia would 'command the world. ${ }^{, 68}$ The crux of Russia's vulnerability lay in the notion that other countries wanted to control the area, also knowing the value of Russia's position in terms of global

${ }^{63}$ Gennady Charodeev, "Vengriia, Pol'sha I Chekhiia uzhe v NATO/ Na ocheredi Ukraina?" Izvestiia, 1999, No. 43.

${ }^{64}$ Smith and Timmins, "Russia, NATO and the EU in an Era of Enlargement," 75-76.

${ }^{65}$ Aurel Braun argues that the expansion of NATO also forced the expansion of military blocs. For more, please see: Aurel Braun, "Russian Policy Towards Central Europe and the Balkans," in The Foreign Policy of the Russian Federation, ed. by Robert E. Kanet and Alexander V. Kozheimiakin (London: Palgrave, 1997), 92

66 “Koalitsionnoe Pravitel'stvo," Argumenty i Fakty, 10 December 1997, No. 50.

John Berryman supports the view that the influence of NATO on newly recruited former soviet countries, and the integration of the Baltics into NATO would place a barrier in what was regarded as Russia's gateway to the West. For more, please see: John Berryman, "Russian Foreign Policy: An overview," in Russia after the Cold War, ed. by Mike Bowker and Cameron Ross (United Kingdom: Longman, 2000), 348-349.

${ }^{67}$ Smith and Timmins, "Russia, NATO and the EU in an Era of Enlargement," 71.

${ }^{68}$ Ibid, 69. 
power. NATO's eastward expansion affected Russia. It threatened Russia's power status and control of the former Soviet region. The media even reported as one of the top three threats facing Russia in the 1990s, demonstrating the extent of Russian insecurity. It supported Russia's military doctrine of 1993, which was shaped by the threat of NATO expansionism. These discourses came together to support the existing self-perception that Russia faced challenges by reemerging Cold War threats, leading to nostaligic notions of heightened nationalism. The media showcased Russia's growing isolation at the expense of NATO's increasing influence.

As noted by Yevgeny Primakov, former Russian Minister of Foreign Affairs and Russian Prime Minister, NATO expansion was widely exclusionary. ${ }^{69}$ This resulted in Russia advocating for a partnership with NATO similar to the Treaty of Paris (1815), rather than the Treaty of Versailles, which excluded powers from the process of cooperation. ${ }^{70}$ The "Partnership for Peace programme" discussed in 1995 allowed Russia to be somewhat involved in discussions with NATO on its expansionist goals, but it did not give Russia the equal stance it wanted. As noted in May 1995 in Izvestiia, hesitation of Russia to accept NATO expansion was "understandable."71 It claimed that along with internal crises (economic, political), it faced an external crisis. Author, Alexander Sychov suggested that NATO expansion demoted Russia into a secondary position within the post-cold war world order. He claimed:

A great power retreated to an unusual second role, and NATO's eastward expansion would mean another concession to Washington's political initiative. In addition there are strong fears that Russia, left behind the threshold of the alliance will expect political isolation in the future. ${ }^{72}$

69 Andrey A. Sushentov and William C. Wohlforth, "The Tragedy of US-Russia Relations: NATO centrality and the revisionists' spiral," International Politics 57, (2020): 435.

As noted by Stephen White, Yeltsin was concerned that NATO not only threatened Russia's territorial integrity but also could provoke tensions between countries accepted into the alliance, and those on the outside. For more, please see: Stephen White, Russia's New Politics: The Management of a Postcommunist Society (Cambridge: Cambridge University Press, 2000), 237

${ }^{70}$ Ibid.

${ }^{71}$ Alexander Sychov, "Rossiia budet Sotrudnichat' s NATO, Tol'ko esli etot Blok ne Popolzet na Vostok," Izvestiia, 25 May 1995, No. 94.

72 Ibid. 
This was not a theme that solely resided in newspapers but was spoken by Yeltsin in a number of his political speeches. ${ }^{73}$

Russia's desire for equal partnership with NATO, or the creation of a new allEuropean organisation highlighted Russia's fear of being excluded from decision-making processes that would affect international affairs. Two noteworthy occasions legitimise Russia's concerns. First, Bill Clinton's claim that NATO would expand, with or without Russia's blessing and finally, during the Yugoslav war. ${ }^{74}$ Foreign Minister Primakov warned NATO not to use force in peacekeeping projects without the authorisation of the United Nations. In October 1998, Russia repeated its view that NATO should not intervene in the Yugoslav war "without the sanction of the UN Security Council" and that "an excess of power will occur" if NATO was to do so. ${ }^{75}$ Russia's downgraded global position from a superpower to a country secondary to the United States was confirmed in 1999. In March of that year, America launched Operation Allied Force against the Federal Republic of Yugoslavia without U.N. approval. ${ }^{76}$ Argumenty i Fakty journalist Vitaly Tseplyaev showed his disdain. In 1999 he claimed:

We have not met SUCH unceremoniousness of the USA and NATO in international politics for a long time. International law has been violated, the Security Council, the United Nations, even the UN Charter!... They showed Europe who the owner of the house is and they want to point out to her: even though you, Europe, are economically strong, politically, you are a dwarf. The Yugoslav tragedy is a cover for an even greater tragedy: the intention to impose US hegemony on the world. ${ }^{77}$

Following NATO's Operation Allied Force, Defence Minister Igor Sergeev questioned the point of the United Nations and NATO if Russian views were to be ignored. ${ }^{78}$ Russia's isolation from world affairs through the expansion of NATO was not the only fear of political elites during this time. In March 1997, Dmitry Tasmanskiy, journalist of the investigative news outlet Novaia Gazeta, wrote;

\footnotetext{
${ }^{73}$ Smith and Timmins, "Russia, NATO, and the EU in an Era of Enlargement," 71.

${ }^{74}$ Ibid, 3.

75 Vladimir Mikheev, "NATO razbombit serbov I bez soglasiia OON," Izvestiia, 2 October 1998, No. 185.

${ }^{76}$ Smith and Timmins, "Russia, NATO, and the EU in an Era of Enlargement," 78.

77 Vitaly Tseplyaev, "Mikhail Gorbachev: Zdravstvui, oruzhie?" Argumenty i Fakty, 1999, No. 15.

${ }^{78}$ Smith and Timmins, "Russia, NATO and the EU in an Era of Enlargement," 79.
} 
The main trouble for the Russians lies in the desires of the Poles, Czechs and Hungarians to join the North Atlantic Treaty... [after discussing rise of antiNATO sentiments by State Duma officials] Yes, NATO expansion is an alarming bell. But the question is: why is the whole of Eastern Europe, including the Baltics, and now Ukraine, seeking to hide under the NATO umbrella? Is it enough for at least a short time to imagine yourself in the place of the Eastern Europeans and look at the West and East? Who would you like more? Moscow or Brussels? ...The discussion with NATO highlighted one unpleasant truth - Russia did not have a single ally in the world. And soon, apparently quite a lot of enemies will form. ${ }^{79}$

In the quote above, Novaia Gazeta confirmed Russia's worst fear; that a new grand alliance was emerging, in which former 'colonies' were now in support of a former adversary. Russia's feeling of isolation went beyond the formal institution of NATO and related to the creation of other alliances absent of a Russian counterpart. An article in June 1997 by Argumenty i Fakty confirmed the outlook of Novaia Gazeta. Entitled "Russia in a ring of enemies," Vitaly Tseplyaev conducted an interview in 1997 with State Duma Deputy Nikolai Gonchar and member of the Presidential Council Andronik Migranyan on the question of Russia in Eurasia at the dawn on the new century. ${ }^{80}$ Both spoke of new alliances outside Russia. They hinted the creation of a Turkish "Islamic NATO" from an alliance of eight Asian countries, and the developing relationship between the Baltic States and Ukraine. Migranyan suggested that these alliances risked the isolation of Russia, claiming, "Instead of becoming a bridge between East and West, we run the risk of being peripheral." ${ }^{\prime 1}$ Argumenty $i$ Fakty added to the debate, noting Russian isolation and "separatism of some Russian subjects is rooted in the history of the Tatar-Mongol yoke." 82 They ended the interview by claiming, "It seems that history is repeating itself in a new spiral. And if so, then the revival of Russia should be repeated." 83 It must be noted, however that despite agreement over NATO's movement eastwards, the nature of the newspapers arguments differed. Novaia Gazeta was suggesting that issues in Russia and of the Soviet Union pushed countries of the FSU to seek help and

\footnotetext{
${ }^{79}$ Dmitry Tasmanskiy, "V ochered', sukiny deti, v ochered!' (P. P. Sharikov o rasshirenii NATO)," Novaia Gazeta, 10 March 1997, No. 10.

${ }^{80}$ Vitaly Tseplyaev, "Rossiia v Kol'tse vragov?," Argumenty $i$ Fakty, 17 June 1997, No. 25.

${ }^{81}$ Ibid.

82 Ibid.

${ }^{83}$ Ibid.
} 
partnership with NATO. Therefore, suggesting that the West had something more attractive to offer. On the other hand, the piece in Argumenty $i$ Fakty showcased NATO expansion as a form of encroachment. Despite these differences, Russia’s ‘isolation' from international affairs in the shape of NATO and other developing alliances, raised two anxieties. First, the anxiety that Russia was being downgraded from superpower status to one that was secondary to the United States. Second, it increased anxieties that potential adversaries surrounded Russia. As noted in the title of the Argumenty $i$ Fakty article above, the author proposed that "Russia [was] in a ring of enemies." 84

The theme of Russia as a 'besieged fortress' existed centuries before the collapse of the Soviet Union, underwritten by the large number of invasions Russia has endured since its existence. In this thesis, emphasis on the discourse of Russia as a 'besieged fortress' was also evident in educational textbooks and in the discourse and symbolisms of the 1995 Victory Day celebrations. In fact, it remains a key justification of Russian aggression today. Both the Russian-Georgian war of 2008 and the conflict in Crimea (2014) were legitimised on the premise that NATO was threatening Russian security. ${ }^{85}$ However, it was in the Russian media of the 1990s that NATO expansion was first characterised as a threat to Russian security in the post-Soviet period. NATO was depicted as aggressive and threatening, with media outlets justifying military action to ensure Russian security. An article in August 1994 by Communist news outlet Sovetskaia Rossiia, for example, claimed:

Any expansion of NATO, and in particular the inclusion of the states that are former members of the Warsaw Treaty - Poland, the Czech Republic, Slovakia and Hungary - would undoubtedly mean a clear threat to the peace and security of both Russia and Europe as a whole... Obviously, this should be qualified as an act of aggression, as an act of preparing for war against Russia. Russia, like other republics belonging to the Commonwealth of Independent States, should have taken all necessary measures for collective self-defence. ${ }^{86}$

The nature of this article was provocative, written to provoke discontent and to mobilise its readership to adopt an anti-NATO stance. First, the author called upon

\footnotetext{
${ }^{84}$ Ibid.

${ }^{85}$ Mary Elise Sarotte, "One Inch Eastward? Bush, Baker, Kohl, Genscher, Gorbachev, and the Origin of Russian Resentment toward NATO Enlargement in February 1990," Diplomatic History 34, No. 1 (2010): 123.

${ }^{86}$ Nikolai Klaus Von Cretor, "Esli by ia byl Russkim Marshalom." Sovetskaia Rossiia, 30 August 1994, No. 62.
} 
members of the CIS to mobilise in support of Russia against NATO aggression. Here the author was warning countries of the CIS that NATO could soon be encroaching on their borders. Second, it called for unity, suggesting that together the countries could overcome the growth and continued expansion of NATO. "Aggression" is a powerful word. The epithet of an aggressive NATO was established during the soviet era. Vladimir Nadein wrote for Izvestiia in February 1995 on NATO and Russia. He stated, "We have never loved the North Atlantic Treaty Organisation," reminding the readership of that popular song of the 50s, which included lyrics of an "aggressive NATO" firing half of Europe. ${ }^{87}$ He continued, stating, "Two generations grew up, not suspecting that the word "NATO" could be used without adding aloud, or mentally, the epithet "aggressive." 88 While Izvestiia stopped serving as a mouthpiece for the Soviet government during its demise in 1991, the background of the journalists writing for the newspaper were evidenced during NATO's eastward expansion. As noted by Nadein, who wrote for multiple media outlets of different worldviews - the relationship between Russia and NATO was historical and mainly negative. While the new post-Soviet government was initally open to strengthening the relationship between the East and West, NATO's expansionist goals in the 1990s acted as reminders of the formal rivalry between the Warsaw Pact and NATO. CDA takes into account this important context, and pinpoints how and why such discourses are popularised over others. A negative image of NATO emerged in the media because the movements of NATO in this new era replicated those taken during the Cold War. The media framed NATO as a reemerging threat, using 'othering' techniques to legitimise military readiness, heightened nationalism and anti-NATO sentiments.

This was most notable in an exchange that took place in Argumenty $i$ Fakty. In November 1997, a "“For' or 'Against" expose on potential Russian affiliation with NATO depicted Russia as a "guardian angel." NATO was portrayed as an "external threat" with a "heavy boot" drawing "arrows to the Volga." 89 A. Somov, in response to the editorial wrote, "Against who are you my friends? 'Friend Bill,' 'Friend Helmut,' 'Friend Jacques'... These phrases make me laugh. What friendships can we talk about

\footnotetext{
${ }^{87}$ The newspaper article refers to the song as a Chastushki. A chastushki is a traditional type of satirical folk song/ rhyme. They are more commonly popular in peasant culture and tend to be reflective of events taking place during the time of their creation.

${ }^{88}$ Nadein, "Budushchee NATO reshaetsia v Moskve."

${ }^{89}$ Alexander Sargin and Vitali Tseplyaev, “'Za' I 'protiv' razoruzheniia. Kto seichas ugrozhaet Rossii," Argumenty i Fakty, 19 November 1997.
} 
when these gentlemen are pushing their troops closer to our borders?" 90 Here, Somov indicated that NATO was not only considered a threat to Russia's regional power, but also to Russia itself. Newspaper articles claimed that once NATO has expanded its borders eastwards to Hungary, Poland and even Ukraine, it would start to look towards Russia. Russia's decision to delay the ratification of START-2 became a topic of contention in the American press. In response, Krasnaia Zvezda (January 1997) author Gennady Obolensky claimed, "Recently in the American media a large number of publications appeared regarding the delayed ratification of the START-2 Treaty in the State Duma of the Russian Federation. What is not in these publications?! That these are threats to the Russians, and slammed allegations on NATO's eastward expansion."91

NATO's involvement in the Yugoslav war furthered anti-NATO literature in Russia's media outlets. While openly against war, these newspapers justified a Russian response on the basis that they were dragged into the conflict. The newspapers also presented the viewpoint that the crisis on the Balkans was a practice for NATO involvement in Russian-Chechen affairs. In this context, the Russian media aimed to mobilise its citizens through emphasis on Russia's vulnerability.

First, reports on the Yugoslav war seemed to have had an impact on how Russians viewed NATO and more generally America. NATO was considered a synonym of American hegemony, and this sentiment changed Russia's views towards America. ${ }^{92}$ As reported in April 1999 by Argumenty i Fakty, a poll held by Russia's Public Opinion Research Centre VTsIOM in 1999 found that in response to the question, "How do you feel about the United States of America?" 53\% of respondents claimed they felt "very bad" or "mostly bad." This was quite different from the 1998 poll, in which $62 \%$ of Russian's viewed America as a friend. ${ }^{93}$

More direct use of force by NATO in Kosovo, under American consent, strengthened the link between rise of anti-NATO sentiments to rising discontent for America. For example, in 1999 Ogoniok journalist Aleksander Nikonov claimed, "I know a man who stopped riding his Ford in protest against "NATO aggression." 94 In a

\footnotetext{
${ }^{90}$ A. Somov, “'Za' I 'Protiv,”" Argumenty i Fakty, 26 November 1997, No. 48.

${ }^{91}$ Gennady Obolenskii, "Ne Nado na Nas Davit'," Krasnaia Zvezda, 18 January 1997, No. 12-13.

92 Oleg Saveiliev, "Snova razlyubili SSHA, VTsIOM Press-sluzhba," Argumenty i Fakty, 20 April 1999, No. 16.

93 Ibid.

${ }^{94}$ Aleksander Nikonov, "Strannaia Voyna," Ogoniok, 1999, No. 15.
} 
discussion with Krasnaia Zvezda in October 1999, Colonel General of the Russia Ministry Defence spoke at length on the topic of American hegemonic goals, claiming that the imposition of a "puppet existence and suppression of independence... was clearly demonstrated by the aggression of the [NATO] bloc against Yugoslavia."95 Similarly to the Argumenty i Fakty editorial on the issue of Russia's potential accession into NATO, he emphasised that Russia wanted to improve relations with America in the name of collective security. He noted, however, that the "actions of the United States aimed at destroying the system of international norms and principles in the field of security, [and that] appropriating the right to decide for other states and entire regions" were limiting steps to improve relations. ${ }^{96}$ Arguing for the creation of an all-European collective security organisation, he attributed blame to American hegemonic goals within the European region to the formation of a robust $21^{\text {st }}$ century European security model. $\mathrm{He}$ claimed, "We reject the natocentric model, because we don't agree that a military bloc that is constantly strengthening its potential and expanding throughout Europe, arrogating to itself the right to act uncontrollably, should play a major role in the European security system."97

The Yugoslav conflict, and NATO's peacekeeping role within the region were characterised by many Russians as part of America's goal to seek power within the region. This was confirmed by America's decision to bomb Kosovo without consent from the UN Security Council. As acknowledged by A. Somov earlier on in this section, Russia's approval of NATO's eastward expansion could also result in NATO's involvement in Russian affairs. This remained a salient view, especially in the newspaper Argumenty $i$ Fakty. While this comment was made in view of the eastward expansion of the organisation, accusations started to arise regarding NATO's role in the breakdown of the Russian Federation. In January 1998, Argumenty i Fakty noted:

Information coming from Russian special services from a number of Arab countries suggest that after the collapse of the USSR, the United States and some other NATO countries, which for many years sought to destroy the Soviet Union and achieved this goal, now passed the baton onto their Muslim allies, especially

As is noted further on in the chapter, NATO was considered a synomyn for American hegemony. This therefore explains the man's refusal to drive the Ford.

95 Vitaly Stugovets, "V oboronnoy Politike Rossiia iskhodit iz prioriteta mirnykh sredstv obespecheniia svoey bezopasnosti," Krasnaia Zvezda, 27 October 1999, No. 229.

${ }^{96}$ Ibid.

${ }^{97}$ Ibid. 
fundamentalists, who work in the former union and republics and autonomous republics of the Russia federation, traditionally considered to be Muslim. The current long-term goal of the fundamentalists is the complete separation of Muslim regions from Russia. ${ }^{98}$

The statement promoted by Argumenty $i$ Fakty suggested that NATO was supporting Chechen separatists in their desire for independence from Russia. This is particularly interesting. Since NATO was supporting separatist movements within Yugoslavia, the claim was not unreasonable but highlighted the level of distrust that the Russian public and media felt towards the organisation. This rumour clearly had strong currency within the public domain. In 1999 Aleksander Nikonov of Ogoniok, in confusion over Russia's reaction towards NATO's intervention in Yugoslavia also contemplated the very same idea. He questioned "Perhaps they are afraid that following the restoration of order in Kosovo, NATO will climb out to sort out Chechnya and bomb Russia?"99 State Duma member Colonel General Edvard Vorobyev, when questioned by Argumenty i Fakty in March 1999 on whether Russia should have used force against NATO in the context of Yugoslavia, suggested that showing force would only provoke NATO. However, he did confirm that there existed serious rumours. He stated:

They say that the Yugoslav [situation is a] training ground, [and that] NATO is working out a scenario of possible interference in Russia's internal affairs. But I still think that NATO will never allow itself to bomb Russia, for example, because of Chechnya, [in the same way that] today Yugoslavia is [being] bombed because of Kosovo. As long as we have nuclear weapons, aggression does not threaten us. It seems to me that Russia is now even more afraid than during the Cold War. Then they feared our strength, now unpredictability. ${ }^{100}$

Vorobyev's account showed that Russian militarism was not totally formed by insecurity on the basis of arms, and even exposed a deeper siege mentality beyond the physical state of the Armed Forces. Rather, it was through creating and perpetuating stories of threat. These stories encouraged continued cultural militarisations, even when Russia had weapons capable of fighting back. In March 1999 Sergei Kuznetsov and Lyudmila Proshak, of Argumenty $i$ Fakty, noted that a positive outcome of NATO involvement in the Yugoslav conflict was that it would legitimise Russia's need for a

\footnotetext{
98 “Terror bez granits," Argumenty i Fakty, 28 January 1998, No. 5.

99 Nikonov, "Strannaia Voyna."

${ }^{100}$ Vitaly Tseplyaev, "Pugat' Ameriku sebe dorozhe?" Argumenty i Fakty, 3 March 1999, No. 13.
} 
strong military. They stated that, "It [would become] clear even to the most ardent pacifists that Americans can only respect force. Therefore, our people will now treat with understanding the additional hardships and will not regret the money for high-precision heavy-duty weapons."101 The view that NATO would use Yugoslavia as a practice for later invasion of Russia was not only held in the minds of Russians. Only a month later, in April 1999, Igor Popov and Boris Muradov wrote of their experiences in Yugoslavia. They came across numerous café workers who gave them food for free and joked that Russia should give them weapons. They claimed:

We tried to object: don't you understand that if Russia provides military assistance, then a Third World War is inevitable?

The answer was: "The NATO operation is a dress rehearsal of a strike against Russia, there is always a reason to take at least the same [approach to] Chechnya. If you don't intervene now, they will make sure that you are afraid of them and will try to completely ruin and crush Russia! " Controversial, but very common in Yugoslavia judgment. ${ }^{102}$

The view that NATO was using Yugoslavia as a "dress rehearsal" for a future attack on Russia was a dominant theme in Russia's media. First, it showed that Russia's public deeply distrusted NATO. More importantly, however, it emphasised the narrative that Russia was continuously vulnerable to outside threat. The view was not held by all Russians as noted in articles of Ogoniok and by Edvard Vorobyev, but the discourse was out there, within the public sphere. These threats added to those already in circulation on neighbouring conflicts in the FSU and with the situation in Chechnya. ${ }^{103}$

101 Sergei Kuznetsov and Lyudmila Proshak, "Komu voyna, komu - mat' rodna?" Argumenty i Fakty, 30 March 1999, No. 13.

${ }^{102}$ Igor Popov and Boris Muradov, "Za fasadom Balkanskogo krizisa," Argumenty $i$ Fakty, 7 April 1999, No. 14.

103 The term conspiracy mentality best explains the emergence of the viewpoint that NATO's actions in Kosovo were a dress rehearsal for NATO's eventual role in Russia and Chechnya. As noted by Boban Petrović at al., conspiracy theories, and therefore a conspiracy mentality is adopted when people "attribute significant events to the intentional actions of ill-intentioned mean-intending groups of individuals who are sufficiently powerful to carry out the suspected conspirational act." This mentality usually arises during a period of societal crisis and effects relationships between two groups, gaining momentum when a less-likable and more threatening group is present. In 1990s Russia, Chechen independence threatened the territorial integrity of the Russian Federation. In their aim to gain independence, some Chechen separatists adopted terrorist tactics; owing to a growth of societal narratives in Russia that Chechnya was motivated by Islamic fundamentalism. NATO expansionism, and its subsequent role in the 
The media had an important role to play in sustaining the militarisation of public discourse. While not outwardly pro-war, or pro-military, it was in agreement that Russia was vulnerable to new threats in the post-Cold War world. NATO's expansion caused concern for Russia as it encroached on its borders. Without assigning an equal voice to Russia in post-Cold War peace-building efforts, Russia felt largely isolated and threatened by its new secondary position in the world. The growth of NATO was seen as a growth of American hegemonic goals, with its denial of equal partnership with Russia, and ignorance towards UN approval in its role in Kosovo, confirming its powerful role in the new world order. Anti-NATO discourses in the media had a profound impact on public opinion during this period, as shown throughout the section, the public responded to NATO aggression with the boycotting of American goods and in letters to the editor, highlighting their discontent towards the organisation. Public opinion polls even confirmed a change in attitude towards Americans, especially after the bombing of Kosovo. Narratives on NATO's role in Yugoslavia as a practice for intervention in Chechnya highlighted that Russia still deeply distrusted NATO, and felt threatened by its role in neighbouring countries. It did however, also allow the media to legitimise the use of public funds towards the maintenance of the military sector and for strengthening military capabilities and ties among the CIS. Most of all, the media sustained the topic of war in the public domain, and maintained the idea of external threats in public consciousness.

\section{The threat in Chechnya}

Chechnya dominated headlines in the 1990s Russian newspapers. This was expected, since Russia and Chechnya's turbulent relationship reached a pinnacle, when the First Chechen War started in 1994. Russia and Chechnya's volatile relationship was

\footnotetext{
Yugoslav conflict threatened Russian power in the region. In response, a number of conspiracy theories arose, villifying Russia's opposition and adding to the deep-rooted societal discourses of Russia's vulnerability. The conspiracy mentality helped fuel the siege mentality, keeping Russia's society aware of the number of threats facing the country. In addition, NATO's participation in the Yugoslav war was a direct example that the media and government could latch onto, in order to strengthen distain for the alliance. For more, please see: Boban Petrović, Janko Mededović, Olivera Radović and Sanja Radetić Lovrić, "Conspiracy Mentality in Post-Conflict Societies: Relations with the ethos of conflict and readiness for reconcilliation," Europe's Journal of Psychology 15, No 1 (2019): 59-81, https://doi.org/10.5964/ejop.v15i1.1695.
} 
historical. Tensions arose under Tsarist leadership and into the Soviet period when Stalin banished many ethnic Chechens to Kazakhstan, concerned they had collaborated with Nazi Germany during the war. ${ }^{104}$ The tension was caused by Chechnya's desire to gain independence from Russia. Opportunity for independence arose during the collapse of the Soviet Union, when other Soviet satellite states sought autonomy. Chechnya lobbied for self-determination, establishing the Chechen Republic of Ichkeria. In retaliation, Yeltsin sent troops into Chechnya on the $10^{\text {th }}$ November 1991, but his plans were quickly thwarted as pro-independent Chechen nationalists surrounded Russian troops in Grozny airport. ${ }^{105}$ Yeltsin decided to formally invade the region in 1994 to maintain the territorial integrity of Russia and combat Chechen lawlessness.

Response to this war differed to previous conflicts, because a new 'free' media existed. ${ }^{106}$ Media coverage of the war was conflicting, as some media outlets held a more critical view to the official line of the state. Such criticism would resonate with a public that was still coming to terms with the disaster of Afghanistan. This contradiction, however, could also be considered a blessing to the government. Critical evaluations of the conflict were embedded within some of the boundaries and discourses established by the government. First, those against Russian intervention did acknowledge Chechen lawlessness and banditry. Second, government officials, for the most part, publicly advocated peace and emphasised their participation in the war as forced upon them and ultimately necessary - these discourses were reflected in a number of newspapers. Finally, the media helped promote an image of chaos and instability, showcased through depictions of harmed Russian and Chechen residents under Dudaev's leadership and uncontrolled bandits and terrorists. The next section focuses on the chaotic and contradictory representation of the Chechen crisis in Russian newspapers. The remaining sections unpack and analyse two sub-narratives or in this case tactics of the media. This includes the actions of Russia's power institutions (including the state and military) and

${ }^{104}$ Brian Glyn Williams, "Commemorating "the Deportation" in Post-Soviet Chechnya: The Role of Memorialisation and Collective Memory in the 1994-1996 and 1999-2000 Russo-Chechen Wars," History and Memory 12, No. 1 (2000): 104-106; Jeffrey Burds, "The Soviet War against 'Fifth Columnists': The Case of Chechnya, 1942-4," Journal of Contemporary History 42, No. 2 (2007): 303-307.

105 Ibid.

${ }^{106}$ In addition, Non-Governmental Organisations like Memorial launched studies into Russia's role in the First Chechen War, including investigations into the Samashki massacre (1995) 
the demonisation of the enemy; with Chechens most commonly framed in the media as bandits and terrorists.

When trying to understand events unfolding in Chechnya, Russia's readership faced major challenges. First, media accounts of the war were contradictory. This chaos was rooted in the new freedoms the media gained during the period of democratisation, and the confusing situation in Chechnya. Glasnost liberated the media. Consequently, for the first time in decades, the media's coverage was no longer limited to the government line. Instead the readership was actually offered a number of media accounts. While the conflicting accounts were largely a result of the newspaper's standpoint, journalists were also trying to write about a conflict they considered just as confusing as the conflicting discourses. In November 1994 Pravda reporter, Nikolai Kozhanov, stated, "It is not easy for even the sophisticated reader to understand the kaleidoscope of controversial reports about the events in Chechnya." 107 Questions by key newspapers asked, "But did the troops invade Chechnya by orders?" and "With who [does Russia] fight in Chechnya?" highlighting little understanding of the initiation and development of the Chechen conflict. ${ }^{108}$ Even leaders from outside Russia struggled to comprehend a situation that they described as messy. ${ }^{109}$ Newspapers at the time, for example, Kommersant, decided to reserve sections of their newspapers to the situation in Chechnya. Other newspapers like Ogoniok dedicated segments of the magazine to the theme of the "Armiia," providing a broader analysis of the Army's actions. The main priority was to initially understand why Russia had decided to intervene in the region.

According to the media, Russia's desire to maintain power in the region was the most important factor leading to its intevention. Russia lost a lot of Soviet territory during the collapse of the Union - however, this separatist movement now threatened Russia's borders. Chechen sovereignty had the ability to motivate more independence bids from other Russian regions like Tatarstan. The official reason for Russia's intervention in the

\footnotetext{
${ }^{107}$ Nikolai Kozhanov, 'Grozhnyi: Razrushaem, potom budem stroit' - I vse za schet Rossiiskogo Byuzheta," Pravda, 10 November 1994, No. 3.

During the early 1990s, Pravda was defined as a conservative-nationalist newspaper. In 1997, it became an official mouthpiece of the Communist party.

108 Victor Zortkal'tsev, “Est' u tankov zadnii khod?" Pravda, 20 December 1994, No. 235.

"S kem voyuem v Chechne?" Ogoniok, August 1996, No. 34, 12-13.

${ }^{109}$ Pontis Siren, "The Battle of Grozny: The Russian Invasion of Chechnya, December 1994-1996," in Russia and Chechnya: The Permanent Crisis: Essays on Russo-Chechen Relations, ed. by Ben Fowkes (London: Springer Link, 2016), 87-88.
} 
region was as a necessary protection of its territorial integrity. ${ }^{110}$ In December 1994 Yeltsin justified the militaristic venture by claiming the soldiers were "defending the integrity of Russia." 111 Government action on this basis was supported by other political figures, like Mayor Luzhkov. In August 1995, Luzhkov sent Yeltsin a telegram of support. The telegram said:

The Moscow government received with great satisfaction the decision of the Constitutional Court of the Russian Federation, which confirmed the constitutionality of the decrees you adopted to stabilize the situation in the Chechen Republic. The decrees are the guarantor of the unity of our great Russia and warn [against] all kinds of adventurers to play the nationalist card to satisfy personal ambitions. Dear Boris Nikolayevich we assure you that multinational Moscow, as the capital of the Russian Federation - it will always do everything it can to ensure that there is always peace and prosperity in the vast expanses of our country. ${ }^{112}$

Luzhkov backed the government's decision to enter Chechnya. By offering his unwavering support to ensure "stability" and "peace" in all areas of Russia, Luzhkov indicated that there was instability and conflict currently in the region. Second, Luzhkov also reaffirmed Russia's position in the Chechen War - as the peacekeeper. Various media reports in this chapter outline Russia's purpose in Chechnya, to establish law and order, bring about peace and stability; Luzhkov's telegram supported this. In addition, and more subtle, Russia's military role in Chechnya was a gesture. It acted as a symbol to other Russian regions hoping to achieve independence - Russia would use military force to ensure territorial integrity, stability and peace. Luzhkov's statements were supported in the media.

According to many Russian newspapers of the 1990s, and in political speeches, Chechens were lawless, criminals, terrorists and bandits. These reports moved society towards militarisation by helping fostering a 'besieged fortress mentality' through threatening images of conflict, instability and insecurity. They used 'othering' techniques to unite Russians under a common enemy. States and institutions commonly use 'othering' techniques to produce and promote dangerous worldviews. In 1990s Russia,

${ }^{110}$ Ibid, 96-97.

111 "Excerpts from Yeltsin Speech on Chechnya With PM-Russia-Chechnya, Bjt," The Associated Press, 28 December 1994, accessed 21 January 2019, https://apnews.com/40b126a5acf44c58e82ab6d6cd3997b2.

Tracey German, Russia's Chechen War (London: Routledge, 2003), 128-129.

112 Yeltsin Centre, f. 6, op. 1, d. 175, 1. 20, 1 August 1995. 
territorial issues underscored the issues in Chechnya. At this point, Russia was in no position to lose more territory. When Chechnya first voted for independence in 1991, Russia attempted to oppress the separatist movement in order to defend its territorial integrity. However, this mission failed when Chechnya sent Russian soldiers out of the Chechen region on a bus to Vladikavkaz. Russian military operations were carried out without public knowledge. In order to overcome the humiliation of Russia's first action and formally invade in 1994, society needed to be convinced that military action was necessary. While not pro-war, Russia's media brought the Chechen issues to the forefront of public consciousness, reaffirming discourses outlining internal crises, instability and imminent threat. Similar to earlier accounts on the Yugoslav media's reporting of the war in major cities, where society never really experienced the realities of war, the media ensured that Russians were subjected to these discourses. Russian society was therefore exposed to, what Åhäll calls, the idea of war. ${ }^{113}$ In addition, the media used 'othering' techniques to create particular images of the Chechen people, in an attempt to heighten aspects of the chaos in the region. It helped justify military action in the region, as it dehumanised the Chechen population and promoting Russia's role as a cause for establishing law and order.

While Chechen lawlessness and criminality was reported in the media, it was also a common attribute of political speeches concerning the conflict. For example, in December 1994, Yeltsin claimed:

Russian troops and policemen are on the front lines of the fight with the most dangerous, powerful and rabid forces of Russian and international criminals and extremists. With lies, with playing on patriotic and religious feelings, with threats, those forces managed to drag a part of the local people into this fighting. Among those who offer resistance are professional terrorists and mercenaries from other states. $^{114}$

Numerous media outlets started a campaign against the Chechen people in an attempt to mobilise Russian society against Chechnya. First, they drew connections between the Chechen separatists and terrorists, lawless bandits and criminals. Not all Chechens were regarded this way, but generalisations did occur. The media and the state were careful to include representations of peaceful Chechens that the Russian government

113 Åhäll, “The Dance of Militarisation,” 12-13.

114“"Excerpts from Yeltsin Speech on Chechnya." 
was also protecting. An article in Pravda in September 1994 best demonstrated this boundary. It stated that an agreement to solve the Chechen problem in a democratic election was met by the "armed provocative actions" of the Chechen leader Dudaev who began using military equipment against "peaceful citizens." ${ }^{115}$ Pravda echoed this discourse in April 1995. The article confirmed:

Of course, not only Russians, but also Chechens suffered from terror and lawlessness during the reign of Dudayev. Salambek Khadzhiev writes: "When on June 4, 1993, a peaceful demonstration in Grozny was shot at from Dudayev's cannons and 58 people were killed, we turned to many people for help, including Kovalev. When in August 1994 the militants killed about 260 people in [Urus] Martan, we also appealed to Moscow and to Sergei Adamovich. We did not hear [back]. "116

Dudaev's provocative actions, as displayed in the media, helped Russia legitimise using force in the region. The media's depiction of Chechen lawlessness as an action promoted by higher-ranking officials of the Chechen region helped cement this image of an oppressor leading an oppressed nation. As noted by Gennady Selenev, for example, Chechen society was overwhelmed by Dudaev's calls to mobilise against Russia and to send terrorists to Russia. ${ }^{117}$

Other examples of the media's depiction of lawlessness from high-ranking Chechen elites are documented here. Dudaev's regime was described as a "criminal separatist regime," "Criminal fraternity" and as "gangs." 118 These phrases not only refered to Dudaev and his team but also to the gangs that formed to counter Russia's "act

115 Gennady Selenev, "Ruslan Khasbulatov: V oppozitsii k razhimu Dudaeva vse chechenskoe obshchestvo," Pravda, 22 September 1994, No. 174.

Gennady Selenev (1947-2015) was a Russian politician and Chairman of the State Duma (1996-2003). He had a background in journalism and started working for Pravda in 1969. Selenev was a member of the Communist Party of the Soviet Union/ Russian Federation and regularly spoke in opposition to Boris Yeltsin.

${ }^{116}$ Igor Shafarevich, "Voyna Vyigrana. Chechnia Proigrana?” Pravda, 13 April 1995, No. 68. Salambek Khadzhiev (1941-2018) served as the Chairman of the Government of the National Revival of Chechnya between 1995 and 1996.

117 Ibid.

118 “Chechnya: Trudnyi Vybor Kremlia (Ekspress-analiz nedeli)," Izvestiia, 10 December 1994, No. 234.

"Vmesto novgorodnikh podarkov v detskie ladoni lozhitsia smert - chechenskii uzel vse tyzhe," Pravda, 20 December 1994, No. 235,

"Situatsiia v Chechne," Kommersant, 26 August 1994, No. 160. 
of aggression." ${ }^{119}$ In an October 1995 article by Izvestiia, Dudaev confirmed that there was an increasing amount of rogue battalions. They were characterised in the media as "small, uncontrolled detachments of militants." This played positively into the hands of the Russian government, since the recognition supported the view of the Russian state that militant activity and lawlessness in the region was increasing. ${ }^{120}$ In June 1995 Yuri Baturin, Presidential Aide for National Security, wrote for Izvestiia, stating that, "People are tired of chaos, devastation and criminal lawlessness." ${ }^{121}$ In April 1995 Igor Shafarevich, who documented his experiences of visiting Chechnya in a small delegation, illustrated further examples of Chechen lawlessness. ${ }^{122}$ He noted the mass expulsion and torture of the Russia population, using testimonies taken by witnesses in the region. In general accounts, Chechen bandits would "burst into Russian houses" pressuring the Russian occupants to sell their houses by beating them up and [sometimes] murdering family members. An individual testimony taken from a Chechen refugee, stated:

According to a refugee from Grozny, at the end of December a group of Chechen fighters broke into the boarding school where she worked as a teacher. Both Russian and Chechen children were in the boarding school. The bandits raped all the children and the entire staff of the boarding school, including the storyteller. ${ }^{123}$

Also in the same article was a letter from a Russian Cossack who confirmed the explusion and killing of Russian people. It said:

The killings of Russian people occur every day. Morgues in Grozny are overflowing with corpses, many of which have been disfigured. Identified corpses are taken by relatives, if found. The rest are buried without coffins in common trenches. ${ }^{124}$

The media's representation of Chechen lawlessness and brutality, to both the Russian and Chechen population, helped create a chaotic image of the conditions in Chechnya. While not promoting military action, the media fostered notions of insecurity

\footnotetext{
119 "Chechnya: Trudnyi Vybor Kremlia (Ekspress-analiz nedeli)."

${ }^{120}$ Igor Rotar, "Chechniia: Davniaia smutab sobytiia v respublika budut razvivatsia po alzhirskomu variant," Izvestiia, 27 October 1995, No. 204.

${ }^{121}$ Yuri Baturin, "Moskva-Groznii: Nuzhny kompromissy, na voprosy," Izvestiia, 24 June 1995, No. 115.

${ }^{122}$ Igor Shafarevich (1923-2017) was a famous mathematician and soviet dissident. In the post-soviet period he created the National Salvation Front and ran unsuccessfully for the State Duma in 1993.

${ }^{123}$ Shafarevich, "Voyna Vyigrana. Chechnia Proigrana?"

${ }^{124}$ Ibid.
} 
and threat to Russian livelihood by focusing on the lack of law and order, which formed the basis for Russian militarism during this time. Yet, while the Chechen population was mainly targeted in these discursive attacks, the Russian military did not escape criticism either. In October 1995, Izvestiia reported on the Samashki Massacre of 1994, which saw Russian paramilitary troops ambush and murder civilians in Samashki. ${ }^{125}$ The story was especially gruesome as it speculated that those who carried out the massacre did so under the influence of drugs and alcohol - highlighting the barbaric actions of the Russian military. ${ }^{126}$ Sergei Kovalev, of Memorial, addressed US congress. ${ }^{127} \mathrm{He}$ outlined the details of the Samashki massacre. In May 1995 Izvestiia reported on his presentation, where Kovalev claimed:

I have just returned from the Chechen Village of Samashki, where more than a hundred of its inhabitants were killed during the punitive expedition and many houses were burnt to the ground. ${ }^{128}$

Claims of "punitive action" were echoed by refugees of Samashki, representatives of S. Kovalev's group, and by State Duma deputies, who noted "real punitive action was carried out against Samashki." 129 The phrase punitive, defined as cruel and severe, created an image of Russian federal troops using unjust force on the residents of Samashki.

Further reports strengthened media discourses outlining the Russian forces unprofessionalism in the region. On the topic of Sergey Kovalev's presentation to the US congress, America's Congress was also in the possession of articles from The Sunday Times. Izvestiia (May 1995) reflected on the content in this article, entitled, the "Massacre in Samashki." Samashki was a result of the "atrocities of the drunk, drug-filled soldiers who invaded the village. There were 3,000 armed men against the defenseless civilian population." 130 This was apparently not the first and only time that the Russian internal

\footnotetext{
${ }^{125}$ Rotar, "Chechniia: Davniaia smutab sobytiia."

126 Ibid.

${ }^{127}$ Memorial is a Non-Governmental Organisation aimed at protecting human rights. Founded in 1987 in Moscow, it is committed to sharing the experiences of those facing repression and protecting the Russian peoples human rights. They were opposed to the First Chechen War.

128 Vladimir Nadein, "Sergey Kovalev - Kongressu SSHA: Chechenskaia Voyna Ozhestochla nashe obshchestvo," Izvestiia, 4 May 1995, No. 81.

${ }^{129}$ Valery Yakov, "Samashki: Aktsiia na Ystrashenie," Izvestiia, 18 April 1995, No. 71.

${ }^{130}$ Nadein, "Sergey Kovalev - Kongressu SSHA."
} 
forces were accused of using force whilst inebriated. Local residents in Chechnya noted "drunken soldiers of the internal troops and riot police" when having fun, "fire in all directions as soon as they think [that] something [is] suspicious." ${ }^{131}$ News of Russian Federal Forces using unnecessary force against the Chechen nation went beyond Samashki. Examples of barbaric actions by the Russian Armed Forces were emphasised by Alexei Chelnokov of Izvestiia in December 1994. After interviewing two female Ingush refugees, he found that Russian soldiers raped and killed Ingush in the Prigorodny district. He wrote:

I was traveling from Karabulak with other fellow travelers - two Ingush women refugees from the Prigorodny region of North Ossetia.

- Why did the Russian soldiers come to Chechnya? Why are they trying to shoot at refugees, peaceful people, - the younger one is indignant. - We do not believe Yeltsin; we do not trust the Russian army, especially after what it did in the Prigorodny region. They are responsible for the raped and murdered Ingush. ${ }^{132}$

These media discourses documented Russian brutality against the Chechen community. However, they were contradicted on many fronts. First, and in reference to the massacre in Samashki, media reports suggested that there was a media blackout, with journalists being unable to gain access to the village. Nikolay Gritchin of Izvestiia in April 1995, noted, "At a post of Russian internal troops near the outskirts of Samaski, our car was stopped. The officer carefully examined my editorial card and stated that a special Grozny accreditation was needed to travel to this village... what caused the special travel conditions for journalists?" 133 The journalist's inability to gain access to Samashki was one problem. The second problem was the journalist's ability to acquire information, which relates to the controversy and confusion over the timeline and happenings of the event. A journalist who visited the village of Samashki wanted to find answers to the following question, "What happened in the village after all - the bloody massacre or the pacification of the resisting Dudayev militants?" 134 Valery Yakov emphasised the difficult conditions presented to journalists wanting to gain more information. He stated,

${ }^{131}$ Valery Yakov, "V Groznom Solntse, Vesna I strel'ba," Izvestiia, 25 April 1995, No. 76.

132 Alexei Chelnokov, "Cherez Chechnyu-Avtostopom, spetsialnyi correspondent 'Izvestiia,", Izvestiia, 24 December 1994, No. 247.

${ }^{133}$ Nikolai Gritchin, "Po Samashkam ogem I mechom," Izvestiia, 18 April 1995.

${ }^{134}$ Yaroslav Shimov, "Samashki: Zhizn'na peplishche," Izvestiia, 25 April 1995, No. 76. 
"Every day the information about what actually happened in the Chechen village of Samashki, through which the fiery roller of the federal troops rolled, becomes more and more contradictory." 135

In this sense, Russia's free media lost opportunities because of Russian militarism. While the reports show that the media initially had some freedom over reporting, increasing criticism within the press pushed the state and military institution to restrict media access to key sites, like Samashki. It showcased a prioritisation of the government's military goals and ambitions, over the democratic freedoms of the media. Krasnaia Zvezda journalists ultilised the contradictory claims and converging stories to establish key dominant discourses. These discourses echoed the state line. In April 1995, for example, Krasnaia Zvezda contradicted reports of Russian brutality in its aim to correct the "lightweight conclusions" of reporters on the issue of Samashki. They did this by highlighting the exaggerations of journalists and non-governmental organisations like Memorial. For example, they criticised the comparison made by reporters, which linked the devastation in Samashki to Coventry and the Katyn. ${ }^{136}$ The author of the article dismissed the comparison by referring to Samashki as an "unremarkable Chechen village," and downplaying the comparison by noting that justification for such comparisions "was hardly worth mentioning." 137 Other media outlets also noted false and exaggerated reports in the field. Yaroslav Shimov noted that the devastation in Samashki was not as extensive as previously thought. He wrote:

Before the war, about 12,000 people lived in Samashki. The village is large; there are more than a dozen streets in it. Several central ones were destroyed. These streets give about the same impression as the destroyed quarters of individual buildings in Grozny: there is practically not a single surviving building, there are traces of bullets on the walls, and several houses were left without roofs. Apparently it was on them that artillery fire was fired. There are very few such buildings, so one can hardly speak of a massive shelling of Samashki by Russian artillery. ${ }^{138}$

\footnotetext{
135 Yakov, "Samashki."

136 “'Stanislav Govorukhin predlagaet privech' S. Kovaleva I K k otvetstvellosti za klevetu," Krasnaia Zvezda, 21 April 1995, No. 89.

The references to Coventry and Katyn refer to the devastation caused during World War Two to Coventry and the massacre of Polish Soldiers in a Forest in the Katyn.

${ }^{137}$ Ibid.

${ }^{138}$ Shimov, "Samashki."
} 
Krasnaia Zvezda questioned the integrity of Memorial by associating them with Dudaev's regime. On the topic of Stanislav Govorukhin's desire to sue Memorial leader Sergey Kovalev, the author noted that those working for Memorial were sympathetic to the Dudaev regime. ${ }^{139}$ Finally, the actions taken in Samashki were justified as a result of militants not meeting an ultimatum deadline. In April 1995, Krasnaia Zvezda noted that militants in Samashki were given an ultimatum to "voluntarily surrender their weapons." ${ }^{140}$ Actions against the militants were considered a "success" by the newspaper. It claimed, "More than 130 Dudaevites were killed, 124 were taken prisoner." ${ }^{141}$ In this sense, the actions that took place in Samashki were legitimised as a form of punishment delivered to militants that were warned in advance.

While the media raised stories of Russian brutality, representations were within the boundaries of the First Chechen War. State and Military leaders were challenged about the military's role in the region and Russian brutality was justified as a result of their suspicions of militant activity in region. In an expose on the Budennovsk crisis, for example, although the overall portrayal of Russian force in response to the hostage crisis was negative, questions were directed towards leaders like Federal Security Minister Sergei Stepashin. In contrast, general troops were described as those "whose nerves cannot withstand the strain...[who] start an assault without an order, spontaneously." 142 In contrast, Chechen's were portrayed as culturally criminal, as if their militancy was a way of Chechen tradition and heritage. Stories on blood feud and teip culture in Chechnya helped cement the notion that Chechnya's militancy was further ingrained in its heritage. ${ }^{143}$ Shafarevich in April 1995, for example, while noting the woes of Chechen population at the hands of Dudaev, claimed they were "still protected by the support of their teip, by the threat of bloodshed." ${ }^{144}$ In addition, difference in laws also drove media

\footnotetext{
${ }^{139}$ Stanislav Govorukhin (1936-2011) was a prominent Soviet and Russian film director, turned political figure. In 1993 he became a member of the State Duma, and was supportive of Boris Yeltsin in the 1996 Presidential election.

140 "Chechnya: Nashi Voyska uspeshno zavershili operatsiyu v rayone Smashek," Krasnaia Zvezda, 11 April 1995, No. 80.

${ }^{141}$ Ibid.

${ }^{142}$ Irina Dementieva, "“Ne meshayte rabotat', g-n gubernator," Izvestiia, 20 June 1995, No. 111.

143 “U detei voiny pal'tsy pokhozhi na kurok," Novaia Gazeta, 24 June 1996, No. 23.

144 Shafarevich, "Voyna Vyigrana. Chechnia Proigrana?"

A teip is a Chechen and inguish tribal organisation, referred to also as a clan or gang.
} 
discourses. For example, journalist Galina Kovalskaya documented implementation issues with the December 1994 peace agreement. She wrote:

It is impossible to seize weapons from the Chechen population, for all the lawlessness of such a situation; it will have to be reconciled. It's more important that there is no temptation to use these weapons again against Russian soldiers and against their fellow tribesmen, declared "collaborators." The symbolic acts of surrendering and burning weapons here play the role of a kind of ritual of reconciliation - about the way the Indians stuck their tomahawks into the ground. ${ }^{145}$

Similar to previous descriptors, noting the tribal/ clan heritage and ritual of the Chechen population, this assessment by the author furthered the notion that militancy was central to a Chechen's culture. Descriptions of Chechens as lawless and bandits also emphasised the division between the Russian and Chechen identities, and built on the idea that the Chechen people were the 'other.' Linda Colley argues that emphasising otherness in the British context, invoked exaggerated feelings of nationalism. In the Russian case, 'othering' helped mobilise and unify Russian citizens behind a feeling of "Russianness." ${ }^{146}$ In doing so, it helped promote Russian militarism, by 1) establishing that there was an issue of Chechen lawlessness and militancy to deal with, and 2) internal chaos and crises threatened the stability of Russia. While Russian military leader's actions were questioned, the troops' role was legitimised by their nerves.

$\mathrm{CDA}$ is of particular value in debates like the ones above, whereby the political and social orientations of the media outlets diverge. Vladimir Olegovich Potanin owned Izvestiia in the Post-soviet period and had close links with the government. Yet, even with these links Izvestiia still questioned the political decisions and events in Chechnya and reported on the brutality of Russian soldiers in the Chechen region. In contrast, Krasnaia Zvezda, the newspaper of the MOD, defended the actions of the military in Samashki. They framed the decisions taken by Russian soldiers as necessary and ones carried out with sufficient warning. CDA highlights the diverse representation of events in Chechnya, taking into consideration the ideological background of the media outlets. The news reports of Krasnaia Zvezda, as a mouthpiece of Russia's military, worked towards

145 Galina Kovalskaya, "Khuzhe mozhet byt' tol'ko voina," Ogoniok, 10 February 1995, No. 40.

${ }^{146}$ Linda Colley, "Britishness and Otherness: An argument," Journal of British Studies 24, No. 4 (1992): 311. 
creating a positive image of the Armed Forces and legitimising their role in the Chechen War and in the broader Russian society.

The descriptions above alongside increasing terrorist activities in Russia by Chechen militants further justified the case for a military response in the region. In the media, Chechens were widely depicted as terrorists, with attacks of an insurgent nature being blamed on the ethnic group. The actions of Chechen militants also became increasingly associated with professional terrorist groups beyond Russia's borders. As noted in Yeltsin's December 1994 speech, those working on Dudaev's team were also "professional terrorists and mercenaries from other states." ${ }^{147}$ In a number of newspapers, it was noted that terrorists from the Eastern World beyond Chechnya were joining the war in opposition to Russia. These stories only added to the pre-existing discourses that Russia remains vulnerable to numerous domestic and international threats.

Increasing emphasis on the Chechen as a terrorist, and terrorist attacks at the hands of Chechens, allowed for generalisations to occur. An increasing number of terrorist attacks were reported in the media. In November 1994, Ogoniok reported on a terrorist attack that took place in Stavropol Krai in July 1994, whereby witnesses recounted stories of Caucasian men wearing black masks as the perpetrators. ${ }^{148}$ The Budennovsk hospital hostage crisis (another terrorist attack in Stavropol Krai in 1995) included an attack on a hospital, police station and government buildings in Budennovsk, which saw the taking of hostages in exchange for the withdrawal of Russian troops in Chechnya. ${ }^{149}$ The event was condemned by Dudaev, which reaffirmed notions of criminality and lawlessness in Chechnya beyond his regime. Emphasis on stories linked to terrorism went beyond the widely known events of Budennovsk and towards smaller attacks on transport vehicles on Russian soil.

The increase in terrorist acts on Russian territory was addressed in the same October 1995 Ogoniok magazine, where Yeltsin released a report highlighting the increase in terrorist activity and provided potential strategies for the removal of such threats. The report stated, "Various forms of violence are increasingly being used as a

\footnotetext{
147“"Excerpts from Yeltsin Speech on Chechnya."

148 “Terrorizm: Igry Diletantov," Ogoniok, November 1994, No. 46-47, $20-25$.

${ }^{149}$ Rotar, "Chechniia: Davniaia smutab sobytiia."
} 
means of gaining power, exerting political pressure and intimidation." ${ }^{\text {"150 }}$ The report's release was an extremely clever tactic utilised by the government as it provided a detailed and factual account of the numerous terrorist incidents that had taken place in Russia since the demise of the USSR. In addition, as experts wrote the report, any claims made by the government, which may have been seen previously as ideologically loaded, were strengthened. CDA affirms that the voices of powerful people are important in establishing and favouring certain discourses in society over others. In this case, the report added legitimacy to the statements made by the government, because it was a product of research conducted by specialists (or experts) and presented the data through the media.

The representation of Chechens as terrorists, criminals and bandits was highly problematic. Writing for Ogoniok in December 1994, Elena Berezina discussed her experience on a bus in Stavropol Krai, titled "Don't want to be Armenian!."151 Berezina described the impact that blame had on the Chechen community as a whole. She stated that the mention of Chechnya and the Chechen people produced a change in expression and the statement "Chechens are not liked here." 152 Berezina used her voice to highlight the danger of generalisations. She questioned how easy it had been for the public to "indiscriminately condemn the whole [Chechen] people for the guilt of a handful of unbundled rifles?" 153 The experiences of Berezina demonstrated only a small glimpse of the impact the media had on demonising the Chechen population. When questioned by Argumenty i Fakty journalist Natalya Zhelnorova in January 1996, Anatoly Pristavkin supported this notion. ${ }^{154}$ She questioned him on the image of a Chechen as a thief or bandit as painted by General Barsukov, head of the Federal Security Service of the Russian Federation (FSB). Asking whom Barsukov was referring too, Pristavkin stated:

The image of the "evil Chechen" was created for a long time. But when I met these people, I was convinced that it seems impossible to break the stereotype and legend. And rarely does anyone try to analyse. There are few of them. I lived in Chechnya. And I met Victory Day in Kizlyar and made sure that they [the

\footnotetext{
${ }^{150}$ Ibid.

${ }^{151}$ Elena Berezina, “Ne khochu byt' armianinom!” Ogoniok, December 1994, No. 48-49, 7.

152 Ibid.

${ }^{153}$ Ibid.

154 Anatoly Pristavkin (1931-2008) was a writer and academic. He was anti-Soviet, contributing significantly towards the writing of the Perestroika era. He initially supported Boris Yeltsin, later criticising the government for their actions in the First Chechen War.
} 
Chechen people] are very worthy, proud people. In their blood - veneration of the elderly, amazing politeness, patriotism towards their homeland, history. Yes, there are Abreks there, but these are not Chechens. ${ }^{155}$ Abrek is an outcast of society, he was expelled from his land, and he became very dangerous for the Chechen population. In general, the Chechen's image as assassins, bandits was cultivated throughout the last century, to morally justify the conquest of the Caucasus - so that people go to war, knowing that they are doing a holy work. ${ }^{156}$

Pristavkin's assessment is important for two reasons. First, he acknowledges that the Chechen nation has been generalised under the term "evil" and notes that the Chechen people he met did not reflect such a description - calling them polite and patriotic. The second interesting aspect of Pristavkin's interview was his acceptance that there did exist an evil component of Chechen society, this being the Abrek. These stories, while not supporting that the Chechen population should be referred to as terrorists, indicate that the Chechen population was widely associated with terrorism and banditry. Acknowleding the Abrek's existence helped strengthen militarised state discourses, which warned of internal instability, its threat to Russian livelihood and promoted a state of continued mobilisation.

The association of Chechens as terrorists, and lawless bandits was further emphasised through the media's investigation of Chechnya and its connection with the act of "blood feud." Blood feud is the act of revenge, acted upon when a member of certain families or political faction is murdered. In relation to Chechnya, the war with Russia had created such a divide in society that even if Russian troops decided to withdraw, the fighting between the Dudaevites and "traitors" would continue (on the basis of "blood feud"). ${ }^{157}$ An article in Novaia Gazeta in June 1996, discussing the implications of war on children, emphasised the idea of "blood feud" by stating,

With the outbreak of hostilities, the number of affected children is growing. There are disabled children, orphans, refugee children in Nagorno-Karabakh, Abkhazia, Georgia, South Ossetia, Budennovsk, Chechnya ... Doctors from these longsuffering places and physicians detect post-traumatic disorders [in children] associated with military operations. Children are afraid of loud noises, expecting bombing and shelling, experiencing the loss of loved ones or relatives or fear of the loss in their future.

\footnotetext{
${ }^{155}$ Abrek is a phrase used to refer to the people of the North Caucasus before the invasion of Chechnya by Russia in 1817. It is now used in a derogatory way to describe a bandit. ${ }^{156}$ Natalia Zhelnorova, "Chechnya - otdushina dlia voennykh," Argumenty i fakty, 25 January 1996, No. 4.

${ }^{157}$ Rotar, "Chechnya: Davniaia smutab sobytiia."
} 
Studies have shown that this category of children has a need for revenge. One report noted that children from refugee families were very upset by the inability to participate in the war themselves with their fathers or older brothers. Such children subsequently have an attitude to live and act according to the laws of evil and violence, according to which, in their opinion, the world around them lives and exists. ${ }^{158}$

The article raised some important issues. Similar to scholarship on the rise of terrorism in the Middle East, it showed that there were deep-rooted issues associated with the invasion of Chechnya in Russia. For those children who lost family, it created an element of resentment, and as noted in the article, desire to seek revenge. While only occurring a short period after the First Chechen Conflict, another war erupted between Russia and the region in 1999 - showing that such invasions can set the scene for future conflict. It also notes that these children, who are suffering because of war, want to seek vengeance and will grow up "according to the laws of evil and violence," which may contribute to continued instability in the region. As noted by Igor Rotar in October 1995, "disarming the Chechen population in the near future is unrealistic." 159

The lawless, evil Chechen bandits were created by historical discourses, which underpinned Russia's tumultuous relationship with the region. 'Othering' was an important tactic used to ensure society's support for the war, whether financially or for the war to continue with little protest. One element of the demonising process is to dehumanise and vilify the enemy to such an extent that it reduces empathy towards them. ${ }^{160}$ Emphasis of lawlessness, violence and even acts of terrorism and its association with the Chechen people did that. It mobilised society against a common enemy, and helped justify what Russia was fighting for. It also played an integral role in strengthening the worthiness of the state's official justification, which was based on the notion that Russia's use of force would be carried out "to fulfil the objectives of restoring law and order." "161 These descriptions helped militarise society as they created a common enemy against which society should be pitted and fully mobilised. These tactics allowed for the

\footnotetext{
158 "U detei voiny pal'tsy pokhozhi na kurok."

${ }^{159}$ Ibid.

${ }^{160}$ Paul Fussel, Wartime: Understanding and behaviour in the Second World War (Oxford: Oxford University Press, 1989), 116.

Robert T. Tally, "Demonizing the Enemy, Literally: Tolkien, Orcs, and the Sense of the World Wars," Humanities 8, No, 54 (2019): Introduction, https://doi.org/10.3390/h8010054.

161 "Vmesto novgorodnikh podarkov v detskie ladoni lozhitsia smert.".
} 
continued militarisation of society in the 1990s and was a method adopted again by Vladimir Putin at the start of his Presidency and the Second Chechen War in 1999. With this in mind, and as highlighted above, the Russian government needed to guide its strategy towards ensuring peace and stability in the region and to nip lawless activity in the bud.

Discussions on the decision to go to war and the consolidation of peace were another feature of the media, highlighting a clear reluctance by society to continue a war. Decisions to go to war, for the most part, were described in the media as forced. Efforts to consolidate peace were defined more positively on the Russian side. As the conflict unfolded, society was fed messages about positive peace negotiations which acted as snippets of reassurance that the war would soon be over. In addition, it highlighted that the Russian state was actively involved in these peace negotiations and that their continuation in the war was not desired on a state level - reemphasising the ideas that Russia's involvement was forced and a last resort to the Chechen question.

Scholarship on the origins of the First-Chechen conflict paid particular attention to the tricky relationship between Russia and Chechnya. They suggested Russia's formal intervention in December 1994 was an outcome of tensions that began even before the collapse of the Soviet Union. A November 1991 article in Ogoniok stated that Chechen's were seen carrying weapons in case it was "attacked by Russia." ${ }^{162}$ An interview with Dudaev confirmed the normalisation of weaponry in Chechnya's everyday life. He stated, "I remembered a guy about seventeen or eighteen, who at a restaurant, waiting for dinner, turned a hand grenade on the table like a hard-boiled egg." 163 Dudaev acknowledged the rising tensions, claiming that threats to Chechen independence would force the redistribution of weapons, which were previously confiscated. ${ }^{164}$ By 1994 the tensions reached a tipping point, as Chechnya's political status remained under deliberation. ${ }^{165}$

In September 1994, Gennady Seleznev from Pravda stated, "All August there were peace talks held among senior officials, intellectuals and Chechen leaders," with

\footnotetext{
162 "Na vechnom ogne," Ogoniok, November 1991, No. 46.

163 Gennady Zhukovets, "Dzhokhar Dudaev: Vlast' my mogli vziat' v techenie chasa," Ogoniok, December 1991, No. 49, 3-4.

${ }^{164}$ Ibid.

165 Gail W. Lapidus, "Contested Sovereignty: The Tragedy of Chechnya," International Security 23, No. 1 (1998): 7.
} 
reports two months later stating that Russian leadership was still investigating "peaceful ways out of the crisis." ${ }^{\prime 66}$ In hindsight, Chechen surrender was the only possible (and peaceful) way to avoid war. As noted by Robert Kornetov in September 1994, Moscow was "ready to provide the broadest independence to Grozny, but only within the federation." 167 Approaching December 1994, the rhetoric changed, with the inevitability of military conflict being the main form of updates within the media. Yeltsin's voice became stronger as he reassured the public. He claimed, "order and peace in Chechnya will soon be restored." 168 In December 1994, Izvestiia confirmed Yeltsin's rhetoric, stating, "Active military actions would end in a week."169

In retrospect, peace talks were not successful. In December 1994, Dmitry Kamyshev, of Kommersant, claimed that while a peaceful solution was still under debate, "only the military can affect the situation now." 170 Yet, alongside the war, which would continue for another two years, peace negotiations remained dominant within the media, as demonstrated in June 1995 by Albert Plutnik in Izvestiia in an article entitled "It would be a crime to miss the chance to end the war in Chechnya." ${ }^{171} \mathrm{He}$ discussed what the conclusion of peace could mean for Russia. He disclosed that supporters of the power ministries in Russia saw the conclusion of peace [not on Russian terms] as a defeat to Russia and "demonstration of the inability of the government to nip the terrible evil in the bud." 172

While there remained a corpus of supporters for the Chechen War and those who saw surrender as a sign of weakness, negative assessments of the government's desire to achieve peace were also in circulation. This was best demonstrated by key Russian officials like Arkady Volsky, who stated, "I am convinced that there is no sincere desire

\footnotetext{
166 Selenev, "Ruslan Khasbulatov."

Maksim Zhukov and Dmitry Kamyshev, "Situatsiia v Chechne," Kommersant, 1 December 1994, No. 228.

${ }^{167}$ Robert Kornetov, "Situatsiia v Chechne," Kommersant, 17 September 1994, No. 176.

168 Albert Plutnik, "Bylo by prestupleniem upustit' shans pokonshit' s voynoy v Chechne," Izvestiia, 24 June 1995, No. 115.

${ }^{169}$ Nikolai Gritchin, "Vlasti Stavshimi predprinimayut mery dlia zashchity mestnykh kavkaztsev," Izvestiia, 23 December 1994, No. 246.

170 Dmitry Kamyshev, "Situatsiia v Chechne," Kommersant, 23 December 1994, No. 244.

${ }^{171}$ Plutnik, "Bylo by prestupleniem upustit' shans pokonshit' s voynoy v Chechne."

172 Ibid.
} 
[on Russia's behalf] to find the perpetrators of the terrorist acts that provoked the breakdown of talks."173

Russia's strategy did not escape criticism, as the media's representation of the fighting called for further legitimisations beyond the restoration of law and order. While the negative portrayal of the Chechen population suggests that the media supported the government's use of force, the press's negative portrayal of the actions of the Armed Forces further confused readers. As noted in Izvestiia, Yeltsin was widely criticised for his commitment to the bombing of Grozny. The same article further highlighted that those supporting the war in Chechnya meant an "early end to a political career, since militarism in the eyes of the Russian electorate seems extremely unattractive." ${ }^{174}$ The extent to which the media reported on opposition within the political sphere facilitated questions relating to who pushed for military action in Chechnya. Kommersant reporters Maksim Zhukov and Dmitry Kamishev associated the use of force in Chechnya with the 1996 presidential election. They stated, "Having conquered Chechnya, the president will demonstrate he is in control of the situation." ${ }^{175}$ Scholars of the Chechen War subscribe to this justification also, determining that the image of a quick and decisive victory would bolster Yeltsin's popularity. ${ }^{176}$

The military's role in the initiation of the Chechen War was also discussed. In January 1996, Natalia Zhelnorova of Argumenty i Fakty questioned novelist and Chechen expert Anatoly Pristavkin on the War in Chechnya

NZ - Who, from your point of view, can negotiate [peace]?

AP - "Not the military." Among them there are many people interested in continuing this war. The military flocked there like a holiday. Those who were driven out of the Baltic States, from Germany, found a "vent" there. What is a military in peacetime? This is a vegetative person that no one needs. And suddenly a springboard appears for the realization of all its capabilities. I saw there was one pilot-deputy, regiment commander, who flew there to shoot from a helicopter. $\mathrm{He}$ returned from flight, his eyes were on fire, he was happy. The generals will not voluntarily surrender this military site. They get orders there, titles - endless money. ${ }^{177}$

\footnotetext{
${ }^{173}$ Rotar, "Chechnya: Davniaia smutab sobytiia."

174 "Chechnya: Trudnyi vybor Kremlia."

175 Zhukov and Kamishev, "Situatsiia v Chechne."

176 Vera Tolz, "The War in Chechnya," Current History 95, No. 603 (1996): 318.

${ }^{177}$ Natalia Zhelnorova, "Chechnya - otdushina dlia voennykh."
} 
In December 1994 Otto Latsis of Izvestiia paid extensive attention to the role of the military elite towards Chechnya, claiming that while some high-ranking officials sacrificed their career in opposition to the initiation of the conflict, others wanted the war. It ensured a "stronger voice of the military in the division of the budget pie." 178 Also in December 1994, another report in Izvestiia highlighted the conflict's ability to write off the irrelevancy of the Armed Forces, and bolster the standings of power ministries. ${ }^{179}$ This was extremely important, since Russia's military was undergoing a period of low prestige. The Soviet Union's role in Afghanistan was prominent in the public's consciousness, and contributed towards the downfall of the Russian military - therefore, a quick and decisive victory in Chechnya could better the military's position in society. Lev Gudkov pinpoints the roots of the Chechen War in the military's desire to preserve and strengthen the military institution and to popularise support for Russia's Armed Forces at a time of low prestige. ${ }^{180}$ As noted, the conflict did legitimise the need for a military in society, and allowed for the military to gain access to more funding, which projected their importance in society.

Divisions within the military institution weakened Russia's strategy in Chechnya. As mentioned previously, some of those in high-ranking positions opposed the war, and sacrificed their careers over their opposition. This was not the case for Major General Viktor Vorobyov, who perished in the first few months of the War. The obituary read; "Knowing Vorobyov, I am sure he did not approve of the senseless slaughter. But he was first of all a solider. And perished as he lived, on the front." ${ }^{181}$ Even with these divisions, there were also reminders in the media of duty. In January and February 1995 Sovetskaia Rossia, for example, stated that the "assessment of the bloody events in Chechnya...underlined the direct responsibility of the President and his entourage" to serve and defend the fatherland, which was also emphasised by Sergey Kovalev as "a

\footnotetext{
${ }^{178}$ Otto Latsis, “Chechenskaia voyna proigrana v Moskve," Izvestiia, 29 December 1994, No. 250.

179 "Chechnya: Trudnyi vybor Kremlia."

${ }^{180}$ Lev Gudkov, "The Army as an institutional model," Translated by Jennifer G. Mathers in Military and Society in Post-Soviet Russia, ed. by Jennifer G. Mathers and Stephen Webber (Manchester and New York: Manchester University Press, 2006), 49.

${ }^{181}$ Viktor Artemenko, "Pogib, kak zhil, - na peredovoy," Pravda, 10 January 1994, No. 333; Viktor Artemenko "Pamiati general-mayora Viktora Vasil'evicha Vorob'eva," Pravda, 10 January 1994, No. 333.
} 
sacred duty of every young man." 182 These comments acted as small legitimisers for the role of the military in Chechnya, or at least to those who took part in the hostility. They were openly critical of the military; yet also justified the role of the soldier under the image of the protector and defender of the fatherland.

The repetitive attachment of ideas linked to lawlessness to the Chechen populace further justified Russia's role in Chechnya and the loss of life in the region. The use of anti-terrorist and anti-criminal narratives furthered reactive policies, which justified conflict in the region, as emphasised by Badyakina. ${ }^{183}$ What is seen here is the shifting of blame towards those who initiated the war in Chechnya, rather than those involved in the actual conflict. Patriarch Aleksei II, head of the Russian Orthodox Church in the 1990s, stated, "May God prevent that a shadow, which is caused by the politicians' wrong actions, is cast on soldiers and officers who fulfil their duties to the fatherland with dignity. May service in the army- the duty of every son of the fatherland- become a truly heroic deed and a true honour and joy." 184 The acceptance of the military institution and the actions of those soldiers within the military, as shown here, highlights the persistence of cultural militarisation during this time. The stories emphasise an acceptance of the Armed Forces and its duty to protect and defend Russia's border, whereas discontent is directed towards the government.

As the media looked toward war responsibility, conclusions drawn from the debate suggested that demilitarisation and militarisation was happening simultaneously, with the failure to forge peace resulting in warfare. This was best displayed in a July 1995 interview between Argumenty $i$ Fakty journalist Dmitry Makarov (DM) and Chairman of the Government of the National Revival of Chechnya, S. Khadzhiev (SK):

182 Sergey Kovalev, "Elena Badyakina: 'Opalennye Bedoy,"” Sovetskaia Rossiia, Moscow, 28 January 1995, No. 11.

"Postanovlenie III Sezda KP RF “O bratoubiystvennoy voyne v Chechenskoi Respublike I merakh po vykhodu iz voznikshego krizisa," Sovetskaia Rossiia, Moscow, 20 February 1995, No. 13.

${ }^{183}$ Joseph T. Ripsberger, Hank C. Jenkins-Smith and Kerry G. Herron, "How Cultural Orientations Create Shifting National Security Coalitions on Nuclear Weapons and Terrorist Threats in the American Public," PS: Political Science and Politics 44, No. 4 (2011): 716.

${ }^{184}$ Katya Richters, The Post-Soviet Russian Orthodox Church: Politics, Culture and Greater Russia (Oxon: Routledge, 2012), 62. 
DM - Which side shows more rigidity in the [Peace] negotiations?

SK - "I think both sides are striving to show goodwill." However, the delegation headed by Imaev, if he shows goodwill and finds reasonable approaches, then, having talked with Dudaev, takes a tough position again ... And everything starts all over again.

DM - How much does Dudaev influence the negotiations?

SK - He still seeks to resolve the Chechen issue by force. ${ }^{185}$

Khadzhiev acknowledged that both sides were engaged in the peace negotiations. However, based on Khadzhiev's assessment the Chechen delegation was taking a "tough position" in the negotiations, suggesting that Dudaev's desired outcome was through military conflict. This feeds into previous media discourses that noted Chechen surrender as the only route to Russian withdrawal. In this sense, Dudaev found his only route to independence through war. In Khadzhiev's assessment, Russia comes across more positively, with Chechnya's tough stance pushing both parties to restart peace negotiations. In this sense, the Chechen delegation was blocking potential peace agreements. This portrayed Russia's involvement in the region as forced and seen as a last minute necessary tactic for the consolidation of peace. The discussions of peace negotiations, while conflicting, created a more positive image of Russia's consistent efforts to bring the conflict in Chechnya to a peaceful end. While a peaceful end to the war would suggest demilitarisation, the continued struggle for peace showcased desires on both sides to take a military stance to achieve their goals. On the side of Chechnya, Dudaev wanted independence and to solve the issue through military means, while Russia saw Chechen surrender as the only means of establishing peace. The continued negotiations highlighted persistent issues related to stability and security. The Second Chechen War, only a few years later, confirmed this.

In relation to Chechnya, the media demonised the enemy, analysed state institutions (including Yeltsin and the military) and focused on peace negotiations. 'Othering' tactics are key elements of wartime propaganda, with the Chechen population branded as terrorists, bandits and criminals. Russia's military did not escape disapproval either. The media highlighted the military's incompetence and brutality but suggested that such behaviour took place specifically within the boundaries of the Chechen War. In

${ }^{185}$ Dmitri Makarov, "S. Khadzhiev 'Ya ne marionetka," Argumenty i Fakty, 27 July 1995, No. 30. 
contrast, negative representations of the Chechen population as terrorists and bandits hinted at a criminality that was embedded in Chechen heritage. By linking ideas of criminality to the Chechen populace, notions of national security were brought to the forefront of Russian public consciousness. Issues of national security justified the soldiers' actions in the North Caucasus region. This treatment was not unique to the PostSoviet period or even this region. Scholarship on demonising techniques spans geographic boundaries. The main aim of this demonising was to create an 'us' versus 'them' discourse, an exaggerated emphasis of the other, and this emphasis was neither positive or at times, humane. In doing so, it legitimised force, sparking a sense of fear to mobilise society against an enemy.

The actions of Russia's state institutions were not always discussed in a positive way, with the military's desire to prolong the war for their own needs being a major topic of criticism. It did demonstrate however, the important role of the military in society, and the weight they bore on the political decisions of the nation and therefore suggests an element of militarism as conceptualised alongside Brian Taylor's argument, which suggests that the military's autonomy is a reflection of militarism. ${ }^{186}$ While the military officers were depicted negatively, the military itself received some praise. Russia's strategy during the war reinforced notions of citizenship, through the idea of a soldier's duty. Differing opinions regarding the initiator of the war were contrasted by reports on the duty of the soldier. Shifting the responsibility or blame for the conflict onto the government took the focus away from the military, instead praising the military for fulfilling its duty in protecting the fatherland. It reinforced the notion that regardless of the public perception of war, the soldiers should still be supported.

Although the government was discussed negatively in that aspect, the Russian state was also displayed in a positive manner in some of the discussions, especially in terms of the peace negotiations. Chechen leader Dudaev, a former military officer in the Soviet period, was represented as a warmongering militant, desiring that issues between Russia and Chechnya be solved through military means - therefore forcing a military response from Russia.

As noted, such discussions do not suggest a promotion of militarisation, since we are discussing the topic of peace. Yet, they do very little to demilitarise society as it shows Russian efforts to consolidate peace, and emphasises the image of an aggressive

186 Taylor, Politics and the Russia Army, 1, 154-164, 312. 
Chechnya, forcing Russia's hand. What can be taken away from these discussions is that militarisation was sustained during this period. Russia's role in the Chechen war was legitimised through aspects of demonisation. This justified Russia's aim of invading the regions to stamp out lawlessness, and their forced invasion is justified through an exaggeration of Dudaev's militancy.

The amalgamation of these different discourses played a significant role in the militarisation of Russia's society during this period. The negative representations of Russia's during role the Chechen war did not necessarily imply the demilitarisation of Russia's society, in fact, the vast number of times in which stories of the military, military strategy and the war in Chechnya were discussed meant that the topic of war and Chechnya remained a constant aspect of public consciousness and aided the readership to "cruise down the ramp onto the militarisation highway." 187

The 1990s media was anti-war and contributed significantly to the military's loss in prestige. It was critical of Russia's role in the Chechen War and promoted caution when discussing Russia's possible role in the Yugoslav conflict. Yet, at the same time, the media was a mechanism of militarisation. It mobilised society through emphasis of narratives on growing threats to Russia's security. The media highlighted Russia's role in peacekeeping projects within neighbouring countries and Russian disapproval of NATO expansion, which both underwrote the larger narrative, that Russia was surrounded by instability and threats that could seep over into its borders. To this end, the media militarised society through the manifestation of a siege mentality. NATO expansion eastward and Russia's accession to the organisation was criticised heavily first by politicians, and second, within the media. Such narratives had an impact on how parts of the public perceived NATO, even going as far as to accuse NATO of using its role in Kosovo as a "dress rehearsal" for its eventual invasion of Russia, and aid in facilitating Chechen independence. The success of the media in shaping public opinion was confirmed in interviews, where the interviewer highlighted that the epithet of terrorist and criminal became the general Russian view of the Chechen population. It demonstrated that tactics such as "the demonisation of the enemy" were successful in shaping public attitudes towards an opposition. These descriptors are not positive, and therefore highlight a growing difference between the Russian people and the Chechen population. The media

${ }^{187}$ Enloe, Maneuvers, 4. 
managed to prevent demilitarisation through mobilising techniques. Even where narratives relating to the military were negative, society remained militarised. The general narrative of war and the armed forces remained salient in the discourse of the media, ensuring that Russia's society remained exposed to a threat-filled worldview, and ensured the narrative of the military and war in everyday consciousness. Therefore, the media was an important mechanism of militarisation during the Yeltsin period, as it ensured public consciousness was militarised, even when the military was underfunded and in decline. 


\section{CHAPTER 3}

\section{GEROI, VRAGI i KONFLIKTY: THE MILITARISATION OF RUSSIA'S HISTORICAL EDUCATION}

A period of crises underwrote the beginning of Peter I's reign. E. V. Anisimov and A. B. Kamenskiy's 1996 secondary school textbook, Istoriia Rossii 1682-1861, noted "The first and strong signals of the crisis came from the battlefields...Neither the Polish, or Turkish, not even the Tatar troops ... were distinguished then with modern weapons and advanced combat techniques, and yet the Russian army either lost the battle to them, or - at best, she fought with varying success. All this painfully reflected on the international prestige of Russia, which was not [considered] in the "high society" of the European powers." ${ }^{1}$ The quote demonstrates threat from the West, issues of military development, Russia's ineffective (or at least inconsistent) military and Russia's long historical relationship with conflict, showing that: 1) Russia was under threat by numerous enemies from various fronts; 2) Russia's inability to defend itself demoted the country to a secondary position within the international order; and 3) progress and EastWest competition was linked to the military and militarisation.

Even into the $19^{\text {th }}$ century, invasions and military conquests shaped Russian society. As noted by Victor Shnirelman, Russian textbook author A. N. Bokhanov, writing in 1998, claimed that the entire world was against Russia. ${ }^{2}$ According to

\footnotetext{
${ }^{1}$ E. V. Anisimov and A. B. Kamenskiy, Istoriia Rossii, 1682-1861 (Moscow: Terra, 1996), 20-21. The print-run of this textbook was 40,000. Evgeny Viktorovich Anisimov (born 1947) is Soviet-Russian historian. He specialises in Russian history of the $17^{\text {th }}, 18^{\text {th }}$ and $19^{\text {th }}$ centuries, especially on the leadership of Peter I. Alexander Borisovich Kamenskiy (born 1954) is a Soviet-Russian historian with special interest in historiography and the history of Russia in the $17^{\text {th }}, 18^{\text {th }}$ and $19^{\text {th }}$ centuries.

${ }^{2}$ Aleksandr Nikolaevich Bokhanov (1944-2019) was a Soviet and Russian historian. As noted on a personal website to him: "Alexander Nikolaevich was the greatest Russian historian and artist. He possessed a bright research talent, created biographical portraits of Russian princes from Tsar Ivan the Terrible to Emperor Nicholas II. He devoted his whole life to free historical creativity, not engaged either by the communist authorities, or by wealthy customers, or by a liberal get-together." For more, please see: "Vernut'sia v Rossiyu: Pamiati Aleksandra Nikolaevicha Bokhanova," Bokhanov.ru, 14 January 2021, accessed 12 February 2021, https://xn--80abe7bdc0c.xn--p1acf/.
} 
Shnirelman, Bokhanov argued that Russian expansion in the $19^{\text {th }}$ century was largely driven by its struggle to survive aggression from the South, West and East rather than by a desire for influence and access to key trade routes. ${ }^{3}$ These testimonies by Russian textbook authors represent only a snippet view of some of the content of historical textbooks in the 1990s. At times, the authors created lists of historical wars and invasions that Russia was subjected too. In other cases, they emphasised the atrocious actions of Russia's opponents. The testimonies only highlight and add fuel to the pre-existing discourse that Russia is a vulnerable country surrounded by hostile neighbours. These notions and the turbulent, conflict-ridden landscape of 1990s Russia strengthened this discourse, allowing cultural forms of militarisation to persist.

In 1990s Russia, the Polish, Turkish and Tatar troops were now the Chechen separatists, using guerrilla tactics against a military with better military technology and a bigger economy. The testimonies above may not have been a purposeful attempt to make Russia's youth reflect on its current military situation. They did, however, highlight that through such crises, Peter I turned towards comprehensive military reforms to solve issues of Russia's international prestige and to claim victory militarily. Do these passages confirm that Russia lives in a cycle of external threat, military conflict, military demise and reconsolidation of military power? In hindsight, and when considering remilitarisation efforts under Putin, especially since 2008, this is true. Education, like the media, is a forum in which such anxieties can be raised and patterns or trends become recognisable. To this end, Russian history textbooks of the 1990s were venues of militarisation.

Beyond external danger, the educational textbooks highlighted glorious Russian victories over "insidious" and "evil" enemies [Vragi/ Protivniki]. They used methods of militarisation (like atrocity propaganda) to pit the reader against a historical opponent and create a view of the outside world as hostile and opportunistic. This method is typical in practices that utilise history to create meaning, like commemoration for example. ${ }^{4}$ Russia's education system faced many challenges in the immediate Post-Soviet period. Documents found in GARF (including drafts of laws, laws, letters and speeches) revealed

\footnotetext{
${ }^{3}$ Victor Shnirelman, "Stigmatised by history or by historians? The people's Russia in School history textbooks," History and Memory 21, No. 2 (2009): 119-120.

4 Mariana Achugar, "Critical Discourse Analysis and History," in The Routledge handbook of Critical Discourse Studies, ed. by John Flowerdew and John F Richardson (Oxon: Routledge, 2018), 298-300.
} 
concerns among members of the State Duma and veteran organisations of the militarypatriotic spirit of the nation. Discussions within the State Duma showed a desire to reestablish a patriotic-militaristic education. Political elites suggested including the youth in commemorative activities and memorial upkeep in order to bring them together with the veterans.

This chapter demonstrates that Russia's historical education did not change fundamentally. It remained ideologically driven, and militaristic histories continued to underscore and dominate the different historical eras under discussion. Any changes were directed toward emphasising Russia's new identity as a continuation of the Russia that existed prior to 1917.5 Discourses chosen, as evident in the scholarship on education, were largely picked to reflect the current and future aims of the Russian Federation as it set out to establish itself on the world stage. ${ }^{6}$ In historical education, students were reminded that to be a powerful state was to have a powerful army that would overcome hostile adversaries. To this end, Russia's historical education was a vehicle of militarisation. These textbooks reminded Russia's youth of military campaigns, persistent enemies, of glorious pursuits and Russian victories. Together they reaffirmed and strengthened Russia's besieged fortress mentality.

\section{Critical Discourse Analysis and History Textbooks}

Critical Discourse Analysis (CDA) is a powerful tool for analysing educational discourses. First, content within school textbooks is regarded as official and legitimate knowledge. ${ }^{7}$ That is, the information in the textbooks is gathered and reproduced to inform and educate. ${ }^{8}$ Todd Nelson, on the issue of Russian High School historical textbooks, notes that textbooks "purport to represent the truth of historic events." He also

\footnotetext{
${ }^{5}$ Hans Bagger, "The Study of History in Russia during the Post-Soviet Identity Crisis, Scando-Slavica 53, No. 1, (2007): 110.

${ }^{6}$ As noted by Murod Ismailov and Nozima Ganieva, school textbooks are created not only to pass on uncontested knowledge but to also "play a powerful role in intepreting and giving meaning to the world." For more, please see: Murod Ismailov and Nozima Ganieva, "In search for the Russian national identity: Do history textbooks hold the answer?" Journal of alternative perspectives in the social sciences 5, No. 2 (2013): 368. ${ }^{7}$ Ibid, 369.

${ }^{8}$ Yongbing Liu, "The construction of cultural values and beliefs in Chinese language textbooks: A Critical Discourse Analysis," Discourse: Studies in the cultural politics of education 26, No.1 (2005): 17.
} 
acknowledges that they have a certain authority, which makes it challenging to dispute the content. ${ }^{9}$

Linked to this point is access to the educational discourses. This is a key consideration to scholars of CDA. The debates centre on identifying who has access to the discourses and at what level. For example, students have access to educational discourse only once it has been constructed. Even then, the information presented to them in the textbook is supplemented by the teacher who has planned a lesson and set a task on that topic from their own interpretation of the textbook's information. Therefore, even before students read the textbook or attempt to complete any tasks, the information they receive will have already gone through two processes of interpretation and construction at the author and teacher level. Teachers control communication within the classrooms. They tell the student what to read, what to answer, correct their mistakes and control classroom discussion. According to Teun A Van Dijk, the ability to control communication within the classroom gives teachers special access to educational discourses. ${ }^{10}$ In Russia, the role of the teachers in the 1990s in controlling educational discourses was even more important. They had more autonomy than in the Soviet period to choose which textbooks they used in class. ${ }^{11}$ There was no official checklist when selecting textbooks. Russian textbooks that underwent expert examination were recommended or authorised by Russia's Ministry of Education (MERF). MERF also outlined that a good textbook would not readily give students the answer, but would push them to think critically about a topic. ${ }^{12}$ Textbooks, however, became a luxury. The economic crisis and the chaos of school decentralisation meant that some state schools were as autonomous as private schools. In this sense, while MERF did recommend some textbooks, financial constraints and educational staff ultimately drove the choices made. ${ }^{13}$

${ }^{9}$ Todd Nelson, "History as Ideology: The Potrayal of Stalinism and the Great Patriotic War in Contemporary Russian High School books," Post-Soviet Affairs 31, No. 1, (2015): 39.

10 Teun A. Van Dijk, "Discourse, Power and Access," in Text and Practices: Readings in Critical Discourse Analysis, ed. by Carmen Rosa Caldas-Coulthard and Malcolm Coulthard (London: Routledge, 2015), 86.

${ }^{11}$ Bagger, "The Study of History in Russia during the Post-Soviet Identity Crisis," 120121.

12 Tatyana Volodina, "Teaching History in Russia after the collapse of the USSR," The History Teacher 38, No. 2 (2005): 183-186.

Information about the Ministry of Education is outlined in footnote 64 on page 44.

${ }^{13}$ Bagger, "The Study of History in Russia during the Post-Soviet Identity Crisis," 120121. 
Finally, while regarded as official knowledge, textbooks are also considered a "cultural product sitting within the educational domain." 14 Scholars of CDA agree that textbooks go beyond their role in disseminating knowledge. First, they argue that textbooks are underpinned by ideologies, values and attitudes that reflect the surrounding society. ${ }^{15}$ Felicitas Macgilchrist, for example, notes, "Textbooks are one of the few media which are explicitly aimed at shaping values, knowledge and the subjectivities of future generation." 16 Second, the role of textbook authors in the construction of the educational discourse is an important consideration to take. Mariana Achugar states that historiography is: 1) a construction of the past written by authors impacted by the present; and 2) a process that includes choices and interpretations "that are determined by the location of the historian." 17 This therefore emphasises the pervasiveness of cultural, social and ideological messages within the content of historical textbooks. In the case of Russia, one of these values and discourses had to do with militarisation. Since CDA is a methodology concerned with outlining dominant and minority discourses, taking into consideration the social, political and economic landscape in which these discourses are created are key for scholars conducting CDA. These reasons above are only some, which highlight the value of CDA in analysing school textbooks.

The 25 textbooks discussed in this chapter are those focused on Russia's national history from the $9^{\text {th }}$ century until the end of the $20^{\text {th }}$ century. They were randomly selected using search terms, "Istoriia Rossii" or "Rossiiskaia istoriia" and the timeframe "19902000." By randomly selecting the sources, the chapter was able to draw on a number of different history textbooks published during the 1990s. These textbooks targeted various school ages. They are uniquely structured and have different circulation figures. While the target ages of each textbook varied, the topics covered remained the same - they were nuanced to fit the needs of the different age groups. For example, Ishimova (1996) and Golovin's (1992) books were established to provide a history of Russia in stories for

\footnotetext{
${ }^{14}$ Urip Sulistiyo, Supiani, Ahmad Kailiani and Rani Puspitasari Dewi Lestariyana, "Infusing moral content into Primary School English Textbooks: A Critical Discourse Analysis," Indonesian Journal of Applied Linguistics 10, No. 1 (2020): 251.

Liu, "The construction of cultural values and veliefs in Chinese language textbooks," 1617.

${ }^{15}$ Sulistiyo et al. "Infusing moral content into Primary School English Textbooks," 251. ${ }^{16}$ Felicitas Macgilchrist, "Textbooks," in The Routledge handbook of Critical Discourse Studies, ed. by John Flowerdew and John F. Richardson (Oxon: Routledge, 2018), 525. ${ }^{17}$ Achugar, "Critical Discourse Analysis and History," 298-300.
} 
children. Their presentation of Russia's history was more descriptive, to capture the interest of the youth that the books were aimed toward. This was a characteristic that was lacking in official history textbooks. That being said, authors of official history textbook accounted many of the stories in Ishimova and Golovin's books - showing that the discourses remained the same but were altered to suit the needs and knowledge base of the different age groups.

Most of the textbooks discussed in this chapter are structured to provide a chronology of events, ask questions at the end of chapter and recommend extra resources. However, some textbooks were structured differently. Georgieva and Georgiev (1995) and Zuev's (1995) textbooks, for example, were structured in lists. While Georgieva and Georgiev's book regularly set lists of conflicts or events that students needed to provide dates to, or match up, Zuev presented a chronological list of Russia's history from its conception to the end of the $20^{\text {th }}$ century. Kislitsyn's 1999 textbook, on the other hand, presented Russia's history in the form of questions and answers.

The print-run of the textbooks examined in this thesis range from 100,000 to 100 . Although it must be noted that some of these textbooks have earlier and later editions than those published in the 1990s with a much larger circulation. This chapter was not focused on only examining popular textbooks - popular Russian history textbooks of the 1990s like Istoriia Otechestva by V. P Ostrovskiy (1992) have already received a lot of attention. ${ }^{18}$ Rather, the purpose of this study was to identify dominant discourses across a range of textbooks published in the 1990s. CDA is of particular use here, as it also takes into consideration the persuasive value driven messages of privileged groups, which drive and construct the dominant narratives identified in this chapter. ${ }^{19}$

\section{LAST DAYS OF AN ERA PAST: HISTORY'S HISTORY AND EDUCATION REFORM}

\section{History of Russia's historical education system.}

Education under the Tsarist regime and in the Soviet period was highly militarised. Both regimes believed in the readiness of its youth to fight upon their

\footnotetext{
${ }^{18}$ Valeriy Petrovich Ostrovskiy is a Soviet-Russian historian and specialist of $20^{\text {th }}$ century Russian history.

${ }^{19}$ Macgilchrist, "Textbooks," 525.
} 
conscription into the military. Therefore, under Tsarist leadership the number of institutions offering a military education or institutions solely providing a military education grew. In the $19^{\text {th }}$ century in particular, Russia expanded its military-educational sector. By 1830, a fifth of Russia's elementary school children were recipients of a militaristic education. By the 1850s, just under a third of Russia's elementary students were receiving this type of education. Cadet-specific training facilities increased to 19 by the middle of the $19^{\text {th }}$ century. ${ }^{20}$ The Soviet Union, which promoted an ideology that was ironically against war, created a state education system aimed at educating a generation of "true sons of the [Soviet] motherland, steadfast ideological fighters." 21 The militaryeducational complex expanded as new perceived dangers continued to threaten the communist state. The number of military colleges increased, and Soviet leaders even created military departments in civilian colleges. In 1939, the number of militaryeducation institutions increased by a third from 123 to 161 . These figures were moderate, as they did not include institutions that trained the KGB, for example. ${ }^{22}$

For both the Tsars and Soviets, the military was considered a form of education and socialisation. Peasants drafted into the Imperial Army were disciplined through military pageantry, for example. The peasants were moulded by repetition of military drills. ${ }^{23}$ Writing in 1998, Russian history textbook author G. A. Ammona noted that Peter I militarised bureaucracy to instil the same level of military discipline in the administrative structures of society as in the army and navy. ${ }^{24}$ Soviet leaders recruited the youth into voluntary extracurricular programs, such as the Dobrovol'noye Obshchestvo Sodeystviia Armii, Aviatsii i Floti (DOSAAF) or the All Union Pioneers. The youth were militarised not only through activities like parachuting and abseiling, but more subtly through uniforms, rank badging and their promise in the oath to "love and cherish my motherland." 25

${ }^{20}$ Odom, "The 'Militarization' of Soviet Society," 40.

For more information on the extent of military-educational institutional growth, please see page 61-64 of this thesis.

${ }^{21}$ James V. Wertsch, "Narratives as cultural tools in sociocultural analysis: Official History in Soviet and Post-Soviet Russia," Ethos 28, No. 4 (2001): 521.

22 Odom, "The 'Militarization' of Soviet Society," 37.

${ }^{23}$ Bushnell, "Peasants in Uniform," 565.

${ }^{24}$ Ammona, Istoriia Rossii, IX-XX vv., 204. The print-run for this book was 3,000. G. A. Ammona was a historian who worked primarily on Russia's navy.

25 Odom, "The 'militarisation' of Soviet society," 34-44; Simes, "The Military and militarism," 140; Keep, "Military Style of the Romanov Rulers," 62. 
Throughout this thesis, a core discourse within the Russian cultural landscape was this need for Russia to defend itself against aggressive neighbours. Educational discourses added to this societal discourse. The Soviet Union's retelling of the Great Patriotic War (for example) in both an educative setting and in political discourse mythologised the event. It became a historical epic that underlined Soviet military capabilities, and acted to justify continued military power. Yet, discourses promoting a military-patriotic society were under threat.

\section{Structural Changes}

The collapse of the Soviet Union took place over night. Political and economic changes transformed society, with the collapse of the totalitarian state paving the way for a new liberal, civic society. ${ }^{26}$ As noted by Joseph Zajda:

It is difficult to imagine what any ex-soviet citizen felt during this process, let alone an alienated history teacher, all suffering from the crisis of identity, after decades of a totalitarian regime, one party rule and censorship. ${ }^{27}$

Yeltsin's first priority was to change education. ${ }^{28}$ In 1992, MERF developed a law On Education, while the Ministry of General and Professional Education (MGPE) undertook the revision of history texts and schooling curriculum throughout the 1990s. ${ }^{29}$ There were, however, many elements that stifled these attempts. First, teachers and parents provided little support for reform. Second the economic issues of the 1990s posed a huge threat to the implementation of these changes. ${ }^{30}$ In addition, the rising volume of revisionist accounts rewriting Russia's history threatened current policy objectives of the

${ }^{26}$ Joseph Zajda, "Russian History Textbooks: An Analysis of Historical Narratives depicting key events," Curriculum and Teaching 28, No. 2 (2013): 73.

${ }^{27}$ Ibid.

28 Ben Eklof, "Introduction - Russian Education: the Past and the Present," in Educational Reform in Post-Soviet Russia: Legacies and Prospects, ed. by Ben Eklof, Larry E. Holmes and Vera Kaplan (Oxon: Frank Cass, 2005), 7; Yeltsin Center, f. 8 op. 1 d. $11.1-311^{\text {th }}$ July 1991.

${ }^{29}$ Joseph Zajda, "Globalisation, Ideology and History School Textbooks: The Russian Federation," in Nation-building and history education in a global culture, ed. by Joseph Zajda (New York: Springer, 2015), 5; Zajda, "Russian History Textbooks," 75.

The Ministry of General and Professional Education worked under the auspicies of MERF.

Bagger, "The study of History in Russia during the Post-Soviet Identity Crisis," 120-121.

${ }^{30}$ Eklof, "Introduction - Russian Education," 7. 
Russian Federation (in Chechnya for example) and proved a liability to the legitimacy of their use of history in contemporary nation-building efforts. As early as 1995, State Duma representatives and veteran organisations called for the re-establishment of a militarypatriotic education and in 1998, the state began to officially retake control over textbooks. The number of textbooks approved for use in schools got smaller and smaller each year. ${ }^{31}$

Gorbachev's reforms turned Russia's education system upside down. First, debates emerged questioning the truth behind the historical discourses presented in soviet textbooks. ${ }^{32}$ In 1988, school examinations were cancelled on the basis that what the students had learnt could not be considered real history. ${ }^{33}$ These claims however, were met with much public disagreement, especially in the media. ${ }^{34}$ Despite this disagreement, authorities moved to reform the educational system. The first textbooks of the post-Soviet era were published from 1991 onwards. ${ }^{35}$ Many historians making an effort to rewrite these histories faced criticism from the press. ${ }^{36}$

While tasked with the job of creating new syllabi that reflected the new Russian system, teachers and textbook publishers lacked direction. Teachers were required to reject the previous Soviet model of teaching. ${ }^{37}$ While waiting for new textbooks to be published, they searched for alternatives. ${ }^{38}$ As a result, teachers often used translated foreign textbooks on the topic of the Soviet Union or simply continued to refer to old

\footnotetext{
${ }^{31}$ Natalia Potapova, "Normativity in Russian History Education: Political Patterns and National History Textbooks," Journal of Social Sciences of Education 14, No. 1 (2015): 49-50.

${ }^{32}$ Wertsch, "Narratives as cultural tools in sociocultural analysis," 519; Volodina, "Teaching History in Russia after the Collapse of the USSR," 182; Nelson, "History as Ideology," 58-59.

${ }^{33}$ Wertsch, "Narratives as cultural tools in sociocultural analysis," 521; Volodina, "Teaching History in Russia after the Collapse of the USSR," 182; Vera Kaplan, "History teaching in Post-Soviet Russia: Coping with antithetical traditions," in Educational Reform in Post-Soviet Russia: Legacies and Prospects, ed. by Ben Eklof, Larry E. Holmes and Vera Kaplan (Oxon: Frank Cass, 2005), 247.

${ }^{34}$ Wertsch, "Narratives as cultural tools in sociocultural analysis," 519.

${ }^{35}$ Ibid, 521-522.

${ }^{36}$ Ibid.

${ }^{37}$ Kaplan, "History teaching in Post-Soviet Russia," 248-249.

${ }^{38}$ Nelson, "History as Ideology," 59.
} 
Soviet History books. ${ }^{39}$ This was also the case for schools facing financial trouble. In some cases schools were unable to afford the newly available textbooks. ${ }^{40}$

The financial issues facing schools also affected teachers. Teachers were often poorly paid and at risk of losing their jobs to school closures. ${ }^{41}$ The situation in higher education was also poor. As noted by Bagger, "In general the policy was to try and retain old teaching staff as far as possible." Teachers were expected to adapt their previous specialisms to the new curriculars that were developed..$^{42}$ There is no evidence to suggest that Soviet teachers were forcibly removed from their posts in favour of a new post-Soviet teaching cohort - in fact, it seems quite the opposite. However, teachers from the Soviet period needed to adapt (fairly quickly) to new conditions within Russia. These changes included transforming traditional teaching strategies and improving the diversity of their content within their classrooms. On 13 April 1992, a decree 'On the development of humanities education' suggested the retraining and advanced training of humanities teachers was put forward. It is unclear, however, if this training was mandatory. ${ }^{43}$ Some teachers faced abuse from former students who were not pleased by claims they had been deceived.

Soviet educational practices continued in the formative period of the Russian federation because of economic issues, which stifled attempts to revolutionise Russian pedagogy. Teachers from the Soviet era, who were forced to adapt their specialisms with little to no additional training reverted back to the traditional pedagogical system that they had used in the Soviet period, recycling old textbooks and teaching methods. This enabled the continued presence of militarised discourses in post-Soviet educational discourses, as teachers adapted their traditional knowledge to the new Russian landscape - Soviet textbooks promoted patriotic-militarised discourses.

\footnotetext{
${ }^{39}$ Vyacheslav Karpov and Elena Lisovskaya, "Educational change in ta time of social revolution: The case of Post-Communist Russia in Comparative Perspective," in Educational Reform in Post-Soviet Russia: Legacies and Prospects, ed. by Ben Eklof, Larry E. Holmes and Vera Kaplan (Oxon: Frank Cass, 2005), 24.

${ }^{40}$ Bagger, "The study of History in Russia during the Post-Soviet identity crisis," 120121.

${ }^{41}$ Catherine Merridale, "Redesigning History in Contemporary Russia," Journal of Contemporary History 38, No. 1 (2003): 21.

${ }^{42}$ Bagger, "The study of History in Russia during the Post-Soviet identity crisis," 121.

${ }^{43}$ G. Burbulis, "O razvitii gumanitarnogo obrazovaniia v Rossiiskoi Federatsii," Pravo, 13 April 1992, accessed $20 \quad$ February 2021, http://ips.pravo.gov.ru/?doc itself=\&backlink=1\&nd=102015761\&page=1\&rdk=1\#I0.
} 
As for textbook publishers, Viacheslav R. Leshchiner and David I. Poltorak note:

Textbook publishers do not know what manuals to prepare for the market. They are no longer sure of permanent state orders for textbooks because the system for distributing textbooks by the state is still being questioned. ${ }^{44}$

Perestroika offset an era of pluralism in Russia's education system. While teachers were given more autonomy over the materials they could employ in their classes, they also had more materials to work with. Several publishing houses emerged in the late Soviet/ early post-Soviet period, competing to penetrate the education market. ${ }^{45}$ Unfortunately, some textbooks got it wrong. Textbooks published by the SOROS foundation, for example, were criticised for its anti-Russian, pro-western stance. ${ }^{46}$ One example was Aleksander Kreder's 1995 history textbook, Noveyshaia istoriia. XX vek. ${ }^{47}$ As noted by Volodina, following her participation in a radio show where she complimented the work of educators associated with the SOROS foundation, like Kreder, she received a lot of criticism. She claimed that many people, especially older generations, “expressed intense hatred for Kreder's book, characterising it as an "antiRussian zionist plot." ${ }^{48}$ According to his critics, Kreder muted the role of the Soviet Union in the Second World War victory - who simply wanted to show students a history not already present in Russian history textbooks. ${ }^{49}$ Such views led to some local governments prohibiting the adoption of Kreder's book into schools. As noted in October 1997 by Kommersant, Voronezh regional duma was one example of a local government that recommended against using Kreder's book. ${ }^{50}$ The article in Kommersant stated:

Their decision notes that this textbook, being biased in the selection of historical facts, anti-Russian in its spirit and content, belittles the history of the Fatherland and gives a distorted idea of the history of Russia, does not instill in students a

${ }^{44}$ Viacheslav R. Leshchiner and David I. Poltorak, "The Standard for History Education in Russia's Schools," The History Teacher 27, No. 3 (1994): 317-318.

${ }^{45}$ Kaplan, "History teaching in post-Soviet Russia," 247.

${ }^{46}$ Bagger, "The study of History in Russia during the Post-Soviet identity crisis," 120 121.

${ }^{47}$ Aleksander Kreder (1947-2000) was a Russian historian.

${ }^{48}$ Volodina, "Teaching history in Russia after the collapse of the USSR," 183.

${ }^{49}$ Ibid.

${ }^{50}$ Olga Rachkova and Vladimir Danshin, "Uchebnik noveyshey istorii popal v istoriyu," Kommersant, 31 October 1997, No. 188, 4.

Rachkova and Danshin's article noted that MERF still placed Kreder's 1995 textbook on its list of recommended textbooks. 
sense of civic consciousness and patriotism. The deputies refer to the fact that only a few lines are devoted to the Great Patriotic War in Kreder's "Recent History", Lenin is mentioned only once, Stalin - twice. ${ }^{51}$

Russia's 1992 law On Education set a number of educational standards, in the aim that they be applied by 1994 . These standards, in relation to history education, included:

- The accumulation by students of the basics of the history of mankind from ancient to modern times, including mankind's social, spiritual and ethical experiences;

- The development of students' ability to interpret events from present day life or from the past in terms of historical analysis (their uniqueness and/or unity with other historical phenomena);

- Helping students to form their own ethical values through the study of the historical experience of mankind, the ideas of humanism, patriotism, human rights, and democracy;

- Developing students' interest in and respect for the culture of their own and other countries, showing them the necessity to retain and multiply the cultural legacy of humanity. ${ }^{52}$

The educational standards not only outlined the skills students would harness during their time in education but also highlighted key core values that would underscore Russian historical education. Since history education is "often the prime curricular vehicle for official promotion of the national "self,", the value-driven nature of the educational standards demonstrated a concerted effort of the state to use education as a nation/ identity-builder. ${ }^{53}$ The values were driven by a number of key aims that underscored reforms made in the early 1990s. When developing the law, the Minister of Education for Russia between 1990 and 1992, Eduard Dneprov (1936-2015), promoted the following key slogans:

- Decentralisation

- Regionalisation

- Democratisation

- Deideologisation

- Diversification

- Humanisation

- Humanitarianisation ${ }^{54}$

\footnotetext{
51 Ibid.

${ }^{52}$ Leshchiner and Poltorak, "The standard for History Education in Russia's schools," 318-320.

${ }^{53}$ Ismailov and Ganieva, "In search for the Russian national identity," 269.

${ }^{54}$ Karpov and Lisovskaya, "Educational Change in the time of Social Revolution," 27.
} 


\section{$\underline{\text { Regionalisation and De-ideologisation }}$}

This section first focuses on the tenet of regionalisation. Then it outlines the process and (un) successful efforts taken to de-ideologise Russia's educative landscape. During the Perestroika years, representation of Russia's diverse ethnic landscape was a dominant topic of discussion. At an All-Union conference on historical education in Estonia in 1988, for example, delegates called for more classroom hours dedicated to the teaching of regional history. This proposal was in opposition to Russia's state mandated history, known as "History of the Fatherland," which centered largely on Russia's history prior to the Soviet state, and then the Soviet Union - where the regional populations of both empires played a supportive role. Moscow rejected the proposals. ${ }^{55}$ Upon the collapse of the Soviet Union, the law On Education favoured a new history school curriculum that integrated both state and regional histories. As noted by Volodina, Russia was initially open to regionalising its history education. There was a suggestion that textbooks on history of the Soviet Union could be adapted to the specific histories of the national republics and Russia's ethnic minorities. ${ }^{56}$ In Tatarstan, for example, regional political elites were able to direct the construction of textbooks that covered the local and distinctive regional history of the Tatar region. ${ }^{57} 10-15$ percent of the curriculum was meant to be dedicated to regional histories. As noted by Shnirelman, however, schools in Tartarstan "alloted as much as 25-50 percent of the course to the history of Tatarstan." 58

Including ethnic and regional histories in Russia's historical education system sparked much debate. Non-ethnic Russians in Russian regions wanted to dedicate more time to their regional history. However, MERF felt that the unequal growth of regional histories would pit non-ethnic Russians against ethnic Russians, in the non-ethnic Russian regions like Chechnya and Tatarstan. On the other hand, teachers and educators were worried that the exclusion of ethnic minorities from textbooks would further marginalise these non-ethnic Russian communities from ethnic Russian communities. This is a particularly important issue to deal with, especially in the late 1980s and 1990s. Gorbachev's democratisation reforms, as documented in chapter two, influenced a number of independence movements. In 1991, Chechnya (a region within Russia) also

\footnotetext{
${ }^{55}$ Shnirelman, "Stigmatised by history or by historians?" 112. Kaplan, "History teaching in Post-Soviet Russia," 250.

${ }^{56}$ Kaplan, "History teaching in Post-Soviet Russia," 251.

${ }^{57}$ Volodina, "Teaching history in Russia after the collapse of the USSR," 185-186.

${ }^{58}$ Shnirelman, "Stigmatised by history or by historians?" 112.
} 
claimed independence. Many media discourses justified Russia's military intervention in the Chechen region on the basis that ethnic Russians were under threat. The debate surrounding the inclusion and exclusion of ethnic, regional histories in historical discourses (and the objectives surrounding these discussions) were focused on achieving a balance that would hinder conflict between ethnic and non-ethnic Russians wherever they were located. In the end, textbooks acted on the recommendations of the MERF, to include a balance of Universal, Russian and regional histories in a number of ways. ${ }^{59}$ This was completed to hinder conflict between different ethnicities, yet the continued use of "othering" techniques in educational textbooks ensured students remained open and exposed to discourses on external and internal threats, the need to remain alert and united against adversity, adding to cultural militarisation during this time. These changes occurred during the time of Glasnost, a period of relative openness.

Glasnost provided a platform for people to speak freely about any topic. The term was first introduced to create a level of transparency between the state and its people. One of the main tasks of the Communist state in the 1980s was to de-ideologise the education system. ${ }^{60}$ In 1994, the Minister of Education, A. M. Vodianskii wrote that the deideologisation of the educational system was a failure, and merely a process that rid the educational system of communist tropes. ${ }^{61}$ In 1995, textbook authors A. A. Danilov and S. V. Leonov confirmed the de-communisation of Russian historical textbooks. In the foreword of their textbook, they acknowledged the process of de-ideologisation which began in 1985, and claimed, "Unlike previous textbooks on history of the USSR, which were reduced in many respects to the history of the Communist Party of the Soviet Union (CPSU), this course is free from the super-ideological "Marxist-Leninist" concept of history, the artificial training of the revolutionary movement and the Bolshevik party."

${ }^{59}$ Ibid, 112-114.

${ }^{60}$ Kaplan, "History Teaching in Post-Soviet Russia," 248-249.

${ }^{61}$ Ibid, 254.

${ }^{62}$ A. A. Danilov and S. V. Leonov, Istoriia Rossii v XX veke: Teotricheskii kurs (Moscow University of Humanities, Moscow, 1995), 3-4. This book has a print run of 200. Alexander Anatolievich Danilov (born 1954) is a Soviet and Russian historian. He has written a number of school textbooks, is an award holder of the Honoured Scientist of the Russian Federation and has held a number of high-ranking posts in Russian society. For example, from 1993-2014, he was Deputy Chairman of the Scientific and Methodological Council of the Ministry of Education of the Russian Federation. Sergey Viktorovich Leonov (born 1961) is a soviet and Russian historian with a specialism in the History of Russia. He is a prolific textbook author and is a Professor at Moscow State Pedagogical 
While Danilov and Leonov removed the communist ideology from their textbook, it did not go unnoticed that the removal of one ideology was replaced with another, militarism. Known as militaristic nationalism, the relationship between militarism and ideology in this sense "encourages polarisation in which one group is defined as being opposite to the 'other,"' whereby those who are not Russian or Soviet take on the role of the enemy. In doing so, this heightens a sense of nationalism amongst Russian students. ${ }^{63}$

Many of the textbooks under review in this chapter harboured pro-militaristic tendencies. They vilified the enemy, created images of a hostile world and campaigned for a strong military in the view that a weak Russia has always lost out in previous wars. Scholars of education widely accept ideology as an indispensable component of schooling and especially textbooks. ${ }^{64}$ With reference to Russian education, Natalia Potapova claims that, "textbooks enable expression of prejudice in a normative situation in which expression of prejudice is usually prohibited." ${ }^{\prime 65}$ This is because these "expression[s] of prejudice" fulfill the state's desired objective to produce a positive image of the country's history. This ideology is part of a national identity building process to instil students with attributes desirable to the government and to inform the future policy aims of the Russian Federation. ${ }^{66}$ Scholars like Ben Eklof even claim that the government aimed to use schools as the main forum for changing society. ${ }^{67}$ Some changes to Russia's historical education were vast. For one, Russia's historical education, in an attempt to unite Post-

University. This particular textbook was written for University students, which explains the lower print-run.

${ }^{63}$ Colleen Burke, "Women and Militarism," Women's International League for Peace and Freedom, (1994): 2-3, accessed 12 July 2018, https://www.wilpf.org/wpcontent/uploads/2012/10/Unknownyear_Women_and_Militarism.pdf.

64 This thesis builds on Henry Giroux's conceptualisation of ideology. He defines ideology as an "active process" of "production, consumption, and the representation of ideas and behaviours all of which either distort or illuminate reality." Giroux rejects the view by some Marxist orthodox scholars who understand ideology as relations of dominance, claiming that it depicts ideology as a "false consciousness." He argues instead that ideologies are formed in "concrete social practices" and also shape and impact upon these practices. He sees schooling as a form of communication, transmitting ideologies to the students. For example, please see; Henry Giroux, "Ideology and Agency in the Process of Schooling," Journal of Education 165, No. 1 (1983): 13-16; Kevin B. Smith, The Ideology of Education: The Commonwealth, the Market, America 's Schools (Albany: SUNY Press, 2003), 1-2; Potapova, "Normativity in Russian History Education," 47-49. ${ }^{65}$ Potapova, "Normativity in Russian History Education," 47.

${ }^{66}$ Zajda, "Russian History Textbook," 4; Zajda, "Globalisation, Ideology and History School Textbooks," 4; Smith, The Ideology of Education, 2.

${ }^{67}$ Eklof, "Introduction - Russian Federation," 1-2. 
Soviet Russia with pre-1917 Russia, saw a renewed interest in religious history. ${ }^{68}$ This was a noticeable phenomenon in a number of historical textbooks under review in this chapter. For example, Dvornichenko et al. 1999 school textbook emphasised the role of Christianity in the founding of the Kievan Rus state. ${ }^{69}$ At the same time, Russia's historical education mirrored that of the Soviet Union. From 1994, Russia's government took a more "hands on" approach, especially in regards to youth patriotism. For example, Yeltsin stated that Russia's youth should be familiar with the Russian constitution. ${ }^{70}$ In 1998, the government sought more control over the narratives within the textbooks. ${ }^{71}$

Democratisation threatened Russia's pursuits in neighbouring regions. Following the collapse of the Soviet Union, conflicts broke out in the near abroad as inter-ethnic tensions within these countries peaked. Russia justified its role in the region as part of a "peacekeeping" mission and to ensure the security of Russia's borders. Economic issues, as a result of shock therapy, alongside the revelation of Red Army atrocities during the Great Patriotic War, placed the military into a precarious position. ${ }^{72}$ How could the government justify diverting money towards the military when people could not afford basic foods, and an increasing number of people were unable to pay for housing? Russian historical educational textbooks, which for the most part emphasised the idea of Russia

${ }^{68}$ Kaplan, "History Teaching in Post-Soviet Russia," 254.

W. John Morgan and Grigori Kliucharev, "Higher Education and the Post-Soviet Transition in Russia," Journal of Education 47, No. 1 (2012): 5.

${ }^{69}$ A. Yu. Dvornichenko, A. V. Kirillov, E. A. Shaskol'skaya and Z. O. Dzhaliashvili Istoriia Rossii, IX-XX veka: Uchebnik dlia abiturinentov I studentov, (Saint Petersburg: Nestor, 1999), 44; S. A. Kislitsyn, Istoriia Rossii v Voprosy I Otvetakh, (Rostov-On-Don: Feniks, 1999), 98-104.

Dvornichenkov et al. book listed above sold 100 copies. However, this book is a later version of previous editions and has continued to be published into the 2000s. Andrei Yuriyevich Dvornichenko (born 1957) is a Soviet-Russian historian with a specialism in old Russian state history. A. V. Kirillov, Elena Shaskol'skaia and Z. O. Dzhaliashvili are Russian historians and textbook authors. They contributed to earlier and later versions of the textbook in this thesis. The print-run of Kislitsyn's book was 10,000. Sergei Alekseevich Kislitsyn is a Russian historian working in Rostov-On-Don.

${ }^{70}$ Janet G. Valliant, "Civic Education in Changing Russia," in Educational Reform in Post-Soviet Russia: Legacies and Prospects, ed. by Ben Eklof, Larry E. Holmes and Vera Kaplan (Oxon: Frank Cass, 2005), 221.

${ }^{71}$ Potapova, "Normativity in Russian History Education," 49.

72 Shock Therapy, in economic terms, is the sudden release of price and currency controls and includes privatisation and the withdrawal of state subsidies. In Russia, this caused many economic issues. Prices for most goods and services increased by 900 percent by March 1992, while wages only doubled in that period. This caused economic hardship, rise in unemployment and homelessness. 
as a historical besieged fortress, helped legitimise the necessity of a strong military and Russia's justified role as a stabiliser in the Post-Soviet region.

\section{The downfall of prominent Soviet discourses.}

As noted by Leshchiner and Poltorak in 1994, Russia's school system faced very serious difficulties in the initial post-Soviet period. The democratisation reforms of the Perestroika era, alongside the economic chaos of the 1990s propelled Russia's education system into a state of unknown. ${ }^{73}$ Glasnost threatened conventional narratives of Russian history in history textbooks as it had done in the Soviet media. As information regarding the true extent of Stalinist and Soviet suppression arose, scholars began to revise dominant discourses of Soviet greatness. ${ }^{74}$ R. W. Davies highlighted a situation in 1987 whereby student Dmitri Yurasov challenged a Lecturer of Stalinism, Yuri Borisov, with new and shocking evidence about the repressions. As a result, Borisov prepared a new textbook for publication in 1988 that included a section on Russia in the 1930s, which was "unambiguously anti-Stalinist." 75 Second, investigation into the numbers of deaths in the Great Patriotic War and subsequent wars initiated a debate around the nature of the victory of the Great Patriotic War. To what extent could it be considered a victory since so many people died $?^{76}$ In their 1995 textbook, Danilov and Leonov outlined the war's impact on loss of life. They also noted that the Great Patriotic War destroyed factories, villages and infrastructure, which had a profound impact on the national wealth of the country. The author asked at the end of the section, "Why, in your opinion, were human losses so great?"77

Other authors like Viktor Suvorov wrote revisionist materials on Soviet strategy in the Second World War. ${ }^{78}$ In his 1987 piece, Icebreaker: Who started the Second World War? Suvorov argued that Joseph Stalin already had plans in place to stage an offensive attack against Nazi Germany in 1941. His work was met with both praise and criticism.

\footnotetext{
${ }^{73}$ Leshchiner and Poltorak, "The Standard for History Education in Russia's Schools," 317.

${ }^{74}$ R. W. Davies, Soviet History in the Yeltsin Era (New York: St. Martin's Press inc, 1997), 119.

${ }^{75}$ Ibid.

${ }^{76}$ In Danilov and Leonov, Istoriia Rossii v XX veke, 110-111.

77 Ibid.

${ }^{78}$ Viktor Suvorov (born 1947) was a former intelligence officer and author of many Soviet/ Russian military non-fiction books.
} 
Authors like Yuri Gorkov and Valeri Danilov, who found new information in the archives, which documented similar ideas, supported him. ${ }^{79}$ While facing widespread criticism, these pieces of work inspired a canon of literature seeking to revisit Soviet strategy on the eve of the Great Patriotic War. Their findings threatened the militarisation of society, as they reframed the history of the Great Patriotic War, which was previously shaped by military-patriotism and formed a basis of Soviet society and legitimacy.

The initial wave of revisionist literature was naturally condemned by a number of veteran groups on the eve of the 1995 Victory Day Parade. In March 1995, a letter from the Novosibirsk Veteran Organisation, addressed to the "Young warriors of the Siberian Military District" [Novosibirsk], stated:

Today there are some false teachings and the new appearance of 'historians' who are trying to rewrite the history of the Great Patriotic War and the Second World War as a whole. They falsify events, distort the course and outcome of the war...it's a lie and a scoundrel!...The current youth should know not to be deceived. The truth of the history of the Great Patriotic War is that it's the victory won by the Soviet people and its Armed Forces...this story cannot be blackened and crossed out. As you know, people who have lost respect for their past have no future. ${ }^{80}$

A rise in revisionist publications and the $50^{\text {th }}$ anniversary of the end of the Great Patriotic War furthered conversations about the general state of militarisation in Russian society and the youth's role within it. Discussions within the State Duma on the issue of the military-patriotic spirit of the youth went far beyond the formal education setting. Discussion participants called for connections to be made between the youth and the veteran community, hoping it would reignite patriotic passion within Russia's youth (many of whom were evading the draft in Chechnya). Russia's youth, as the future generations of Russia, were considered the bridge between past and present. For some State Duma officials and veteran organisations, the repatriotisation of Russia's youth ensured the continued popularisation of a patriotic identity, with the belief that it would restore national pride in Russia and the youth's willingness to protect it. For example, in

\footnotetext{
${ }^{79}$ Valeri Danilov is a Russian military historian. Yuri Gorkov (1928-2005) was a Soviet and Russian military leader and historian. For more information regarding the specific content of these books, please see: Yuri Gorkov and Valeri Danilov, "Gotovil li Stalin unprezhaiushchi udar protiv Gitlera v 1941 g.," Novaia I Noveishaia Istoria, No. 3 (1993): 29-45; Viktor Suvorov, Ledokol: Kto nachal Vtoruyu Mirovuyu Voyna? (Russia: Dobraia Uniga, 1987).

${ }^{80}$ GARF, f. 10100, op. 1, d. 1003, 1. 29-30, March 1995.
} 
June 1994 Russian Prime minister Viktor Chernomyrdin outlined a draft programme for the preparation and conduct of the $50^{\text {th }}$ anniversary celebrations. ${ }^{81} \mathrm{He}$ noted that the anniversary should be used to "consolidate society, educate the younger generation of love for the motherland, a sense of responsibility for the fate of Russia." 82 Chernomyrdin's statements of patriotism and the defense of Russia as a form of civic duty highlight concerted efforts to revive a military patriotic education in society.

In February 1995, State Duma officials and veteran organisations discussed the topic of new historians "blackening the history of the Great Patriotic War." ${ }^{\text {" Documents }}$ noted the ousting of "patriotic and military education from educational institutions" and called for new initiatives to counteract and challenge such accounts. ${ }^{84}$ In March 1995, the veterans' organisation of Novosibirsk, for example, called on the youth to ignore this new history, claiming, "We are aware that not everything is smooth in our history. However, this story cannot be blackened and crossed out." ${ }^{85}$ Such blackening highlighted the importance of a patriotic narrative for the future security of the country. An appeal to the Heroes of the Soviet Union in the War years, Knights of the Order of Glory and Parliaments and Governments of the Commonwealth of Independent States during a $50^{\text {th }}$ anniversary jubilee meeting, noted:

In modern conditions, the importance of a military-patriotic education of youth is growing. Everyone sees our duty in doing this... to pass on our life experience to them. [The] Youth [should be] proud of his Fatherland, [and] if necessary, be ready to protect the material and spiritual values of his homeland...We, veterans, consider inadmissible the distortion and falsification of the heroic history of the Great Patriotic War. Our whole history testifies that the strength and invincibility of [the] fraternal peoples [is] in their unity and friendship. A convincing confirmation of this is [in] our global historical victory over Fascism. ${ }^{86}$

\footnotetext{
${ }^{81}$ Viktor Chernomyrdin (1938-2010) was Prime minister of the Russian Federation between 1993 and 1998.

82 Viktor Chernomyrdin, "Ob utverzhdenii Programmy podgotovki I provedeniia prazdnovaniia 50-letiia Pobedy I drugikh pamiatnykh dat Velikoi Otechestvennoi Voiny 1941-1945 godov," Pravo, No. 614, 1 June 1994, accessed 4 February 2021, http://pravo.gov.ru/proxy/ips/?docbody $=\&$ prevDoc $=102034863 \&$ backlink $=1 \& \&$ nd $=10$ 2030419.

83 GARF, f. 10100, op. 1, d. 1003, 1. 37, 24 February 1995; GARF, f. 10100, op. 1, d. 1003, 1. 28, 19 April 1995.

${ }^{84}$ Ibid.

${ }^{85}$ GARF, f. 10100, op. 1, d. 1003, 1. 29-30, March 1995.

${ }^{86}$ GARF, f. 10100, op. 1, d. 1003, 1. 37, 24 Feburary 1995.
} 
While the changes made to educational textbooks were not significant, calls for a revised patriotic education were reflected in some of them. Questions posed in books like V. A. Potseluev's 1997 and A. A. Kreder's 1996 history textbook included, "What other examples of heroism of the Red Army, do you know?" and "How do you prove the Soviet-German front remained the main front of the Second World War?" 87 These questions matched those identified by Zajda in Putin-era textbooks. He claims that such questions were designed to reinforce the importance of the war in society. ${ }^{88}$ Aleksandra Ishimova's 1996 children's history book depicted patriotism in a difference sense, noting that it was impossible to count the times Russian soldiers had shown their courage. ${ }^{89}$ Emphasis was placed on identifying and recognising the victories of the Soviet Union in the Great Patriotic War and other historical exploits, rather than the shortcomings.

The reconfiguration of Russia's historical education was accompanied by calls to connect generations. State Duma Deputy V. Volkov promoted the creation of links between Russia's youth and the military, claiming, "It's time to restore the connection of times." He suggested reviving activities that saw veterans visiting neighbourhoods and schools, where children honoured the veterans with concerts and parties. ${ }^{90}$ The Veterans Organisation of Novosibirsk suggested, "Prepare to celebrate the $50^{\text {th }}$ anniversary of the Great Victory with dignity, as a national holiday, show your recognition and respect for the older generation... take your fate into your own hands." 91 The calls made by Volkov

\footnotetext{
${ }^{87}$ V. A. Potseluev, Istoriia Rossii XX Stoletia (Osnovnye problemy) (Moscow: Vlados, 1997), 283; A. Kreder, Noveyshaia Istoriia XX vek: Uchebnik dlia osnovnoy shkoly, (Moscow: Tsentr Gumanitarnogo Obrazovaniia, 1996), 144. (Please note, this edition of Kreder's textbook is different to the one published by the SOROS foundation). Vladimir Alekseevich Potseluev is a Russian historian. He has written history textbooks since the Perestroika years. In the foreword of his 1997 textbook, he calls the ideological hold that the Soviet Union had over its people, a "mystery." This book has a print-run of 30,000. This book was "Recommended by the ministry of General and Professional Education of the Russian Federation as a textbook for students in higher educational institutions." A. Kreder's textbook has a print-run of 40,000. Kreder (1947-2000) was a contemporary historian interested in global history.

${ }^{88}$ Zajda, "Russian History Textbooks," 14.

${ }^{89}$ Aleksandra Ishimova, Istoriia Rossii v Rasskazakh Dlia Detei, (Moscow: AST publishing house, 1996), 121. The print-run for this particular edition was 15,000. Aleksandra Ishimova (1804-1881) was a famous children's book author. The first edition of this book was published in St. Petersburg in 1837 and in six parts. The book was awarded the Demidov Prize a non-state prize for outstanding contribution to science. The Demidov Prize was reinstated in 1993.

${ }^{90}$ GARF, f. 10100, op. 1, d. 1003, 1. 28, 19 April 1995.

${ }^{91}$ GARF, f. 10100, op. 1, d. 1003, 1. 29-30, March 1995.
} 
and the Veteran organisation were ones echoing the suggestions made in the draft programme established by Chernomyrdin in June 1994. Section Three of the programme, titled "Advocacy and cultural events" called for the promotion of the military and labour exploits, of those within the Armed Forces and in supportive roles, in the media, in literature and art and in other forms of active work. This promotion was organised to educate the population, "especially among young people, a sense of pride in the perfect older generations during the Great Patriotic War."92

Connecting the youth to veterans is an effective tool of political manoeuvring and initiative in the militarisation of the younger generations. Similarly to studies focusing on the rise of the Siloviki (Russian politicians with a military background), the veterans' views have been shaped by their experiences of war. Their experiences within the Armed Forces are the experiences they would pass down to the younger generations. Such rhetoric facilitated the militarisation of society as it encouraged, as Danilova suggests, the support for the military cohort. While negative images of the war arose in educative and commemorative landscapes, these pictures were accompanied by ideas of duty. Russia's youth, for example, were called upon by the Veterans' organisation of Novosibirsk to continue the sacrifices of their ancestors. They said, "In memory of the fallen [in the name of] the Fatherland, for their military and labour exploits, now living as veterans...love the motherland...die and protect it."93

Discussions within the State Duma and concerns raised by Veterans' organisations were driven by a rise in revisionist literature, rewriting the history of the Great Patriotic War. These accounts questioned the victory of the war when considering the death figures, and threatened the viewpoint that the Soviet Union was vulnerable when it was invaded by Nazi Germany. In response, political figures, members of the State Duma and veterans rallied to revive the military-patriotic spirit of the nation. As documented in this section, anniversary events, including the popularisation of the veterans' exploits across various domains, were aimed at Russia's younger generations. They believed their participation in these events would raise youth patriotism, national pride in Russia and instil a sense of civic duty to protect their country. This is particularly

92 Chernomyrdin, "Ob utverzhdenii Programmy podgotovki I provedeniia prazdnovaniia 50-letiia Pobedy."

${ }^{93}$ GARF, f. 10100, op. 1, d. 1003, 1. 29-30, March 1995. 
salient in chapter five, which addresses the memory of the Great Patriotic war in the 1995 Victory Day parade.

\section{HISTORICAL EDUCATION AS A VEHICLE OF MILITARISATION}

On a global scale, schooling systems are considered the main and trusted institution for the education of youth, with teachers, as specialists, holding a high level of authority. As trusted spaces of knowledge, the information that passes through these institutions are regarded and accepted as the truth by the majority of students. ${ }^{94}$ Educators and school systems bring past experiences into the process of learning, with their experiences influencing how the teachers and the students interact with new ideas and events. ${ }^{95}$ This process, however, while important, is only partial. In formal state education, the state has some control over the content and curriculum undertaken by the students. ${ }^{96}$ Like many other countries around the world, Russia created a curriculum that would best reflect its present and future goals. During the Second World War, Japan's educational system was utilised as a common instrument for militarisation, socialising society's youth to support an aggressive worldview. ${ }^{97}$

Indonesia as a case study is slightly different. Even after the fall of Suharto's military regime in 1998 and the implementation of a civilian government, militaristic discourse largely remained dominant in historical textbooks. The most interesting aspect of the Indonesian case, which was similar to the continued militarisation of society under Yeltsin's administration, was that militaristic discourse had been so prevalent under the Suharto regime that such a tradition could not be undone immediately under the following civilian leadership. Hieronymus Purwanta suggested the continuation of militarised

\footnotetext{
${ }^{94}$ Marcia Baxter Magolda, Making their own war: Narratives for Transforming Higher Education to promote self-development (Virginia: Stylus Publishing, 2004), 236.

${ }^{95}$ While on the topic of children's book authors, Robert Sutherland claims that books are shaped by the authors' values and world view and that events may be reflective not only of the authors' view but of culture at large. See for example: Robert Sutherland, "Hidden Persuaders: Political Ideologies in Literature for Children," Children's Literature in Education 16, No. 3 (1985): 143-157.

96 Ekaterina Lenintova, and Jim Butterfield, "History Education and History Remembrance in Contemporary Russia," Communist and Post-Communist Studies 43, No. 2 (2010): 2.

97 Saburo Ienaga, "The Glorification of War in Japanese Education," International Security 18, No. 3 (1993-1994): 116-117.
} 
discourses beyond Suharto's military regime was there to promote "the power of arms and supports violent means of conflict resolution by glorifying the military." 98 Textbooks were the material structures of this ideology, in which discourses were established and perpetuated.

This thesis conceptualises education as a tool of state-led militarisation in postSoviet Russia. As sources of information promoting an "approved knowledge" of the state, the educational discourses acted as official stories of Russia's historical past. ${ }^{99}$ Scholars of education in Post-Soviet Russia claim that efforts to reform and reaffirm a militaristic-patriotic education started in the Putin era. Zajda, for example, notes that efforts to create a more nationalistic education system were motivated by revisionist accounts of Russia's participation in the Great Patriotic War. He claimed that these accounts lessened Russia's role in the victory over Nazi Germany. ${ }^{100}$ However, these efforts appeared much earlier in the chronology of the Post-Soviet Russian State. These revisionist accounts, while impactful to some extent, did not topple the dominant narratives present in the Soviet period - i.e. the victory of the Great Patriotic War. This allowed for a greater re-patriotisation of education during the Yeltsin years, which

98 Hieronymus Purwanta, "Militaristic Discourse in Secondary Education History Textbooks during and after the Soeharto Era," Journal of Educations Media, Memory and Society 9, No. 1 (2017): 36.

A similar phenomenon occurred in France following the Franco-Prussian War (18701871). Fearing the demise of French Society, historian Ernest Lavisse wrote a number of school history textbooks, aimed at restoring the students pride in the French nation following the defeat. He paid particular attention to nationalist militaristic narratives, which he believed would 'invigorate them with patriotism.' Lavisse believed his textbooks would inspire a new age of 'good citizen-soldiers,' who would be enthusiastic to bear arms for his nation. While not in a textbook capacity, youth fiction in 1914 Germany held similar mobilising techniques and were vastly mobilised. The stories in these books were a reflection of the interests of the authors who, usually from aristocratic communities, supported German Imperialism. The First World War catapulted the war literature genre into the spotlight, motivating a canon of new militaristic war literature, which pushed notions of nationalism and militarism further into the public sphere. Andrew Donson claims the literature paved the way for the rise of fascist and radical right paramilitary groups after 1918. See for example: Andrew Donson, "Models for Young Nationalists and Militarists: German Youth Literature in the First World War," German Studies Review 27, No. 3 (2004): 579-582; Denis M. Provencher and Luke L. Eilderts, "The Nation According to Lavisse: Teaching Masculinity and Male Citizenship in ThirdRepublic France," French Cultural Studies 18, No. 1 (2007): 31-32.

99 Zheng Wang, "National Humiliation, History Education, and the Politics of Historical Memory: Patriotic Education Campaign in China," International Studies Association, 52, No. 4 (2008): 786.

${ }^{100}$ Zajda, "Globalisation, Ideology and History School Textbooks," 6. 
underpinned the militarisation of society under current Russian President Vladimir Putin. ${ }^{101}$

\section{Conceptualising the military-educational complex in Post-Soviet Russia}

In Post-Soviet Russia, there was a clear military-educational complex. The 25 textbooks under review in this chapter focus on Russian history. They encompass different historical periods, with some textbooks concentrating on the $20^{\text {th }}$ century, and others covering Russian history from the $9^{\text {th }}$ century up to the $20^{\text {th }}$ century. As noted by Danilov and Leonov in the foreword to their 1995 textbook, the $20^{\text {th }}$ century was an unprecedented time not just for Russia, but also around the world. This led to an influx of textbooks written solely about the $20^{\text {th }}$ century. However, these historians also wrote exclusively about the $20^{\text {th }}$ century to correct the communist ideological frames that existed in the Soviet period. ${ }^{102}$

Military conquests, external threats and stories of heroes dominated historical textbooks. Potapova notes that textbooks in the Putin era are "lessons in patriotism." She claims that authors write with the aim of forging civic solidarity, or to pull on the emotional strings of its recipients with phrases of "love" for their country and "pride" they should feel for their history. ${ }^{103}$ However, this was a tactic also used in the immediate Post-Soviet period. Students were introduced to the history of their "ancestors," told they would be "pleased to find out where and how they lived," and that they should be "proud of the glorious deeds of their ancestors." 104

Events were evaluated with the values of the author and the wider ideals of the state being communicated through the textbooks. Therefore, this chapter is split into two sections and will combine evidence of the military-educational complex under the subtitles of Politics of Advocacy and Politics of Attack. These headings are classifications employed by Robert D. Sutherland, as "ways in which inherent ideologies are expressed." 105 The Politics of Advocacy classification is "the upholding of a particular

\footnotetext{
${ }^{101}$ Marina Erokhina and Alexander Skevurev, "Old Heritage and New Trends: School History Textbooks in Russia," in School History Textbooks across Cultures: International Debates and Perspectives, ed. by Jason Nicholls (Oxford: Symposium Books Limited, 2006), 90.

102 Danilov and Leonov, Istoriia Rossii v XX veke, foreword.

${ }^{103}$ Potapova, "Normativity in Russian History Education," 50.

${ }^{104}$ Ishimova, Istoriia Rossii v Rasskazakh Dlia Detei, 11.

${ }^{105}$ Sutherland, Hidden Persuaders, 3.
} 
view or course of action as valid and right." It is seen as a method of indoctrination and for promoting a specific set of values. ${ }^{106}$ He uses biographies of famous people to state that the Politics of Advocacy in this sense, and the promotion of a patriotic narrative, would omit negative parts of their record that would overshadow the greatness of their achievements. ${ }^{107}$ The Politics of Attack would be an attack on anything that conflicted with the author's view and in the case of Russia's education textbooks, the view of the state. Sutherland uses the discrediting of characters as an example to explain his point. ${ }^{108}$ The chapter does not introduce a section under the title, the Politics of Assent. This term was conceptualised by Sutherland as the point where the author confirms the dominant narratives of the state. In Sutherland's understanding, the Politics of Assent highlights the normalisation of an establishing ideology, through the notion that the author has internalised that ideology without question. ${ }^{109}$ The classifications used in this chapter help identify dominant discourses, one glorifying certain aspects of the state, while the other vilifies anything that threatens the dominant discourse. In Russia, militarised discourses were prominent under the themes Politics of Advocacy and Politics of Attack. Brave heroes, defending the motherland against hostile invaders served to glorify the role of historic figures performing military deeds, while 'othering' reaffirmed the Russian perception that the 'world is a dangerous place.' Both ensured that Russia's youth remained exposed to military-patriotic discourses, which popularised defence readiness, sacrifice and state loyalty.

However, textbook authors also attempted to remove themselves from the content of the textbooks, by providing a number of contesting views and challenging the students to think critically. Danilov and Leonov's 1995 textbook showed the darker sides of the Great Patriotic War (by showing loss of life) in its content. In addition, Danilov and Leonov asked students; "What problems of the history of war need, in your opinion, rethinking and re-evaluation?" 110 This question pushes students to reconsider issues with Soviet literature on the history of the war. This threatened (to some extent) the militarypatriotic discourses that were common in Soviet textbooks, because it promoted the use of critical analysis among its students. However, they were also asked to maintain a

\footnotetext{
106 Ibid.

${ }^{107}$ Sutherland, Hidden Persuaders, 2.

${ }^{108}$ Ibid, 3-4.

${ }^{109}$ Ibid, 7.

110 Danilov and Leonov, Istoriia Rossii v 20 veke, 105.
} 
critical line. Danilov and Leonov also asked: "What new points of view of these problems in recent literature seem unacceptable to you, and why?" 111 In this sense, the textbooks did not work to de-militarise society, but to raise the critical awareness of the youth. Calling on students to identify what histories should be reframed and discussing issues with new revisionist historical discourses did not diminish the glorious messages associated with Great Patriotic War history.

This chapter does not include a section under the title, Politics of Assent. This is because the narratives under the Politics of Advocacy and Politics of Attack are those that are already in line with the status quo - and the prominent acceptance of such narratives highlights its establishment as an ideological norm. In this chapter, the Politics of Advocacy will demonstrate a clear desire of educational authors to valorise Russia "heroes." The Politics of Attack section will show that textbook authors played a salient role in the demonisation of the enemy, and the creation of the image of Russia as a besieged fortress.

\section{POLITICS OF ADVOCACY}

Russian historical textbook authors of the 1990s promoted a largely patriotic image of the military. While of course, revisionist accounts threatened the dominant discourse of Soviet victory during the Great Patriotic War, Russia's history was not solely a history of the Great Patriotic War, or one dependent on Soviet history. ${ }^{112}$ Actually, historical textbooks of the 1990s recognised a longer history of Russia, from its early conception in the $9^{\text {th }}$ century up to the modern day. It was a motivation of the state to unite post-Soviet Russia with the Russia that existed prior to the Bolshevik Revolution. ${ }^{113}$

As a result, religious history became a forum where historians of the post-Soviet era were able to reject aspects of the Soviet regime; i.e. state-sponsored atheism. ${ }^{114}$ Historians paid particular attention to how important Christianity was to the creation of the Russian state. Some accounts noted that Christianity civilised the early Eastern Slavic tribes, and that key figures like Olga and Prince Vladimir were those who drove the

\footnotetext{
111 Ibid.

112 Ibid.

${ }^{113}$ Kaplan, "History Teaching in Post-Soviet Russia," 254.

${ }^{114}$ Morgan and Kliucharev, "Higher Education and the Post-Soviet Transition in Russia," 5.
} 
popularisation of Christianity in the region. ${ }^{115}$ As noted in Dvornichenko et al.'s 1999 textbook:

It was then (as the Viatichi threat, to Vladimir's aim to grow his super union, enhanced) that Prince Vladimir turned his eyes to Christianity, [as] a religion in which the moment of centralisation, monotheism is predominant. In 988, Christianity began to be introduced to Russia as a state religion. In Kiev it was introduced painlessly with the consent of the national assembly...but in other lands it was imposed by force. ${ }^{116}$

The attention paid to religious history in new Russian textbooks of the 1990s, especially those documenting Russian history from the $9^{\text {th }}$ century, demonstrated a concerted effort to unite Russian identity with the Orthodox Christian faith. Passages like this highlighted a particular departure from the Soviet Union, which promoted scientificrationality over religion, in an effort to root Russia's heritage and origins in the growth of Russian orthodoxy. The increasing use of religious figures and tropes in commemorative events, for example, alongside the increasing presence of religion, strengthened the notion that Russia in the 1990s had made considerable changes in order to create distance from its Soviet predecessor.

Yet, while some changes were made, a number of procedures remained the same. For example, Russian leaders and soldiers who participated in military action were glorified. In Ammona's 1998 history textbook for example, Sviatoslav I (943-972) was described as a "glorious warrior and murderous ruler." 117 The contradiction in the representation of Sviatoslav is similar to depictions of Stalin. Davies noted that many new publications of the 1990s were tested to challenge the Stalinist myth. While many wrote about totalitarianism in the Soviet period as a whole, they refused to discuss totalitarianism more directly as they believed it would highlight more negative features of Stalinist rule. Instead they focused more on the injustices of the Soviet system, and spoke more generally on the economic, cultural and social developments made under his rule. ${ }^{118}$ In line with Sutherland's Politics of Advocacy, the more altruistic and glorious deeds of historical figures remained vastly more prominent than their mistakes. ${ }^{119}$

\footnotetext{
115 Ammona, Istoriia Rossii, IX-XX vv., 54.

${ }^{116}$ Dvornichenko et al., Istoriia Rossii, IX-XX veka, 44.

117 Ammona, Istoriia Rossii, IX-XX vv., 54.

${ }^{118}$ Davies, Soviet History in the Yeltsin Era, 123-125.

${ }^{119}$ Sutherland, "Hidden Persuaders," 3-4.
} 
Some authors were more explicit in their aim of outlining Russia's glorious past. As noted by author Nikolai Nikolaevich Golovin in the foreword to his 1992 book on Russian history for children, "it is known that children are interested in stories about heroes and exploits." 120 The book, which was written and published originally 90 years before it was republished in the post-Soviet era claimed, "Russian history is rich with examples of heroic deeds and good beginnings." ${ }^{121}$ Golovin, an Imperial Russian General, wrote with the purpose of communicating with his readers about the history of "love of the homeland and self-sacrifice." 122 The republishing of the book in 1992 highlighted continuity between the historical narratives in the educational sector of Yeltsin's Russia and Imperial Russia and an attempted re-rooting of student's heritage in the immediate post-Soviet period.

Like Golovin's 1992 book, many other authors of textbooks published in the 1990s left ample room for discussion of Russia's militaristic history and the key figures involved. In a foreword to V. A. Potseluev 1997 textbook Istoriia Rossii XX Stoletiia, T. Bataeva wrote that the author had written a number of original works "on heraldry, foreign policy and labour activity of the Soviet people and the heroes of the country." 123 Ishimova's 1996 book justified her inclusion of Russia's militaristic past as a form of preparation. Writing on the topic of poor living conditions in the military, she stated that one day readers might also need to endure poor living conditions to protect the fatherland. ${ }^{124}$ Therefore, these textbooks should not only be considered a form of education but also socialisation - providing the students with historical information, but and preparing them to devote themselves to ensuring the security of its country. ${ }^{125}$

${ }^{120}$ N. N. Golovin, Moia Pervaia Rossiskaia Istoriia v Rasskazakh dlia Detei, (Moscow: Terra, 1992), foreword. This edition had a print-run of 50,000. Nikolay Nikolaevich Golovin (1875-1944) was a Russian military leader and Russian historian. He was mainly interested in history on the First World War. This particular book was republished in the 1990s.

${ }^{121}$ Ibid.

122 Ibid.

${ }^{123}$ T. Bataeva, Predislovie to Istoriia Rossii XX Stoletia (Osnovnye problemy), by V. A. Potseluev (Moscow: VLADOS, 1997), 3-7. This book has a print run of 30,000. T. Bataeva was a Professor of History at the International Academy of Sciences of Higher Education.

${ }^{124}$ Ishimova, Istoriia Rossii v Razzkazakh dlia Detei, 4.

${ }^{125}$ Not all of the textbooks explored in this thesis are as militaristically charged as those by Golovin and Ishimova. Many of the textbooks examined do prioritise military history over other aspects of Russian history, not only showcasing just how much Russia has been involved in war, but also promoting the view that Russia today is built on narratives 
People and leaders of the early Kievan Rus era were especially glorified in textbook literature for their role in the establishment of the modern Russian landscape. Slavs until 862 were defined as "Brave heroes," and classified as self-sacrificing through their willingness to fight neighbours and wild beasts that threatened their neighbours. ${ }^{126}$ Rurik, Prince of Novgorod became leader of Kievan Rus in $862 .{ }^{127}$ Noted as the founder of the Russian state, Rurik was characterised as a protective leader who wanted to defend the Russian people from hostile opposition. Golovin's 1992 book stated that Rurik ensured "that no one should offend the Russian people." "28 It is clear from the textbooks that Rurik not only founded dynastic rule in the region, but also established a foundation for further expansion of Kievan Rus. As noted in 1999 by Dvornichenko et al., subsequent leaders, for example, have continued to expand the "patchwork empire of Rurikovich."129 These textbooks suggest that even during the conception of the modern Russian state, leaders of Rus were concerned by external threats. In doing so, these textbooks indicate early signs of Russia's beseiged fortress mentality, and the evolution of the pre-existing notion that Russia is a vulnerable country surrounded by hostile neighbours. This discourse is only strengthened by historical accounts and evidence that documents Russia's ability to overcome invasions and conquests. This was certainly the experience of Oleg and Sviatoslav I.

Upon Rurik's death in 879, his son, Igor, was too young to ascend the throne, and therefore Oleg became the leader of Kievan Rus. ${ }^{130}$ While many of Rus' conquests were characterised as defensive, there were of course times in which the leaders of Rus performed their own invasions - although, at times, these were framed within the context of Rus' leaders trying to create a buffer zone. This was the case with Oleg, who was characterised as being clever. He was known most for his role in the defeat of Kievan

and Russia's experience of war. However, as is noted throughout the thesis, the textbooks do examine other aspects of Russian history also, such as religion, culture, Russian leadership and foreign trade.

126 Ishimova, Istoria Rossii v rasskazakh dlia detei, 11; Golovin, Moia Pervaia Rossiiskaia Istoriia v Rasskazakh dlia Detei, 11.

${ }^{127}$ Rurik (830-879) ruled Kievan Rus from 862-879. He, alongside Sineus and Truvor were Varangians, invited by Slavs to rule the land. As noted by Dvornichenko et al. "Our land is abundant and there is no order in it." For more on this, please see: Dvornichenko et al. Istoriia Rossii, IX-XX veka, 41; A. A. Danilov, Istoriia Rossii, IX-XIX: Spravochnik Shkol'nika, (Moscow: Drofa, 1999), 4-10. Danilov's book has a print-run of 10,000.

${ }^{128}$ Golovin, Moia Pervaia Rossiiskaia Istoriia v Rasskazakh dlia Detei, 15.

${ }^{129}$ Dvornichenko et al. Istoriia Rossii IX-XX veka, 42.

${ }^{130}$ Oleg of Novgorod (845-912) ruled Kievan Rus between 879 and 912. 
Princes Askold and Dir. Ishimova's 1996 history book noted that Askold and Dir "loved war very much," depicting them as warmongering princes who posed a threat to the early Rus' state. Oleg defeated them through the use of sly tactics. ${ }^{131}$ Ammona's 1998 textbook claimed that Oleg travelled to Kiev upon hearing of Kiev's successful trading structure with the East and its control over many southern areas. According to Ammona (1998), Oleg told merchants that he wanted to talk to the Princes. ${ }^{132}$ Ammona's account supported that of Ishimova (1996), who claimed, "Once inside, Oleg's warriors surrounded the people [of Kiev] and claimed he was [the] Prince. The warriors then killed the Princes."133 The defeat allowed Rus to expand into Kiev.

A number of textbooks agree that the people of Kievan Rus characterised Oleg as "prophetic." ${ }^{134}$ As Skrynnikov wrote in his 1997 textbook, "Oleg was a hero of Kiev epics. The annalistic history of his wars with the Greeks is permeated with folklore motifs... Kiev epics, retold by the chronicler, described Oleg's campaign [against the Greeks] as a grandiose military enterprise." ${ }^{135}$ It is clear, similar to depictions of Sviatoslav I, that the story of Oleg's cunning scheme to trick Askold and Dir was downgraded to satisfy this narrative of a "hero." Textbook authors muted the violent aspects of Oleg's conquests. This was the case with the depiction of Oleg's raid into Byzantium (907). He was glorified as a hero of Kiev epics, yet as noted in Golovin's 1992 book:

From Kiev, Oleg and his soldiers went to fight in the Greek land. On horses and on boats, the Russians approached the city of Tsargrad and began to burn houses and churches and kill residents. The Greeks got scared and said to Oleg: "Don't ruin our city. We'd better give you tribute as much as you want." And the Greeks sent him a lot of silver and gold and other expensive things. Oleg made peace with them and went back to Kiev with his rich booty, but before leaving, he nailed his shield on the gates of Constantinople in memory of his successful campaign. ${ }^{136}$

\footnotetext{
${ }^{131}$ Ishimova, Istoriia Rossii v Rasskazakh dlia Detei, 13.

132 Ammona, Istoriia Rossii IX-XX vv., 35.

${ }^{133}$ Ishimova, Istoriia Rossii v Rasskazakh dlia Detei, 15.

${ }^{134}$ Ishimova, Istoriia Rossii v Rasskazakh dlia Detei, 15.

Danilov, Istoriia Rossii, 11.

R. G. Skrynnikov, Istoriia Rossiiskaia IV-XVII vv., (Moscow: Ves Mir, 1997), 15. This book has a print run of 10,000. Ruslan Grigorievich Skrynnikov (1931-2009) was a Soviet-Russian historian and specialist of Russian history in the $16^{\text {th }}$ and $17^{\text {th }}$ centuries. He was awarded in 1997 as a Honored Scientist of the Russian Federation.

135 Ibid.

${ }^{136}$ Golovin, Moia Pervaia Rossiiskaia Istoriia v Rasskazakh dlia Detei, 15-18.
} 
Skrynnikov's 1997 textbook, for example, reduced Oleg's role to crafty tactics. Skrynnikov stated, "Oleg outwitted the Greeks." ${ }^{137}$ Ishimova's 1996 book, while acknowledging the sly tactics of Oleg, still characterised him as "brave" and selfsacrificing. ${ }^{138}$ In doing so, the authors were trying to promote a better image of Oleg, to present him as a worthy hero. These narratives fit within Sutherland's Politics of Advocacy classification, as they popularise a more glorious image of Oleg over the reality, which was that Oleg cunningly tricked Askold and Dir and then killed them and was brutal in his conquest of Constantinople.

These textbooks, through the omission of Sviatoslav and Oleg's dishonourable characteristics, demonstrated that they were aiming to create a more positive outlook on Russia's heroes. The popularisation of historical figures from Kievan Rus' and Imperial Russia served the state well. In trying to unite contemporary Russia with Russia pre-1917, the state needed to promote recognisable and worthy role models for Russia's youth that created enough distance between the new Russian state and the Soviet period. By prioritising attributes that glorified the individual, the textbooks were establishing and promoting a set of desirable attributes. It just so happened that these attributes were ones of bravery, courage and state loyalty - which matched those being promoted across a number of Russia's societal domains. This would continue beyond Oleg's reign.

The Drevylians killed Oleg in 912. His wife Olga succeeded him while his son, Sviatoslav I, grew. ${ }^{139}$ Sviatoslav I was commonly characterised as a "warlike" prince for his role in the many conquests and conflicts in his era of rule. ${ }^{140}$ In her 1996 textbook, Ishimova noted that people knew him as "Proud fearless Sviatoslav," "brave hero" and "our hero Sviatoslav." In accounting his struggles against the Byzantium Empire, she claimed, "so bravely did the Russian fight." ${ }^{141}$ This notion of Sviatoslav as a fearless leader was echoed in other textbooks. During a battle in 971 on the banks of the River Danube and within the Dorostol Fortress against the Byzantine Empire, for example,

\footnotetext{
${ }^{137}$ Ibid.

${ }^{138}$ Ishimova, Istoriia Rossii v Rasskazakh dlia Detei, 15.

${ }^{139}$ Dvornichenko et al., Istoriia Rossii, IX-XX veka, 42.

${ }^{140}$ Dvornichenko et al., Istoriia Rossii, IX-XX veka, 43.
}

V. V. Vedernikov, Istoriia Rossii dlia Uchashchikhsia 10-go klassa: Otvety na Ekzamenatsionnye Voprosy, (Volgograd: Bratiia Gruniny, 1997), 4-5. This book has a print-run of 2,000. Vladimir Viktorovich Vedernikov is a Soviet-Russian historian. In 1999 he was working with pupils in Volgograd on an All-Russian competition "Man in History. Russia XX Century." His students took first place.

${ }^{141}$ Ishimova, Istoriia Rossii v Rasskazakh dlia Detei, 21-22. 
Sviatoslav was noted in the annals as stating, "We shall not shame the Russian land, but we will lay bones, for the dead do not have shame" and, "I wanted to die for my fatherland and for the children of my sovereign." 142 These messages not only glorified sacrifice in war but also provided a role model for students. Sviatoslav, characterised as a brave hero for his role as this fearless leader, provided a clear representation for students to follow. The use of the term "warlike" highlighted a culture of militarisation in Russia, with the view that those with an obsession with the military or military background shaped their foreign policy around such militaristic endeavours. ${ }^{143}$ The glorifying representations of Sviatoslav, which mostly surrounded his actions in war, are similar to depictions of key figures in chapter four and five on such as Marshal Zhukov. These discourses helped contribute toward notions that should a citizen sacrifice themselves through war and show similar courage, that they too would be praised in a similar way.

Sviatoslav was killed under Byzantine Emperor John Tzimiske's orders. Other characters of the early Russian state, such as Prince Vladimir I and Prince Danil Romanovich also received similar praise. Vladimir's era was characterised as "heroic," while Danil's victory at the Battle of Yaroslav in 1245 was confirmed by the phrase, "But great-willed men are a formidable adversary for enemies on their own land." 144 Participants in the Neva Battle (1240), including Prince Alexander, were glorified for their role in the defeat of Sweden. Ammona's 1998 textbook claimed, "The actions of the talented commander and the heroism of Russian soldiers ensured a quick and glorious victory." He also noted that the victories at the Battle of Neva and Battle of Ice were only possible because the Russian people demonstrated, "evidence of the unshakable courage." 145 Many of the textbooks, as noted above, place a higher emphasis on leaders of the Kievan Rus - perhaps because these figures are well known and can be imagined by the Russian population. However, in Ishimova's (1996) and Ammona's (1998) accounts, ordinary people played a role in the victories that Russia forged.

${ }^{142}$ Dvornichenko et al., Istoriia Rossii, IX-XX veka, 43; Ishimova, Istoriia Rossii v Rasskazakh dlia Detei, 21.

${ }^{143}$ The militaristic policies of Peter I have been considered in a similar way to Sviatoslav I, as with the other Tsarist leaders, such as Paul I., Nicholas I and Alexander I. Their obsession with the military influenced militarism in Russia during the Tsarist Era. For more, please see: Keep, "The Military Style of the Romanov Rulers," 70-71.

${ }^{144}$ Dvornichenko et al., Istoriia Rossii, IX-XX veka, 49-51.

${ }^{145}$ Ammona, Istoriia Rossii IX-XX v., 74-76. 
Literature on the Great Patriotic War speaks predominantly of the role of everyday Soviet citizens, highlighting a sense of social unity against an adversary. ${ }^{146}$ This total war concept, in regards to support from the home front, is not a phenomenon new to the $20^{\text {th }}$ century. As noted in these textbooks, participation from all elements of society, not just on the battlefield, was considered important in understanding the Great Patriotic War victory. Potseluev's 1997 textbook, for example, raised the questions, "In what way and how much did the rear provide [support] for the front?" and "what was the effectiveness of the struggle of Partisan and Underground fighters?"147 These questions promoted the effectiveness of the united efforts of the Russian people in the Great Patriotic War, strengthening the notion that state loyalty and unity leads to victory. This is a particularly salient notion for consideration during the 1990s. The period was tumultuous, at best. Support for the President, for the war in Chechnya and for the military was fractured. Many scholars argue that this rupture played a role in Russia's initial loss against Chechnya. By highlighting Russia's unity (on all levels) as a reason for victory, it reflected on contemporary matters, suggesting that through unity, Russia could prevail in current conflicts. It also humanised the war. Textbook authors were framing the everyday Russian person within heroic terms, providing a clear role that Russian students could relate to. By emphasising the participation of "courageous" Russians, the audience could also imagine their role in the conflict. It bore recognisability to the reader, that anyone, even the ordinary Russian people, could be acknowledged should they show the same courage.

Accounts of brave Russians continued past the $13^{\text {th }}$ century. The reign of Peter I was greatly documented. As noted by authors of the late $17^{\text {th }}$ century, a comprehensive modernisation programme was underway in Russia. Developments were made on improving trade and foreign policy for example, however, it still lagged behind much of Western Europe. ${ }^{148}$ As observed in Dvornichenko et al's 1999 textbook:

The country needed a strong personality, which would possess not only supreme power, but also an understanding of the need for change, courage and decisiveness

\footnotetext{
${ }^{146}$ Richard Bidlack and Nikita Lomagin, The Leningrad Blockade, 1941-1944: A New Documentary History from the Soviet Archives (New Haven: Yale University Press, 2012), 1-3; Anna Reid, Leningrad: Tragedy of a City Under Siege, 1941-1944 (London: Bloomsbury, 2012), 3-4.

${ }^{147}$ Potseluev, Istoriia Rossii XX Stoletiia, 308.

${ }^{148}$ Dvornichenko et al., Istoriia Rossii, IX-XX veka, 149-150.
} 
of action, intelligence, energy and talent... Such detail appeared on the historical stage in the person of Peter I. ${ }^{149}$

Noted as a "great reformer" and praised and thanked for his creation of the powerful navy and "energetic measures" to restructure and rearm the army, which resulted in victories at war, Peter I was considered the father of modern Russia. ${ }^{150}$ Various textbook authors noted that the transformative activities of Peter I "finally undermined" Sweden's military power from 1713 until the end of the Northern Wars in 1721. ${ }^{151}$ Golovin's 1992 book depicted Peter I's eventual victory in the Northern Wars as an outcome of his patience and positive outlook. He claimed:

"If the Russians become scientists and strong people, it will be bad for us: they will conquer our country," said the Swedes. Then Peter remembered that these lands once belonged to the Russians and wanted to conquer them again. Swedes

${ }^{149}$ Dvornichenko et al., Istoriia Rossii, IX-XX veka, 150.

${ }^{150}$ Ammona, Istoriia Rossii, , IX-XX vv., 205; 229-230.

Peter I not only reformed the military, but was also seen as a figurehead in the modernisation of Russia more generally, and usually considered an Europeaniser. For example, please see: A. A. Danilov, Po Istoriia Rossii - Rabochnaia Tetrad dlia studentov vyzov, (Moscow: Vlados, 1998), 39-40; Tugan-Baranovskaia, Istorii Rossii dlia Uchashchikhsia 8-go Klassa, 23-31. Danilov's textbook had a print-run of 50,000. Tugan-Baranovskaia's textbook book had a print-run of 2,000.

${ }^{151}$ Dvornichenko et al., Istoriia Rossii, IX-XX veka, 150.

A list of the different reforms Peter I undertook after Russia's first loss against Charles VII of Sweden can be found in the following texts: A. L. Yurganov and L. A. Katsva, Istoriia Rossii XVI-XVIII vv. (Moscow: MIROS, 1996), 222- 223; V. I. Buganov and P. $\mathrm{N}$. Zirianov, Istoriia Rossii konets XVII-XIX vek, Uchebnik dlia 10 klassa obshchestobrazovatelnykh uchrezhdenii, (Moscow: Prosveshchenie, 1996), 22-23; Vedernikov, Istoriia Rossii dlia uchashchikhsiia 10-go klassa, 24-26.

Yurganov and Katsva's textbook has a 50,000 print-run. Andrei L'vovich Yurganov (born 1959) was a Soviet and Russian historian. He is a specialist in Russian medieval history. Leonid Aleksandrovich Katsva (born 1957) is a Russian teacher and textbook author. This particular edition of Buganov and Zirianov's textbook printed 50,000 copies. The 1995 edition circulated 180,000 copies. Viktor Ivanovich Buganov (1928-1996) was a Soviet and Russian historian. In 1993 he was a member of the Russian Academy of Education in the Department of General Secondary Education. In 1994 he was a member of the Russian Academy of Sciences in the History Department. He has published history books since 1962 and was particularly prolific in the 1980s. He is a popular historian with most of his books circulating in the 10,000+. Pavel Nikolavich Zirianov (1943-2007) was a historian and leading researcher within the institute of Russian history. He also served as an editor of the journal Otechestvennaya Istoriia [History of the Fatherland]. His books have been republished many times. 
and Russians began to fight. The Russians still did not know how to fight well, and the Swedish king Charles XII first defeated the troops of Tsar Peter.

"Nothing! - said Peter, - patience! We will learn from the Swedes to defeat them."

The king [Peter I] gathered a new army; taught it again. Monasteries and merchants gave the king money. With this money, Peter dressed and fed his soldiers. The tsar led his army against the Swedes, and the Russians took the Oreshek fortress from the enemies on the banks of the Neva. ${ }^{152}$

This view was supported by the stories written in Ammona's 1998 textbook, which noted, "In the heroic battles of Gangut (1714) Grengam (1720)... the young Russian fleet defeated Swedish naval forces." ${ }^{153}$ Peter I was the person who showed "courage, firmness and willingness to incur large expenses and risks" to dissolve the old army and create a new one. ${ }^{154}$

His transformations, however, did come at a heavy cost to the masses i.e. taxes, expansion of serfdom and endless levies. ${ }^{155}$ Similar to Sviatoslav I, Peter I was characterised by his obsession with the military. Upon taking the throne in the early 1680 s, he was only ten years old. By the end of the 1680s his "war games" were described as realistic as "manoeuvres of a small army" and he was noted for forging relations with military personnel like General Patrick Gordon, who "guessed the future commander and statesman in the restless youth." 156 Although in some cases Peter's obsession with the military was recognised as a reason for his fixation on reforming the military and militarising the bureaucratic affairs of Russian society, it was actually his conviction that "the army [and] navy... were perfect social structures, [and] should become a worthy model of the whole society." ${ }^{157}$ On the whole, Peter I's militarisation and subsequent victory in battles brought glory to Russia. Golovin (1992) noted:

The Poltava victory glorified Russia. Other lands began to marvel at her wealth and power, the courage of her troops and the greatness of her Tsar Peter. The Metropolitan, on behalf of all the people, called Peter the Great Emperor, and since then the whole world has called him that.

${ }^{152}$ Golovin, Moia Pervaia Rossiiskaia Istoriia v Rasskazakh dlia Detei, 119-124

${ }^{153}$ Ammona, Istoriia Rossii, IX-XX vv., 229.

${ }^{154}$ Anisimov and Kamenskiy, Istoriia Rossii, 1682-1861, 21-22.

${ }^{155}$ Dvornichenko et al., Istoriia Rossii, IX-XX veka, 153.

${ }^{156}$ Anisimov and Kamenskiy, Istoriia Rossii, 1682-1861, 22-24.

${ }^{157}$ Ammona, Istoriia Rossii IX-XX vv., 204. 
Peter the Great worked hard for the glory of Russia and the benefit of his people. ${ }^{158}$

Peter I's heroism was characterised not only through his patience and determination but also by his military exploits and successes. His exploits brought 'glory' to Russia, showing that international prestige was contingent on military successes. These passages above promoted action in the military, patience to overcome military failures and continued loyalty to the state. These were particularly important messages during the 1990s. Russia's military faced defeats in the late Soviet period and early years of the Russian Federation, yet in contrast to Peter I's efforts, morale within the military was low, with a large number of conscripts evading the draft. These educational messages promoted and reaffirmed the discourses that to serve in the military was a worthwhile activity and that veterans deserve respect. It lent itself towards militarisation by showing how Peter I overcame failure, relying on his perseverance and military reform to face his challenges.

The glorification of military figures and societal structure in this way continued beyond Peter I's reign. In reference to the Japanese War of 1905, "Russian soldiers showed amazing manhood and steadfastness." ${ }^{159}$ The soldiers' role in the Russo-Japanese conflict continued to be characterised as heroic and fierce. In the First World War, Russian soldiers were described as having "fiercely fought," even though they were defeated. ${ }^{160}$

One debate included in textbooks of the 1990s surrounded the desire of Russian politicians to pursue war. The political figures were depicted as incompetent. For example, when making a decision to continue the Russo-Japanese war, the Defence Council justified the continued participation on the basis that there was a "patriotic

${ }^{158}$ Golovin, Moia Pervaia Rossiiskaia Istoriia v Rasskazakh dlia Detei, 119-124.

${ }^{159}$ A. A. Danilov and L. G. Kosulina, Istoriia Rossii, XX vek: Dopolnitel'nye materialy $k$ uchebniky. 9 Klass, (Moscow: DROFA, 1997), 22-24. The print-run for this book was 8,400 . Lyudmila Gennad'eva Kosulina is a Soviet and Russian historian. She works at the Moscow State Pedagogical University. She has co-authored over 200 textbooks, most of which are with A. A. Danilov and are recommended by the Ministry of Education.

${ }^{160}$ Yu. A. Shchetinov, Istoriia Rossii v XX vek, (Moscow: Fair, 1998), 35.

Yuri Aleksandrovich Shchetinov is a Soviet and Russia teacher with specialisms in Soviet history. 
upsurge of soldiers and sailors [in Russia], a willingness to stand up to the end."161 Authors discussing Russian society on the eve of the First World War also documented this same patriotic upsurge. On July $26^{\text {th }}$, Nikolai II went to the State Duma for an emergency meeting regarding the potential outbreak of war. According to Ammona in 1998, "He was met with enthusiasm" at a state level, but also managed to gain the support of the ordinary citizen. He noted that worker strikes stopped, many oppositionist praised the war, and "most parties supported a defensive war." 162 Potseluev's 1997 textbook, similar to Ammona's account of the First World War, claims that the Japanese War offered Russia an opportunity to stifle revolutionary action within the country. Following an ultimatum by Japan for Russia to stop pursuing its interests in the Far East, the Minister of Internal Affairs Pleve, in a conversation with Nikolai II, stated, "we need a small victorious war" to suppress the revolution. ${ }^{163}$ Russia's foreign policy in the Far East, with the creation of a defensive alliance with China against Japan and garrisons at both Port Arthur and Vladivostok being strengthened prior to the 1904 attack by Japan, had already helped the Tsarist regime. As noted by Ammona in 1998, "The Tsarist government, fearing a looming revolution considered the small victorious war with Japan to be a good anecdote."164

Danilov and Leonov's (1995) and Potseluev's (1997) textbooks note that Russia's defeat in the Russo-Japanese war (1904-1905) has been considered a cause of the 1905 revolution. ${ }^{165}$ This is a particularly interesting notion to consider. In 1994, the First Chechen War began. Russian leaders were forced to go to conflict with the region in hope that a victory would popularise the Russian president. ${ }^{166}$ As with Nikolai II's experience at the start of the century, while the early years of the war suppressed dissent in Yeltsin's war, the loss in the war affected the popularity of the leaders. Their vanity and desire to remain in power resulted in a miscalculated entrance of Russia into war, unnecessary loss of life and decline of Russian prestige. While certainly not a story of great militarism, the assessment of Russia's role in the Russo-Japanese War showed that discourses

\footnotetext{
${ }^{161}$ Danilov and Kosulina, Istoriia Rossii, XX vek, 26.

${ }^{162}$ Ammona, Istoriia Rossii, IX-XX vv., 440.

${ }^{163}$ Potseulev, Istoriia Rossii XX Stoletia, 33.

${ }^{164}$ Ammona, Istoriia Rossii, IX-XX vv., 353.

${ }^{165}$ Danilov and Leonov, Istoriia Rossii v XX veke, 18.

Potseluev, Istoriia Rossii XX Stoletia, 35.

166 Anatol Lieven, Chechnya: Tombstone of Russian Power (New Haven and London: Yale University Press, 1999), 196.
} 
surrounding Russia's loss concentrated more on the weakness of Russia in terms of military superiority and poor command, rather than the initial decision to go to war. This preferred emphasis stressed the greater importance of military technology, preparedness and unity, which acted as a form of justification for the maintenance of a strong military. Although it would not have been unusual for students to question whether the government's decision to go to war was rightly legitimised. ${ }^{167}$

While more emphasis was placed on the brave actions of leaders and people of Kievan Rus, soldiers of 20th century Russia also demonstrated the same levels of willingness and self-sacrifice. This continuity highlighted a heritage of martyrdom in Russia's historical narratives. The commonality of such discourses demonstrated a passing down of values to future generations of society. For students of the 1990s, the emphasis and glorification of such character attributes created an image of the ideal citizen, one that contributed towards the present Russian society through acts of heroism and to which continuation of a strong nation was indispensable. It was through the persistence of state loyalty and unity that Russia would continue to progress.

Sutherland's Politics of Advocacy helps us to decode how key figures and events were displayed in Russian historical textbooks. As noted by Sutherland, in glorifying a certain aspect, the author will leave out or downplay the more dishonourable attributes of the individual. This was certainly the case with characters such as Sviatoslav I and Oleg I. As a reflection of "cultural politics," the textbooks outlined a selective construction of the historical event to reflect current ambitions of the Russian state, which was to maintain pride in the military. ${ }^{168}$ Therefore, the author chose to represent a more militarypatriotic version of the past. One of the most striking aspects of the glorification tactic was the role that textbooks played in the mythologisation of these characters. On the topic of the Siege of Kozelsk, for example, Ishimova wrote that courageous people died, "but

\footnotetext{
${ }^{167}$ Although the textbooks by Potseluev and Ammona were published after the beginning of the First Chechen War, they do not reference the war explicitly as they do not go that far forward in history. It is also unclear when these books were produced. While not explicitly asking students to compare contemporary issues with historical ones, issues in late Tsarist Russia reflected the situation in 1990s Russia. Textbooks from 2000 onwards include Russian history into the $21^{\text {st }}$ century but focus on Yeltsin's Russia as part of the ongoing "Memory wars."

168 Yannis Hamilakis, "Learn History! Antiquity, National Narratives, and History in Greek Educational Textbooks," in The Useable Past: Greek Metahistories, ed. by Brown K. S and Yannis Hamilakis (Lanham: Lexington Books, 2002), 40-41.
} 
that they are alive in history, alive in the hearts of all Russians... alive in heaven, in the rays of immortality." 169 These narratives of their immortalisation were also common rhetoric of the political elite in the commemorative activities associated with the Great Patriotic War. Chapter five shows that society was pushed to maintain the memories of the victory and participants in their hearts and minds. The heroic depictions, not only of individual characters, but also of the everyday soldier, promoted a career within the military institution and the values associated with it.

Comparable to the glorification of the veteran in the pension reforms of the 1990s (as noted in chapter four), the characters that these soldiers demonstrated - courage, for example, perpetuated attributes such as sacrifice and bravery into the public sphere and pushed to promote and embed nationalistic tendencies. ${ }^{170}$ The clear and selective depictions of certain figures, and downplaying of their more negative attributes, demonstrated a distinct desire of the authors to create a more glorifying and patriotic depiction of the past. This is not to say that students would readily accept the depictions presented to them in the textbooks, since textbook authors were still recovering from accusations made against them in the Perestroika years. These accusations, as outlined in the introduction of this chapter, highlighted that historical discourses in the Soviet period were framed to suit the needs of the communist leadership, rather than to provide an objective truth. Subsequently, they raised questions about the reliability of the education that students had received and questioned the integrity of these authors. That being said, these textbooks were now operating under a system that promoted pluralism, not only in textbooks but also in perspectives. These factors, and the disapproval of Kreder's textbook, which was criticised for its negative portrayal of Russia's history, show that society remained open to accepting a glorious representation of its historical past. These textbooks paved the way for the persistence and growth of militarisation, as discourses of hero worship increased not only within the educational setting, but became a trend that moved among a number of societal domains.

\section{POLITICS OF ATTACK}

${ }^{169}$ Ishimova, Istoriia Rossii v Rasskazakh dlia detei, 85-92.

${ }^{170}$ Robert G. Wesson, "The Military in Soviet Society," The Russian Review 30, No. 2 (April 1971): 142-143. 
In 1990s Russian history textbooks, when one figure was glorified, they were contrasted with an evil counterpart. The dichotomy between the two characters gave a clear indication to the audience of the villain and hero in each story. The vilification of the enemy is a prominent tactic used across many discursive forums to create a disparity between the desired groups. It is a standard method of any militarised nation, since the process of militarisation depends on the citizens' ability to envisage the opponent. ${ }^{171}$ This was particularly salient in the second chapter of this thesis. The 'us versus them' rhetoric, through its repeated use, contributed toward the normalisation of the beseiged fortress discourse. In Russia's history textbooks, Russia's opponents were typically described as evil, alien and wicked. ${ }^{172}$ Increased interest by scholars on education textbooks, have arisen because these are forums where such discourses evolve. ${ }^{173}$

The creation of an enemy was a topic of interest in an exhibition held at the Nobel Peace Centre in Oslo, Norway in 2016. The exhibition was titled, "Targets." It outlined the ways that different countries trained their soldiers. One aspect of this was the creation of an enemy in target practice. Mali, for example, used cardboard cut outs during training to offer a physical representation of the opponent. In post-Soviet Russia, Russia's youth were 'trained' through narratives. ${ }^{174}$ The textbooks introduced them to multiple enemies from different corners of the world, contributing to the image of a hostile and

171 Jochen Schulte-Sasse, and Linda Shulte-Sasse, "War, Otherness, and Illusionary Identifications with the state," Cultural Critique, No. 19 (1991): 80.

${ }^{172}$ V. P. Ostrovskiy and A. I. Utkin, Istoriia Rossii v XX vek, Klass 11, (Moscow: Drofa, 1996), 248; Ishimova, Istoriia Rossi v Rasskazakh Dlia Detei, 21; 84; Golovin, Moia Pervaia Rossiiskaia Istoriia v Rasskazakh dlia Detei, 14; Ammona, Istoriia Rossii v IXXX veka, 76; B. V. Lichmana, Istoriia Rossii: XX Vek: Kurs lektsiy po istorii Rossii Vtoraia polovina XIX-XX vv. (Yekaterinburg: USTU, 1993), 14.

Ostrovskiy and Utkin's textbook had a print-run of 30,000, while Lichmana's textbook circulation was 100,000. Anatoly Ivanovich Utkin (1944-2020) was a Soviet-Russian historian with a specialism in Russia's political history. Boris Vasilyevich Lichmana (born 1946) is a Soviet and Russian historian. Characterised as "A world renowned scientist, a talented teacher, and a prominent specialist in the field of national history." $\mathrm{He}$ is popular textbook author, with his textbooks garnering a total circulation of 400,000. For more, please see: "Boris Vasilievich Lichman," Ural'skiy Institut ekonomiki, upravleniia I prava, published 14 April 2016, accessed 11 February 2021, http://www.urep.ru/index.php?option=com_content\&view=article \&id=2232\%3A14042 0162\&catid=5\%3A2009-10-10-14-21-17\&lang=ru.

${ }^{173}$ Hamilakis, "Learn History!" 40.

${ }^{174}$ The success of the military-educational complex of the Yeltsin period is rooted in the fact that the youth of the 1990s are now adults under the Putin regime and will have played a significant role in enabling the militarization efforts of the current Russian government. 
untrustworthy world outside of Russia. These discourse furthered the persistence of a 'siege mentality,' whereby Russia needed to sustain a level of readiness against the next hostile invasion.

By vilifying the 'other,' the educational textbooks worked as a vehicle of militarisation, as they contributed toward the construction of a hostile and unfriendly world. These same tactics were used in other domains to justify the need for a strong and prepared military. ${ }^{175}$ In addition, it forced students to reflect on Russia's current situation. In the early post-Soviet period, Russia was involved in a number of domestic and neighbouring conflicts and in debate with a former Cold War adversary about the latter's expansion eastwards. Media discourses played a significant role in the demonisation of NATO as it sought to expand its membership to include former countries of the USSR. ${ }^{176}$ For the most part, opponents of Russia were branded as the enemy [Vrag, Protivnik, Nepriiatel'] within the textbooks. Support for Russia by its citizens, regardless of the circumstances, was depicted as strong. A. A. Danilov and Kosulina's 1997 textbook, on Russian History in the $20^{\text {th }}$ century, showed that "whatever the circumstances" (whether the citizens agreed with the conflict or not), Russians would unite to defend their land against an adversary. They claimed that an attack against the country, by a Vrag, meant that it "was necessary [for Russia] to repulse them." ${ }^{177}$ Passages like the one above offer a glimpse of some of the deeper messages communicated in these textbooks. For example, here, Danilov and Kosulina were promoting state unity and loyalty. The Russians in Danilov and Kosulina's account were showing patriotism through their love for Russia and willingness to protect it.

The sense of responsibility and civic duty that was communicated in these messages were also conveyed by key political and social figures on the topic of Russia's wider role in the world. At the 1995 Victory Day parade, for example, Yeltsin reinforced Russia's role in saving the world from Fascism.

\footnotetext{
${ }^{175}$ Miguel Antonio Levario, Militarising the border: When Mexicans Became the Enemy (Texas: Texas A\&M University Press, 2012), 3; Brian Galaviz, Jesus Palafox, Erica R. Meiners and Therese Quinn, "The Militarisation and Privatisation of Public Schools," Berkley Review of Education 2, No. 1 (2011): 35.

${ }^{176}$ For example, see: Von Cretor, "Esli vy ia byl Russkim Marshalom," Sovetskaia Rossiia, 30 June 1994; Nadein, "Budushchee NATO reshaetsiia v Moskve," Izvestiia, 14 February 1995; Sargin and Tseplyaev, "Za" I "Protiv."

${ }^{177}$ Danilov, Kosulina, Istoriia Rossii, XX vek, 25.
} 
Similar messages were popularised in history textbooks, for example, when debating the Great Patriotic War. However, while claims of the same scale could not be used to describe Russia's role in World War One, authors like Ammona (1998) did include speeches of key figures that indicated Russia's desire to have a global impact. When debating whether to participate in the war, these key figures discussed the "rightful cause" to fight against foreign invasion, but also to save "the whole world" from German predominance. ${ }^{178}$ Brendan Humphrey's "mission exceptionalism," which is used to explain a country's belief that it holds a unique place in this world and that it has a distinct role to play. ${ }^{179}$ Similar to America's historic role of foreign intervention under the justification of maintaining security and to "rid the world of evil," Russia was cultivating a discourse that insisted Russia also played an important role in international affairs, and that it was their duty/mission to do so. ${ }^{180}$ These discourses were heard in other discursive domains. Yeltsin, for example, claimed Russia's role in the former Soviet Union was to bring peace to the region - and in the case of Chechnya, to rid the world of Islamic fundamentalism.

These discourses promoted a sense of civic duty, of Russia's responsibility in the world and acted as a form of justification for Russia's militaristic and current participation in neighbouring wars. While fought on Russian soil, people did not fully understand the same dangers that politicians felt Chechnya posed to Russian society. While (possibly) not a primary aim of the textbook authors, the messages within these textbooks were ones that students could apply to contemporary circumstances. Russian society was not united in the 1990s. Division and lack of support from home were only some of the examples used to justify Russia's losses in Chechnya. Therefore it was not only books of the Putin era that pushed towards cultivating societal unity, but was actually a tactic used in Russian textbooks of the Yeltsin regime. While the historical discourses in these textbooks, as Cynthia Enloe put it, may not have convinced the school children of the 1990s to pick up a gun and enter the military, stories of consistent warfare, of Russia's weakened state and aggressive neighbours strengthened the discourse that Russia was a vulnerable country in need of maintaining an effective defense system.

\footnotetext{
178 Ammona, Istoriia Rossii, IX-XX vv., 440-441.

${ }^{179}$ Brendan Humphreys, "Russia Exceptionalism: A Comparative Perspective," Politics in Central Europe 12, No. 1 (2016): 10.

${ }^{180}$ Bacevich, The New American Militarism, 1-5.

Humphreys, "Russian Exceptionalism," 13.
} 
Another interesting feature of Russian historical textbooks of the 1990s was the grouping of Russia's opponents under term the enemy. Placing the opponents within the same frame meant that boundaries between the different adversaries were less clear as they became part of this larger network of enemies that Russia needed to defend against. Russia's defensive needs were demonstrated fairly early on.

Kievan Rus was a union of Eastern Slavic areas under the leadership of three Varangian (Viking) princes, Rurik, Sineus and Truvor. They formed a triangular union of Kiev, Chernigov and Pereiaslavl. As noted in Ammona's 1998 textbook, and echoed by Dvornichenko et al. (1999), "The reason for the formation of this super union, as, by the way of other super unions, was [to do with] an external danger, the need to deal with external enemies - the Khazars, Pechenegs, Varangians." ${ }^{181}$ As noted by Ishimova in 1996, 'they [key figures in Kievan Rus'] thought only that they should fight and defeat their enemies." 182

Through representations like those produced by Ammona, Dvorninchenko et al. and Ishimova, Russia's textbooks of the 1990s depicted Russia as a weakened state, vulnerable to external threat - even from its conception. In recent years, the issue of creating a patriotic education that popularises a more glorious image of Russia's history has become a topic of the Putin regime. As noted by Zajda in 2013, textbooks of the 1990s that have been republished under Putin's leadership no longer include information, for example, on how many people were captured by Nazi Germany and its allies during World War Two. ${ }^{183}$ By removing or muting the issues that Russia faced during the Great Patriotic War, there is a sense that these new glorious histories will contribute toward creating a new patriotic society. While such accounts do instil a sense of pride in a nation, negative depictions of Russia's past serve another purpose. The stories feed into wider societal perceptions that Russia is a vulnerable country living within a hostile world. It contributes toward the militarisation of society, not only because of the scaremongering which is evident in these passages, but because of the prominence of these stories. While they did not lead to an increase of Russia's youth enlisting in the army, consistent

${ }^{181}$ Dvornichenko et al., Istoriia Rossii, IX-XX veka, 42; Ammona, Istoria Rossii, $1 X-X X$ v., 56.

${ }^{182}$ Ishimova, Istoriia Rossi v Rasskazakh Dlia Detei, 13

183 Zajda, "Russian History Textbooks," 10. 
messages within these textbooks of Russia's weakened state meant they remained regularly in dialogue with a number of militarised discourses.

The vulnerability of Russia was further exaggerated through exact examples of war. For example, at battle with the Byzantium Empire Sviatoslav's army was ten times smaller than its counterpart. ${ }^{184}$ While Sutherland's Politics of Attack concentrated predominantly on weeding out the value-driven aspects of the author, it also revealed the anxieties of the wider cultural realm. Listing Russia's longstanding relationship with conflict militarises society in a myriad of ways. First, by asking students to pair up the dates with a long list of conflicts, the author is showing the student that Russia has been involved in many wars. Georgieva and Georgiev's 1995 textbook of tests for teachers and application, for example, asked:

Task 10. Indicate in which years the listed military clashes took place:

1. Battle of Kalka

2. Battle of Poltava

3. Battle on the River Shelon

4. The Battle of Cape Gangut

5. Neva Battle

6. The Battle of Grunwald

7. The Battle at the village of Lesnaia

8. The Battle of Ice

9. The Battle of Grengam Island

10. The Battle of the River Sit

11. The Battle of the River Emajõgi

12. The Battle on the River Vozha

13. "Standing on Ukre"

14. The Defeat of the Russian Troops near Narva

15. The Defeat of the Livonian Order

16. The Capture by the Russian Troops of the Turkish Fortress Ishmael

17. The Battle of the Russian Fleet with the Turkish at Cape Kaliakra

18. Chesme Naval Battle. ${ }^{185}$

${ }^{184}$ Dvornichenko et al., Istoriia Rossii, IX-XX veka, 58-59.

${ }^{185}$ N. G. Georgieva and V. A. Georgiev, Istoriia Rossii, IX v-nachalo XX v.: Testy v pomoshch' prepodavateliam I abiturientam (Moscow: Moscow University Publishing House, 1995), 13. Natalia Georgievna Georgieva is a historian working at the People's Friendship University of Russia. Vladimir Anatol'evich Georgiev (born 1944) is a Soviet and Russian historian. He specialises in the history of Russian foreign policy and was awarded the 1978 Lenin Komsomol Award for his 1976 book on Russian foreign policy. He currently works at Lomonosov Moscow State University. 
The answers ranged from 1234 to 1790 , highlighting the long period of time during which Russia was constantly at war. Zuev's 1995 textbook reinforced the notions presented in Georgieva and Georgiev's 1995 textbook. His book, which covers the History of Russia as a chronicle, establishes a timeline of important events that have taken place in Russia since its conception. From page 21 until at least page 59, 16 pages present lists of wars or invasions, defeats and victories. Military themes were also prominent in other textbooks. ${ }^{186}$ In Ishmova's 1996 book, Istoriia Rossii v Rasskazakh dlia Detei, just under half (65 out of 131) of the chapters were military themed. ${ }^{187}$ In Potseluev's 1997 textbook Istoriia Rossii XX Stoletiia, around a fourth of its contents in the textbook focused on military narratives. Forty-six pages focused on the First World War, fall of the Tsars and the Russian Civil War, whereas 27 pages were dedicated to the Second World War. Sixty-nine pages focused on the Post-War reconstruction, the Cold War and territorial disputes during the Cold War. ${ }^{188}$ Other topics within the textbooks included religion, culture, literature, and foreign and domestic politics - yet the military played a more dominant role.

Showcasing the extent of Russia's militaristic past highlighted the vast role that war, conquests and the military played in Russia's heritage. The sheer volume of militarised narratives in these textbooks, as listed above, confirmed Russia's historical experience of continuous conflict. As noted in chapter two under the term 'Geopolitics of vulnerability,' Russia's position in the world meant it was exposed to certain threats. ${ }^{189}$ This position was also acknowledged in Russian historical textbooks. As noted in TuganBaranovskaia's 1996 textbook, "The following geopolitical conditions usually affect the specifics of Russian history: a vast, sparsely populated territory, a border unprotected by natural barriers, isolation from almost the whole of history from the seas and sea trade, a river network conducive to the territorial unity of Russia, an intermediate position between Europe and Asia." 190 The "border unprotected by natural barriers" confirmed and strengthened the discourse that Russia was a vulnerable country. It also strengthened the notion that the "unprotected... natural barriers" invited so many countries to invade

\footnotetext{
${ }^{186}$ M. N. Zuev, Khronika Rossii Istoriia, (Moscow: Drofa, 1995), 21-59. The print run for this book was 50,000. Mikhail Nikoleavich Zuev (1958-2012) was a Soviet-Russian historian with a specialism in military history.

${ }^{187}$ Ishimova, Istoriia Rossii v Rasskazakh dlia Detei, Contents.

${ }^{188}$ Potseluev, Istoriia Rossii XX Stoletiia, 33-34; 44-58; 107-120; 122-154; 279-393.

${ }^{189}$ Smith and Timmins, "Russia, NATO and the EU in an Era of Enlargement," 71.

${ }^{190}$ Tugan-Baranovskaia, Istorii Rossii dlia Uchashchikhsia 8-go Klassa, 4.
} 
it. As noted by Spykman and Mackinder, whoever claimed the Heartland [Russia] would have a command over the world - for its profound positioning. ${ }^{191}$ This made Russia vulnerable to invasion. Mackinder and Spykman regularly updated their views, claiming in 1943, at the height of Soviet militarisation, that it was finally manned properly.

Of course, it was also the same security concerns that led to many of Russia's historical figures, including Igor, to expand the territory of Russia. As noted by Ammona in 1998, Igor's main expansionist activities were "to protect the country from raids by the Pechenegs and preserve the unity of the state." He therefore participated in a number of campaigns to expand the territory of the early Kievan Rus' state. He most notably campaigned in Byzantium, the Northern Caucasus and Transcaucasia. ${ }^{192}$ Russia's expansion continued into the era of Peter the Great and Catherine the Great. While Peter I's campaigns were driven by his desire to access the Black Sea, expansion under Catherine II's leadership was as a result of external threat and invasion. According to Golovin's 1992 book, Catherine II confronted many dangers. He claimed:

The enemies envied the glory and greatness of Russia. Once, three hundred thousand Tatars and Turks attacked the Russians. At that time, Russia was ruled by Empress Catherine II, whom the people called the Great for her glorious deeds... the Russians won and took from the Turks many strong cities along the Danube. ${ }^{193}$

Potseluev's 1997 textbook highlighted the same concerns of the Soviet government under Stalin. When asking the question, "Why was the Red Army not ready for War?" he claimed, “The Soviet-German agreements of 1939 did not secure the borders of the USSR," which led Stalin to employ "aggressive methods" for resolving territorial disputes. Yet, while showing obvious disagreement with Stalin's expansionist actions, Potseluev also justified the Soviet's expansionist goals. He claimed that after Germany declared war on Poland, that “the USSR's mutual assistant treaties with Estonia, Latvia and Lithuania were violated by provocative, terrorist acts against the soldiers and officers of the Soviet troops." ${ }^{194}$ Questions asked by Posteleuv at the end of this chapter included,

${ }^{191}$ Smith and Timmins, "Russia, NATO and the EU in an Era of Enlargement," 71.

${ }^{192}$ Ammona, Istoriia Rossii IX-XX vv., 54.

${ }^{193}$ Golovin, Moia Pervaia Rossisskaia Istoriia v Rasskazakh dlia Detei, 126-130.

${ }^{194}$ Potseluev, Istoriia Rossii v XX veka, 258-262. 
"What goals did the USSR pursue in the struggle for collective security?" and "[list] the forms and methods of strengthening state borders and expanding the USSR.”195

The same security issues felt by the different historical figures of Russian history motivated them to increase the territory of Russia. Yet this same expansion also led to increased insecurity as the country became attractive to those who wanted to lead a centrally located, vast space. In the Post-Soviet period, Russia's territory decreased. The collapse of the Soviet Union not only lessened Russia's influence in key areas of the world, for example, the Black Sea but also limited the size of its military - although Russian politicians aimed to reclaim some form of security through the CIS. The postSoviet period became a period of renewed vulnerabilities and new security concerns. With the loss of its 'buffer zone,' Russia's territory faced new threats, not only from NATO expansionism, but also from domestic disputes within its own borders. The histories of the past acted to remind Russia's students that their country had faced many geopolitical issues. It contributed to the notion that Russia has and continues to remain vulnerable to outside threat. ${ }^{196}$ Such notions formed the basis for the legitimisation of a strong military.

Military alliances also posed a risk to Russian security. In V. I. Buganov and P. N. Zirianov's 1996 textbook, their chapter on the era of 'Peter the Great,' began with an anecdote on Russia's aims to renegotiate with Turkey to end the Russo-Turkish War. According to Buganov and Zirianov, leading Western Powers, including; "England, Austria, France, Netherlands, Sweden - influenced the Sultan to continue the War with the Russian king." 197 As noted by Ammona in 1998, Turkey was "hostile to Russia," and “treacherously" (Verolomno) attacked Russia. ${ }^{198}$ It was also Ammona who claimed that it was England and France that pushed Russia into participating in the First World War. ${ }^{199}$ It was these alliance systems that had pushed Russia into war, with ideas of obligation and duty from Russia to support England and France (also members of the Triple Entente), during World War One. Potseluev's 1997 textbook highlighted, that even after

\footnotetext{
195 Ibid, 262.

${ }^{196}$ Michael Bradshaw and Jessica Prendergrast, "The Russian Heartland Revisited: An Assessment of Russia's Transformation," Eurasian Geography and Economics 46, No. 2 (2005): 83-84; 115-118.

${ }^{197}$ Buganov and Zirianov, Istoriia Rossii konets XVII-XIX vek, 19-20.

${ }^{198}$ Ammona, Istoriia Rossii, IX-XX vv. 230-231.

${ }^{199}$ Ammona, Istoriia Rossii, IX-XX vv. 437.
} 
Russia joined in the war, Russia was left largely unaided by the allies and that "the activity of the Russian troops was more beneficial not to Russia, but to the allies."200

The passages above outline a series of events that led to a better understanding of the difficult relationship between Russia and the West. Only two centuries before, for example, England was pushing Turkey to pursue a war with Russia. The mention of alliances noted first that Russia's involvement in a war was sometimes linked to fulfilling an obligation with another country, but also highlighted the superficiality of these alliances and gave meaning and understanding to Russia's deep distrust of this hostile world. In the lead up to the Russo-Japanese war and First World War, some authors placed the origins of the war within the context of the growing American, German and French power. Potseluev (1997) also noted the increasingly militaristic landscape of the early $20^{\text {th }}$ century, by outlining not only Russia's military growth but also the increase in Austro-Hungary's military capabilities. ${ }^{201}$

Growing militarism and imperialism were given as justifications for tensions between countries in the early $20^{\text {th }}$ century. Ammona (1998) suggested the increase of colonies through diplomatic and military means, and Russia's foreign policy aims in the Far East were much to the "discontent of Japan, USA and Germany."202 Potseluev's 1997 textbook noted Japan's alarm at Russia's “peaceful expansion” eastward. ${ }^{203}$ Russia's participation in the First World War was justified along a similar line. As noted in a speech by P. N. Milyukov, "In this war, all our past and future is our rightful cause, we are fighting for the liberation of our homeland from foreign invasions; Europe and Slavism from German predominance; the whole world from the unbearable oppression of constantly growing weapons, ruining peaceful working people." ${ }^{204}$ It was in Milyukov's statement that we not only see a vilification of the enemy, but also a nod to Russia's duty to save the country and world from "unbearable oppression." While (possibly) not a purpose of the textbooks, some of the justifications for Russia's participation in World War One, for example, were reflective of the justifications for Russia's role in events in the post-Soviet Period. It offered a form of understanding into Russia's current role in the Chechen region. Since Chechens in 1990s Russia were

\footnotetext{
${ }^{200}$ Potseluev, Istoriia Rossii v XX veka, 47.

${ }^{201}$ Ibid, 44-46.

${ }^{202}$ Ammona, Istoriia Rossii, IX-XX vv. 353.

${ }^{203}$ Potseluev, Istoriia Rossii v XX veka, 33-35.

${ }^{204}$ Ammona, Istoriia Rossii, IX-XX vv. 440-441.
} 
predominately depicted as terrorists, criminals and through a militant lens, Russia's duty in the First World War offered Russia's youth a moment of clarity and interpretation of the situation in the Chechen region. ${ }^{205}$ Was it their duty, like those of Russia in 1914, to hinder the spread of terrorism and criminality and to forge peace in the Post-Soviet region? Students were confronted with such considerations in these textbooks.

Alongside the vilification of Russia's opponents in these conflicts, the recounting of these militaristic endeavours established narratives that would contribute to the preexisting anxieties of the readers. The accounting of these conflicts only confirmed a pattern of invasions that endangered the Russian state. They substantiated pre-existing anxieties that events like the Great Patriotic War were just another incident in a cycle that could re-emerge again, but with a different cohort and under different circumstances. Such exposure emphasised Russia's historical experience with war, contributing to the militarisation of society as it fortified notions that Russia was a vulnerable country surrounded by hostile neighbours.

For Russia, the recounting of historical conflicts was not done in a simple and factual way. Rather, the romanticisation of the historical events and effort to vilify the enemy ensured that events were vividly detailed and even slightly exaggerated. Known as atrocity propaganda/ story, especially in the British context of the First World War, the graphic description of opponent atrocities in and against Russia acted in a similar way. Atrocity propaganda is defined as a "presentation of that event (real or imaginary) in such a way as to (a) evoke moral outrage by specifying and detailing the value violations, (b) authorise, implicitly or explicitly, punitive sanctions, and (c) mobilise control efforts against the alleged perpetrators." ${ }^{206}$ It is considered an important mechanism in the "war of accusations. ${ }^{207}$

Atrocity propaganda is best known for its use in British accounts in the First World War. It exaggerated and sensationalised factual events of the war in the discourses of popular culture and the media. Jo Fox wrote about the British use of atrocity propaganda, "These shocking stories allowed propagandists to justify the war, encourage

205 For examples, please see: "Chechnya: Trudnyi Vybor Kremlia."; "Vmesto novgorodnikh padarkov v detskie ladoni lozhnitsia smert."; "Situatsiia v Chechne."

${ }^{206}$ David G. Bromley, Anson D. Schupe and J. C. Ventimigla, "Atrocity Tales, the Unification Church, and the Social Construction of Evil." Journal of Communication 29, No. 3 (1979): 43.

${ }^{207}$ Ibid. 
men to enlist, raise funds for war loan schemes, and shake the United States from its neutrality. The impact of such propaganda was enduring, lasting well into 1918 and beyond." ${ }^{208}$ After World War One, propaganda started to be discussed in a negative way. British Parliamentarian Arthur Ponsonby, for example, asserted that it was propaganda based on lies, with Australian and British historians claiming that it tricked their countries into fighting a war based on false, exaggerated tales of German atrocity. ${ }^{209}$ As noted by Steffan Bruendel, since violence is a common theme in war, atrocity propaganda arose and became internalised as a form of propaganda in which the creator could create a dehumanised image of the 'other.' In Britain during the second half of the First World War it was used to attract support from the home front. ${ }^{210}$

In a similar capacity, heightened images of violence and the vilification of the other in historical textbooks was a more subtle and child appropriate form of "atrocity propaganda." Atrocity propaganda highlighted the consistent vulnerability of the Russian state to aggressive invaders, Russia's weakness and (at times) ability to overcome far more superior forces, but only through mass loss of life. It was through the atrocity story that Russian textbooks were able to legitimise the need for a strong military.

As noted in the section on The Politics of Advocacy, it was clear that some authors made a concerted effort to diminish the shortcomings of Russian figures in favour of their more glorifying attributes. Therefore, it should not be a surprise that they emphasised narratives of wicked enemies who performed inhumane deeds against the Russian people and spread distasteful images of the opponent in the textbooks. This was particularly salient in the books by Ishimova (1996) and Golovin (1992). As their mission was to write Russia's history in stories for children, the books created a vastly more emotional account of Russia's history than official educational textbooks at the time. However, they did establish, very early on in a Russian child's life, that Russia had enemies and their depictions only set to establish a sense that outside of Russia, there was a hostile world. Some of the atrocious acts identified included the burning of Slavic houses by

\footnotetext{
${ }^{208}$ Jo Fox, “Attrocity Propaganda,” British Library, 29 January 2014, accessed 28 October 2019, https://www.bl.uk/world-war-one/articles/atrocity-propaganda.

${ }^{209}$ Emily Robertson, 'Propaganda and 'Manufactured Hatred:' An Appraisal of the ethics of First World War British and Australian Atrocity Propaganda," Public Relations Enquiry 3, No. 2 (2014): 246.

${ }^{210}$ Steffan Bruendel, "Othering/ Atrocity Propaganda," International Encyclopaedia of the First World War (2017): 2-3, accessed 10 March 2020, https://encyclopedia.19141918-online.net/pdf/1914-1918-Online-otheringatrocity_propaganda-2014-10-08.pdf.
} 
neighbouring warriors. ${ }^{211}$ On the topic of 13 year old Tatar leader Temiyin, Ishimova wrote, "You will be frightened to learn what the 13 year old Temiyin did!" continuing to document how he ordered the killing of his opponents by boiling them alive. ${ }^{212}$ These stories of Tatar cruelty were supported by Golovin's 1992 book. He noted:

Soon, many Tatars came to Russia. The Russian people were scared! The Tatars even looked very scary: their faces were evil, their eyes were tiny, their mouths were huge and wide; every Tatar was hung with weapons.

They were cunning and cruel: they only thought about how to deceive; you could not believe them in anything. They began to burn down Russian cities and villages, and they killed people. Those whom they did not want to kill, they took with them and made them serve [and] work hard. The houses they did not want to burn down, they often took away from its inhabitants. People became poor [and] often died of hunger. ${ }^{213}$

By attaching graphic and descriptive visuals of individual attacks by Russia's many opponents, the authors played a role in creating the image of a hostile 'other.' As noted above, this same level of description was not indicative of all official history textbooks at this time, but since they were designed for children, they did present the 'dangerous world' discourse fairly early on in a child's life. The gruesome descriptions of the repulsive acts of the Tatar leader Temiyin were worsened by the statement that the Russian people would continue to suffer 200 years of "cruel" Tatar rule. ${ }^{214}$ These depictions, once again, strengthened the point of view that Russia has historically been vulnerable to outside threat and that the Russian people had survived and persisted despite these troubles.

Russia's weakened state as a result of "aggressive" invasions was the topic that dominated many textbooks. ${ }^{215}$ When asked by Georgiev and Georgieva (1995) to "Indicate what caused: a) the aggression of German and Swedish feudal lords against Russia; b) the aggressive campaigns of the Mongol-Tatars in Russia and in Europe; c) the rapid conquest of Russian lands by the Mongol-Tatars," the list of possible answers included: "2) The desire to expand their dominance at the expanse of their neighbours... 5) The strife of the Princes, causing a lack of unity of the Russian principalities 6) The

${ }^{211}$ Golovin, Moia Pervaia Rossisskaia Istoriia v Rasskazakh dlia Detei, 14.

${ }^{212}$ Ishimova, Istoriia Rossii v rasskazakh dlia detei, 84-86.

${ }^{213}$ Golovin, Moia Pervaia Rossisskaia Istoriia v Rasskazakh dlia Detei, 55.

${ }^{214}$ Ishimova, Istoriia Rossii v Rasskazakh dlia Detei, 85.

${ }^{215}$ Kislitsyn, Istoriia Rossii v Voprosy I Otvetakh, 104. 
organisation of the Mongol campaign - the unification of the military forces of different parts of the Tatar-Mongol Empire... 11) Tough military discipline of the Mongol-Tatars; 12) The weakening of Russia as a result of the struggle against the Mongol-Tatars."216 Other options included the blessing of the Pope to organise the campaign and the success of nomadic cattle breeding. ${ }^{217}$

These accounts confirmed that Russia had undergone a vast period of prolonged suffering and provided a discursive representation of what life could look like, should it be conquered. Another interesting issue raised by Georgieva and Georgiev's list was the juxtaposition between Russia's lack of unity and the Mongol-Tatar strong unity. Golovin (1992) also raised this point. The Tatars offered Russia an ultimatum "Give us as much tribute as you can - then we will not fight with you." ${ }^{218}$ According to Golovin:

The Russians knew that the Tatars were only deceiving them: they would take tribute, and they would fight. Russian princes replied: "We'd better fight! If you kill all of us, then you will take all our property for yourself." And they themselves sent to ask for help from the senior Grand Duke in the city of Vladimir.

But the Grand Duke was angry with the Ryazan princes and did not send help. The Tatars set fire to the city of Ryazan, and killed the inhabitants. They took all the property of the killed.

The Tatars also came to the city of Vladimir. They began to burn the city. The wife and children of Grand Duke Yuri and many people locked themselves in the large Vladimir Church. They decided not to surrender themselves to the Tatars alive, but rather die. The Tatars lit the church, and all the people, and the little children of the prince, along with their mother, were burned to death.

The servants ran to the Grand Duke Yuri, who at that time was gathering an army in another city, and told about the terrible death of his dear family.

The prince wept bitterly and exclaimed: "I am now alone in the world!"

...The Russian princes said: "God punished us for quarreling with each other, taking away each other's lands, for not gathering all together to help each other when the Tatars came to the Russian land!"219

These accounts noted that division of the Russian people threatened its ability to gain victory. This was also highlighted under the Politics of Advocacy section, whereby the united efforts of the Russian peoples helped them overcome adversity in the Great Patriotic War, for example. It confirmed the discourse that sacrifice and unity of the Russian people was a worthwhile civic duty as it generally leads to victory.

${ }^{216}$ Georgieva and Georgiev, Istoriia Rossii IX-kontse XX vv., 8.

${ }^{217}$ Ibid.

${ }^{218}$ Golovin, Moia Pervaia Rossisskaia Istoriia v Rasskazakh dlia Detei, 54-55.

${ }^{219}$ Ibid. 
Russia's relationship with military campaigns did not end after the Mongol-Tatar Empire. A number of campaigns against Lithuania and the Livonian Order, alongside Ivan III's desire to regain control of Russia from the Mongol-Tatars were documented in textbooks focussing on that period. ${ }^{220}$

In the $18^{\text {th }}$ century, Peter I's reign was characterised by a series of campaigns and invasions against Russia, although Russia was not short of pursuing any of its own foreign policy goals. The Northern Wars were a popular conflict of discussion. It is certainly an important case study, since the wars continued for 21 years and it was during this time that Russia's military transformation took place. Yurganov and Katsva's 1996 textbook, for example, notes that following the first defeat of Russia by the Swedish, Charles XII had the option of either choosing to invade Russia again, or go to Poland and dispose of Augustus III. He chose to divert his attention towards Poland, claiming that it would take years to recover the army, and claimed "to go to the immense Russia, having behind him the Saxon Army, more combat ready than Russia, was simply dangerous." 221 This afforded Peter I the time to reform his military and led to the end of the war with Sweden in 1721 after a series of Russian victories. As noted earlier in this chapter (pages 169170), Golovin's 1992 textbook writes an identical account of this story, outlining the patience and optimism of Peter I in his ability to regroup, reform and emerge victorious. ${ }^{222}$ Histories of Russia's comeback, especially under the leadership of Peter I added to the discourse of militarisation of society, as it showed that through reform Russia was able to improve its prospects and, in the best case, achieve victory. These stories are just another historical example that allowed students and teachers to pause for reflection on the current issues within Russia's military. It justified the need for military reform and the dedication of resources and materials towards the reform efforts.

The general notion of Russia as backward compared to an adversary has served as a general staple of Russian historical textbooks. These authors emphasised Russian weakness and the superiority of the opposition, to highlight a vulnerable Russia. By emphasising the vulnerability of Russia, the textbook militarised society in two ways. First, it allowed opportunity for Russia's youth to consider the current state of the military. Russia's military in the 1990s was in decay and in desperate need of reform and

${ }^{220}$ Danilov, Istoriia Rossii, IX-XIX vv, 29-31.

${ }^{221}$ Yurganov and Katsva, Istoriia Rossii XVI-XVIIIvv., 221-223.

${ }^{222}$ Golovin, Moia Pervaia Rossiiskaia Istoriia v Rasskazakh dlia Detei, 119-124. 
weapon modernisation - soldiers were poorly trained and were involved in a war where the opposition had lesser technological capabilities, yet Russia was still losing. The circumstances in the Russo-Japanese war and the First World War, especially the loss of Russia in these conflicts due to incompetent leadership and lack of armaments, reflected the current situation in Russia. Second, the history reminded the youth how Russia had clawed back from defeat to claim victory through the process of reform and modernisation. The weaknesses of Russia in the past and the continuous line of conflicts Russia had historically been involved in acted as a justification of the need for a strong Armed Forces.

On the topic of the Russo-Japanese War, Danilov and Kosulina's 1998 textbook outlined a lack of military materials and ammunition held by the Russians and technological superiority of the Japanese fleet. For example, in the Russo-Japanese war, Japan had fourteen major warships and Russia only had two in the region. ${ }^{223}$ In 1997 , Potseluev noted that in the Russo-Japanese war, Japan was preparing to attack a "fragile rival." 224 Other authors noted the location of the Russo-Japanese war as a reason for failure, stating that the remoteness of the theatre of war, small railway capacity for the transportation of materials and the distance of industrial centres from the war, made Russia's possible victory even harder. ${ }^{225}$ Ammona listed six reasons for the defeat of Russia by Japan. These points included:

1. Economic and military-technical backwardness of Russia compared to Japan

2. Remoteness of the theatre of war and unpreparedness of Russian Army and Fleet

3. Lack of initiative in military command

4. Revolution in Russia and unpopularity of war among the Russian people

5. Financial and material help to Japan by USA and England

6. Military-technical and operational-tactical superiority of Japan's Army and Fleet. $^{226}$

${ }^{223}$ A. A. Danilov and L. G. Kosulina, Istoriia Rossii, XX Vek: Uchebnik dlia starshikh klassov obshcheobrazovatel'nykh uchrezhdeniy, (Moscow: Iakhont, 1998), 22-23. 20,000 print-run.

${ }^{224}$ Potseluev, Istoriia Rossii v XX veka, 33-35.

${ }^{225}$ Potseulev, Istoriia Rossii XX vek Stoletia, 34.

Ammona, Istoriia Rossii, IX-XX vv. 360.

${ }^{226}$ Ammona, Istoriia Rossii, IX-XX vv., 361. 
Despite such weaknesses, Ammona (1998) claimed that the Russians fought an "unequal but heroic" battle." 227 As a consequence, Russia aimed to modernise its Armed Forces. Danilov and Kosulina stated that the lack of success in the Russo-Japanese War "served as a sad lesson for the faithful leadership of Russia." 228 While Russia undertook a serious of military reforms in the early $20^{\text {th }}$ century, so did other countries. Potseluev (1997) claims that other countries like Germany and Austro-Hungary were also expanding their military capabilities. ${ }^{229}$ Therefore new weaknesses also impeded Russia's abilities during the First World War. In 1914 and 1915, Russian losses were accounted as a result of "German superiority." As noted by Ammona (1998), "The Russian army was preparing to advance on the same flanks [as the Germans]... They had strong regiments but were led by incompetent people [and] lacked ammunition and weapons." ${ }^{230}$ Danilov and Leonov's 1995 textbook questioned Russia's loss in World War One, calling it a "heavy defeat" (tiazhelykh porazhenii). ${ }^{231}$

In 1996, Ostrovskiy and Utkin, on the topic of the Great Patriotic War, used phrases like "Our homeland is in great danger."232 Danilov and Leonov (1995) asked, "What subjective factors weakened the defence capability of the USSR in the context of the impending war?"233 Zhukova's 1998 textbook argued that the Red Army's initial defeat was a result of the following:

1. The military-economic potential of Germany, which used the resources of all Western Europe, significantly exceeded the military-economic potential of the USSR;

2. Hitler's army was mobilised, had two years of experience in the conduct of modern warfare, While the professional level of the Soviet troops, especially the commanders, decreased after mass repressions in the army

3. Major miscalculations of the Soviet leadership in military equipment, in particular, underestimation of the role of mechanised formations, outdated ideas about the methods of warfare in the initial period.

\footnotetext{
${ }^{227}$ Ibid, 360.

${ }^{228}$ Danilov and Kosulina, Istoriia Rossii v XX Vek (1998), 92.

${ }^{229}$ Potseluev, Istoriia Rossii v XX veka, 44-46.

${ }^{230}$ Ammona, Istoriia Rossii, IX-XX vv., 447.

${ }^{231}$ Danilov and Leonov, Istoriia Rossii v XX veke, 31.

${ }^{232}$ Ostrovskiy and Utkin, Istoriia Rossii $v$ XX vek, 253.

${ }^{233}$ Danilov and Leonov, Istoriia Rossii v XX veke, 107.
} 
4. The miscalculations of Stalin and his entourage in analysing the international situation, in determining the timing of a possible outbreak of war, which led to the surprise attack of the enemy. ${ }^{234}$

Again, and as noted above, Russia's defeat at war was linked to a lack of military superiority. "A fundamental turning point in the course of the war was the seizure of strategic initiative, the transition from defence to a strategic offensive, a change in the balance of forces," claimed Zhukova in 1998. ${ }^{235}$ Again, and similar to discourses from other wars, it denoted the image that Russia's loss in war was caused by its technical backwardness, poor leadership and superiority of its opponents. It established the notion that in order for Russia to be successful, and to be able to defend itself efficiently, the military needed to be well prepared, readily mobilised and supported by society with great unity within the barracks. It supported the notion that Russia needed to maintain a strong military in order to ensure its security.

The same authors who glorified Russian actors were those who also vilified Russia's enemies. In doing so, they created a disparity between the Russian heroes and opponents. Such demonisation fulfilled and added gravity to the anxieties Russian people felt - since there was a historical trail of invasion from belligerent nations, or that Russia would be pulled into wars from the antagonistic and warmongering actions of other nations. The textbooks maintained the militarisation of society by sustaining the discourse that Russia was vulnerable to invasion. It also gave meaning and understanding to why Russia was so distrustful of other nations, since it found itself under constant threat of invasion from the other countries.

Another storyline that sustained the need for a strong military was the emphasis by authors of the dichotomy between the superiority of the opposition and weakness of

${ }^{234}$ L. V. Zhukova, Istoriia Rossii XX veka: Uchebnoe posobie dlia uchashchikhsia 10-11 klassov, (Moscow: Ekzamen, 1998), 115-116. Lekkha Vilyevna Zhukova (1963-2017) was a Russian historian with specialisms in the Russo-Japanese War. As noted in an obituary, Zhukova was "a famous author of teaching aids for schoolchildren and applicants. Written in an intelligible and understandable language for young people, and at the same time academic, devoid of simplifications and schematism, they helped several generations of high school graduates to successfully master and pass the history program, and opened the way for many to higher education in history and the humanities. Lekkha Vilyevna's manuals were regularly reprinted in mass editions and were highly appreciated by school teachers and teaching methodologists." For more, please see: "Lekkha Vilyevna Zhukova," Novosti Istoricheskogo Fakul'teta, published 25 March 2017, accessed 11 February 2021, http://www.hist.msu.ru/about/gen_news/28036/.

235 Ibid, 118. 
Russia. These discourses were most commonly seen as a cause for reforms under Peter I and for Russia's loss in the Russo-Japanese War. Authors even pointed to German superiority as a reason for initial defeat of Russia's army in the First World War. These periods were followed by rapid reform, which, apart from the case of Nikolai II, resulted in victories for Russia/ the Soviet Union. The discourses highlighted that division, lack of preparedness and the right military technology, were Russia's main weaknesses. It was another discourse that supported the need of a strong military. The militaristic nature of these textbooks was rooted in their ability to make the student reflect on issues of contemporary Russia. 1990s Russia was undergoing the same fragmentations, with the decay of the military apparatus and growing discontent in leadership threatening the military's potential in Chechnya, as Russia had experienced in the past.

The rise of a militaristic-patriotic education is often attributed to Putin's leadership. However, as demonstrated throughout the chapter, the militaristic education of contemporary Russia had roots in the Yeltsin era. The rise of revisionist accounts, as a result of the democratisation reforms, led to the initiative for the re-patriotisation of the education system. As early as 1995 the government took greater control over the discourses of the textbooks. This trend has increased under the Putin regime.

The textbooks, examined by Sutherland's classifications of the Politics of Advocacy and the Politics of Attack, demonstrate that, in some aspects, there was an effort by authors to produce a militaristic-patriotic education. In the Politics of Advocacy section, for example, it was obvious that by downplaying the Russian historical figures' darker attributes that authors were trying to promote the more glorifying aspects of Russia's history. The positive depictions of Russian historical figures, praised for their action in war, created a clear role model for Russia's youth to measure themselves against. The repetitive use of discourses on ideas of sacrifice and loyalty are similar to those used in the commemorative activities and veteran pension reforms of the 1990s, outlining the key attributes of an ideal citizen. The glorification of such attributes played a role in the militarisation of the education system and highlighted a top down effort to militarise youth during this period as it promoted virtues that the state wanted to pass down to future generations. It also fed into and strengthened the discourse that it is a worthwhile civic duty to defend the fatherland.

While Russian actors were brave, courageous heroes, Russia's opponents were insidious, evil and aggressive. The juxtaposition of the two types created a clear disparity 
between Russia and an adversary - students were told exactly who they should support. The repetitive reference to the enemy in a historical context, to the acts of foreign invaders, and Russia's weakness against a superior adversary fed into pre-existing notions and discourses of Russia as a besieged fortress. It also helped legitimise the need for societal unity, society's support for the military and the need for a strong military. The gruesome and graphic depictions of the individual acts against the Russian people further pitted the reader and praised Russia's role in overcoming such adversity.

Many of the discourses reflected the situation in 1990s Russia. While not a purpose of the Russian textbooks, the stories they perpetuated provided an opportunity for the youth to reflect on current circumstances in Russia, in which factionalism (inside and out of the military), the decay of military power and poor training was considered the main reason for the loss of war in Chechnya. These discourses, although under the topic of the Politics of Advocacy and Attack, also fall under the classification of the Politics of Assent, as they remained within the dominant narratives of the state, as highlighted in chapters two, four and five.

In addition, political discussions regarding changes to formal educational narratives, the re-emphasis of glorifying narratives and calls for extra-curricular activities, including the linkage of youth with veterans, provide further support for the argument that this period was one of persistent militarisation. Some of the activities pursued in the Yeltsin era have grown and flourished under Putin. 


\section{CHAPTER 4}

\section{"CARING FOR PARTICIPANTS OF WAR IS A HISTORICAL DUTY OF THE STATE": VETERAN SOCIAL WELFARE POLICY AS A MECHANISM OF MILITARISATION.}

In her 2010 study, Nataliya Danilova claimed that war veterans remain an understudied group in civil-military relations, especially on aspects in society that shaped the social welfare programme. ${ }^{1}$ This is still the case. Scholars of veteran studies and civilmilitary relations focus predominately on the rise of ex-military personnel in elite political positions (siloviki), and the reintegration of the veteran into civil society. ${ }^{2}$ Research on veterans and veteran pension and benefits often focus on war-induced disability and cases of Post-Traumatic Stress Disorder (PTSD) and memory. ${ }^{3}$ These studies offer an invaluable insight on the implication of veteran reintroduction into society and on the development of medicine in light of war-induced traumas. However, they do not consider the more subtle effects veteran rehabilitation has on society, for example, the valorisation of the veteran community in political and public discourse.

As highlighted in chapters two and three, in the late 1980s and early 1990s, Soviet history (including their victory in the Great Patriotic War) was challenged and rewritten.

\footnotetext{
${ }^{1}$ Nataliya Danilova, “The Development of an Exclusive Veterans' Policy: The Case of Russia," Armed Forces and Society 26, No. 5 (2010): 890.

Nataliya Danilova, "Veteran's Policy in Russia: A Puzzle of Creation," The Journal of Power Institutions in Post-Soviet Societies, No. 6/7 (2007): 1.

${ }^{2}$ For debates on the role of Siloviki in contemporary Russia, see: Kryshtanovskaya and White, "Putin's Militocracy," 289-306; Sharon Werning Rivera and David W. Rivera, "The Russian Elite under Putin: Militocratic or Bourgeois?" Post-Soviet Affairs 22, No. 2 (2006): 125-144; Renz, "Putin's Militocracy? 903-924.

${ }^{3}$ Scholarship referred to in this paragraph includes: Samuel P. Huntington, Soldiers and the State: The Theory and Politics of Civil-Military Relations (Cambridge Massachusetts: Harvard University Press, 1957), 348-349; Taylor, Politics and the Russia Army, 1-23; Christop Koenig, "Loose-Cannons - War Veterans and the Erosion of Democracy in Weimar Germany," Warwick Economics Research Paper Series, (2015), 60-62; David Gillespie, "Confronting imperialism: the ambivalence of war in post-Soviet film," in Military and Society in Post-Soviet Russia, ed. by Stephen Webber and Jennifer G. Mathers (Manchester and New York: Manchester University Press, 2006), 80-93; Eichler, Militarising Men, 121-127.
} 
Those challenging the Soviet narrative of the Great Patriotic War initially marginalised veterans from society. ${ }^{4}$ They saw the veterans' victory as the further empowerment of the oppressive system. ${ }^{5}$ However, in 1993 , discourse surrounding the veteran population changed, as the values they embodied, such as sacrifice, loyalty and heroism, became attributes the state wanted to promote in order to ensure a new generation of patriots. This is best reflected in Russia's military oath. Established in January 1992, soldiers were required to say:

I (name and nationality) enter the military service of the Russian Federation and swear allegiance to its people. I swear to comply with the constitution and laws of the Russian Federation, to comply with the requirements of military regulations, orders of commanders and leaders, duties legally assigned to me. I swear being in military service, to be honest, conscientious, worthy of the difficulties associated with it. Courageously, in sparing our lives, to defend the people and state interests of the Russian Federation. ${ }^{6}$

The oath highlighted the soldier's commitment and loyalty to the security of the state by "swearing allegience to its people." The sacrificial aspect of the oath was highlighted in the soldier's commitment to "courageously" defend the state and its people. Veterans had made similar commitments. As noted by Anna Krylova, both Yeltsin and Gennady Zyuganov realised the "mobilising potential" of the veteran population, who they saw as signifiers of "moral and heroic ideals.",

\footnotetext{
${ }^{4}$ The patriotic-educational programme, devised in the 1990s but established under Putin, was also used as a way to reconfigure the position of the veteran in post-Soviet society. It played a role in both disciplining youth, in controlling the veterans, and in establishing a role for them out of war. Please see: Elisabeth Sieca-Kozlowski, "Russian Military Patriotic Education: A control tool against the arbitrariness of veterans," The Journal of Nationalism and Ethnicity 38, No. 1 (2010): 81.

${ }^{5}$ Krylova, "Dancing on the Graves of the Dead," 86-89.

${ }^{6}$ Ibid, 93.

Yeltsin Centre, f. 8, op. 1, d. 2, 1. 11, 5 January 1992.

${ }^{7}$ Krylova, "Dancing on the Graves of the Dead," 94.

In addition, V. I. Ivanov asserts the relevancy of veterans in contemporary society for the 'forming of patriotic qualities in current generations.' For more, please see: V. I. Ivanov, "Veterany O Velikoi Otechestvennoi Voine," Sotsiologicheskie Issledovaniia, No. 5 (2015): 12.

Gennady Zyuganov (1944 - present) is the General Secretary of the Communist party and has served within the State Duma since 1993. He competed for the Russian Presidency in 1996.
} 
This chapter addresses the role of Great Patriotic War veterans in Post-Soviet Russia. In 1990s Russia, veteran and military social welfare structures changed. Exclusive pensions and military social welfare packages were discussed within the State Duma, with new provisions set to start in 1995. Economic issues, however, dampened effective reform implementation. Consequently, soldiers' wages and veteran pensions were largely unpaid. That being said, the state's intended provision of the exclusive pensions to its military population highlighted a symbolic prioritisation of the Armed Forces above other sections of society. Such prioritisations (even without effective implementation) signalled the development of militarisation at this time. First, it showcased a greater commitment of the government to military issues. Second, the government's dedication to veteran and military welfare was legitimised by the veteran/ soldier's service to the state. The loyal, self-sacrificing and heroic attributes of the veteran/ soldier were those that were promoted into public consciousness. ${ }^{8}$ To this end, the chapter specifically examines the influence that veterans and current military personnel had on the development of militarism in Russia through the case study of Russian veteran and military social welfare policy, which was reconfigured in 1995.

This chapter captures the process of militarisation through the concept of sponsorship, with enhanced pensions and benefits acting as an indicator of an informal hierarchical system. In this hierarchy, the veteran and current soldier sat on a higher pedestal than a civilian, since the sponsorship demonstrated the state's commitment to the veteran and military population, and the prioritisation of the military over other societal groups. ${ }^{9}$ As a consequence, discourses of hero-worship became prominent in

${ }^{8}$ This chapter focuses predominately on veterans of the Great Patriotic War, since they became a main topic of discussion within the State Duma. That being said, 1995 was also a pivotal year for veterans of the Soviet Afghanistan War (known as Afghansty), who were recognised in the legislature in 1995. Prior to legislative changes in 1995, developments were being made to alter the mechanisms through which these provisions could be made, with the government providing tax benefits to Afghanistan veteran organisations on the condition that they support the veterans. Please see: Danilova, "Veteran's Policy in Russia," 17-18.

While the state did use the veteran to gain support and in its aim of popularising military values, the veterans emerged as a salient group that campaigned for their needs and place in society.

${ }^{9}$ As noted by Burke, "Power-over-the-other" is a basic characterisation of militarism and is hard to identify because it is present where the population accepts and internalises such hierarchies. In the example of the war veteran, militarism manifests where the exclusive pension and benefits system is assigned to the veteran community on the basis of its service to the state in war. As highlighted throughout this chapter, society accepts the 
state discourse, not only in terms of pension reforms but in commemoration also. In January 1995, a Federal Law “About Veterans" [O Veteranakh] was introduced. Article 8 of this law outlined the intended use of "mass media, targetted propaganda, information on the importance of conscientious military service and labour activity, [and] the prestige of state awards for military labour and exploits." 10 The state's policy on social reforms showcased its secondary goal to change the discourses around the veteran population and Armed Forces and even popularise and revive the military-patriotic spirit of the nation. ${ }^{11}$

Government documents, including laws, drafts of laws, appeals and letters circulated within the State Duma, indicate that the government targetted veterans of the Great Patriotic War and Russia's current military cohort. The documents deliberated the creation of an exclusive benefit and pensions package for Russian veterans, especially those who fought between 1941 and 1945, and was framed as a responsibility of the government and society to provide the resources. This was highlighted in a document created as a result of a parliamentary hearing held on June 7, 1994 on the issue of Social protection of military personnel, persons discharged from military service, and their family members, housing, condition and problems in the army. The document noted that a "person (citizen) who decides to link his life to the army must be sure, that the state ensures the fulfilment of obligations established by law, [and] that each soldier... will not be worried about his future before leaving the reserve and the future of his family." 12 In addition, a project relating to the Federal Law On perpetuating the victory of the Soviet people in the Great Patriotic War, noted that it was a tradition of the state to protect the memory of Great Patriotic War victors and to "take care of those who gave their lives in the struggle for its [the Soviet Union's] freedom and independence."13 These ideas were carried over into other areas of society also. For example, an undated information document relating to the law On the perpetuation of the memory of those killed in defence of the fatherland, outlined the Ministry of Defence's task to search for the remains of soldiers killed in war. ${ }^{14}$ These statements, outlining the government's duty of care to its

exclusive reforms in line with the governmental rhetoric that they are deserving of it. Please see: Burke, "Women and Militarism," 2.

${ }^{10}$ Yeltsin Centre, f. 8, op. 3, d. 3, 1. 28-34, 12 January 1995.

${ }^{11}$ GARF, f. 10100, op. 2, d. 1126, 1. 17-24, 7 June 1994.

12 Ibid.

${ }^{13}$ GARF, f. 10100, op. 1, d. 989, 1. 2, [Undated: 1993-1995].

Some of the documents located in GARF were undated with no evidence of author.

${ }^{14}$ GARF, f. 10100, op. 1, d. 989, 1. 14, [Undated: 1993-1995]. 
veterans, justified the state's role in enhancing the veteran's provision. It also contributed towards our understanding of militarisation through the prism of veteran and military social welfare. The state's 'duty' to the military institution was characterised on the basis that those within this line of work provide a unique but vastly important service to the state.

The veteran's role in the Great Patriotic War was conceptualised as a sacrifice that went beyond the norms of Russian citizenship, even though Article 59 of the Russian constitution as of 1993 clearly stated, "Defence of the Fatherland shall be the duty and obligation of a citizen of the Russian Federation." 15 The use of sacrificial discourses, as described in this state documentation, suggested that the veterans were more worthy and deserving of the provision of enhanced pensions benefits, than a non-participant of war. Documentation to be discussed in this chapter, and as shown also in chapter five, demonstrates that the veterans' sacrifice formed the basis for legitimising enhanced compensation and elaborate commemoration. The veteran gained these benefits through their role in war and by demonstrating loyalty to the state through self-sacrifice and heroic action. The creation of this informal hierarchy through emphasis on worthiness established a set of desirable qualities which society could measure itself against. Having provided enhanced resources to former participants of war, the relationship between the military community and the civilian population altered, promoting the image of the veteran with an aim to popularise the values they embodied and the institution to which they were attached.

\section{Critical Discourse Analysis and political texts}

Political Discourse Analysis (PDA) is a form of analysis that refers specifically to political speeches or texts usually conducted within the wider field of Critical Discourse Analysis (CDA), with an aim to "decode" and highlight powers, ideology and the rise of

When I say targeted here, I mean in terms of prioritisation. The veteran organisations proved their agency through their drive to fight for the rights they believed they deserved, but the government also understood the power of the veteran group as an electoral group and as role models to the future of Russia and prioritised the veteran and military community for such reasons. For more, please see: Danijela Dolenec, "A Soldier's State? Veterans and the welfare regime in Croatia," Anali 14, No. 1 (2017): 61.

15 "Russian Federation's constitution of 1993 with amendments through to 2008," constituteproject.org, modified 19 February 2021, accessed 11 April 2020, https://www.constituteproject.org/constitution/Russia_2008.pdf. 
hegemonic discourses. ${ }^{16}$ The popularisation of dominant discourses is a key consideration of scholars like Teun A. Van Dijk, for example. He considers political discourse as a form of interaction and outcome of the discursive practices of professional politicians and associating institutions, which involves the participation of the masses. He claims that political texts or speeches are constructed to promote and even achieve a political goal. ${ }^{17}$ This is a similar consideration of Jane Muldering et al. Muldering et al. argues that CDA plays a particularly important role in policy analysis because it highlights the ideological unpinnings and "hidden interests" of the creator. ${ }^{18}$ As such, political discourse is constructed with the worldviews of the creator in mind. One of the main topics of study, in relation to CDA and PDA, are political speeches. Charteris-Black's 2005 piece, for example, explains the impact of metaphors in political speeches on society. He notes that the speeches of politicians use metaphor to pull on the emotional strings of its audience, to strengthen the politicians' authority and in myth making. ${ }^{19}$ Political speeches, aimed at addressing an audience, are favourable avenues of study in relation to CDA because these speeches represent the views of the government, created with state policy and the art of persuasion in mind.

However, while political speeches are obvious sources of examination for scholars interested in the dominance and popularisation of certain discourses, the governmental discussions and documents that underpin these public texts, are also worthy sources of study in the field of CDA. As noted by Eva Vetter, powerful discourses transform social life in terms of social relations, representation and identity. According to Vetter, official documents standardise and control these future discourses. ${ }^{20}$ Therefore

16 Jiayu Wang, "A New Political Communication Agenda for Political Discourse Analysis: Critical Reflections on Critical Discourse Analysis and Political Discourse Analysis," International Journal of Communications 10, (2016): 2766.

Eva Vetter, "Hegemonic Discourse in the Habsburg Empire: The case of education. A Critical Discourse Analysis of two mid-19 ${ }^{\text {th }}$ century government documents," in Diglossia and Power: Language policies and practice in the $19^{\text {th }}$ century Habsburg Empire, ed. by Rosita Rindler Schjerve (Berlin: Mounton De Gruyter, 2003), 272-273.

17 Teun A. Van Dijk, "What is political discourse analysis?" in Political linguistics, ed. by Jan Blommaert and Chris Bulcuen (Amsterdam: Benjamins Publishers, 1998), 12-13. 18 Jane Muldering, Nicolina Montesane Montessori and Michael Farrely, "Introducing Critical Policy Discourse Analysis," in Critical Policy Discourse Analysis, ed. by Jane Muldering, Nicolina Montesane Montessori and Michael Farrely (Cheltenham: Edward Elgar, 2019), 6-7.

19 Jonathan Charteris-Black, Politicians and Rhetoric: The persuasive power of metaphor (Basingstoke: Palgrave, 2005), 13-14.

${ }^{20}$ Vetter, "Hegemonic Discourse in the Habsburg Empire," 274. 
text produced in political environments from "expert advice and dominant mode of governing," are important documents to be examined using CDA because they are considered as texts which contribute toward the evolution of a hegemonic discourse on issues that eventually impact society in some form or another. ${ }^{21}$

This chapter examines a number of State Duma documents, including laws, draft of laws, letters, memorandum and decrees from the 1990s. Many of the documents found in GARF were focused on veteran and military welfare changes. They discussed introducing exclusive pensions and social welfare reforms for those who perfomed a service to the state in the military. CDA is a valuable tool of analysis in this chapter. First, analysing governmental documents through CDA helps identify key considerations taken during deliberations on the issue of veteran and social welfare. Second, CDA highlights the dominant discourses used to help legitimise welfare reform during this period. Finally, CDA aids our understanding of how and why these discourses arose. This chapter found that the primary aim of the government was to enhance veteran and military social welfare in line with their service to the state. The secondary aim of the government was to use these justifications to enhance the prestige of the military and military service in society. Therefore, changes to veteran and military welfare in 1990s Russia were a vehicle of militarisation.

\section{HISTORY OF VETERAN AND MILITARY SOCIAL WELFARE POLICY}

Glorification of veterans was not new to the Post-Soviet period, but began under Leonid Brezhnev as he promoted the cult of the Great Patriotic War. ${ }^{22}$ However, while the valorisation has remained a staple of the Victory Day parade, it is surprising that a comprehensive exclusive pension and benefits package did not exist until the 1990s. The idea of an exclusive veteran's package existed in the Soviet era, but was extremely flawed and not reflected in official legislation. ${ }^{23}$ This is suprising, since the foundations of social

${ }^{21}$ Ibid, 274.

Muldering et al., "Introducing Critical Policy Discourse Analysis," 6-7.

${ }^{22}$ Mark Edele, "Soviet Veterans as an Entitlement Group, 1945-1955," Slavic Review 65, No. 1 (2006): 112.

${ }^{23}$ According to Danilova, exclusive pensions in Russia are attributed to three factors; political situation, rituals in civil-military relations and the social welfare system. She surveys Russia's veteran welfare policy in conjuction with such factors, finding that patterns in civil-military relations and the ideologcal character of the Armed Forces 
welfare in the USSR were embedded in the principles of Marxism-Leninism. ${ }^{24}$ These principles included the promise of improved living conditions, free health, medical protection and housing accommodation. ${ }^{25}$ State pensions were introduced fairly early on in the Soviet period, established in 1917 to cover all workers. ${ }^{26}$ However, under Joseph Stalin's leadership, changes were made to the system in order to fulfil Stalin's desire to implement a programme that would benefit only those who demonstrated their loyalty to the state. As early as Stalin, we can see an emergence of an informal hierarchical system in which the veterans were glorified for their role in conflict. ${ }^{27}$ Edele claims, however, that such glorification ended in 1948, after a period of mass mobilisation when the provision of extra resources would have benefit most. He states that following a period of mobilisation, veterans were reintegrated into society without the privileges they received months earlier, and that they "ceased to exist as an officially recognised status group." 28

Failure to recognise veterans of the Great Patriotic War, led to the emergence of Veterans' organisations and policies after the death of Stalin. ${ }^{29}$ These organisations lobbied for aid, which they believed they were entitled to. ${ }^{30}$ Organisations like the Soviet Committee of War Veterans, grew under Brezhnev, and aimed to create an all-soviet network of veterans, with the establishment of "participant of the Patriotic War"

contribute to a type of civil-military relations based on mutual benefit. She claims that in the Soviet period, exclusive pensions were created but the mechanisms were not in place to implement them. For more, please see: Danilova, "Veteran's Policy in Russia," 2.

${ }^{24}$ Aleksandra Wiktorow, "Soviet Union," in Social Welfare in Socialist Countries, ed. by John Dixon and David Macarov (Oxon: Routledge, 2016), 184-185.

${ }^{25}$ Ibid.

26 Andrea Chandler, Shocking Mother Russia: Democratisation, Social Rights and Pension Reform in Russia, 1990-2000 (Toronto: University Toronto Press, 2004), 24-25.

${ }^{27}$ Robert Dale, Demobilised Veterans of the late Stalinist Leningrad: Soldiers to Civilians (London: Bloomsbury Publishing, 2015), 48.

Mark B. Smith, "Social Rights in the Soviet Dictatorship: The constitutional Right to Welfare from Stalin to Brezhnev," Humanity: An International Journal of Human Rights, Humanitarianism and Development 3, No. 3 (2012): 394.

${ }^{28}$ Edele, "Soviet Veterans as an Entitlement Group," 110.

Sieca-Kozlowskia, "Russian Military Patriotic Education," 78.

${ }^{29}$ Andrea Chandler claims the 'Big Deal' demonstrated the government's commitment to improve post-war conditions for veterans, with the 1956 Victory Day the date in which the government announced that such provisions would be created to honour participants of the war. Please see: Andrea Chandler, "Veteran's Rights in the Russian Constitutional Court, 1993-2010," Canadian Slavonic Papers 54, No. 3-4 (2012): 322.

${ }^{30}$ Edele, "Soviet Veterans as an Entitlement Group," 112. 
becoming a recognised category in $1978 .{ }^{31}$ Those who sat within this recognised group were eligible for special access to medical care, and discounted travel benefits. While the rise in social welfare seems to suggest a duty of care to its veterans, in fact, the standards of Soviet healthcare had fallen rapidly - confirming that while these veterans had access to such benefits, the quality of such facilities highlighted flaws in the system. ${ }^{32}$ These flaws were not limited to the quality of medical services provided to the veteran, but also in the devaluation of the pensions when compared to the increasing costs of living in the Post-Soviet period and in the lack of legislation protecting budgets set out for veteran welfare. ${ }^{33}$

This was a particular issue of 1990s Russia. As noted in a reference by the Department of the Defence on the issue of Financing from the federal budget of state centralised capital investments under the "housing" programme on the territory of the Russian Federation in 1993-1994, "Letters from unions of reserve officers of the territory of the Russian Federation show that the funds allocated from the budget are not always used for their intended purposes." 34 In other words, the creation of more robust legislation controlling the budget on veteran issues was necessary. Other issues of veteran policy legislation included the disparity (in terms of provisions) between veteran groups, which was dependent on the conflict they were associated with. Historically, veterans of the Great Patriotic War have received more resources than veterans of other wars. Veterans of the First World War, for example, received marginally less than Veterans of the Great Patriotic War. While the renewed memorialisation and valorisation of the Great Patriotic War veterans suggests little changed in this era, higher allowances were also given to participants of Afghanistan and the war in Chechnya.

Veterans are an important group in society. Their exclusive status is rooted in the special relationship that is present between the soldier and the state. At the crux of this relationship is the soldier's duty as a guarantor of state security and for the renewal of the state. ${ }^{35}$ The soldier's role as state protector has been a historical part and parcel of the job.

31 Ibid.

Smith, "Social Rights in the Soviet Dictatorship," 399.

32 Ibid, 399.

${ }^{33}$ Chandler, "Veteran's Rights in the Russian Constitutional Court," 322.

${ }^{34}$ GARF, f. 10100, op. 2, d. 1126, 57-58, [Undated: 1993-1995].

35 David Shambaugh, "The Soldier and the State in China: The Political Work System in the People's Liberation Army," China Quarterly, No. 127 (1991): 527-529. 
Initially, the citizen-soldier was created from the idea that their role in protecting the state was simply a repayment for the rights and privileges of citizenship. ${ }^{36}$ This idea has formed the basis for future expectations of a soldier. For example, in the Middle Ages, serfs served a period of time in the military as payment to their rulers. ${ }^{37}$ However, conflicts fought during the 100 Years War of the $14^{\text {th }}$ and $15^{\text {th }}$ centuries changed the dynamics between the soldier and the state. No longer was the soldier primarily making a payment to the state through military service, but now the state needed to provide a duty to the military; most appropriately through social welfare guarantees. In waging bigger wars, nations and empires needed larger armies. Under Cardinal Richelieu, $17^{\text {th }}$ century French Clergyman and Statesman, there was a struggle to amass the manpower required to defend France against other European countries. This led him to improve health and welfare services for members of the military in an aim to recruit extra men. ${ }^{38}$ The dedication of the monarchto Richelieu's military institution was shown by their continued commitment to the welfare of the French army, which was increasing in size. ${ }^{39}$ Both attitudes have remained a staple of a citizen's duty to protect the state, and with that, is the state's duty to protect the soldier. For example, in democratic states, the role of the soldier is to protect democracy - with many narratives of war discussing the preservation of this democracy and attributes attached to it.

The state's duty to the military institution, however, is the most interesting discursive frame as it creates a clear hierarchy within society. American case studies dominate research on this topic but can be used to illustrate the situation in Post-Soviet Russia, with a clear emergence of a transnational notion of "deserving." In post-Civil War America, those appealing for governmental help were categorised into deserving and undeserving. ${ }^{40}$ The viewpoint centred on the notion that provisions of welfare should not be given to those who are un-deserving. As noted by Theda Skocpol, from 1880 to 1910 s, "veterans pensions became a keystone of an entire edifice of honourable income

\footnotetext{
${ }^{36}$ Caroline Varin, Mercenaries, Hybrid Armies and National Security: Private Soldiers and the state in the $21^{\text {st }}$ Century (Oxon: Routledge, 2014), 30.

${ }^{37}$ Ibid.

${ }^{38}$ Colin Jones, "The Welfare of the French Foot-Soldier," History 65, No. 214 (1980): 193.

Olivier Burtin, "The History of Veteran's Policy in the United States," Historical Social Research 45, No. 2 (2020): 243.

${ }^{39}$ Jones, "The Welfare of the French Foot-Soldier," 194.

40 Theda Skocpol, Protecting Soldiers and Mothers (Cambridge, Massachusetts: Harvard University Press, 1995), 5.
} 
supplements and institutional provision." ${ }^{41}$ Therefore the civil war pension system was defined within the terms that those who received governmental help, deserved it. Skopcol notes that governmental rhetoric pushed toward the creation of an informal hierarchy that justified the provisions on the basis that they would hinder a former veteran, "who honourably wore the Federal Uniform," from entering an almshouse. ${ }^{42}$ In the era of Ronald Reagan, the G. I. Bill reignited the juxtapositions between deserving and underserving, with those deserving being characterised within the prism of military service. ${ }^{43}$ However, and most interestingly, Olivier Burtin argues that many scholars of veteran affairs and pension reforms have taken it for granted. He claims that scholars explicitly examine veteran pensions without placing them within the wider context of state pensions, because these scholars treat the creation of veteran pensions as a natural process, whereas they are actually the outcome of long historical processes of lobbying, protests and entitlement. ${ }^{44}$ Having already indicated veteran struggles in post-Stalinist Soviet Union and during the period of Perestroika, the pension and benefit policies awarded to the veteran population, in the 1990s, cannot be considered an outcome of a natural process. ${ }^{45}$

While the provision of enhanced pensions and benefits are mainly an outcome of rallies and lobbying by interest groups, they have enjoyed success because of the lack of prominent opposition. In the American case study, Burtin notes that critics of enhanced veteran pensions may have slowed the process, but that actions to develop veterans' rights have persisted because of political elites who first, want to garner support of the veteran population for electoral purposes, and because they did not want to be typecast as antiveteran. ${ }^{46}$ We can see commonalities between the American case study and Post-Soviet Russian veteran politics.

\section{${ }^{41}$ Ibid, 7.}

42 Ibid, 149-150.

43 Jennifer Mittlestadt, The Rise of the Military Welfare State (Cambridge, Massachusetts: Havard University Press, 2015), Chapter 4.

${ }^{44}$ Burtin, "The History of Veteran's Policy in the United States," 241.

Amir Weiner, "In the Long Shadow of War: The Second World War and the Soviet and Post-Soviet World," Diplomatic History 25, No. 3 (2001): 455.

${ }^{45}$ Chandler, "Veteran's Rights in the Russian Constitutional Court," 322-323. Edele, "Soviet Veterans as an Entitlement Group," 112.

${ }^{46}$ Burtin, "The History of Veteran's Policy in the United States," 242.

We may also want to take into consideration the threat posed by the military to the government. As noted by M. Duverger, the military is a constant danger to civilian leaders. They must be consistently reminded that their role is to serve the state. As is 
The Presidential election of 1996 motivated Yeltsin to foster a positive relationship with veterans, in the view that they were a key voting constituency. ${ }^{47}$ First, promoting and legalising increased benefits to veteran and military figures were tactical moves made to secure the vote of these constituents. Second, rejecting veteran and military pension policies that enhanced the quality of their welfare would be considered anti-veteran. Since the various presidential candidates were hoping to secure the veteran and military vote, they acted in favour of military community in this sense. Finally, and in relation to anti-veteranism, governmental literature largely emphasised the point that it was a duty of the state and society to care of war participants, claiming that actions to the contrary would highlight depreciation in the role of the veterans in the war. For example, in an information leaflet made for the law On the perpetuation of the memory of those killed in the defence of the Fatherland, it was the responsibility of the Russian state and society to participate in and help fund "search work," which included establishing "the fate of the soldiers who were missing during the Great Patriotic War." Another document, which was an appeal made in a meeting of the Heroes of the Soviet Union, again highlighted the state's responsibility to improve conditions of veterans in Russian society. In addition, however, and as noted in the previous chapter, veteran groups and state duma representatives claimed that the small amount of laws in this area, alongside the rise of an anti-military-patriotic education, showed lack of respect for the veterans who forged victory over Nazi Germany. This was also a key argument for those working outside the federal government. For example, V. Konev, Chairman of the Yekaterinburg City Council Union "Rear Front", appealed to the government for enhanced pensions for the Workers of the Rear during the Great Patriotic War. He noted

highlighted in scholarship by Wendy Hunter and Duverger, history of military coups show that a civilian authority must maintain a cautious attitude towards the military with the provision of enhanced benefits a form of maintaining a positive relationship. For more, please see: M. Duverger, The Study of Politics (Berlin: Springer Science and Business Media, 2012), 181-183; Wendy Hunter, Eroding Military Influence in Brazil: Politicians Against Soldiers (Chapel Hill and London: University of North Carolina Press, 1997), 43.

${ }^{47}$ As noted by Danilova, the 'mutual benefit' is in play here, by supporting the veteran community, there is the expectation that the veteran will reciprocate by being supportive of the government in which instilled such privileges and their politics. Please see: Danilova, "The Development of an Exclusive Veterans' Policy," 899. 
that current provisions to labour workers did not reflect the dire conditions they faced during the Great Patriotic War. ${ }^{48}$

Veteran and military social welfare reforms of the 1990s were driven by 1) presidential campaign of 1996,2 ) motivation to provide the veteran and military community with the benefits believed to match the service they had provided to the state and 3) to increase the prestige of the veteran community in society. They were not the outcome of a natural process, but an outcome of lobbying by veteran organisations, tactical political maneuvers made by the government prior to the presidential campaign and opportunities to alter the standing of the military in Russia's society. These changes, despite poor implementation, highlighted the prioritisation of the veteran and military community in society, which was motivated by various factors.

\section{DEFINING THE VETERAN}

Many developments were made in the 1990s to change the position of the veteran and the military community in society. For example, organisers of the 1995 Victory Day parades made a significant effort to reconcile the past with the present by having the current military cohort, participants of war in Chechnya and of military schools in Moscow, acting out the role of the veterans. This reconciliation is imagined as a process of mythologisation and future militarisation. However, in the context of veteran affairs, the use of the current and future military regiments highlighted that current and future generations will continue to go to war, and if injured, need appropriate care and support. ${ }^{49}$

One major debate of the 1990s was on the definition of the veteran, since the state was scrutinised for the "expansive interpretation of the concept, "veteran"

${ }^{48}$ GARF, f. 10100, op. 1, d. 989, 1. 2, [Undated: 1993-1995].

GARF, f. 10100, op. 1, d. 1003, 1. 37, 13 February 1995.

GARF, f. 10100, op. 1, d. 1003, 1. 54-55, [Undated 1993-1995].

Unfortunately, some of these documents were undated, identified as documentation from the years 1993 to 1995 . This was challenging because there was no way to chronologically organise this work. Usually corresponding documents were placed next/ close to each other in the archive folders, which was noted on collection. Otherwise, documents were organised by theme and topic.

${ }^{49}$ Shaun Walker, The Long Hangover: Putin's New Russia and the Ghosts of the Past (New York: Oxford University Press, 2018), 8-9.

Weiner, "In the Long Shadow of War," 455-456.

50 "Vesenniaia sessiia gosudarstvennoy dumy 1995 goda," Izvestiia, 1995, 19-20. 
the government took steps to construct a fixed interpretation of the veteran, but in doing so, were forced to consider the boundaries of who could be regarded as a veteran of the Great Patriotic War. In a letter by the Committee of Labour and Social Support, calls for change claimed that there were "new veterans in our time, [and that] it is necessary to reflect their problems in new legislation." ${ }^{51}$ In January 1995, a Federal Law was introduced under the title "About veterans" $(O$ Veteranakh $)$, in which the government set out to establish a number of different veteran groups, which were determined on the account of "merits during the defence of the Fatherland, impeccable military service and long conscientious work." ${ }^{, 52}$ Those included in this line-up were, Veterans of the Great Patriotic War, Veterans of military operations on territories of other states, veterans of military service, veterans of internal affairs bodies, and veterans of the prosecution office of Justice. ${ }^{\prime 53}$ This definition, not only solidified recognition for those who participated in the Great Patriotic War, but provided recognition for other conflicts fought since 1945, for example, the Soviet-Afghanistan conflict.

Changes to the definition of the veteran also initiated a dialogue on the role of civilians and workers of the rear in previous wars. While there is no documentation showing an expansion of the term 'veteran' in official legislation, workers of the rear received greater attention in pension discussions and were celebrated through the provision of medals. These medals are documented in Figure thirteen of chapter five and are the same as those given to combative participants of the Great Patriotic War. The Law for the Jubilee Medal for "50 years of victory in the Great Patriotic War, 1941-1945" was established in $1993 .{ }^{54}$ In 1994 , recipients of the medal were stipulated as:

Persons who have a 'certificate of a participant of war';

Workers in the rear, awarded for self-sacrificing labour during the Great Patriotic War with orders of the USSR, medals 'for valiant work in the Great Patriotic War,' 'For labour valour,' 'For labour distinction., ${ }^{55}$

Those eligible for these medals were identified via a military identification card, or by proof of employment history. ${ }^{56}$

${ }^{51}$ GARF, f. 10100, op. 1, d. 1003, 1. 26, [Undated: 1993-1995].

${ }^{52}$ Yeltsin Centre, f. 8, op. 3, d. 3, 1. 28-34, 12 January 1995.

${ }^{53}$ Ibid.

${ }^{54}$ GARF, f. 10100, op. 1, d. 1003, 1. 64, 24 January 1994.

${ }^{55}$ Ibid.

${ }^{56}$ GARF, f. 10100, op. 1, d. 1003, 1. 64, 24 January 1994. 
Placing the worker of the rear into the same category as a frontline veteran is particularly interesting because it promotes/ glorifies supporters of war. While the role of home-front worker has been appreciated in political discourse globally, for example, the role of women in factories during the First World War, for the workers' ability to maintain farms, food supplies, to create ammunition and uniforms, it is only in the Russian case that such a close comparability has been made. ${ }^{57}$ As justified by Konev, "Participants in the war and workers in the rear actually lived their lives in difficult but similar extreme conditions, but in modern times they live in different conditions." 58 What Konev suggested is that workers of the rear made similar sacrifices under parallel conditions. However, veteran policy did not reflect these similarities, and workers of the rear were not receiving the care they deserved. Konev's comments are strongly justified for some workers, especially those in Leningrad, for example, whose residents were required to uphold the blockade with few resources. ${ }^{59}$ As noted in a letter to veterans of the Leningrad Blockade in 1993, Yeltsin wrote, "The feat of the war veterans, and the residents of the Neva, will never fade in the memory of Russians, of all the people in the world. History knows no examples like this...the residents of the Neva stronghold waged a selfless struggle against the Fascist invaders. The city survived in a fierce battle with the enemy." ${ }^{60}$ Both sources note the sacrifice of veterans of the Soviet Union during the Great Patriotic War, and indicate that the victory of the conflict was not solely limited to the soldiers on the front but also depended on the work of civilians. Another reason why Konev's comments hold a sense of legitimacy is situated in the fact that the Great Patriotic War was fought on Soviet soil. Unlike workers of the rear in Britain during the First World War, many of the Soviet labourers were confronted with the direct terrors of war. Konev's statement viewed the labourer's role and experience of war as equal to the soldiers on the front and questioned the disparity in the provision of aftercare.

Research carried out on the boundaries between the soldier and citizen has mostly been drawn from a British and First World War perspective. While British home-front

\footnotetext{
${ }^{57}$ Scholars of the First World War have mostly made this link, claiming that air raids, for example, blurred the boundaries between the front line and home front as the war was taken away from the battlefield and civilians became the targets. Susan R. Grayzal, At Home and Under Fire: Air Raids and Culture in Britain from the Great War to the Blitz (New York: Cambridge University Press, 2012), 1-3.

${ }^{58}$ GARF, f. 10100, op. 1, d. 1003, 1. 54-55, [Undated: 1993-1995].

${ }^{59}$ Bidlack and Lomagin, The Leningrad Blockade, 1-3; Reid, Leningrad, 3-4.

${ }^{60}$ Yeltsin Centre, f. 6, op. 1, d. 120, 1. 4, 17 January 1993.
} 
labourers would not have had the same experience as a country where the war was directly fought on their soil, scholars of this topic argue that changes made to normal life in Britain in the First World War, for example food rationing and limitations on leisure activities, were characterised by civilians as "doing their bit" and a strike against Germany. ${ }^{61}$ Dean Evans argued that despite a clear difference in the experiences of soldiers and civilians of the First World War, the war was causing changes on the home front and that scholars should consider revising the boundaries between soldiers and civilians. ${ }^{62}$ Tammy Proctor comes to a similar conclusion, noting that the dichotomy between the soldier and civilian positively served the government in terms of propaganda, but ignored the problems that civilians faced and the important contribution they made in order to facilitate the war. ${ }^{63}$

The contribution of the civilian population in the Great Patriotic War was great. During the inter-war period, Stalin industrialised the Soviet Union at a dramatic rate, creating a military industrial complex that was compatible with the demands required in a conflict with a magnitude of the Great Patriotic War. Industry and agriculture were reconfigured to suit the needs of the conflict, which in functioning within a wartime capacity, led to a larger mobilisation of society beyond the battlefield. As Enloe wrote, "few other institutions can command such a vast financial, labour and material resources as a military." ${ }^{\circ 4}$ From the perspective of Fredrick W. Kagan, "The Great Patriotic War was a war of the entire Soviet people," claiming that Soviet men and women "willingly" went to work in factories to support the armed forces. ${ }^{65}$

Efforts were made by the Yeltsin government to provide some sense of social protection to these civilian groups. For example, in January 1994, he introduced a decree to ensure "social guarantees and privileges" to residents of Leningrad, who were awarded a medal "For the Defence of Leningrad" and the badge "Resident of the besieged Leningrad." ${ }^{66}$ Although these guarantees remain unclear, the acknowledgement of the government's need to support civilians who played a role in protecting Leningrad

${ }^{61}$ Dean Evans, "How Far were the Lines between the Frontline and the Homefront blurred in East Kent (Canterbury)," Masters diss., (University of Kent, 2016), 4-7.

${ }^{62}$ Ibid.

${ }^{63}$ Tammy Proctor, Civilians in a World at War, 1914-1918 (New York: NYU Press, 2010), 37.

${ }^{64}$ Enloe, Manuevers, 47.

${ }^{65}$ Fredrick W. Kagan, "The Great Patriotic War," in The Military History of the Soviet Union, ed. by Kagan, Fredrick W. and Robert Highham (New York: Palgrave, 2016), 150.

${ }^{66}$ Yeltsin Centre, f. 8, op. 1, d. 4, 1. 80, 18 January 1994. 
highlighted a clear disregard of the historical lines that previously separated a soldier's role from a civilian. That being said, the everyday citizen was not rewarded for their role in the defence of Leningrad - it was only those who had already been ceremonially recognised through medal provisions. While not always regarded in the form of pensions, the inclusion of the worker in the rear was an important step taken by the government in the 1990s.

During this period, Russia was involved in a number of neighbouring and local wars, including the conflict in Chechnya. While technically taking place on Russian soil, the war seemed far-flung for much of Russia's population. Support for rear workers of the Great Patriotic War showcased the importance of home-front workers to the political institution. It also demonstrated that sacrifice and loyalty to the state could be shown through war-supportive roles. On 7 May 1995, Yeltsin signed a decree establishing the title of Veteran of Labour (Veteran truda). ${ }^{67}$ Reemphasising the role of Labour Veterans in previous conflicts, the decree highlighted the continued integral role that workers of the rear would play in the present and future conflicts. The expansion pushed new ideas relating to civic duty into the public sphere, as those who participated in such supportive roles and demonstrated attributes of loyalty to the country found recognition as key citizens of the state.

By expanding the definition of the veteran, the government publicised the role that society plays in conflict. It noted, similar to studies on a civilian's role in the First World War, that the roles played by soldiers and citizens in war are parallel when considering the sacrifices made by both parties for the war effort. ${ }^{68}$ Factory workers and farmers, comparable to soldiers, were acknowledged as vital cogs in the war machine. While the role of "citizen-soldiers" had received attention in political discussion in the State Duma, the recognition of these groups through the medals further embedded this understanding on a societal level.

By acknowledging the role these extra actors played in conflict, the state was popularising the link between civic duty and the state defence. First, it forced the citizen to consider their part in a war and how they would contribute towards it in a supporting role. The second objective was to glorify participation in conflict, whether on the

${ }^{67}$ Yeltsin Centre, f. 8, op. 1, d. 5, 1. 13, 7 May 1995.

${ }^{68}$ Evans, "How Far were the Lines," 4-7.

Proctor, Civilians in a World at War, 37. 
battlefield or on the home front. Konev demonstrated the state's desire to cultivate these discourses, by claiming, "Workers of the rear require substantial extra pensions, so that at least the rest of their lives will be worthy of the people who forged the Victory in the Great Patriotic War." ${ }^{69} \mathrm{He}$ was not the only person calling for a reward system for workers of the rear. As noted in a statement by the Communist Party of the Russian Federation on the 17 February 1995, Oleg Orestovich Mironov acknowledged that a number of proposals were received by the Communist Party from voters calling for the state "to award the workers of the home front "for selfless labour in the years of the Great Patriotic War."70 These statements highlighted the all-encompassing impact that war and conflict had on society, noting that soldiers on the battlefield were not the only important actors in a war, but that the possibility of victory was also reliant on those working to maintain the forces and society on the home front.

\section{SPONSORING THE VETERAN}

Changes made to veteran social policy during the 1990s significantly changed the position of the veteran community in society. The steps taken by the government to alter veteran policy during this period demonstrated that Russia was still militarised in some respects, through a series of steps being made by the government to popularise the Armed Forces and to prioritise the military over other parts of civil society. The transformation of veteran and military welfare policies and the provision of enhanced pensions and benefits to former military personnel unveiled a subtle state-led effort to militarise society. In this chapter, the process of militarisation is captured through the concept of sponsorship. The phrase "sponsorship" is being used to describe the provision of enhanced pensions and benefits to the veteran population.

Scholars of commercial and sports sponsorship agree on the main actors involved in a sponsorship transaction. Participants in the sponsorship paradigm include the sponsor, sponsee and consumer. ${ }^{71}$ Researchers also concur that in sponsorship the brand image of both the sponsor and sponsee will affect the image of one another, and will

${ }^{69}$ GARF, f. 10100, op. 1, d. 1003, 1. 54-55, [Undated 1993-1995].

${ }^{70}$ GARF, f. 10100, op. 1, d. 1003, 1. 35, 17 February 1995.

${ }^{71}$ Tony Meenaghan, "Understanding Sponsorship Effects," Psychology and Marketing 18, No. 2 (2001): 105-106. 
determine the response of a consumer. ${ }^{72}$ In the field of commercial and sports sponsorship, the process of sponsorship is a form of promotion that will benefit each actor, and may even benefit the community. ${ }^{73}$ Through sponsorship, the community will foster a relationship between the sponsor and consumer and between the sponsee and consumer. ${ }^{74}$ Research on sponsorship shows there is a mutually beneficial aspect of sponsorship for each actor involved in the process. While the brand image may affect the image and therefore the identity of the sponsor and sponsee, fan involvement (which refers to the extent to which a consumer identifies with the sponsored) demonstrates another element, whereby the consumer also buys into the values being displaced by the sponsor/ sponsee relationship. ${ }^{75}$ In the sponsorship-militarisation paradigm, the State inhibits the role of the sponsor, the veteran/military community represents the sponsee and society plays the role of the consumer. A reconceptualisation of Tony Meenaghan's process (study-specific phrasing is in brackets) is documented below:

\section{Sponsor (State)}
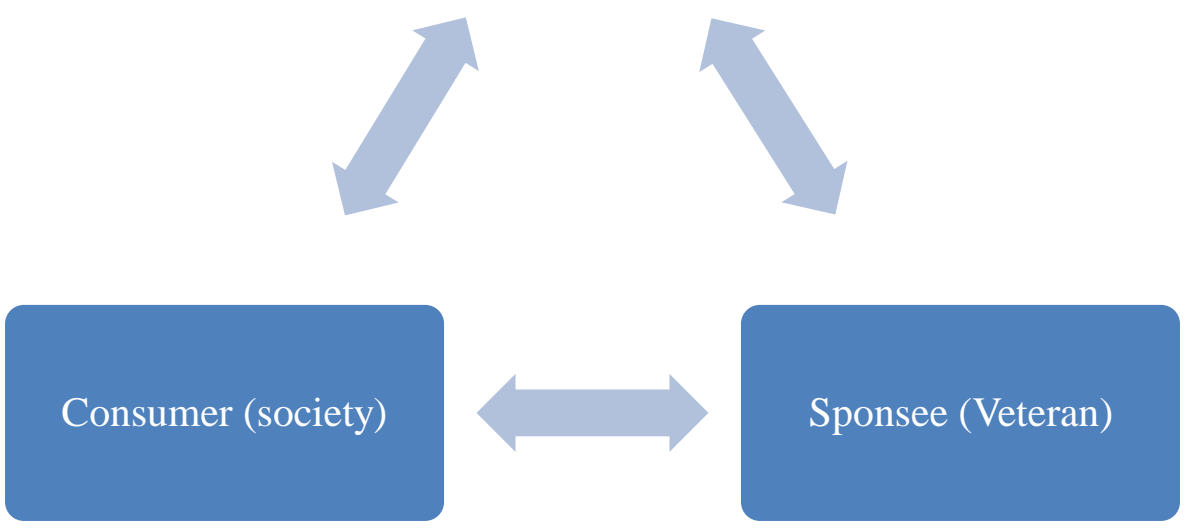

\footnotetext{
${ }^{72}$ Robert Madrigal, "Social Identity, Effects in belief - attitude-intentions hierarchy: Implications for Corporate Sponsorship," Psychology and Marketing 18, No. 2 (2001): 147; Meenaghan, "Understanding Sponsorship Effects," 99-106.

${ }^{73}$ Colin Macdonald, "Sponsorship and the Image of the Sponsor," European Journal of Marketing 25, No. 11 (1991): 31.

${ }^{74}$ Meenaghan, "Understanding Sponsorship Effects," 99-106.

75 Allain Ferrand and Monique Pages, "Image Sponsoring: A Methodology to Match Event and Sponsor," Journal of Management 10, No. 3 (1996): 279; Meenaghan, "Understanding Sponsorship Effects," 99-106; Madrigal, "Social Identity Effects in a Belief-Attitude-Intentions Hierarchy, 146.
} 


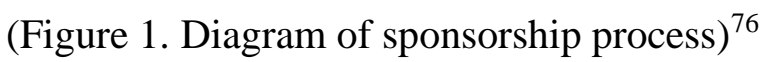

Figure One outlines the main processes of the sponsorship-militarisation nexus. However, there are a number of mini-processes taking place during the sponsorship transaction. The first process involves the state-veteran-society course. On this course, the state dedicates enhanced provisions to veteran and military groups. Through the endowment of these resources, the group is then politicised in a number of ways. This politicisation occurs because the government expects a sense of loyalty from veteran groups in return. This is particularly important to consider since changes to veteran pensions occurred in the lead up to the 1996 Presidential elections. While we can conceptualise the initial process of enhanced pensions and benefits as an aspect of neopatrimonialism, it does not explain the other advantages gained by the state as a result of this exclusive social welfare policy. ${ }^{77}$ Through the concept of sponsorship, these other aspects can be captured. A sponsorship transaction usually takes place when the sponsee represents attributes that are desirable to the state. This includes characteristics and values which they want to be associated with, and that they want to pass on to their consumers. A sportsperson is a good sponsee, not only because they win, but also because they embody important values such as discipline, determination and resilience. A brand will choose to sponsor an athlete with these values over an athlete who is arrogant, selfish and demonstrates poor sportsmanship because they want the athlete to reflect the ethos of the

\footnotetext{
${ }^{76}$ Meenaghan, "Understanding Sponsorship Effects" 105-106.

${ }^{77}$ Neopatrimonialism is a staple mechanism of power and control in the Post-Soviet space. The embeddedness of neopatrimonialism has been documented as having existed in pre-Petrine Russia. Since the collapse of the union, many of the Post-Soviet states, including Russia, have been characterised as hybrid regimes with aspects of democracy and the use of non-democratic devices. Put simply by Alisher Ilkhamor in his 2007 study, neopatriomonialism is a process in which a patron purchases the loyalty of a client and in return that client protects the interests of the patron. The patron can be anyone in a leadership role, including a president, a business manager and even a parent. Clients as 'rent-seeking actors' compete for money, power and even resources, with the simple request that they would prop up the power, control or even provide security for the patron. Please see; Alisher Ilkhamor, "Neopatrimonalism, interest groups and patronage networks: The Impasses of Governance System in Uzbekistan," Central Asian Survey 26, No. 1 (2007): 65-67; Vladimir Gel'man, "The Viscious Circle of Post-Soviet Neopatriomonialism in Russia," Post-Soviet Affairs 32, No. 5 (2016): 458; Oleksandr Fisun, "Rethinking Post-Soviet Politics from a Neopatrimonial Perspective," The Journal of Post-Soviet Democratisation 20, No. 2 (2012): 91-93.
} 
brand. ${ }^{78}$ The state chose to provide veterans with an enhanced pension and benefits package, not only because the state believed it was their duty to do so, but because they wanted to promote the values associated with the former participants of war. The government also wanted those characteristics to reflect on the state in order to revive values of militarised patriotism in society. These values include self-sacrifice, loyalty to the state and heroism.

However, Madrigal notes that brands do not simply sponsor an athlete, event or television programme to inform the audience of the brand's core values, claiming that sponsorship as a vehicle of communication works in a multitude of ways in order to project the core values of the sponsor and sponsee onto the consumer. ${ }^{79}$ How does this lend to militarisation? By 'sponsoring' the veteran/military population through an enhanced pensions and benefits package, the state was promoting militaristic values of self-sacrifice, loyalty and heroism to society. Veterans still remain relevant today as the "most important means of forming patriotic qualities in current generations." 80 The sponsorship sent a message to society that those who demonstrate such attributes are worthy of receiving the same level of benefits. Partnering state justifications for enhanced pensions with emphasis on a veteran's loyalty to the state, to narratives presented in commemorative activities and in educational textbooks, further legitimised the provision of such benefits as it called attention to the role that veterans played in the preservation and renewal of the state. For example, the appeal by Konev outlined the need to compensate the workers of the rear for the sacrifices they made to ensure the victory of the Soviet Union in the Great Patriotic War. ${ }^{81}$ The prevalence of such discourses in society helped embed such narratives into societal discourse. Russian citizens were less likely to question the exclusivity of the pension and social protection protocols laid out for the veteran population, as doing so meant questioning the worthiness of the veteran and downplaying their role in the Great Patriotic War - doing such would be blasphemy. ${ }^{82}$

\footnotetext{
${ }^{78}$ Meenaghan, "Understanding Sponsorship Effects," 102-104. Ferrand and Pages, "Image Sponsoring," 278.

${ }^{79}$ Madrigal, "Social Identity, Effects in belief - attitude-intentions hierarchy," 146.

${ }^{80}$ Ivanov, "Veterany o Velikoi Otechestvennoi Voine," 12.

${ }^{81}$ GARF, f. 10100, op. 1, d. 1003, 1. 54-55, [Undated 1993-1995].

${ }^{82}$ In 1997, two million veterans received personalised congratulatory messages from Boris Yeltsin. In an opinion poll study by FOM, 1,500 people were told about the messages. When asked why they thought Yeltsin did this, 26\% claimed it was a neutral motive, while $16 \%$ saw it as a positive motive. Those who believed the action of the president was neutral argued he sent the message because "veterans deserve it." Those
} 
The process of sponsorship, in this case, demonstrates a clear state effort to saturate society with militaristic-patriotic narratives. It highlights a transfer of values from the sponsee to the sponsor, and from the sponsee to the consumer - the values propagated here are those attached to serving in the military or contributing towards the war effort from the home front. The veteran policy, which was legitimated as an award for those who demonstrated worthiness by emphasis on sacrifice, loyalty and heroism, established a standard by which society would be measured, where demonstration of such values would result in the same benefits.

Another process in the sponsorship-militarisation paradigm to consider is the relationship between the sponsor and society, and in this case, the state and society. While changes to veterans' social welfare policy during this period can be attributed to the state's need for veteran participation in the $50^{\text {th }}$ anniversary celebrations, commitment to the social needs of ex-military personnel also positively affected the image of the government. Since brand image is affected by the image of the sponsor and vice versa, it is important to consider in what ways this transaction would have affected the relationship between the government and society. Interestingly enough, and in what can be seen as a victory of the state, when asked "The Leadership of Russia and President B. Yeltsin have given the holiday of the $50^{\text {th }}$ anniversary of Victory a special place. Has your attitude to President B. Yeltsin changed?" eight percent of the 1368 respondents answered that their views of the President improved, while eight percent answered that their opinion of the president declined. Ten percent stated answered, "it was hard to say." $74 \%$ claimed that their views had not changed, but it is unknown what their views were initially. ${ }^{83}$ Positive changes to the veteran's pension system had more chance of changing public opinion towards the state, since it actually altered the veterans' lives in ways the parade could not. Simply honouring the veteran in the ceremony did very little to improve their lives and did not mean they would then have access to medical care, money to pay their rent and to live a comfortable life.

who saw Yeltsin's messages as a positive motive, believed it was motivated 'out of respect for veterans." "O Prezidentsikh pozdravleniiakh veteranam," FOM, 27 July 1995, accessed 27 April 2020, https://bd.fom.ru/report/map/of19972903.

83 "Shirokoe prazdnovanie 50-letiia Pobedy ne povliialo na otnoshenie Rossiian Prezidentu," FOM, May 1995, accessed 13 April 2020, https://bd.fom.ru/report/map/of19952001. 
By providing more resources to the veteran/ military community, it not only demonstrated the state's commitment to its forces, but also benefitted society by removing the burden from friends and family members. As noted by Koustuv Dalal and Leif Svanstrom, war fatalities and war-induced injuries can cause financial problems within a family setting. They claim, "Losing a breadwinner to injuries and/ or death often results in huge economic burdens by pushing families into poverty, or poorer families deeper into poverty." 84 This is because other family members need to make up for the loss of income resulting from such injury, and may need to pay for new medical costs as a result of the injury and even take on the burden of care as an informal caregiver. ${ }^{85}$ This is an obvious outcome of enhanced pensions and benefits to war veterans and increased social welfare to current military personnel. It removes the strain from the family who either fill the gap left by active service men or those unable to fulfil the jobs they left behind before the conflict - either through injury of loss of life in war. This is where there is a slight difference between the government-veteran or government-society relationship and the sponsor-sponsee relationship in the sponsorship paradigm - the veteran's agency in comparison to the sportsperson or celebrity. In a sports/ commercial sponsorship transaction, the sponsee has the power to reject the sponsorship. This is not the same case for the average veteran, who in most cases, would rely on either help from a relative or from the state in order to survive. The differentiation however, strengthens the concept of sponsorship in this sense, as the role of the sponsor is enabled with little protest except, in most cases, to increase welfare.

By releasing the burden of family members to financially support the veteran, it highlighted the importance of the veteran to the state and generated goodwill towards the government. As noted by Colin McDonald, "sponsorship is not just talking directly about the company and products but is about supporting something dear to your heart." 86 The government's support of the veteran community through these enhanced pensions demonstrated a strong sense of goodwill from the sponsor, who was making an investment. This investment by the Russian government towards the veteran community,

\footnotetext{
${ }^{84}$ Koustuv Dalal and Leif Svanstrom, "Economic Burden of Disability Adjusted Life Years (DALYs) of Injuries," Health, 7, (2015), 488; Roxana E., Delgado, Kimberly Peacock, Barbara Elizondo, Margaret Wells, Jordan H. Grafman and Mary J. Pugh, "A Family's Affair: Caring for Veterans with Pentrating Traumatic Brain Injury," Military Medicine, 183, 3/4, (2018), 379-380.

${ }^{85}$ Delgado et al., "A Family's Affair," 379.

${ }^{86}$ McDonald. "Sponsorship and the Image of the Sponsor," 34.
} 
a personal cause for most Russian families, (since nearly every Soviet family was touched by the Great Patriotic War), played a role in fostering a better relationship between state and society. A letter sent by the All-Russian Council of Veterans to Yeltsin, demonstrated warm relations between the veteran community and Boris Yeltsin. In the letter, they expressed gratitude to Yeltsin for greeting the veterans, and asked that proposals to change veteran policy be taken into consideration. They signed the letter by wishing health and happiness to Yeltsin in the New Year. ${ }^{87}$

While there are similarities between the process of sponsorship and the sponsorship-militarisation nexus, there are also some differences. For example, the benefits for the sponsor are different in the government-veteran-society paradigm than that of the sponsor-sponsee-consumer nexus. In a sports/ commercial sponsorship process, the sponsor expects economic benefits, such as increased sales of its merchandise. In the government-veteran-society arrangement, the benefit to the government was not material, but symbolic. In this process, society was confronted with militaristic values of loyalty, patriotism and state-protections, which not only became embedded in state policy, but also in the discourses associated with veterans more generally. These narratives had been re-cultivated not only through state legislature, but also in historical educational textbooks and in the commemorative rituals of the Victory Day parade. The justification of enhanced veteran pensions alongside glorifying narratives not only associated ideas of heroism with stories of sacrifice in war, but also created a baseline of attributes that need to be demonstrated in order to receive similar treatment. Scholars of sponsorship show that investments are made to those who demonstrate desirable values because the sponsor wants to expand and promote these values into the future.

The success of the veteran sponsorship as a viable mechanism of militarisation is similar to a commercial, sports sponsorship journey. Not only were the values of the sponsee being promoted through the process, but also a strong relationship was being cultivated between the government and veteran population, the government and society

\footnotetext{
${ }^{87}$ Yeltsin Centre, f. 6, op. 1, d. 183, 1. 109, 27 December 1996. In 1997, Yeltsin sent a message of congratulations to two million veterans by May $9^{\text {th }}$. As noted in an opinion poll by FOM, " $59 \%$ of the respondents whose families received congratulations said they were very pleased, moved and grateful for their attention." "O Prezidentsikh pozdravleniiakh veteranam," FOM, 27 July 1995, accessed 27 April 2020, https://bd.fom.ru/report/map/of19972903.
} 
and the veteran and society. Stronger connections were made through recognition of the sacrifice of the veteran by the state, in state discourses and the creation of enhanced pensions and benefits. Relationships were bettered between the state and society, through acknowledgement of the state that care of the veterans was part of a wider responsibility of the state. ${ }^{88}$ It is difficult to measure the true impact of the changes of veteran policy in regard to the popularisation of the Russian Armed Forces, because there were other mechanisms in place. As noted throughout this chapter, discourses of the veterans' sacrifice were not only present in state discourses surrounding welfare discussions. In fact, these discourses were further cemented into public consciousness by their presence across societal domains and within commemorative activities and in educational historical discourses. Collectively, these narratives worked well to propagate and promote patriotic-militaristic narratives into the public sphere. ${ }^{89}$ There are, however, major differences in the way these narratives were cultivated. The process of veteran sponsorship was much more subtle. In a traditional way, the government was performing a duty of care. However, what was also taking place was the permeating of key militaristic values in society, which not only popularised the military service and rebranded the government as caring, but also renewed a sense of citizenship based on loyalty, patriotism and self-sacrifice.

\section{SOCIAL WELFARE AND VETERAN POLICY IN 1990's RUSSIA}

During the 1990s a number of social welfare policies were introduced to provide additional allowances to certain societal groups. According to Irina Sinitsina, these groups included:

${ }^{88}$ Yeltsin Centre, f. 6, op. 1, d. 183, 1. 109, 27 December 1996.

"O Prezidentsikh pozdravleniiakh veteranam," FOM, 27 July 1995, accessed 27 April 2020, https://bd.fom.ru/report/map/of19972903.

${ }^{89}$ Ruth Wodak and Rudolf De Cillia, on a study of Austrian commemorative events in 1988, define official commemoration as 'open publication of matters of historical consciousness, which can be supported by consensus within the political field and among its principal actors." Non-official sites, like the media, also reproduce these views. While not distinctly on the topic of pension reform, the study can be used to explain how propatriotic and militaristic narratives permeated amongst society, since narratives used to justify enhanced pensions and benefits to veteran and military sectors were complemented by those spoken at the 1995 Victory Day parade and within historical textbooks. For more, please see: Ruth Wodak and Rudolf De Cillia, "Commemorating the Past: The Discursive Construction of Official Narratives about the 'Rebirth of the Second Austrian Republic,"” Discourse and Communication 1, No. 3 (2007): 338-339. 
a) The 'deserving disadvantaged,' that is, those who mostly through no fault of their own, would suffer impoverishment in the absence of assistance (e.g. orphans, the disabled and the elderly without pensions);

b) Those who had rendered special services to their country (e.g. labour heroes, veterans of the Second World War and other conflicts, and those who are working in particularly hazardous professions or demanding locations, such as first responders at Chernobyl);

c) Public servants, where benefits provided a hidden salary supplement (e.g. members of the military, the security services and judges). ${ }^{90}$

Additional benefits provided to these 'special groups' created an informal hierarchy. ${ }^{91}$ With two of the groups included in the list of beneficiaries being related to the Armed Forces, the government created a disparity in privileges between the military institution and rest of society. It was the prioritisation of the military community over other factions of society that demonstrated the state's commitment to those from and within the military industry. Since the provision of an exclusive pension and benefits package was through the worthiness of the soldier, by their service to the state, the pension had wider implications for the notion of civic duty and the popularisation of the Armed Forces, as it pushed the notion that the commitment of the soldier to the country meant that they would be looked after accordingly and receive the same benefits.

Sacrificial discourses became the basic justification given by state figures for enhanced social packages. Some scholars argue that veterans believe, on the basis of such sacrifice, they are entitled to benefits. ${ }^{92}$ Dale suggests this sense of entitlement was

${ }^{90}$ Irina Sinitsina, "Experience of Implementing Social benefits Monetization Reform in Russia. Literature Review," SSPRN Electronic Journal, (2009), accessed 24 April 2020, 10.2139/ssrn.1436409, 8-9.

${ }^{91}$ As noted by Anna-Karina Kolb, a citizen's status is largely demonstrated by the distribution of provisions by the state through social policy. This policy is created on the civil and political rights of the citizen. Adding to Kolb's conceptualisation, we can consider Russia's distribution of enhanced pensions as an added form of legitimacy, or as the rebranding of the veteran as a 'super-citizen,' since the increased pensions and benefits had been calculated on the basis of their sacrifice for the state. Therefore, the formation of a societal hierarchy, in this sense, happens when a caste of Russia's population is excluded from receiving the same benefits as a veteran on the basis of military service. For more, please see: Anna Karina Kolb, "European Social Rights Towards National Welfare States: Additional, Substitue, Illusory?" in Citizenship and Welfare State Reform in Europe, ed. by Jet Bussemaker (London: Routledge, 1999), 166. 92 Edele, "Soviet Veterans as an Entitlement Group,"137.

Deborah Cowen, Military Workfare: The Soldier and Social Citizenship in Canada (Toronto: University of Toronto Press, 2008), 58. 
cultivated by the publication of posters released during the Great Patriotic War, which outlined soldiers' rights to special social welfare during and after military service. ${ }^{93}$ While not displayed on propaganda posters, political discussion in the 1990s on veteran policy made similar revelations. Appeals calling for changes to veteran pensions legitimated the creation of a social welfare scheme based on and reflective of the soldiers/ veterans' sacrifice. These discourses, used repeatedly in both commemorative and legislative environments, were ones that became normalised. Since veterans and soldiers were the main beneficiaries of the exclusive pension system, it was the character attributes that they demonstrated during their service to the state and the sacrifices they made in a military capacity that became a requisite for what was deemed worthy. The veteran, a clear poster boy for the exclusive pension scheme, was a symbolic representation of the values that needed to be adopted and demonstrated by other civilians who might also want to benefit from the same allowances. The emphasis on this topic in governmental documentation, and the commitment (and even enthusiasm) from the political elite to support this initiative, highlights a state-led effort to militarise society.

This section outlines changes to pension and benefit provisions for the veteran/ military community during the 1990s. It shows that a comprehensive system of social welfare was established for the benefit of the military institution. The provision of such benefits was the start of the state-veteran-society transaction, whereby veteran groups were privileged through the state's creation of an exclusive veteran social welfare system. The state justified the exclusive pension system through the idea of worthiness, which is one of the main proponents that has driven the sponsorship paradigm, as core values demonstrated by the veteran (loyalty, patriotism and sacrifice) dominated society. Suzanne Mettler best documents the effect of state policy on society. She draws on the work of E. E. Schattschneider and Theodore Lowi to argue that policies act as institutions and therefore establish a set of norms that not only change politics but profoundly affect and may shape an audience's notion of their duty as a citizen. ${ }^{94}$ Similarly to Mettler's argument, changes to veteran policy during this time demonstrate a state-led effort to develop the militarisation of society - for it not only promoted the core values of the military - but also formed a social hierarchy with the veterans at the pinnacle.

${ }^{93}$ Dale, Demobilised Veterans in the Late Stalinist Leningrad, 48.

${ }^{94}$ Suzanne Mettler, "Bringing the State Back in to Civil Engagement: Policy Feedback Effects of the G. I. Bill for World War 2 Veterans," The American Political Science Review 96, No. 2 (2002): 352. 


\section{Pension Reform in Yeltsin's Russia}

In February 1995, Chernomyrdin wrote a letter to State Duma Federal Assembly Chairman, Ivan Rubkin on the issue of the $50^{\text {th }}$ anniversary of the end of the Great Patriotic War. His letter outlined further possible improvements to Great Patriotic War veteran pensions. He noted that pension differences acted as a catalyst of rising "social tensions among participants of the Great Patriotic War." He justified his initiative, which outlined pension provisions to widows of deceased servicemen (who did not remarry) and same pension provisions for rear workers, on the basis that it would reduce the systemic disparities in pensions between those injured in the war and other participants of the Great Patriotic War. Chernomyrdin was echoing the remarks of A. Lukiankov. In October 1994, Lykiankov noted that the volunteer who was "eager for the front," but played a supporting role in the rear instead, should not receive a lesser pension. He claimed, "In an ethical sense, the division is immoral." 95

Changes made to the pension system were done with this differentiation in mind, but also, and as reflected in the forthcoming documentation, to provide the veterans with a social welfare policy they deserved. By creating a veteran social welfare policy that reflected the veterans' service to the state and legitimated on the basis of worthiness, the government established a goal for members of society wanting to also be 'worthy' of exclusive entitlements - with displays of sacrifice and loyalty to the state being some of the main objectives. ${ }^{96}$ It established a set of core values that became central to the idea of

${ }^{95}$ GARF, f. 10100, op. 1, d. 1111, 1. 7, 24 February 1995.

GARF, f. 10100, op. 2, d. 135, 1. 12, 19 October 1994.

96 The theme of sacrifice is one of salience in social policy reforms in the twentieth century. As noted by Cowen, the scale of sacrifices made during the Second World War in Canada cultivated the understanding that such sacrifice elicited an expansion to social welfare. In interwar Germany, veteran organisations used the theme of sacrifice to demand compensation from the community. Greg Eghigian claims that these different organisations presented the moral obligation of the state as one in which would offer monetary rewards for their sacrifice in the First World War. As noted by Communist leader Gennady Zyuganov in a Communist Party Statement made on the $11^{\text {th }}$ January 1995, "there is no more significant and memorable event than the victory of the Soviet people...[than]...in the Great Patriotic War." For more, please see: Cowen, Military Workfare, 45; Greg Eghigian, "Injury, Fate, Resentment, and Sacrifice in German Political Culture, 1914-1939," in Sacrifice and National Belonging in Twentieth-Century Germany, ed. by Marcus Funck, Greg Eghigian and Matthew Paul Berg (Texas: Texas A\&M University Press, 2002), 105-206; GARF, f. 10100, op. 1, d. 1003, 1. 1, 11 January 1995. 
the ideal Russian citizen, which permeated amongst society from such emphasis in government documentation and through state-organised initiatives such as exclusive social welfare reforms and commemorative events.

The first of two changes to the minimum old-age pension provisions took place on the $1^{\text {st }}$ May 1995. Minimum pension for veterans was fixed at 45,460 roubles per month. The next change occurred on the $1^{\text {st }}$ August 1995, whereby there was an increase of 3,182 roubles to these pensions. Pensions at this stage stood at 48,642 roubles per month. ${ }^{97}$ These modifications were 'officially' motivated by the upcoming $50^{\text {th }}$ anniversary of the Great Patriotic War, with Prime Minister Victor Chernomyrdin calling for the acceleration of these changes in light of the "social significance of the planned events." ${ }^{98}$ Deputy Yu. Yarov placed similar pressures on State Duma Chairman Ivan Rubkin, assuming the approval of these changes. He stated, "In accordance with the agreement, I urge you to consider this bill at a meeting of the State Duma today... Submit it to the Federation Council for approval, so that it is approved by the Federation Council tomorrow." 99

The transformation of the veteran social welfare policy during this period is particularly interesting as it serves a number of the state's aims. The changes can be analysed as an innocent act of the government, which saw the changes as a part of their duty to provide care for the (ex) members of the military institution. However, veteran participation in the commemorative celebrations may have also played a particular role in these alterations. Another reason for the changes to pensions were the upcoming 1996 presidential elections. ${ }^{100}$ However, the establishment of an exclusive veteran policy also created an informal societal hierarchy that elevated the position of the veterans in society. Discourses noted that veterans deserved these pensions because of their service to the state. This discourse was reinforced across a number of societal domains, in educational textbooks, where historical figures were praised for their heroism in war, and in the

${ }^{97}$ GARF, f. 10100, op. 1, d. 1111, 1. 12, [Undated: 1993-1995].

This was less than a tenth of Russia's average monthly salary, which stood at 472,400 roubles $(\$ 130.38)$ in 1995 . For more, please see: “Average monthly salaries in Russia 1991-2000," Elena's Blogs (blog), accessed 7 March 2021, https://blogs.elenasmodels.com/en/average-salaries-in-russia/.

${ }^{98}$ GARF, f. 10100, op. 1, d. 1111, 1. 15, [Undated: 1993-1995].

${ }^{99}$ GARF, f. 10100, op. 1, d. 1111, 1. 16, 13 April 1995.

100 "O Prezidentsikh pozdravleniiakh veteranam," FOM, 27 July 1995, accessed 27 April 2020, https://bd.fom.ru/report/map/of19972903. 
commemorative activities for the state. For example, Yeltsin outlined his "deep respect for the heroism and dedication [of the defenders] of the fatherland," in a statement made at an award ceremony, where he presented the Order of Zhukov to six veterans of the Great Patriotic War. ${ }^{101}$ The discourses strengthened and added legitimacy to the veterans' right to these exclusive pensions. By introducing an exclusive pension reform on the basis of the veterans" demonstration of their "dedication" to the state and "heroism," during the Great Patriotic War, it established a list of core values that would become a basic requirement for someone who would want to achieve the same benefits. Therefore, it lended itself to the militarisation goals of society as it aimed to create a positive image of a career within the Armed Forces.

This is not unique to Russia and is best demonstrated by Christopher Dandeker et al., who claim that veteran policy of the Dutch and French all-volunteer forces was driven by the concern that "the climate for recruitment and retention is as favourable as possible." ${ }^{102}$ By providing society with a direct visual example of the veteran as a character who encompassed these desirable attributes, the state was making a concerted effort to militarise society - which was best achieved through the reemphasis of certain militarised values associated with the military institution. A statue of Marshal Zhukov was unveiled on the eve of the 1995 Victory Day Parade, with the Medal of Zhukov and Order of Zhukov also being established in the name of the famous Marshal. ${ }^{103}$ Speeches

\footnotetext{
${ }^{101}$ Yeltsin Centre, f. 21, op. 1, d. 128, 5 May 1995.

${ }^{102}$ Christopher Dandeker, Simon Wessely, Amy Iversen and John Ross, "What's in a Name? Defining and Caring for "veterans": The United Kingdom in International Perspective," Armed Forces and Society 32, No. 2 (2006): 169.

103 The medal of Zhukov was established by decree in May 1994. It was initially awarded to veterans of the Great Patriotic War but has since been extended to current Russian soldiers. The order of Zhukov is an award for leadership excellence during the Great Patriotic War.

For more, please see: "Ukaz Prezidenta Rossiiskoi Federatsii ot 9 Maia 1994 goda, No. 930 "Ob uchrezhdenii ordena Zhukova I medali Zhukova," Gosudarstvennye Nagrady Rossiiskoi Federatsii, accessed 24 June 2020, https://web.archive.org/web/20120311063109/http://award.adm.gov.ru/doc/u930.htm. "Statut ordena Zhukova," Gosudarstvennye Nagrady Rossiiskoi Federatsii, accessed 24 June 2020 , https://web.archive.org/web/20060302222704/http://www.award.adm.gov.ru/orden/orde n_14.htm.
} 
by Luzhkov and Yeltsin noted Zhukov's decisive role in the victory and protection of the fatherland, further pushing narratives of hero-worship, courage and state loyalty. ${ }^{104}$

Veteran policy provided old-age pensioners with a monthly payment of 45,460 or 48,642 roubles per month, with additional allowance to a few specified groups. Double the minimum pension was provided to disabled veterans, and veterans over 80 years old. The extra payment was legitimised to aid extra costs associated with the external care for the disabled person. ${ }^{105}$ As noted by Chernomyrdin in a letter and an attached explanatory note from 1995, "Widows of servicemen who lived in the Great Patriotic War, who did not enter into a new marriage, have the right to be given two pensions, one of which is the survivor's pension." 106 By creating a fixed minimum payment, the policy demonstrated the government's attempt to regulate veteran pensions, yet it did not wholly confront issues of disparity, as noted above. War invalids, for example, still received more benefits. A non-disabled veteran could also benefit in a similar way, but only if that veteran reached the age of 80 . The government's inability to address the pension disparity between invalids of war and other participants of the Great Patriotic War, demonstrates that the 'official' aim of the government was not the main one on their agenda.

The creation of an exclusive veteran's pension, however, affected society in other ways. Not only did it take the burden away from the veteran's family, but it also created a clear distinction between the military institution and Russian society. It acted as an official recognition of the soldier's sacrifice in war, and used stories of this sacrifice to legitimise the government's prioritisation of the veteran/military community. ${ }^{107}$ As noted by P. G. Coleman and A. Podolskij, veterans of the Great Patriotic War were popular recipients of an exclusive veteran reform because of the "enormity of their sacrifice." 108 Russian militarism during this period persisted due to the unquestionable justifications of the government, which legitimised reform to veteran social welfare pensions to reflect the sacrifices made by the veterans - with little protest from society. As noted in a parliamentary hearing On social protection of servicemen, persons dismissed from the military service and their family members in 1994, members of the military "for a long

${ }^{104}$ Yeltsin Centre, f. 8, op. 1, d. 2, 1. 11, 5 January 1992. These attributes were also outlined in the military oath of 1992.

${ }^{105}$ GARF, f. 10100, op. 1, d. 1111, 1. 2-5, [Undated: 1993-1995].

${ }^{106}$ GARF, f. 10100, op. 1, d. 1111, 1. 15, [Undated: 1993-1995].

107 Dandeker, "What's in a Name?" 161.

108 P. G. Coleman and A. Podolskij, "Identity Loss and Recovery in Life Stories of Soviet World War Two Veterans," The Gerontologist 47, No. 1 (2007): 52. 
time bore and endured the hardships associated with being in a public service of a special kind, risking their lives." ${ }^{109}$ Promotion of the military's core values, alongside notions of worthiness enabled the persistence of militarism during this period. Not only did the promotion of these key core values permeate among society through official governmental discourse, but also the laws and changes to pensions were passed with little to no protest because they were justified on the basis of worthiness.

\section{Benefit Reforms under Yeltsin}

Beyond pensions, veterans were also entitled to receive extra benefits. In Britain, in recent years, discount offers have opened up beyond the usual concession groups (children, students and old-age pensioners), to include National Health Service workers and members of the Military. This process had already taken place in 1990s Russia with the military cohort and military veterans being the main beneficiaries of these subsidies. As with pensions, the state's decision to offer extra benefits to ex-military personnel may have been motivated by a number of influences such as moral sense of duty, by the upcoming 1995 celebrations, because of the 1996 presidential election or because the state wanted to popularise a career in the Armed Forces. The benefits were arguably more of an important contribution to the veteran, in the sense that non-military citizens (whether for old age or because of work) are entitled to a pension. In comparison, not every member of society was entitled to the similar benefits. As stipulated in calculations on the Federal Law, "On the establishment of a unified status of a participant of the Great Patriotic War":

In the event of the adoption of the law, citizens of the Russian Federation awarded with medals, "For Victory over Germany" and "For Victory over Japan"... [will] receive rights for the following benefits:

a) Free travel on road, rail and water transport on suburban land/ right to free travel in public transport they already use/:

b) Right for multiple annual travel with a 50\% discount and a discount for rail, water and long-distant air transport/:

c) The right to receive free medicines/ in the present time they have rights to receive food with a $50 \%$ discount

d) An additional payment in the amount of $50 \%$ of the established minimum, that is, by adding to the resulting pension a complete minimum amount, because half of it they do not get. ${ }^{110}$

${ }^{109}$ GARF, f. 10100, op. 2, d. 1126, 1. 6-7, June 1994.

${ }^{110}$ GARF, f. 10100, op. 1, d. 793, 1. 13, [Undated: 1993-1995]. 
The provision of these benefits was similar to the extra pension allowances. They acted as a form of sponsorship, whereby the government gave the group exclusive access to benefits not open to other members of the public. The exclusive nature of these benefits militarised society in a subtle way. Unlike the Victory Day celebrations, these packages allowed the continued glorification of the veteran through everyday state legislation. As noted in an appeal from the $24^{\text {th }}$ February 1995 to the Heroes of the USSR, Knights of the Order of Glory, Parliament, Government and the CIS, the pensions and the benefits should be enacted to improve the living conditions of veterans, "To war veterans, providing a standard of living worthy of the great achievement of this generation."111 The language used in this appeal was similar to that used by Konev on the topic of Workers of the Rear, and highlights the emergence of a common discourse linking the exclusive pension reform to the worthiness of a veteran's role in society. By justifying improved pension and benefit costs in terms of worthiness and tying this level of worthiness to the veteran's role in the Great Patriotic War, the government reiterated this idea of the model citizen, by providing extra and exclusive awards for carrying out aspects of civic duty. The provision of such 'luxuries' to ex-military members and more exclusively to those who served the military between 1941 and 1945, demonstrated the government's commitment and prioritisation of the military community above civil society. By envisaging the extra benefits that could be gained through service to the nation, the state was also attempting to popularise careers that contribute towards the protection of the motherland and provide a service of loyalty to the state. It also highlighted the state's duty to support the troops not only during their service, but also in their retirement. As noted previously, and stated by Aparina and Lukianov, the "duty of caring for participants and victims of war is a historical tradition in Russia."112

Exclusive benefit entitlement to ex-military personnel acted in a similar way to the provision of extra pensions in the state-veteran-consumer sponsorship transaction. However, it could be argued that the provision of extra benefits actually created a greater division between the veteran/military population and the remaining members of society. This is due to that fact that while veterans received a larger pension, members of the public were also entitled to a pension. In contrast, they were not entitled to any extra

${ }^{111}$ GARF, f. 10100, op. 1, d. 1003, 1. 37, 24 February 1995.

112 GARF, f. 10100, op. 1, d. 989, 1. 2, [Undated: 1993-1995]. 
benefits. With a desire to improve the prestige of the military, the provision of such resources elevated the position of the veteran and career within the military through the creation of an exclusive veteran policy.

\section{Social Protection of the Current Military Cohort under Yeltsin}

While defence and foreign policy budgets were $100 \%$ financed by the federal government, aspects of veteran privileges such as veteran hospitals were financed by regional governments, and in some cases, partly through enterprises. ${ }^{113}$ This was problematic to an extent, since the regional governments did not always have the resources to support funding necessities. This issue was rectified in 2002 when the Russian government reformed its social policy, placing veteran welfare under the responsibility of the federal government. ${ }^{114}$

While veteran benefits were a main topic of discussion within the State Duma during the $1990 \mathrm{~s}$, the $50^{\text {th }}$ anniversary and re-emergence of social issues associated with veterans and veteran policy influenced the issue of social welfare policy of the current military cohort. A number of parliamentary hearings were held in June 1994 to discuss the "Social protection of servicemen, persons dismissed from military service and their family members." 115 These forums would discuss social protection, housing and medical access for the current military cohort. The chairman in the parliamentary hearing under the same title demonstrated the urgency of such a topic, claiming:

Today's parliamentarians are the ones our committee devotes to one of the most urgent problems of the Armed Forces of Russia, and society as a whole - the social protection of military personnel, persons dismissed from the military service, army and navy veterans, members of their families. In terms of numbers, this nonsettlement group of the Russian Federation is estimated at more than 10 million people. A significant part of them throughout their lives bore and endured the hardships associated with being in the public service of a special kind, risking their lives... We can talk without a reason that the army of Russia today remains

113 Galina Kurliandskaia, "Decentralisation in the Russian Federation," Economic Change and Restructuring 39, No. 3-4 (2006): 221.

Sinitsina, "Experience of Implementing Social Benefits Monetization Reform in Russia. Literature Review," 9.

Elena Maltseva, "Welfare Reforms in Post-Soviet States: A Comparison of Social Benefits Reform in Russia and Kazakhstan," PhD diss., University of Toronto (2012), 234.

${ }^{114}$ Kurliandskaia, Decentralisation in the Russian Federation," 231-232.

${ }^{115}$ GARF, f. 10100, op. 2, d. 1126, 1. 6-7, June 1994. 
the guarantor of the stability and security of our society. This and my opinion is associated with a high level of intelligence, education and potential, which is still inherent in the majority of the officer corps and enlistees of our army... [who are] ready to step over their own "want" in the name of public "need" by the performance of official duty, even if it involves a risk to life. Evidence of this is more than enough. ${ }^{116}$

The urgency of such a topic was influenced by the fact that only one law on pension benefits for those undergoing military service and in service to the state of internal affairs and their families existed. ${ }^{117}$ Described as guarantors of stability and security and as those who overcome "their own 'wants' in the name of public 'need,", adjustments to the social protection of this category of citizens were legitimised, again, on a basis of worthiness. As outlined in the decision by the Defence Committee of the State Duma on the topic of Social Protection:

2. The list of 'protected articles' of the annual state budget, the availability of money in the state treasury and percentage of the GNP [must be] intended to ensure the security of the forces, [and] must necessarily include:

a) Monetary maintenance of military personnel, including compensation paid in return for food rations and sublease housing;

b) Financing of technical support and to the life support of missile defence, air defence, strategic missile defence facilities, communications, arsenals, district warehouses for the storage of weapons, landfills etc. - all connected with the real danger of death, environmental catastrophes, military danger; this is not only the initial condition of social security, but also the guarantee of the state's right to life of all veterans

c) Provision of food and items of the first necessity to 'closed' garrison and city enterprises...primarily remote from densely populated regions of the country

Fixing these provisions in the defence budget for 1994 is the main task of each deputy of the committee. ${ }^{118}$

In a separate law the construction of housing for military personnel who have been transferred to the reserve or resigned was set at a limit of 279.9 million roubles. ${ }^{119}$ The significant amount of monetary resources allocated to fulfil the needs of the social welfare policy highlights a growth in Russian militarism in this period. One of the main components of militarism is the requirement that an excessive amount of state budget is

\footnotetext{
116 Ibid.

117 Ibid.

${ }^{118}$ GARF, f. 10100, op. 2, d. 1126, 1. 17-24, 7 June 1994.

${ }^{119}$ GARF, f. 10100, op. 2, d. 1126, 1. 56-57, [Undated: 1993-1995].
} 
dedicated to the military institution. ${ }^{120}$ The veteran pension and benefits system already acquired a significant portion of the state and regional funding total budget. The proposed dedication of more money from the state budget for the purposes of veteran and military social welfare showcased the importance of the veteran and military community in society. ${ }^{121}$ This is an extremely important aspect to take into consideration when reflecting on the state of militarism during this period. Not only was the level at which the state budget was dedicated to military spending an indication of militarism, but the fact that the government made the decision to make such commitments highlighted the favourable position of the military in society. These benefits were utilised by the government for two reasons: to raise support from military/veteran institutions; and to popularise a career within the Armed Forces. ${ }^{122}$ In official state discourse, the provision of social welfare was documented, rather, as a form of duty by the state. For example, as noted in the parliamentary hearing from 7 June 1994, "A person (citizen) who decides to link his life to the army must be sure, that the state really ensures the fulfilment of obligations established by law, that each soldier, while still in the [role], will not be worried about his future before leaving the reserve and future of his family." ${ }^{123}$ However, narratives surrounding this official justification highlighted the underlying goals of the government in adopting such legislation, as the chairman called for efforts to "restore the best in the army," and "revive the military-patriotic spirit of Russians." 124 The enhanced social welfare opportunities offered to the military cohort at the time highlighted a government commitment to the care of its military. On the surface, the government justified this action as a duty of the state to support a worthy cause. They legitimised such

\footnotetext{
${ }^{120}$ L. I. Radway, "Militarism," 300-305.

${ }^{121}$ Scholars of militarism argue that such a process is in play when the needs and value of the military are placed above the needs of society. Having provided a significant amount of the state budget to social welfare for veterans and serving members of the military, this demonstrates a clear commitment by the state to the military. Please see; Mittlestadt, The Rise of the Military Welfare State, Introduction; Volker Rolf Berghan, Militarism: The History of an International Debate: 1861-1979 (Cambridge: Cambridge University Press, 1984), 39.

${ }^{122}$ As documented at the start of this chapter, in order to popularise a career in the Armed Forces, countries have often used social welfare as a form of persuasion to encourage enlistment into the military. For more on this, read; Robert K. Griffith, U.S. Army's Transition to the All-Volunteer Force, 1864-1974 (Washington DC: DIANE Publishing, 1997), 34-36.

${ }^{123}$ GARF, f. 10100, op. 2, d. 1126, 1. 17-24, 7 June 1994.

124 Ibid.
} 
duty based on the risk these soldiers would be taking. ${ }^{125}$ However, also included in this discourse was the desire of the state to reignite patriotic feeling amongst society and to popularise the military institution. The examples presented above highlight a number of elements in play. First, by promoting the enhanced social welfare provisions to military personnel as an act of duty, the government was presenting the image of an ideal citizen, one whose demonstration of loyalty to the state was worthy of exclusive benefits. It not only promoted the idea of a career in the military, but also created a civic role for those in non-military careers. If a soldier's role is to die defending the country, then it is society's role to commemorate them. Similarly in this case, if it is a soldier's role to risk their lives for society, then it is the duty of society to ensure they are cared for after service. ${ }^{126}$ Here, the rhetoric of the government demonstrated that they were trying to lead by example.

\section{VETERAN WELFARE AS A FORM OF MILITARISATION}

Changes to veteran and military welfare policy during this period demonstrate a state-led effort to militarise society. While official justifications legitimated changes based on lack of laws, non-implementation of laws and rise of social tension, there were a number of underlying rationalisations that enabled the persistence of militarisation in society. The first justification demonstrating a state-led effort to militarise society was based on creating a pension to match the sacrificial deed of the veteran. By basing pension legislation on the veteran's role in the Great Patriotic War, the government was enhancing the veteran's position in society and separating their contribution to society from those who did not work in the army or contribute towards the war effort by promoting the worthiness of a veteran over non-participants in war. This level of glorification not only showed the state's effort to popularise a career in the Armed Forces, but also raised questions regarding the conceptualisation of the ideal citizen. The act of sponsorship,

\footnotetext{
125 As noted in Richard Alston, Soldier and Society in Roman Egypt: A Social History (London: Psychology Press, 1995), 53-58 privileges provided to Roman soldiers in the second century highlighted a commitment of the government to increase the status of soldiers and to deal with 'special problems of the soldier's career.' While Alston uses length of service as an example, he highlights risk of sudden death in the capacity of a soldier further on in his analysis.

${ }^{126}$ Deborah D. Buffton, "Memorialisation and the selling of war," Peace Review: A Journal of Social Justice 17, No. 1 (2005): 28.
} 
carried out through the government's provision of an exclusive pension and benefit policy, contributed towards the renewed notions of the ideal citizen and therefore the militarisation of society, as it enabled certain character attributes (loyalty, patriotism and willingness to sacrifice), as demonstrated by veteran participation in conflict, to permeate amongst society and to become a basic requirement for anyone wanting to gain similar allowances.

Another justification that contributed towards the militarisation of society during this period was the governmental legitimisation that these changes were being made to reflect upon the worthiness of the veteran/ military community. Since such worthiness was attached to ideas of sacrifice and loyalty, the creation of an exclusive veteran pension and growth in disparity in allowances between the military population and civilian cohort were accepted on the basis that civilian society (apart from war time labourers) could not justify a similar worthiness in their own field. Any opportunity to protest on these grounds would have been well and truly stamped out by the repetition of narratives, not only in political documentation, but also in governmental rhetoric during the commemorative activities glorifying the veteran and military community for their sacrifice and role in the protection of the motherland. A number of documents in preparation for the Victory Day parade and in creating the reform justified such reforms on the basis of the soldier's role in war. As noted in A Federal Law On perpetuating the victory of the Soviet people in the Great Patriotic War, special measures for veterans including commemorative practices were justified on the premise that the 'defenders of the motherland...gave their lives for its freedom and independence." In a Federal Assembly speech, similar words were spoken when the speaker announced, "We will always remember the names of courageous sons and daughters of the motherland, who gave their dearest life for the sake of the freedom of the motherland."127

The final justification was based on underlying narratives relating to the current military-patriotic position in society. Those involved in the parliamentary hearings on social protection called for a revival in a military-patriotic nation and improvement to the prestige of the Russia's military. A government commission was approved on $30^{\text {th }}$ December 1994 on the subject of 'social issues of military personnel, citizens discharged from military service, and members of their families.' One of the tasks of the commission

${ }^{127}$ GARF, f. 10100, op. 1, d. 989, 1. 2, [Undated: 1993-1995].

GARF, f. 10100, op. 1, d. 135, [Undated: 1993-1995]. 
was "Regeneration and implementation of nationwide measures aimed at increasing the prestige of military service, improvement of socio-economic, legal and sociological conditions of drafting for the military service." 128 Such rhetoric highlighted a growing concern of the position of the military in society. Changes to veteran and military policy were seen as a solution that could be used not only to elevate the position of the military institution but also to demonstrate the government's commitment to supporting current and future servicemen. Such narratives demonstrated that changes to social welfare policy, in both a current military setting and for veterans of previous conflicts, were made with the intention by the government to popularise the military institution and militarise society.

In conclusion, a number of changes were made to veteran social welfare policy under Yeltsin's leadership. First, the changes to veteran policy confronted the term 'veteran' and created a fixed definition that not only recognised those veterans from the Great Patriotic War, but also recognised all ex-military personnel that had participated in a conflict in defence of the motherland. Fixing the definition for the term veteran raised questions regarding who could be deemed a veteran. These questions sparked a discussion regarding the sacrifices of home-front workers during the Great Patriotic War and contributed towards the development of militarism as it forced society to think of their own role in a potential future conflict. The second of these changes to veteran policy acted as a form of sponsorship by the government. Similar to commercial and sports sponsorship schemes, the creation of an exclusive veteran's pension contributed towards the militarisation of society as it promoted the three core values of loyalty, patriotism and self-sacrifice that are associated with the military and enabled them to permeate society. In addition, the provision of an exclusive pensions, benefits and money scheme for social protection of the current military cohort required a significant proportion of the state budget, demonstrating the state's commitment to the military institution over civilian society and therefore highlighting the importance of the Armed Forces in society. Government documentation shows that these changes were not made by the government as a form of duty, but to revive the military-patriotic spirit of the nation. Therefore, and as evidenced above, changes to veteran policy were used by the government as a

${ }^{128}$ GARF, f. 10200, op. 1, d. 174, 1. 81-84, [Undated: 1993-1995]. 
mechanism of militarisation, and demonstrates that there was a government-led continuation of societal militarisation under the leadership of Yeltsin. 


\section{CHAPTER 5}

\section{PAYING THE DEBT: A CASE STUDY OF THE 1995 VICTORY DAY PARADE AND ASSOCIATED CELEBRATIONS}

On $9^{\text {th }}$ May 1995, the Russian state commemorated the $50^{\text {th }}$ anniversary of the Great Patriotic War victory. They celebrated the anniversary with two elaborate military parades, and by opening memorials, monuments and museums built for the occasion. National military parades were a custom of both Imperial Russia and the Soviet Union but were discontinued after the collapse of the Soviet Union. ${ }^{1}$ In 1995, they were reintroduced as part of the $50^{\text {th }}$ anniversary celebrations. Its renewal marked a new age of militarism in Russia, demonstrating a serious state-led effort to revive military-patriotic wartime discourses and use them to shape Russian national identity. ${ }^{2}$ Aims to control the wartime discourses were three-fold. First, the government wanted to use the basis of the Great Patriotic War and the Union's eventual victory to reinforce a nationalistic-patriotic Russian identity, which crumbled after the Soviet collapse. Second, the promotion and celebration of this anniversary validated the veterans' place in society. Glasnost marginalised veterans in the early years of the Russian Federation for furthering the oppressive Soviet system through their military victories. ${ }^{3}$ This process of inclusion was also to acquire votes in the lead up to the 1996 Presidential election. ${ }^{4}$ Finally, the most

\footnotetext{
${ }^{1}$ Yan Mann, "(Re)cycling the Collective Memory of the Great Patriotic War," The Journal of Slavic Military Studies 33, No. 4 (2020): 512.

${ }^{2}$ Markku Kangaspuro and Jussi Lassila, "Naming the War and Framing the notion in Russian Public Discussion," Canadian Slavonic Papers 54, No. 3-4 (2012): 377.

${ }^{3}$ This marginalisation is best demonstrated by Anna Krylova. She discusses a change in journalistic portrayal of the Great Patriotic War veteran in the mid 80s and early 1990s. She argues that among other denunciations of the past were also the veterans, whose role in the victory of the Great Patriotic War allowed for the continuation of the Soviet State. While these narratives were more anti-Soviet than anti-military and anti-veteran, they played a role in the depopularisation of the Armed Forces, leaving the veterans feeling 'betrayed.' She notes the demonstrations that took place on Victory Day 1993 as a turning point in which demonstration participants in their 40s and 50s wanted to not only protect the veterans, but to protect their victory. For more, please see: Krylova, "Dancing on the Graves of the Dead," 88-93.

${ }^{4}$ Ibid, 97.

Roger D. Marwick, "The Great Patriotic War in Soviet and Post-Soviet Collective Memory," in The Oxford Handbook of Postwar European History, ed. by Dan Stone (Oxford: Oxford University Press, 2012), 695-696.
} 
important reason for such grandeur was to popularise an institution and part of society that was in serious demise after its defeat in Afghanistan and ongoing conflict in Chechnya. ${ }^{5}$ In doing so, the celebration aimed to promote military-patriotic discourses and promote a career in the military.

The chapter builds upon the work of Markku Kangaspuro and Jussi Lassila, which argues that the 1995 Victory Day has been largely neglected in scholarship. They claim that the event was important for a multitude of reasons, including the re-emergence of Soviet symbolism. This chapter focuses on the celebration's role in glorifying the veteran, maintaining the Great Patriotic War's relevance in the Post-Soviet era and legitimising the Armed Forces through emphasis of past, present and future national threats. ${ }^{6}$ The chapter asks why and how the anniversary was celebrated? With an aim to identify its role in the militarisation of society, it also asks to what extent the theme of sacrifice, in regard to the Great Patriotic War and the Russification of the wartime narrative, contributed towards its evolution from a historical event to one of 'mythical timelessness. ${ }^{7}$ It notes that emphasis on sacrifice and spectator responsibility militarised Russia's society through the cultivation of a debt ideology. This debt ideology framed the

5 As noted by Kangaspuro and Lassila, Izvestiia, which was a newspaper critical of the state in 1995, wrote comparisons between Stalin's exile of the Chechen population on the eve of the Great Patriotic War with Yeltsin's war in Chechnya six months before the celebration day. For more, please see: Kangaspuro and Lassila, "Naming and Framing the nation in Russian Public Discussion," 380.

${ }^{6}$ Ibid, 381.

The term Russification is usually used to describe the cultural assimilation of non-Russian communities with the cultural and political norms of the Russian Federation; this can include imposition of the Russian language, for example. In this thesis, the term Russification refers to the assimilation of Soviet events, tropes and symbols with the policies and identity of the Post-Soviet Russian Federation. The term Russification is favoured over the phrase de-Sovietisation, as this case study is specific to the actions of the Russian Federation.

${ }^{7}$ Mythical Timelessness in relation to the Great Patriotic War was a term first used by Dr. Mikhail Nemtsev in a workshop held at Swansea University in 2017. Nemtsev argued that the prominence of the Great Patriotic War in the discourse of Russia's daily landscape allowed soldiers of Russia's current army to fight with that victory in their mind, seeing the conflict in Crimea, for example, as an extension of the victory forged in 1945. The mythologization process, as highlighted later in this chapter will demonstrate how the Great Patriotic War remains prominent in society on a grassroots level. For more, please see: Mikhail Nemtsev, "Life of a devoted militant out of a battlefield: Variations of everyday militarism in Russian Communities," workshop, Militarisation of Everyday Life in Europe: Past Practices and Future Challenges, Swansea University, Swansea, November 2017. 
sacrifice of war veterans as a debt which could only be paid off through society's participation in commemorative activities. It also finds that the Russification of certain wartime discourses, especially in the symbolisms of the commemorative landscape, demonstrated a clear objective of the state to integrate the victory into the current Russian context - allowing for militaristic-patriotic discourses to endure the regime change that took place in 1991.

To this end, the chapter shows that current processes under Putin had their origins in Yeltsin's Russia. The chapter investigates such forms of militarisation from the top down, creating a foundation for further research. As the case study chapter of this thesis, the chapter examines the Victory Day celebrations by drawing on a rich range of sources. To understand how the commemorative events contributed toward the militarisation of Russian society, the chapter examines prominent discourses in laws, appeals and letters circulating within the State Duma at this time. It also analyses the rituals, symbolisms and discourses in speeches made at events taking place in the lead up to (and on) Victory Day by assessing videos of the parade and associating celebrations. It also investigates the symbolic nature of monuments, commemorative spaces and souvenirs specifically created for this commemorative date. In doing so, it shows to what extent the Russian state relied on the past to cultivate pro-military sentiments in the newly formed Russian Federation.

The first part of this chapter outlines the historical role of military ceremonies in power play activities. It shows that parades acted as a forum of discipline and control beyond the Soviet era and was a tradition of Imperial Russian leaders. The chapter then discusses the relationship between military parades, commemoration and mythbuilding state practices. The section highlights the common use of history to create "universality of experience," noting the role of military spectacle and associating discourses in legitimising past experiences in contemporary day contexts. ${ }^{8}$ The following section investigates the role of the spectator in military parades. The final two sections of this chapter focus on the 1995 Victory Day celebrations. They outline why and how the anniversary was commemorated, with an in-depth analysis of the two parades, monuments and commemorative souvenirs. They examine the remobilisation of Soviet discourses, and the increasing use of Russian symbols, which demonstrated a clear departure from the Soviet era and goal of the Russian state to reshape the Soviet victory

\footnotetext{
${ }^{8}$ Mann, "(Re)cycling the collective memory," 509-510.
} 
into a Russian one. Together, this chapter shows a clear aim of the state to revive militarypatriotic discourses and to place them within the current Russian context. The promotion of these discourses ensured that society remained exposed to glorified images of the military, coupled with notions of sacrifice and state loyalty.

\section{Multi-modal Critical Discourse Analysis (MCDA)}

Parades, political speeches, monuments and collectable souvenirs come together to form commemorative rituals. Ron Scollon and Philip Levine note that language is "constructed across multiple modes of communication." Speeches produced discourses of veteran valour through spoken text; while parades, monuments and souvenirs were discursive spaces communicated through visual means. Multi-modal critical discourse analysis is a useful tool for analysing commemoration. It emerged as a form of analysis from Gunther Kress and Theo Van Leeuwen's work, which argued that language is shaped through its social and cultural use. ${ }^{10}$ The political speeches, parades, monuments and collectable souvenirs created for the Great Victory's $50^{\text {th }}$ anniversary were shaped to fit the celebration, the state's desire to popularise the victory and promote collective memory. Therefore the discourses in isolation were given extra layers of meaning through their association with the commemorative event and similar bonds that tied these memorial discourses together. Known as monomodality, it means that we cannot consider the following sources in isolation. David Machin highlights that "in multimodal communication, the different modes [have] become more integrated and visual elements were being used to communicate complex ideas and attitudes." Only by bringing together the textual, symbolic, ceremonial, visual and architectural changes made for this event can we truly understand 1) what discourses the state aimed to instil in society and 2) how shared discourses across these domains helped reaffirm particular dominant discourses.

Chapter four outlined CDA's value for understanding and examining political discourses. CDA is also valuable for analysing monuments. Monuments are visual

\footnotetext{
${ }^{9}$ Philip Levine and Ron Scollon, "Multimodal Discourse Analysis as the confluence of Discourse and technology," in Discourse and Technology: Multimodal Discourse Analysis, ed. By Ron Scollon and Philip Levine (Washington DC: Georgetown University Press, 2004), 1-2.

${ }^{10}$ Per Ledin and David Machin, "Multi-modal critical discourse analysis," in The Routledge Handbook of Critical Discourse Studies, ed. by John Flowerdew and John E. Richardson (Oxon: Routledge, 2018), 62.
} 
representations of ideas, attitudes and ideologies. ${ }^{11}$ As symbols and identity-shapers, they must be "easily de-codable by an average mass receiver." 12 Monuments symbolise a society's heritage, identity, values and future goals; they perpetuate historical myth, give importance to a particular issue and "function as local landmarks." 13 War memorials are a significant aspect of war commemoration. On commemorative holidays, they are used as ceremonial grounds where political and societal elite lay wreaths and enact moments of silence as a sign of respect to the war dead. However, as a permanent part of the landscape's architecture, monuments act as signifiers of death, victory and glory; reminders of the veterans' sacrifice for the greater good. They mute debates on war futility by highlighting war and the soldiers' sacrifice as worthwhile, necessary and normal. This helped feed into and reaffirm prevailing militarising discourses, which considered soldiery an important form of civic duty. ${ }^{14}$ Souvenirs are considered in a similar way. Souvenirs are pocket monuments, decorated with symbols aimed at transporting, supporting and establishing a series of desired messages. Some are functional, acting more than just nuggets of sentimentality. Their functionality makes it more difficult for a person to contest the symbolic imagery, since they are necessary everyday items. A monument and souvenir's symbolic contribution to societal militarisation can be assessed through CDA, as it identifies what messages are being communicated and where/ how they dominate discourses.

CDA is also a helpful tool for analysing ceremonial rituals. Monuments become ceremonial grounds during memorial days, as political elite gather and ceremoniously pay their respects to the veterans by laying wreaths and committing to a minute's silence. These rituals reiterate the memorial's symbolic importance in society as elites gather in this one space to show gratitude. Second, monuments are usually placed in central locations of town squares in order to represent "cherished values and hegemonic version of our shared history." ${ }^{15}$ In the same sense, a political elites' wreath laying ritual is done

\footnotetext{
${ }^{11}$ David Machin, "What is multimodal critical discourse studies?" Critical Discourse Studies 10, No. 4 (2013): 350.

${ }^{12}$ Natalia Krzyzanowska, "The discourse of counter-monuments: semiotics of material commemoration in contemporary urban spaces," Social Semiotics 26, No. 5 (2016): 470. ${ }^{13}$ Krzyzanowska, "The discourse of counter-monuments," 468

Gill Abousnnouga and David Machin, "The changing spaces of war commemoration: a multimodal analysis of the discourses of British monuments," Social Semiotics 21, No. 2 (2011): 175-176.

${ }^{14}$ Machin, "What is multimodal critical discourse studies?" 350.

${ }^{15} \mathrm{Ibid}, 351$.
} 
on behalf of society, representing a collective appreciation of the memory being commemorated. Usually televised and photographed, onlookers remain part of this ritual without actually needing to be there. A monument's unveiling is also a crucial part of establishing the statue's importance. Krzyzanowska notes that monument unveiling ceremonies bring the relevance of the memory into the present. She claims that a monument's creation confirms the importance of that memory in society, showing that it remains a significant part of a society's current and future political culture. ${ }^{16}$ Beyond monument ceremonial rituals, military parades are forms of power. Speeches, music, visuals and symbols come together to reaffirm military-patriotic discourses that popularise military potency, veteran valour and worthwhile victory. This form of power undergoes a detailed examination in the next section.

MCDA and CDA are valuable tools for analysing commemoration. Memory discourses are multifaceted; built from memories, rewritten histories, state performances, permeated in a country's architectural sites and in visuals. Together they reaffirm a desired and dominant discourse. Commemoration is thoughtfully designed. While elites work to commemorate the sacrifices of the war dead, they look to avoid futile representations of the war, instead framing the veteran's sacrifice as a necessary action for the nation's survival. This was the case in 1990s Russia. MCDA and CDA help us to understand how the various modes of commemoration symbolise the Great Patriotic War and their intended contribution to other societal discourses during this time. Together, they confirmed Russia's long history with conflict and the veteran's enhanced position in society.

Military Parades and Power.

On the $9^{\text {th }}$ May 1995, Russia celebrated the $50^{\text {th }}$ anniversary of the Great Patriotic War victory (1941-1945). As the New York Times reported:

The Russian Government, eager to show the world and its own people that theirs remains a proud and powerful nation, put on perhaps the most elaborate military pageant seen here since the early 1980's, at the end of the Brezhnev era. The hammer and sickle and the Soviet star, symbols of the Communist Party, which led the nation to victory, were prominently displayed despite its fall from power. ${ }^{17}$

\footnotetext{
${ }^{16}$ Krzyzanowska, "The discourse of counter-monuments," 468.

${ }^{17}$ R.W. Apple Jr., "V-E Day Plus 50: The Overview; Allied Victory in Europe Is Commemorated in Moscow, The New York Times," 10 May 1995, accessed 20 September
} 
The event was an extravagant display of Soviet paraphernalia and military hardware thundering down the Red Square and on Poklonnaia Gora. ${ }^{18}$ Numerous memorials, including Moscow's Great Patriotic War museum, were opened to the public. The parades and commemorative landscape portrayed Russia's military in positive terms, emphasising the victory of the Soviet Union to enforce current day ambitions. The commemorative landscapes provided a picture of Russia's military institution that was vastly different to reality. In actual terms, Russia's military was in turmoil. The media exposed issues like Dedovshchina and failures in the Soviet-Afghan War (1979-1989) to the public. ${ }^{19}$ Negative coverage affected public perception of the military, while many soldiers in Russia's military cohort questioned what they were fighting for. In the age of glasnost, glorified victories of the past, like the Great Patriotic War, became a distant memory. ${ }^{20}$ At the time of the celebration, Russia's army was involved in the First Chechen War (1994-1996), which further exacerbated the military's poor position in society. $^{21}$

2018, https://www.nytimes.com/1995/05/10/world/v-e-day-plus-50-the-overview-alliedvictory-in-europe-is-commemorated-in-moscow.html.

${ }_{18}$ The display of Soviet paraphenalia was widely debated within the State Duma, with officials arguing that the victory was Soviet and should be memorialised as such. This issue is further debated below but has been highly confronted in literature on the PostSoviet era, with scholars arguing that the use of Soviet symbols was to first, allow the Russian government to transform the Soviet victory into a Russian one, and secondly, the Post-Soviet Russian society was ready to adopt its Soviet past because it was not so different from the regime it succeeded. For more, please see: Lev Gudkov, "The Fetters of Victory: How the War provides Russia with its Identity," Osteuropa 55, No. 4 (2005), accessed 18 July 2020, https://www.eurozine.com/the-fetters-of-victory/; Tomas Kavaliauskas, "Different Meanings of May $9^{\text {th }}$ : Victory Day over Nazi Germany, for Russia and the Baltic States," Interdisciplinary studies on Central and Eastern Europe 9 (2011): 321-326; Kangaspuro and Lassila, "Naming and Framing the nation in Russian Public Discussion," 381.

${ }^{19}$ Herspring, "Dedovshchina in the Russian Army," 609-610; Herspring, "Undermining Combat Readiness," 515-516; Trenin, "The Revival of the Russian Military," 23-24; Leon Aron, "Russia's New Foreign Policy," 2.

${ }^{20}$ Michael Galbas, "Our Pain and Our Glory," Social Strategy of legitimisation and functionalisation of the Soviet-Afghan War in the Russian Federation," Journal of Soviet and Post-Soviet Politics and Society 1, No. 2 (2015): 103.

${ }^{21}$ Lieven, Chechnya, 196.

Kangaspuro and Lassila, "Naming and Framing the nation in Russian Public Discussion," 380. 
The Russian state used the commemorative date to rewrite discourses around the military, and to identify parallels between the military of the Great Patriotic War and Russia's current military institution. They used Russia's victorious past to show that victory was possible again. Military parades are notorious for representing control and power. They showcase the military capabilities of that country, manpower and level of discipline of that military and the power of the leader. Commemorative military parades demonstrate a country's physical level of power and control. However, they also showcase the state's control over historical discourses. Similar to educational textbooks, the parades used history to promote a sanitised discourse of the event being commemorated. In this case, Russia in the 1990s relied on Russia's glorious militaristic past to shift public perception of the current military apparatus, while also trying to show the world that Russia was a serious military power.

Military parades were a key aspect of both Imperial Russia and the Soviet Union. The regimes held absolute power and needed to find a way to exercise control. Leaders used parades to exercise power, to discipline the military, to demonstrate a level of subordination to domestic audiences, and project an image of power within the international domain. ${ }^{22}$ Power and control was therefore represented through human discipline and military technology. This form of control is in line with Michel Foucault's perception of the docile soldier. He considered the soldier as an excellent subject to use when executing control, power, and forming national identity, as the soldier was recognisable to the masses. In addition, the values the soldiers embodied were desirable to the state - ones that the state wanted to promote. The most important characteristic of the eighteenth century soldier, however, was their ability to be shaped, as if "formless clay." ${ }^{23}$ Through marches, drills and parades, the soldier learnt to march a certain way, to correct their posture, "turning silently into the automatism of habit." 24 In a similar way, the continuous and replicated displays of the Victory Day parade from the Soviet to the Post-Soviet periods slowly turned the audience into a recipient of the same discipline, subordination and ritual.

During Imperial and Soviet rule, control over society was exercised through secret police networks, labour camps, censorship laws and economic constraints. In the newly

\footnotetext{
${ }^{22}$ Keep, "The Military Style of the Romanov Rulers," 70-71.

${ }^{23}$ Michel Foucault, Discipline and Punish: The Birth of the Prison. (London: Penguin, 1991), 135.

${ }^{24}$ Ibid.
} 
formed "democratic" Russian Federation, new approaches were needed to influence a population with new and increased political participation rights. One mechanism was the continued use of these ritualistic parades. The victory parades, which resumed under the same justification of commemoration, enabled government control without the autocratic powers of the previous regime. In a sense, the discursive nature of this event was even more important to the newly formed Russian State, which did not have censorship on its side because this landscape was organised by state organisations that were able to produce a standardised discourse about the Great Patriotic War victory. ${ }^{25}$ The success of these parades is evident in the enormous role they continue to play in Putin's Russia. The rituals established in the Tsarist and Soviet period and revived under Yeltsin continue to be used as a discursive forum, to control and perpetuate certain discourses.

At these forums, the act of remembering reminded Russian society of the devastating impact of the Great Patriotic War, while the political speeches drew temporal lines between the past and present. Stories of danger and threat were exemplified by discourses of veteran sacrifice and heroism, which justified society's participation in these events. The veterans' role in these parades was (and remains) most crucial to ensuring the participation (and therefore, the control) of society. Militarism was a product of this control, since the military-patriotic discourses that valorised the veteran community, and their sacrifice, shamed the public into participating in public remembrance activities. The public's participation therefore acted as a form of recognition, acknowledging the important role society was willing to play to support and pay respects to the veteran community. While the military's prioritisation was directed from the top, it was the participation from below that validated this level of priority and demonstrated the success of these parades in militarising society. While these parades were initially discontinued on a national level, after 1991, localised and small-scale parades continued. ${ }^{26}$

\footnotetext{
${ }^{25}$ While the Media Law in 1992 did limit the discourses of journalists, they were still able to operate in a more open environment than was possible in the Tsarist and Soviet era.

${ }^{26}$ Events would still take place on a local and regional level and were usually organised by political parties such as the Communist party. Veterans "flocked to the streets and squares of Moscow to defend their version of the War story," which became increasingly under threat by the new independent media. For more on this, please see: Krylova, "Dancing on the Graves of the Dead," 90.
} 
In 1995 and for the special 50 ${ }^{\text {th }}$ anniversary of the Great Patriotic War, the Russian government decided to revive the Victory Day parade and to establish it on an annual basis. An undated project document by State Duma Deputies Aparina and Lukiankov from between 1993 and 1995, linked to the Federal Law On perpetuating victory of the Soviet people in the Great Patriotic War, claiming "The Day of May the $9^{\text {th }}$ is declared a national holiday [known as] Victory Day. Victory Day is a non-working day and is annually marked by a military parade and artillery salute." 27 The sensational military displays in Moscow and St. Petersburg promoted the militarisation of society as they encouraged the public to participate in the events of the National holiday. These performance rituals popularised the military, demonstrated the close relationship between the Armed Forces and political institutions, and the use of memory in present and future political and societal goals and in institutional legitimisation. ${ }^{28}$ As highlighted in chapter four, the Victory Day also popularised military values of sacrifice and state loyalty into public space, creating a set of ideal attributes that the rest of society should strive to

${ }^{27}$ GARF, f. 10100, op. 1, d. 989, [Undated: 1993-1995].

This Federal Law was an outcome of efforts by veteran organisations who called for a Moscow Jubilee to be held alongside associating events and the establishment of the $9^{\text {th }}$ May as a state holiday for all the state (republics) of the USSR. The suggestions made by M. Tronov of the All-Russian Council of Veterans of War, Labour, Armed Forces and Law Enforcement Agencies, included the introduction of a 20 hour "History of the Great Patriotic War 1941-1945 and the feat of the people in the defence of the fatherland" course into higher education institutions, to create exhibitions from 1993 to 1995 on films and art about the main battles and operations of the Great Patriotic War, to hold an open art exhibition on Manezhe Square etc. For more, please see: GARF, f. 10026, op. 1, d. 2861, 1. 30-34, 15 April 1993.

${ }^{28}$ This thesis adopts Jan Kubik's use of legitimacy/ legitimisation as the process, "when rulers invoke the ultimate values and symbols of a given group in constructing their public image." As demonstrated throughout this chapter, the values and images that are being promoted in the ceremonial activities of Yeltsin's Russia are being cultivated in a similar vein and, to some extent, in purpose of seeking political/ institutional legitimacy. For more links between commemorative rituals and political legitimacy, please see: Jan Kubik, "Polish May Day Celebrations in the 1970's and in 1981: An Essay on Symbolic Dimension of a Struggle for Political Legitimacy," The Polish Review 34, No. 2 (1989): 100; Janice M. Irvine and Jill A. Irvine, "The Queer Work of Militarised Parades," Contexts: Sociology for the Public 16, No. 4 (2017): 3; Klinka Locmele, Olga Procevska and Vita Zelce, "Celebrations, Commemorative Dates and Related Rituals: Soviet Experience, its Transformation and Contemporary Victory Day Celebrations in Russia and Latvia," in The Geopolitics of History in Latvian-Russian Relations, ed. by Nils Muiznuks (Riga: Academic Press of the University of Latvia, 2011), 110; Hung ChaingTai, "Mao's Parades: State Spectacles in China in the 1950s," The China Quarterly, No. 190 (2007): 430. 
achieve. The ritual element of the Victory Day Parade played a specific role in promoting and legitimising the military institution. ${ }^{29}$

\section{Telling a story?}

In addition to building legitimacy, parades are also myth builders. Brezhnev era Victory Day parades contributed toward the cult of Victory - with rituals and practices organised to elevate war participants above non-participants in an informal social hierarchy. ${ }^{30}$ In Post-Soviet Russia, this cult was revived. ${ }^{31}$ Participants of war were promoted in the Victory Day parade and through the popularisation of a debt ideology, which emphasised stories of their sacrifice and loyalty during the wartime.

The veterans' victory was immortalised through emphasis on their sacrifice. Boris Yeltsin spoke of such sacrifice in a speech to veterans who were awarded the Order of Zhukov on the $5^{\text {th }}$ May 1995 . He said, "the war is past but the memory of it is timeless, the immortal feat of soldiers and underground commanders and the Partisans of the Workers... who all ensured the defeat of the Nazi hordes, we will always remember the enormous efforts of deprivation and sacrifice, [in which] the Great Victory was achieved." ${ }^{32}$ First, the collective act of remembering was acknowledged by the phrase "we will always remember." Yeltsin placed himself in the same position as an audience member, promoting communal responsibility. This responsibility, mobilised by using "we," was to remember the veterans' sacrifice in the Great Patriotic War. Calls like this actively engaged with audience members and rallied them to participate. Second, the act of remembering was linked to veterans' sacrifice. Yeltsin noted the "enormous efforts of deprivation and sacrifice" to muster support for the veteran community and justify the role that non-participants of war should play in perpetuating the memory of the soldier's

\footnotetext{
${ }^{29}$ Dominic Bryan claims that by legitimising political regimes, rituals usually include characters that are deemed superior and inferior. He uses the example of a Merina, whose rulers referred to themselves in rituals as conquerers, whereas the everyday person (or inferior) is personified as the conquered. We can use this conceptualisation to understand the aims of the Russian political elite to legitimise the military institution. Veterans and the current military cohort (as the superiors) are portrayed as the sacrificial lamb, as heroes, while the rest of society is depicted as the generations saved by their actions. For more, please see: Dominic Bryan, Orange Parades: The Politics of Ritual, Tradition and Control (London: Pluto Press, 2000), 19-21.

${ }^{30}$ Locmele et al. "Celebrations, Commemorative Dates and Related Rituals," 116.

${ }^{31}$ Kangspuro and Lassila, "Naming the War and Framing the Nation in Russian Public Discussion," 380.

${ }^{32}$ Yeltsin Centre, f. 21, op. 1, d. 128, 5 May 1995.
} 
sacrifice. Immortalising the veterans' sacrifice further, at a Federal Assembly meeting in March 1995, the final victory of the Soviet Union over Nazism in May 1945 was characterised within a messianic frame. Chairman of the State Duma Ivan Rubkin claimed, "Your meeting is dedicated to the 50th anniversary of the most memorable and most significant date of the 20th century - May 1945 - the day of the triumph of good and freedom, the final deliverance of peoples from the threat of fascist enslavement." 33 Combining the victory with notions of sacrifice, Russian exceptionalism, and religious tropes added several layers to the memory of the Great Patriotic War. It helped legitimise elaborate forms of remembering, reinforced positive images of the veterans' sacrifice and immortalised their victory.

Lev Gudkov investigates the adoption of godly tropes in commemorative activities, claiming that war is often likened to biblical events to immortalise the veteran. ${ }^{34}$ This 'immortalisation' mythologised the anniversary. Another way the commemoration became timeless was through the cultivation of a debt ideology; not only by emphasising ideas of sacrifice, but also outlining current generation's indebtedness to such sacrifice. These discourses acted to promote youth participation. Finally, the victory was mythologised by its annual celebration. Onlookers paid their debt by participating in memorialisation activities, only for the process to occur again a year later. The commemorative process was thus cyclical.

Maoz Azaryahu, writing about militarism in Israel, argues that military parades are ideological and political, with each spectacle displaying specific political ideologies and particular power relations. ${ }^{35}$ The debt ideology, which emerged in Russia, added a layer of emotion to existing patriotic sentiments being displayed. It was built by common reference to veterans' sacrifice and the future sacrifice that should be committed to preserving and ensuring the protection of the fatherland and in consolidating peace. Those who did not sacrifice themselves in the same way were indebted to those who did. At the

${ }^{33}$ GARF, f. 10100, op. 2, d. 135, 1 March 1995.

${ }^{34}$ Gudkov, "The Fetters of Victory."

Lisa A. Kirschenbaum, and Nancy M. Wingfield, "Gender and the Construction of Wartime heroism in Czechslovakia and the Soviet Union," European History Quarterly 39, No. 3 (2009), 483.

${ }^{35}$ Maoz Azaryahu, "Military and Militarism in Israeli Society," in Independence Day Military Parade: A Political History of a Patriotic Ritual, ed. by Edna Lomsky-Feder and Eyal Ben-Ari (Albany: SUNY Press, 2012), 91.

Peter G. Goheen, "Symbols in the Streets: Parades in Victorian Urban Canada," Urban History Review 18, No. 3 (1990): 237. 
Federal Assembly meeting in March 1995, Rubkin stated, "Time separates us more and more from May $9^{\text {th }}$, 1945, but no one has to be forgotten and nothing should be forgotten. We will always remember the names of the courageous sons and daughters of the motherland, who gave their dearest life for the sake of freedom of the Motherland." ${ }^{\text {36 }}$ Boris Yeltsin echoed similar sentiments. When presenting State Awards on the $27^{\text {th }}$ April 1995, he noted:

Glory, the highest insignia of which we have awarded a well-deserved award. For selfless service to the Motherland of Russia, I sincerely thank you for your work... The state award is given to veterans of the Great Patriotic War. They made a great contribution to the defeat of Nazi invaders. They showed strength on the battlefields, the heroism of veterans [and showed the] inexhaustible strength of spirit of our people. ${ }^{37}$

Calls to "always remember" and providing "well-deserved" awards for the veterans' victory were only few examples where society was asked to repay the debts of the war victors. Commemoration turns to militarisation when the debt is being repaid. Russian society was being called upon to commemorate. To commemorate is to be aware of the history that is being memorialised, to worship and pay respects to those who participated in the event under commemoration. The commemorative events, therefore, furthered the militarisation of society by maintaining sacrificial discourses, building debt and establishing society's responsibility to perpetuate the Veterans' victory. At each stage of this paradigm, society was exposed to military-patriotic discourses enacted to continue the victory of the Great Patriotic War in living memory.

According to Daniel Sherman, organisers of public commemorations coordinate these events to memorialise the past and promote the state's current political goals. ${ }^{38}$ These parades not only demonstrated the country's military capabilities but were also created to make society feel proud of its military. Pride was considered an important element influencing military support. ${ }^{39}$ Ceremonies are framed and created around the

\footnotetext{
${ }^{36}$ GARF, f. 10100, op. 2, d. 135, 1 March 1995.

37 Yeltsin Centre, f. 21, op. 1, d. 126, 27 April 1995.

${ }^{38}$ Daniel J. Sherman, "Commemoration," in The French Republic: History, Values, Debate, ed. by Edward Berenson, Vincent Duclert and Christopher Prochasson (Ithaca and London: Cornell University Press, 2011), 327.

${ }^{39}$ Natalia Bertuol notes that Victory Day, while centered on the historical narratives, uses the debates to enforce "blind national pride and militarism." Please see: Natalia Bertuol, "In the event of shelling: Remembering the Great Patriotic War," Junior Year Abroad
} 
public. Jack Santino claims that the 'public' parades ensured that issues central to the agenda of political elites remained a collective interest and priority of the public. ${ }^{40}$ Agreeing with Santino, Azaryahu argues that ritualised communications exchanged between national leadership, military command and army are "the supreme values of the nation as a political community." 41 On the day of the Victory Parade, society was confronted with the political aims of the state, packaged neatly into a choreographed military parade and communicated in the name of those who forged the Victory of the Great Patriotic War.

Reviving militaristic-patriotism required the Russian state to commemorate the anniversary by emphasising sacrifice and heroism. Scholars of commemoration note that remembrance activities not only supported the history but provided opportunities for onlookers to re-familiarise themselves with the history, to 'reaffirm and reconfirm' the existence of the institutions attached, and to reflect on the military's role in society. ${ }^{42}$ Therefore, war commemoration militarises society as it exposes them to romanticised stories of sacrifice and honour, while shaming them into participating and playing an active role in the event.

\section{THE ROLE OF THE SPECTATOR}

The anniversary was an opportunity for the Russian state to draw upon the country's history to reignite interest in the military institution, which had reached a nadir. ${ }^{43}$ To change societal attitudes, the government included them in the celebration of the event, since the most important aspect of a parade is the relationship between the performer and spectator. The performer-spectator relationship is not only significant for institutional legitimacy, but hinges on the parade's ability to transport values and ideals. The spectator would take on four roles. First, the spectator became a participant through

Network (JYAN) Blog (blog), 3 May 2018, accessed 17 March 2020, https://berkleycenter.georgetown.edu/posts/in-the-event-of-shelling-remembering-thegreat-patriotic-war.

40 Jack Santino, "Performative commemoratives, the personal, and the public: Spontaneous shrines, Emergent Rituals, and the field of Folklore," Journal of American Folklore 117, No. 466 (2004): 368.

${ }^{41}$ Azaryahu, "Military and Militarism in Israeli Society," 91.

${ }^{42}$ Locmele et al. "Celebrations, Commemorative Dates and Related Rituals," 110.

${ }^{43}$ Olga Malinova, "Political Uses of the Great Patriotic War in Post-Soviet Russia from Yeltsin to Putin," in War and Memory in Russia, Ukraine and Belarus, ed. by John Fedor, Markku Kangaspuro and Jussi Lassila (London: Palgrave Macmillan, 2017), 53. 
the establishment of Victory Day as a Russian national holiday. ${ }^{44}$ Removing obstacles (such as work) enabled more people to attend the celebrations and outlined the significance of the commemoration day to the state (unfortunately, there is no information documenting how many people attended or watched the $50^{\text {th }}$ anniversary event in Russia). In addition, nationalising the date, coupled with statements such as ' $\left[9^{\text {th }}\right.$ May $]$ will be for us all a day of remembrance' imposed the collective duty to commemorate on society. ${ }^{45}$ The second role of the spectator was as a performer as part of the collective. An undated Federal Law on perpetuating the memory of the war victors, which centered on commemoration and enhanced social welfare benefits, stated, "Bearing in mind that caring for participants and victims of war is a historical duty of society and the state." ${ }^{46}$

The flamboyant display of military prowess in the parades and exhibition of Soviet paraphernalia became instruments manipulated by the state to create social cohesion and shape public consciousness by cultivating and popularising pro-military narratives that promoted the "glorious victory" of the Great Patriotic War. ${ }^{47}$ In this second role, the spectator became a bystander to the state's militarisation project. By performing their civic duty, participating in the commemorative events and paying respects to the veterans in memorial activities, the spectator was engaging with (or even mobilised by) the military-patriotic discourses popularised by the state. This was enhanced by the spectator's third role as the onlooker.

The third role was more traditional. The spectator needed to view a performance. Encouraging a performer-spectator relationship is not only constructed by political messages, but in its entertainment-value. Military spectacles are important forms of

${ }^{44}$ GARF, f. 10100, op. 1, d. 989, 1. 2, [Undated: 1993-1995].

As noted by Locmele et al. the Victory Day parade was not deemed a national holiday in previous Soviet regimes, for example, under the leadership of Stalin, because state leaders believed it would promote the importance of participants of war above that of Stalin. In the Post-Soviet period, the aims of the parade were to promote the veteran community and the values in which they embodied. It was also an opportunity for the government to showcase the career of the military in a positive light and to rally societal support of the military.

45 "Istoricheskii parad v chest' 50-letiia Pobedy v Velikoi Otechestvenoi Voine," YouTube video, 1:01:08, posted by Sovetskoe Televidenie. GOSTELERADIOFOND Rossii, 8 May 2018, accessed 11 October 2018, https://www.youtube.com/watch?v=oSKqdWfyJjI.

${ }^{46}$ GARF, f. 10100, op. 1, d. 989, 1. 2, [Undated: 1993-1995].

${ }^{47}$ Locmele et al., "Celebrations, Commemorative Dates and Related Rituals," 110-111. Santino, "Performative commemoratives, the personal, and the public," 367.

Kavaliauskas, "Different Meanings of May $9^{\text {th }}, " 321$. 
entertainment. ${ }^{48} 18^{\text {th }}$ century Britain considered parades as theatrical forms of war. Neil Ramsey notes that spectators displayed a desire for representations of war, which were spectacular and stimulating rather than reflective of real warfare. ${ }^{49}$ This was similar to Eric Kit-Wai's experience of Hong-Kong Military Parades. He claims that the parades allowed him to appreciate the "physical strength, discipline, and the ultimate obedience of the People Liberation's Army war machine," adding that images of heavy rifles and fierce soldiers made him feel excited and fearful at the same time. ${ }^{50}$ Parades require a phenomenal level of organisation, with geographical layout and time schedule taken into consideration to produce the "most dramatic and symbolic effect." Adolf Hitler's colossal and tightly choreographed parades were instrumental to the success of societal militarisation in Nazi Germany, with the romantic and symbolic elements taking society on a journey of exaggerate militarised-patriotism. ${ }^{51}$ The All-Russian Council of Veterans of War, Labour, Armed Forces and Law Enforcement Agencies wanted to ensure that everyone could access the victory day parade. On $15^{\text {th }}$ April 1993 they suggested that the press, central television, radio, public institutions and creative groups should provide "wide coverage of events and side events related to the $50^{\text {th }}$ anniversary of the Great Patriotic War." 52

By guaranteeing that society could access the anniversary events without leaving the comfort of their living room, military-patriotic discourses were brought to the spectators as they watched/ listened and read about the memorial activities. It moved society towards militarisation by exposing them to discourses of heroism, sacrifice and with little need to step away outside the front door. While not active in the same way as a spectator physically attending these events, the homebound observer remained in dialogue with the discourses that validated veteran prestige and historical danger. Linking the Great Patriotic War victory to contemporary security issues brought the historic conflict into modern day context, therefore propelling the spectator into its fourth role the advocate.

\footnotetext{
${ }^{48}$ Scott Hughes Merely, British military spectacle: from the Napoleonic wars through the Crimea (Cambridge, Massachusetts: Harvard University Press, 1996), 139.

49 Neil Ramsey, The Military Memoir and Romantic Literary Culture, 1780-1835 (Surrey: Ashgate Publishing Ltd, 2016), 81-82.

${ }^{50}$ Eric Kit-Wai, "Re-Nationalisation and me: My Hong-Kong story after 1997," InterAsia Cultural Studies 1, No. 1 (2000): 176.

${ }^{51}$ Hung, "Mao's Parades," 412-413.

${ }^{52}$ GARF, f. 10026, op. 1, d. 2861, 15 April 1993.
} 
As an advocate, the spectator linked the historical content to current day political ambitions. History has been utilised by many countries and in various ways to commemorate or raise concerns regarding social issues. It also informs present day discourses. Marita Sturken claims that memory plays a considerable role in the present and future, with memory forming a basis of identity. ${ }^{53}$ Myths, memories and symbols touch the "emotional depth of national identity," mobilising individuals and collective groups. ${ }^{54}$ Following the collapse of the Soviet Union, Russia underwent a crisis of identity. The 'Communist Utopia,' which sought to promote an ideology to transcend borders, left Russia without its own distinct identity. ${ }^{55}$ Lack of public unity and collective support toward the First Chechen War, for example, impeded Russia's ability to win the conflict in the Caucasus region. One historical event did achieve national reconciliation, namely the Great Patriotic War. While a Soviet Victory, the event's memory was resilient to the collapse of the Soviet Union on the basis that it affected almost every Russian family. As stated by Olga Malinova, "the memory of the Great Patriotic War has proven to be the most "politically usable" element of Russia's past," due to its "high level of social acceptance" and popularity in different societal domains during the demise of the Soviet Union. ${ }^{56}$ It is through understanding its popularity that we can comprehend why it remains central to Post-Soviet identity formation. ${ }^{57}$ In this sense, Russia's politicians were subjected to militarism, by their use and reliance on the memory of the Great Patriotic War to unite society and communicate/ promote contemporary issues. Like leaders before them, Yeltsin and his team were able to shape the discourses to fit their needs, utilising militarised-patriotism to reconcile divisions within society and restore pride in the Armed Forces.

\footnotetext{
${ }^{53}$ Marita Sturken, Tangled Memories, The Vietnam War, The Aids Epidemic, And the Politics of Remembering (Berkeley: University California Press, 1997), 1.

${ }^{54}$ Lorenzo Zamponi, Social Movements, Memory and Media: Narrative in Action in the Italian and Spanish Student Movements (London: Palgrave Macmillan, 2018), 237.

${ }^{55}$ Malinova, "Political Uses of the Great Patriotic War in Post-Soviet Russia from Yeltsin to Putin," 43.

Kavaliauskas, "Different Meanings of May 9 $9^{\text {th }}$, 325-326.

${ }^{56}$ Malinova, "Political Uses of the Great Patriotic War in Post-Soviet Russia from Yeltsin to Putin," 45. Gudkov, "The Fetters of Victory."

${ }^{57}$ For links between the Great Patriotic War and its use in post-soviet identity formation, please see: Gudkov, "The Fetters of Victory"; Kavaliauskas, "Different Meanings of May 9 ," 323; Malinova, "Political Uses of the Great Patriotic War in Post-Soviet Russia from Yeltsin to Putin," 43; GARF, f. 10100, op. 1, d. 1003, 1. 1, 11 January 1995.
} 
Parades are an excellent mechanism of control, power and communication. They demonstrate the discipline of the soldiers/veterans, who practice and perform a tightly choreographed routine. Power is showcased not only by the synchronised actions of the performers but also by the display of modern weapons and technology. Communication was the most important element of the parade. Without the pervasive nature of the parade, ideas of control and power would not be demonstrated. The most important role of the parade was to communicate grand narratives of the past, and to use them to inform the future. During the 1995 parade, Russia's military was in turmoil. The state used the parade to reconfigure societal views of the Russian military. They did this by emphasising the veterans' glorious victory, by reaffirming Russia's historic relationship with conflict and reproducing Russia's besieged fortress mentality. In doing so, the parade was used as a vehicle of militarisation and to justify a strong military.

\section{WHY COMMEMORATE THE GREAT PATRIOTIC WAR?}

The Soviet Union's victory over Nazi Germany was not inevitable; in fact it was a long, grim struggle that hindered Soviet advancement and contributed towards huge loss of Soviet life. For every American soldier who perished against Nazi Germany in the Second World War, another 79 died for the Soviet Union. ${ }^{58}$ On $11^{\text {th }}$ January 1995 , Communist Party Leader Gennady Zyuganov claimed, "In the history of the twentieth century there is no more significant and memorable event than the victory of the Soviet people and their allies over Hitler's fascism in the Great Patriotic War." ${ }^{59}$ He outlined the Great Patriotic War's significant role in modern Russian history as an outcome of the high death rates, which saw most Soviet families acquiring their own personal experience of war. ${ }^{60}$ The Great Patriotic War's importance in Russian society, as publicised in other domains, validated the elaborate celebration of its victorious conclusion. Similar to France, where public commemoration was transformed after World War One, Russia needed to re-establish the victory day parades to ensure "the ritual repetition of tribute to

\footnotetext{
${ }^{58}$ Evgeny M. Andreev, Leonid E. Darsky, and Tatiana L. Kharkova, "Population Dynamics: Consequences of Regular and Irregular Changes," in Demographic Trends and Patterns in the Soviet Union before 1991, ed. by Wolfgang Lutz, Sergei Scherbov and Andrei Volkov (London: Routledge, 1994), 435.

Kavaliauskas, "Different Meanings of May 9", 319.

${ }^{59}$ GARF, f.10100, op. 1, d. 1003, 1. 1, 11 January 1995.

${ }^{60}$ Ibid.
} 
the War dead." ${ }^{61}$ As declared in a draft Federal Law from 1995 On the Perpetuating Victory of the Soviet People in the Great Patriotic War 1941-1945, "The anniversary of the 50th anniversary of the Great Victory of the Soviet people over Nazism obliges us to take this federal law into force and to apply it until May 9, 1995." ${ }^{62}$ The persuasive properties of a military spectacle attracted the government as it presented opportunities to change public attitudes towards the Armed Forces through emphasis on associated topics like memory and sacrifice.

The state emphasised public participation in anniversary activities. They encouraged collective input by emphasising society's indebtedness to the veteran's sacrifice. In this case, commemoration can be considered a form of currency, where civic participation in the memorial activities acted as a payment to previous generations for their role in the victory of war. Emphasis on civic indebtedness, however, showed that this debt would never be fully repaid, leading to a memory cycle (which has continued to this day). This has enabled the Great Patriotic War to gain mythical status, for the hold it still has on society. The Federal Law above demonstrated this best. Aparina and Lukiankov legitimised proposed commemoration and welfare activities to "keep and protect the memory of the defenders of the motherland, to take care of those who gave their lives in the struggle for its freedom and independence." 63 The mythic nature of Great Patriotic War memory practices enabled the persistence of militarisation, as it reiterated the importance of the in Russian society and to its heritage. However, the cycle, maintained by the yearly occurrence of the parades, means that society remains exposed to discourses of militarised patriotism, serving to remind them of this debt and their civic duty to appreciate the veterans' sacrifice.

Dominant discourses around the Victory Day celebrations blurred the lines between the state responsibility and civic duty. The discourses reshaped commemorative practices, making them a fundamental part of civic duty. In March 1995 the All-Russian Volunteers [subbotnik] of Victory appealed to the State Duma, stating, "The current generations of Russian citizens, like the other post-Soviet states, remain indebted to the heroic warriors and the workers of the rear." ${ }^{64}$ In other words, and as Deborah D. Buffton notes, if a soldier's highest duty is to die in war, then it is a duty of the civilian population

\footnotetext{
${ }^{61}$ Sherman, "Commemoration," 326.

${ }^{62}$ GARF, f. 10100, op. 1, d. 989, 1. 2, [Undated: 1993-1995].

${ }^{63}$ Ibid.

${ }^{64}$ GARF, f. 10100, op. 1, d. 1003, 1. 24, 21 March 1995.
} 
to commemorate and memorialise that sacrifice. ${ }^{65}$ Intensified interest in civic duty, relating to commemoration, demonstrated the state's desire to increase public participation in war memorialisation. The public's participation in the commemorative activities influenced the militarisation of society.

First, it legitimised the military institution. When commemorating a veteran of war, the participant not only memorialises the individual, but also the wider institution with which they were associated - for example, the Armed Forces, arms manufacturers, wartime economy. In this sense, the participant not only popularised the position of the veteran, but also 'celebrated' and promoted the institution that won the war. Second, the memorialisation promoted societal militarism as it forced public familiarity with the war's history and discourses that the state was endorsing. Known as "Victory Day" or Den' Pobedy, public commemoration was organised under the pretext that society was celebrating the victory of the Great Patriotic War. The term Victory repressed the true horror of the war. Instead, Russia focused on the eventual win over Nazi Germany rather than the losses. ${ }^{66}$ Third, increasing civic responsibility facilitated societal militarisation by forcing the youth of 1995, with no direct recollection of the war, to engage with the historical discourses and to perpetuate these discourses onto future generations. For example, Yeltsin stated the youth should not "dull the memory" of the war's victory. ${ }^{67}$ In doing so, Russia's younger generations were placed into an imagined community, performing commemorative activities for those they may not have a direct link with. This is perhaps the most sinister mechanism of militarisation. With the greatest distance from the Great Patriotic War, Russia's younger generations were learning about an event from sanitised discourses and interpretations. ${ }^{68}$ They carried particular versions of this history

${ }^{65}$ Deborah D. Buffton, "Memorialisation and the selling of war," 28.

${ }^{66}$ Kaviauskas, "Different Meanings of May 9"th," 323.

Gudkov, "The Fetters of Victory."

67 "Istoricheskii parad v chest' 50-letiia Pobedy v Velikoi Otechestvenoi Voine."

${ }^{68}$ As noted by Gudkov, when memorialising on a state level and for purposes of social cohesion, the history is not produced as an exact account but is actually an accumulation and knitting together of carefully selected metanarratives. He claims that in creating this cult of victory, a whole section of the history is repressed in order to construct a narrative promoting the desires of the state. Kavaliauskas' research notes that the narrative of the 'glorious' victory of the Great Patriotic War is the one that has been selected by the state and cultivated in past, current and future commemorative events. What is noticable in this chapter is that certain ideas have been selected over others, so that the losses in the war are trumped by stories of victory. Locmele et al. adds to this scholarship, claiming that 
forward, with memorial events becoming platforms where these stories could garner momentum and normalisation. ${ }^{69}$

Militarisation was sustained through this notion of debt, which resurfaced on an annual basis. Emphasis on the present and future society's responsibility to commemorate, to fulfil this debt, ensured that Russian society remained in dialogue with militarised-patriotic discourses of sacrifice, state loyalty and justified memorialisation. Nataliya Danilova notes that war commemoration fashions a new solidarity in societies by continuing "a patriotic mission." In the context of Russia and the Great Patriotic War the "patriotic mission" was to continue the sacrificial actions of previous generations. ${ }^{70}$ This contributes towards our understanding of the state's decision to memorialise the Great Patriotic War with such extravagance. By emphasising society's responsibility to commemorate, the eternal glorification of the military reaffirmed the Victory Day anniversary.

Victory Day served as a reminder of Russia's heritage and informed public identity. By fortifying the public's role in the commemorative activities of the Great Patriotic War anniversary, the state redefined Russia's national identity. In addition, it reaffirmed what Benedict Anderson's calls an "imagined community.” Russia's citizens were bound together by their collective responsibility to commemorate the veterans' victory and memorialise their sacrifices. ${ }^{71}$ The victory saved past, present and future generations from Fascism and ensured the survival of the Russian state. These ideas connected participants who observed the commemorative activities. In addition, and taking into consideration Russia's low life expectancy rate, many of the wartime veterans would have died by 1995. Therefore, the representations of their experiences in the commemorative landscape were also more likely to be imagined. ${ }^{72}$

By encouraging the public to commemorate, the state ensured that society remained exposed to militarised-patriotic discourses. This was demonstrated in a message

mass celebrations like those of Victory Day were used to transport narratives, which ensured a representation of Russia and the Armed Forces at their best.

${ }^{69}$ Locmele et. al, "Celebrations, Commemorative Dates and Related Rituals," 110.

${ }^{70}$ Nataliya Danilova, The Politics of War Commemoration in the UK and Russia (Basingstoke: Palgrave Macmillan, 2016), 3.

${ }^{71}$ Benedict Anderson, Imagined Communities: Reflections on the Origin and Spread of Nationalism (London and New York: Verso, 1983), 6.

${ }^{72}$ Russian males born between 1896 and 1927 were predicted to live between 30.9 and 39.3 years. For more, please see: France Mesle and Jacques Vallin, Morality and causes of death in $20^{\text {th }}$ century Ukraine (London: Springer, 2012) 5-6. 
to veterans of the Great Patriotic War during a Federal Assembly meeting held on $1^{\text {st }}$ March 1995. Rubkin declared, "Time separates us more and more from May 9, 1945, but no one has to be forgotten and nothing should be forgotten. We will always remember the names of courageous sons and daughters of the Motherland, who gave their dearest life for the sake of freedom of the Motherland." ${ }^{, 73}$ The anniversary was justified by the veterans' sacrifice. This was illustrated in a February 1995 meeting for the Heroes of the Soviet Union. The appeal stated, "Veterans of war have every reason to be proud of their military and labour exploits for the benefit of the fatherland. They deserve honour and respect. These were the years of our immortal glory; it was a feat that will forever remain in the hearts of all subsequent generations."74 The state's promotion of the Victory Day celebrations, as evident in the above sources, served the state's objective to promote positive militaristic sentiments. Promoting the celebrations and assigning this day national holiday status formulated a ritual where May $9^{\text {th }}$ would become a day Russian citizens commemorated the war dead. In doing so, civilians were annually reminded of the military's victory, which also helped reshape civilian attitudes towards the Armed Forces. The commemoration inserted the Armed Forces into their lives, but on the terms of the military.

The $50^{\text {th }}$ anniversary celebrations were integral for a number of reasons. They memorialised the war-dead, aimed to unite society and to shape Russia's identity (which was undergoing transformation at this point). As the military's power diminished, the victory celebrations promoted emblematic notions of patriotism, which had the ability to help foster feelings of positivity towards the military institution. The audience was

${ }^{73}$ GARF, f. 10100, op. 1, d. 135, 1 March 1995.

${ }^{74}$ GARF, f. 10100, op. 1, d. 1003, 1. 37, 13 February 1995.

Motherland and Fatherland have been used interchangeably a couple of times, but I believe with purpose. The use of Motherland is done to commemorate the loss of life. Similar to commemorative statues presented in the thesis, death is commonly feminised with images of a dead soldier being held by a womanly figure, normally conceptualised as a soldier's mother, the Virgin Mary (to symbolise notions of sacrifice with the image of a sacrificed son, much like the sacrifice of Jesus) and Mother Russia. The image is usually produced to cultivate images of loss, sacrifice and bereavement. In contrast, the use of Fatherland is coupled with narratives of the military exploits of survivors of war. The use of Fatherland alongside militaristic and labour campaigns highlights the masculinised dimensions of war - with the masculine aspect of homeland representing power, aggression and heroism. For more, please read: Kirschenbaum and Wingfield, "Gender and the Construction of Wartime heroism in Czechslovakia and the Soviet Union," 483. 
confronted with enticing displays and militaristic-patriotic messages that went far beyond patriotic messages in the education and media domains. ${ }^{75}$ These activities contributed towards the maintenance of militarisation of society during a time of low military prestige.

\section{How did the state commemorate the Great Patriotic War?}

On May $9^{\text {th }} 1995$, two parades marked the $50^{\text {th }}$ anniversary of the Great Patriotic War. The first parade was held on Poklonnaia Hill. ${ }^{76}$ In this parade, military hardware, including tanks and planes, were showcased. The second parade was held on Moscow's Red Square. The parade aimed to pay respect to Great Patriotic War veterans. Numerous monuments were erected, including the statue of Marshall Zhukov in front of the State History Museum on the Manezhe Square and the statue of St. George at Moscow's Victory Park. ${ }^{77}$ In addition, the state commissioned new medals and other collectables, such as commemorative coins, for the anniversary. These commemorative spaces and keepsakes enabled militarisation to permeate within society and beyond the 24 hours of the victory day, since it stamped usable everyday objects with military-patriotic symbols.

The total cost of the celebrations, excluding the enhanced veteran pensions, was 293 billion roubles. ${ }^{78}$ The event's large price tag demonstrated the government's

\footnotetext{
${ }^{75}$ Merely, British military spectacle, 139.

Chapters three and four documented the prominence of militarised narratives in a textual sense. The parades added a level of entertainment unimagined in these textbooks. Rather than use their imagination, parade onlookers gain a visual representation of the retelling of war through these commemorative activities. Referred to as 'technofetishism,' which is the worship of high-tech weaponry, the audience of the 9 May 1995 was not only 'wowed' with a grand display of ceremonial pageantry.

76 The location of this parade on Poklonnaia Gora was not coincidental, but purposeful. For Russian society, Poklonnaia Hill has a very militarised past and is closely associated with previous victories of the Russian state, in particular Napoleon's invasion of Russia in 1812 and subsequent forced retreat, which is widely regarded by historians as the turning point of the Napoleonic Wars. Poklonnaia Gora was chosen as the location for the Great Patriotic war museum, which was opened on May 9, 1995, in order to evoke this sense of continuity with previous Russian resistance against foreign invaders. For more, please see: Alexander Mikaberidze, Russian Officer Corps of the Revolutionary and Napoleonic Wars (New York: Savas Beatie, 2005), Introduction.

${ }^{77}$ At the time of writing (March 2020) Marshall Zhukov's statue is in the process of being replaced. The statue, which was photographed and referred to in this study, is the one that was built and erected in 1995. Deemed as not patriotic enough, it will be replaced with a more 'patriotic' version, with patriotic seemingly to be a new way to describe masculinity.

${ }^{78}$ GARF, f. 10100, op. 1, d. 135, 25 January 1995.
} 
dedication to commemorating the anniversary. In the context of John Keep's militarism checklist, which regarded "disproportionately heavy state expenditure on military ends" as a requisite, the high cost of the event showed the prioritisation of the military institution and therefore signs of militarism. ${ }^{79}$ During the 1990s, Russia faced serious economic difficulties - with rising unemployment and increasing rates of homelessness. Rather than fulfilling the economic needs of the Russian people, the government attempted to achieve its own aims by dedicating extensive resources to ceremonial purposes. Not only were the economic issues of society overlooked, but also discussions regarding the commemoration date trumped debates on the topic of societal welfare. These topics involved the parade's organisation and subjects associated with it, including symbols, collectables and youth engagement. Topics relating to the parade included veteran welfare and education.

Symbols became an important discussion point in preparation of the celebration day. As with any parade, symbols are important as they transmit values and ideals from the performers or organisers to the spectator's consciousness. They are not just considered historical pieces that told an objective truth but objects, which justified and reaffirmed ideas of submission and loyalty to leaders and the country and legitimised existing institutions - such as the military. ${ }^{80}$ In the case of the $50^{\text {th }}$ anniversary of the Great Patriotic War, Soviet symbols reminded the audience of the military institution that existed alongside these symbols, which in 1945 was triumphant. Jakob Vogel's work on folkloric militarism shows that symbols and uniforms shape the "persistent nationalmilitary significance of the celebrations." Here, the temporal dimensions of symbols as representations of the past and reminders for the future can be furthered. ${ }^{81}$ Symbols discussed in this chapter created authentic images of the past, while also reminding society of the victory it once experienced.

Symbols referred to in State Duma documents included the Soviet flag. One appeal in particular compared the Russian flag to that of the flag used by the Russian

This is the equivalent of $£ 56,000,000$ in today's British Pound Sterling, converted via "Historical Currency Converter," Historical Statistics, accessed 26 March 2020, http://www.historicalstatistics.org/Currencyconverter.html.

${ }^{79}$ Radway, "Militarism," 300-305.

${ }^{80}$ John Bodnar, "Commemorative Activity in Twentieth Century Indianapolis: The Invention of Civic Tradition," Indiana Magazine of History 87, No. 1 (1991): 2.

${ }^{81}$ Jakob Vogel, "Military, Folklore, Eigensinn: Folkloric Militarism in Germany and France, 1871-1914," Central European History 33, No. 4 (2000): 493. 
liberation Army, which fought against the Red Army during the Great Patriotic War. ${ }^{82}$ A. Melnikov, chairman of the Veteran Committee of the Kemerovo region justified the use of the Soviet flag in the following excerpt from January 1995 :

We believe that the Great Victory Day must be held in Moscow and other cities of the country under the red flag...

It is known that the red colour of the flag in Russia has centuries-old history. Under Dmitri Donskoy's victory was won on the Kulikovo field, the crimson colour was the military banner of Dmitri Pozharsky. The white-crimson-blue banner was used in the $18^{\text {th }}$ century by Peter I in the Northern Wars, and then it was transferred to the merchant Navy. After the February revolution of 1917, the re-coloured flag became the symbol of Russia and was approved by the provisional government. And it was this flag that was used by Vlasov. It is sprinkled with betrayal.

Please do not discard our offer. Imagine what feelings we veterans of the Great Patriotic War will experience if we go in the columns under this flag.

The red colour of the flag is the colour of our victory in the greatest war. It roared over the defeated Reichstag in Berlin in 1945.

Understand us. We will cover ourselves with eternal disgrace, desecrate the graves of millions of Soviets who fought under the red banner, liberated Russia, Europe from the mouth of the Fascist plague, we therefore humiliate the now living veterans of the front and rear, who did not think the $50^{\text {th }}$ anniversary of the victory would have been marked under the banner of the traitor Vlasov, who was fighting against his own camp. ${ }^{83}$

This comparison showed strong and emotional links between the veteran community and the flag. The tricolour flag was adopted in the Post-Soviet state as a continuation of the Russian flag that existed before the Soviet period. The proposal to use the Soviet flag, however, represented the emotional reach of the Great Patriotic War, showing that society was 'triggered' by images of the enemy during this time. While this meant the Victory parade was coupled with images of the Soviet past, its use showed the state conforming to the wishes of those who fought at the time. Therefore, using the Soviet flag in the commemoration of the Great Patriotic War was important as it demonstrated the government's desire to unite a larger audience, with that larger audience still potentially associating their identity with their Soviet past.

As demonstrated in a study conducted between June 2015 and July 2016, 20 years after the 1995 commemoration, $69 \%$ of Russians do not view the collapse of the Soviet

${ }^{82}$ GARF, f. 10100, op. 1, d. 1003, [Undated: 1993-1995].

${ }^{83}$ GARF, f.10100, op. 1, d. 1003, 30 January 1995. 
Union in a positive light. ${ }^{84}$ Using Soviet paraphernalia in the victory parades ensured wider participation in the commemorative events. The use of the Soviet flag was also linked to its representation of the war dead. An open letter to Boris Yeltsin and other prominent leaders of the State Duma by Great Patriotic war veterans stated, "We have the right to celebrate the victory anniversary as we want. And the desire is right and simple: the jubilee identities must pass under the flag of the USSR... for which we shed blood and our young comrades died in the field of battle quite young." 85 Another appeal supported the content of the open letter by claiming that the extinction of Soviet symbols during the celebration of the $50^{\text {th }}$ anniversary would be "blasphemy over the dead, with the infliction of great resentment, an insult to all living people who forged the victory at the front and in the rear." ${ }^{86}$ As displayed in Figure One, the Soviet flags were subsequently included in the $50^{\text {th }}$ anniversary celebrations.

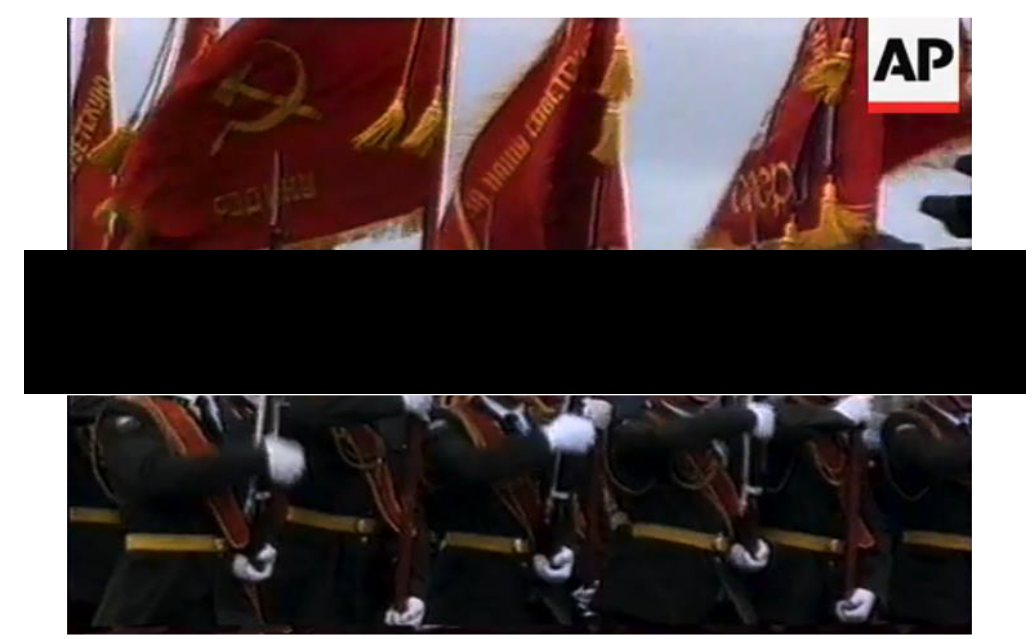

(Figure 1. Close up image of soldiers marching in St. Petersburg on May $9^{\text {th }} 1995$ under Soviet Paraphernalia). ${ }^{87}$

These statements are interesting as they impede the state's ability to link the commemoration to post-Soviet Russian identity. Yet, they acknowledge and allow the Russian government to use these symbols in their renewal of these parades. In doing so,

\footnotetext{
${ }^{84}$ David Masci, "In Russia, nostalgia for Soviet Union and positive feelings about Stalin," Pew Research Centre, 29 June 2017, accessed 6 November 2018, http://www.pewresearch.org/fact-tank/2017/06/29/in-russia-nostalgia-for-soviet-unionand-positive-feelings-about-stalin/. ${ }^{85}$ GARF, f.10100, op. 1, d. 1003, [Undated: 1993-1995].

${ }^{86}$ GARF, f.10100, op. 1, d. 1003, [Undated: 1993-1995].

87 "Russia: V.E. Day Celebrations Update," AP Archive Video, 2:51:10, posted by APTV, 8 May 1995, accessed 12 November 2018, https://bit.ly/3syYve8.
} 
the symbols transcended the regime change and reinforced the continuity of militarisation in society. Rather than seeing a 'break' of militarisation in society, people were being reminded of the Soviet parades, and their revival was just that - a revival. It continued and, for the most part, replicated events that took place several years before. However, newer elements were introduced to these parades, showing a clear departure from the Soviet period.

In addition to the historic Soviet symbols, the new Post-Soviet military uniform and MiG-31 fighter-interceptor was unveiled. ${ }^{88}$ The introduction of the modern objects alongside the vision of Soviet memorabilia reinforced the Great Patriotic War's timelessness as it muddied the boundaries between the past and present. The use of historical paraphernalia in the commemorative activities of the state was important to the continuation of militarisation practices in the post-Soviet period as it placed the historical victory at the Great Patriotic War within the current frame of the Russian state. Hughes noted, "uniforms operate at a symbolic level; most importantly; this genre of clothing raises interesting questions about individuality and conformity, self-control, and the visual representation of identity." 89 Connecting both eras through historic and contemporary symbols played an informing role on Russia's national identity. The temporal connections impacted the militarisation of society at this time. Linking the past to the present, in relation to historic wars and contemporary military readiness showed that the world continued to be a dangerous place. The symbols reaffirmed the discourse that Russia is a vulnerable country facing new and potentially hostile threats every day, enforcing ideas of defence readiness and continued mobilisation. The connections placed the romanticised retelling of the war into the context of real authentic threats facing Russia at that time.

The use of Soviet paraphernalia and historical hardware authenticated the memorialisation of the event. It provided a utopian and romantic image of military power, subsequently provoking "great interest and excitement from onlookers." 90 Many onlookers relied on stories from family members to supplement their understanding of

\footnotetext{
88 "Istoriia Muzeia," Muzei Pobedy, accessed 12 October 2018, https://victorymuseum.ru/about/history/.

${ }^{89}$ Merely, British military spectacle, 43.

${ }^{90}$ Roger McDermott, "Russia's Armed Forces: The Power of Illusion," Russie. Nei. Visions, No. 37, (2009): 6.

Merely, British military spectacle, 139.
} 
the event. Historical symbols validated these stories, providing greater understanding of the memorialisation beyond the commemoration event. The festivities, coupled with the display of Soviet paraphernalia and new equipment, enabled the government to influence current societal debates on the country's Armed Forces. It provided an opportunity for them to construct a dialogue with the past that contributed toward altering how the victory of the Great Patriotic War was remembered - as enduring. ${ }^{91}$

As demonstrated above, there was a clear public interest in the anniversary events of the Great Patriotic War. This was best shown in an open letter to Yeltsin, where onlookers noted their concern about the symbols that would be used to commemorate the war victims and participants. They argued that Soviet flags and symbols should be used. The structure and organisation of the parades significantly affected militarism during this period. Not only was the public mentally invested in this event, but the symbols' use also allowed the government to create a sense of continuity between the parades of the Soviet period and the Post-Soviet era. This was particularly important, as the parades were considered a simple revival of a tradition that occurred before - rather than as a mechanism of state militarism. These symbols authenticated the memorialisation, creating a visual for participants and those from the war period to re-familiarise themselves with the history. Those born after the war were able to create an image of it from these visuals. Building on the work of Bryan, who claims that rituals construct a sense of timelessness, Soviet paraphernalia created links between the past and present. ${ }^{92}$ For example, the government showcased new technology and uniforms, with very little push back, since the theme of the commemoration still centred on the wishes of the past generations. The Soviet symbols were able to entice the historically informed, while the new technologies were able to lure in the "New Russian" community of the post-Soviet period.

\section{$\underline{\text { Parades }}$}

The first parade of 1995 was held on Poklonnaia Hill. It included traditional aspects of the first Victory Day parade in 1945 by incorporating old regiment formations, but also introducing new elements with the exhibition of Russia's military hardware. The second parade, held for the veterans of the Great Patriotic War on Red Square, was more

${ }^{91}$ Meyer, "Memory and Politics," 176.

92 Bryan, Orange Parades, 19-21. 
traditional. The elaborate ceremonies militarised society by showing excessive allegiance to war veterans, which promoted military's societal position. This is especially the case when considering the role of Russia's current military cohort, which was acting out the role of the veterans in the parade on Poklonnaia Hill. It allowed the celebration of Russia's current military cohort, which was performing the role of the Great Patriotic War veterans. Following Russia's failure in Afghanistan and its tumultuous role in Chechnya, which saw the demise in military prestige, the parades aimed to foster positive attitudes towards the military. As an annual event, Russian civilians were regularly exposed to glorified militaristic discourses. The parades marked a permanent fixture in the holiday calendar, dominating national television channels and news outlets. Posters of the upcoming parade were placed on every sidewalk, while merchandise adorned pop-up fixtures in supermarkets. These parades were not limited to $9^{\text {th }}$ May but were an outcome of months of preparation and marketing. They maneuvered the Russian people, forcing them to think about their understanding and familiarity of the event.

Glorifying the Armed Forces was a major goal of the state. In the context of the parade, the military institution was promoted through emphasis on the veterans' sacrifice. This sacrifice was acknowledged early on in both parades, as the inspector and commander approached each group with a congratulatory messages. ${ }^{93}$ They thanked the different regiments for their sacrifice in war, and for perpetuating the victory on the $50^{\text {th }}$ anniversary. The use of sacrificial discourses is not unique to Russia. Rather, references to sacrifice are used quite regularly in war commemoration. Its use is multifaceted, to immortalise and heroise the war participants, to dispel stories of war futility by justifying the sacrifice in the name of the state's survival or renewal, to emphasise the victory over loss, and to ensure the continuation of memorialisation. Sacrifice is commonly framed in a spiritual sense, adding a mythic element to the memory. In May 1995, Yeltsin said:

We remember the roar we sang and the dying testaments of the mothers of orphaned children who fell in incomplete tears, we recall the war years heavy nights to the point of exhausion, but we [also] remember the jubilant Reichstag soldier and the handshake on the Elbe and the joy of the liberated world, this memory is sacred. ${ }^{94}$

93 "Istoricheskiy parad v chest' 50-letiia Pobedy v Velikoi Otechestvennoi Voine."

${ }^{94}$ Yeltsin Centre, f. 21, op. 1, d. 130, 9 May 1995. 
Yeltsin's statement did not stand on its own. Just months prior, in February 1995, veterans were told "[they] have every reason to be proud of their military and labour exploits for the benefit of the fatherland. They deserve honour and respect. These were the years of our immortal glory, it was a feat that will forever remain in the hearts of all subsequent generations." 95 Both statements showcased the veteran's immortalisation for their participation in the Great Patriotic War. As the process took place, the veterans adopted a divine position in society, as those who should be revered and whose values should be replicated. ${ }^{96}$ These values were popularised in the victory celebrations and through enhanced welfare provisions, as documented in chapter four. ${ }^{97}$

This valorisation was a positive development for the veterans and was also a "gift" to state unity and for state goals. Salih Can Acikoz's study on Turkish veterans in the 1990s noted that the glorification of the veteran community enabled the Turkish government to create a militarised, nationalistic political culture, with ritualistic and ceremonial landscapes. It aided the creation of "local communities of loss," unified by common discourses of loss of mobility (injury) and life. ${ }^{98}$ In Russia, the educational textbooks' use of 'ancestor' sought to unite students under this common metanarrative of the Great Patriotic War, therefore highlighting that the sacrificial discourses displayed in the victory celebrations did not stand alone, but added and complemented preexisting societal discourses on the historical event. Having enforced discourses of ancestral sacrifice across the different domains demonstrated a state-led effort to unify and therefore militarise society. Discourses of ancestral sacrifice bridged the Soviet and PostSoviet period. James Booth's study on political identity highlights the importance of

${ }^{95}$ GARF, f. 10100, op. 1, d. 1003, 22 February 1995.

${ }^{96}$ Michael Rowlands, "Trauma, Memory and Memorials," British Journal of Psychology 15, No. 1 (1998): 59.

Jackie Feldman, "Between Yad Vashem and Mt. Herzl: Changing Inscriptions of Sacrifice on Jerusalem's 'Mountain of Memory,"' Anthropological Quarterly 80, No. 4 (2007): 1163.

Paul Gough, "The Commemoration of War," in The Ashgate Research Companion to Heritage and Identity, ed. by Brian Graham and Peter Howard (Aldershot: Ashgate, 2008), 3-4.

${ }^{97}$ As noted by Krylova, Yeltsin's Presidential Campaign promised a redressing of the veterans grievances and public recognition of their heroic deeds. For more, please see: Krylova, "Dancing on the Graves of the Dead," 97.

98 Salih Can Acikoz, "Sacrificial limbs of Sovereignity: Disabled Veterans, masculinity and Nationalist Politics in Turkey," Medical Anthropology Quarterly 26, No. 1 (2012): 5-10. 
'continuity of community across time' for the creation of a political identity. He argues that political identity is subject to attribution, responsibility and accountability of the past and of a country's future. The ancestor is important in this sense. Booth argues that feelings of responsibility and indebtedness to a country's past are only possible when feeling connections with something from the previous regime. In post-Soviet Russia, Soviet traditions, narratives and the people of the Union still existed. Memories of the Great Patriotic War enabled unity and promoted collective responsibility to memorialise past events and perpetuate this tradition into the future. ${ }^{99}$ In addition, Acikoz points out that valorising the veteran community in Turkey also led to the veterans' adoption of ultra nationalistic tendencies and exaggerated state loyalty. The veterans then acted as gatekeepers and protectors for pro-militaristic laws. ${ }^{100}$ Veterans who felt marginalised in the early Post-Soviet period by an anti-Soviet press were encouraged to continue their mission despite the betrayal, with their own rituals established in place of those that existed in the Soviet period. ${ }^{101}$

The inspector's message of gratitude in the parade was spoken to each 'front' present. Numerous 'fronts' were addressed with the same messages, which demonstrated the government's desire to show personal gratitude to that specific regiment. ${ }^{102}$ In doing so, the messages stressed the veterans' special role in society and set an example for others to follow. If high level political and military elites were prepared to dedicate extensive time to thanking the various Great Patriotic War fronts and provide the resources for an elaborate commemoration, then it should also be in the interests of the public, for whom the sacrifice was made, to commit and show the same level of gratitude. ${ }^{103}$ The political and military elites' actions in the parades pushed society closer

99 James W. Booth, "Communities of Memory: On Identity, Memory and Debt," American Political Science Review 93, No. 2 (1999): 249-252.

${ }^{100}$ Acikoz, "Sacrificial limbs of Sovereignty," 4.

${ }^{101}$ Krylova, "Dancing on the Graves of the Dead," 88-89.

Veteran organisations were dominant forces in pushing for and planning the events of the $50^{\text {th }}$ anniversary. They suggested the use of Soviet paraphernalia, the adoption of the organisation of the day from Soviet times and extra events to supplement the victory day. Please see: GARF, f. 10100, op. 1, d. 1003, 30 January 1995; GARF, f. 10026, op. 1, d. 2861, 1. 30-34.

102 "Istoricheskii parad v chest' 50-letiia Pobedy v Velikoi Otechestvenoi Voine."

103 The role of political elite in commemorative activities is documented by Jonathan Trigg. Trigg links the appearance of politicians and high rank societal figures at these ceremonies as integral to the validity and empowerment of the cause. Please see: Jonathan Trigg, "Memory and Memorial: A study of official and military commemoration of the 
to militarisation. It set an example for others to follow, showing simple actions that could be taken to show gratitude and emphasising the military's importance to the state by dedicating excessive resources and time to the veterans' celebration. The actions of the political and military elites reinforced the discourse that a person's sacrifice for the state was worthy of praise and was the highest form of civic duty.

As an active mode of commemoration, these parades enacted a similar level of historicalisation as a war memorial. As the parade took place, the parade's landscape transformed into the battleground of the Great Patriotic War and into a landscape of history. Speeches and visuals focused on the Great Patriotic War's history, which transported onlookers to the parade of June 1945. Emphasis on societal indebtedness was highly instrumental in the militarisation of society during this period. The veterans' sacrifice was highlighted in Yeltsin's speech, where he acknowledged the "unprecedented price" paid for saving the world from fascism. ${ }^{104}$ Russia had a historical relationship with conflict, war and invasion, however the Great Patriotic War was unmatched in its scale. Twenty-seven million people died in this conflict. Historically Russians had sacrificed themselves in conflict in a similar way to Great Patriotic War participants. However, collectively the huge extent of loss, which was a product of this conflict, fortified the war's importance. ${ }^{105}$ Highlighting the "unprecedented price" demonstrated a clear effort by the government to immortalise the veteran, and to place them on at a higher rank in the hierarchical society. Doing so enabled the state to promote desirable traits - attributes such as self-sacrifice and loyalty. Pavel Grachev's speech echoed Yeltsin, stating, "the unity of the whole country, love for the fatherland, the highest patriotism of the people, the feat of arms of soldiers and officers, the talent of military leaders and the sacrifice of rear workers became the most important factors of the Great Victory." ${ }^{106}$ In addition to this claim, Yeltsin addressed the youth of Russia, stating that May 9th would "be for us all a day of remembrance," and that the youth should not "dull the memory" of the war's

dead, and family and community memory in Essex and East London," Journal of Conflict Archaeology 3, No. 1 (2008): 300-302.

104 "Istoricheskii parad v chest' 50-letiia Pobedy v Velikoi Otechestvenoi Voine."

${ }^{105}$ Marwick, "The Great Patriotic War in Soviet and Post-Soviet Collective Memory," 693-694.

${ }^{106}$ Voennyi Parad Pobedy 9 Maia 1995- 50 letie Pobedy/ Military Parade May 9 Victory 1995," YouTube video, 1:00:26, posted by Rota Pochyotnogo Karaula, 31 January 2016, accessed 5 December 2018, https://www.youtube.com/watch?v=9-cbz6KPEdY. 
victory. ${ }^{107}$ The shifting of responsibility onto the youth to maintain a cult of memory of the Great Patriotic War shows the youth's role in these commemorative events.

Nataliya Danilova's 2016 study on war commemoration and militarisation connects the two processes by highlighting the political elite's calls for society to participate in the commemorative process. She uses President Clinton's 'support the troops' slogan as an example. This was similar to Yeltsin's demands for Russia's youth to perpetuate the memory the Great Patriotic War victory. ${ }^{108}$ This statement was justified by Yeltsin's emphasis on the veterans' determination to "save future generations, rid them of the disasters of war." ${ }^{\prime 109}$ His statements on societal indebtedness formulated new ideas of civic duty, where commemoration was integral. In doing so, Yeltsin elevated the veteran's role and image in society. It also told onlookers what part they should play in future memorialisations.

Some aspects of the June 1945 parades were replicated in the 1995 parades. These similarities were recognisable to those who had witnessed these parades before. The parades' rituals and exciting displays of military might were integral to the state's ability to attract a large audience. After all, the performative aspects of the ceremonies were key to cultivating the parade's popularity. ${ }^{110}$ Therefore, the parade was an invaluable tool of militarisation as it fostered an image of military grandeur through displays that excited and interested its spectators. The grand spectacles, with glorified visuals of Russia's military, bridged the gap between commemoration and militarisation as it enforced military-patriotic discourses and reaffirmed messages of pride and state loyalty. Society was exposed to these discourses through dazzling performances of military might and speeches of veteran valour.

The parade on Poklonnaia Gora was unique. It was ritualistically similar to the parade on Moscow's Red Square. However, in contrast to the veterans' parade, the veterans were the audience. ${ }^{111}$ Current units of the Moscow Garrison and cadets from the

\footnotetext{
107 "Istoricheskii parad v chest' 50-letiia Pobedy v Velikoi Otechestvenoi Voine."

${ }^{108}$ Danilova, The Politics of War Commemoration in the UK and Russia, 213.

109 "Istoricheskii parad v chest' 50-letiia Pobedy v Velikoi Otechestvenoi Voine."

${ }^{110}$ Azaryahu, "Military and Militarism in Israeli Society," 90.

${ }^{111}$ Voennyi Parad Pobedy 9 Maia 1995- 50 letie Pobedy/ Military Parade May 9 Victory 1995."
} 
military schools acted out the role of the veteran. ${ }^{112}$ Similar to the parade on Red Square, the soldiers lined up within their regiments on one side of Kutuzovsky Avenue. They faced the audience, who were located on the same side as the Victory Memorial Complex. ${ }^{113}$ The parade's sequence mirrored the 1945 victory day parade. The inspector and commander of the parade (in this ceremony, Minister of Defence Pavel Grachev and Colonel-General Leonid Kuznetsov) approached each regiment and congratulated them on the victory of the Great Patriotic War. ${ }^{114}$ They moved in sync. Two aspects are important here. The repeated sequence reinforced the rituals established immediately after the Soviet victory, creating continuities between the Soviet and post-Soviet period. Yet, using a younger cohort to represent the veterans placed the procedures, traditions and the histories of the Soviet period in current context. As Danilova notes, by looking at the youth as newer generations of the 'glorious dead,' the past can be preserved but also placed within a contemporary context. ${ }^{115}$

The ritual was repeated on Moscow's Red Square. This time Veteran Marshall of the Soviet Union Viktor Kulikov and Veteran General of the Army Vladimir Govoro took on the roles of the inspector and commander. ${ }^{116}$ The regiments, which stood in the same positions as those on Poklonnaia Hill, were filled with veterans, to whom messages to the "war victors" were more appropriately directed. ${ }^{117}$ In both spectacles, the military orchestra played and displayed banners of the various Fronts that were used in the 1945 parade. Using the same music and Soviet symbols is important for the militarisation of society. First, using music from 1945 demonstrated a clear desire by the state to transport the audience to the origin of the victory - to create a sense of authenticity to this parade. In addition, those veterans and onlookers who were present in the 1945 parade would remember these different ceremonial aspects and also feel closer to Great Patriotic war victory. Chapter three noted state efforts to unite veterans and youth, hoping to establish a relationship between the two groups. ${ }^{118}$ These ceremonies provided a historical

\footnotetext{
112 Doug Clarke, "Moscow Victory celebrations continue," RadioFreeEurope RadioLiberty, 10 May 1995, accessed 1 November 2018, https://www.rferl.org/a/1140932.html.

${ }^{113}$ Ibid.

${ }^{114}$ Ibid.

${ }^{115}$ Danilova, The Politics of War Commemoration in the UK and Russia, 209.

116 "Istoricheskii parad v chest' 50-letiia Pobedy v Velikoi Otechestvenoi Voine."

117 Ibid.

118 GARF, f. 10100, op. 1, d. 1003, 1. 28, 19 April 1995.

GARF, f. 10100, op. 1, d. 1003, 1. 29-30, March 1995.
} 
representation of the first victory parade and drew the youth into the story of the Great Patriotic War victory. As participants of the commemoration, the veterans' involvement added a further layer of legitimacy to the stories being told on Red Square. The veterans' participation suggested they supported the discourses being promoted by the state. According to Mann, veterans often favoured state discourses of the war to their own experiences. He stated:

In one instance, during a conversation between a librarian and a veteran who liked to 'read about the war,' the librarian asked, 'But why? You yourself were a soldier in the war. Wasn't that enough?' The veteran replied, 'Oh, what kind of war was that? I like to read about a real war that has heroism. ${ }^{119}$

Veterans participated in these events because it enabled them to engage with discourses largely absent in the late 1980s and early 1990s. The discourses that did exist questioned the Great Patriotic War victory and the veterans' role in upholding the repressive Soviet state. This marginalised the veteran community. The veterans' relevance was reestablished by celebrations, enhanced pension reforms, and moves to create a military-patriotic education. In this sense, the veteran community was moved by militarisation - relying on glorified militarised discourses to reaffirm their position in society and to rewrite their own Great Patriotic War experiences.

In both parades, the different regiments marched past the audience. They faced the audience as they marched. ${ }^{120}$ Facing the audience, which included political and military elites, displayed a gesture of submission to the political and state institutions. This is particularly important to take into consideration. Grachev, who was a key player in the infamous Chechen War, stood on top of Lenin's mausoleum. This was another ritual of the Soviet period. Leaders of the Soviet Union stood upon Lenin's mausoleum during parades. Their high physical position represented the greater power they held over society. ${ }^{121}$ The veterans' salute, which demonstrated loyalty and submission, was also considered an exhibition of the support for the Defence Minister and his endeavours. The public display of submissiveness contradicted media discourses that presented a divided

\footnotetext{
${ }^{119}$ Mann, "(Re)cycling the Collective Memory," 509.

${ }^{120}$ Istoricheskii parad v chest' 50-letiia Pobedy v Velikoi Otechestvenoi Voine."

"Voennyi Parad Pobedy 9 Maia 1995- 50 letie Pobedy/ Military Parade May 9 Victory 1995."

${ }^{121}$ Locmele et al. "Celebrations, Commemorative Dates and Related Rituals," 113.
} 
military, especially in terms of the Chechnya question. In keeping with the traditional sequences of the historical parades, this public image of accordance created a counternarrative to the stories constructed by the media. At the apex of power, Yeltsin, Grachev and other military figures demonstrated their control by repeating tradition that originated in the Soviet period. Its continuation enabled the political and military elite to imitate popularity, control and legitimacy.

The government achieved a number of its aims by constructing a set of ritualistic traditions. First, it established continuities between the past and present. The younger cohort in the Poklonnaia Hill parade, reenacting a sequence reminiscent of the first parade, created temporal links between the 1945 parade and the parades of 1995. In addition, the traditional choreography, including the salutes, enabled the government to gain legitimacy in the eyes of an ordinary spectator, who may have considered these salutes an act of submission. Therefore the Great Patriotic War had the ability to reconcile periodic and political division. It was at many levels that the parade militarised society. From a political point of view, the commemorative activities militarised the political elite by their reliance of the event to unite society. The veteran community benefitted from ceremonial militarism as it altered discourses that previously erased their societal importance. Society was militarised by the elaborate preservation of memory, visuals of veteran subordination and images of military grandeur. The rituals which were renewed during this period persisted into contemporary Russia, with President Putin continuing to build upon the militaristic patriotic reach of these parades.

Showcasing Russia's military might was also a motivation behind these parade. In the early 1990s a new post Cold War world order was being shaped. The Poklonnaia parade ensured that foreign dignitaries, including U.S. President Bill Clinton, were subjected to huge spectacles of military potency. It displayed Russia's military hardware, including tanks and aeroplanes (strategic bombers TU-95 and Tu-160). ${ }^{122}$ The military hardware's use was a new aspect to the parades. A parade of tanks and an airshow including these new bombers stormed down/over Kutuzovsky Avenue. This display was followed by Grachev's speech. He claimed that Russia's Armed Forces were deemed "battleworthy" and ready to defend Russia in case of external threats and "encroachment"

122 "Voennyi Parad Pobedy 9 Maia 1995- 50 letie Pobedy/ Military Parade May 9 Victory 1995."

"Den' Pobedy: Istoriia voennykh paradov," TASS, 8 May 2015, accessed 5 November 2018, https://tass.ru/obschestvo/1171423. 
on the country's interests. ${ }^{123} \mathrm{He}$ also used the emergence of new threats to legitimise the strengthening of the Armed Forces, claiming, "Unfortunately, today the difficult interweaving of historical territorial, political, economic and national contradictions remains a military danger, and while there is danger, we must strengthen and qualitatively renew our armed forces." 124 Grachev's emphasis on military readiness and future development was most important, as tensions between East and West had risen at this time as a result of NATO expansion. Chapter two showed that NATO expansion was not only a political concern but also a concern to society, who saw NATO expansion as a threat to the security of Russia. ${ }^{125}$ Since military reform had not yet taken place in Russia, this grandiose display was an effective portrayal of Russia's renewed military power. Figure two best exhibits the extent of military might on display in the parade.

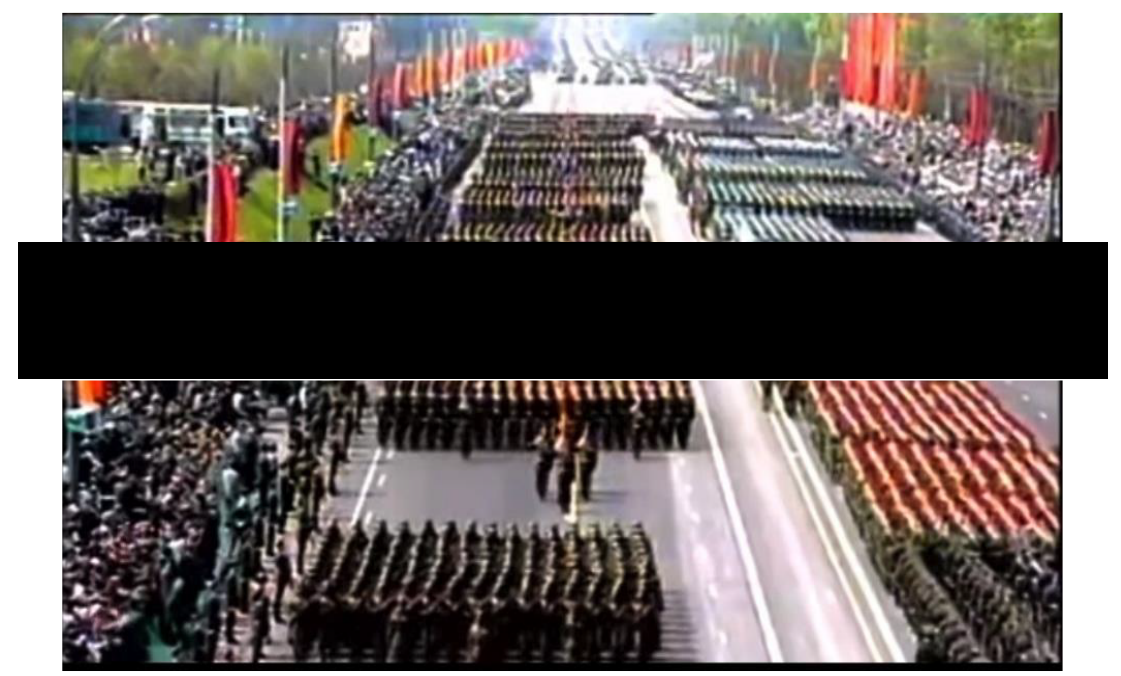

(Figure 2. Armed Formations marching up Kutuzov Avenue, in parallel to Poklonnaia Gora $)^{126}$

Russia's elaborate display of military strength also 'entertained' the spectator who was receptive to the excitement of the theatrics displaying Russia's war machine. Roger Stahl discusses the use of a military-media-entertainment complex (MMEC) in order to entice and engage spectatorship. ${ }^{127} \mathrm{He}$ discusses the Gulf War more specifically,

\footnotetext{
123 Voennyi Parad Pobedy 9 Maia 1995- 50 letie Pobedy/ Military Parade May 9 Victory 1995."

${ }^{124}$ Ibid.

${ }^{125}$ Somov, "'Za' i 'Protiv."”

126 "Voennyi Parad Pobedy 9 Maia 1995- 50 letie Pobedy/ Military Parade May 9 Victory 1995."

${ }^{127}$ Roger Stahl, Militainment, Inc, 24-25.
} 
highlighting differing tropes that came to typify spectacular warfare. Stahl highlighted the pervasiveness of consumer warfare and demonstrated the overwhelming reach of a war that was situated in a far-flung region through the workings of the MMEC. According to Stahl, the MMEC promotes clean warfare, technofetishism and support-the-troops rhetoric. ${ }^{128}$ Taking specifically ideas relating to technofetishism, which is defined as the "worship of high-tech weaponry," the Russian state wanted to wow the audience by showcasing these weapons, especially considering aviation had not been included in a military parade since $1957 .{ }^{129}$ While discussions on militainment are usually linked to film media, and discussions of technology and its use in cinema, news and other virtual capacities, it is also relevant to war theatrics. To produce a parade of commemoration, one that draws in an audience, it must be a spectacle. As noted by Paul Virilio in 1989, "war can never break free from the magical spectacle because its very purpose is to produce that spectacle," and that there is "no war...without representations, no sophisticated weaponry without psychological mystification." 130 Virilio's own assessment demonstrates that the crux of the citizen-spectator relationship is not fundamentally the truthful reflection of the event, and not solely in the mourning of lost generations, but is located in the entertaining value of the parade. The Victory Day parade's use of modern technology, organised and disciplined military parade and the "remember the war dead" rhetoric very much reflected a spectacle that wanted the audience to take on the role as a 'mere consumer-of-content.' 131

Beyond its ability to demonstrate Russia's military might and to entertain, the parade also generated discussion about the future of Russia's Armed Forces. This was showcased more appropriately in Grachev's speech, and more specifically by his reference to military reform. He asserted that, "we must qualitatively renew our armed forces," using regional disputes and new challenges to Russia's national security as justification. ${ }^{132}$ This was particularly important since Grachev played a key role in the initiation of the Chechen Conflict. His alarming messages regarding new threats to

\footnotetext{
${ }^{128}$ Ibid, 25.

${ }^{129}$ Ibid, 28.

${ }^{130}$ Paul Virilio, War and Cinema: The Logistic of Perception (London and New York: Verso, 1989), 5-6.

131 Paul Cling, "Militainment" In Post 9/11 American War Movies," PhD diss., (University of Leiden, 2018), 4.

132 "Voennyi Parad Pobedy 9 Maia 1995- 50 letie Pobedy/ Military Parade May 9 Victory 1995."
} 
national security of course acted as a legitimator for his actions in Chechnya and a common tactic in efforts to militarise society. Chapters two and three show that media and educational discourses drew upon previous and current threats to Russia's security. Prolific reference to war in Russian history textbooks, for example, reaffirmed the discourse that Russia has always needed to defend its borders. Yeltsin reinforced these ideas in his Red Square speech. Unlike Grachev's speech, which was set in the present context, Yeltsin emphasised Russia's historical relationship with conflict. He underlined Russia's war torn past by stating that Moscow and Russia "stand and will stand...[as for] centuries they have risen from the ruins." ${ }^{133}$ Emphasising Russia's historical relationship with war, Yeltsin fortified the traditional Russian justification for the necessity of a large military institution based on the principle that it is vulnerable to outside hostility. Both discourses played an instrumental role in the persistence of militarisation of society during this period. Grachev's speech covered issues of national security in a rational manner. ${ }^{134}$ Without directly mentioning the Chechen War, he provided a general assessment of the geopolitical situation at the time, simply warning that Russia should maintain a certain level of mobilisation. His message was then reinforced by Yeltsin, who outlined a pattern of death and devastation in Russia as a result of war.

Eric Meyer argues that Geschichtspolitik ("Politics of History"), defined by Edgar Wolfrum as a "political-instrumental way of dealing with history and historiography which aims to influence contemporary debates," should be defined as a political domain whereby actors use historical narratives to serve specific and political interests. ${ }^{135}$ In the context of the Chechen War, placing emphasis on Russia's devastating past legitimised Russia's continuing protective role, especially since Russia justified its role in Chechnya on the basis that ethic Russians in the region were in danger. In addition, Yeltsin manipulated Great Patriotic War memory to inform future goals of the state. He promoted partnership and renewed alliance through images like the "handshake on the Elbe." He reinforced Russia's obligation to ensuring that fascism did not prevail. ${ }^{136}$ His comments on fascism are laid out in the undated project related to the Federal Law On Perpetuating the victory of the Soviet People in the Great Patriotic War, 1941-1945. The project's

\footnotetext{
133 “Istoricheskii parad v chest' 50-letiia Pobedy v Velikoi Otechestvenoi Voine."

134 "Voennyi Parad Pobedy 9 Maia 1995- 50 letie Pobedy/ Military Parade May 9 Victory 1995."

${ }^{135}$ Meyer, "Memory in Politics," 177.

136 “Istoricheskii parad v chest' 50-letiia Pobedy v Velikoi Otechestvenoi Voine."
} 
authors, Aparina and Lukianov, stated the "most important direction of state policy of the Russian Federation in the manifestations of the memory of victory in the Great Patriotic War is a decisive struggle against the manifestations of fascism." ${ }^{137}$ By drawing on historical discourse to inform future policy goals, Yeltsin showcased the multifaceted nature of commemoration, as an instrument not only to remember the past but also to accomplish present and future political goals.

Both parades fulfilled numerous state goals. On a superficial level, the elaborate ceremony reestablished rituals for subsequent parades and displayed the extent of Russia's military might. On a deeper level, sacrificial and debt discourses shifted the responsibility towards the civilian, promoting collective commemoration as a substantial part of civic duty. ${ }^{138}$ The rituals enabled the government to exercise power within the public realm and in front of an audience. The audience witnessed discipline, choreography and military submissiveness to the political and military elite. Images of a fractured Armed Forces were overshadowed by this moment of choreographed submissiveness, reaffirming and legitimising the state's domestic and foreign political endeavors. Victory Day allow certain actors to reintroduce glorified images of the military into the public realm. Both parades were extremely instrumental to the militarisation of Russian society. Through the synchronised, exciting displays, which included symbolic representations of the war's victory, the audience was more likely to absorb messages beyond those presented in the media. Speeches by politicians, like Yeltsin, reaffirmed preexisting discourses. He popularised the notion that serving the military was a worthwhile cause, that veterans deserve respect and that Russia has and will continue to rise against inevitable adversity. Grachev's speech promoted the idea that Russia needed to remain ready and up-to-date, highlighting current and future national security threats. Both speeches strengthened the idea that Russia is a vulnerable country in a hostile world. Though the parades were an invaluable tool of the Russian state, commemorative monuments and souvenirs allowed the military institution to permeate society beyond victory day.

\section{Monuments}

${ }^{137}$ GARF, f. 10100, op. 1, d. 989, [Undated: 1993-1995].

${ }^{138}$ Frank Ellis, "The Great Fatherland War in Soviet and Post-Soviet Russian literature," The Journal of Slavic Military Studies 20, No. 4 (2007): 610. 
The Great Patriotic War's $50^{\text {th }}$ anniversary not only warranted a vast and expensive military parade, but a complete rejuvenation of the physical commemorative landscape. Numerous monuments dedicated to the celebration of the Great Patriotic War were introduced. As noted by Benjamin Forest and Juliet Johnson, the event enabled the state to lead an ambitious campaign to revive and re-interpret the war's history. ${ }^{139}$ Monuments built in time for this anniversary included the "Marshal of Victory," a memorial statue built to commemorate the victories of Marshal Zhukov, a key leader in the Great Patriotic War. These monuments were built in Russia's administrative centre, demonstrating the importance of the Great Patriotic War to the nation's history. Forest and Johnson and Michael Bernhard and Jan Kubek claim that memorials placed within the capital city of a nation reflected the role the political elite envisaged that the event would play in current identity formation. In addition, it emphasised the importance that had been attached to these past events. ${ }^{140}$

Moscow Mayor Yuri Luzhkov and Yeltsin worked extensively to ensure that these monuments were refined to represent Russian national identity. Luzhkov especially, "amassed symbolic capital in the city...to promote an image of Russia as a great military and spiritual power bridging the gap between East and West." ${ }^{141}$ However, Russifying the Great Patriotic War was problematic. For example, Victory Park housed churches and other religious structures, which drew a line between Sovietism and the new Russian state. ${ }^{142}$ While the introduction of religion into the narrative around the Great Patriotic War allowed the newly formed Russian federation to gain some autonomy over the Great Patriotic War memory, it also removed some of its significance. Instead of being showcased as a "victory over fascism" in the case of this Victory Park, the Great Patriotic War was being restructured to be an extension of the "age-old Christian story," another external enemy the Russian military bravely fought against. ${ }^{143}$ It also highlighted tensions between the speeches given by political leaders in the parades and memory discourses that were being communicated by the memorials and exhibitions at the Great Patriotic

\footnotetext{
${ }^{139}$ Benjamin Forest and Juliet Johnson, "Unravelling the Threads of History: Soviet-Era Monuments and Post-Soviet National Identity in Moscow," Annals of the Association of American Geographers 92, No. 3 (2002): 531.

${ }^{140}$ Ibid, 529.

${ }^{141}$ Ibid.

142 Nurit Schleifman, "Moscow's Victory Park: A Monumental Change," History and Memory 13, No. 2 (2001): 25-27.

${ }^{143}$ Krylova, "Dancing on the Graves of the Dead," 97.
} 
War museum. However, it remained important to the Russian government that these monuments promoted longevity, and a mythologisation that would allow their existence to remain eternal.

From the day they were erected, these monuments became embedded in the concrete landscape of the city. They showcased a continuation of commitment to the memorialisation of their predecessors, while informing Russia's future national identity. Paul Gough notes that monuments "provided a sense of anchoring... in a mobile and disjointed society." 144 While Gough is more concerned with British memorials, his ideas can be linked to the Russian case, since the Russian Federation lacked a sense of collective identity in its early years. The monuments linked the past, present, dead and living, and the current society under a static and common historical symbol of the war. Noted as 'official memory,' these monuments exhibited devotion to the Great Patriotic War memory and to the institution that forged the victory - the Armed Forces. ${ }^{145}$ These memorials maintained societal militarisation, as their erection demonstrated continuity and loyalty to the past and the institutions concerned. ${ }^{146}$

In addition, not all monuments constructed in the Post-Soviet period were specific. While they sat in places of specificity like Victory Park, they glorified and represented a common theme that ensured their everlasting relevance. These monuments fit into Anderson's understanding of national imaginings. When discussing the Tombs of Unknown Soldiers, he states that tombs are "void...of identifiable mortal remains or immortal souls... [yet] are nonetheless saturated with ghostly national imaginings."147 Jacques Le Goff's portrayal of the Unknown Soldier's Tomb is similar to that of Anderson, showing that the monument's anonymity helped reconcile the nation in a shared memory. ${ }^{148}$ In such cases, the monuments did not create a direct representation of war but constructed a sense of meaning and feeling. Therefore, these monuments were simply about giving substance and physicality to the material. ${ }^{149}$ While the Zhukov

\footnotetext{
${ }^{144}$ Gough, "Commemoration of War," 6.

${ }^{145}$ Feldman, "Between Yad Vashem and Mt. Herzl," 1146.

146 Alison Landberg, Prosthetic Memory: The Transformation of American Remembrance in the Age of Mass Culture (New York: Columbia University Press, 2004), 7

${ }^{147}$ Anderson, Imagined Communities, 9.

148 Jacques Le Goff, History and Memory, trans. Steven Rendall and Elizabeth Claman, (New York: Columbia University Press, 1992), 88-89.

${ }^{149}$ Feldman, "Between Yad Vashem and Mt. Herzl," 1146.
} 
monument, discussed below was a portrayal of an individual, the obelisk in Victory Park is more abstract, representing the theme of war rather than memorialising individuals associated with the Great Patriotic War. The monument is more relatable and easier to accept.

On the $8^{\text {th }}$ May 1995, the Russian state revealed a new monument called "Marshal of Victory" dedicated to Marshal Zhukov. ${ }^{150}$ The statue was situated on Manezhe Square, which neighbours Red Square. ${ }^{151}$ The monument depicted Zhukov on horseback, as a reminder of his role in the Victory Day Parade of June 1945. The statue also depicts his horse trampling on Nazi symbols. The trampling of the swastika was a common image in Great Patriotic War monuments, and symbolised that Zhukov was an important individual in the defeat of Nazi Germany. The statue was revealed in a small ceremony. Luzhkov delivered a speech at the unveiling ceremony, stating, "We are opening a monument to the great son and commander of Russia whose most decisive contribution to the victory has been acknowledged by the whole world, to Marshal Zhukov." 152 Following Luzhkov's speech, Russian President Boris Yeltsin, who was surrounded by other state officials including Patriarch Alexei II, revealed the statue. Figure three shows Boris Yeltsin cutting the ribbon around the monument and removing the wrapping. A small public audience attended the ceremony, and soldiers carried out a ceremonial march to pay homage to Zhukov. Two guards protected the statue, for the purposes of the ceremony only. Jonathan Trigg notes that the presence of political elites at the opening of a monument or its placement near public buildings highlighted the significance of the memorial because of the "immense official involvement in the planning element of these

${ }^{150}$ As documented by Michael Rowlands, memorials are either based on showcasing a list of the dead or on notions of collective bravery in the face of adversary. In this case, Zhukov is being used as a symbol of the collective bravery and acts of heroism which soldiers demonstrated in protecting the Soviet Union. Through the image of Zhukov, the onlookers would be able to see a physical representation of values such as self-sacrifice, loyalty, bravery and heroism. For more, please see: Rowlands, "Trauma, Memory and Memorials," 57.

${ }^{151}$ As noted by Mikhail Lukanin the statue of Marshal Zhukov was originally meant to be situated on Poklonnaia Gora. While no newspaper addresses the change, such a change of location may have been intended to spread the boundaries of the commemorative landscape of the Great Patriotic War. In addition, the location of the status in such a central location in Moscow meant that many civilians would pass it on an ordinary day, as opposed to the Victory Park, which unless driving past, would require a purposeful visit. For more, please see: Mikhail Lukanin, "Sobytiiai Komentarii. Tak kak zhe budet vygliadet pamiatnik Zhukovu?” Krasnaia Zvezda, 20 September 2009, No. 216.

152 "Russia: V.E. Day Celebrations Update." 
memorials." 153 This was the case with the 'Marshal of Victory.' The location of the monument and the official opening ceremony, which was sanctioned by prominent political and religious elites, showed respect for Zhukov as an individual and acknowledged the indispensable role which he played in the victory of the Great Patriotic War. Zhukov's historical importance was cemented in history even before 1995 . On $17^{\text {th }}$ June 1994, Svetlana Migdisova and Elena Petrenko of FOM asked Russian citizens the question, "Which of the listed historical workers of Russia and the USSR do you most consider a Russian patriot?” Out of 1,200 respondents, Peter I scored highly at 46\%, with Marshal Zhukov following in second with 29\%. Other 'patriots' included Russian military leader Alexander Suvorov and first leader of the Soviet Union, Vladimir Lenin. ${ }^{154}$

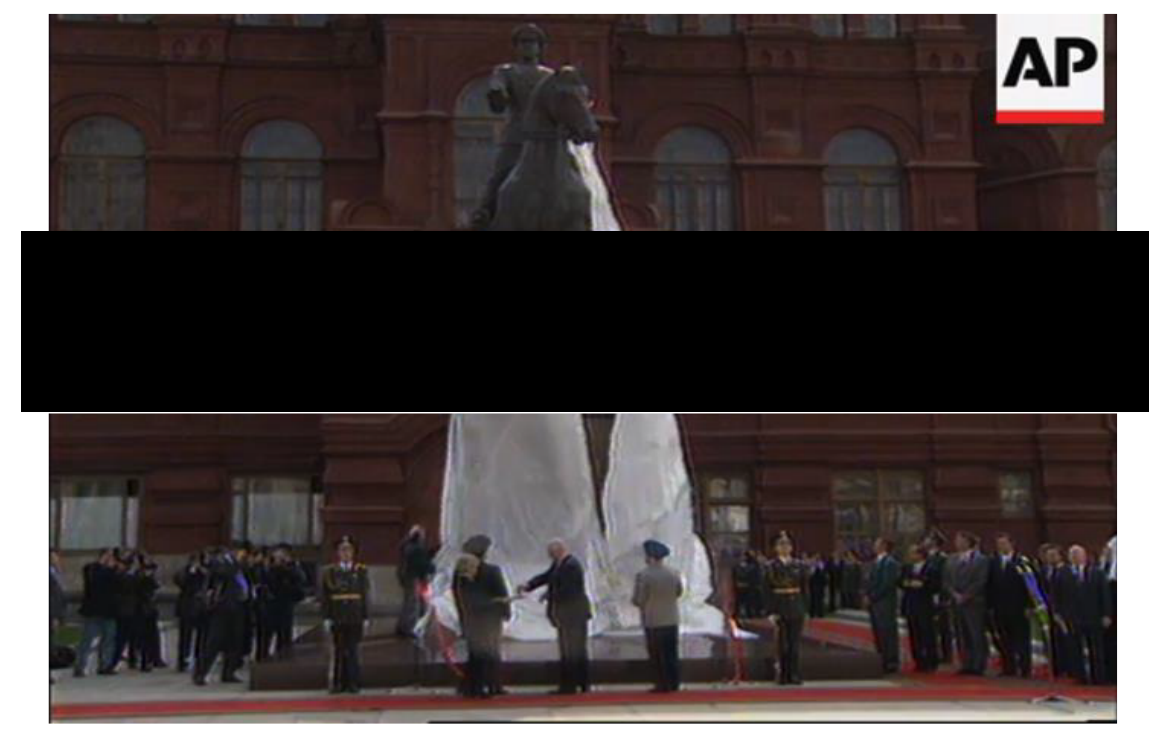

(Figure 3. Unveiling of Marshall Zhukov Monument by President Boris Yeltsin) ${ }^{155}$

Patriarch Alexei II's attendance was most interesting. While his involvement was only ceremonial, it demonstrated a growing departure from Soviet Union and efforts to Russify the commemoration. As noted by Trigg, utilising religious symbolisms, discourses and even religious elites in memorialisation practices added a level of spirituality and validity to the event and people that were being commemorated. ${ }^{156}$ However, this was not the main target of the state. The religious dimensions to the Victory

\footnotetext{
153 Trigg, "Memory and Memorial," 300-302.

154 Svetlana Migdisova and Elena Petrenko, "Desiat' imen, bolee vsego sootvetstvuyushchikh predstavleniyu o russkom patriote, - ot Petra I do Lenina," FOM, $17^{\text {th }}$ June 1994, accessed 5 April 2020, https://bd.fom.ru/report/map/of19941206.

155 "Russia: V.E. Day Celebrations Update."

156 Trigg, "Memory and Memorial," 299.
} 
Day celebration symbolised that the Russian State wanted to separate itself from the Soviet Union. Having repressed religious organisations during the Soviet period in favour of scientific rationalism, the victories of the Soviet Union were packaged within a wider discourse of saving the Communist state rather than by God.

The collapse of Communist Party rule left the victory without a justification since both the country and the cause that the soldier originally died for no longer existed. Roger Marwick claims the demise and devaluation left citizens of the Russian Federation with little social identity and political purpose. ${ }^{157}$ The rebirth of the cult of the Great Patriotic War alongside a reenergised and politicised Russian orthodoxy filled the gap and allowed for the Great Patriotic War to assume greater significance in the Post-Soviet period. In 1993, a survey found that $98 \%$ respondents regarded the Great Patriotic War as Russia's most important historical event. ${ }^{158}$ Combining the commemorative events with religious tropes demonstrated a clear use of the event to inform and generate support for state policies. Yeltsin aimed to saturate images of heroism and patriotism with "orthodox motifs" of self-sacrifice and other Russian values, such as loyalty to the state. Krylova refers specifically to Yeltsin's desire to renew feelings of "imperial military valour." 159 These new religious elements show the political elite's desire to commemorate the event within the boundaries of the new Russian state. They demonstrated the state's aim to militarise society by valorising the veteran population through pro-religious discourses. The use of religious motifs and presence of religious figures helped sanctify the discourses that were produced, reaffirming the discourse that veterans were worthy of respect. The choreography at the Marshal of Victory opening ceremony reinforced messages of the veterans' heroism. Soldiers marched in front of the statue and held a salute aimed at Zhukov, showing similar subordination and respect to Zhukov as was shown to state leaders in the Victory Day parade on Red Square. Figure four shows this sequence.

\footnotetext{
${ }^{157}$ Marwick, "The Great Patriotic War in Soviet and Post-Soviet Collective Memory," 695.

${ }^{158}$ Ibid, 694-696.

${ }^{159}$ Krylova, "Dancing on the Graves of the Dead," 97.

Yeltsin's phrase "victory despite the inhumane state" to refer to the Soviet victory in the Great Patriotic War emphasized the heroic actions of Soviet soldiers of the Great Patriotic War in contrast to the cruel and inhumane conditions that the Soviet state forced them to endure.
} 


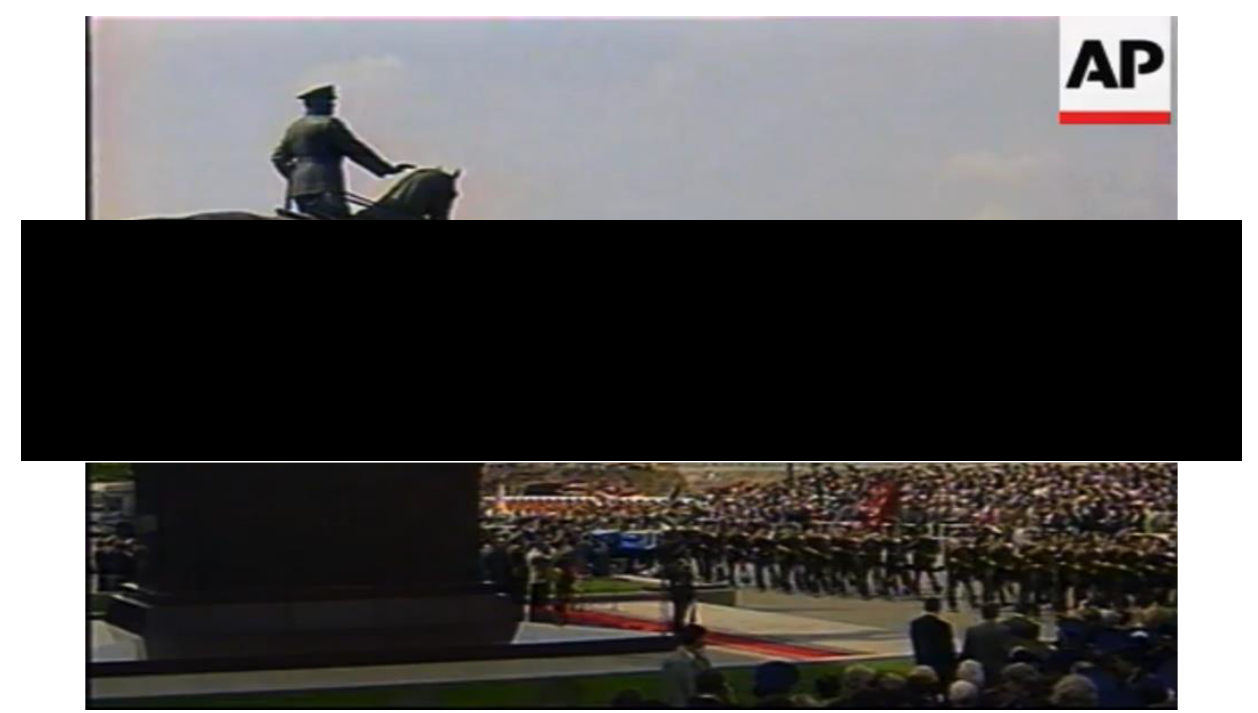

(Figure 4. Soldiers marching in front of Marshall Zhukov's monument on Manezhe Square in Moscow) ${ }^{160}$

The monument and opening ceremony showcased Marshal Zhukov as a hero of the Great Patriotic War. Having been created in Post-Soviet commemorative practices and narrated as the son and commander of Russia by Luzhkov, Zhukov was recharacterised as a hero of Russia, rather than the Soviet Union. ${ }^{161}$ This showed the state's effort to reconceptualise Zhukov's historical role within the context of modern-day Russia. In doing so, the government attributed significance to his role in the Post-Soviet period, and promoted aspects of his heroism, bravery and courage. This reconfiguration demonstrated a clear state objective to militarise society. Since these traits were deemed only recognisable within the confines of a military pursuit, it deemed a career in the military as the only route that similar characteristics could be demonstrated. In doing so, it popularised these traits and promoted the institution he was attached too.

A day after the Marshal of Victory's unveiling, Victory Park and the Great Patriotic War museum opened. The project, which originated during the Brezhnev era, finally came into fruition under Yeltsin and Luzhkov's direction. The museum and park's construction and opening, under Post-Soviet leadership, posed many questions. Why were Soviet leaders unable to create this commemorative landscape? And why did postSoviet leaders decide to do it? Schleifman notes his surprise that authoritarian regimes before Yeltsin lacked the ability to produce a grand narrative about the Great Patriotic

160 "Russia: V.E. Day Celebrations Update."

161 Ibid. 
War and the park. ${ }^{162}$ Rather, Great Patriotic War discourses fluctuated under the regime's different leaders. For Stalin, the commemorative landscape lay rather bare. He worried that veteran glorification would threaten his own power base. ${ }^{163}$ In the Khrushchev era, and during de-Stalinisation, marginalised characters like Marshal Zhukov were reglorified. The cult of the Great Patriotic War was constructed under Brezhnev, while Gorbachev's glasnost uncovered the Soviet horrors and destroyed the discourses cultivated by Brezhnev. The park's building plans were laid out in 1978, but not imagined until the 1990s. ${ }^{164}$ Despite severe political, economic and social issues, the Post-Soviet leaders succeeded in creating and constructing the victory park "in a new post-soviet language." 165 Schleifman indicates that the Victory Park's creation was done under the notion that it not only represented the Soviet victory over Nazi Germany, but also embodied deeper discourses of Russia's heroism over other foreign invaders. ${ }^{166}$ Marwick supports this idea, stating that the complex offered the newly formed Russian state the opportunity to incorporate the Great Patriotic War as a national myth. ${ }^{167}$ The state's desire to promote a more general depiction of Russian victory through the Victory complex showcased the state's desire to militarise society. First, it ensured the Great Patriotic War was reframed within the modern-day Russian context. Second, it placed the Great Patriotic War within a larger network of historical Russian conflicts. Both contributed toward, created and reaffirmed the discourse that Russia was a vulnerable country, historically prone to invasions and hostility. The importance of the Victory Park's location went beyond the Great Patriotic War.

Grachev spoke of Poklonnaia Hill's importance within the frame of the Great Patriotic War, claiming:

We must always remember here on Poklonnaia Gora, the sacred place of military glory in Moscow, that hero city that never obeyed the enemy. With the celebration of the $50^{\text {th }}$ anniversary of the victory of the Great Patriotic War here on Poklonnaia

\footnotetext{
${ }^{162}$ Schleifman, "Moscow's Victory Park," 7-8.

${ }^{163}$ Robert Dale, "Remobilising the Dead: Wartime and Postwar Soviet Burial Practices and the Construction of the Memory of the Great Patriotic War," Kritika: Explorations in Russian and Eurasian History 22, No. 1 (2021): 42-43.

${ }^{164}$ Schleifman, "Moscow's Victory Park," 24-25.

165 Ibid, 7-8.

${ }^{166}$ Ibid, 24-25.

${ }^{167}$ Marwick, "The Great Patriotic War in Soviet and Post-Soviet Collective Memory," 695-696.
} 
Gora we confirm our loyalty to the sacred ideals of freedom and the independence of the motherland. ${ }^{168}$

The term "never obeyed the enemy" emphasised the many times foreign armies marched on Moscow. More generalised discourses of Russia's insecurity against hostile neighbours served as a reminder that Russia has always needed to secure its borders with a large army. These discourses fed into a popular Russian perception that wars of the past would occur again, under different circumstances and with a new generation acting as Russia's saviours. The militaristic dimension is more interesting here. By placing the Great Patriotic War within the context of Russia's wider history of military struggles, the state pushed a 'scaremongering discourse,' one that justified the need for a strong military.

On $9^{\text {th }}$ May 1995, the Great Patriotic War museum situated at Park Pobedy (Victory Park) opened. A number of monuments dedicated to the Second World War were located in this park. The landscape's organisation was largely symbolic and purposeful. The seven fountains situated on the main walkway towards the museum represent the seven years or the Second World War, rather than the five years of the Great Patriotic War. ${ }^{169}$ The site of the Victory Park also housed a Russian Orthodox Church, a Synagogue and Mosque. Both aspects suggest a deliberate attempt to Russify the commemorative landscape, with homage to the Second World War rather than the Great Patriotic War and inclusion of religious tropes demonstrating a clear distinction between the Soviet era and the newly formed Russian state. ${ }^{170}$ Why would the state want to Russify the victory? As noted before, Russifying the victory allowed Russia's civilians to lay claim and adopt the victory of the Great Patriotic War within the confines of the new Russian state. It assisted militarisation efforts during this period, demonstrating a clear state objective to reconfigure the victory's relevance in present day Russia. In doing so, it reframed the Soviet victory as a Russian one and enabled it to remain an important historical event of for Russia.

\footnotetext{
168 "Voennyi Parad Pobedy 9 Maia 1995- 50 letie Pobedy/ Military Parade May 9 Victory 1995."

${ }^{169}$ Schleifman, "Moscow’s Victory Park," 25-27.

${ }^{170}$ Ibid.
} 


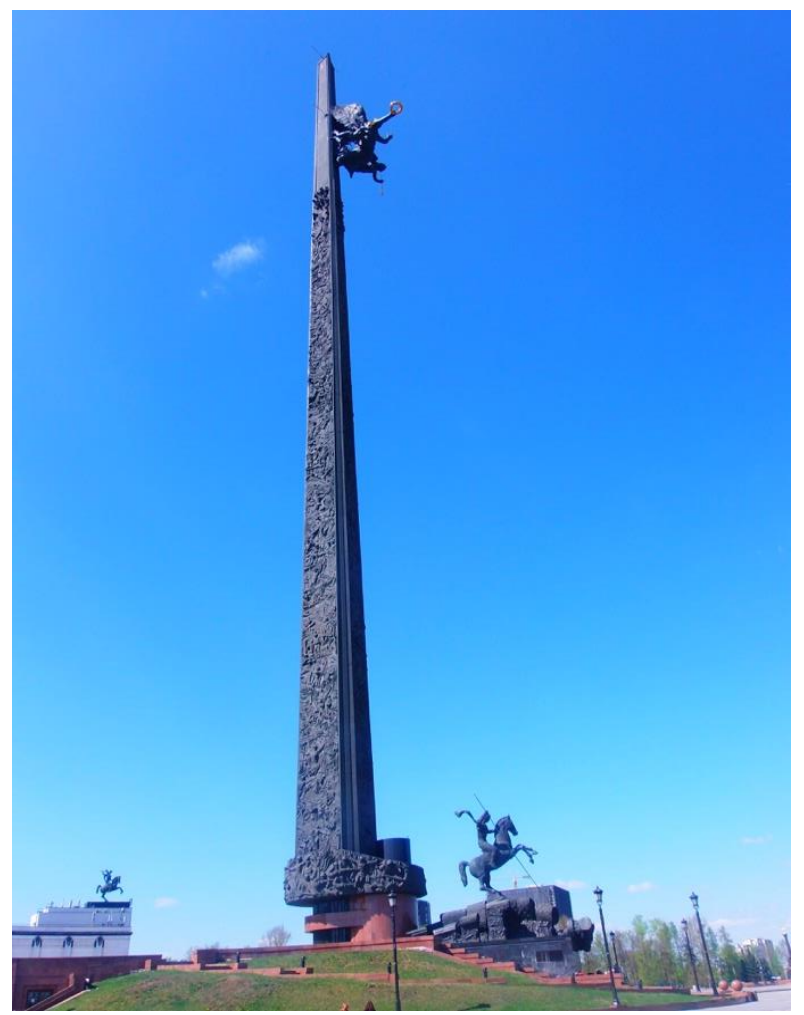

(Figure 5. Monument to the Great Patriotic War located in front of the Great Patriotic War Museum in Moscow's Victory Park) ${ }^{171}$

The most important monument on the site of the Great Patriotic War museum was the Obelisk, created by Zurab Tsereteli and situated outside the entrance to the museum. ${ }^{172}$ As pictured in Figure five, the obelisk is a colossal statue dedicated to the Great Patriotic War. The height of the Obelisk is 141.8 metres, marking the 1418 days of the Great Patriotic War. ${ }^{173}$ The column is intricately designed, displaying the names of key cities of the Soviet Union during the Great Patriotic War. Nike, which represents victory in Greek mythology, ${ }^{174}$ sits at the top of the obelisk. Placing Nike's image on top of the obelisk personified not only Russia's struggle but also its eventual victory. While the column represents the Soviet Union's involvement in the Great Patriotic War, the statue at its base depicts a more general notion of Russia and war. As shown in Figure six, a statue of St. George lies at the base on the obelisk. It is slaying a dragon (covered

\footnotetext{
${ }^{171}$ Victory Monument, 9 May 1995, Obelisk, Victory Park, Moscow, Photo courtesy of author (2018).

${ }^{172}$ Marwick, The Great Patriotic War in Soviet and Post-Soviet Collective Memory, 695696.

Krylova, "Dancing on the Graves of the Dead," 97.

${ }^{173}$ Krylova, "Dancing on the Graves of the Dead," 97.

${ }^{174}$ Nina Tumarkin, "The Great Patriotic War as myth and memory," European Review 11, No. 4 (2003): 609.
} 
in Nazi symbols). ${ }^{175}$ The image is similar to Moscow's coat of arms, which depicted a horseman with a spear in his hand slaying a basilisk. It remained closely linked to the legend of St George who slayed a dragon that demanded human sacrifices and created closer links between religion and military. ${ }^{176}$

It also mirrored the 'Marshal of Victory,' unveiled a day earlier. While depicting a different person, together the Marshal of Victory and St. George at the base of the obelisk created familiar checkpoints around Moscow, where onlookers could connect with the Great Patriotic War's history. Replicating or mirroring militaristic symbols/ images is a tool of militarisation. As highlighted earlier in CDA literature, repeated ideas, signs and visuals help establish a dominant discourse. By standardising a certain image of heroism, in this case the strong masculine male upon a horse trampling on Nazi symbols, observers become accustomed to this certain type of militarisation. First, it creates a certain familiar image - onlookers associate heroism with masculinity. This is particularly important. The statues replicated monuments dedicated to other Russian historical figures like the Statue of Yuriy Dolgorukiy (1099-1157), erected on Moscow's Tverskaia Square in 1954. Dolgorukiy founded Moscow but was also famous for his military conquests in Kiev. He was depicted, like Zhukov and St. George, on horseback. Other similar statues include the Bronze Horseman (dedicated to Peter the Great) and the Monument of Nicholas I (1796-1855).

These checkpoints standardised heroic action at the hands of a strong, masculine man on a horse. Second, they established the story - these men (Zhukov and St. George) are trampling on the enemy. It reaffirmed the notion that a veteran's sacrifice deserves respect as their participation prolonged the state's existence. Third, this is an image that Russian citizens can find, not only on Manezhe Square, but 20 minutes away at the Victory complex. Again, it created a sense of familiarity, which standardised definitions of heroic figures and military valour. Zhukov became part of a larger network of Russian heroes, defending Russia from outside threats. It reinforced the discourse that Russia was a vulnerable country surrounded by hostile neighbours. By placing the Great Patriotic

\footnotetext{
175 Ibid, 609.

${ }^{176}$ For more, please refer to section: "The Dragon Episode in the St. George Legend" in St. George and the Dragon: Introduction, ed. by E. Gordon Whately, Anne B. Thompson and Robert K. Upchurch, (2004), accessed 5 April 2020, https://d.lib.rochester.edu/teams/text/whatley-saints-lives-in-middle-english-collectionsst-george-and-the-dragon.
} 
War memory within Russia's wider military history, the victory of the Great Patriotic War became an extension of Russia's contemporary national identity, especially since Russia's wider history became more salient in Russia's new landscape. For example, the Coat of Arms of Moscow was reinstated as an emblem of the Russian Federation following the collapse of the Soviet Union in $1993 .{ }^{177}$

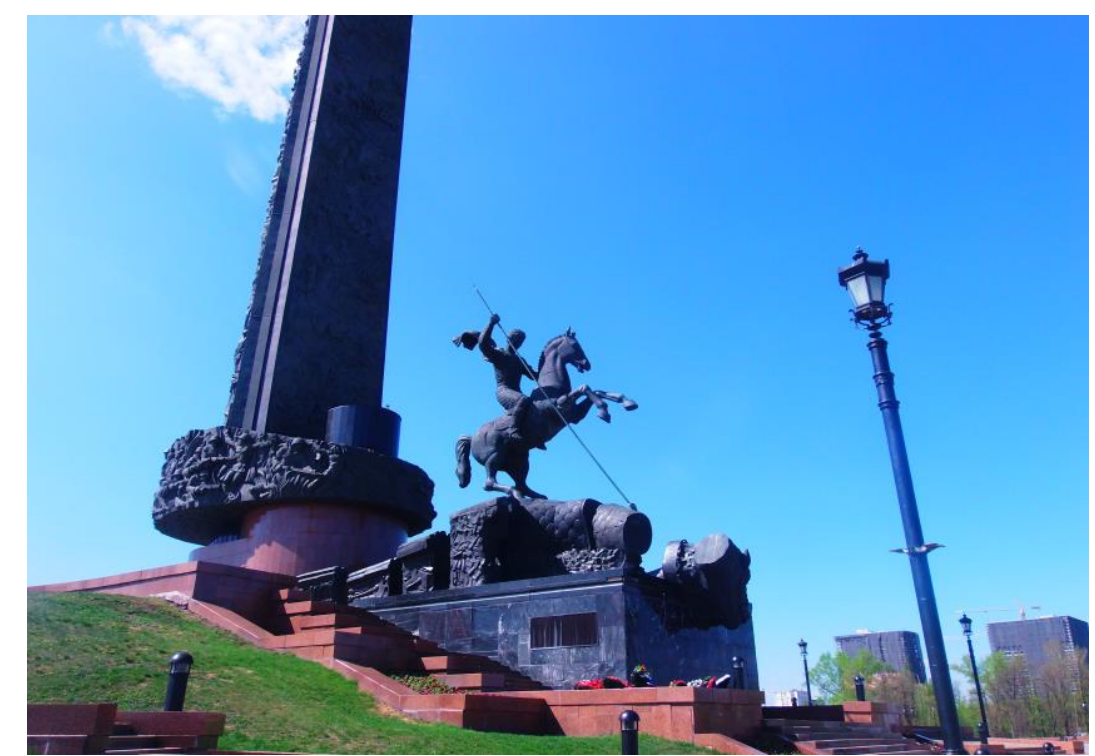

(Figure 6. Base of Monument to the Great Patriotic War located in front of the Great Patriotic War Museum in Moscow's Victory Park) $)^{178}$

The obelisk was unveiled alongside the Museum's opening on the $9^{\text {th }}$ May 1995. The ceremony is shown in Figure Seven. Foreign dignitaries, Russia's political and military elite and members of the public were in attendance. The ceremony began with Yeltsin cutting the ribbon to the Great Patriotic War obelisk, marking the official opening of the site. Krasnaia Zvezda reported on the opening ceremony, stating, "At the climax, the President of Russia Boris Yeltsin cuts a symbolic scarlet ribbon: The anthem of Russia sounds. Hundreds of colourful balloons soar into the sky. The victory memorial complex to the Great Patriotic War on Poklonnaia Hill is now open." ${ }^{179}$ Chinese, British and

177 Yevgeny Ukhnalyov (1931-2015), Member of the Russian guild of Heraldic Arts, was responsible for the creation of the Coat of Arms that was introduced in 1993. Details of his projects, including the creation of the $50^{\text {th }}$ anniversary medal can be found here: "Evgeniy Ily'ich Ukhnalyov (1931-2015)," Geral'dika.ru, accessed 6 April 2020, https://sovet.geraldika.ru/article/17588.

${ }^{178}$ Victory Monument, 9 May 1995, Obelisk, Victory Park, Moscow, Photo courtesy of author (2018).

${ }^{179}$ Aleksander Pelts, "V Pamiat pavshizh I vo slavu zhivykh," Krasnaia Zvezda, 11 May 1995, No. 105. 
American political figures spoke during the ceremony. Bill Clinton's speech outlined the Soviet Union's integral role in the victory of the Second World War, emphasising that the Cold War clouded America's judgement and realisation of the Union's part in the victory. ${ }^{180}$ Reinforcing Russia's colossal role in the Great Patriotic War consolidated the need to treasure and commemorate the victory of the Great Patriotic War and the Soviet Union, including Russia's role in it. While each speech highlighted the Soviet Union's role in the Great Patriotic War, the foreign dignitaries also reinforced the notion of allied victory in World War Two, emphasising future cooperation in a world no longer consumed by the Cold War. The ceremony was well attended by the political elite, veteran groups and a public audience. Figure Eight shows the massive crowd gathered for the event. The audience was colourful as celebratory banners and balloons assimilated into the crowd. The monument opening also meant the opening of the newly restructured Victory Park Complex, including the Great Patriotic War Museum, which stands directly behind the monument. A number of monuments are held in the commemorative rooms within the museum, demonstrating a different form of commemoration based on space.

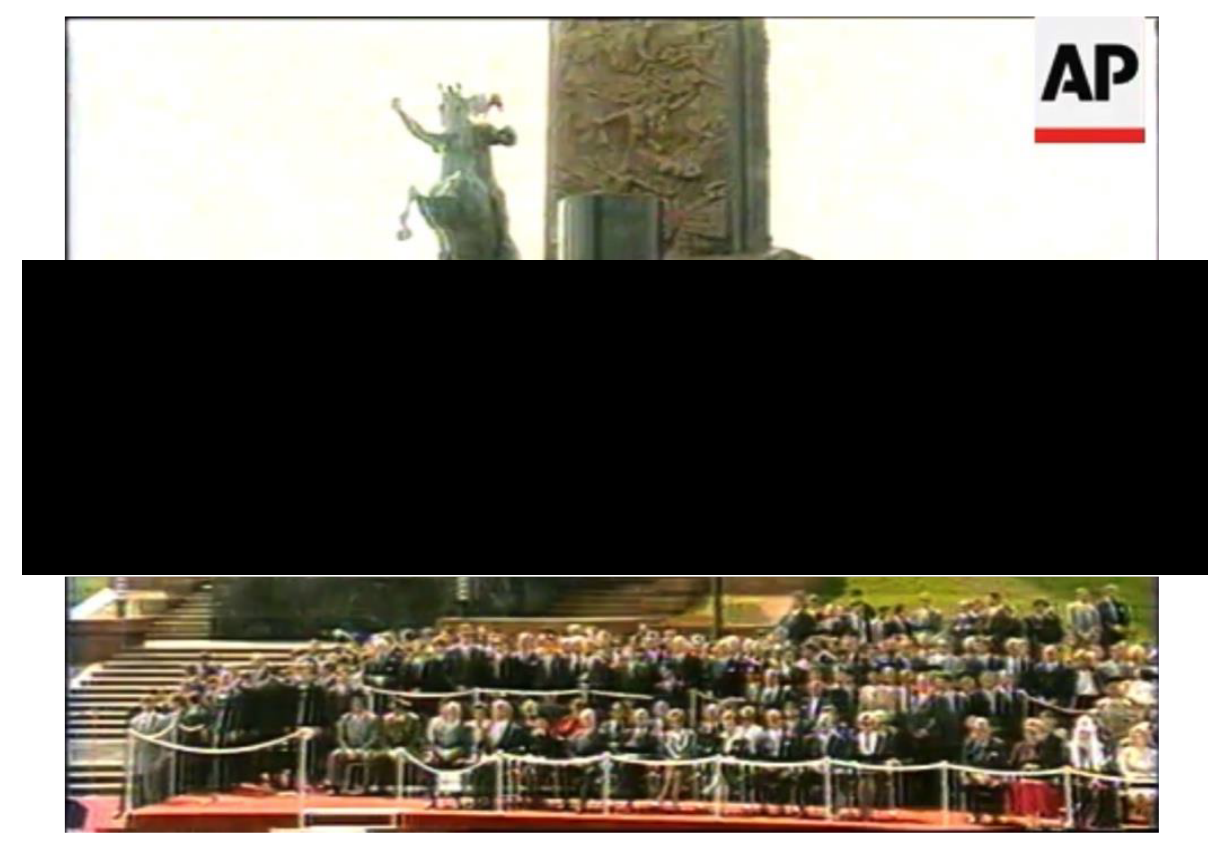

(Figure 7. Unveiling of the obelisk statue located in front of the Great Patriotic War Museum in Moscow's Victory Park) ${ }^{181}$

\footnotetext{
180"Russia-Yeltsin, Clinton Among Leaders Honouring," AP Archive video, 2:19:18, posted by WTN Pool, 15 May 1995, accessed 12 November 2018, https://bit.ly/2QbSPJ2. ${ }^{181}$ Ibid.
} 


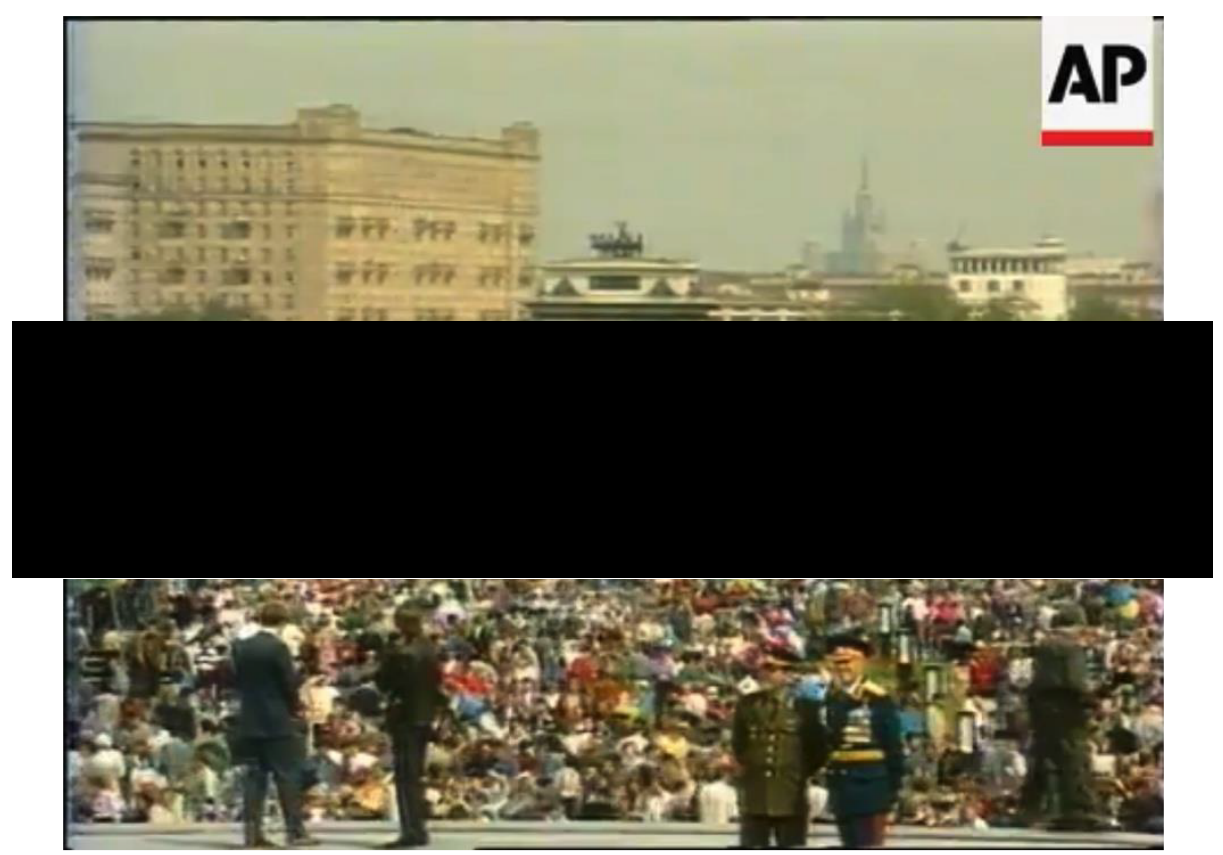

(Figure 8. Crowds gathered at the opening of the Great Patriotic War Museum and ceremony unveiling the monument to the GPW) ${ }^{182}$

The Great Patriotic War museum holds numerous visual representations of war in forms other than monuments, for example, in panorama displays. This section however, focuses on the two main monuments within the walls of the Great Patriotic War Museum. These monuments are focal points of the museum. They are housed in rooms which act as shrines to participants and victims of the Great Patriotic War but have also been generalised to some extent. While this may have been an attempt to Russify the victory, this generalisation also made the memorials relatable. The first monument under analysis is the monument situated in the Hall of Remembrance and Sorrow.

This monument is displayed in Figure nine. As exhibited, while the monument is brightly lit, it sits within a dark space dimly lit from above by strings of glass beads, symbolising tears of mourning. The monument is of a woman, identified as a mother, crying over a fallen soldier. The use of the woman/soldier discourse is not uncommon in commemorative practices. ${ }^{183}$ Buffton, for example, notes that monuments depicting a

182 Ibid.

${ }^{183}$ In scholarship on commemoration, the image of a fallen soldier in the arms of a female figure is common. With the female, through her role as a mother is depicted as life, the male as the 'warrior' and protector is portrayed as death. The image not only depicts an image of life and death but of the emotional image of a mother who has lost her son to war. In a more glorifying image, the symbolic significance of this depiction lies also in the representation of the female as the mother of the nation, in which the soldier's death is not in vain but for the renewal of the state - this is a common feature of war memorials in order to depict that the war was not futile but that the sacrifice was made for the greater 
female figure holding the frame of a dead soldier in her arms were used in post-World War One France. ${ }^{184}$ According to Buffton, the woman's identity is often ambiguous, representing either mother, widow, the nation itself or the Virgin Mary, which reinforces the image of a soldier who has sacrificed himself. This sanctified image of the soldier is further intensified by the fact that the statue is made from white marble, which signifies not only the purity of love between mother and son but adds a sense of spirituality or timelessness to the commemorative piece. Most statues in marble are those created to memorialise Greek or Roman histories and therefore the "marble lends antiquity to the meaning potential of the commemorative war monument." 185 Shleifman notes that the monument portrays the image of pieta, which is reminiscent of the image of Jesus on the lap of Mary following his crucifixion. ${ }^{186}$ This statue reaffirmed societal discourses relating the soldier and veteran to saviours and protectors through sacrifice, further justifying their privileged position in society. As noted by Machin, often a soldier's death is framed as a sacrifice made for the nation. Therefore, the woman's possible role as mother Russia represented the worthwhile role of war and sacrifice, "silencing the own soldier's suffering, fear and bewilderment at the war and horrors it brought." ${ }^{187}$ In addition, the abstract representation of the fallen soldier, either in the arms of a mother, mother Russia or within the arms of the Virgin Mary, enabled the observer to attach their own experiences and values to the monument.

The monument's location is important to establishing a dialogue between the space, monument and spectator. The abstract monuments helped make these connections. While some of those visiting the memorial may have a direct understanding of the war, this museum was produced in a time when a new generation would be visiting the war museum. This younger generation may not have a direct understanding of the Great Patriotic War and therefore the exhibit needed to draw people in and "make the unfamiliar familiar." 188 The Hall of Remembrance and Sorrow is long, with a walkway leading to

good. For more on this, please see: Rowlands, "Trauma, Memory and Memorials," 58; Gough, Commemoration of the War, 7; Catherine Speck, "Women's War Memorials and Citizenship," Australian Feminist Studies, 11:23 (1996), 137.

${ }^{184}$ Buffton, "Memorialisation and the selling of war," 30.

${ }^{185}$ Gillian N. Abousnnouga, "Visual and Written Discourse of British Commemorative War Monuments," PhD diss., (Cardiff University, 2012), 207.

186 Shleifman, "Moscow's Victory Park," 25-27.

${ }^{187}$ Machin, "What is multimodal critical discourse studies?" 350.

${ }^{188}$ White, "Museum, Memorial, Shrine," 9. 
the monument. Dimmed lighting, contrasted with the brightness of the monument entices the spectator to view the statue, often adding magic or guiding the spectator to different exhibitions. ${ }^{189}$ As noted by Fabienne Galangau-Querat on The Grande Galerie de l'Evolution, "lighting expresses numerous messages that can direct, inform, part or gather, conceal or reveal, enlarge or limit." ${ }^{190}$ It has the ability to reshape space, placing emphasis on monuments deemed more important than others. The central positioning of this monument at the end of the 'hall' emphasised the importance of the monument to our understanding of sorrow, which is greatly displayed as the woman leans over the soldier with a sad facial expression.

The monument reaffirmed notions of sacrifice, in both religious and secular terms. The religious dimension not only russified the monument but added further layers to the monument. The monument's abstract and multifaceted nature allowed more than one type of person to find value and meaning in the monument. For example, it was not only a former participant of war who might find familiarity with the monument, but also the religious person who might envisage the war participants' own sacrifice within the story of Jesus. Whether deliberate or not, adding religious tropes to the monument demonstrated a state led effort to mythologise the war and to militarise society. The statue remained significant and relevant in the new Post-Soviet period because of the generalised images of sacrifice in war, which embodied a number of different symbolic meanings. The nature of the monument was timeless and promoted ideas of self-sacrifice through the image of the womanly figure mourning over the soldier. The soldier's sacrifice is popularised through ideas of state loyalty, as depicted by the woman's role as mother Russia. In addition, the woman, as a symbol of the Virgin Mary promoted the notion that such sacrifice was not futile. It showed that sacrifice was a worthwhile activity as it aided the renewal of the nation and added purpose to the soldier's role in war. Since many of the discourses and symbols situated on the Victory complex were focused towards saving the state from past and future acts of aggression, the monument was an important symbol of militarisation. It encompasses history, mythology and hope, uniting past sacrifice to the present and future aims of the state.

189 Fabienne Galangau-Querat, "The Grande Galerie de 1'Evolution," in Reshaping museum space architecture, design, exhibitions, ed. by Suzanne Macleod (Oxon: Routledge, 2005), 99.

${ }^{190}$ Ibid, 102. 


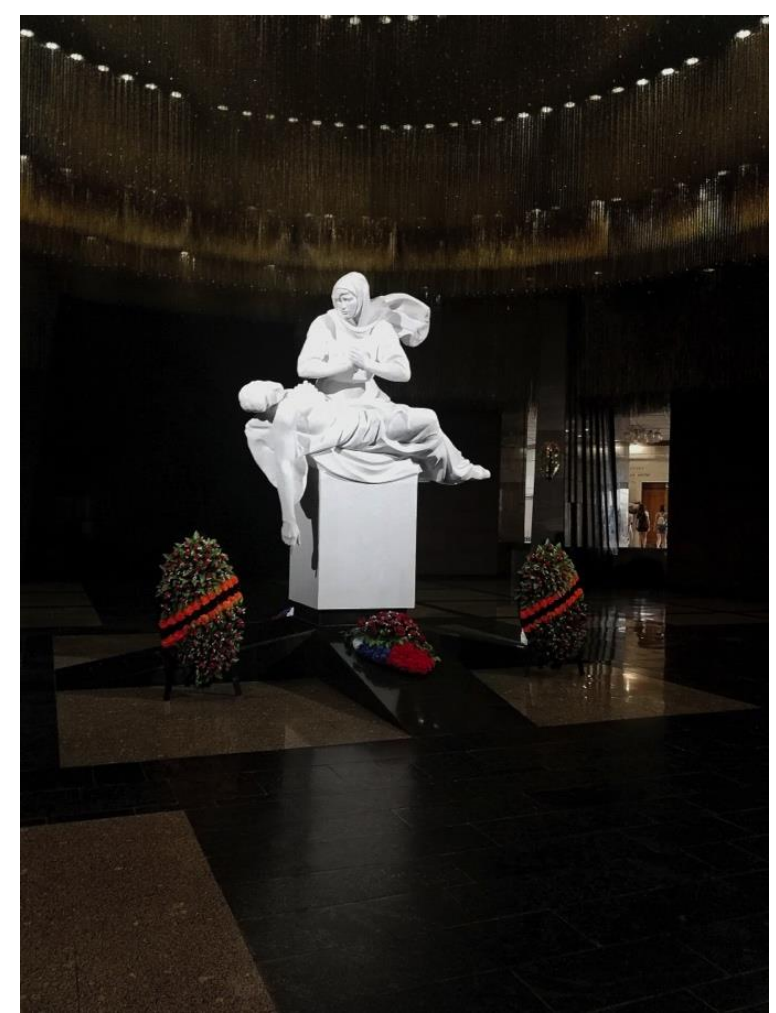

(Figure 9. Monument in the Hall of Remembrance and Sorrow, situated in the Great Patriotic War Museum located at Moscow's Victory Park $)^{191}$

The next monument under analysis is known as the Soldier of Victory, displayed in the Museum's Hall of Glory. As seen in Figure ten, the monument is situated in a commemorative space that bears the names of recipients of the Hero of the Soviet Union distinction. The Soldier of Victory is located in the centre of the room. He is a large bronze male figurine holding an olive branch under a bowl of fire. The addition of a cape depicted billowing behind the figure helps bring the monument to life. A war medal is displayed on his left breast. The olive branch is a universal symbol of peace and victory, similar to the image of a flame torch, which resembles notions of enlightenment and hope. ${ }^{192}$ The soldier's uniform is ambiguous. The outfit is neither a military uniform nor is it showing a soldier belonging to a particular unit of the nation's Armed Forces. This allows the Soldier of Victory to be recognised as a worker in the rear, soldier and hero in a mythical sense. By doing so, the monument's reach is extensive. The colossal figure embodies the concept of glory as embedded in the human action of the war. While this

${ }^{191}$ Grieving Mother, 9 May 1995, white marble sculpture, Great Patriotic War Museum, Moscow, Photo Courtesy of Author (2018).

192 Andrew A. Rigby, “Peace Symbol's Origins,” Peace Review, 10:3 (1998), 476. 
statue does not represent a specific individual like the 'Marshal of Victory,' it does produce an image (or point of reference) of heroism and glory for an onlooker.

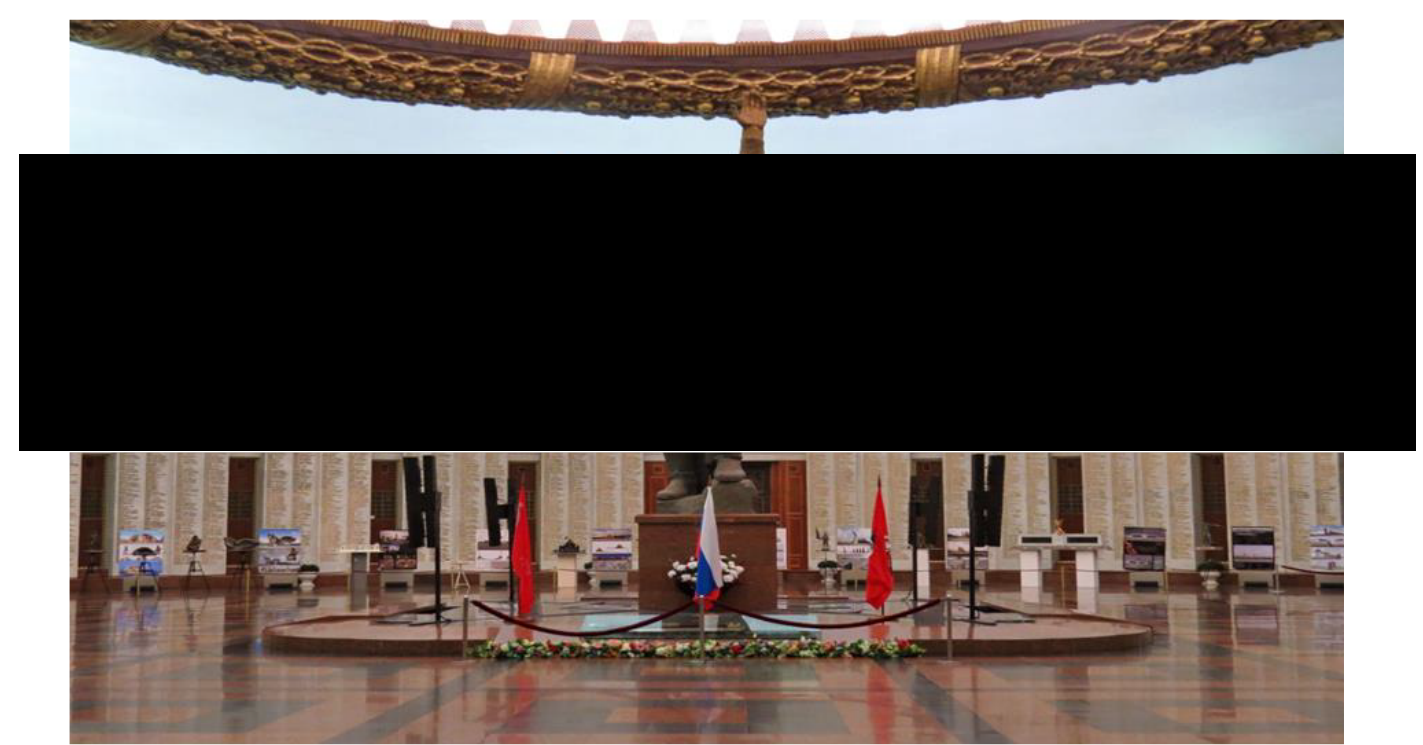

(Figure 10. "Soldier of Victory Monument" situated in the Hall of Glory in the Great Patriotic War Museum Located in Moscow's Victory Park) $)^{193}$

The Hall of Glory is a monument itself. Figure eleven shows the Soviet-themed emblem displayed at the centre of the hall's ceiling. This emblem includes the Order of Victory. The word 'Victory' [Pobeda] is inscribed on it. The Hall of Glory is a vast space, decorated with a number of white and bronze artefacts. Small-sculpted images of cities within the Soviet Union and their names are adorned in sculpted in ribbons above a list of recipients of the Hero of the Soviet Union award. Figures ten and twelve show that these features decorate the circumference of the room.

193 Soldier of Victory, bronze sculpture, Great Patriotic War Museum, Moscow, Pinterest, https://bit.ly/3fiJKID. 


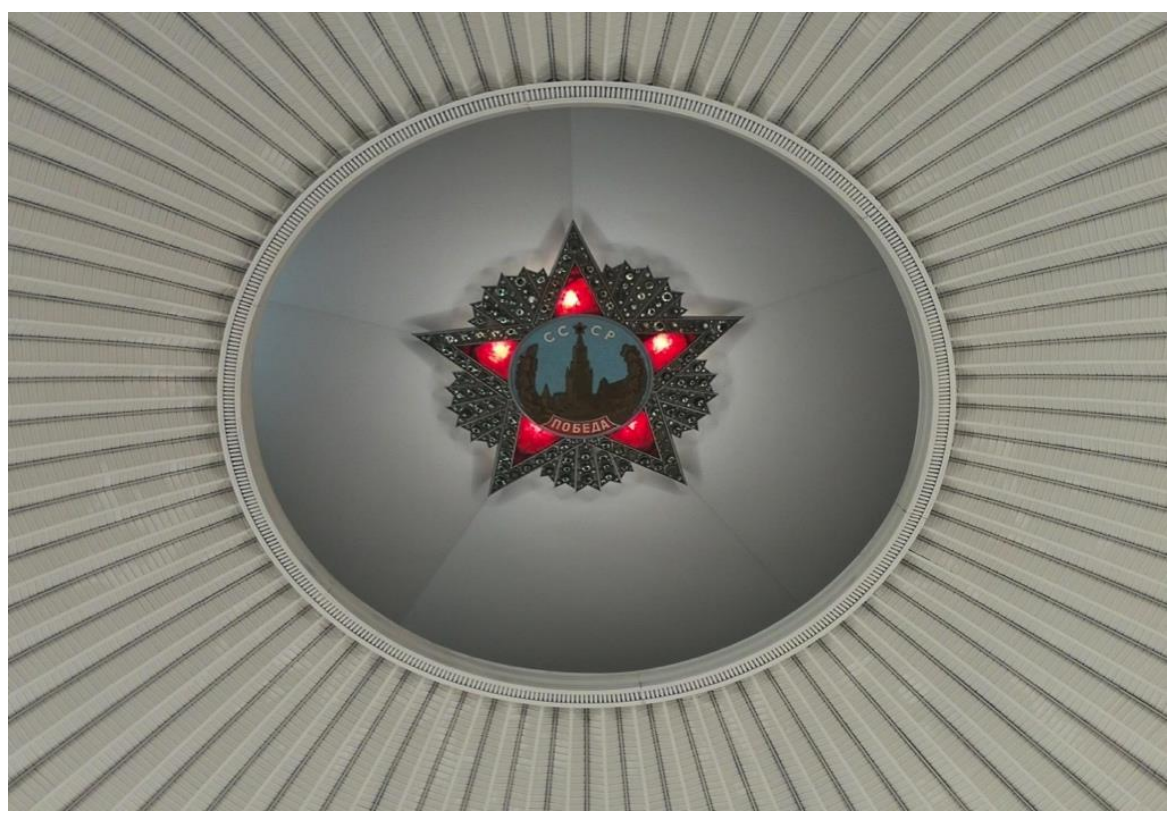

(Figure 11. Soviet-themed emblem displayed on ceiling of the Hall of Glory in the Great Patriotic War museum located in Moscow's Victory Park) ${ }^{194}$

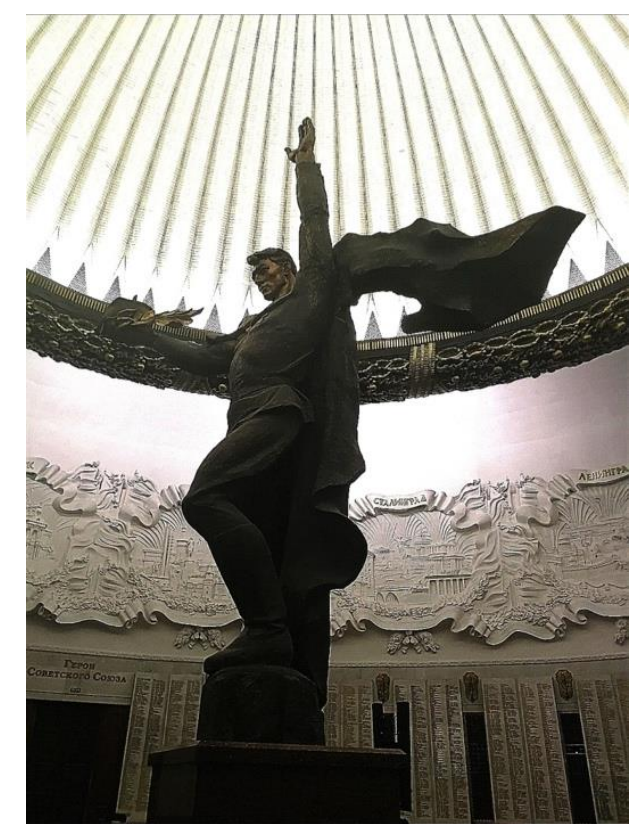

(Figure 12. "Soldier of Victory" monument situated in the Hall of Glory in the Great Patriotic War Museum Located in Moscow's Victory Park) ${ }^{195}$

Monuments introduced during the $50^{\text {th }}$ anniversary celebrations showcased different aspects of war. The monument situated in the Hall of Remembrance and Sorrow, for example, displayed a mournful image of war, whereas the Soldier of Victory exhibited

${ }^{194}$ Order of Victory, 9 May 1995, ceiling ornament, Great Victory War Museum, Moscow, Photo courtesy of author (2018).

195 Soldier of Victory, 9 May 1995, bronze sculpture, Great Patriotic War Museum, Moscow, Photo courtesy of author (2018). 
a more glorified vision. The multifaceted dimensions of war are highlighted by the differences between these two memorials. The monument in the Hall of Remembrance and Sorrow sanctified the image of war, which added importance to the soldier's role in conflict. The Soldier of Victory depicted heroism and glory. These values were desirable to the state.

Some monuments were more specific than others. The Marshal of Victory, for example, was specific to Zhukov and memorialised the individual. Whereas the Obelisk, while attached to some attributions of the Great Patriotic War, presented a more vague representation of victory by including the image of Nike at the top and St. George at its base. Attaching symbols that encompassed a sense of Russianness extended the statue's ideological reach. However, these monuments were also similar. For example, the Marshal of Victory and St. George were later versions of other Russian heroes riding on horseback. They created standardised images of heroic figures as military figures, masculine and strong. Additionally, the monuments in the Great Patriotic War museum were not stand alone items, but components of the display within the room they were situated. The location and lighting of the monument in the Hall of Remembrance and Sorrow, was produced to draw the spectator in, while the Soldier of Victory within the Hall of Glory was the actor who made glory, as displayed on the walls, possible. Unveiling these monuments in extravagant ceremonies and in the presence of international attendees was another way for the government to display the immense importance of these commemorative monuments to society.

All monuments mentioned above which honoured victims of the Great Patriotic War were also saturated with emblematic notions of patriotic-militarism that were relevant to present day Russia. The concentration of these monuments in Russia's political capital demonstrated its importance to Russia's political culture of the 1990s and its importance within the government's agenda. This 'memorial canon' enabled the government to revive positive symbols of the military in society through monuments that glorified victory, military service and sacrifice. Danish journalist Asne Seierstad questioned a participant from Nashi (a youth movement in Russia since 2005) on the use of the Soviet past in contemporary society. She asked "Is that [the use of soviet past] what happens when the present is too...confusing?" The participant responded by saying, "We are patriots. That's why we're concerned about the past." ${ }^{196}$ Similar to the views

${ }^{196}$ Asne Seierstad, Angel of Grozny: Life Inside Chechnya (London: Virago, 2007), 187. 
expressed by the Nashi member, the creation of these monuments highlighted the reemergence of a nationalist stance by the Russian government, which established symbols of Soviet past to evoke nationalist sentiments. These monuments demonstrated a sense of continuity and commitment to the past and the institutions concerned. ${ }^{197}$ Etching visuals of militarised-patriotism into Russia's physical landscape, demonstrated the government's commitment to raising patriotism and pride in society, and popularising the Armed Forces.

\section{Commemorative Collectables}

Commemorative souvenirs were launched as part of the Great Patriotic War anniversary, including medals, state prizes, postal stamps and coins. The souvenirs' creation demonstrated a state-led effort to militarise society beyond the battlefield as national and international postal routes, together with everyday monetary transactions, became saturated with military symbols. These collectables promoted values of selfsacrifice, loyalty and heroism in warfare. These collectables were arguably more important vehicles of militarisation than the monuments. Unlike the monuments, the population could keep these small artefacts in their own personal spaces, for example, their apartments. In addition, some of these collectables were functional, for example, postal stamps and money. The functionality of these articles meant the values they represented pervaded deeper in society, moving from the location of a park, museum or square and invading private space.

Souvenirs constructed for the anniversary added agency to the event. The souvenirs' creation showed that the event was of great political importance, as it immersed itself within many layers of commemoration. As representations of historical significance, for some, they functioned as tokens of sentimentality. ${ }^{198}$ On the other hand, these souvenirs also served as substitutes for memories that did not exist. ${ }^{199}$ Souvenirs created for particular events provide a synchronised practice of collective

197 Barbara A. Misztal, "Durkheim on Collective Memory," Journal of Classic Sociology 3, No. 2 (2003): 124-126.

198 D. Roland Gerber, “Souvenirs: Many Dimensions and One Definition, ” International Journal of Management Cases 10, No. 3 (2008): 26.

${ }^{199}$ Verena-Susanna Nungesser, "I Forgot to Remember (to Forget): Personal Memories in Memento (2000) and Eternal Sunshine of the Spotless Mind (2004)," in Mediation, Remediation, and the Dynamics of Cultural Memory, ed. by Astrid Erll and Ann Rigney (Berlin and New York: Walter De Gruyter, 2009), 36. 
remembering. ${ }^{200}$ For example, the dated commemorative coins created links across society. The souvenir's owner was placed into an imagined community and transported to the date depicted on the collectable piece. ${ }^{201}$ The anniversary date, its emphasis across numerous societal domains, and the celebratory commemorative pieces constructed a symbolic web, which informed the process of collective remembering. On the topic of commemoration and India's film industry, keepsakes created from anniversary events are physical and material forms of spoken and symbolic discourses. In Russia, political discourses were carved into these keepsakes, which persisted beyond the 24-hour celebration date. ${ }^{202}$ The mementos served as continuous reminders of the Soviet victory and helped contribute towards the transformation of the Great Patriotic War from an historical event to one of mythical timelessness. In doing so, the souvenirs discussed in this section maintain the importance of the military victory in society, and therefore sustained Russian militarism.

In war commemoration there are two types of medals: gallantry medals and campaign medals. Gallantry medals are ones awarded for acts of bravery whereas campaign medals were handed out to participants in war for 'simply being there. ${ }^{203}$ The Russian State introduced a number of commemorative campaign medals for the $50^{\text {th }}$ Anniversary celebration. In 1995, the Russian state created a commemorative medal to memorialise the $50^{\text {th }}$ anniversary of the Great Patriotic War (See figure thirteen).

Yeltsin signed an Approved Law of the Russian Federation On the Establishment of the Jubilee Medal in 1993. The medal front (left hand picture displayed in Figure Thirteen) included a picture of the "Kremlin Wall, Spassky Tower, and the Cathedral of the Intercession [Red Square's St. Basil's Cathedral] and the festive Salute," with the "image of the Order of the Great Patriotic War and the figure "1941-1945," along the

${ }^{200}$ Meike Holscher, "Performances, Souvenirs, and Music: The Diamond Jubilee of Queen Victoria 1897," in Mediation, Remediation, and the Dynamics of Cultural Memory, ed. by Astrid Erll and Ann Rigney (Berlin and New York: Walter De Gruyter, 2009), 184.

${ }^{201}$ Anderson, Imagined Communities, 33.

202 Neepa Majumdar, "The Nostalgia Industry and Indian Film Studies," South Asian Popular Culture 13, No. 1 (2015): 86-87.

${ }^{203}$ Matthew Richardson, "Medals, Memory and Meaning: Symbolism and cultural significance of Great War Medals," in Contested Objects: Material Memories of the Great War, ed. by Nicholas J. Saunders and Paul Cornish (Oxon: Routledge, 2014), Chapter 7. 
circumference of the laurel branches." ${ }^{204}$ The phrase "50 years of victory in the Great Patriotic War" was displayed on the medal's reverse side above a laurel wreath. ${ }^{205}$ Servicemen and civilian personnel who participated on the front in the Great Patriotic War, partisans of the Great Patriotic War, members of the Underground, servicemen and persons of civilian personnel who served during the Great Patriotic War, including the workers of the rear, were eligible to receive the Jubilee Medal. ${ }^{206}$ The Jubilee Medal was another instrument utilised to remind citizens of the debt that they owed to the war victors. Alongside the parades, political speeches and discourses on enhanced veteran welfare, these collectables reaffirmed the notion that the veteran paid the ultimate sacrifice, that their sacrifice was worthwhile and that they deserve respect (and therefore, commemoration). It also showcased the type of awards current and future soldiers could achieve by serving the state in a similar way. These discourses permeated further because they were repeated across a number of domains. This repetition added legitimacy and reinforced the extent of the veteran's sacrifice and society's duty to remember and celebrate, while also ensuring that society was confronted with these discourses throughout the process of commemoration. In this way, society remained exposed to military-patriotic discourses that established that veterans merited privileged roles in society and society's collective duty to commemorate. The Jubilee medal was not the only award established on this date.

The Order of Zhukov was another award founded in time for the Victory anniversary. On the 5 May 1995, Boris Yeltsin presented the Order of Zhukov to numerous high-ranking Soviet military personnel. Yeltsin introduced the award with the following statement:

Dear friends, today on the eve of the anniversary of the Great Victory, prominent military leaders and heroes of the battles of the Great Patriotic War are the first to be awarded with the new Order of Russia, the Zhukov Order... The memory of him approved a new Russian order, a military commander's order awarded to military leaders for merits in the development and successful conduct of major military operations to protect the fatherland. Dear veterans, along with Marshal Zhukov you had the opportunity to fight to bring about the great victory. I think the Zhukov order will be especially dear to you. You deserve this high award for

${ }^{204}$ GARF, f. 10100, op. 1, d. 1003, 7 July 1993.

205 Ibid.

${ }^{206}$ Ibid. 
military labour and can rightfully be proud of it on the eve of the anniversary of the Great Victory. ${ }^{207}$

The Order of Zhukov was not widely awarded, showing the award's greater prestige when compared to the Jubilee medal. The award's creation showcased that the hierarchical spirit of Russia's militarisation efforts during this period existed not only between the military and non-military but was woven within the culture of the military apparatus. This structure was further imposed by Yeltsin's words, which highlighted the glorious deeds of "military leaders for merits in the development and successful conduct of major military operations to protect the fatherland." Zhukov, as a military leader in the Great Patriotic War, embodied attributes of heroism, sacrifice and strategic success in the same sense that recipients of this award embodied Zhukov and his values. As demonstrated already with the creation of the Zhukov monument, Zhukov remained salient in the war commemoration activities of the Yeltsin period.

The Zhukov State Prize was also established for the anniversary date. It was awarded to those who produced "outstanding achievements in the field of military science and technology, as well as the best works of literature and art dedicated to the Great Patriotic War." 208 The prizes attempted to motivate society to support the state's militaristic goals as it essentially encouraged citizens who had not actively fought in the war to support it mentally, spiritually and culturally. Cynthia Enloe considers militarism as a process that is cultural as well as physical. The Zhukov State Prize combined literature and art with militaristic narratives, allowing militarism to pervade Russia's cultural domain. No longer was military power so easily contested as it slipped into public life beyond the boundaries of the actual conflict. In fact, embracing militarism was rewarded.

While only specific groups of people were eligible for these awards, they were still important indicators of state-led efforts to militarise society. By deploying these prizes, the government glorified the anniversary and military institution. They were utilised as instruments to elevate the standing of the military institution in society and ensure continued memorialisation.

207 Yeltsin Centre, f. 21, op. 1, d. 128, 5 May 1995.

${ }^{208}$ GARF, f. 10100, op. 1, d. 989, [Undated: 1993-1995]. 


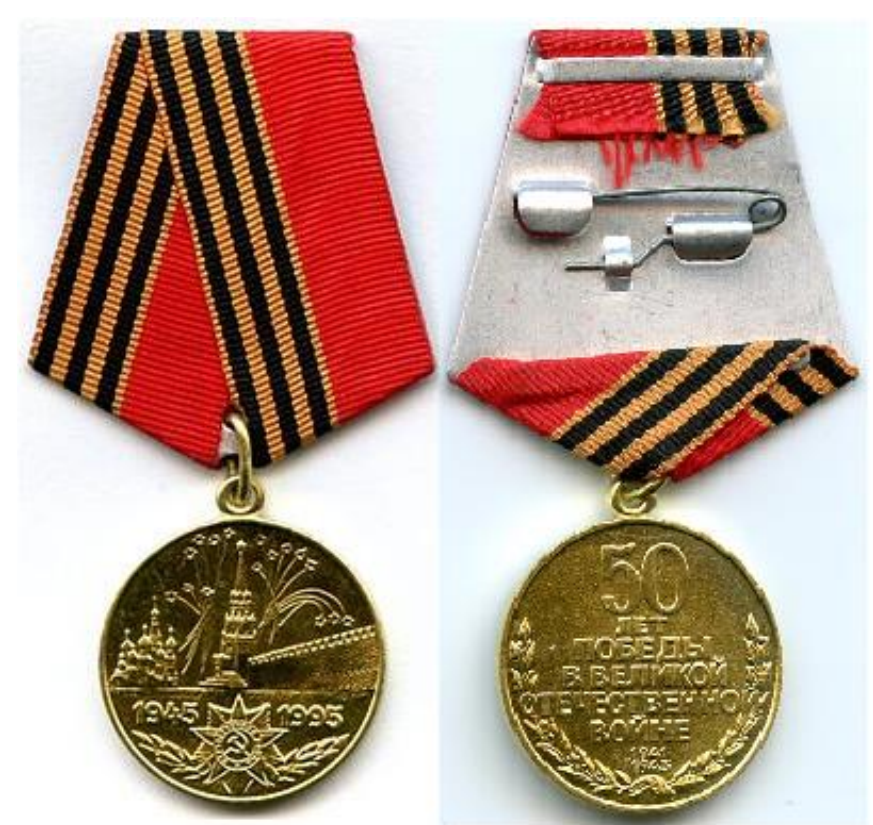

(Figure 13. Commemorative medal released in 1995 for veterans of the Great Patriotic War. On the back of the medal (displayed in right picture) includes the inscription "50 years of victory in the Great Patriotic War") ${ }^{209}$

Alongside new medals and prizes, commemorative postal stamps were released for the anniversary. Robert Jones notes that stamps are "official products of governments, who use them to send messages to the public." ${ }^{210}$ Russian commemorative stamps of 1995 were created to embed militaristic-patriotic messages within society. They fostered positive and nostalgic images of the military and also highlighted the global importance of Russia's role in the war. This is best shown in Figure fourteen. Figure fourteen displays the image of three men, including one soldier standing in front of a tomb, with the image of a concentration camp forming the backdrop of this stamp. The inscription on the top right hand corner translates as, "Liberation of prisoners from Fascist Concentration Camps." The stamp exhibits the devastation caused by the Great Patriotic War, while reminding society of the reason for which the war was waged. This is particularly important in the context of the First Chechen War. As new negative interpretations of the Great Patriotic War emerged, the stamps showed that war was not necessarily futile and that the outcomes can be positive. Ahmadreza Afshar emphasises the role of postal stamps

20950 ann WW2 obverse, last modified 14 October 2020, Wikimedia, https://bit.ly/3ruzC22.

50 ann WW2 reverse, last modified 14 October 2020, Wikimedia, https://bit.ly/3spHlQd. ${ }^{210}$ Robert A. Jones, "Heroes of the nation? The celebration of scientists on the Postage Stamps of Great Britain, France and West Germany," Journal of Contemporary History 36, No. 3 (2001): 403. 
as a form of communication by claiming, "Postage Stamps are always used as a propaganda medium with which they transfer messages to a broad audience." 211 This particular stamp legitimised military action and sacrifice as an action taken for a great cause. It added to the militarisation of society by reaffirming, discourses of veteran sacrifice and promoting collective forms of commemoration by placing it within the wider context of international security.

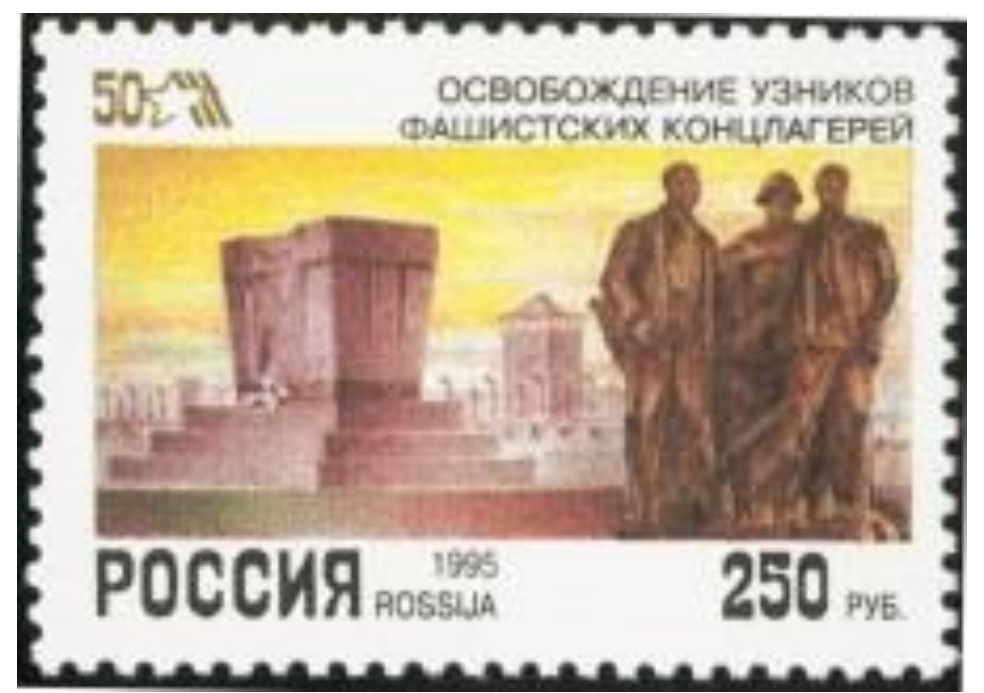

(Figure 14. Commemorative Stamp with the inscription "Liberation of prisoners from Fascist Concentration Camps") ${ }^{212}$

Figure fifteen displays the Eternal Flame of the Fallen, under the same inscription. It depicts a tomb decorated by a helmet and piece of material with a flame emerging from a star-shaped sconce. An abstract representation of planes flying over the tomb sits at the background. Igor Cusack observes, "Stamps can be seen as small pieces of art." He claims that previous scholars have failed to uncover the ideological nature of this form of art. The stamp symbolises mythical timelessness. The Eternal Flame personified the perpetual memory of the Great Patriotic War, providing a visual reminder of the sacrifices made for the war, and therefore justifying lasting forms of commemoration.

${ }^{211}$ Ahmadreza Afshar MD, "A Brief Iranian Medical History through Commemorative Postage Stamps," Arch Iran Med 13, No. 2 (2010): 161.

212 Stamp Russia 1995 Konclager, last modified 18 November 2020, Wikimedia, https://bit.ly/3w8eYbq. 
The postal stamp displayed in Figure sixteen exhibited an image of Marshal Zhukov at the Victory Day Parade reflecting his role as inspector in the first Victory Day Parade of 1945. Forming the background of this stamp were visuals of armed formations. Zhukov was sitting on a horse, which closely replicated the monument on Manezhe Square. The replicated image of Zhukov added to his immortalisation. Zhukov became a symbol of the Great Patriotic War, which demonstrated Zhukov's indispensable role in society's understanding of the war and its victory. Zhukov's prominence in the 1995 Victory Day celebrations created continuity across various commemorative landscapes. He became an icon that others could measure themselves against, glorifying the role of the military service and the idolatry that comes from it.

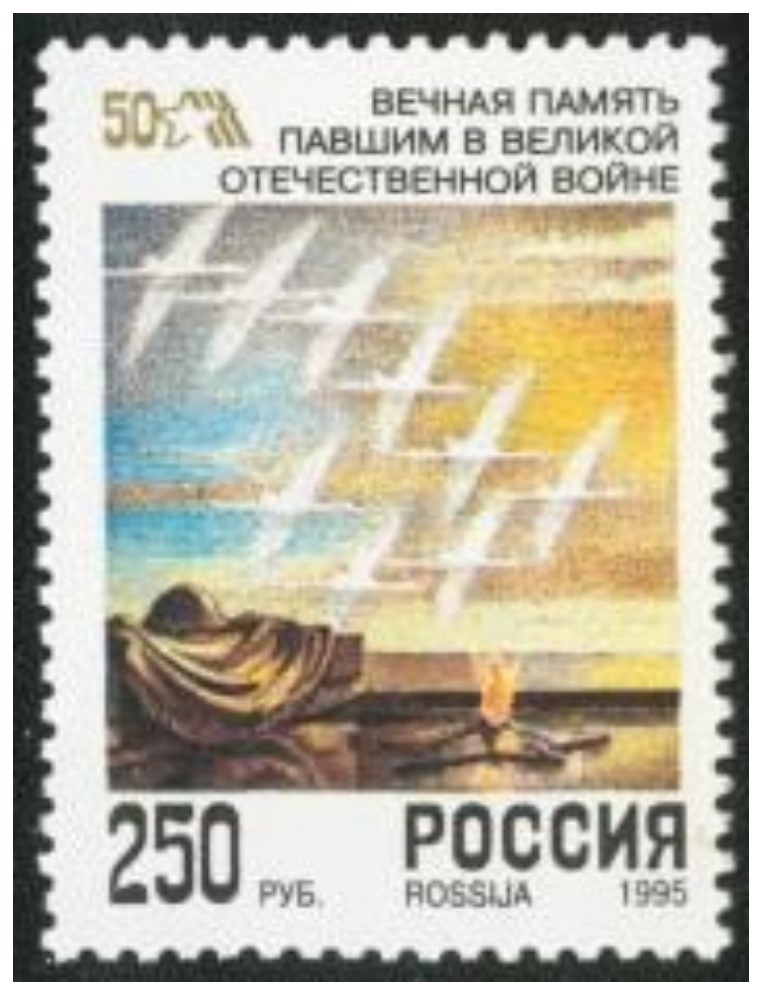

(Figure 15. Commemorative Stamp of Eternal Flame of the Fallen with the inscription "Eternal memory to the Fallen in the Great Patriotic War") ${ }^{213}$

213 "Russia stamp 1995 No. 211," Wikimedia, last modified 31 October 2020, $<$ https://bit.ly/2P5L7Qx> Copyright Wikicommons. 


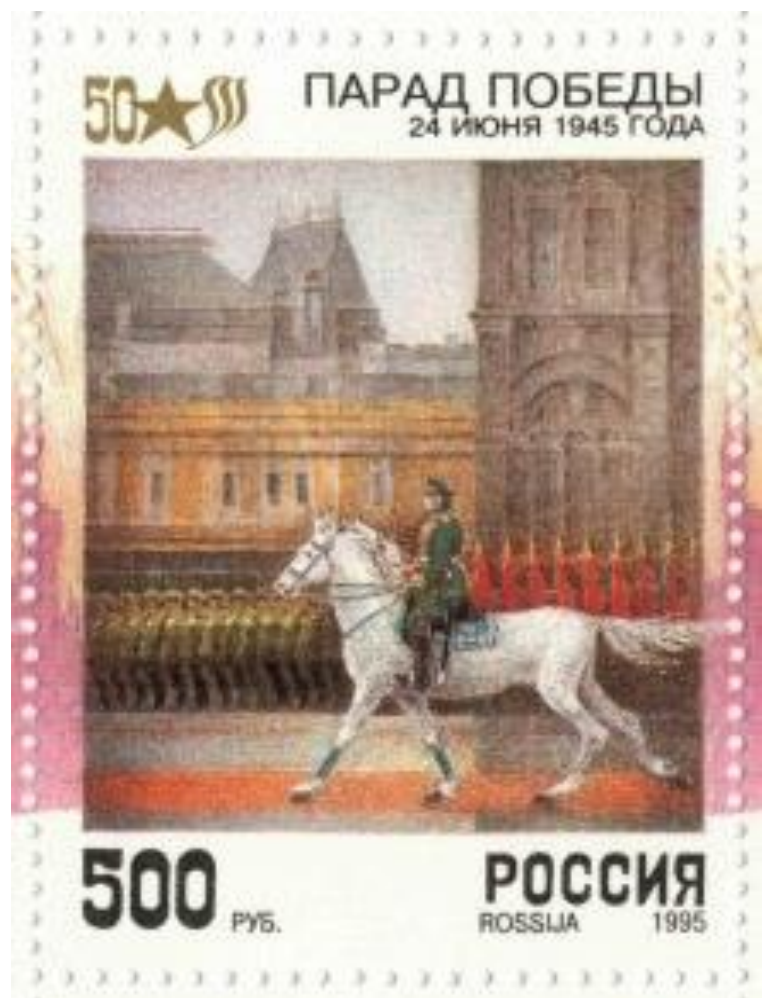

(Figure 16. Commemorative Stamp of Marshall Zhukov in front of crowds at the First Victory Day Parade in Red Square. Includes the inscription "Victory Parade") ${ }^{214}$

Alongside the commemorative postal stamps, the government introduced numerous coins created for the $50^{\text {th }}$ anniversary. Josh Lauer notes, "The effectiveness and worth of paper currency does not depend on visual persuasion of rhetoric." 215 This is because currency is functional and necessary. Money's necessary role makes it a popular medium to convey and transport messages. The symbolic power of currency is widely noted in literature on nation-state building and legitimacy. State leaders and icons are popular images on currency because they act as legitimisers, validating the institutions they represent. Jan Penrose and Craig Cumming's work on bank note iconography in Scotland outlines the communicative aspects of currency, linking the use of the thistle to represent Scottish-ness. ${ }^{216}$ The coins created for the $50^{\text {th }}$ anniversary were also used to communicate messages. These coins displayed images of famous battles linked to the Great Patriotic War, war outcomes and important military figures. As "vehicles of state propaganda," these coins satisfied the government's desire to issue militarised-patriotic

214 "Russia stamp 1995 No. 214," Wikimedia, last modified 19 November 2020, <https://bit.ly/2O5VXp6> Copyright Wikicommons.

215 Josh Lauer, "Money as Mass Communication: U.S. Paper Currency and the Iconography of Nationalism," The Communication Review 11, No. 2 (2008): 11.

${ }^{216}$ Jan Penrose and Craig Cumming, "Money Talks: Banknote iconography and symbolic constructions of Scotland," Nations and Nationalism 17, No. 4, (2011): 830. 
messages beyond the 24-hour scope of the Victory Parade. ${ }^{217}$ As functional and necessary items, they were greater mediums "of mass communication," since they could not be contested for their required use in everyday life.

The coins offered a nostalgic representation of the military, depicting specific historical moments rather than presenting the various concepts relating to war. In doing so, the coins demonstrated desired militarisation of society despite a breakdown and regime change. Figure seventeen displays three commemorative coins honouring the "50th Anniversary of the Great Victory." The image of a popular Soviet wartime propaganda poster by Irakly Toidze entitled, "The Motherland is calling us," is on the first coin. The central coin depicts a group of Soviet soldiers during a tank attack, while the coin on the far right includes an illustration of Soviet military sailors situated in front of a warship and warplane. These coins exhibit historical snapshots of war, using images that create an authentic image of the war, drawing upon historical symbols to engage with older generations who lived during this period. They also acted as a cue for younger generations without a direct connection to the war. Some of the coins commemorated specific Great Patriotic War victories.

Figure sixteen, for example, exhibits three commemorative coins memorialising the Soviet's role in the liberation of Europe from Fascism. The coin on the far left displays four Soviet Soldiers in military action, with the Hungarian parliament building in the background. "Budapest 13.02.1945," is inscribed on the bottom of the coin. The central coin depicts an image of two soldiers, one American and Soviet. The American soldier is leaning on the Soviet Soldier's shoulder. They face each other, which can be considered as a representation of the bond between them. They stand against a backdrop of both the American and Soviet flags. "Meeting on the Elbe 25.04.1945," is inscribed on the base of the coin. The last coin illustrates the image of Soviet soldiers sitting atop a tank, receiving greetings from residents of the city. The tank is positioned in front of Prague's Old Town Hall. The coin is inscribed "Prague 09.05.1945." These coins, released under the title "The Liberation of Europe from Fascism" portrayed the Soviet Union's international role in the Great Patriotic War. While the Soviet Union's primary goal was to defend its own borders, it liberated other countries from Nazi Germany. Yeltsin echoed

217 Jacques E. C. Hymans, "East is East, and West is West? Currency Iconography as Nation-Branding in the wider Europe," Political Geography 29, No. 2 (2010): 97. 
the significance of the events displayed on the coins in his Victory Day Red Square speech. He claimed:

We remember the Reichstag Soldier jubilant and the handshake of the Elbe and the job of the liberated world, this memory is sacred...For the sake of a common goal, Europe's best sons and daughters shoulder to shoulder in the liberation struggle, participated in the Great Resistance Movement...Dear guests, we are united. Not only in our hatred of fascism. We are united in our efforts to preserve the future generations. ${ }^{218}$

As necessary, functional everyday items, the coins were in constant use, moving from one family to the next after each monetary transaction. These coins were forums of communication, decorated to transport a series of discourses relating to the $50^{\text {th }}$ anniversary of the Great Victory. Some of these coins were decorated with iconic images from the time of the conflict, while others popularised the global impact of the Soviet Union's victory. Together, they legitimised the war effort, valorised the veterans' sacrifice and justified the memorial event. Together, the political discourses, elaborate parades, new commemorative landscape and souvenirs ensured society was confronted with militaristic-patriotic discourse. Numerous lines were drawn across the commemorative landscape, linking together common discourses of sacrifice and state loyalty. These discourses acted to legitimise the actions of the veterans and to glorify the institution that they were attached too, providing images of sacrifice, glory and heroism.
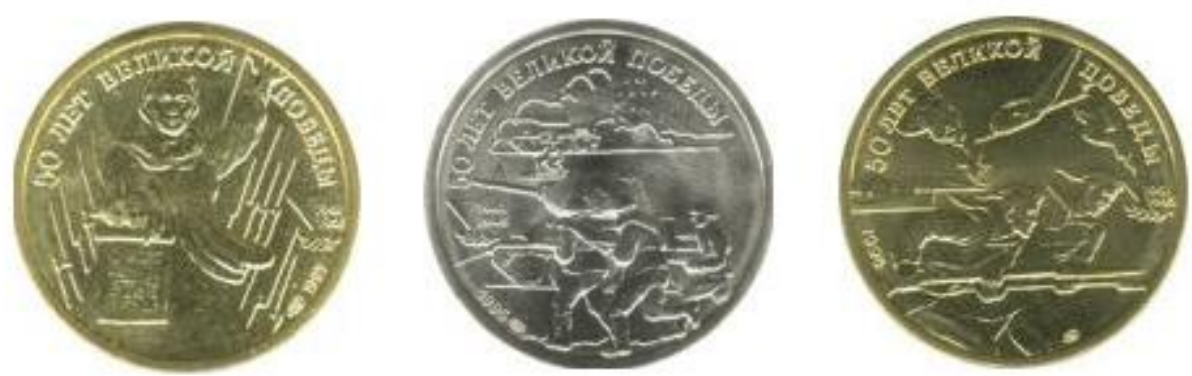

(Figure 17. Three commemorative coins created for the GPW anniversary, all issued on the 28.04.1995 with the inscription " $50^{\text {th }}$ Anniversary of the Great Victory $)^{219}$

${ }^{218}$ Yeltsin Centre, f. 21, op. 1, d. 130, 9 May 1995.

${ }^{219}$ For the left coin, please see: "50 years of the Great Victory," Wikimedia, last modified 3 July 2019, <https://bit.ly/3d5RT0g> Copyright Wikicommons.

For the central coin, please see: "50 years of the Great Victory," Wikimedia, last modified 13 June 2019, <https://bit.ly/3flGaOc> Copyright Wikicommons.

For the right coin, please see: "50 years of the Great Victory," Wikimedia, last modified 3 July 2019, <https://bit.ly/2PykovM> Copyright Wikicommons. 

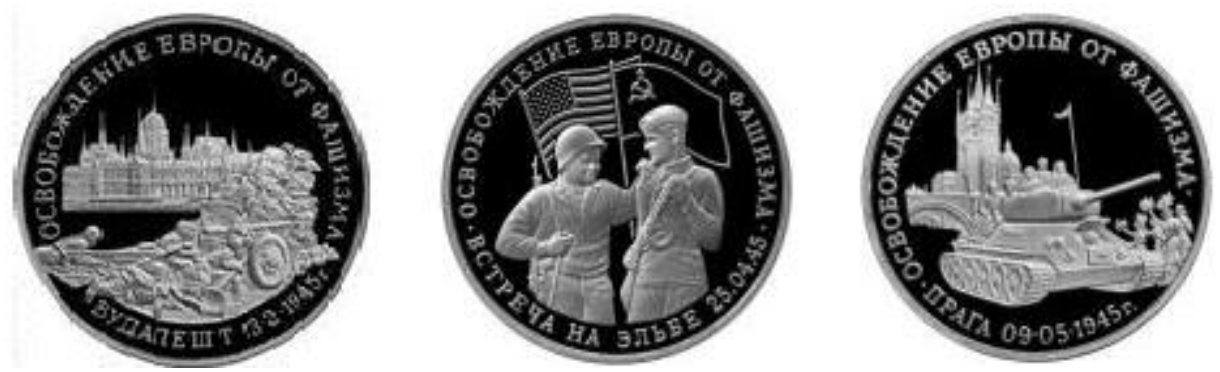

(Figure 18. Commemorative coins created for the GPW anniversary, issues between 14.02.1995 and the 21.04.1995 under the inscription "The Liberation of Europe from Fascism) $)^{220}$

The souvenirs listed above are paramount to our understanding of identity and tradition formation in the Post-Soviet Period. They validated the military's societal importance, despite cuts to military budget and a rising number of draft evasions during the First Chechen War. Souvenirs are unique forums of communication in the sense that some are functional and crucial to everyday life. Because of this, they are circulated more widely and regularly, and in the private domain. Some symbols on the coins, like the propaganda poster, were recognisable and evoked nostalgic sentiments. The duplicated images of Zhukov on the stamps are one example of how these souvenirs "provide an image field for the play of representation of heroic subjects."221 The image of Zhukov on a horse, reminiscent of his role in the Great Patriotic War parade, was a familiar visual across numerous commemorative domains. This reinforced Zhukov's important role in the victory, but also created a respectable role model, someone who embodied desirable patriotic values of heroism, state loyalty and sacrifice.

${ }^{220}$ For the left coin, please see: "Liberation of Europe from Fascism- Budapest," Wikimedia, last modified 10 June 2019, <https://bit.ly/3ctPLR7> Copyright Wikicommons.

For the central coin, please see: "Liberation of Europe from Fascism - Meeting on the Elbe," Wikimedia, last modified 11 June 2019, $<$ https://bit.ly/3rvic5a $>$ Copyright Wikicommons.

For the right coin, please see: "Liberation of Europe from Fascism- Prague," Wikimedia, last modified 19 June 2020 <https://bit.ly/3wgwXN8> Copyright Wikicommons.

${ }^{221}$ T. Unwin and V. Hewitt, "Banknotes and national Identity in Central and Eastern Europe," Political Geography 20, No. 8 (2001): 1014. 
Both the monuments and the commemorative souvenirs played a paramount role in the militarisation of society. As material objects, they permeated society beyond the national holiday date. Entrenched with militaristic symbols, they referenced veterans' sacrifice, promoted the image of Russia as a liberator and established a set of war icons that helped sanctify the military institution. In addition, prominent discourses on the veteran's sacrifice fed into other societal discourses, thus legitimising the necessity for annual commemorations. As a result, it satisfied the goals of the government in facilitating the militarisation of society.

The symbolic capital amassed from the organisation and construction of commemorative activities, as products of the $50^{\text {th }}$ anniversary, were instrumental in the persistence of societal militarisation in the formative years of the Russian Federation. This chapter has shown that the parades and organisational discussions aimed to glorify the veterans' sacrifice and their associating institution. In light of the first Chechen War, which was fought during this celebration, this commemoration had the exciting qualities necessary for fostering positive attitudes towards the military. The memory of the Great Patriotic War was exploited by the Russian political elites, who used Russia's war-torn past to promote military preparedness. Political and historical discourses emphasised historical threats, which justified the maintenance of a strong military. Outlining the veterans' sacrifice also served another purpose. By accentuating the veterans' courage and selflessness, commemoration became a currency used by Russian society to demonstrate gratitude for their ancestors' sacrifice. Yet the notion that future generations will "remain indebted" to the veterans, meant that full payment would never be received. The sacrificial discourses facilitated the persistence of societal militarisation, effectively shifted responsibility from the state and ensuring the motivation of the memorialisation became an integral part of civic duty.

The parades were elaborate spectacles demonstrating military potency, gratitude for veterans' sacrifice and glorification of the Armed Forces. Tsarist and Soviet rituals continued into the post-Soviet period through exciting displays and rituals revived during the 1990s. The Poklonnaia Parade showed Russia's military potential by choreographing an intricate spectacle of precision and military power. The parades were entertaining. The anniversary date's popularity, and its ability to draw in support, depended on the theatrical aspects of the parades. The use of Soviet symbols in a highly choreographed parade sequence ensured that the spectators were confronted with a nostalgic and symbolic 
display of militarised patriotism, which created a genuine representation of war. The symbols used in this "elaborate military pageant" were instrumental in the militarisation of society. Unlike educational textbooks and discourses in the media, the symbols and parade choreography acted as an exciting visual representation of the war, which effectively linked together the past with current and future day ambitions.

The commemorative souvenirs, including coins and stamps were most effective in transferring messages to the society. As functional pieces, the symbolisms they carried were less likely to be contested. The commemorative mementos, alongside the messages within the parades, helped outline the victorious elements of the war, overshadowing the horrors of war by emphasising the Soviet Union's eventual victories. These messages were extremely instrumental, especially in the context of the war in Chechnya. They propagated the notion that while the Great Patriotic War was destructive in some ways, it was necessary, possibly changing attitudes towards the Chechen War and its objectives. The erection of commemorative monuments also facilitated the militarisation of society beyond the date of the victory parade, as symbolic concrete reminders embedded in Moscow's architectural landscape. These monuments, built in areas of political importance, highlighted the military's elevated standing in Russian society and place in national identity, also demonstrating its significance to Russia's political agenda.

The sensational military display, alongside the creation of the commemorative monuments and keepsakes, were effective mechanisms of militarisation in 1990s Russia. They enabled the government to create discourses that emphasised veterans' sacrifice, which reaffirmed notions that military service was a worthwhile civic duty and that veterans deserve respect. By holding the parades, Russia revived Tsarist and Soviet traditions with the elaborate displays of military grandeur acting as a continuous reminder of the victory once gained and possible again. These parades were successful and have gained further popularity under the leadership of President Putin, who uses these parades for his own militarisation project. 


\section{CONCLUSION}

In July 2020, Russia adopted a new constitution via a state referendum. The new constitution was a reconfiguration of the one created during the Yeltsin period. It now includes a clause on "historical truth." As noted on the State Duma website, "The Russian Federation honours the memory of defenders of the Fatherland and protects historical truth. Diminishing the significance of the people's heroism in defending the Fatherland is not permitted,' the text of the new law says. Children are declared the most important state policy priority in Russia. The state should create conditions that contribute to the comprehensive spiritual, moral, intellectual and physical development of children, fostering patriotism, civic engagement and respect for elders." ${ }^{11}$ In the lead up to the referendum, and on the $24^{\text {th }}$ June 2020 , Putin spoke at the Victory Day parade of Russia's duty in perpetuating the "pure truth" of the Soviet victory in the Great Patriotic War; that the burden fell predominately on the Soviet Union and that great sacrifices were made in order to achieve this victory. He called for the truth to be passed on to children and grandchildren, further adding to the immortalisation of the historical event. ${ }^{2}$

Just twenty-five years prior to Putin's "pure truth" speech, discussions within the State Duma spoke of Russia's need to preserve the truth of the Great Patriotic War, and to warn off revisionist accounts of the Soviet victory. It was under Yeltsin that current generations were told of their duty to preserve the memory of those who sacrificed themselves in the war and to pass that memory onto future generations. ${ }^{3}$ It was also Yeltsin who aimed to immortalise and mythologise that historical event, with the Federal Law of December $8^{\text {th }}$ 1997, titled, On immortalising the Soviet People's Victory in the Great Patriotic War of 1941-1945, placing a permanent Guard of Honour at the Tomb of the Unknown Soldier.

As with the cult of the Great Patriotic War, the success of Russian militarism in contemporary Russia is often attributed to Vladimir Putin. However, this is not the case.

\footnotetext{
1 "What changes will be in the Constitution of the Russian Federation," duma.gov.ru, 12 March 2020, accessed 15 July 2020, http://duma.gov.ru/en/news/48039/.

2 "Putin's Victory Day Parade Speech," Youtube video, 1:34:16, posted by Russia Today, steamed live 23 June 2020, accessed 24 June 2020, https://www.youtube.com/watch?v=z4pFnlr0zck.

3 "Istoricheskii parad v chest' 50-letiia Pobedy v Velikoi Otechestvenoi Voine." GARF, f. 10100, op. 1, d. 1003, 1. 29-30, March 1995.
} 
In fact, many of the prevailing discourses of the Putin regime were rooted in the Yeltsin era. This thesis set out to understand militarisation in the 1990s Russia. It challenged the widespread assumption that the collapse of the Soviet Union constituted a break in the militarisation of society, arguing that literature on the topic saw cuts to defence budgets and the declining prestige of the military as an indication of demilitarisation, with little regard for the cultural dimensions of militarisation. Scholars claiming that the physical demise of the military showcased a process of demilitarisation were not entirely wrong, but were far too focused on what the military was lacking from a physical perspective to appreciate the cultural continuation and revival of military narratives and rituals amongst society. These accounts focused on one aspect of militarisation but claimed to represent the process in its entirety.

The thesis addressed these limitations by focusing on prominent societal discourse from a top-down perspective, to demonstrate how and with what mechanisms the state and other dominant societal institutions were popularising and promoting pro-militaristic narratives. It achieved this through the method of Critical Discourse Analysis and the examination of documents located at the State Archive of the Russian Federation, the Russian State Library, and the Yeltsin Centre. The thesis found that the militarisation of society persisted beyond the collapse of the Soviet Union because the narratives of ancestral sacrifice and a siege mentality remained dominant in the discourses of the four domains under review. These narratives, as in Tsarist Russia and the Soviet Union, made Russian militarism resilient to regime change and allowed for the continued militarisation of society. The thesis showed that Yeltsin reproduced and established a number of militarised rituals that have formed a basis for Putin's own militarisation efforts. It is through understanding the mechanisms of militarisation in place under Yeltsin that we can pinpoint the origins of the militarised traditions and myths that are located under Russia's contemporary leadership.

\section{WIDER IMPLICATIONS}

What does this study tell us about Russian identity more generally? Russian identity is built on militarism and its anxieties lie largely within its geography. Russia is a vast country. With no natural barriers on its western boundaries inviting invasion and its multi-ethnic population threatening divisions within society, Russia has relied on its military in order to feel protected. From the West, Russia has experienced many 
invasions, from Poland, Sweden and Germany. Japan during World War Two and the growth of China threatened Russia on its Eastern borders. The Tsarist and Soviet regimes aimed to face this threat by creating 'buffer zones' through foreign campaigns: Peter I with his annexation of Narva and Catherine II with the annexation of Crimea. The Soviet Union expanded into Eastern Europe under the premise of Communism. During both regimes, society was mobilised against outside threats in an educative setting, through administrations and in the media. Both the Tsarist and Soviet regimes used their autocratic power to enforce such mobilisation. The onset of democracy threatened the discourses established during these periods, initially questioning the level of Western threat and the over-exaggerated and costly security measures in place. Over a short amount of time, even democracy fell prey to militarism, with the discourses of a vulnerable Russia and duty to protect against hostile neighbours gaining salience alongside hostility to the strengthening of NATO and Islamic fundamentalism. In this context, militarism united Russia's multi-ethnic society under stories of a common enemy, justified strong autocratic measures in lieu of personal freedom and has formed the basis of Russian nationalism and the strengthening and maintenance of a strong military apparatus.

What does the thesis tell us about Russian militarism? The thesis shows that Russian militarism goes well beyond the material values of the military and permeates within society in a multitude of ways. Narratives of external and internal threat unite society and bolster leadership, in the same way that stories of sacrifice instil a desire to defend the legacy of such heroes onto the current and future generations of Russia. Russian militarism is not dependent on a strong military apparatus, but its great power status is. Rather, Russian militarism depends on Russia's vulnerability, which intensifies militaristic-nationalistic action, justifies increased funds towards militaristic equipment and pursuits and mobilises societal consciousness on the home front. Russian militarism depends on traditions; a tradition of historical conflict and invasion, ritual of Russian sacrifice for the greater good of society and the world and tradition of the military in solving nonmilitary issues. Scholars of Russian and Soviet history often frame Russian militarism within the concept of Samobytnost', which acknowledges Russia's unique path, underlined by authentic military ideas, culture, values and goals. ${ }^{4}$ Many of the traditions that Russia created, however, were adopted during the European enlightenment.

\footnotetext{
${ }^{4}$ Eugene Miakinkov, War and Enlightenment in Russia: Military Culture in the Age of Catherine II (Toronto: University of Toronto Press, 2020), 129.
} 
What is unique to Russian militarism is, in fact, what motivates it. Russia's insecurity triggered by its unique geography influences Russia's need to maintain a mobilised society on a grassroots level, to show off its military might in elaborate parades and justify excessive spending on the military apparatus. The term Samobytnost' does, however, explain the messianic nature of Russian militarism, which showcases Russian people, united, as saviours of the state and the world. The thesis demonstrated that veterans of the Great Patriotic War, and participants of war (in the historical textbooks) were immortalised through their glorification in societal narratives. The growing relationship between Russia's military and the Orthodox Church denotes a wider aim of the Putin regime to tie together images of the Russian veteran and soldier within religion. ${ }^{5}$ It shows that Russian militarism requires a hierarchy in which the veteran and soldier is deemed above a nonparticipant of the military and war.

\section{QUESTIONS OF THE THESIS}

In an attempt to understand the state of militarisation under Boris Yeltsin, the thesis answered three questions: 1) what top-down mechanisms militarised Russian society?; 2) What discourses and narratives were prominent in the four societal domains, and in what way did they contribute towards the militarisation of society?; and 3) How did the discourses within the different societal domains fit into (and add to) current literature on the state of militarism and militarisation in Post-Soviet Russia?

\section{What top-down mechanisms militarise Russian society?}

The thesis defined cultural militarisation as a function of "public pedagogy" and as a process where there is a "pervasive injection of military themes and references into the cultural arena." Four domains identified as places of knowledge-exchange included the media, education sector, veteran welfare, and commemorative outlets. The educational sector, for example, is one of socialisation - producing Russia's new

\footnotetext{
${ }^{5}$ Robert A. Saunders and Vlad Strukov, "Historical dictionary of the Russian Federation: Samobytnost," enacademic.com, 2010, accessed 16 July 2020, https://russian_federation.enacademic.com/504/Samobytnost.

${ }^{6}$ Giroux, "War on Terror," 211.

Waley-Cohen, "Militarisation of Culture in Eighteenth-Century China," 279.
} 
generations, while the media and political institutions (including commemorative) were of a pedagogic nature in their ability to spread information and knowledge to a mass audience. $^{7}$

Chapter two introduced the media as a mechanism of militarisation, or "tool of warfare" in its ability to bring military issues to the forefront of public consciousness. This was achieved through the sheer prominence of military themes in the print media, influenced by poor economic conditions and its need to increase readership numbers. The media also strengthened societal militarisation through emphasis on Russia's vulnerability and othering techniques. This did not mean that such discourses led to increased numbers joining the military. However, it did expose the public to a militarised worldview.

Chapter three utilised the classifications created by Robert Sutherland in his study on ideology in children's books in order to assess the discourses within historical educational textbooks published in the 1990s. These classifications included the Politics of Advocacy and the Politics of Attack. The education system can be considered a vehicle of militarisation by highlighting a pattern of historical warfare, the vulnerability of Russia and stories of glorious heroes. It allowed Russia's youth to reflect upon the current conditions in which Russia found itself. Russia's youth of the 1990s are adults under the Putin regime; the chapter best shows how and why Putin's militarisation project has been received so well in contemporary times.

Chapter four captured the process of militarisation through the concept of sponsorship, arguing that the provision of enhanced social welfare created an informal hierarchical system in which the veteran and soldier sat at the apex of society. Through a comparison with sports and commercial sponsorship practices, the pension and military social welfare reforms made during the Yeltsin period showed the state's determination to alter attitudes towards the veteran population and highlight the veteran's heroic acts in an effort to militarise society. The attributes associated with the military, such as heroism, courage and loyalty, are those the state wanted to popularise in society, and thus by 'sponsoring' the veteran and soldier with exclusive pensions and benefits, the government deemed them worthy of receiving such provisions measured by their military service to the state.

\footnotetext{
${ }^{7}$ Meyer, "Politics of Memory," 176.
} 
Chapter five argued that commemoration in Russia was a vehicle for militarisation through the cultivation of a debt ideology. It was the case study chapter that brought together the theories and understandings of cultural militarisations found in the previous chapters. In this process, discussions made around the commemoration date, both at the planning stages and in the actual event, emphasised the veterans' sacrifice and their loyalty to the state. Society was then offered the opportunity to repay this debt through their participation in commemorative events. The introduction of the Victory Day celebration as an annual event meant that members of society who had paid their debt through their participation in commemorative activities went through the process repeatedly, year by year.

The different mechanisms of militarisation located in this study showcase that militarisation goes beyond its physical dimensions. Rather, we should consider the word militarisation as an umbrella term, and even phrases such as cultural militarisation and physical militarisation as a second-tier umbrella, which also encompasses a number of dimensions. Physical militarisation, for example, would be an umbrella term for studies on budget, recruitment, weapons procurement, while cultural militarisation includes education, use of memory, social welfare and the media. The various mechanisms in play during the Yeltsin period demonstrate that the cultural militarisation of society persisted, while the physical dimensions of the military continued to decay.

What discourses and narratives were prominent in the four societal domains, and in what way did they contribute towards the militarisation of society?

The thesis uncovered two main discourses that spanned across the different chapters. The most prominent discourse was that of a weak Russia in a world full of hostile enemies. As documented throughout the thesis, this discourse is one that had prevailed in Russia prior to the collapse of the Soviet Union and has been able to gain relevance under the different regimes. Russia's history has played an integral role in the cultivation of such discourses, with stories in Russian historical textbooks and in the commemorative events and even in reference to NATO acting as a reminder to Russian society that Russia has faced a number of invasions and conflicts. The second dominant discourse was of ancestral sacrifice and loyalty to the state. Well documented in Russian historical education and in political discussions, the emphasised heroics of Russia's forebearers forged a sense of civic duty to protect and to continue the victories of the past. 
As in Russia today, there was a clear (while gestured) prioritisation of the military and veteran community justified by their (militarised) service to the state.

In chapter two this discourse found its roots in the conflicts located in the former Soviet region and in Chechnya. The media demonised the Chechen population, characterising them as criminals, terrorists and bandits. Yeltsin legitimised Russia's intervention in the region on the basis of re-establishing law and order. ${ }^{8}$ Various newspaper interviews confirmed that a prevailing generalisation of the Chechen population had emerged on the basis of societal discourse. NATO became a topic of interest more seriously in the later stages of the 1990s. Reports by the media on NATO had a profound impact on Russian opinion, with accounts of Russian people boycotting American goods, and growing discontent towards Russia's possible membership. Some newspapers even speculated that NATO action in Kosovo was a practice test for its eventual intervention in Chechnya. While the media was not outwardly pro-war, it was anti-NATO. This siege mentality was also dominant in the educational sector.

Chapter three analysed 25 Russian history textbooks of various periods of Russian history and a number of state documents on the topic of youth historical education during the 1990s. First, the textbooks dedicated a vast amount of space to the topic of military and warfare, emphasising Russia's historical ties with conflict - and therefore adding further impetus to the discourse of Russia as a besieged fortress. Students were able to read about the vulnerable state of Russia's army in the formative years of Peter I's leadership and hold a mirror to events taking place in 1990s Russia. It was through military modernisation that Russian leaders aimed to solve the military's inefficiencies, adding legitimacy to Russia's need for a strong and modern military apparatus in contemporary times. Such findings prompt further questions; is the success of Russian militarisation contingent on the use of history? Russia's historical past has been used by the state to achieve its militaristic aims; the history of Russia's militaristic past adds grounds for a strong defence sector. However, Russian militarism is also rooted in messianic-style concepts, glorifying the role of the military as saviours of the state, who "liberated Russia [and] Europe from the mouth of the Fascist plague." 9 The discourse of ancestral sacrifice and heroism found salience in the educational historical textbooks of the 1990s. Under the classification of Politics of Advocacy, Russian historical actors were

\footnotetext{
${ }^{8}$ Yeltsin, Midnight Diaries, 54-59.

${ }^{9}$ GARF, f. 10100, op. 1, d. 1003, 30 January 1995.
} 
largely glorified for their actions, while negative aspects of their leadership were muted. Students were told that they should be proud of their ancestors "glorious deeds." Political actors and veteran groups called on the youth to join with the veteran population, to show their gratitude for their sacrifice by holding parties, concerts and cleaning memorials. ${ }^{10}$

The discourse of ancestral sacrifice and loyalty to the state was most noticeable in chapters four and five. Chapter four emphasised the sacrificial deeds of veterans and Russia's current military in order to legitimise the provision of enhanced benefits and pensions. The documents found at GARF and the online archives of the Yeltsin centre showed that social welfare changes were justified on the basis of worthiness. The military and veteran population were deemed most deserving of the benefits based on their service to the state. In doing so, the government created a catalogue of values that needed to be showcased through service in a military way in order for a person to claim the same benefits. It created a sense of citizenship in which the ideal citizen would be rewarded for their role in the protection of the state. In addition, the government sought to extend the definition of the veteran, on the grounds that 'workers of the rear' were just as important in the Soviet Union's victory over Nazi Germany. The extension was symbolic since it signified the victory of the Great Patriotic War as possible only with the contribution of the entire society. The $50^{\text {th }}$ anniversary of the Great Patriotic War drew upon both discourses in order to popularise the Armed Forces and reproduce the significance of the Soviet victory over Nazism into contemporary consciousness. The anniversary emphasised the heroic deeds of the veteran population, pushing the responsibility of continued commemoration onto the current and future generations of Russia. The debt ideology created as a result acted as a form of guilt, in which gratitude could only be showcased through participation in commemorative activities. It was framed as a sense of civic duty, in which the soldiers' duty was to protect society, while society's duty was to protect the soldiers' memory. This discourse was furthered in the monuments and collectables unveiled for this event with the image of the weeping mother over the soldier in the Hall of Remembrance (Zal pamiati I skorbi) and the Soldier of Victory in the Hall of Glory (Zal slava), mythologising the memory of the Great Patriotic War soldiers. Yeltsin and Grachev used the events to speak of new and emerging threats and security concerns facing the country, emphasising the important role of the military to the defence of Russian society.

${ }^{10}$ GARF, f. 10100, op. 1, d. 1003, 1. 29-30, March 1995. 
Both discourses worked in a tandem, with sacrifice and loyalty to the state acting as the solution to the external dangers threatening Russian security. These discourses have formed the basis for the militarisation efforts of former regimes in Russia and have found salience under Vladimir Putin. It is through the reproduction and revival of such discourses that Russian militarism has been able to persist beyond regime change, underpinning Russia's complex relationship and reliance on the military.

How do the discourses within the different societal domains fit into (and add to) current literature on the state of militarism and militarisation in Post-Soviet Russia?

Beyond the main purpose of investigating militarisation in the Yeltsin period, the thesis made a number of contributions to our understanding of Russian militarism. First, it challenged the dominant viewpoint that 1990s Russia was a decade of demilitarisation. As a result, it disputed the claim that the successes of current militarisation efforts in Russia are an outcome of the Putin administration and argued instead that today's trends are rooted in Yeltsin's Russia. Finally, the thesis demonstrated that the development of societal militarisation is situated in processes beyond the scope of its physical dimensions.

Literature on the Post-Soviet period largely argued that 1990s Russia was undergoing a process of demilitarisation. This viewpoint is not entirely wrong, yet scholars primarily examined documents, subjects, individuals and institutions with a direct link to the military. ${ }^{11}$ Militarisation is not limited to the material aspects and is situated in areas beyond its physical dimensions. Scholars like Cynthia Enloe and Henry Giroux pinpointed that the process of militarisation goes beyond the military institution, and is also cultural, institutional and behavioural. Scholarship on the Yeltsin period, however, is largely outdated. Over the last couple of years, vast research has been conducted within the subfield of critical military studies, with scholars such as Victoria Basham, Linda Åhäll and Jonathan Dunnage et al., updating and redefining the boundaries of militarisation and militarism. ${ }^{12}$

\footnotetext{
${ }^{11}$ One of the only studies that currently exists, which links together the state of Russia's military from a cultural and societal perspective is an edited volume assembled by Jennifer G. Mathers and Stephen Webber. Accounts within the volume note how films of the post-Soviet period demonstrated a soldier's loss of identity as a result of decaying military power, highlighting that the Russian people were nostalgic for a strong military. 12 For research on militarism and militarisation, please see: Åhäll, "The Dance of Militarisation," 154-168; Victoria Basham, "Waiting for war: Soldiering, temporality and the gendered politics of boredom and joy in military spaces," in Emotions, Politics and
} 
A growth of such literature prompted a revision of the Yeltsin period. Chapter one sought to define the concept militarism and militarisation, identifying that the power of militarisation is not only measured by its material value but also its bureaucratic dimensions, the habits of institutions and within the cultural sphere. Scholars of Russian militarism under Putin have attempted to do this. White and Kryshtanovskaya, for example, showed that military power is not totally driven by the physical aspects, but that actually, it is the people who are in power that have control over the material.

Yet, a rereading of Yeltsin's Midnight Diaries showed that leaders with a civilian background can also hold militarised worldviews - especially considering that Yeltsin was not entirely separated from militarism, having been socialised in a militarised Soviet Union. Yeltsin's presidency was shaped by war. He began his democratic political career on top of a tank, retiring from office only two months after the start of the Second Chechen War. In between, he launched 'peacekeeping' missions in the former Soviet space, sent troops to Chechnya and called on the military's help to solve political crisis. Beyond the use of the military in a physical way, Yeltsin revived militaristic traditions of the state, rebranding the Soviet victory in the Great Patriotic War as a Russian one in an effort to unite Russian citizens, to inform current and future political goals and reemphasise threats to Russian security. These acts of revival by Yeltsin show that the cult of the Great Patriotic War under Putin was built on the foundations created by Yeltsin's administration. Yeltsin reinvented the Victory Day parade, adopting rituals of the Soviet era and adding new traditions, such as its annual occurrence. The speeches of Yeltsin, calling for the continued memorialisation of the event and its passing down to future generations are calls that are replicated by Vladimir Putin. Veteran organisations and State Duma deputies made efforts to join the youth with veterans and implemented a pro-patriotic education in order to revive the patriotic spirit of the youth, in the same way that the recent constitutional changes have prohibited a negative portrayal of the Great Patriotic War in the public sphere. Yeltsin built the house that Putin decorated.

Having examined the state of Russia's military through a cultural lens, the thesis was able to overcome a number of limitations. The thesis examined the processes of

War, (Interventions), ed. by Linda Åhäll and Thomas Gregory (New York: Routledge, 2015), 128-140; Jonathan Dunnage, Susan T. Jackson, Eugene Miakinkov and Michael Sheehan, "Understanding militarism after the end of the Cold War: History, International Relations and Media studies ask new questions," History Compass 17, No. 12 (2019): 113. 
militarisation beyond its physical dimensions and sought to understand whether a society could be militarising without the physical presence of strong military. The thesis found that there was a clear state-led effort to maintain pro-militaristic themes in everyday discourses. The media, while not directly under the control of the state, highlighted the important place that the military and war had taken in societal discourses as it continued to utilise methods of mobilisation through the use of scaremongering techniques. The thesis does not argue that such discourses led to increased numbers of military volunteers; however, they ensured that issues of the military sat at the forefront of mass consciousness. The thesis was able to show that in lieu of a physical military, society remained exposed to a militarised worldview

The thesis contributes to current literature on militarisation by proposing a number of original ways in which the process of militarisation can be captured. The notion of a debt ideology or measurement of militarisation through the concept of sponsorship outlined the many subtle ways in which Russia's dominant state institutions have continued to militarise its society. The models and mechanisms introduced in this thesis can certainly be used to understand and track the process of militarisation under the Putin administration, and within a comparative capacity to understand processes of militarisation in other countries. Since many of the discourses found in this thesis were a result of deep-rooted traditions of the Tsarist and Soviet regimes, a wider study on countries of the former Soviet Union, for example Belarus, may reveal the adoption and continuation of similar rituals. In its aim to understand the process of militarisation from a cultural perspective, the thesis found that indeed, the militarisation of society can continue without a physical military as long as military themes and the discourse that "we must be defended" remain dominant. This was the case in Yeltsin's Russia.

\section{FOUNDATIONS FOR FUTURE RESEARCH}

\section{Scope for future research}

The thesis investigated the cultural militarisation of Russian society from a topdown perspective and had little room (with a few exceptions) to showcase how people on the ground received the militarised discourses. Therefore, the study should act as a step or foundation for future research on the period, especially concerning society's response to such mechanisms and discourses. In addition, there are places in which the scope of this thesis can be extended. First, future research should investigate the link between 
religion and militarism in 1990s Russia. Current research by Victoria Fomina, for example, focuses on religion, morality and militant nationalism. Her case study on Evgenii Rodionov, an orthodox Russian soldier killed by Chechens in 1996 for his refusal to remove the cross and convert to Islam, demonstrates the first steps towards the creation of the strong connection that currently exists between the military and Orthodox Church. ${ }^{13}$ Through his relationship with the church, as showcased by his refusal to betray the cross, Rodionov became a model for the ideal Russian citizen. According to Fomina, the newspaper Zavtra framed Rodionov's story through a pseudo-religious lens in which a renewed image of the military man was created by emphasising his strong commitment to his principles and sense of morality. Future research should include a focus on the Orthodox Church as a form of pedagogy in which sermons are assessed to examine their militaristic dimensions.

Second, the connection between gender and militarism in Russia during this period largely remains within the structure of dedovshchina. Upon the examination of historical textbooks during the 1990s, there was a noticeable contradiction. Those heroic participants in glorious wars and military campaigns were mainly men, and the campaigns of Catherine II were largely limited to diplomatic exchanges. Men prevailed in these histories, pushing women to the margins of these glorious wars and military exchanges. It was also primarily men who were recognised by Yeltsin for state prizes, awarded during the Great Patriotic War celebrations - thus women lacked suitable role models that reflected on their strength, loyalty and heroism during war. It is through the books and state recognition that militarisation ensued and as Cynthia Enloe claimed, "masculinity [continued] to be the currency for domination and exclusion." ${ }^{14}$ Even as the masculinised role of the male was shortened by the cutbacks in the military, the patriarchal structures of society were maintained through the projected role of the heroic and strong male within

\footnotetext{
${ }^{13}$ Victoria Fomina, "Between heroism and sainthood: New martyr Evgenii Rodionov as a moral model in Contemporary Russia, History and Anthropology 29, No. 1 (2018): 101102.

${ }^{14}$ Cynthia Enloe, "Understanding militarism, militarisation and the Linkages with Globalisation: Using a Feminist Curiosity," Gender and Militarism: Analysing the Links to Strategise for Peace, Women Peacemakers Program, (2014), accessed 14 November 2019 , http://www2.kobeu.ac.jp/ alexroni/IPD\%202015\%20readings/IPD\%202015 9/Gender\%20and\%20Milita rism\%20May-Pack-2014-web.pdf, 7.
} 
societal discourses. This thesis forms the basis to which such further research can be conducted. 


\section{BIBLIOGRAPHY}

\section{ARCHIVAL SOURCES}

\section{Gosudarstvennoi Arkhiv Rossiiskoi Federatsii (GARF)}

Fond 10026 - “S'ezd narodnykh deputatov Rossiiskoi federatsii, verkhovnyi Sovet Rossiiskoi federatsii i ikh organy," 1990-1993.

Fond 10100 - "Federal'noe Sobranie Rossiiskoi Federatsii.” 1993-.

Fond 10200 - "Pravitel'stvo Rossiiskoi Federatsii.” 1992-.

\section{$\underline{\text { Yeltsin Centre }}$}

Fond 21 - “Audiozapisi meropriiatii s uchastiem B. N. El'tsina iz Arkhiva Prezidenta RF. Kopii."

Fond 6 - "Dokumenty lichnogo fonda B. H. El'tsina iz Arkhiva Prezidenta Rossiiskoi Federatsii. Kopi."

Fond 8 - “Kollektsiia. Normativno rasporiaditel'nye akty i materialy k nim iz Arkhiva Prezidenta Rossiiskoi Federatsii (1991-1999). Kopii.”

\section{PRIMARY SOURCES}

Newspapers

"Chechnya: Nashi Voyska uspeshno zavershili operatsiyu v rayone Smashek." Krasnaia Zvezda, 11 April 1995. No. 80.

“Chechnya: Trudnyi vybor Kremlia (Ekspress-analiz nedeli).” Izvestiia, 10 December 1994. No. 238.

“Koalitsionnoe Pravitel'stvo.” Argumenty i Fakty, 10 December 1997. No. 50.

"Na vechnom ogne.” Ogoniok, November 1991. No. 46.

"Postanovlenie III Sezda KP RF 'O bratoubiystvennoy voyne v Chechenskoi Respublike i merakh po vykhodu iz voznikshego krizisa." Sovetskaia Rossiia, Moscow, 20 February 1995. No. 13.

“Rel'sovaia Voina.” Nezavisimaia Gazeta, 27 May 1998.

“S kem voyuem v Chechne?" Ogoniok, August 1996. No. 34

“Shakhtry Nachali 'Rel'sovoi voiny."” Izvestiia, 16 May 1998. 
“Situatsiia v Chechne.” Kommersant, 26 August 1994. No. 160.

“Situatsiia v Tadzhikistane.” Kommersant, 15 December 1992. No. 61.

“Stanislav Govorukhin predlagaet privech' S. Kovaleva I K k otvetstvellosti za klevetu.” Krasnaia Zvezda, 21 April 1995. No. 89.

“Terror bez granits.” Argumenty i Fakty, 28 January 1998. No. 5.

“Terrorizm: Igry Diletantov.” Ogoniok, November 1994. No. 46-47.

"Vesenniaia sessiia gosudarstvennoy dumy 1995 goda." Izvestiia, 1995.

"Vizit Gracheva v Tadzhikistan.” Kommersant, 6 February 1993.

"Vmesto novgorodnikh podarkov v detskie ladoni lozhitsia smert - chechenskii uzel vse tyzhe." Pravda, 20 December 1994. No. 235.

"Y detei voiny pal’tsy pozhozhi na kurok." Novaia Gazeta, 24 June 1996. No. 23.

Artemenko, Viktor. "Pamiati general-mayora Viktora Vasil'evicha Vorob'eva." Pravda, 10 January 1994. No. 333.

Artemenko, Viktor. "Pogib, kak zhil, - na peredovoy." Pravda, 10 January 1994. No. 333.

Baturin, Yuri. "Moskva-Groznii: Nuzhny kompromissy, na voprosy.” Izvestiia, 24 June 1995. No. 115.

Berezina, Elena. "Ne khochu byt' armianinom!” Ogoniok, December 1994. No. 4849.

Bolotin, Alexander. "Eta Pulia Eshche ne tvoia." Ogoniok, April 1992. No. 14-15.

Charodeev, Gennady. "Vengriia, Pol'sha i Chekhiia uzhe v NATO/ Na ocheredi Ukraina?" Izvestiia, 1999. No. 43.

Chelnokov, Alexei. "Cherez Chechnyu-Avtostopom, spetsialnyi correspondent 'Izvestiia."” Izvestiia, 24 December 1994. No. 247.

Dementieva, Irina. "Ne meshayte rabotat', g-n gubernator." Izvestiia, 20 June 1995. No. 111.

Golts, Alexander. "Ukreplenie SNG - Vazneishaia Zadacha Nashei Diplomatii," Krasnaia Zvezda. 08 July 1995. No. 152-153.

Gritchin, Nikolai. "Po Samashkam ogem i mechom," Izvestiia, (18 April 1995).

Gritchin, Nikolai. "Vlasti Stavshimi predprinimayut mery dlia zashchity mestnykh kavkaztsev." Izvestiia, 23 December 1994. No. 246.

Gromok, Valerii. “Zalukhniki Rel’sovoi Voiny.” Krasnaia Zvezda, 10 February 1998. Ilia Mishtein. "Nato ili ne nado?” Ogoniok, February 1994. No. 8. 
Kamyshev, Dmitry. "Situatsiia v Chechne.” Kommersant, 23 December 1994. No. 244.

Klaus Von Cretor, Nikolai. "Esli by Ia byl Russkim Marshalom.” Sovetskaia Rossiia, 30 August 1994. No. 62.

Kornetov, Robert. "Situatsiia v Chechne.” Kommersant, 17 September 1994. No. 176.

Kovalev, Sergey. "Elena Badyakina: 'Opalennye Bedoy." Sovetskaia Russia, Moscow, 28 January 1995. No. 11.

Kovalskaya, Galina. "Khuzhe mozhet byt' tol'ko voina.” Ogoniok, 10 February 1995. No. 40.

Kozhanov, Nikolai. 'Grozhnyi: Razrushaem, potom budem stroit' - i vse za schet Rossiiskogo Byuzheta." Pravda, 10 November 1994. No. 3.

Kuznetsov, Sergei and Lyudmila Proshak. "Komu voyna, komu - mat' rodna?" Argumenty i Fakty, 30 March 1999. No. 13.

Latsis, Otto. "Chechenskaia voyna proigrana v Moskve." Izvestiia, 29 December 1994. No. 250.

Lukanin, Mikhail. "Sobytiiai Komentarii. Tak kak zhe budet vygliadet pamiatnik Zhukovu?” Krasnaia Zvezda, 20 September 1994. No. 216.

Makarov, Dmitri. "S. Khadzhiev 'Ia ne marionetka."” Argumenty i Fakty, 27 July 1995. No. 30.

Mikheev, Vladimir. "NATO razbombit serbov i bez soglasiia OON." Izvestiia, 2 October 1998. No. 185.

Muradov, Boris and Igor Popov. "Za fasadom Balkanskogo krizisa." Argumenty $i$ Fakty, 7 April 1999. No. 14.

Muradov, Boris, and Igor Popov. "Yugoslavskie Strasti." Argumenty i Fakty, 30 March 1999. No. 13.

Nadein, Vladimir. "Budushchee NATO reshaetsiia v Moskve." Izvestiia, 14 February 1995. No. 28.

Nadein, Vladimir. "Sergey Kovalev - Kongressu SSHA: Chechenskaia Voyna Ozhestochla nashe obshchestvo.” Izvestiia, 4 May 1995. No. 81.

Nikonov, Aleksander. "Strannaia Voyna.” Ogoniok, 1999. No. 15.

Obolenskii, Gennady. "Ne Nado na Nas Davit.” Krasnaia Zvezda, 18 January 1997. No. 12-13.

Pelts, Alexander. "V Pamiat pavshizh i vo slavu zhivykh." Krasnaia Zvezda, 11 May 1995. No. 105. 
Plutnik, Albert. "Bylo by prestupleniem upustit' shans pokonshit' $\mathrm{s}$ voynoy $\mathrm{v}$ Chechne." Izvestiia, 24 June 1995. No. 115.

Rachkova, Olga and Vladimir Danshin. "Uchebnik noveyshey istorii popal v istoriyu." Kommersant, 31 October 1997. No. 188.

Rotar, Igor. "Chechniia: Davniaia Smutab Sobytiia v respublika budut razvivatsia po alzhirskomu variant." Izvestiia, 27 October 1995. No. 204.

Rozhnov, Georgii. "Voiska na Ulitsakh.” Ogoniok, February 1991. No. 7.

Sargin, Aleksander, and Vitaly Tseplyaev. "Za" i "Protiv" razoruzheniia. Kto seychas ugrozhaet Rossii?" Argumenty i Fakty, 19 November 1997. No. 47.

Saveiliev, Oleg. "'Snova razlyubili SSHA,' VTsIOM Press-sluzhba." Argumenty $i$ Fakty, 20 April 1999. No. 16.

Selenev, Gennady. "Ruslan Khasbulatov: V oppozitsii k rezhimu Dudaeva vse chechenskoe obshchestvo." Pravda, 22 September 1994. No. 174.

Selunin, Vasily. “Chto u Nas Poluchitsia?” Ogoniok, February 1991. No. 6.

Shafarevich, Igor. "Voyna Vyigrana. Chechnia Proigrana?" Pravda, 13 April 1995. No. 68.

Shimov, Yaroslav. "Samashki: Zhizn'na peplishche." Izvestiia, 25 April 1995. No. 76.

Somov, A. “"Za' i 'Protiv.”” Argumenty i Fakty, 26 November 1997. No. 48.

Stugovets, Vitaly. "V oboronnoy politike Rossiia iskhodit iz prioriteta mirnykh sredstv obespecheniia svoey bezopasnosti." Krasnaia Zvezda, 27 October 1999. No. 229.

Sychov, Alexander. 'Rossiia budet Sotrudnichat' s NATO, Tol'ko esli etot Blok ne Popolzet na Vostok.” Izvestiia, 25 May 1995. No. 94.

Tasmanskiy, Dmitry. “VV ochered, sukiny deti, v ochered!' (P. P. Sharikov o rasshirenii NATO).” Novaia Gazeta, 10 March 1997. No. 10.

Tseplyaev, Vitaly. "Mikhail Gorbachev: Zdravstvui, oruzhie?” Argumenty i Fakty, 1999. No. 15.

Tseplyaev, Vitaly. "Pugat' Ameriku sebe dorozhe?” Argumenty i Fakty, 30 March 1999. No. 13.

Tseplyaev, Vitaly. “Rossiia v Kol’tse vragov?” Argumenty i Fakty, 17 June 1997. No. 25.

Yakov, Valery. "Samashki: Aktsiia na Ystrashenie.” Izvestiia, 18 April 1995. No. 71. 
Yakov, Valery. "V Groznom Solntse, Vesna i strel'ba.” Izvestiia, 25 April 1995. No. 76.

Zhelnorova, Natalia. "Chechniia - otdushina dlia voennykh.” Argumenty i fakty, 25 January 1996. No. 4.

Zhukov, Maksim, and Dmitry Kamyshev. "Situatsiia v Chechne." Kommersant, 1 December 1994. No. 228.

Zhukovets, Gennady. "Dzhokhar Dudaev: Vlast' my mogli vziat' v techenie chasa." Ogoniok, December 1991. No. 49.

Zortkal'tsev, Victor. "Est' u tankov zadnii khod? Pravda, 20 December 1994. No. 235.

\section{Educational Textbooks}

Ammona, G. A. Istoriia Rossii, IX-XX vv. Uchebnoe pospobie v dvukh tamakh, Tom. 1. Moscow: Infra-M, 1998.

Anisimov E. V. and A. B. Kamenskiy. Istoriia Rossii, 1682-1861, Moscow: Terra, 1996.

Bataeva, T. Predislovie to Istoriia Rossii XX Stoletia (Osnovnye problemy), by V. A. Potseluev, 3-7. Moscow: Vlados, 1997.

Buganov, V. I., and P. N. Zirianov. Istoriia Rossii konets XVII-XIX vek, Uchebnik dlia 10 klassa obshchestobrazovatelnykh uchrezhdenii. Moscow: Prosveshchenie, 1996.

Danilov, A. A. and L. G. Kosulina. Istoriia Rossii, XX vek: Dopolnitel'nye materialy k uchebniky. 9 Klass. Moscow: DROFA, 1997.

Danilov, A. A. and S. V. Leonov. Istoriia Rossii v XX veke: Teotricheskii kurs. Moscow: Moscow University of Humanities, 1995.

Danilov, A. A. Istoriia Rossii, IX-XIX: Spravochnik Shkol'nika Moscow: Drofa, 1999.

Danilov, A. A. Po Istoriia Rossii-Rabochnaia Tetrad dlia studentov vyzov. Moscow: Vlados, 1998.

Danilov, A. A. and L. G. Kosulina. Istoriia Rossii, XX Vek: Uchebnik dlia starshikh klassov obshcheobrazovatel'nykh uchrezhdeniy. Moscow: Iakhont, 1998.

Dvornichenko A. Yu, A. V. Kirillov, E. A. Shaskal'skaya and Z. O. Dzhaliashvili. Istoriia Rossii, IX-XX veka: Uchebnik dlia abiturinentov $i$ studentov. Sankt Petersburg: Nestor, 1999. 
Georgieva, N. G. and V. A. Georgie. Istoriia Rossii, IX v-nachalo XX v.: Testy v pomoshch' prepodavateliam i abiturientam. Moscow: Moscow University Publishing House, 1995.

Golovin, N. N. Moia Pervaia Rosskaia Istoriia v Rasskazakh dlia Detei. Moscow: Tovarishchestvo M. O. Vol'f, 1992.

Ishimova, Alexandra. Istoriia Rossii v Rasskazakh Dlia Detei, (Moscow: AST Publishing House, 1996)

Kislitsyn, S. A. Istoriia Rossii v Voprosy I Otvetakh. Rostov-On-Don: Feniks, 1999. Kreder, A. Noveyshaia Istoriia XX vek: Uchebnik dlia osnovnoy shkoly. Moscow: Tsentr Gumanitarnogo Obrazovaniia, 1996.

Lichmana, B. V. Istoriia Rossii: XX Vek: Kurs lektsiy po istorii Rossii Vtoraia polovina XIX-XX vv. Yekaterinburg: USTU, 1993.

Ostrovskiy, V. P. and A. I. Utkin. Istoriia Rossii v XX vek, Klass 11. Moscow: DROFA, 1996.

Potseluev, V. A. Istoriia Rossii XX Stoletia (Osnovnye problemy). Moscow: Vlados, 1997.

Shchetinov, Yu. A. Istoriia Rossii v XX vek. Moscow: Fair, 1998.

Skrynnikov, R. G. Istoriia Rossiiskaia IV-XVII vv. Moscow: Ves Mir, 1997.

Tugan-Baranovskaia, L. I. Istorii Rossii dlia Uchashchikhsia 8-go Klassa; Otvety na Ekzamenatsionnye bilety Volgograd: Bratiia Grininy, 1996.

Vedernikov, V. V. Istoriia Rossii dlia Uchashchikhsia 10-go klassa: Otvety na Ekzamenatsionnye Voprosy. Volgograd: Bratiia Grininy, 1997.

Yurganov, A. L. and L. A. Katsva. Istoriia Rossii XVI-XVIII vv. Moscow: MIROS, 1996.

Zhukova, L. V. Istoriia Rossii XX veka: Uchebnoe posobie dlia uchashchikhsia 1011 klassov, Moscow: Ekzamen, 1998.

Zuev, M. N. Khronika Rossii Istoriia, Moscow: Drofa, 1995.

\section{VIDEOS, ONLINE SOURCES AND OPINION POLLS}

“About the Newspaper." Sovross.ru. Accessed 23 November 2020. sovross.ru/newspaper.

“About the Newspaper.” Zvezda.ru. Accessed 23 November 2020. http://redstar.ru/ogazete/?attempt=1. 
“Average monthly salaries in Russia 1991-2000.” Elena's Blogs (blog). Accessed 7 March 2021. https://blogs.elenasmodels.com/en/average-salaries-in-russia/.

"Boris Vasilievich Lichman." Ural'skiy Institut ekonomiki, upravleniia i prava. Published 14 April 2016. Accessed 11 February 2021. http://www.urep.ru/index.php?option=com_content\&view=article\&id=2232\%3A14 0420162\&catid=5\%3A2009-10-10-14-21-17\&lang=ru.

“Den' Pobedy: Istoriia voennykh paradov." TASS. 8 May 2015. Accessed 5 November 2018. https://tass.ru/obschestvo/1171423.

“Evgeniy Ily’ich Ukhnalyov (1931-2015).” Geral'dika.ru. Accessed 6 April 2020. https://sovet.geraldika.ru/article/17588.

"Excerpts from Yeltsin Speech on Chechnya With PM-Russia-Chechnya, Bjt." The Associated Press. 28 December 1994. Accessed 21 January 2019. https://apnews.com/40b126a5acf44c58e82ab6d6cd3997b2.

"History." Rossiiskii Uchebnik. Accessed 11 December 2020. https://rosuchebnik.ru/about/.

“Istoricheskii parad v chest' 50-letiia Pobedy v Velikoi Otechestvenoi Voine." YouTube video. 1:01:08. Posted by Sovetskoe Televidenie GOSTELERADIOFOND $\begin{array}{llllll}\text { Rossii. } & 8 & \text { May 2018. Accessed } & 11 & \text { October } & \end{array}$ https://www.youtube.com/watch?v=oSKqdWfyJjI.

"Istoriia Muzeia." Muzei Pobedy. Accessed 12 October 2018. https://victorymuseum.ru/about/history/.

“Izdel'stvy 'Terra' knizhnaia iarmarka vruchila priz: Knigu utrom, knigu vecherom.” Kommersant. 5 September 1997. Accessed 17 December 2020. https://www.kommersant.ru/doc/183569.

“Japan Tsunami: Military begins search for bodies.” 1 April 2011. BBC News. Accessed 28 February 2017. http://www.bbc.co.uk/news/world-asia-pacific12931418.

“Lekkha Vilyevna Zhukova.” Novosti Istoricheskogo Fakul'teta. Published 25 March 2017. Accessed 11 February 2021. http://www.hist.msu.ru/about/gen_news/28036/. “O Izdatel'stve.” Ves' Mir Izdatel'stvo. Accessed 17 December 2020. https://www.vesmirbooks.ru/about/.

“O Izdatel'stvo." Izdatel'stvo Nestor Academik. Accessed 17 December 2020. http://www.nestor.su/about.html. 
“O Kompanii.” INFRA-M Gruppa Kompaniy. Accessed 17 December 2020. https://infra-m.ru/about/o_kompanii/.

“O Prezidentsikh pozdravleniiakh veteranam.” FOM. 27 July 1995. Accessed 27 April 2020. https://bd.fom.ru/report/map/of19972903.

“Ob izdatel'stve." Izdatel'stvo Vlados. Accessed 11 December 2020. http://vlados.ru/ob-izdatelstve/.

"Obshie Trebovaniia K Tekstovym dokumentam: Edinaia sistema konstruktorskoi dokumentatsii." Mezhgosudarstvennyi Standart. 8 August 1995. Accessed 20 November 2020. http://docs.cntd.ru/document/1200001260.

“Putin's Victory Day Parade Speech." YouTube video. 1:34:16. Posted by Russia Today. Steamed live 23 June 2020. Accessed 24 June 2020. https://www.youtube.com/watch?v=z4pFnlr0zck.

"Russia-Yeltsin, Clinton Among Leaders Honouring." AP Archive video. 2:19:18. Posted by WTN Pool. 15 May 1995. Accessed 12 November 2018. https://bit.ly/2QbSPJ2.

"Russia: V.E. Day Celebrations Update.” AP Archive Video. 2:51:10. posted by APTV. 8 May 1995. Accessed 12 November 2018. https://bit.ly/3syYve8.

"Russian Federation's constitution of 1993 with amendments through to 2008." constituteproject.org. Modified 19 February 2021. Accessed 11 April 2020. https://www.constituteproject.org/constitution/Russia_2008.pdf.

"Shirokoe prazdnovanie 50-letiia Pobedy ne povliialo na otnoshenie Rossiian Prezidentu." FOM. May 1995. Accessed 13 April 2020. https://bd.fom.ru/report/map/of19952001.

"Statut ordena Zhukova." Gosudarstvennye Nagrady Rossiiskoi Federatsii. Accessed 24 2020.

https://web.archive.org/web/20060302222704/http://www.award.adm.gov.ru/orden/ orden_14.htm

"The Deputy Director of the DROFA publishing house was killed." Kommersant. 16 November 1996, No. 196. Accessed 11 December 2020, https://www.kommersant.ru/doc/243221.

"The Dragon Episode in the St. George Legend." In St. George and the Dragon: Introduction, edited by E. Gordon Whately, Anne B. Thompson and Robert K. Upchurch, 2004. Accessed 5 April 2020, 
https://d.lib.rochester.edu/teams/text/whatley-saints-lives-in-middle-englishcollections-st-george-and-the-dragon.

“Ukaz Prezidenta Rossiiskoi Federatsii ot 9 Maia 1994 goda, No. 930 “Ob uchrezhdenii ordena Zhukova i medali Zhukova." Gosudarstvennye Nagrady $\begin{array}{lllll}\text { Rossiiskoi } & \text { Federatsii. } & \text { Accessed } & 24 & \text { June }\end{array}$ https://web.archive.org/web/20120311063109/http://award.adm.gov.ru/doc/u930.ht m.

"Vernut'sia v Rossiyu: Pamiati Aleksandra Nikolaevicha Bokhanova." Bokhanov.ru. 14 January 2021. Accessed 12 February 2021. https://xn--80abe7bdc0c.xn--p1acf/. "Voennyi Parad Pobedy 9 Maia 1995- 50 letie Pobedy/ Military Parade May 9 Victory 1995." YouTube video. 1:00:26. Posted by Rota Pochyotnogo Karaula. 31 January 2016. Accessed 5 December 2018. https://www.youtube.com/watch?v=9cbz6KPEdY.

"What changes will be in the Constitution of the Russian Federation." duma.gov.ru. 12 March 2020. Accessed 15 July 2020. http://duma.gov.ru/en/news/48039/. "Historical Currency Converter." Historical Statistics. Accessed 26 March 2020. http://www.historicalstatistics.org/Currencyconverter.html.

Apple Jr., R.W. "V-E Day Plus 50: The Overview; Allied Victory in Europe Is Commemorated in Moscow." The New York Times. 10 May 1995, accessed 20 September 2018. https://www.nytimes.com/1995/05/10/world/v-e-day-plus-50-theoverview-allied-victory-in-europe-is-commemorated-in-moscow.html.

Bertuol, Natalia. "In the event of shelling: Remembering the Great Patriotic War." Junior Year Abroad Network (JYAN) Blog (blog). 3 May 2018. Accessed 17 March 2020. https://berkleycenter.georgetown.edu/posts/in-the-event-of-shellingremembering-the-great-patriotic-war.

Blackburn, Joshua. "War Sells.” Provokateur. March 2003. Accessed 20 January 2017. www.provokateur.com/war-sells-1.

Burbulis, G. "O razvitii gumanitarnogo obrazovaniia v Rossiiskoi Federatsii." Pravo. 13 April 1992, accessed $20 \quad$ February 2021. http://ips.pravo.gov.ru/?doc_itself=\&backlink=1\&nd=102015761\&page=1\&rdk=1\# I0.

Chernomyrdin, Viktor. "Ob utverzhdenii Programmy podgotovki i provedeniia prazdnovaniia 50-letiia Pobedy i drugikh pamiatnykh dat Velikoi Otechestvennoi Voiny 1941-1945 godov." Pravo. No. 614. 1 June 1994. Accessed 4 February 2021. 
http://pravo.gov.ru/proxy/ips/?docbody=\&prevDoc=102034863\&backlink=1\&\&nd $=102030419$.

Clarke, Doug. "Moscow Victory celebrations continue." RadioFreeEurope RadioLiberty. 10 May 1995. Accessed 1 November 2018. https://www.rferl.org/a/1140932.html.

Fox, Jo. "Attrocity Propaganda." British Library. 29 January 2014. Accessed 28 October 2019. https://www.bl.uk/world-war-one/articles/atrocity-propaganda.

Gallagher, James. "Ebola: British Military sent to tackle West Africa.” BBC News. 8 September 2014. Accessed 28 February 2017. https://www.bbc.co.uk/news/health29113530.

Heinrich, Markus. "New Century, Old Rivalries: Russian Military Modernisation and NATO.” E-International Relations. 2016. Accessed 9 June 2018. https://www.eir.info/2016/06/25/new-century-old-rivalries-russian-military-modernisation-andnato-responses/.

Lexico.com. $\quad$ s.v. "Militarise." Accessed $14 \quad$ June 2020. https://www.lexico.com/en/definition/militarise.

Lexico.com. $\quad$ s.v. "Militarism." Accessed 12 June 2020. https://www.lexico.com/en/definition/militarism.

Lipman, Maria. "Media Manipulation and Political Control in Russia: Russia and Eurasia Programme: REP PP 09/01.” Chatham House. 2009. Accessed 7 February 2020.

https://www.chathamhouse.org/sites/default/files/public/Research/Russia\%20and\%2 0Eurasia/300109lipman.pdf, 3-4.

Masci, David. "In Russia, nostalgia for Soviet Union and positive feelings about Stalin." Pew Research Centre. 29 June 2017, Accessed 6 November 2018. http://www.pewresearch.org/fact-tank/2017/06/29/in-russia-nostalgia-for-sovietunion-and-positive-feelings-about-stalin/.

McCann, Paul. "War Sells Serious Newspapers." The Independent. 20 April 1999. Accessed 20 January 2017. https://www.independent.co.uk/arts-entertainment/warsells-serious-newspapers-1088456.html.

Migdisova, Svetlana and Elena Petrenko. "Desiat' imen, bolee vsego sootvetstvuyushchikh predstavleniyu o russkom patriote, - ot Petra I do Lenina." FOM. $\quad 17^{\text {th }}$ June $1994 . \quad$ Accessed 5 April 2020. https://bd.fom.ru/report/map/of19941206. 
Saunders, Robert A. and Vlad Strukov. "Historical dictionary of the Russian Federation: Samobytnost." enacademic.com. 2010. Accessed 16 July 2020. https://russian_federation.enacademic.com/504/Samobytnost.

\section{SECONDARY SOURCES}

Abousnnouga, Gill, and David Machin. "The changing spaces of war commemoration: a multimodal analysis of the discourses of British monuments." Social Semiotics 21, No. 2 (2011): 175-196.

Achugar, Mariana. "Critical Discourse Analysis and History." In The Routledge handbook of Critical Discourse Studies, edited by John Flowerdew and John F Richardson, 298-311. Oxon: Routledge, 2018.

Acikoz, Salih Can. "Sacrificial limbs of Sovereignty: Disabled Veterans, masculinity and Nationalist Politics in Turkey." Medical Anthropology Quarterly 26, No. 1 (2012): 4-25.

Adamsky, Dima. The Culture of Military Innovation: The Impact of Cultural Factors on the Revolution in Military Affairs in Russia, the US and Israel. Stanford: Stanford University Press, 2010.

Afshar MD, Ahmadreza. "A Brief Iranian Medical History through Commemorative Postage Stamps.” Archives of Iranian Medicine 13, No. 2 (2010): 161-165.

Åhäll, Linda. "The Dance of Militarisation: A Feminist Security Studies Takes on 'the political."' Critical Studies on Security 4, No. 2 (2016): 154-168.

Albrecht, Ulrich. “Red Militarism.” Journal of Peace Research 17, No. 2 (1980): 135 149.

Alston, Richard. Soldier and Society in Roman Egypt: A Social History. London: Psychology Press, 1995.

Anderson, Benedict. Imagined Communities: Reflections on the Origin and Spread of Nationalism. London and New York: Verso, 1983.

Andreev, Evgeny M., Leonid E. Darsky, and Tatiana L. Kharkova. "Population Dynamics: Consequences of Regular and Irregular Changes." In Demographic Trends and Patterns in the Soviet Union before 1991, edited by Wolfgang Lutz, Sergei Scherbov and Andrei Volkov, 423-440. London: Routledge 1994.

Anitasari, Deti. "Critical Discourse Analysis: Mass Media." INA-Rxiv, January 13, 2018. doi:10.31227/osf.io/a23y6. 
Aron, Leon. "Russia's New Foreign Policy.” American Enterprise Institute, (1998) https://www.aei.org/research-products/report/russias-new-foreign-policy/ Askerov, Ali. "The Chechen Wars, media and democracy in Russia." Innovative issues and approaches in Social Sciences 8, No. 2 (2015): 8-24.

Azaryahu, Maoz. "Military and Militarism in Israeli Society.” In Independence Day Military Parade: A Political History of a Patriotic Ritual, edited by Edna LomskyFeder and Eyal Ben-Ari, 89-116. Albany: SUNY Press, 2012.

Bacevich, Andrew. The New American Militarism: How Americans are seduced by War. New York: Oxford University Press, 2013.

Bagger, Hans. "The Study of History in Russia during the Post-Soviet Identity Crisis, Scando-Slavica 53, No. 1 (2007): 109-125.

Barylski, Robert V. The Soldier in Russian Politics, 1988-1996: Duty, Dictatorship and Democracy under Gorbachev and Yeltsin. New Brunswick: Transaction Publishers, 1998.

Basham, Victoria M. "Gender, Race, Militarism and Remembrance: The Everyday Geopolitics of the Poppy." Gender, Place and Culture: A Journal of Feminist Geography 23, No. 6 (2016): 883-896.

Basham, Victoria M. "Waiting for war: Soldiering, temporality and the gendered politics of boredom and joy in military spaces." In Emotions, Politics and War, (Interventions), edited by Linda Åhäll and Thomas Gregory, 128-140. New York: Routledge, 2015.

Belin, Laura. "The Russian Media in the 1990s." The Journal of Communist Studies and Transitional Politics 18, No. 1 (2002): 139-160.

Benn, David Wedgewood. "The Russian Media in Post-Soviet Conditions." EuropeAsia Studies 48, No. 3 (1996): 471-479.

Berghan, Volker Rolf. Militarism: The History of an International Debate: 18611979. Cambridge: Cambridge University Press, 1984.

Bernazzoli, Richelle M., and Colin Flint. "Power, Place and Militarism: Toward a Comparative Geographic Analysis of Militarisation." Geography Compass 3, No. 1 (2009): 393-411.

Berryman, John. "Russian Foreign Policy: An overview." In Russia after the Cold War, edited by Bowker, Mike and Cameron Ross, 336-358. United Kingdom: Longman, 2000. 
Bidlack, Richard and Nikita Lomagin. The Leningrad Blockade, 1941-1944: A New Documentary History from the Soviet Archives. New Haven: Yale University Press, 2012.

Blum, Jerome. Lord and Peasant in Russia: From the Ninth to the Nineteenth Century. Princeton: Princeton University Press, 1961.

Bodnar, John. "Commemorative Activity in Twentieth Century Indianapolis: The Invention of Civic Tradition.” Indiana Magazine of History 87, No. 1 (1991): 1-23.

Booth, James W. "Communities of Memory: On Identity, Memory and Debt." American Political Science Review 93, No. 2 (1999): 249-263.

Bradshaw, Michael, and Jessica Prendergrast. "The Russian Heartland Revisited: An Assessment of Russia's Transformation.” Eurasian Geography and Economics 46, No. 2 (2005): 83-122.

Braithwaite, Rodric. "Dedovshchina: Bullying in the Russian Army." Open Democracy. 2010. https://www.opendemocracy.net/en/odr/dedovshchina-bullyingin-russian-army/.

Braun, Aurel. "Russian Policy Towards Central Europe and the Balkans." In The Foreign Policy of the Russian Federation, edited by Robert E. Kanet and Alexander V. Kozheimiakin, 49-77. London: Palgrave, 1997.

Bromley, David G., Anson D. Schupe and J. C. Ventimigla. "Atrocity Tales, the Unification Church, and the Social Construction of Evil." Journal of Communication 29, Vol. 3 (1979): 42-53.

Brown, Douglas J. "Dedovshchina: Caste Tyranny in the Soviet Armed Forces." The Journal of Soviet Military Studies 5, No. 1 (1992): 53-79.

Bruendel, Steffan. “Othering/ Atrocity Propaganda," International Encyclopaedia of the First World War. (2017): 1-22. https://encyclopedia.1914-1918online.net/pdf/1914-1918-Online-otheringatrocity_propaganda-2014-10-08.pdf.

Bryan, Dominic. Orange Parades: The Politics of Ritual, Tradition and Control. London: Pluto Press, 2000.

Brzezinski, Zbigniew $\mathrm{K}$ and Paige Sullivan. Russia and the Commonwealth of Independent States: Document, Data, and Analysis. New York: M. E. Sharpe, 1997. Buffton, Deborah D. "Memorialisation and the selling of war." Peace Review: A Journal of Social Justice 17, No. 1 (2006): 25-31. 
Burck, Charlotte. "Comparing qualitative research methodologies for systemic research: the use of grounded theory, discourse analysis and narrative analysis." Journal of Family Therapy 27, No. 3 (2005): 237-262.

Burds, Jeffrey. "The Soviet War against 'Fifth Columnists': The Case of Chechnya, 1942-4.” Journal of Contemporary History 42, No. 2 (2007): 267-314.

Burke, Colleen. "Women and Militarism." Women's International League for Peace and $\quad$ Freedom. $1994 . \quad$ https://www.wilpf.org/wpcontent/uploads/2012/10/Unknownyear_Women_and_Militarism.pdf.

Burrett, Tina. "The end of independent television? Elite Conflict and the reconstruction of the Russian television landscape." In The Post-Soviet Russian Media: Conflicting Signals, edited by Birgit Beumers, Stephen Hutching and Natalia Rulyova, 71-86. Oxon: Routledge, 2009.

Burtin, Olivier. "The History of Veteran's Policy in the United States." Historical Social Research 45, No. 2 (2020): 239-260.

Bushkovitch, Paul. "The Romanov Transformation 1613-1725." In The Military History of Tsarist Russia, edited by Fredrick W. Kagan and Robin Higham, 31-46. New York: Palgrave, 2002.

Bushnell, John. "Peasants in Uniform: The Tsarist Army as a Peasant Society." Journal of Social History 13, No. 4 (1980): 565-576.

Caiazza, Amy. Mothers and Soldiers: Gender, Conscription, and Civil Society in Contemporary Russia. New York and London: Routledge, 2002.

Chaing-Tai Hung. "Mao's Parades: State Spectacles in China in the 1950s." The China Quarterly, No. 190 (2007): 411-431.

Chandler, Andrea. "Veteran's Rights in the Russian Constitutional Court, 19932010.” Canadian Slavonic Papers 54, No. 3-4 (2012): 319-339.

Chandler, Andrea. Shocking Mother Russia: Democratisation, Social Rights and Pension Reform in Russia, 1990-2000. Toronto: University Toronto Press, 2004.

Charteris-Black, Jonathan. Politicians and Rhetoric: The persuasive power of metaphor. Basingstoke: Palgrave, 2005.

Chimombo, Moira P. F., and Robert L. Roseberry. The Power of Discourse: An Introduction of Discourse Analysis. New Jersey: Lawrence Erlbaum Associates, Inc. Publishers, 1998.

Coleman, P. G. and A. Podolskij. "Identity Loss and Recovery in Life Stories of Soviet World War Two Veterans." The Gerontologist 47, No. 1 (2007): 52-60. 
Colley, Linda. "Britishness and Otherness: An argument." Journal of British Studies 24, No. 4 (1992): 309-329.

Cooper, Julian. "Conversion is Dead, Long Live Conversion!" Journal of Peace Research 32, No. 2 (1995): 129-132.

Cooper, Julian. "Demilitarising the Russian defence economy: a commentary." Security Dialogue 26, No 1 (1995): 35-39.

Cooper, Julian. "Social-Military Relations in Russia: The Economic Dimension." In Military and Society in Post-Soviet Russia, edited by Stephen Webber and Jennifer G. Mathers, 131-156. Manchester and New York: Manchester University Press, 2006. Cowen, Deborah. Military Workfare: The Soldier and Social Citizenship in Canada. Toronto: University of Toronto Press, 2008.

Cremades, Pelegri Sancho. "An overview of Critical Discourse Analysis Approaches to Mass Communication." In Critical Discourse Analysis of Media Texts, edited by Pelegri Sancho Cremades, Jose Maria Bernardo Paniagua, Guillermo Lopez Garcia and Enric Serra Alegre, 17-38. Valencia: Los Autores, 2007.

Dalal, Koustuv and Leif Svanstrom. "Economic Burden of Disability Adjusted Life Years (DALYs) of Injuries.” Health 7, (2015): 487-494.

Dale, Robert. "Remobilising the Dead: Wartime and Postwar Soviet Burial Practices and the Construction of the Memory of the Great Patriotic War." Kritika: Explorations in Russian and Eurasian History 22, No. 1 (2021): 41-73.

Dale, Robert. Demobilised Veterans of the late Stalinist Leningrad: Soldiers to Civilians. London: Bloomsbury Publishing, 2015.

Dandeker, Christopher, Simon Wessely, Amy Iversen and John Ross. "What's in a Name? Defining and Caring for "veterans:" The United Kingdom in International Perspective." Armed Forces and Society 32, No. 2 (2006): 161-177.

Danilova, Nataliya. “The Development of an Exclusive Veterans' Policy: The Case of Russia." Armed Forces and Society 26, No. 5 (2010): 890-916.

Danilova, Nataliya. "Veteran's Policy in Russia: A Puzzle of Creation." The Journal of Power Institutions in Post-Soviet Societies, No. 6/7 (2007). http://www.pipss.org/document873.html .

Danilova, Nataliya. The Politics of War Commemoration in the UK and Russia. Basingstoke: Palgrave Macmillan, 2016.

Danks, Catherine J. Russian Politics and Society: An Introduction. Essex: Pearson Education, 2011. 
Davies, R. W. Soviet History in the Yeltsin Era. New York: St. Martin's Press inc, 1997.

De Monchy, Marike Finley. Powermatics: A Discursive Critique of New Communications Technology. Abingdon: Routledge, 2015.

Delgado, Roxana E., Kimberly Peacock, Barbara Elizondo, Margaret Wells, Jordan H. Grafman and Mary J. Pugh. "A Family's Affair: Caring for Veterans with Penetrating Traumatic Brain Injury.” Military Medicine 183, No. $3 / 4$ (2018): 379385.

Dezhnev, Vladimir N. and G. Shadrinsk. "Nikolai II i Rossiiskaia Imperatorskaia Armiia." Vestnik Shadrinkskogo Gosudarstvennogo Pedagogicheskogo Universiteta, (2016): 146-150.

Dolenec, Danijela. "A Soldier's State? Veterans and the welfare regime in Croatia," Anali 14, No. 1 (2017): 55-76.

Donson, Andrew. "Models for Young Nationalists and Militarists: German Youth Literature in the First World War." German Studies Review 27, No. 3 (2004): 579598.

Dunnage, Jonathan, Susan T. Jackson, Eugene Miakinkov and Michael Sheehan. "Understanding militarism after the end of the Cold War: History, International Relations and Media studies ask new questions." History Compass 17, No. 12 (2019): $1-13$.

Duverger, M. The Study of Politics. Berlin, Germany: Springer Science and Business Media, 2012.

Edele, Mark. "Soviet Veterans as an Entitlement Group, 1945-1955." Slavic Review 65, No. 1 (2006): 111-137.

Eghigian, Greg "Injury, Fate, Resentment, and Sacrifice in German Political Culture, 1914-1939." In Sacrifice and National Belonging in Twentieth-Century Germany, edited by Marcus Funck, Greg Eghigian and Matthew Paul Berg, 90-117. Texas: Texas A\&M University Press, 2002.

Eichler, Maya. Militarizing Men: Gender, Conscription and War in the Post-Soviet Russia. California: Stanford University Press, 2012.

Eklof, Ben. "Introduction - Russian Education: the Past and the Present." In Educational Reform in Post-Soviet Russia: Legacies and Prospects, edited by Ben Eklof, Larry E. Holmes and Vera Kaplan, 1-20. Oxon: Frank Cass, 2005. 
Elliott, Jane. Using Narrative in Social Research: Qualitative and Quantitative Approaches. London: SAGE Publications, 2005.

Ellis, Frank. "The Great Fatherland War in Soviet and Post-Soviet Russian literature." The Journal of Slavic Military Studies 20, No. 4 (2007): 609-632.

Enloe, Cynthia. "Understanding militarism, militarisation and the Linkages with Globalisation: Using a Feminist Curiosity." In Gender and Militarism: Analysing the Links to Strategise for Peace, edited by Isabelle Geuskens, Merle Gosewinkel and Sophie Schellens, 7-9. Accessed 14 November 2019 Women Peacemakers Program, 2014. http://www2.kobe-

u.ac.jp/ alexroni/IPD\%202015\%20readings/IPD\%202015_9/Gender\%20and\%20M ilitarism\%20May-Pack-2014-web.pdf

Enloe, Cynthia. Globalisation and Militarism: Feminists Make the Link. Maryland: Rowman and Littlefield, 2016.

Enloe, Cynthia. Maneuvers: The International Politics of Militarizing Women's Lives. Berkley: University of California Press, 2000.

Enloe, Cynthia. The curious feminist: Searching for women in a new age of Empire. Berkley: University of California Press, 2004.

Erokhina, Marina, and Alexander Skevurev. "Old Heritage and New Trends: School History Textbooks in Russia." In School History Textbooks across Cultures: International Debates and Perspectives, edited by Jason Nicholls, 83-92. Oxford: Symposium Books Limited, 2006.

Esin, Cigdem."Narrative Analysis Approaches." In Qualitative Research Methods in Psychology: Combining Core Approaches, edited by Nollaig Frost, 92-118. New York: Open University Press, 2011.

Evren Eken, Mehmet. "The Un-Scene Affects of On-Demand Access to War." In Understanding Popular Culture and world politics in the digital age, edited by LJ Shepherd and C Hamilton, 137-152. United States: Taylor and Francis, 2016.

Fairclough, Norman. Analysing Discourse: Textual Analysis for Social Research. London: Routledge, 2003.

Fedor, Julie. "Dedovschina and the Committee of Soldiers' Mothers under Gorbachev." The Journal of Power Institutions in Post-Soviet Societies, No. 1 (2004): $2-5$. 
Feldman, Jackie. "Between Yad Vashem and Mt. Herzl: Changing Inscriptions of Sacrifice on Jerusalem's 'Mountain of Memory." Anthropological Quarterly 80, No. 4 (2007): 1147-1174.

Ferrand, Allain and Monique Pages. "Image Sponsoring: A Methodology to Match Event and Sponsor.” Journal of Management 10, No. 3 (1996): 278-291.

Fish, Steven M. "Reform and Demilitarization in Soviet Society from Brezhnev to Gorbachev" Peace and Change 15, No. 2 (1990): 150-172.

Fisun, Oleksandr. "Rethinking Post-Soviet Politics from a Neopatrimonial Perspective." The Journal of Post-Soviet Democratisation 20, No. 2 (2012): 87-96.

Fomina, Victoria. "Between heroism and sainthood: New martyr Evgenii Rodionov as a moral model in Contemporary Russia." History and Anthropology 29, No. 1 (2018): 101-120.

Forest, Benjamin and Juliet Johnson. "Unravelling the Threads of History: Soviet-Era Monuments and Post-Soviet National Identity in Moscow." Annals of the Association of American Geographers 92, No. 3 (2002): 48-72.

Foucault, Michel. Discipline and Punish: The Birth of the Prison. London: Penguin, 1991.

Frank, William C. and Phillip S. Gillette. Soviet Military Doctrine from Lenin to Gorbachev, 1915-1991. Westport Connecticut: Greenwood Publishing Group, 1992. Frost, Nollaig. "Qualitative Research in Psychology." In Qualitative Research Methods in Psychology: Combining Core Approaches, edited by Nollaig Frost, 3-15. New York: Open University Press, 2011.

Froumin, Isak and Igor Remorenko. "From the 'Best-in-the World' Soviet school to a Modern Globally Competitive School System." in Audacious Education Purposes: How Governments Transform the Goals of Education Systems, edited by Fernando M. Reimers, 233- 250. Switzerland: Springer Open, 2020.

Fuller, William C. Strategy and Power in Russia, 1600-1914. New York: The Free Press, 1998.

Fussell, Paul. Wartime: Understanding and behaviour in the Second World War. Oxford: Oxford University Press, 1989.

Gaddy, Clifford G. The Price of the Past: Russia's Struggle with the Legacy of a Militarised Economy. Washington DC: Brookings Institution Press, 1997. 
Galangau-Querat, Fabienne. "The Grande Galerie de 1'Evolution.” In Reshaping museum space: Architecture, design, exhibitions, edited by Suzanne Macleod, 95107. Oxon: Routledge, 2005.

Galaviz, Brian, Jesus Palafox, Erica R. Meiners and Therese Quinn. "The Militarisation and Privatisation of Public Schools." Berkley Review of Education 2, No. 1 (2011): 27-45.

Galbas, Michael. "Our pain and our glory: Social strategy of legitimisation and functionalisation of the Soviet-Afghan War in the Russian Federation." Journal of Soviet and Post-Soviet Politics and Society 1, No. 2 (2015): 91-132.

Gel'man, Vladimir. "The Vicious Circle of Post-Soviet Neopatriomonialism in Russia.” Post-Soviet Affairs 32, No. 5 (2016): 455-473.

Gerber, D. Roland. "Souvenirs: Many Dimensions and One Definition." International Journal of Management Cases 10, No. 3 (2008): 24-29.

Gerber, Theodore P., and Sarah E. Mendelson. "Strong Public Support for Military Reform in Russia.” PONARS Public Memo 288 (2003): 1-9.

German, Tracey. Russia's Chechen War. London: Routledge, 2003.

Gillespie, David. "Confronting imperialism: The ambivalence of war in post-Soviet film." In Military and Society in Post-Soviet Russia, edited by Jennifer G. Mathers and Stephen Webber, 80-93. Manchester and New York: Manchester University Press, 2006.

Gillis, John R. The Militarization of the Western World. London: Rutgers University Press, 1989.

Giroux, Henry A. "War on Terror: The Militarising of Public Space and Culture in the United States." Third Text 18, No. 4 (2004): 211-221.

Giroux, Henry. "Ideology and Agency in the Process of Schooling." Journal of Education 165, No. 1 (1983): 12-34.

Goffman, Erving. Frame Analysis: An Essay on the Organisation of Experience. Boston: Northeastern University Press, 1996.

Goheen, Peter G. "Symbols in the Streets: Parades in Victorian Urban Canada," Urban History Review 18, No. 3 (1990): 232-243.

Golburt, Luba. "Vasili Petrov and the Poetics of Patronage." E-Journal of EighteenthCentury Russian Studies 3, (2015): 47-69. 
Golts, Alexander M., and Tonya L. Putnam. "State Militarism and Its Legacies: Why Military Reform Has Failed in Russia.” International Security 29, No. 2 (2004): 121158.

Golts, Alexander. Military Reform and Militarism in Russia. Washington DC: The Jamestown Foundation, 2018.

Gonzales, Roberto J. Hugh Gusterson and Gustaaf Houfman. Militarisation: A Reader. Durham and London: Duke University Press, 2019. Kindle Edition.

Gorkov, Yuri and Valeri Danilov. "Gotovil li Stalin unprezhaiushchi udar protiv Gitlera v 1941 g." Novaia i Noveishaia Istoria, No. 3 (1993): 29-45.

Gough Paul. "The Commemoration of War." In The Ashgate Research Companion to Heritage and Identity, edited by Brian Graham and Peter Howard, 323-347. Aldershot: Ashgate, 2008.

Grayzel, Susan R. At Home and Under Fire: Air Raids and Culture in Britain from the Great War to the Blitz New York: Cambridge University Press, 2012.

Gresh, Jason P. “The Realities of Russian Military Conscription.” Journal of Slavic Military Studies 24, No. 2 (2011): 185-216.

Griffith, Robert K. U.S. Army's Transition to the All-Volunteer Force, 1864-1974. Washington DC: DIANE Publishing, 1997.

Gudkov, Lev. "The Army as an institutional model," translated by Jennifer G. Mathers. In Military and Society in Post-Soviet Russia, edited by Jennifer G. Mathers and Stephen Webber, 39-60. Manchester and New York: Manchester University Press, 2006.

Gudkov, Lev. "The Fetters of Victory: How the War provides Russia with its Identity." Osteuropa 55, No. 4 (2005). https://www.eurozine.com/the-fetters-ofvictory/

Hamilakis, Yannis. "Learn History! Antiquity, National Narratives, and History in Greek Educational Textbooks." In The Useable Past: Greek Metahistories, edited by K. S. Brown and Yannis Hamilakis, 39-67. Lanham: Lexington Books, 2002.

Hassan, Aaminah. "Language, Media and Ideology: Critical Discourse Analysis of Pakistani News Bulletin Headlines and its impact on viewers." Humanities: SAGE Open 8, No. 3 (2018): 1-15.

Hassell, James. "Implementation of the Russian Table of Ranks during the Eighteenth Century.” Slavic Review 29, No. 2 (1970): 283-295. 
Hassid, Jonathan. "Four Models of the Fourth Estate: A Typology of Contemporary Chinese Journalists.” The China Quarterly 208 (2011):813-832.

Herspring, Dale R. "Dedovshchina in the Russian Army: The Problem that won't go Away." Journal of Slavic Military Studies 18, No. 4 (2005): 607-629.

Herspring, Dale R., "Undermining Combat Readiness in the Russian Army, 19922005," Armed Forces and Society 32, No. 4 (2006): 513-531.

Herspring, Dale R., "Vladimir Putin and Military Reform in Russia." European Security 14, No. 1 (2005): 137-155.

Hirshleifer, Jack. The Dark Side of the Force: Economic foundations of conflict theory. Cambridge: Cambridge University Press, 2001.

Holscher, Meike. "Performances, Souvenirs, and Music: The Diamond Jubilee of Queen Victoria 1897." In Mediation, Remediation, and the Dynamics of Cultural Memory, edited by Astrid Erll and Ann Rigney, 173-186. Berlin and New York: Walter De Gruyter, 2009.

Hoskins, Andrew, and Ben O'Loughlin. War and Media; The Emergence of a Diffused War. Cambridge: Wiley and Sons. 2013.

Hughes, Lindsey. Russia in the Age of Peter the Great. New Haven and London: Yale University Press, 2004.

Humphreys, Brendan. "Russia Exceptionalism: A Comparative Perspective," Politics in Central Europe 12, No. 1 (2016): 9-20.

Hunter, Wendy. Eroding Military Influence in Brazil: Politicians Against Soldiers. Chapel Hill and London: University of North Carolina Press, 1997.

Huntington, Samuel P. Soldiers and the State: The Theory and Politics of CivilMilitary Relations. Cambridge, Massachusetts: Harvard University Press, 1957.

Hymans, Jacques E. C. "East is East, and West is West? Currency Iconography as Nation-Branding in the wider Europe.” Political Geography 29, No. 2 (2010): 97108.

Ienaga, Saburo. "The Glorification of War in Japanese Education," International Security 18, No. 3 (1993-1994): 113-133.

Ilkhamor, Alisher. "Neopatrimonalism, interest groups and patronage networks: The Impasses of Governance System in Uzbekistan.” Central Asian Survey 26, No. 1 (2007): 65-84.

Irvine, Janice M. and Jill A. Irvine. "The Queer Work of Militarised Parades." Contexts: Sociology for the Public 16, No. 4 (2017): 32-37. 
Isaacs, Jeremy, and Taylor Downing. Cold War: For forty-five years the World held its breath. London: Abacus, 2008.

Ismailov, Murod, and Nozima Ganieva, "In search for the Russian national identity: Do history textbooks hold the answer?" Journal of alternative perspectives in the social sciences 5, No. 2 (2013): 366-392.

Ivankine, Alex and Tom Perlmutter, “A Very Russian Coup,” YouTube Video, 47:26, April 11, 2014, https://www.youtube.com/watch?v=KFkomwe7ZnM.

Ivanov, V. I. "Veterany o Velikoi Otechestvennoi Voine." Sotsiologicheskie Issledovaniia, No. 5 (2015): 12-17.

Jackson, Camille. "Legislation as an indicator of Free Press in Russia; Patterns of Change from Yeltsin to Putin." Problems of Post-Communism 63, No. 5-6 (2016): 354-366.

Jacobsen, C. G. "Russia's Revolutionary Arbiter? Arms and Society, 1988-1994," War and Society 13, No. 1 (1995): 101-146.

Jacobsen, C. G. The New World Order's defining Crises, the Clash of Promise and Essence. Dartmouth: Darmouth Publishing Co. Ltd, 1996.

Jones, Anthony. "The educational legacy of the Soviet period." In Education and Society in the New Russia, edited by Anthony Jones, 3-24. New York: M. E. Sharpe, 1994.

Jones, Colin. "The Welfare of the French Foot-Soldier." History 65, No. 214 (1980): 193-213.

Jones, Ellen. "Manning the Soviet Military." International Security 7, No. 1 (1982): 105-131.

Jones, Robert A. "Heroes of the nation? The celebration of scientists on the Postage Stamps of Great Britain, France and West Germany." Journal of Contemporary History 36, No. 3 (2001): 403-422.

Kagan, Frederick W. “The Great Patriotic War.” In The Military History of the Soviet Union, edited by Kagan, Frederick W. and Robert Higham, 137-151. New York: Palgrave, 2016.

Kangaspuro, Markku and Jussi Lassila. "Naming the War and Framing the notion in Russian Public Discussion.” Canadian Slavonic Papers 54, No. 3-4 (2012): 377-400. Kaplan, Vera. "History Teaching in Post-Soviet Russia: Coping with Antithetical Traditions." In Educational Reform in Post-Soviet Russia: Legacies and Prospects, 
edited by Ben Eklof, Larry E. Holmes and Vera Kaplan, 247-271. Oxon: Frank Cass, 2005 .

Karpov, Vyacheslav and Elena Lisovskaya. "Educational change in a time of social revolution: The case of Post-Communist Russia in Comparative Perspective." In Educational Reform in Post-Soviet Russia: Legacies and Prospects, edited by Ben Eklof, Larry E. Holmes and Vera Kaplan, 22-46. Oxon: Frank Cass, 2005.

Kavaliauskas, Tomas. "Different Meanings of May $9^{\text {th }}$ Victory Day over Nazi Germany, for Russia and the Baltic States.” Interdisciplinary Studies on Central and Eastern Europe 9 (2011): 319-336.

Keep, John. "Military Style of the Romanov Rulers." War and Society 1, No. 2 (1983): 61-84.

Keep, John. "Paul I and the Militarisation of Government." Canadian-American Slavic Studies 7, No. 1 (1973): 1-14.

Keep, John. "The Origins of Russian Militarism." Cahiers du Monde russe et sovietique 26, No. 1 (1985): 5-19.

Kenez, Peter. A History of the Soviet Union from the beginning to the end. Cambridge: Cambridge University Press, 1999.

Kipp, Jacob W. "Lenin and Clausewitz, The Militarisation and Marxism, 1914-1921." Military Affairs 49, No. 4 (1985): 184-191.

Kirschenbaum, Lisa A. and Nancy M. Wingfield. "Gender and the Construction of Wartime heroism in Czechslovakia and the Soviet Union." European History Quarterly 39, No. 3 (2009): 465-489.

Kit-Wai, Eric. "Re-Nationalisation and me: My Hong-Kong story after 1997." InterAsia Cultural Studies 1, No. 1 (2000): 173-179.

Koikkalainen, Katya. "The Local and the International in Russian Business Journalism: Structures and Practices." In Globalisation, Freedom and the Media after Communism: The Past as Future, edited by Birgit Beumers, Stephen Hutchings and Natalia Rulyova, 71-85. Oxon: Routledge, 2009.

Kolb, Anna Karina. "European Social Rights Towards National Welfare States: Additional, Substitue, Illusory?" In Citizenship and Welfare State Reform in Europe, edited by Jet Bussemaker, 165-178. London: Routledge, 2003.

Koltsova, Olessia. News Media and Power in Russia. Oxon: Routledge, 2006. 
Kozhemiakin, Alexander V., and Roger E. Kanet. "Russia and its Western neighbours in the 'Near Abroad.'" In The Foreign Policy of the Russian Federation, edited by Robert E. Kanet and Alexander V. Kozhemiakin, 28-48. London: Palgrave, 1997. Kronsell, Annica, and Erika Svedberg. "Introduction: Making Gender, Making War." In Making Gender, Making War: Violence, Military and Peacekeeping Practices, edited by Annica Kronsell and Erika Svedberg, 10-27. New York: Routledge, 2011. Krujit, Dirk, and Kees Koonings. 'From Political Armies to the 'war against crime:' The Transformation of Militarism in Latin America." In Militarism and International Relations: Political economy, security and theory, edited by Anna Stavrianakis and Jan Selby, 91-103. New York: Routledge, 2002.

Krylova, Anna. "Dancing on the Graves of the Dead: Building a World War Two Memorial in Post-Soviet Russia." In Memory and the impact of political transformations in public space, edited by Daniel J. Walkowitz and Lisa Maya Knauer, 83-103. Durham, North Carolina: Duke University Press, 2005.

Kryshtanovskaya, Olga and Stephen White. "Putin's Militocracy." Post-Soviet Affairs 19. No. 4 (2003): 289-306.

Krzyzanowska, Natalia. "The discourse of counter-monuments: semiotics of material commemoration in contemporary urban spaces." Social Semiotics 26, No. 5 (2016): 465-485.

Kubik, Jan. "Polish May Day Celebrations in the 1970's and in 1981: An Essay on Symbolic Dimension of a Struggle for Political Legitimacy." The Polish Review 34, No. 2 (1989): 99-116.

Kurliandskaia, Galina. "Decentralisation in the Russian Federation," Economic Change and Restructuring 39, No. 3-4 (2006): 213-233.

Lambeth, Benjamin. “Russia's Wounded Military." Foreign Affairs 74, No. 2 (1995): 86-98.

Landberg, Alison. Prosthetic Memory: The Transformation of American Remembrance in the Age of Mass Culture. New York: Columbia University Press, 2004.

Lapidus, Gail W. "Contested Sovereignty: The Tragedy of Chechnya.” International Security 23, No. 1 (1998): 5-49.

Lasswell, Harold D. “The Garrison State.” American Journal of Sociology 46, No. 4 (1941): 455-468. 
Lauer, Josh. "Money as Mass Communication: U.S. Paper Currency and the Iconography of Nationalism.” The Communication Review 11, No. 2 (2008): 109132.

Le Goff, Jacques. History and Memory. Translated by Steven Rendall and Elizabeth Claman. New York: Columbia University Press, 1992.

Lebedev, Anna Colin. "From a mother's worry to Soldiers' Mothers' Action: Building Collective Actions on Personal Concerns" In Understanding Russianness, edited by Risto Alapuro, Arto Mustajoki and Pekka Pesonen, 84-98. London: Routledge, 2011.

Ledin, Per, and David Machin. "Multi-modal critical discourse analysis." In The Routledge Handbook of Critical Discourse Studies, edited by John Flowerdew and John E. Richardson, 60-76. Oxon: Routledge, 2018.

Lenintova, Ekaterina, and Jim Butterfield. "History Education and History Remembrance in Contemporary Russia." Communist and Post-Communist Studies 43, No. 2 (2010): 139-166.

Leshchiner, Viacheslav R. and David I. Poltorak. "The Standard for History Education in Russia's Schools.” The History Teacher 27, No. 3 (1994): 317-324.

Levario, Antonio Miguel. Militarising the border: When Mexicans Became the Enemy. Texas: Texas A\&M University Press, 2012.

Levine, Philip and Ron Scollon. "Multimodal Discourse Analysis as the confluence of Discourse and technology." In Discourse and Technology: Multimodal Discourse Analysis, edited by Ron Scollon and Philip Levin, 1-6. Washington DC: Georgetown University Press, 2004.

Lieven, Anatol. Chechnya: Tombstone of Russian Power. New Haven and London: Yale University Press, 1999.

Liu, Yongbing. "The construction of cultural values and beliefs in Chinese language textbooks: A Critical Discourse Analysis." Discourse: Studies in the cultural politics of education 26, No. 1 (2005): 15-30.

Locmele, Klinka, Olga Procevska and Vita Zelce. "Celebrations, Commemorative Dates and Related Rituals: Soviet Experience, its Transformation and Contemporary Victory Day Celebrations in Russia and Latvia." In The Geopolitics of History in Latvian-Russian Relations, edited by Nils Muiznuks, 109-138. Riga: Academic Press of the University of Latvia, 2011. 
Lutz, Catherine. "Making war at home in the United States: Militarisation and the current crisis." American Anthropologist 104, No. 3 (2002): 723-735.

Macdonald, Colin. "Sponsorship and the Image of the Sponsor." European Journal of Marketing 25, No. 11 (1991): 31-38.

Macgilchrist, Felicitas. "Textbooks." In The Routledge handbook of Critical Discourse Studies, edited by John Flowerdew and John F Richardson, 525-539. Oxon: Routledge, 2018.

Madrigal, Robert. "Social Identity, Effects in belief - attitude-intentions hierarchy: Implications for Corporate Sponsorship." Psychology and Marketing 18, No. 2 (2001): 145-165.

Magolda, Marcia Baxter. Making their own war: Narratives for Transforming Higher Education to promote self-development. Virginia: Stylus Publishing, 2004.

Majumdar, Neepa. "The Nostalgia Industry and Indian Film Studies," South Asian Popular Culture 13, No. 1 (2015): 85-88.

Malinova, Olga. "Political Uses of the Great Patriotic War in Post-Soviet Russia from Yeltsin to Putin." In War and Memory in Russia, Ukraine and Belarus, edited by John Fedor, Markku Kangaspuro and Jussi Lassila, 43-70. London: Palgrave Macmillan, 2017.

Mangan, J. A. "Prologue: Combative Sports and Combative Societies." In Militarism, Sport, Europe: War without Weapons, edited by J. A. Mangan, 1-9. London: Routledge, 2004.

Mann, Michael. "The Roots and Contradictions of Modern Militarism." New Left Review 1, No. 162 (1987).

Mann, Yan. "(Re)cycling the Collective Memory of the Great Patriotic War." The Journal of Slavic Military Studies 33, No. 4 (2020): 508-513.

Marshall, Tim. Prisoners of Geography: Ten maps that explain everything about the world. London: Elliott and Thompson, 2016.

Marten, Kimberly. "Reconsidering NATO expansion: a counterfactual analysis of Russia and the West in the 1990s." European Journal of international Security 3, No. 2 (2018): 135-161.

Marwick, Roger D. “The Great Patriotic War in Soviet and Post-Soviet Collective Memory." In The Oxford Handbook of Postwar European History, edited by Dan Stone, 692-713. Oxford: Oxford University Press, 2012. 
Mastny, Vojtech. The Cold War and Soviet Insecurity: The Stalin Years. New York and Oxford: Oxford University Press, 1998.

Mathers, Jennifer G. "The Generals Manoeuvre on the Political Battlefield." World Today 51, No. 12 (1995): 231-234.

McDermott, Roger. "Russia's Armed Forces: The Power of Illusion." Russie. Nei. Visions, No. 37 (2009)

McIntosh Sunstrom, Lisa. 'Soldiers' Rights Groups in Russia: Civil Society Through Russia and Western Eyes." In Russian Civil Society: A Critical Assessment, edited by Alfred B. Evans, Laura A. Henry and Lisa McIntosh Sunstrom, 178-196. New York and London: M. E. Sharpe, 2006.

McNair, Brian. "Reforming and Restructuring in the Soviet media: Before and after the August 1991 coup." In Getting the Message: News, Truth and Power, edited by John Eldridge, 53-72. Oxford: Taylor and Francis, 2003.

McNair, Brian. Glasnost, Perestroika and the Soviet Media. London: Routledge, 1991.

Meenaghan, Tony. "Understanding Sponsorship Effects." Psychology and Marketing 18, No. 2 (2001): 95-122.

Melnick, A. James. "Beyond the Economy: Internal Factors Affecting the Future of the Russian Military." Naval War College Review 47, No. 3 (1994): 33-50.

Menning, Bruce W. "Paul I and Catherine II's Military Legacy, 1762-1801," in The Military History of Tsarist Russia, edited by Fredrick W. Kagan and Robin Higham, 77-106. New York: Palgrave, 2002.

Menning, Bruce W. "The Imperial Russian Army, 1725-1796." In The Military History of Tsarist Russia, edited by Fredrick W. Kagan and Robin Higham, 47-76. New York: Palgrave, 2002.

Merely, Scott Hughes. British military spectacle: from the Napoleonic wars through the Crimea. Cambridge, Massachusetts: Harvard University Press, 1996.

Merridale, Catherine. "Redesigning History in Contemporary Russia." Journal of Contemporary History 38, No. 1 (2003): 13-28.

Mesle, France and Jacques Vallin. Morality and causes of death in $20^{\text {th }}$ century Ukraine.London: Springer, 2012.

Mettler, Suzanne. "Bringing the State Back in to Civil Engagement: Policy Feedback Effects of the G. I. Bill for World War 2 Veterans." The American Political Science Review 96, No. 2 (2002): 351-365. 
Meyer, Eric. "Memory and Politics." In A Companion to Cultural Memory Studies: An International and Interdisciplinary Handbook, edited by Astrid Erll, Ansgar Nünning, and Sara Young, 173-180. Germany: Walter De Gruyter, 2008.

Miakinkov, Eugene. War and Enlightenment in Russia: Military Culture in the Age of Catherine II. Toronto: University of Toronto Press, 2020.

Mikaberidze, Alexander. Russian Officer Corps of the Revolutionary and Napoleonic Wars. New York: Savas Beatie, 2005.

Misztal, Barbara A. "Durkheim on Collective Memory." Journal of Classic Sociology 3, No. 2 (2003): 123-143.

Mittlestadt, Jennifer. The Rise of the Military Welfare State. Cambridge, Massachusetts: Havard University Press, 2015.

Moran, John P. From Garrison State to Nation State: Political Power and the Russian Military under Gorbachev and Yeltsin, Westport: Praeger, 2002.

Morgan, W. John, and Grigori Kliucharev. "Higher Education and the Post-Soviet Transition in Russia." Journal of Education 47, No. 1 (2012): 3-8.

Muldering, Jane, Nicolina Montesane Montessori and Michael Farrely. "Introducing Critical Policy Discourse Analysis.” In Critical Policy Discourse Analysis, edited by Jane Muldering, Nicolina Montesane Montessori and Michael Farrely, 1-22. Cheltenham: Edward Elgar, 2019.

Naimark, Norman M., David E. Powell and Kurt M. Campbell. "Moscow's Cult of Militarism." The National Interest, No. 4 (1986): 53-64.

Nelson, Todd. "History as Ideology: The Portrayal of Stalinism and the Great Patriotic War in Contemporary Russian High School books." Post-Soviet Affairs 31, No. 1 (2015): 37-65.

Nungesser, Verena-Susanna. "I Forgot to Remember (to Forget): Personal Memories in Memento (2000) and Eternal Sunshine of the Spotless Mind (2004)." In Mediation, Remediation, and the Dynamics of Cultural Memory, edited by Astrid Ell and Ann Rigney, 31-48. Berlin and New York: Walter De Gruyter, 2009.

Odom, William E. The Collapse of the Soviet Military. New Haven and London: Yale University Press, 2000.

Odom, William. "The 'militarisation' of Soviet society." Problems of Communism 25, No. 5 (1976), 34-51. 
Oleynik, Anton. "Dedovshchina as an Element of the "Small Society": Evidence from Russia and Other Countries." The Journal of Power Institutions in Post-Soviet Societies, No. 1 (2004).

Paul, Michael C. "The Military Revolution in Russia, 1550-1682." The Journal of Military History 68, No. 1 (2004): 9-45.

Payne, James L. “Marxism and Militarism” Polity 19, No. 2 (1986): 270-289.

Penrose, Jan and Craig Cumming. "Money Talks: Banknote iconography and symbolic constructions of Scotland." Nations and Nationalism 17, No. 4 (2011): 821842.

Petrović, Boban, Janko Mededović, Olivera Radović and Sanja Radetić Lovrić. "Conspiracy Mentality in Post-Conflict Societies: Relations with the ethos of conflict and readiness for reconciliation." Europe's Journal of Psychology 15, No. 1 (2019): 59-81.

Pinter, Walker M. "The Burden of Defense in Imperial Russia, 1725-1914." The Russian Review 43, No. 3 (1984): 231-259.

Pipes, Richard. "Militarism and the Soviet State." Daedalus 109, No. 4 (1980): 1-12. Potapova, Natalia. "Normativity in Russian History Education: Political Patterns and National History Textbooks." Journal of Social Sciences of Education 14, No. 1 (2015): 47-55.

Powe, Lucas A. The Fourth Estate and the Constitution: Freedom of the Press in America. Berkley: University of California Press, 1991.

Proctor, Tammy. Civilians in a World at War, 1914-1918. New York: NYU Press, 2010.

Provencher, Denis M. and Luke L. Eilderts. "The Nation According to Lavisse: Teaching Masculinity and Male Citizenship in Third-Republic France." French Cultural Studies 18, No. 1 (2007): 31-57.

Purwanta, Hieronymus. "Militaristic Discourse in Secondary History Textbooks during and after the Soeharto Era." Journal of Educations Media, Memory and Society 9, No. 1 (2017): 36-53.

Rachbauer, Markus. The Soldiers' mothers of Russia. Munich: GRIN Verlag, 2008.

Radway, L. I., "Militarism.” In Encyclopedia of the Social Sciences, edited by D. L. Sills, 300-305. New York: MacMillan Co and Free Press, 1968.

Raeff, Mark. Peter the Great: Reformer or Revolutionary? Lexington, Massachusetts: D.C. Heath \& Company, 1966. 
Ramanatham, Renugah and Tan Bee Hoon. "Application of Critical Discourse Analysis in Media Discourse Studies." The Southeast Journal of English Language Studies 21, No. 2 (2015): 57-68.

Ramsey, Neil. The Military Memoir and Romantic Literary Culture 1780-1835. Surrey: Ashgate Publishing Ltd, 2016.

Ray, Oliver Allen. "The Imperial Russian Army Officers." Political Science Quarterly 76, No. 4 (1961): 576-592.

Reid, Anna. Leningrad: Tragedy of a City Under Siege, 1941-1944. London: Bloomsbury, 2012.

Renz, Bettina. "Media-military relations in Post-Soviet Russia: Who is the watchdog?" In Military and Society in Post-Soviet Russia, edited by Jennifer G. Mathers and Stephen Webber, 61-79. Manchester and New York: Manchester University Press, 2006.

Renz, Bettina. "Putin's Militocracy? An Alternative Interpretation of the Siloviki in Contemporary Russian Politics.” Europe-Asia Studies 58, No. 6 (2006): 903-924.

Richardson, Matthew. "Medals, Memory and Meaning: Symbolism and cultural significance of Great War Medals." In Contested Objects: Material Memories of the Great War, edited by Nicholas J. Saunders and Paul Cornish, 104-118. Oxon: Routledge, 2014.

Richter, Andrei G. "The Russian Press after Perestroika." Canadian Journal of Communication 20, No. 1 (1995): 7-23.

Richters, Katya. The Post-Soviet Russian Orthodox Church: Politics, Culture and Greater Russia. Oxon: Routledge, 2012.

Rigby, Andrew A. "Peace Symbol's Origins.” Peace Review 10, No. 3 (1998): 475479.

Ripsberger, Joseph T., Hank C. Jenkins-Smith and Kerry G. Herron. "How Cultural Orientations Create Shifting National Security Coalitions on Nuclear Weapons and Terrorist Threats in the American Public." PS: Political Science and Politics 44, No. 4 (2011): 715-719.

Rivera, Sharon Werning and David W. Rivera, "The Russian Elite under Putin: Militocratic or Bourgeois?” Post-Soviet Affairs, Vol. 22, No. 2 (2006), 125-144.

Rivera, Sharon Werning and David W. Rivera. "Is Russia a militocracy? Conceptual Issues and extant findings regarding elite militarisation." Post-Soviet Affairs 30, No. 1 (2014): 27-50. 
Robertson, Emily. 'Propaganda and 'Manufactured Hatred:' An Appraisal of the ethics of First World War British and Australian Atrocity Propaganda." Public Relations Enquiry 3, No. 2 (2014): 245-266.

Rosenblum, Nancy. "Romantic Militarism." Journal of the History of Ideas 43, No. 2 (1982): 249-268.

Ross, Andrew L. "The Dimensions of Militarisation in the Third World." Armed Forces and Society 13, No. 4 (1987): 561-578.

Rowlands, Michael. "Trauma, Memory and Memorials." British Journal of Psychology 15, No. 1 (1998): 54-64.

Sakwa, Richard. Russian Politics and Society. 2nd edition. New York and London: Routledge, 1996.

Santino, Jack. "Performative commemoratives, the personal, and the public: Spontaneous shrines, Emergent Rituals, and the field of Folklore." Journal of American Folklore 117, No. 466 (2004): 363-372.

Sarotte, Mary Elise. "One Inch Eastward? Bush, Baker, Kohl, Genscher, Gorbachev, and the Origin of Russian Resentment toward NATO Enlargement in February 1990.” Diplomatic History 34, No. 1 (2010): 119-140.

Scheufele, Dietram, A. "Agenda-Setting, Priming, and Framing Revisited: Another Look at Cognitive Effects of Political Communication." Mass Communication and Society 3, No. 2-3 (2000): 297-316.

Schleifman, Nurit. "Moscow's Victory Park: A Monumental Change." History and Memory 13, No. 2 (2001): 5-34.

Schreier, Margrit. "Qualitative Content Analysis." In The Sage Handbook of Qualitative Data Analysis, edited by Uwe Flick, 170-183. London: SAGE publications, 2013.

Schulte-Sasse, Jochen, and Linda Shulte-Sasse, "War, Otherness, and Illusionary Identifications with the state," Cultural Critique, No. 19 (1991): 67-95.

Seierstad, Asne. Angel of Grozny: Life Inside Chechnya. London: Virago, 2007.

Service, Robert. The Penguin History of Modern Russia: From Tsarism to the Twenty-First Century. 4th edition. London: Penguin, 2015.

Shambaugh, David. "The Soldier and the State in China: The Political Work System in the People's Liberation Army." China Quarterly, No. 127 (1991): 527-568. 
Shaw, Denis. “'A strong and prosperous condition': The Geography of state building and social reform in Peter the Great's Russia." Political Geography 18, No. 8 (1999): 991-1015.

Shaw, Martin. "Twenty-First Century Militarism: A historical-sociological framework." In Militarism and International Relations: Political economy, security and theory, edited by Anna Stavrianakis and Jan Selby, 19-32. New York: Routledge, 2002.

Sherman, Daniel J. "Commemoration." In The French Republic: History, Values, Debate, edited by Edward Berenson, Vincent Duclert and Christopher Prochasson, 324-333. Ithaca and London: Cornell University Press, 2011.

Shnirelman, Victor. "Stigmatised by history or by historians? The people's Russia in School history textbooks." History and Memory 21, No. 2 (2009): 110-149.

Sieca-Kozlowski, Elisabeth. "From Controlling Military Information to Controlling Society: Political Interests Involved in the Transformation of the Military Media Under Putin.” Small Wars and Insurgencies 20, Vol. 2 (2009): 300-318.

Sieca-Kozlowski, Elisabeth. "Russian Military Patriotic Education: A control tool against the arbitrariness of veterans." The journal of Nationalism and Ethnicity 38, No. 1 (2010): 73-85.

Simes, Dimitri. "The Military and Militarism in Soviet Society" International Security 6, No. 3 (1981-1982): 123-143.

Singh, Anil Kamar. Military and Media. New Delhi: Lancer Publishers, 2006.

Sinitsina, Irina. "Experience of Implementing Social benefits Monetization Reform in Russia. Literature Review." SSPRN Electronic Journal. (2009): 1-65. 10.2139/ssrn.1436409.

Siren, Pontis. "The Battle of Grozny: The Russian Invasion of Chechnya, December 1994-1996." In Russia and Chechnya: The Permanent Crisis: Essays on RussoChechen Relations, edited by Ben Fowkes, 87-169. London: Springer Links, 2016.

Skocpol, Theda. Protecting Soldiers and Mothers. Cambridge, Massachusetts: Harvard University Press, 1995.

Smith Julianne. The NATO-Russia Relationship: Defining Moment or Déjà vu? Europe, Russia and the United States: Finding a New Balance. Washington DC: Rowman and Littlefield Publishers/ Center for Strategic and International Studies, 2008. 
Smith, Kevin B. The Ideology of Education: The Commonwealth, the Market, America's Schools. Albany: SUNY Press, 2003.

Smith, Mark B. "Social Rights in the Soviet Dictatorship: The constitutional Right to Welfare from Stalin to Brezhnev." Humanity: An International Journal of Human Rights, Humanitarianism and Development 3, No. 3 (2012): 385-406.

Smith, Martin A., and Graham Timmins. "Russia, NATO and the EU in an Era of Enlargement: Vulnerability or Opportunity?” Geopolitics 6, No. 1 (2001): 69-90.

Solovenko, I. S. “'Rel'sovye Voiny’ v Rossii v 1998 g.: K Postanovke Problemy.” Istoriia 63.3(2), No. 6-3 (2010): 206-210.

Speck, Catherine. "Women's War Memorials and Citizenship." Australian Feminist Studies 11, No. 23 (1996): 129-145.

Spivak, Andrew L., and William Alex Pridemore. "Conscription and Reform in the Russian Army." Problems of Post-Communism 51, No. 6 (2004): 33-43.

Stahl, Roger. Militainment, Inc War, Media and Popular Culture. New York: Routledge, 2010.

Starovoitova, Galina. "Democratisation and Ethnic Conflict in Post-Soviet Society." In Ethnic Conflict in the Post-Soviet World: Case Studies and Analysis, 1st edn. edited by Leokadia Drobizheva, Rose Gottemoeller, Catherine McArdle Kelleher and Lee Walker, 149-156. New York: M. E. Sharpe, 1998.

Stavrianakis, Anna and Jan Selby. "Militarism and international relations in the twenty-first century." In Militarism and International Relations: Political Economy, Security and Theory, edited by Anna Stavrianakis and Jan Selby, 3-18. New York: Routledge, 2002.

Stemler, Steve. “An Overview of Content Analysis." Practical Assessment, Research and Evaluation 7, No. 17 (2000): 1-7.

Stockdale, Melissa. "The Russian Experience of the First World War." In $A$ Companion of Russian History, edited by Abbott Gleason, 311-314. UK: WileyBlackwell, 2009.

Stone, David R. A Military History of Russia: From Ivan the Terrible to the war in Chechnya. Westport, Connecticut: Praeger Security International, 2006.

Stone, David R. Hammer and Rifle: The Militarisation of the Soviet Union, 19261933. Lawrence, Kansas: University Press of Kansas, 2000.

Sturken, Marita. Tangled Memories, The Vietnam War, The Aids Epidemic, And the Politics of Remembering. Berkley: University California Press, 1997. 
Sushentov, Andrey A., and William C. Wohlforth. "The Tragedy of US-Russia Relations: NATO centrality and the revisionists' spiral." International Politics 57, (2020), 427-450.

Sutherland, Robert. "Hidden Persuaders: Political Ideologies in Literature for Children." Children's Literature in Education 16, No. 3 (1985): 143-157.

Suvorov, Viktor. Ledokol: Kto nachal Vtoruyu Mirovuyu Voyna? Russia: Dobraya Uniga, 1987.

Tally, Robert T. "Demonizing the Enemy, Literally: Tolkien, Orcs, and the Sense of the World Wars." Humanities 8, No. 54 (2019): 95-104. https://doi.org/10.3390/h8010054.

Taylor, Brian D. Politics and the Russian Army: Civil-Military Relations, 1689-2000. Cambridge: Cambridge University Press, 2003.

Tolz, Vera. "The War in Chechnya." Current History 95, No. 603 (1996): 316-321.

Trenin, Dmitri. "The Revival of the Russian Military." Foreign Affairs 95, No. 3 (2016), https://www.foreignaffairs.com/articles/russia-fsu/2016-04-18/revivalrussian-military.

Trigg, Jonathan. "Memory and Memorial: A Study of Official and Military Commemoration of the Dead, and Family and Community Memory in Essex and East London." Journal of Conflict Archaeology 3, No. 1 (2007): 295-315.

Tumarkin, Nina. "The Great Patriotic War as myth and memory." European Review 11, No. 4 (2003): 595-611.

Unwin, T., and V. Hewitt. "Banknotes and national Identity in Central and Eastern Europe.” Political Geography 20, No. 8 (2001): 1005-1028.

Urip Sulistiyo, Supiani, Ahmad Kailiani and Rani Puspitasari Dewi Lestariyana. "Infusing moral content into Primary School English Textbooks: A Critical Discourse Analysis." Indonesian Journal of Applied Linguistics 10, No. 1 (2020): 251-260.

Vagts, Alfred. The History of Militarism: Civilian and Military. New York: The Free Press, 1959.

Vallance, Brenda. "The Rule of Law and Russian Military Reform: The Role of Soldiers' Mothers in Russian Society." The Carl Beck Papers in Center of Russian and East European Studies, No. 1407 (2000): 1-33.

Valliant, Janet G. "Civic Education in Changing Russia" In Educational Reform in Post-Soviet Russia: Legacies and Prospects, edited by Ben Eklof, Larry E. Holmes and Vera Kaplan, 221-246. Oxon: Frank Cass, 2005. 
Van Dijk, Teun A. "What is political discourse analysis?" In Political linguistics, edited by Jan Blommaert and Chris Bulcuen, 11-52. Amsterdam: Benjamins Publishers, 1998.

Van Dijk, Teun A. "Discourse, Power and Access." In Text and Practices: Readings in Critical Discourse Analysis, edited by Carmen Rosa Caldas-Coulthard and Malcolm Coulthard, 84-104. London: Routledge, 2015.

Varin, Caroline. Mercenaries, Hybrid Armies and National Security: Private Soldiers and the state in the $21^{\text {st }}$ Century. Oxon: Routledge, 2014.

Vartanova, Elena. "The Russian Media Model in the Context of Post-Soviet Dynamics." In Comparing Media Systems Beyond the Western World, edited by Hallin, Daniel C., and Paolo Mancini, 119-142. Cambridge: Cambridge University Press, 2011.

Vetter, Eva. "Hegemonic Discourse in the Habsburg Empire: The case of education. A Critical Discourse Analysis of two mid- $19^{\text {th }}$ century government documents." In Diglossia and Power: Language policies and practice in the $19^{\text {th }}$ century Habsburg Empire, edited by Rosita Rindler Schjerve, 271-309. Berlin: Mounton De Gruyter, 2003.

Viggo Jakobsen, Peter. "Focus on the CNN Effect misses the point: The Real Media Impact on Conflict Management is Invisible and Direct." Journal of Peace Research 37, No. 2 (2000): 205-215.

Virilio, Paul. War and Cinema: The Logistic of Perception. London and New York: Verso, 1989.

Vogel, Jacob. "Military, Folklore, Eigensinn: Folkloric Militarism in Germany and France, 1871-1914.” Central European History 33, No. 4 (2000): 487-504.

Volodina, Tatyana. "Teaching History in Russia after the collapse of the USSR." The History Teacher 38, No. 2 (2005): 179-188.

Voltmer, Katrin. "Constructing the Political Reality in Russia. Izvestiya - Between Old and New Journalistic Practices.” European Journal of Communication 15, No. 4 (2000): 469-500.

Waley-Cohen, Joanna. "Militarisation of Culture in Eighteenth-Century China." In Military Culture in Imperial China, edited by Robin D. S. Yates and Ralph D. Sawyer, 278-295. Cambridge, Massachusetts: Harvard University Press, 2009.

Walker, Shaun. The Long Hangover: Putin's New Russia and the Ghosts of the Past. New York: Oxford University Press, 2018. 
Wang, Jiayu. "A New Political Communication Agenda for Political Discourse Analysis: Critical Reflections on Critical Discourse Analysis and Political Discourse Analysis.” International Journal of Communications, 10 (2016): 2766 - 2784.

Wang, Zheng. "National Humiliation, History Education, and the Politics of Historical Memory: Patriotic Education Campaign in China." International Studies Association 52, No. 4 (2008): 783-806.

Weatherford, Doris. American Women During World War II: An Encyclopaedia. New York: Routledge, 2010.

Webber, Stephen L. "Introduction: The Society-Military Interface in Russia." In Military and Society in post-Soviet Russia, edited by Stephen L. Webber and Jennifer G Mathers, 1-36. Manchester and New York: Manchester University Press, 2006.

Weiner, Amir. "In the Long Shadow of War: The Second World War and the Soviet and Post-Soviet World." Diplomatic History 25, No. 3 (2001): 443-456.

Wertsch, James V. "Narratives as cultural tools in sociocultural analysis: Official History in Soviet and Post-Soviet Russia" Ethos 28, No. 4 (2001): 511-533.

Wesson, Robert G. "The Military in Soviet Society." The Russian Review 30, No. 2 (April 1971): 139-145.

White, Stephen: Russia's New Politics: The Management of a Postcommunist Society. Cambridge: Cambridge University Press, 2000.

Whitehood, Peter. "The Purge of the Red Army and the Soviet Mass Operations, 1937-1938." The Slavonic and East European Review 93, No. 2 (2015): 286-314.

Wiktorow, Aleksandra. "Soviet Union." In Social Welfare in Socialist Countries, edited by John Dixon and David Macarov, 184-207. Oxon: Routledge, 2016.

Williams, Brian Glyn. "Commemorating "the Deportation in Post-Soviet Chechnya: The Role of Memorialisation and Collective Memory in the 1994-1996 and 19992000 Russo-Chechen Wars.” History and Memory 12, No. 1 (2000): 101-134.

Wirtschafter, Elise Kimerling. From Serf to Russian Soldier. Princeton: Princeton University Press, 1990.

Wodak, Ruth and Rudolf De Cillia. "Commemorating the Past: The Discursive Construction of Official Narratives about the 'Rebirth of the Second Austrian Republic."” Discourse and Communication 1, No. 3 (2007): 149-173.

Wodak, Ruth. "Critical Discourse Analysis at the End of the $20^{\text {th }}$ Century." Research on Language and Social Interaction 32, No. 1-2 (1999): 185-193. 
Wodak, Ruth. "The Discourse-Historical Approach." In Methods of Critical Discourse Analysis, edited by Ruth Wodak and Michael Meyer, 63-95. London: SAGE, 2001.

Woodside-Jiron, Haley. "Language, Power and Participation: Using Critical Discourse Analysis to Make Sense of Public Policy." In An Introduction to Critical Discourse Analysis in Education, edited by Rebecca Rogers, 173-206. London: Lawrence Erlbaum Associates, Publishers, 2004.

Yeltsin, Boris. Midnight Diaries. Great Britain: Weidenfeld \& Nicolson, 2000.

Zajda, Joseph. "Globalisation, Ideology and History School Textbooks: The Russian Federation." In Nation-building and history education in a global culture, edited by Joseph Zajda, 29-50. New York: Springer, 2015.

Zajda, Joseph. "Russian History Textbooks: An Analysis of Historical Narratives depicting key events." Curriculum and Teaching 28, No. 2 (2013): 73-100.

Zamponi, Lorenzo. Social Movements, Memory and Media: Narrative in Action in the Italian and Spanish Student Movements. London: Palgrave Macmillan, 2018.

Zassoursky, Ivan Ivanovich. Media and Power in Post-Soviet Russia. Oxon: Routledge, 2016.

Zawilski, Valeria. "Saving Russia's Sons: The Soldiers' Mothers and the RussianChechen Wars." In Military and Society in Post-Soviet Russia, edited by Stephen Webber and Jennifer G. Mathers, 228-240. Manchester and New York: Manchester University Press, 2005.

Zorin, Andrei. By Fables Alone: Literature and State ideology in late eighteenth early-nineteenth- century Russia. United States: Academic Studies Press, 2019.

\section{UNPUBLISHED SOURCES}

Abousnnouga, Gillian N. "Visual and Written Discourse of British Commemorative War Monuments." PhD diss. Cardiff University, 2012.

Cling, Paul. “"Militainment' In Post 9/11 American War Movies.” PhD diss. University of Leiden, 2018.

Evans, Dean. "How Far were the Lines between the Frontline and the Homefront blurred in East Kent (Canterbury).” Masters diss. University of Kent, 2016. 
Juskevits, Svetlana. "Professional Roles of Russian Journalists at the End of the 1990s: A Case Study of St. Petersburg Media." Licentiates diss. University of Tampere, 2002.

Koenig, Christop. "Loose-Cannons - War Veterans and the Erosion of Democracy in

Weimar Republic." Warwick Economics Research Paper Series (2015) https://warwick.ac.uk/fac/soc/economics/research/workingpapers/2015/twerp_1079 _koenig.pdf

Maltseva, Elena. "Welfare Reforms in Post-Soviet States: A Comparison of Social Benefits Reform in Russia and Kazakhstan,” PhD diss. University of Toronto, 2012. Nemtsev, Mikhail. "Life of a devoted militant out of a battlefield: Variations of everyday militarism in Russian Communities.” Workshop, Militarisation of Everyday Life in Europe: Past Practices and Future Challenges, Swansea University, Swansea, November 2017.

Simons, Gregory J. "The Impact of Political and Business Interests of the Contemporary Russian Media,” Masters diss. University of Canterbury, 2001. 